

\section{REVISTA BRASILEIRA DE POLÍTICAS PÚBLICAS}




\section{REVISTA BRASILEIRA DE POLÍTICAS PÚBLICAS \\ Brazilian Journal of Public Policy}

Programa de Mestrado e Doutorado em Direito do UniCEUB

Centro Universitário de Brasília

Reitor

Getúlio Américo Moreira Lopes

Presidente do Conselho Editorial do UniCEUB

Elizabeth Regina Lopes Manzur

Diretor do ICPD

João Herculino de Souza Lopes Filho

Coordenador do Programa de Mestrado e Doutorado e Editor

Marcelo Dias Varella

\section{Linha editorial}

"A Revista Brasileira de Políticas Públicas é um periódico acadêmico da área jurídica que tem como finalidade constituir instrumento de veiculação de trabalhos científicos e doutrinários que abordem questões jurídicas da contemporaneidade e, ainda, aspectos da interação entre Direito e Políticas Públicas. Direciona, portanto, seu objeto de interesse a questões referentes a governabilidade, integração, participação cidadã, desenvolvimento e outros temas envolvendo o Estado, a Sociedade e o Direito.

Sendo assim, a proposta de linha editorial a ser seguida pela Revista Brasileira de Políticas Públicas é apresentada a partir de três áreas fundamentais, que se subdividem:

I) Democracia, Políticas de Estado e de Governo e seus aspectos jurídicos: tendências do Direito Constitucional e do Direito Administrativo; teoria das políticas públicas; sistema de governo; sistema eleitoral e cidadania; sistema de partidos e reforma constitucional

II) Políticas Públicas de desenvolvimento econômico e social e suas interfaces com o Direito: políticas de desenvolvimento econômico e produção local/regional, desenvolvimento sustentável e meio-ambiente, desenvolvimento humano e planejamento da ação governamental".

\section{CONSELHO EDITORIAL}

Marie-Pierre Lafranchi, Université d'Aix-en-Provence, Faculté de droit et de science politique, Provence-Alpes-Côte d'Azur, França Frederico Augusto Barbosa, Centro Universitário de Brasília, Programa de Mestrado e Doutorado em Direito, Brasília/DF, Brasil Gilberto Bercovici, Universidade de São Paulo, Faculdade de Direito, Departamento de Direito Econômico-Financeiro, São Paulo/SP, Brasil João Maurício Adeodato, Universidade Federal de Pernambuco, Centro de Ciências Jurídicas, Departamento de Teoria Geral do Direito e do Direito Privado, Recife/PE, Brasil

José Adercio Leite Sampaio, Escola Superior Dom Helder Câmara, Escola de Direito, Belo Horizonte/MG, Brasil

José Heder Benatti, Universidade Federal do Pará, Instituto de Ciências Jurídicas, Belém/PA, Brasil

\section{EDITOR}

Marcelo D. Varella, Centro Universitário de Brasília, Programa de Mestrado e Doutorado em Direito, Brasília/DF, Brasil

\section{EQUIPE TÉCNICA}

Marcelo D. Varella, Centro Universitário de Brasília, Programa de Mestrado e Doutorado em Direito, Brasília/DF, Brasil Max Meirelles Gonzaga, Centro Universitário de Brasília, Revista Brasileira de Políticas Públicas, Brasília/DF, Brasil Aline Assunção Santos, Centro Universitário de Brasília, Revista Brasileira de Políticas Públicas, Brasília/DF, Brasil

\section{Layout capa \\ Departamento de Comunicação / ACC UniCEUB}

\section{Diagramação}

S2 Books

\section{Disponível em:}

http://www.rbpp.uniceub.br

\section{Circulação}

Acesso aberto e gratuito

Matérias assinadas são de exclusiva responsabilidade dos autores.

Citação parcial permitida com referência à fonte. 
Revista Brasileira de Políticas Públicas / Programa de Mestrado e Doutorado em Direito do UniCEUB. - vol. 6, n. 1 (jan./jul. 2016) - . Brasília : UniCEUB, 2011

Semestral.

ISSN 2236-1677

Disponível também on-line: www.rbpp.uniceub.br

1. Direito. 2. Políticas Públicas. I. Programa de Mestrado e Doutorado em Direito do UniCEUB

CDU $34+338.26$

Ficha catalográfica elaborada pela Biblioteca Reitor João Herculino 
EMPRESA QUE FINANCIA CAMPANHA ELEITORAL COMETE ABUSO DE PODER ECONÔMICO .14

Carlos Ayres Britto

1. A proibição que se desata do parágrafo $9^{\circ}$ do artigo 14 da Constituição Federal 14

2. As duas parelhas de bens jurídicos objeto de explícita proteção constitucional.

3. A influência do poder econômico e o abuso do exercício de cargo, ou função, ou emprego estatal como fatores constitucionalmente rotulados de perturbação do processo eleitoral ... . .15

4. A diferença entre uso e abuso, no discurso constitucional alusivo ao exercício de cargo, ou função, ou emprego, todos de natureza pública. ..15

5. A identidade entre uso e influência, no discurso constitucional alusivo ao poder econômico ........16

6. A distinção entre o uso e o abuso do poder econômico no parágrafo 10 do artigo 14 da Constituição. O poder econômico enquanto poder empresarial e vice-versa .............................................................17

7. O sentido atípico da protagonização estatal de atividade econômica e a rigorosa desidentidade jurídica entre os dois poderes: o político e o econômico .............................................................................17

8. A conciliação interpretativa possível entre os $9^{\circ}$ e 10 do artigo 14 da Constituição .........................18

9. O porquê da referência constitucional a abuso do poder econômico, no parágrafo $4^{\circ}$ do artigo 173 da Constituição

10. A diferença jurídica entre participar como cidadão e participar como empresário em tema de eleição popular ....

11. O decidido combate constitucional ao mais temerário dos emparceiramentos eleitorais: o do poder político e o do poder econômico 20

Referências bibliográficas 20

REFLEXõES SOBRE O FUTURO DO ESTADO CONSTITUCIONAL MODERNO .22

Cesar Luiz Pasold, Gabriel Real Ferrer e Paulo Márcio Cruz

1. Introdução 23

2. A refundação democrática da "coisa pública". 24

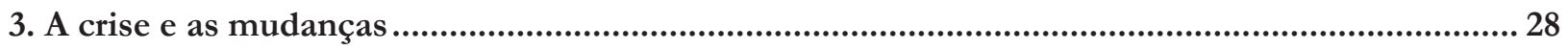

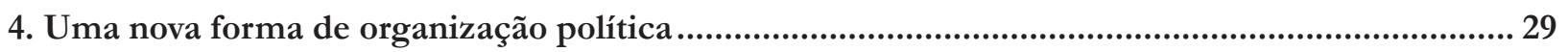

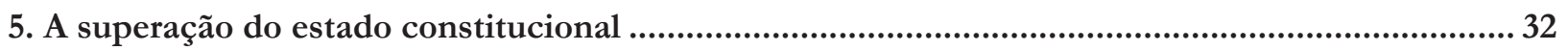

6. Um novo sistema político global e a importância nodal da democracia ..................................... 33

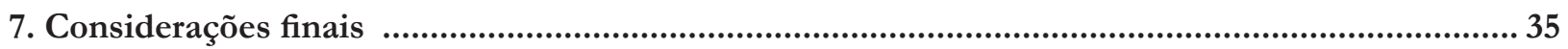

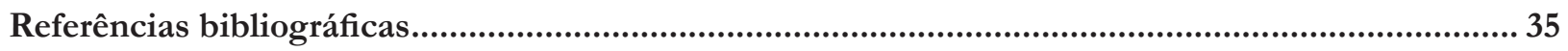


Bruno Ariel Rezzoagli

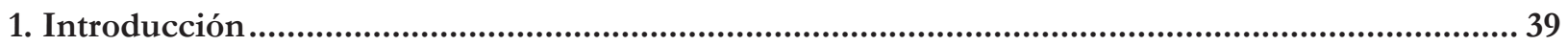

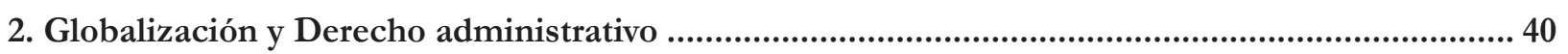

3. La tendencia hacia un Derecho administrativo global de la contratación pública........................ 43

4. Normas jurídicas de carácter internacional en materia de contratación pública........................... 44

4.1. El Acuerdo Plurilateral de Contratación Pública de la Organización Mundial de Comercio ................... 44

4.2. Normas de contratación pública del Tratado de Libre Comercio de América del Norte ......................... 45

4.3. El Protocolo de Contrataciones Públicas del Mercado Común del Sur....................................................... 46

4.4. La Ley Modelo sobre Contratación Pública de Naciones Unidas .............................................................. 46

5. La normativa comunitaria europea sobre contratos públicos ..................................................... 47

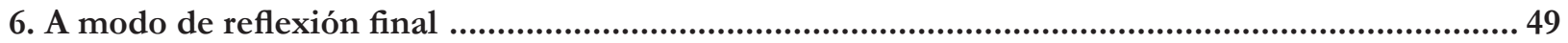

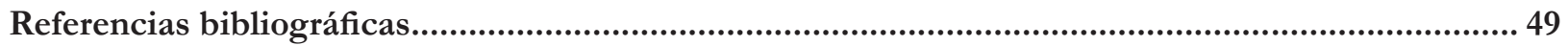

Contratos ADMINISTRATIVOS: CONCEITO E CRITÉRIOS DISTINTIVOS..................................53

Carlos Bastide Horbach

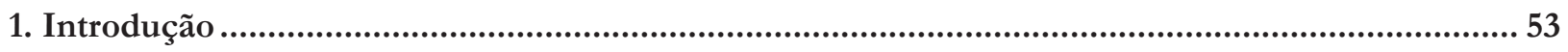

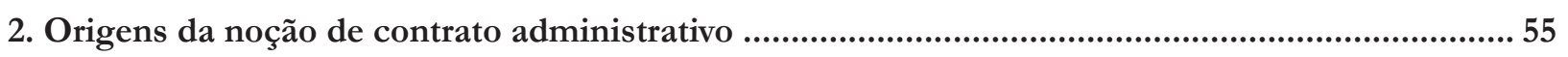

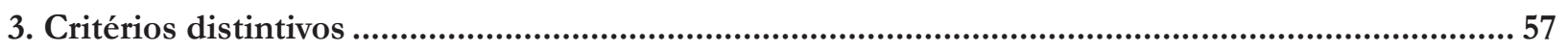

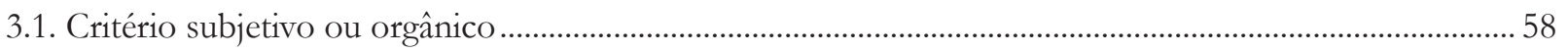

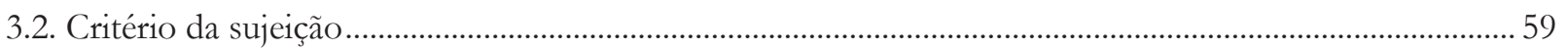

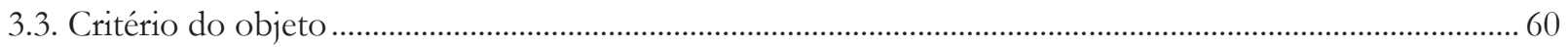

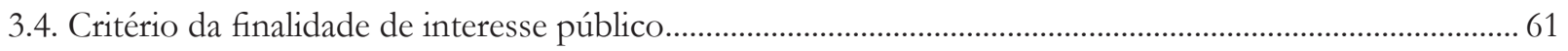

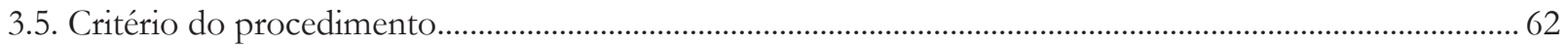

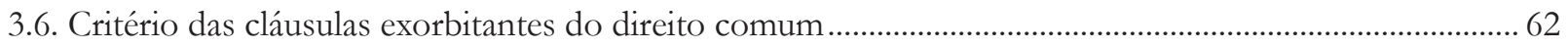

4. O critério distintivo no direito administrativo brasileiro ............................................................... 64

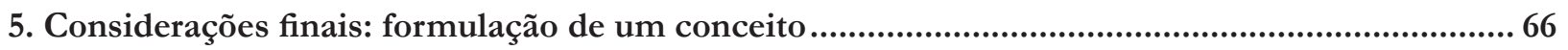

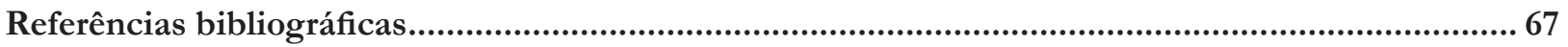

Os incentivos econômicos À compra de colhedoras pelo Pronaf-Mais alimentos para OS PRODUTORES DE ARROZ IRRIGAdo do Rio GRANDE DO SUl......................................70 João Mairton Moura de Araújo, Mário Conill Gomes e André Carraro

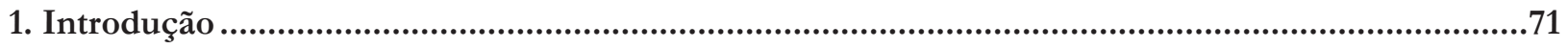

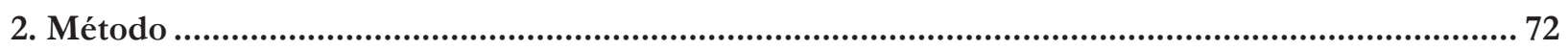

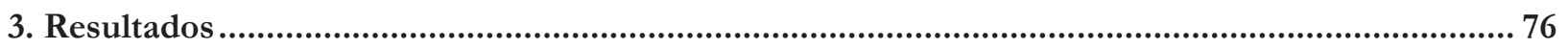

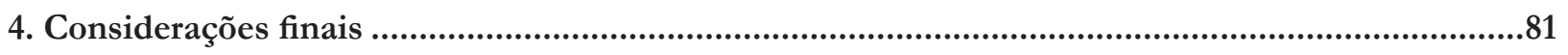


LiMitAÇões À EXTRAFISCALIDADE APLICÁVEIS AO FATOR ACIDENTÁRIO DE PREVENÇÃo - FAP...84 Daniel de Magalhães Pimenta

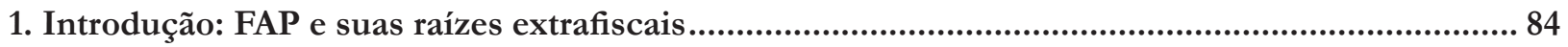

2. Limitações à extrafiscalidade segundo à doutrina .......................................................................... 87

2.1 A classificação dos limites por Marciano Seabra de Godoi ............................................................................. 88

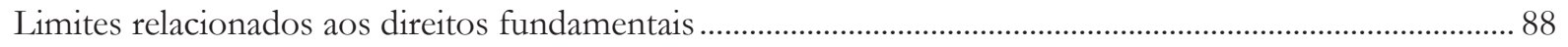

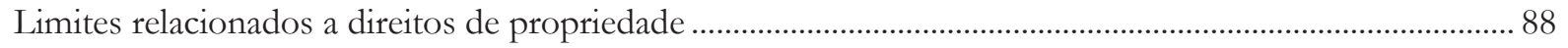

Limites relacionados ao dever de contribuir com os gastos públicos .............................................................. 88

Limites relacionados à competência tributária material e legislativa ………………………………………….... 89

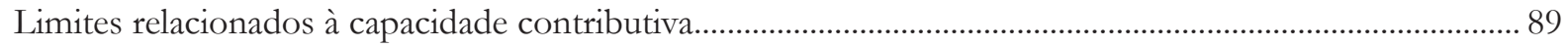

2.2. A classificação abrangente de Marcus de Freitas Gouvêa............................................................................... 90

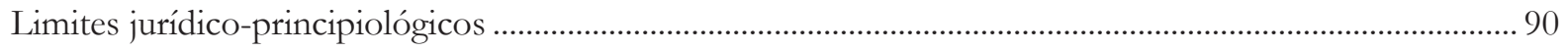

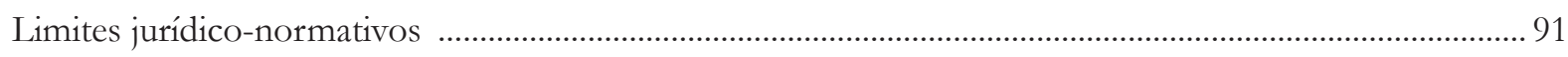

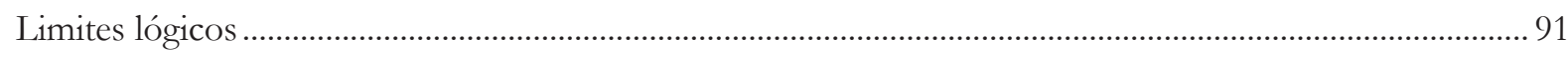

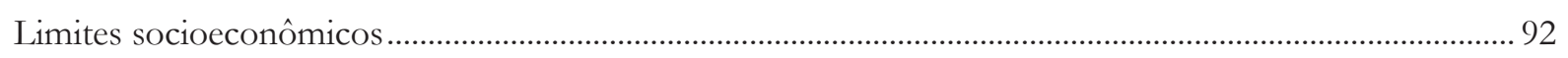

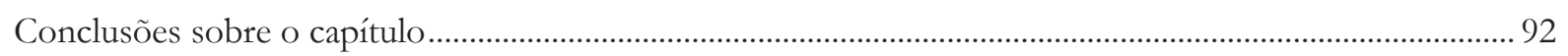

3. FAP em face dos limites extrafiscais definidos na ordem constitucional econômica e tributária ..........93

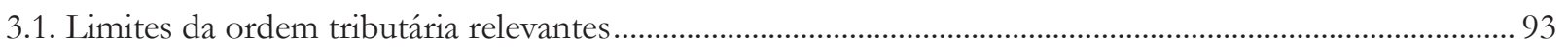

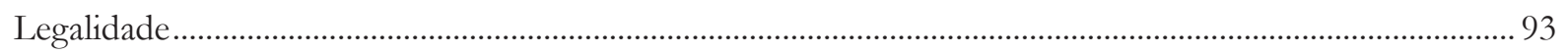

Competência tributária material, isonomia, universalidade e capacidade contributiva................................. 95

A aplicação dos limites objetivos absolutos da extrafiscalidade ao FAP ..........................................................97

3.2. Limites da ordem econômica e demais ramos relevantes ........................................................................ 99

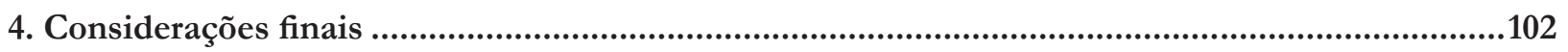

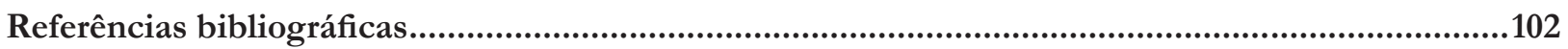

DESCONSTRUINDO A INEFICÁCIA DOS DIREITOS SOCIAIS: POR UMA RECONSTRUÇÃO DOS DIREITOS SOCIAIS DEMOCRÁTICA, PARTICIPATIVA E TRANSNACIONAL ......................................... 106

Daniela Lopes de Faria, Christian Norimitsu Ito e Inês Moreira da Costa

1. Introdução …..........................................................................................................................107

2. Análise crítica às teorias de construção dos Direitos Sociais.........................................................107

3. A crítica à perspectiva dogmática dos direitos sociais e a sua reconstrução ................................. 111

4. Teoria dos Custos, mínimo existencial e reserva do possível........................................................112

5. Proibição de proteção insuficiente e de retrocesso social .............................................................. 115

6. Dimensão objetiva dos direitos sociais ....................................................................................116

7. As garantias dos direitos sociais como instrumento para sua reconstrução democrática, participati- 
va e transnacional 117

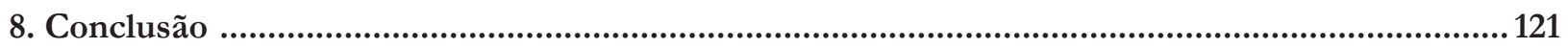

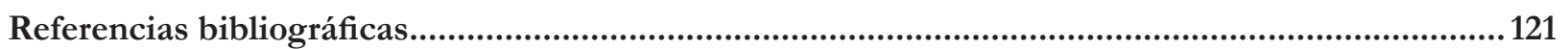

DiREITO PROCESSUAL DE GRUPOS SOCIAIS ATUAL: ENTRE O ATIVISMO JUDICIAL E O GARANTISMO PROCESSUAL ........................................................................................... 125

Jefferson Carús Guedes

1. Introdução. 126

2. Contornos velhos e novos de um binômio aparentemente inconciliável: a) socialismo e individualismo; b) autoritarismo e liberalismo c) publicismo e privatismo; d) ativismo (judicial) e garantismo (processual).........................................................................................................................127

2.1. O debate menos importante: Il Codice de Processo Civile Italiano de 1940 ............................................ 133

3. O debate estrangeiro e brasileiro atual: talvez o mais importante .................................................135

3.1. O que se pode denominar como ativismo (processual civil) e como garantismo processual civil atualmente...........139

4. A favor ou contra o garantismo? ou a favor da terceira via da cooperação e da democracia? .......139

4.1. Mas por que ser contrário a um garantismo processual universal? .............................................................. 140

4.2. E por que se dizer a favor do direito processual de grupos sociais em sociedades com desigualdades com-

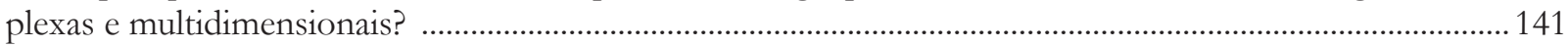

4.3. Escalas e tons de um direito processual de grupos sociais no Brasil, nestes tempos ............................. 143

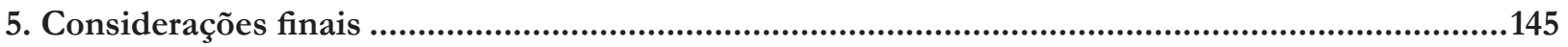

Referências bibliográficas................................................................................................................146

Políticas públicas, mínimo existencial e Poder Judiciário: A QUestão do direito À moRADIA ................................................................................................. 151

Diogo de Calasans Melo Andrade

1. As políticas públicas de moradia no Brasil...................................................................................152

2. Limites à intervenção do Poder Judiciário: o mínimo existencial, a reserva do possível e a separação

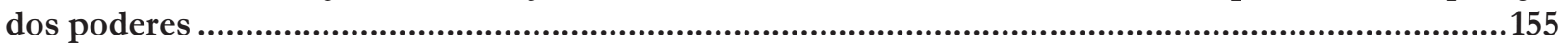

3. Possibilidade/necessidade da interferência do Poder Judiciário nas políticas públicas de moradia

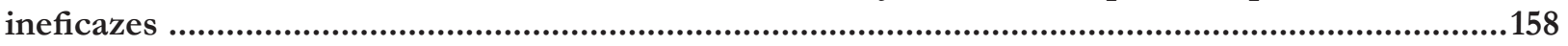

4. Considerações finais .................................................................................................................162

Referências bibliográficas..............................................................................................................162

BENEFíCIOS DE RENDA MÍNIMA COMO UM DIREITO FUNDAMENTAL: ACESSO À JUSTIÇA E INCLUSÃO

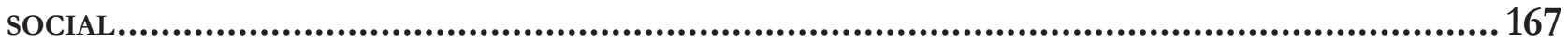

Pedro Bastos de Souza

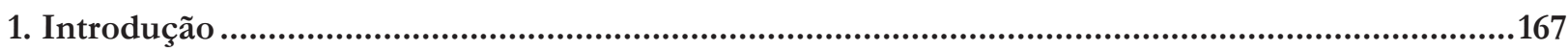

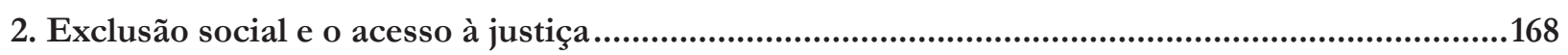

3. Políticas públicas de alívio à pobreza e direitos fundamentais....................................................170 
4. Direito à renda mínima: análise crítica da atuação do poder judiciário 174

5. Considerações Finais ........................................................................................................................ 181

Referências bibliográficas...................................................................................................................182

DESENVOLVIMENTO HUMANO SUSTENTÁVEL E ERRADICAÇÃo DA POBREZA EXTREMA: UMA ANÁLISE

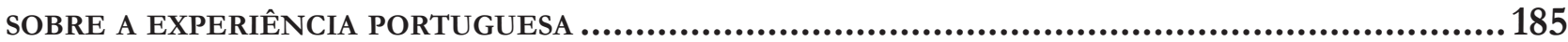

Veyzon Campos Muniz

1. Introdução

2. Interpretação Sistemática, Law \& Development .....................................................................187

3. Direito ao desenvolvimento e sustentabilidade social.............................................................189

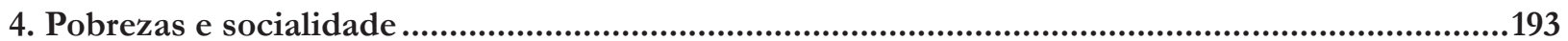

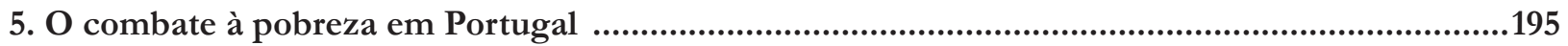

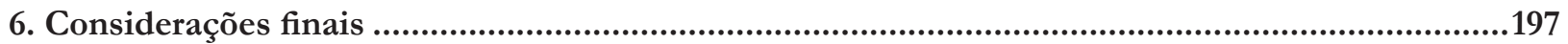

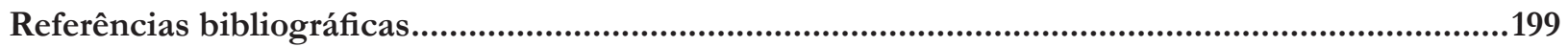

A AÇÃo POPUlaR AMBIENTAL COMO FORMA DE PARTICIPAÇÃo SOCIAL NA DEFESA DO MEIO AMBIENTE ....203 Luciano Marcos Paes e Paulo Roberto Polesso

1. Introdução

2. A participação popular na tutela do meio ambiente .............................................................. 204

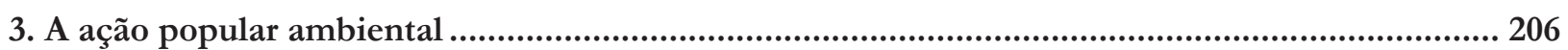

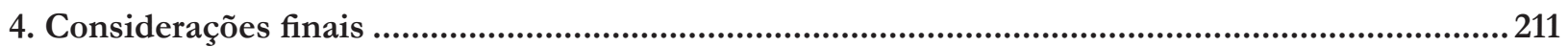

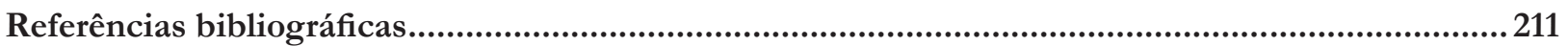

Direito PENAL AMbiental COMO TUTEla de SUSTENTAÇÃo À ATUAÇÃo ADMINiSTRATIVA E CIVIL Nos Estados Unidos da AMÉrica E no JapÃo........................................................... 214

Luiz Gustavo Gonçalves Ribeiro e Lorena Machado Rogedo Bastianetto

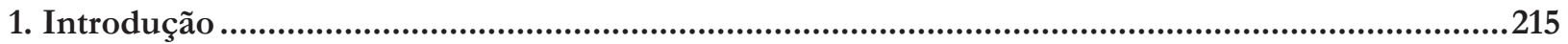

2. Tutela penal ambiental norte-americana.....................................................................................216

3. Proteção penas ambiental no Japão...................................................................................................221

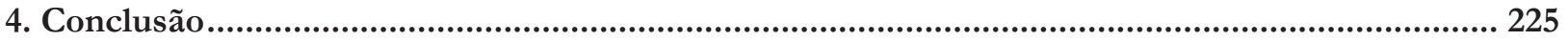

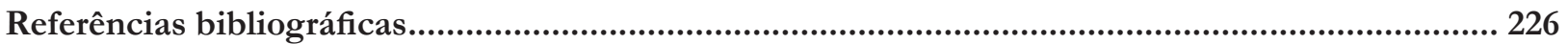

Construção Social do PROJETO POlOS DE PRODUÇÃo DE BIODIESEL NO CONTEXTO Do PNPB:

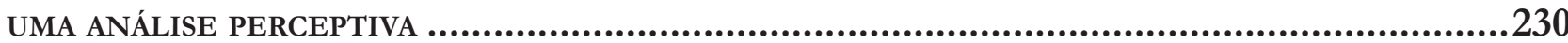

Érika Cristine Silva, Maria das Dores Saraiva de Loreto, Haudrey Germiniani Calvelli e Ronaldo Perez

1. Introdução

2. Metodologia 


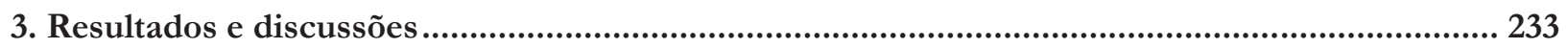

3.1 Criação e Construção do Programa Nacional de Produção e Uso de Biodiesel e do Projeto Polos de Biodiesel.....233

3.2. Processo de Inclusão Social dos Agricultores Familiares na Cadeia de Biodiesel..................................... 238

3.3. Processo de desarticulação do projeto Polos de Biodiesel ......................................................................... 240

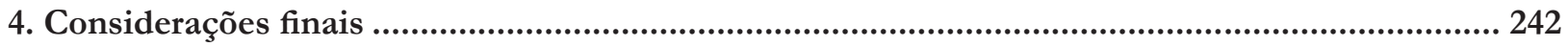

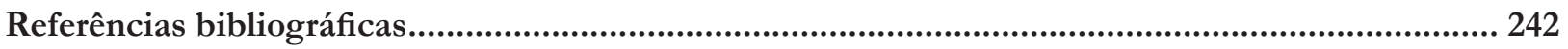

A correlação entre doenças respiratórias e o incremento das Queimadas em Alta Floresta e Peixoto de Azevedo, norte do Mato Grosso - Amazônia Legal ....................246 Lilian Rose Lemos Rocha e Christopher William Fagg

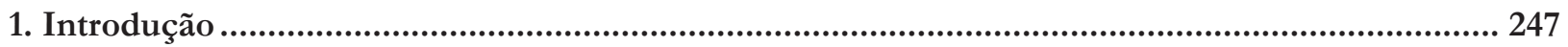

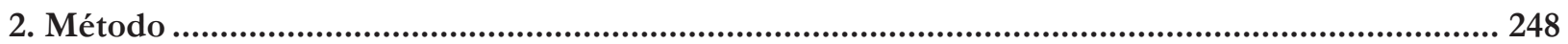

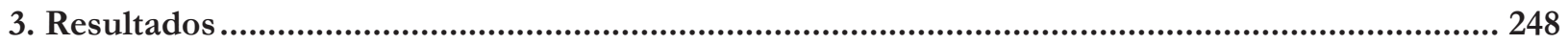

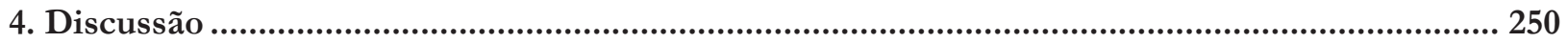

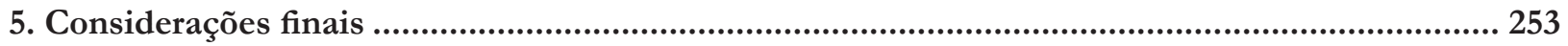

Referências bibliograficas................................................................................................................... 253

Políticas públicas, agricultura familiar e Cidadania no Brasil: o caso do PRONAF ...... 256 Edir Vilmar Henig e Irenilda Ângela dos Santos

1. Introdução

2. A agricultura familiar como sujeito de políticas públicas ......................................................... 258

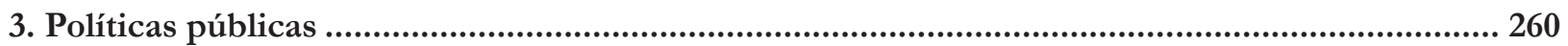

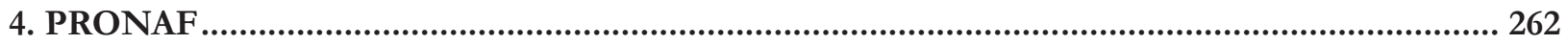

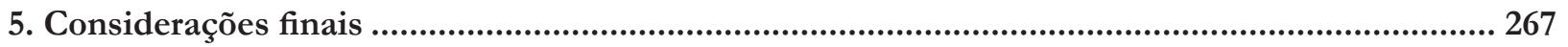

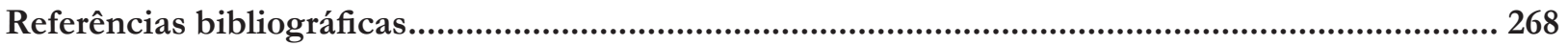

Ativismo judicial e Promoção da Cidadania: Desafios Para A EFETIVAÇÃo dos direitos SoCIAIS CONSTITUCIONALIZADOS ........................................................................ 271

Gerardo Clésio Maia Arruda, Adriana Rossas Bertolini e Jânio Pereira Cunha

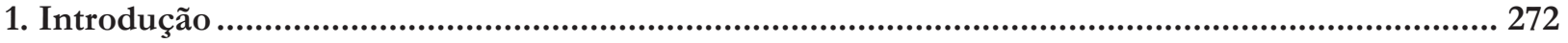

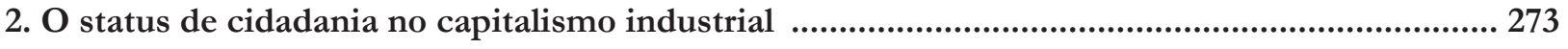

3. Modernização capitalista conservadora e a pobreza no Brasil ..................................................... 277

4. Ativismo judicial e os direitos sociais no Brasil ............................................................................ 284

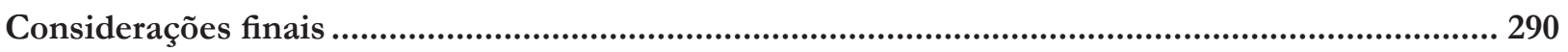

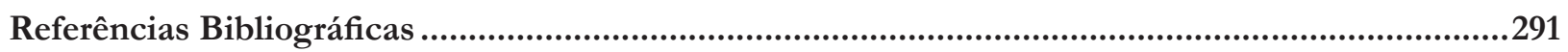

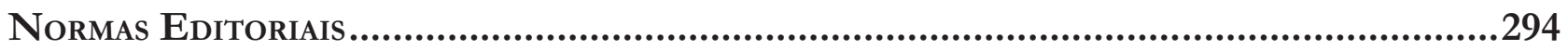

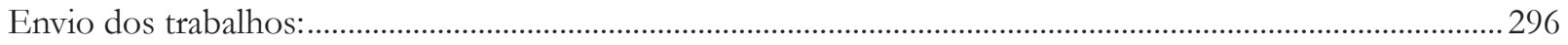


The President of the Republic impeachable offenses .14

Carlos Ayres Britto

REFLECTIONS ON THE FUTURE OF THE MODERN CONSTITUTIONAL STATE

Cesar Luiz Pasold, Gabriel Real Ferrer e Paulo Márcio Cruz

Public contracts and global market: an approach from the XXI Century administra-

TIVE LAW

Bruno Ariel Rezzoagli

ADMINISTRATIVE CONTRACTS: CONCEPT AND DISTINCTIVE CRITERIA

Carlos Bastide Horbach

The economic incentives for purchasing harvester combine via Pronaf-Mais alimenTOS FOR IRRIGATED RICE FARMERS IN Rio GRANDE DO SUL .70

João Mairton Moura de Araújo, Mário Conill Gomes e André Carraro

LiMITATIONS ON EXTRAFISCALITY FOR THE PREVENTION ACCIDENT FACTOR - FAP

Daniel de Magalhães Pimenta

DECONSTRUCTING THE INEFFECTIVENESS OF SOCIAL RIGHTS: FOR A TRANSNATIONAL, PARTICIPATORY, DEMOCRATIC RECONSTRUCTION OF SOCIAL RIGHTS 106

Daniela Lopes de Faria, Christian Norimitsu Ito e Inês Moreira da Costa

CURRENT PRoCEDURAL LAW OF SOCIAL GROUPS: BETWEEN JUDICIAL ACTIVISM AND THE PROCEDURAL SAFEGUARDS. 125

Jefferson Carús Guedes

Public policy, existential minimum and Judiciary: MatTer of the Right to housing. 151 Diogo de Calasans Melo Andrade 
Minimum INCOME BENEFITS AS A FUNDAMENTAL RIGHT: ACCESS TO JUSTICE AND SOCIAL INCLUSION

Pedro Bastos de Souza

SUSTAINABLE HUMAN DEVELOPMENT AND ERADICATION OF EXTREME POVERTY: AN ANALYSIS OF the Portuguese experience 185

Veyzon Campos Muniz

THE ENVIRONMENTAL SOCIAL ACTION AS A TOOL FOR SOCIAL PARTICIPATION IN THE DEFENSE OF THE ENVIRONMENT

Luciano Marcos Paes e Paulo Roberto Polesso

ENVIRONMENTAL CRIMINAL LAW AS THE KEYSTONE TO ADMINISTRATIVE AND CIVIL AUTHORITY IN THE UNited STATES ANd Japan

Luiz Gustavo Gonçalves Ribeiro e Lorena Machado Rogedo Bastianetto

SOCIAL CONSTRUCTION OF BIODIESEL PRODUCTION PROJECT IN THE CONTEXT OF POLES PNPB: AN ANALYSIS PERCEPTUAL.

Érika Cristine Silva, Maria das Dores Saraiva de Loreto, Haudrey Germiniani Calvelli e Ronaldo Perez

The Correlation between Respiratory diseases and the increase in fires in Alta Floresta and Peixoto de Azevedo northern Mato Grosso - Legal Amazon .................246 Lilian Rose Lemos Rocha e Christopher William Fagg

Public policies, family farming and citizenship in Brazil: the case of PRONAF .....256 Edir Vilmar Henig e Irenilda Ângela dos Santos

JUDICIAL ACTIVISM AND PROMOTING CITIZENSHIP: CHALLENGES FOR THE IMPLEMENTATION OF SOCIAL RIGHTS CONSTITUTIONAL 271

Gerardo Clésio Maia Arruda, Adriana Rossas Bertolini e Jânio Pereira Cunha 


\section{Empresa que financia campanha eleitoral comete abuso de poder econômico*}

\section{Company financing electoral campaign commits abuse of economic power}

\section{A PROIBIÇÃo QUe SE desata do PARÁGRAFO $9^{\circ}$ do arTIGo 14 da Constituição Federal}

1.1. Há proibição ao financiamento empresarial de eleição popular? Respondo afirmativamente. Proibição que penso decorrer mais diretamente do parágrafo $9^{\circ}$ do artigo 14 da Constituição, que de logo transcrevo e passo a paulatinamente comentar. Ei-lo:

parágrafo $9^{\circ}$. Lei complementar estabelecerá outros casos de inelegibilidade e os prazos de sua cessação, a fim de proteger a probidade administrativa, a moralidade para o exercício do mandato, considerada a vida pregressa do candidato, a normalidade e legitimidade das eleições contra a influência do poder econômico ou o abuso do exercício de função, cargo ou emprego na administração direta ou indireta.

1.2. Ora, ao dispor que lei complementar estabelecerá outros casos de inelegibilidade, o Magno Texto Federal está a convocar a lei da espécie complementar para ir além do que ele foi nesse mesmo tema: inelegibilidades. Está a requestar a lei da espécie complementar para ampliar o próprio rol constitucional de inelegibilidades. Ponto pacífico! Isso com o mesmo propósito de proteger bens jurídicos de logo explicitados: a probidade administrativa, a moralidade para o exercício do mandato (considerada a vida pregressa do candidato), a normalidade e legitimidade das eleições populares. Mas proteger de quê esses nominados bens jurídicos? Contra a influência do poder econômico, ou o abuso de função, cargo ou então emprego na Administração Pública Direta e Indireta.

\section{As dUAS PARELHAS DE BENS JURídicos OBJETO DE EXPLÍCITA PROTEÇÃO CONSTITUCIONAL}

Deveras, o que centralmente se desata do dispositivo transcrito é a norma de que à lei complementar ali requestada incumbe proteger duas parelhas de valores ou bens jurídicos. A primeira delas, consubstanciada na probidade administrativa e na moralidade para o exercício do mandato (sempre considerada a vida pregressa do candidato, remarque-se). A segunda parelha, residente na normalidade e legitimidade das eleições. Mas normalidade e legitimidade do pleito contra dois explícitos fatores de perturbação: a influência do poder econômico e o abuso do exercício de cargo, função, ou emprego públicos. Dois fatores de perturbação já 
reconhecidos como tais pela própria Constituição. Noutro dizer, o enunciado normativo-constitucional em foco requisita a mediação de lei complementar federal para estabelecer duas modalidades de vínculos operacionais:

I - o vínculo entre novas hipóteses de inelegibilidade e a necessidade de reforço protecional: a) da probidade administrativa; b) da moralidade para o exercício do mandato, sempre considerada a vida pregressa do candidato;

II - o vínculo entre essas novas hipóteses de inelegibilidade e a mesma necessidade de reforço protetivo de mais dois valores ou bens jurídicos: a normalidade e a legitimidade das eleições. Mas a proteção da normalidade e legitimidade das eleições contra o quê, torno a perguntar. Resposta: contra a influência do poder econômico e o abuso do exercício de cargo, ou função, ou emprego, todos de natureza pública.

\section{A INFLUÊNCIA DO PODER ECONÔMICO E O ABUSO do EXERCíCIO DE CARGO, OU FUNÇÃO, OU EMPREGO ESTATAL COMO FATORES CONSTITUCIONALMENTE ROTULADOS DE PERTURBAÇÃO DO PROCESSO ELEITORAL}

3.1. É a segunda parelha de bens jurídicos a proteger que me leva a escrever o presente artigo. Parelha que não é senão a consagração desta ideia-força: as eleições populares hão de transcorrer em ambiência de normalidade e legitimidade quanto à formação da vontade eleitoral dos cidadãos. Ambiência ou atmosfera ou condições de normalidade e legitimidade que resultarão perturbadas, por definição, se houver influência do poder econômico e/ou abuso do exercício de função, cargo ou emprego públicos no processo eleitoral em si.

3.2. Convém repetir, em necessária homenagem aos dizeres da Constituição. Em necessária reverência à intencional compostura semântica da Magna Lei do Estado brasileiro. O que estou a revelar como vontade objetiva do parágrafo $9^{\circ}$ do artigo constitucional de $n^{\circ} 14$ é, quanto ao poder econômico, a proibição de sua "influência". Já no que toca ao exercício de "função, cargo ou emprego" públicos, o que vedou o dispositivo constitucional foi o "abuso". Não o uso. Não a influência. Qual a diferença?

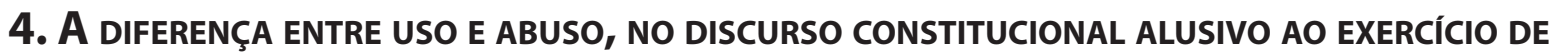 CARGO, OU FUNÇÃO, OU EMPREGO, TODOS DE NATUREZA PÚBLICA}

Explico. O uso, ali no sítio escriturário da Constituição, traduz-se no normal desempenho ou no regular exercício de função, ou cargo, ou emprego públicos. Isso porque certos agentes estatais não têm que se inativar em período de eleição. Mais até, parte desses agentes públicos tanto pode se candidatar (sem necessidade de desincompatilização) quanto oficiar em nome da própria Justiça Eleitoral. Já o abuso, reversamente, significa um proceder transbordante do normal ou regular desempenho de função, ou cargo, ou emprego públicos. Equivale a dizer: o abuso significa um tipo juridicamente inválido de intromissão no circuito das eleições populares, porque interferente na livre e consciente vontade do eleitor. Um fažer a cabeça desse ou daquele eleitor, ou por qualquer modo induzi-lo a votar em candidato do agrado do servidor já em estado de transbordamento dos seus misteres públicos. Ou então constranger o eleitor a votar no próprio agente público, se este encontrar-se, obviamente, em concreta situação de candidato a cargo de provimento eletivo. Em suma, o uso é permitido, o abuso é proibido. 


\section{A identidade ENTRE USO E INFLUÊNCIA, NO DISCURSO CONSTITUCIONAL ALUSIVO AO PODER ECONÔMICO}

Quanto ao substantivo "influência”, especificamente referido ao poder econômico, a minha interpretação é de que a Constituição dele se utilizou com o sentido de simples ação, participação, presença. No sentido de uso, por conseguinte. Não de preponderância ou de saliente protagonismo; não exatamente de abuso, pena de a Constituição incidir em ingênua redundância, pra não dizer em pueril ingenuidade. Se se prefere entender, a Constituição não fez explicito emprego do substantivo "abuso", nessa passagem do seu vocabulário, pois o que ela quis proibir foi a simples intervenção do poder econômico no processo eleitoral. $\mathrm{O}$ uso dele. $\mathrm{O}$ mero tomar parte ou se fazer presente nesse processo, pois não há como o poder econômico, enquanto poder econômico mesmo, participar do pleito sem dar as cartas ou pôr as mangas de fora. Sem comandar factualmente as coisas. Sem dobrar à sua força pecuniária ou fazer vergar ao seu peso patrimonial-financeiro-corporativo a espinha dorsal da vontade do eleitor. É da sua natureza, em tema de eleições. Ele, poder econômico, enquanto aparato de classe e de dinheiro não tem como se apartar de si mesmo. Da sua consubstancial supremacia em tema de competição eleitoral. Supremacia em face do eleitor comum, supremacia em face de candidato não-economicamente corporativo. Donde o saque dos dois diferentes vocábulos constitucionais ("influência" e "abuso"), queé de se presumir intencional. Que é de se supor de caso pensado ou plenamente assumido no discurso constitucional-brasileiro, na medida em que:

I - entre o uso e o abuso não há meio-termo. Inexiste gradação semântica. Ou tanto o fazer quanto o agir humano se dão nos marcos da permissão jurídico-positiva, correspondendo então à noção de uso (redundantemente chamado de normal ou regular ou legítimo), ou passam a resvalar para a zona transbordante de tal permissão. O que tipifica um tipo de excesso que vai corresponder à noção de abuso. Não há entre os dois termos antagônicos, insista-se, o tertium genus da palavra "influência". Como se influência nem significasse uso nem abuso, juridicamente falando. Como se fosse possível o poder econômico participar do processo eleitoral em igualdade de condições com quem não o detém. Ombreando-se aos que se veem privados dele. O que deixaria à mingua de significado o próprio substantivo "poder": aptidão para instaurar verticalizadas relações de mando. Capacidade ou estrutura de mando, domínio, comando. Encarnação da autoridade, embora não-formalmente estatal. A face visível de quem protagoniza, por cima, relações de hierarquia. Razão de ser do ditado popular de que "manda quem pode, obedece quem tem juízo". O poder como causa do mandar, o mandar como efeito do poder, o obedecer como postura natural de quem se põe como destinatário do que não tem: o poder de mando. Realidade que se faz absolutamente incompatível com a ideia de voto livre e consciente do eleitor. Com o mais elementar conceito de voto direto e secreto como expressão de que? Da "soberania popular", nos termos do artigo 14 da Constituição. Não do império em que se traduz o concreto uso do aparato econômico nessa ou naquela circunscrição eleitoral; II - quando quis sacar do vocábulo "abuso", mesmo referido ao poder econômico, a Constituição não se fez de rogada: disse-o com todas as letras. Basta ver o parágrafo 10 do mesmo artigo 14, assim redigido: "o mandato eletivo poderá ser impugnado ante à Justiça Eleitoral no prazo de quinze dias contados da diplomação, instruída a ação com provas de abuso do poder econômico, corrupção ou fraude". Como basta ver o parágrafo $4^{\circ}$ do artigo 173 , sob a seguinte roupagem vocabular: "A lei reprimirá o abuso do poder econômico que vise à dominação dos mercados, à eliminação da concorrência e ao aumento arbitrário dos lucros". Mas esse explícito fraseado ("abuso do poder econômico") a serviço de uma peculiar racionalidade constitucional de que passarei a dar conta um pouco mais à frente. 


\section{A distinção entre O USO E O ABUSO do PODER ECONÔMICO NO PARÁGRAFO 10 dO ARTIGO 14 da CONSTITUIÇão. O PODER ECONÔMICO ENQUANTO PODER EMPRESARIAL E VICE-VERSA}

Com efeito, as coisas se encaixam em congruente unidade. No parágrafo $9^{\circ}$ do seu artigo 14 , a Constituição vedou o uso, a simples participação do poder econômico no processo eleitoral enquanto conjunto de atos e fatos em que transcorrem disputas pessoais e partidárias de cargos públicos de provimento eletivo-popular. Cargos de natureza parlamentar, cargos de chefia do Poder Executivo. Categoria jurídica essa, a do "poder econômico", logicamente associada ao significado de poder empresarial. Como expressão mesma da "livre iniciativa" ou centrado lócus de movimentação das pessoas vocacionadas para os misteres da produção de riqueza material com o objetivo de lucro. Que são os empresários do setor privado. Empresários do setor privado da Economia ou classe empresarial, expressão acabada do poder de organizar os fatores da produção (natureza, capital, trabalho, tecnologia...) para o encarecido fim de lucratividade. Por consequência, classe empresarial enquanto consubstanciação do poder econômico, pois não há como separar as duas categorias jurídicas: poder econômico e classe empresarial. Falar de uma é falar da outra, porque, no rigor dos termos, sequer existe a outra. Tudo é uma coisa só. A classe empresarial como detentora do poder econômico, o poder econômico transfundido ou encarnado na classe empresarial. Mais: o poder econômico a simbolizar a "livre iniciativa", tanto quanto a livre iniciativa a ter por titular a classe dos empresários; ou seja, a classe dos que empresariam os misteres econômicos ou fatores da produção. Classe empresarial, enfim, que atua ou se faz presente por modo usual na ordem econômica (esse o espaço de sua natural e insubstituível movimentação), sendo-lhe vedado apenas incorrer num tipo de "abuso" que venha a caracterizar: "dominação dos mercados", "eliminação da concorrência", “aumento arbitrário dos lucros". Tudo de acordo com o parágrafo $4^{\circ}$ do artigo 173 da Magna Carta, precedido destes emblemáticos dispositivos:

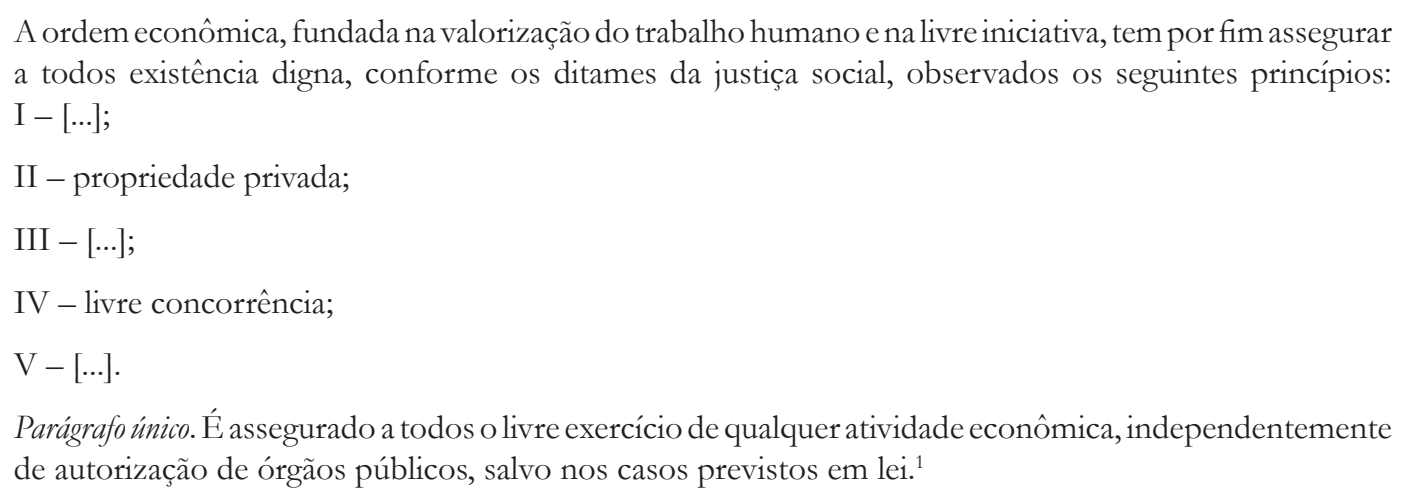

\section{O SENTIDO ATÍPICO DA PROTAGONIZAÇÃO ESTATAL DE ATIVIDADE ECONÔMICA E A RIGOROSA DESIDENTIDADE JURÍDICA ENTRE OS DOIS PODERES: O POLÍTICO E O ECONÔMICO}

7.1. Claro que não se está a ignorar que o Estado também protagoniza atividades econômicas. Ele tem suas empresas públicas, sociedades de economia mista e respectivas subsidiárias, nos termos dos incisos XIX e XX do artigo 37 da Constituição. Ainda ainda assim, o que se tem é o Estado como setor público mesmo, com a diferença de que se põe a intervir diretamente na atividade econômica do País. Intervenção atípica ou a título de exceção, conforme estabelecido pela cabeça do artigo 173 dela própria, Constituição Federal ("Ressalvados os casos previstos nesta Constituição, a exploração direta de atividade econômica pelo Estado

1 BRASIL. Constituição (1988). Constituição da Republica Federativa do Brasil. Disponível em: < http://www.planalto.gov.br/ccivil_03/constituicao/ConstituicaoCompilado.htm>. Acesso em: 11 dez. 2015. 
só será permitida quando necessária aos imperativos de segurança nacional ou a relevante interesse coletivo, conforme definidos em lei"). Por isso que não se pode identificar juridicamente o Estado com o setor privado da Economia. Com a classe empresarial. Com o poder econômico. Ele é sempre e sempre o nervo e a carne da esfera política, tanto quanto a classe empresarial é a carne e o nervo da esfera econômica. O horizonte político a preponderar todo o tempo sobre o horizonte econômico da atuação estatal, pois essa atuação paralela, "Ressalvados os casos previstos" na própria Constituição, "só será permitida quando necessária aos imperativos da segurança nacional ou a relevante interesse coletivo, conforme definidos em lei”, reitere-se o juízo.

7.2. Daqui se deduz que o típico do Estado em face da Economia é mesmo sua atuação como "agente normativo e regulador", em cujo âmbito "exercerá, na forma da lei, as funções de fiscalização, incentivo e planejamento, sendo este determinante para o setor público e indicativo para o setor privado" (cabeça do artigo 174). Com o que se empenhará para que o mercado interno sempre se coloque a serviço de um desenvolvimento que passe pelo desenvolvimento do setor econômico brasileiro, sem dúvida, porém a se constituir em objetivo permanente de todo o País. "Objetivo Nacional Permanente", na direta linguagem da Constituição (inciso II do artigo $3^{\circ}$ ). Por isso que a própria flexibilização operacional-estatutária das empresas governamentais (parágrafo $1^{\circ}$ do artigo 73), embora signifique a possibilidade de o Estado-empresário operar com maior competitividade perante os atores econômicos privados, não pode se desgarrar jamais da sobredita preponderância de interesses e valores já situados na esfera mais abrangente da polis. Ainda que o Poder Público esteja a desfrutar do monopólio de certas atividades produtivas, como se dá em relação ao "petróleo e gás natural e outros hidrocarbonetos fluidos", ao lado de "minérios e minerais nucleares e seus derivados", a teor do artigo constitucional de n $n^{\circ} 177$. E porque assim é, nas empresas estatais o lucro será sempre um meio, e não um fim em si mesmo, porque fim em si mesmo é o respectivo objeto social ou ramo de atividade. Mais exatamente, o objeto social ou ramo de atividade de qualquer empresa estatal é que se põe como fim em si mesmo, porém no plano da imediatidade. Porque no plano da mediatidade, aí, sim, os fins que preponderam são aqueles encartados na esfera definidora do próprio Estado: a esfera essencialmente política. A esfera que os antigos gregos chamavam de polis e que até hoje se define como espaço das relações jurídicas primárias dos governados com os governantes e destes entre si.

7.3. Numa frase, mesmo que a esfera política venha a influenciar o processo eleitoral pelo emprego do vil metal, essa influência é de ser interpretada, juridicamente, como abuso do exercício de cargo, função ou emprego públicos. Não como abuso de poder propriamente econômico. É a fundamental diferença entre os mundos do dever-ser do Direito e do ser da realidade factual, a que voltarei no curso desta intelecção do texto e do contexto da Constituição.

\section{A CONCILIAÇÃo INTERPRETATIVA POSSÍVEl ENTRE OS $9^{\circ}$ E 10 do ARTIGo 14 dA Constituição}

8.1. Retorno à descrição dos parágrafo $9^{\circ}$ e 10 do Artigo 14 da Constituição. O primeiro deles, veiculador de proibição do uso do poder econômico no processo eleitoral, debaixo da presunção absoluta (jure et de jure, portanto) de que tal uso corresponde, na prática, a abuso. Mas não ficou nisso o Magno Texto Federal. Resolveu trabalhar com a hipótese de sua violação em matéria tão umbilicalmente ligada a excelsos princípios constitucionais, como o da moralidade administrativa, o da correlação de forças entre os candidatos, o da soberania popular e o da autenticidade do regime representativo. É a matéria que se lê, com toda imediatidade, no transcrito parágrafo 10 do mesmo artigo 14. Isso para falar do ajuizamento da ação de impugnação de mandato obtido com "abuso" do poder econômico, além de "corrupção", ou "fraude". Donde a seguinte e pertinente indagação: por que "abuso", aqui no parágrafo 10 ? 
8.2. Minha particular resposta: porque o parágrafo $9^{\circ}$ já deixara claro que o simples uso de tal poder (o de compleição econômica), pela sua natureza de sempre implicar abuso, estava pré-excluído do processo eleitoral. Como até hoje está no plano do dever-ser em que o Direito consiste. Pelo que fazer uso eleitoral do poder econômico, no plano do ser - que é o mundo das realidades empíricas ou factuais - vai implicar automático abuso no plano do dever-ser. Dever-ser que é o mundo das normas jurídicas gerais, impessoais e abstratas. Cotejo entre o mundo dos fatos e o mundo das normas que bem explica a razão do comparecimento do vocábulo "abuso" no sítio vernacular desse dispositivo constitucional que não é senão o multicitado parágrafo 10 do artigo 14.

\section{O PORQUÊ DA REFERÊNCIA CONSTITUCIONAL A ABUSO dO PODER ECONÔMICO, NO PARÁGRAFO $4^{\circ}$ do ARTIGO 173 da CONSTItUIÇÃo}

Neste passo da caminhada normativa da Constituição, já externei a minha interpretação de que as atividades econômicas são o habitat dos empresários. Dos empreendedores mercantis em sentido lato. O espaço natural do uso da sua vocação produtivo-negocial de que tanto se faz dependente o desenvolvimento nacional. Nada lhes sendo proibido, como regra geral, quanto a esse uso. O que lhes é vedado já se passa no campo do abuso, consoante o dispositivo constitucional há pouco transcrito (o parágrafo $4^{\circ}$ do artigo 173). Bem diferente do que sucede no campo eleitoral-popular, em que eles, empresários, não concorrem entre si para qualificação dos misteres da produção. Para legitimamente buscar superavits de eficiência e ganhos de produtividade. Não! Nos domínios da disputa eleitoral-popular eles Concorrem é com outros pretendentes à representação política da população, se candidatos forem. O que não lhes é proibido, mas desde que se dispam do seu poder medularmente econômico. Apeamento de poder que também se impõe em tema de financiamento de candidaturas alheias, pois, tanto numa quanto noutra suposição, a presença de tal formato de atuação só pode traduzir um elemento de conturbação nos dois explícitos valores de natureza constitucional: a normalidade e a legitimidade das eleições.

\section{A DIFERENÇA JURÍdicA ENTRE PARTICIPAR COMO CIDADÃo E PARTICIPAR COMO EMPRESÁRIO EM TEMA DE ELEIÇÃO POPULAR}

O entendimento do regime constitucional da matéria passa, percebe-se, pela diferença entre participar como cidadão e participar como empresário em tema de eleição popular. O cidadão não deixa de ser cidadão por se tornar empresário. Prossegue com sua particular maneira de conceber e praticar a vida pública, inclusive na perspectiva da prevalência de um regime jurídico favorecedor da vocação e dos modos de agir de quem é agente econômico. Pelo que, mesmo desse ângulo peculiarmente classista, desfruta de todo o direito de votar, de eventualmente candidatar-se a cargo eletivo (preenchidas as devidas condições jurídicas de elegibilidade) e de participar pró-ativamente de cada pleito. O que não quer a Constituição é que ele o faça enquanto empresário mesmo, porque, aí, já o fará com todo o aparato de poder que é próprio da sua empresa e até mesmo da sua classe. Da sua estrutura de dominação ou de desequilibradora influência material. Do capital enquanto polo contraposto ao do trabalho, ao do consumidor, ao do cidadão comum. Apartando-se de todos esses polos contrapostos pelo plus do seu poderio empresarial e aparato corporativo de influência quase sempre decisiva no resultado da disputa eleitoral. Entendida como influência econômica, portanto, a açãoque transporte o cidadão para os domínios do capital enquanto signo de força corporativo-produtivo-patrimonial-pecuniária. Força elementarmente favorecida e por isso mesmo fortemente propensa à rendição do corpo de eleitores da circunscrição sobre a qual venha a infletir. 


\section{DECIDIDO COMBATE CONSTITUCIONAL AO MAIS TEMERÁRIO DOS EMPARCEIRAMENTOS ELEITORAIS: O DO PODER POLÍTICO E O DO PODER ECONÔMICO}

11.1. Bem, estanco por aqui a presente empreitada intelectual-jurídica ${ }^{2}$ Fazendo-o, reafirmo que a lógica perpassante dos parágrafos $9^{\circ}$ e 10 do artigo 14 da Constituição me parece retratada no seguinte juízo: tolerar o financiamento empresarial de campanha eleitoral é favorecer o próprio somatório do poder econômico e do poder político. É facilitar a formação da parceria que mais historicamente degrada a representação política, nos marcos de uma democracia que se pretenda autêntica: a parceria do poder político e do poder econômico. Parceria, na matéria, mais afeita a todo tipo de voluntarismo, ambição, fraude, cooptação, violência física e psicológica, corrupção e práticas do gênero. A mais reveladora de que nesse mundo da representação política e dos negócios em promíscua atuação eleitoral é preciso livrar ambas as esferas de si mesmas. Das tentações a que não têm como resistir, na linha do queironicamente dizia Epicuro (341/271 a.C.): "Quando a tentação chegar, ceda logo antes que ela vá embora”. Daí que toda cautela jurídica seja pouca. Todarédea curta se faça interpretativamente necessária. Pena de se viabilizar a adoção de mecanismos que, na prática, serão o modo mais eficaz de tornar a Constituição ineficaz.

11.2. Em síntese, tenho como normativamente fundamentada a interpretação de que a Constituição de 1988 optou por um discurso pari passu com as mais alentadoras expectativas democráticas daquela quadra histórica de transição de um regime autoritário de governo para um regime libertário. Que se pegue pela palavra, então, o editor normativo que se autoqualificou como Assembleia Nacional Constituinte. Afinal, uma vez escrito, o texto jurídico-positivo mais e mais se autonomiza da mão que o escreveu. No caso da redação dos parágrafos $9^{\circ}$ e 10 do artigo 14 da Constituição, parece-me argumentativamente sólido neles enxergar um tipo de estrutura normativa:

I - de radical proibição de conluio entre o poder político e o poder econômico;

II - igualmente proibitiva da influência do poder econômico no processo eleitoral, ainda que por modo desemparceirado com a esfera política. Entendida como influência econômica a ação que transporte o indivíduo-cidadão para os domínios do indivíduo-empresário. Do indivíduo-capitalista. Do indivíduo a sacar por conta do aparato empresarial-corporativo e patrimonial-financeiro em que eventualmente inserido;

III - vedatória de qualquer forma de abuso do exercício de cargo, função, ou emprego públicos. As três modalidades de interdição a implicar o definitivo reconhecimento de que a Constituição dispôs no sentido de livrar o processo eleitoral-popular de quem mais historicamente incorre em toda gama de disfunção: o titular do poder político e o detentor do poder econômico. Pré-excluindo este último e contrapondo-se radicalmente à atuação abusiva do primeiro.

\section{REFERÊNCIAS BIBLIOGRÁFICAS}

BRASIL. Constituição (1988). Constituição da República Federativa do Brasil. Disponível em: <http:/ /www.planalto.gov.br/ccivil_03/constituicao/ConstituicaoCompilado.htm>. Acesso em: 11 dez. 2015.

BRASIL. Lei Complementar no 64, de 18 de maio de 1990. Disponível em: <http://www.planalto.gov.br/ccivil_03/leis/lcp/lcp64.htm>. Acesso em: 11 dez. 2015.

2 Em cuja base de inspiração coloco as mais instigantes provocações de Eduardo Mendonça e Ademar Borges, ambos admiravelmente afeitos a detidas reflexões sobre o Direito em geral e o Direito Constitucional brasileiro em especial. 


\section{REVISTA BRASILEIRA DE POLÍTICAS PÚBLICAS BRAZILIAN JOURNAL OF PUBLIC POLICY}

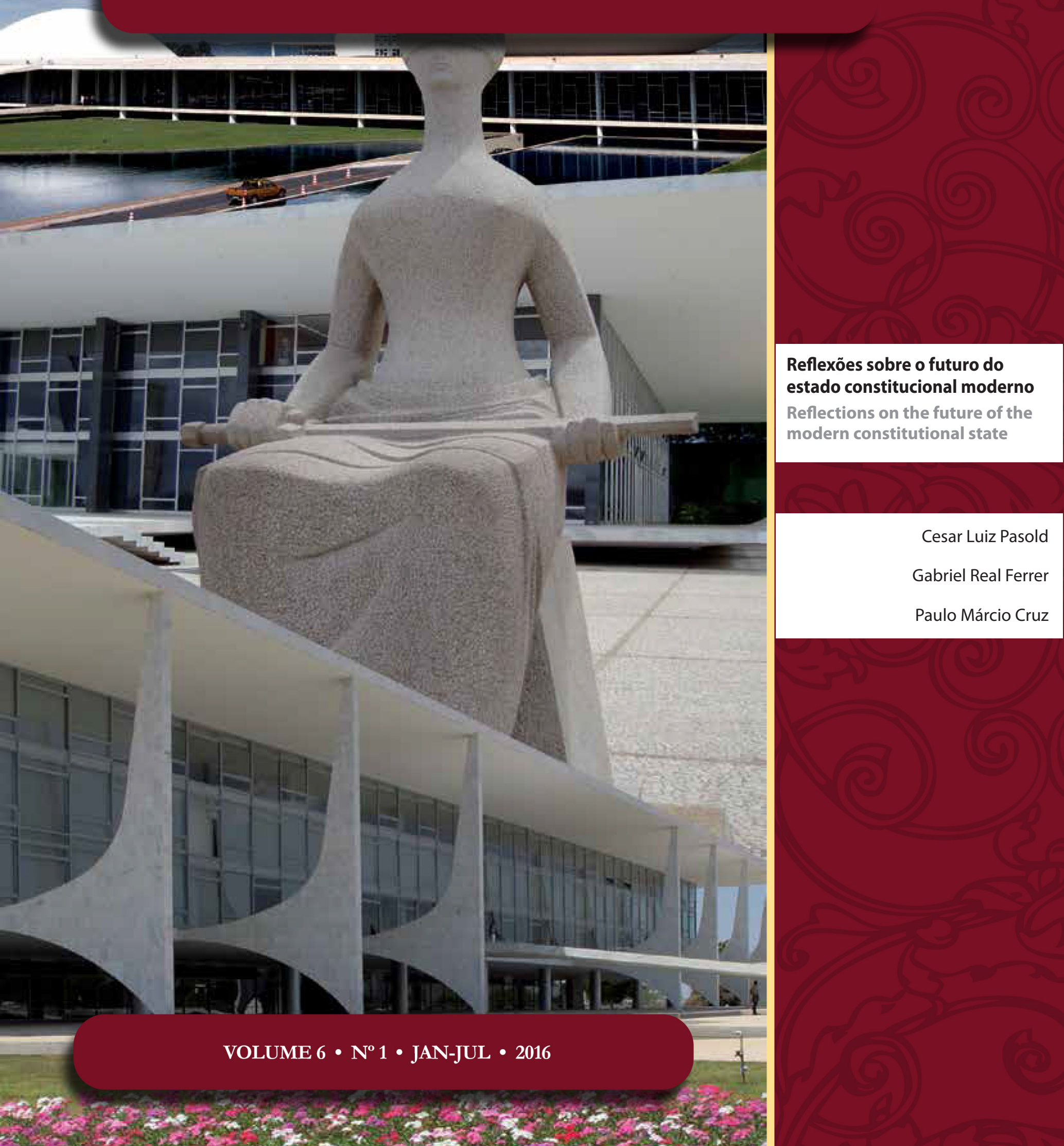




\title{
Reflexões sobre o futuro do estado constitucional moderno*
}

\section{Reflections on the future of the modern constitutional state}

\author{
Cesar Luiz Pasold ${ }^{* *}$ \\ Gabriel Real Ferrer*** \\ Paulo Márcio Cruz ${ }^{* * * *}$
}

* Recebido em 15/02/2016

Aprovado em 01/05/2016

** Doutor em Direito do Estado pela Faculdade de Direito do Largo São Francisco (USP); Pós Doutor em Direito das Relações Sociais pela Universidade Federal do Paraná (UFPR); Mestre em Instituições Jurídico-Políticas pela Universidade Federal de Santa Catarina (UFSC); Mestre em Saúde Pública pela Faculdade de Saúde Pública da Universidade de São Paulo (USP); Graduado em Direito pela UFSC. Docente daUniversidade do Vale do Itajaí (UNIVALI).E-mail: clp@cesarluizpasold.com.br

*** Doutor Honoris Causa pela Universidade do Vale do Itajaí (UNIVALI). Doutor em Direito pela Universidade de Alicante (1992). Professor Titular de Direito Ambiental e Administrativo e Subdiretor do Instituto Universitário da Água e do Meio Ambiente na mesma Universidade. Consultor do Programa das Nações Unidas (ONU) para o Meio Ambiente (PNUMA). E-mail: gabriel.real@ua.es

**** Realizou Estágios de Pós-Doutorado nas Universidades de Perugia (Itália) e Alicante (Espanha), Com bolsa da CAPES. Doutor (1999) e Mestre (1995) em Direito pela UFSC, Especialista em Administração pela UDESC (1987) e graduado em Direito pela UNIVALI (1984). É coordenador dos Cursos de Doutorado e de Mestrado em Ciência Jurídica da UNIVALI.E-mail: pcruz@univali.br

\section{SUMÁRIO}

Introdução. 1. A refundação democrática da "Coisa Pública". 2. A crise e as mudanças. 3. Uma nova forma de organização política. 4. A superação do Estado Constitucional. 5. Um novo sistema político global e a importância nodal da Democracia. Considerações finais. Referências.

\section{Resumo}

Este texto apresenta reflexões sobre o Estado Constitucional Moderno, seu presente e o futuro na Sociedade contemporânea, com o intuito de estimular os leitores a reflexões criticamente responsáveis e voltadas à predição mais do que à previsão, ou seja, focadas, predominantemente, na sequência em função de propostas de tendências e não de especulações.

Palavras-chave: Estado Constitucional Moderno. Refundação democrática da "Coisa Pública". Soberania. Globalização. Transnacionalidade.

\section{Abstract}

This text presents reflections on the Modern Constitutional State, its present and the future of the Contemporary Society, stimulating the readers to responsible reflections more related to prediction than prevision, in other words, mainly focused on trends proposals and not speculations. 
Keywords: Modern Constitutional State. Sovereignty. Democratic "refoundation" of the "Public Affairs". Globalization. Transnationality.

\section{INTRODUÇÃo}

O objetivo central do presente artigo é estimular reflexões, consideradas multidisciplinarmente, sobre o Estado Constitucional Moderno como ente que está sendo superado por forças que ele não consegue disciplinar. O objeto é o estudo do Estado com ou sem expressão adjetiva que lhe seja posposta, na busca de alternativa(s) de organização política que finalmente tenha(m) efetivo compromisso, no discurso e na prática, com a efetivação do interesse público, e, pois, sua predominância eficaz sobre interesses particulares de indivíduos ou de segmentos privilegiados na vida social, econômica e/ou política.

Quanto à temática nuclear do presente artigo, importante iniciar ponderando que Jacques Maritain, em seu El Hombre y el Estado ${ }^{1}$, e Dalmo Dallari, em seu O Futuro do Estado ${ }^{2}$, são bons exemplos dos esforços iniciais para as discussões sobre o que acontecerá com o Estado Constitucional Moderno, que ambos denominaram, cada um a seu modo e em sua época, de herdeiro dos Reis de antigamente e que se autoconcebeu como uma pessoa superior ao corpo político, que ele dominaria de cima ou o absorve - o corpo político - em si mesmo. Mas, como de fato o Estado não é uma pessoa, mas sim uma construção teórica impessoal de leis abstratas e de poder concreto, é essa construção teórica impessoal que se torna uma das mais acabadas proposições do racionalismo moderno quando se trata de Soberania. Atualmente, a Soberania é uma ideia peculiarmente ultrapassada, o que já está bastante discutido pela doutrina contemporânea ${ }^{3}$, pois é impossível, nos tempos atuais, que desenvolva sua potencialidade originalmente prevista. E, assim, o é mercê principalmente da incapacidade que este Estado cultiva quanto a respostas adequadas e céleres às demandas de uma Sociedade Pós-moderna sempre e cada vez mais surpreendente em sua dinâmica.

Não se deve esquecer que a tendência ao domínio supremo e à suprema amoralidade, que se desenvolveu plenamente e encontrou sua plena expressão no Estado Constitucional Moderno, não é inerente ao Estado em sua natureza real e em suas verdadeiras e necessárias funções. Resulta, isso, de uma noção pervertida e parasita do Estado Constitucional Moderno ${ }^{4}$. O Estado já não estaria, como de fato ocorreu e ocorre, a serviço dos homens, mas sim os homens a serviço do Estado. Em um primeiro estágio, o Estado se compõe como uma "macromáquina" partindo no segundo estágio para o exercício da tutela da Sociedade. ${ }^{5}$

Basta que pensemos um pouco sobre que sentido há no fato de a sociedade - que deveria ser a beneficiária dos serviços estatais - apenas desempenhar o papel de provedora do Estado, para saciar sua autofagia e sustentar sua inépcia em exercer uma função social efetiva.

É recuperar a lógica complexa para entender os sistemas abertos, nos quais o paradoxo será incluído, usando-se lógicas tão antigas como a taoísta ou tão modernas como Gödell, Morin o Ibañez ${ }^{6}$. A lógica aristotélica já não é suficiente. Para passar de uns conjuntos de ação para outros, é preciso ter em conta os contextos sociais, sobretudo as condutas de cada coletivo nesses contextos.

Criados os grupos, sem nenhuma conotação étnica, o passo subsequente será a execução de uma política de alinhamento não mais de países, mas de grupos, até a economia mundial assumir, de vez, a planetarização e as fronteiras desaparecerem como uma recordação nefasta que impedia a solidariedade universal, a comunhão dos povos em prol de um desenvolvimento comum. ${ }^{7}$

1 MARITAIN, Jacques. El hombre y el Estado. Madrid: Ediciones Encuentro, 1983.

2 DALLARI, Dalmo de Abreu. O futuro do Estado. São Paulo: Saraiva, 2001.

3 Sobre isso ver, por exemplo: STELZER, Joana; CRUZ, Paulo Márcio. Direito e transnacionalidade. Curitiba: Juruá. 2009.

MARITAIN, Jacques. El hombre y el Estado. Madrid: Ediciones Encuentro, 1983, p.213.

PASOLD, Cesar Luiz. Função social do estado contemporâneo. 4 ed. rev. amp. Itajai: UNVALI, 2013. p. 36.

DALLARI, Dalmo de Abreu. O futuro do Estado. São Paulo: Saraiva, 2001. p. 71.

CRUZ, Paulo Márcio; OLIVIERO, Maurizio. Reflexões sobre a crise financeira internacional e o estado de bem estar. Jurídicas, 
A força avassaladora do princípio de mercado impulsionado pelo capitalismo global fez soçobrar todas as interdependências não mercantis, tanto as que são geradas no contexto da cidadania como as que são geradas na comunidade ${ }^{8}$. E assim o é, como já constatou, no século passado, L. J. Lebret, porque o capitalismo, em função de sua própria lógica, busca o que rende mais e não o que é mais necessário. ${ }^{9}$

Daí a necessidade de se alcançar uma nova congruência entre a cidadania e a comunidade que se contraponha ao princípio do mercado. Essa nova congruência pretenderia alcançar o projeto de reinvenção solidária e participativa do Estado, o que aqui se denomina Poder Público pós-Estado Constitucional Moderno.

\section{A Refundação democrática da "COISA pÚblica"}

Para que esse conjunto de teorias tenha sentido, a refundação democrática da "coisa pública" ou do "interesse público" formador da condição republicana deve ser complementada com uma refundação democrática do Terceiro Setor. A revisão dos debates em torno desse espaço relegado a segundo plano entre o público e o privado deixa entrever que ele está sujeito aos mesmos vícios atribuídos ao Estado, ainda que se considere que possa superá-los com mais facilidade ${ }^{10}$. O debate sobre a localização estrutural desse espaço entre o público e o privado mostrou a dificuldade que ele enfrenta para conferir um caráter genuíno aos seus objetivos, assim como sua propensão à promiscuidade com o Estado e com o mercado.

A crise do Estado Constitucional Moderno e do Direito Moderno, em todo o mundo, permite conjecturar um futuro do que se convencionou chamar de "regionalismo funcional", ou seja, uma superação da atual estrutura estatal por organismos transnacionais e por autonomias regionais e municipais infranacionais ${ }^{11}$. Assim, resulta que esse Estado Constitucional Moderno, ameaçado em suas bases teóricas, parece subsistir realmente como uma débil reserva de integridade meramente territorial, mas sem muito futuro.

Parece que estamos diante de uma verdadeira capitulação, que tem como consequência a emergência do aparato estatal da violência, que surge para tentar conter os protestos contra a globalização excludente e desumana. Mostra-se, dessa forma, o verdadeiro rosto de um poder que esquece com muita frequência o Bem Comum, o interesse da maioria e as necessidades reais de seus cidadãos para dedicar-se a servir ao poder econômico e a aquilo que pode favorecer seus interesses. Utiliza para alcançar tal fim o seu caráter derrogatório, pretoriano e de total insensibilidade social, porque muito comprometido com seu umbigo burocrático e porque de fato consumido pelos apetites e interesses neo (ou mais que tanto) liberais.

Nessa linha, a violência estatal tenta legitimar, mas apenas e quando muito consegue legalizar ${ }^{12}$, as leis do mercado, e o Estado Constitucional Moderno se converte num aparato de segurança a favor das grandes empresas $^{13}$. Por isso, em praticamente todas as partes, o Estado Constitucional Moderno é menos promotor e, portanto, dotado de menor capacidade para organização do vínculo social e muito mais um contorno institucional reduzido à sua condição de polícia de fronteiras para limitar a passagem dos "indesejáveis". Voltado para seu interior, trata de garantir certa perpetuação a quem detenha o poder político.

Colômbia, v. 10, p. 56-70, 2013.

8 CRUZ, Paulo Márcio; REAL, Gabriel. Los nuevos escenarios transnacionales y la democracia asimétrica. Jurídicas, Colômbia, v. 7, p. 12-17, 2010.

9 LEBRET, L.J. O drama do século X: miséria, subdesenvolvimento, inconsciência, esperança. São Paulo: Livraria Duas Cidades, 1962.

10 CRUZ, Paulo Márcio. Repensar a Democracia. Revista da Faculdade de Direito da UFG, Goiânia, v. 33, p. 22-41, 2010.

11 AYUSO TORRES, Miguel. Después del Levitán? Sobre el estado y su signo. Madrid: Dykinson, 1998, p.77.

12 Sobre a Legitimidade como categoria política e jurídica, vide PASOLD, Cesar Luiz. Reflexões sobre o poder e o direito. 2. ed. Florianópolis: Estudantil, 1988. Em especial, p.25 a 31. E sobre a Legalidade compreendida como "a imposição de um limite à atuação estatal", vide: GRAU, Eros Roberto. O direito posto e o direito pressuposto. 8 ed. rev. amp. São Paulo: Malheiros, 2011, p. 172-173.

13 OLLER I SALA, M. Dolors. Un futuro para la democracia: una democracia para la gobernabilidad mundial. Barcelona: Cristianisme I Justícia, 2002, p.15. 
Como enfatiza Sergio Graziano Sobrinho ${ }^{14}$, a sociedade capitalista está marcada pelo confronto e pela violência. A violência apresenta-se em duplo caráter: a "violência estrutural" que é de ordem "econômica e social” e a violência "institucional" na qual destaca-se a utilização do aparato policial "para selecionar os indivíduos, criminalizando muitos e imunizando alguns", barbarizando e atacando em permanente ação combatendo à "dita criminalidade".

Assim, atualmente, as forças do mercado se mostram capazes de condicionar de modo determinante decisões não só de governos individualmente considerados, mas também de organizações políticas internacionais. ${ }^{15}$ É o predomínio severo do econômico sobre o social que é sempre antitético aos compromissos com o Bem Comum ou Interesse Coletivo ${ }^{16}$. Nesse contexto caracteriza-se o completo afastamento do sonho de Hermann Heller, que projetava a bela utopia de um Estado sinônimo, de fato e de direito, da totalidade social na medida em que se caracterizaria como eficaz instrumento servindo ao todo social. Assim, a explicação do Estado seria efetuada pela "conexão social total" em que se encontraria. ${ }^{17}$

Como esse sonho não se realizou até aqui, o resultado é que a geografia da exclusão social está se alastrando a setores e espaços cada vez mais amplos do mundo denominado desenvolvido. A consequência dos duros ajustes econômicos é a precariedade do trabalho, o aumento das desigualdades e a tendência clara à divisão social entre pobres (muitos) e ricos (poucos), esvaziando o conteúdo dos direitos de cidadania. Nos países subdesenvolvidos do Sul, grandes massas de habitantes permanecem sufocadas em condições de vida que atentam contra os mais elementares direitos humanos.

Essa ideia falsa foi formada nos moldes dos modelos europeus, nos quais há o hábito de se considerar a nação como uma forma política óbvia, uma espécie de meta natural de toda Sociedade ${ }^{18}$.

Já é hora de se tomar consciência que a ideia de nação que a Europa deu ao mundo é, atualmente, uma forma política efêmera, uma exceção europeia, precária transição entre a era dos reis e a era do mundo globalizado e sem fronteiras.

A resposta ao padrão organizativo caracterizado pela generalidade, abstração e centralismo - de que o Estado e o direito legalista ou conceitualista são um bom exemplo - estaria, provavelmente, numa nova estrutura organizativa caracterizada:

a) por uma arquitetura em rede, em que cada polo fosse gerido autonomamente, tendo em conta todas as particularidades das situações;

b) em que a flexibilidade e a adaptabilidade do conjunto fossem garantidas pela inexistência de um polo central;

c) e em que a comunicação fosse de um tipo novo, não baseado em modelos gerais e abstratos de informação, mas em descrições personalizadas, exaustivas e atentas às dimensões não puramente racionais das situações.

Considerando-se que o pensamento utópico equivale, em certa medida, à imaginação política (recorde-se o slogan da comuna universitária parisiense de 1968: A imaginação ao poder), o fim da utopia pode ser o fim do poder de imaginação política que construiu a utopia do Estado Constitucional Moderno, agora vítima de suas próprias contradições internas, ontológicas (à moda heideggeriana) e estruturais (à moda weberiana). Nessa linha parece que a crise do pensamento utópico, ao supor o cansaço da imaginação política patente

14 GRAZIANO SOBRINHO, Sérgio Francisco Carlos. Globalização e sociedade de controle: a cultura do medo e o mercado da violência. Rio de Janeiro: Lúmen Juris, 2010. p. 223.

15 CRUZ, Paulo Márcio; PASOLD, Cesar Luiz. Norberto Bobbio e a democracia. Revista da Faculdade de Direito, Uberlândia, v. 38, p. 1-23, 2010.

16 PASOLD, Cesar Luiz. Função social do estado contemporâneo. 4 ed. rev. amp. Itajaí: UNVALI, 2013.

17 HELLER, Hermann. Teoria do Estado. São Paulo: Mestre Jou, 1968. p. 67.

18 HESPANHA, António Manuel. Cultura juridical europeia: síntese de um milênio. Florianópolis: Fundação Boiteux, 2005, p.500501. 
no fracasso do Estado Constitucional Moderno perante os desafios pós-contemporâneos, tanto doutrinários como em sua práxis, é muito forte. De maneira que se percebem, em vários países, a ressurreição, com outros rótulos simbólicos, de soluções políticas ultrapassadas, mesmo que seus mentores neguem. É certo que a história jamais se repete, exatamente como indicou Giambattista Vico ${ }^{19}$, mas não é menos verdade que o risco do pensamento histórico - segunda a terminologia de Jurgen Habermas - consiste em congelar o presente aproximando-o do passado.

Como costuma acontecer em tempos de transição profunda, estão aparecendo posições epistemológicas extremas e até insensatas em relação à condição de subjugado do Estado Constitucional Moderno ${ }^{20}$. Como evoluirá a relação entre ele e a crescente autonomia do mercado mundial? As implicações da desproporção entre capital produtivo e especulativo, as consequências ainda imprevisíveis dos novos sistemas de multimídia - isto é, a convergência da televisão, telefone, cinema e computador numa só tecnologia - e o significado de um desemprego mundial de $30 \%$ da população economicamente ativa. Esses são alguns dos parâmetros da nascente sociedade global, não integrados de maneira apropriada a uma cosmovisão à altura das mudanças que vivemos e capazes de orientar os indivíduos e coletivos sociais na direção de um novo capitalismo ou, se preferirem, de um "novo modo de produção".

Parece inadequado buscar as raízes da atual crise de civilização no Estado Constitucional Moderno ou na Sociedade sua criadora. E há que se tentar a recuperação dessa Sociedade. O Estado Constitucional Moderno está em crise porque suas versões reformadas são incapazes de responder, satisfatoriamente, às solicitações da Sociedade e, inclusive, quando intervém para atendê-la, produz, normalmente, outros problemas novos. A Sociedade atual mostra um crescente e perpétuo dinamismo e complexidade que brotam de cada um dos subsistemas que a compreendem e que não sintonizam com o Estado Constitucional Moderno. A isso se acrescenta a negligência, quando não cumplicidade, dos aparelhos estatais na deterioração e depredação da Natureza e do Meio Ambiente, que são imprescindíveis para a qualidade de vida da Sociedade e das pessoas que a integram. ${ }^{21}$ Aliás, convém ressaltar, desde logo, que qualquer pauta para discutir o futuro do Estado que já neste primeiro quartel do século XXI está se mantendo desvirtuado como foi no século passado, deve conter como prioridade o Meio Ambiente, sempre sob a perspectiva da interdisciplinaridade e concomitante postura cuidadosa quanto à intertextualidade.

O Estado Constitucional começou a ser mudado, na sua essência, primeiramente com a crise de $1929^{22}$. Posteriormente, foi a escalada intervencionista e de desenvolvimento do Estado de Bem Estar, com sérios problemas de tensão, tanto no mercado (distorções regulamentares, inflação, questionamento éticos do trabalho, crescente poder dos sindicatos) como no próprio Estado (déficit crescente, rebelião fiscal, desenvolvimento das práticas burocráticas, tensões corporativas pela distribuição de serviços públicos) ${ }^{23}$. E, também, a não funcionalidade criada pela mundialização e uma estrutura estatal voltada para seu caráter interno, nacional.

O Estado Constitucional Moderno é, atualmente, uma forma esvaziada e, já que à desaparecida Sociedade do antigo regime não há sucedido nenhuma outra, só o vazio, há um grande esforço para se construir uma. A economia moderna, por sua vez, apresenta um esboço de Sociedade na qual os produtores que a

19 Giambattista Vico, filósofo italiano, desenvolve uma nova ciência para a interpretação da realidade e do estudo da história. Sua principal obra, Princípios da nova ciência, é uma revisão dos fundamentos históricos da humanidade, da sabedoria poética e das obras de Homero, levando a sua visão de "nações que seguem o curso"; a maneira como eles organizaram os homens dos tempos mais antigos até seu tempo. Seu maior mérito é ter formulado princípios do método histórico e desenvolver uma filosofia da história. VICO, Giambattista. Oraciones inangurales \& la antiquísima sabiduría de los italianos. Barcelona: Anthropos, 2002.

20 CHONSKY, Noam; DIETERICH, Heinz. A sociedade global: educação, mercado e democracia. Blumenau: FURB, 1999 , p.91.

21 PASOLD, Cesar Luiz. Teoria da constituição e do estado: uma pauta para o tempo XXI. In: SANTO, Davi do Espirito; PASOLD, Cesar Luiz (Orgs.). Reflexões sobre teoria da constituição e do Estado. Florianópolis: Insular, 2013, p.439.

22 CRUZ, Paulo Márcio; OLIVIERO, Maurizio. Reflexões sobre a crise financeira internacional e o estado de bem-estar. Revista de Direito Mackenzie, São Paulo, v.6, p. 27-35, 2012.

23 CRUZ, Paulo Márcio; OLIVIERO, Maurizio. Reflexões sobre a crise financeira internacional e o estado de bem-estar. Revista de Direito Mackenzie, São Paulo, v.6, p. 27-35, 2012. 
dominam estão, necessariamente, unidos entre si para a produção de bens. Todos os Estados Contemporâneos, a margem de cruzadas ideológicas, se comprometeram com esse caminho, de tal modo que cada um deles se considera como uma empresa gigantesca ou como um trust colossal, que agrupa um vasto conjunto de empresas e órgãos - sejam coletivizadas, estatizadas ou livres - dos quais assume a direção. Também, ao mesmo tempo, os produtores situados num sistema assim invertido, que precisam de uma "prótese" eficaz que a faça caminhar no contrapé de sua finalidade natural, dirigem seus olhares ao Estado, como demonstra Ayuso Torres ${ }^{24}$. Raquel Varela, no mesmo sentido, escreveu que o modelo que fundamenta a socialdemocracia se esvaiu, o que se verifica pela constatação de que a denominada União Europeia é uma corporação de acumulação de capitais. ${ }^{25}$

A opinião pública dos países democráticos inquieta ante o nível de degradação da segurança interna é a princípio e, geralmente, a favor do fortalecimento da ação pública. O corpo político entende que é melhor o Estado Constitucional Moderno voltar a centrar-se no conjunto de competências que lhe são próprias em lugar de dispersar-se em outras atividades que as empresas privadas sabem fazer melhor - que faça menos, enfim, mas que o faça bem. Para que esta linha de defesa do papel do Estado pudesse ser convincente, seria necessário que, nos terrenos que parecem ser próprios de sua atuação, sua legitimidade seja indiscutível e não conte com nenhuma concorrência séria. Não é este o caso ${ }^{26}$. As mais tradicionais funções de "soberania", que pareciam claramente ser de competência do Estado Constitucional Moderno, estão submetidas a uma erosão lenta, mas contínua. Aparecem novos atores e a legitimidade do Estado Constitucional Moderno muda de natureza, quando não é diretamente posta em dúvida. Tanto o relativo à defesa nacional como a polícia e a justiça serão, no futuro, assuntos entendidos como meros serviços inseridos no cumprimento de funções e não expressão de Soberania.

Como já foi visto anteriormente, a noção de Soberania se transforma cada vez mais em uma palavra oca e sem conteúdo. É um mero critério formal na caracterização do Estado. Vivemos assim, venia pela repetição, o início da era de desaparecimento do Estado Constitucional Moderno e, em consequência, do eclipse da Soberania como categoria vinculada ao território ${ }^{27}$.

A essência do Estado Constitucional Moderno está ligada a um determinado grau de homogeneidade, como era a sociedade burguesa dos séculos XVIII e XIX. Hoje há um número crescente daqueles que não entram no padrão cada vez mais rigoroso imposto pelas elites liberais capitalistas e que devem ser excluídos: negros, imigrantes, rechaçados, marginalizados. Estes seriam descartados como peças com defeito de fabricação, que não passariam por um "controle de qualidade" rigoroso. Essas peças "defeituosas" são o resultado da política liberal capitalista, que quis impor um padrão de homogeneidade artificial, insensível e desumana.

A globalização está por trás da expansão da democracia liberal ao largo e em torno do mundo ${ }^{28}$. Mas, ao mesmo tempo, o modelo de democracia liberal representativa entrou em crise, cuja origem está na crise do Estado Constitucional Moderno tradicional ${ }^{29}$. A democracia representativa, ainda que tenha sido uma grande conquista na história da humanidade, perdeu sua grandeza. E tal fenômeno relaciona-se com o papel do Estado Constitucional Moderno. Assim, o seu tradicional papel está cada vez mais cedendo posições

24 AYUSO TORRES, Miguel. Después del Levitán? sobre el Estado y su signo. Madrid: Dykinson, 1998, p.36.

25 VARELA, Raquel. O modelo que fundamenta a socialdemocracia se esvaiu. Carta Capital. n. 879. Disponível em: $<$ http:// www.cartacapital.com.br/revista/879/todo-poder-real-aos-cidadaos-1218.html?utm_content=buffer $21 \mathrm{~d} 78 \& u \mathrm{tm}$ medium $=$ social\&utm_source=twitter.com\&utm_campaign=buffer- $>$. Acesso em: 17 jan. 2016.

26 GUÉHENNO, Jean Marie. El porvenir de la libertad: la democratización en la época de la globalización. Barcelona: Paidós, 2000, p.43.

27 CRUZ, Paulo Márcio. Soberanía y transnacionalidad: anatgonismos y consecuencias. Jurídicas, Colômbia, v. 7, p. 13-36, 2010.

28 Sobre isso ver PASOLD, Cesar Luiz; CRUZ, Paulo Márcio. Norberto Bobbio e a democracia Revista da Faculdade de Direito, Uberlândia, v. 38, p. 1-23, 2010.

29 CRUZ, Paulo Márcio; OLIVIERO, Maurizio. Reflexões sobre a crise financeira internacional e o estado de bem estar. Jurídicas, Colômbia, v. 10, p. 56-70, 2013. 
e perdendo influência ante os novos atores da globalização, com perversa diminuição da distância entre o público e o privado.

O Poder Público, desse modo, se diversificou. E a Democracia transformada numa espécie de "poliarquia" deixa a Sociedade sem saber a quem exigir responsabilidade e nem como exercer o controle sobre os poderes públicos ${ }^{30}$. Além disso, as estruturas democráticas tradicionais não são consideradas idôneas para controlar o poder econômico e dos meios de comunicação, que se tornaram transnacionais. Tudo isso requer, com certeza, novos parâmetros para a Democracia, inclusive com o repensar de seu conceito tradicional adstrito à circunstância da condição de regime político/método de "composição de órgãos dirigentes do Estado", levando-a ao patamar de elemento sustentador da "solidariedade do agrupamento social", na lição de Telmo Vieira Ribeiro ${ }^{31}$.

\section{A CRISE E AS MUDANÇAS}

O Estado Constitucional Moderno está em crise, entre outros muitos motivos, por ter mantido sua estrutura com elementos do primeiro liberalismo, que não se ajustaram às mudanças profundas ocorridas na Sociedade, advindas de diversos aspectos ${ }^{32}$. Bastaram, por exemplo, a crise dos anos trinta e dos anos setenta para mostrar, cruelmente, a incongruência entre os conceitos e estruturas herdados e a nova situação crítica.

$\mathrm{O}$ atual momento é de mudanças radicais. Um momento dominado por instituições zumbis (partidos sem partidários, exércitos sem inimigos, aparelhos governamentais caducos e, pois, ineficientes) que estão clinicamente mortas ha muito tempo, mas que são incapazes de deixarem de viver ${ }^{33}$. Por isso é indispensável avançar na história e configurar teoricamente um novo conceito de Democracia e um novo conjunto de instituições capazes de estabelecer e salvaguardar a legalidade no âmbito internacional.

Hora, pois, de prosseguir, ampliando as discussões e reflexões propositivas sobre o tema Direito Transnacional, sempre tendo em conta a necessidade de produção de respostas satisfatórias aos fenômenos globais contemporâneos ${ }^{34}$. Isso inclui possibilidades não apenas epistemológicas quanto ao Estado Transnacional Ambiental ${ }^{35}$, como também o Constitucionalismo ambiental como mera garantia simbólica ou não ${ }^{36}$.

Também convêm reestudar as possibilidades da Teoria da Interconstitucionalidade, com seus tópicos de realce, a "rede de constituições de estados soberanos" e as "turbulências" oriundas de comunidades políticas supranacionais ${ }^{37}$.

A Soberania foi um dos principais alicerces do Estado Constitucional Moderno. Convertia o poder estatal num poder supremo, exclusivo, irresistível e substantivo, único criador de normas e detentor do mo-

30 OLLER I SALA, M. Dolors. Un futuro para la democracia: una democracia para la gobernabilidad mundial. Barcelona: Cristianisme I Justícia, 2002, p. 8. E especificamente sobre a Democracia como paradigma para superação democrática do Estado Constitucional, vide o item 1.5 em: CRUZ, Paulo Márcio; SIRVENT, José Francisco Chofre. Ensaio sobre a necessidade de uma teoria para a superação democrática do Estado constitucional moderno. Disponível em: <https://jus.com.br/artigos/8276/ensaio-sobre-a-necessidadede-uma-teoria-para-a-superacao-democratica-do-estado-constitucional-moderno/3->. Acesso em: 17 jan. 2016.

31 OLIVO, Luis Carlos Cancellier de; PASOLD, Cesar Luiz (Orgs). Duas teses de Telmo Vieira Ribeiro. Joaçaba: UNOESC, 2015, p.16 e 61.

32 CRUZ, Paulo Márcio. Repensar a democracia. Revista da Faculdade de Direito da UFG, Goiânia, v. 33, p. 22-41, 2010.

33 BECK, Ulrich. Qué es la globalización?. Barcelona: Paidós, 1998, p.59.

34 OLIVIERO, Maurizio; CRUZ, Paulo Márcio. Reflexões sobre o direito transnacional. In: SANTO, Davi do Espirito; PASOLD, Cesar Luiz (Orgs.). Reflexões sobre a Teoria da Constituição e do Estado. Florianópolis: Insular, 2013.

35 Vide, por exemplo: ARMADA, Charles Alexandre Souza. O Estado transnacional ambiental como futuro possível para o Estado e para a efetivação do direito ambiental no século XXI. In: CAMPELLO, Lívia Gaigher Bósio; SOUZA, Maria Cláudia da Silva Antunes de; PADILHA, Norma Sueli (Coords.). Direito Ambiental no Século XXI: efetividade e desafios. Curitiba: Clássica, 2013. v.2. p. 149-173.

36 LUNO, Antônio Henrique Pérez. Perspectivas e tendências atuais do Estado constitucional. Porto Alegre: Livraria do Advogado, 2012.

37 CANOTILHO, J. J. Gomes. Direito constitucional e teoria da constituição. 7. ed. 8. reimp. Coimbra: Almedina, 2003. 
nopólio do poder de coação física legítima dentro de seu território. E sustentava-o como único interlocutor autorizado a falar com o exterior. Esse conceito está se desmanchando. O que, também, faz afundar os alicerces sobre os quais se sustentava a teoria clássica do Estado Constitucional Moderno ${ }^{38}$. Por outro lado, a perda da eficiência do Estado Constitucional Moderno provocou a erosão de sua legitimidade perante o cidadão. O Estado Constitucional Moderno cada vez oferece menos respostas às demandas de segurança e desenvolvimento.

E, ainda que essa noção de Soberania exclusiva tenha sido sempre mais um mito do que uma realidade, a verdade é que hoje se assiste a um retrocesso importante do poder do papel do Estado Constitucional Moderno e do controle hierárquico deste sobre outras instâncias. As suas pretensões de controle sobre o território e de ter a última palavra em assuntos políticos perderam sua eficácia tanto em sua dimensão interna como em sua projeção externa. Nessa última, ironicamente, a Soberania do Estado perde seu poder e espaço para uma "supersoberania supranacional". Esta, por sua vez, ignora fronteiras e atua com as forças oriundas dos "círculos globais de produção", formando o que Eros Grau denomina processo de "desterritorialização" da Soberania. Aliás, Grau mesmo localiza o mercado como titular de uma "supersoberania", cuja criadora é a transnacionalidade ${ }^{39}$.

Caso os debates realizados nos fóruns sociais temáticos sejam comparados com a agenda política do Parlamento na Colômbia, no Brasil ou em Portugal, vai-se notar que há uma discrepância total entre as ansiedades, as aspirações democráticas que estão aqui para ser debatidas e o que acontece nos parlamentos ${ }^{40}$. Então, o mais importante é ampliar a agenda política, e isso não pode vir de dentro do Estado, porque ele Estado está aprisionado por sua própria estrutura. É preciso fazê-la de fora, por meio de instrumentos como a Democracia Participativa Digital, por exemplo.

Em consequência desse fato, torna-se cada vez mais difícil manter a ideia do Estado Constitucional Moderno como garantidor do interesse geral, já que é evidente que não pode, por si só, responder adequadamente aos novos desafios que tem por ultrapassar, seja por motivo de ordem estrutural seja, sobretudo, pela falência de sua concepção nodal.

Em termos sociais o efeito acumulado do pré e do pós contratualismo é a emergência de uma classe de excluídos constituída por grupos sociais em mobilidade descendente estrutural (trabalhadores não qualificados, desempregados, trabalhadores imigrantes, minorias étnicas). E por grupos sociais para os quais o trabalho deixou de ser - ou nunca foi - um horizonte realista (desempregados de longa duração, jovens com difícil inserção no mercado de trabalho, incapazes física e mentalmente, massas de camponeses pobres da América Latina, África e Ásia). Essas classes de excluídos - maiores ou menores segundo seja a posição, periférica ou central, de cada sociedade no sistema mundial - assume, nos países centrais, a forma de terceiro mundo interior, o chamado terço inferior, da sociedade dos terços. ${ }^{41}$

\section{UMA NOVA FORMA DE ORGANIZAÇÃO POLÍTICA}

A despolitização do Estado Constitucional Moderno e a "desestatalização" da regulação social induzidas pela erosão do contrato social indica que, sob a denominação "Estado", está emergindo uma nova forma de organização política mais ampla que o Estado convencional: um conjunto híbrido de fluxos, organizações e redes nas quais se combinam e solapam elementos estatais e não estatais, nacionais, transnacionais e globais.

38 OLLER I SALA, M. Dolors. Un futuro para la democracia: una democracia para la gobernabilidad mundial. Barcelona: Cristianisme I Justícia, 2002, p.11.

39 GRAU, Eros Roberto. O direito posto e o direito pressuposto. 8. ed. rev. amp. São Paulo: Malheiros, 2011. p. 335.

40 CRUZ, Paulo Márcio; FERRER, G. R. A crise financeira mundial, o estado e a democracia econômica. Revista da Faculdade de Direito da UERJ, Rio de Janeiro, v. 1, p. 1-23, 2011.

41 CRUZ, Paulo Márcio. Repensar a democracia. Revista da Faculdade de Direito da UFG, Goiânia, v. 33, p. 22-41, 2010. 
Essa nova organização política, esse conjunto heterogêneo de organizações, instituições e fluxos, não tem centro: a coordenação do Estado Constitucional Moderno funciona, apenas, como imaginação do centro.

Já não tem sentido algum recorrer ao Estado contra o mercado e ao mercado contra o Estado. A falha do Estado e a falha do mercado tornam-se idênticas porque a forma de reprodução social da modernidade perdeu completamente sua capacidade de funcionamento e de integração ${ }^{42}$. Com isso torna-se impossível contornar os problemas, tanto na teoria quanto na prática. E isso, no momento em que também os componentes ocidentais do sistema global de produção de mercadorias chegam a experimentar, no mesmo grau de crueldade que o resto do mundo, as consequências da crise.

Nesse novo marco, o Estado Constitucional Moderno é uma relação política fraturada, aberta à competição entre os atores externos da política, na qual transitam concepções alternativas de bem comum e dos bens públicos. Antes de uma materialidade institucional e burocrática, o Estado está chamado a ser o terreno de uma luta política muito menos codificada e regrada que a luta convencional. É nesse novo marco que as diferentes formas de fascismo social buscam articulação para amplificar e consolidar suas pretensões despóticas, transformando o Estado em componente de espaço privado. E será, também, nesse marco que as forças democráticas deverão lutar pela democracia redistributiva e converter o Estado em componente do espaço público não estatal ${ }^{43}$. Essa última transformação é o que Boaventura de Souza Santos denomina Estado como novíssimo movimento social.

Outra evidência da insuficiência do Estado Constitucional Moderno é o resultado da denominada "Democracia da opinião pública", que supera, e muito, a eficácia dos instrumentos habituais de representação política em se tratando de fiscalizar os representantes públicos. Essa teoria tem como principal hipótese o fato de que os meios de comunicação estão debilitando a capacidade decisória dos Poderes Institucionais do Estado, a ponto de que a relação entre governantes e governados está adstrita, apenas, ao desenho original de uma democracia representativa.

A dificuldade está em "quem" e "como" pode controlar esse grande manipulador, que atua a partir dos meios de comunicação ${ }^{44}$. É um instrumento poderosíssimo que tem, por seu caráter cada vez mais globalizado, muitas possibilidades de escapar da fiscalização dos ordenamentos e instituições do Estado Constitucional Moderno, que se mostra claramente insuficiente para tal tarefa. E conivente.

Entramos na era dos sistemas abertos, quer se trate de estados ou empresas, e os critérios de êxito são os opostos da era moderna e dos sistemas fechados. O valor de uma organização já não se mede pelo equilíbrio que tenta estabelecer entre seus diversos componentes nem pela nitidez de suas fronteiras, mas sim pelo número de aberturas, de pontos de articulação que ela mantém com tudo que lhe é exterior.

O debate sobre o futuro do Mundo Ocidental Desenvolvido, em sua falsa simplicidade, ilustra bem as insuficiências de um enfoque institucional da era moderna ${ }^{45}$. A questão está posta a partir de visões ultrapassadas, nas quais o reflexo de um mundo que desaparece revela sua impotência para dar conta do novo mundo que começa.

Portanto, debilitados em sua eficácia, vítimas das mudanças transversais da globalização e da interdependência, os estados padecem de uma profunda erosão de seu poder e de sua capacidade de controle hierárquico ${ }^{46}$. E, por sua incapacidade para manter alguma autonomia em relação às novas forças que surgem, cada vez têm mais problemas para sustentar sua legitimidade ante uma cidadania ávida de segurança e desenvolvimento. A cidadania, por sua vez, também não se sente suficientemente reconhecida e atendida numa

42 CRUZ, Paulo Márcio; OLIVIERO, Maurizio. (Org.) As trajetórias multidimensionais da Globalização. Itajaí: Univali, 2014. v. 1.

43 SANTOS, Boaventura de Souza. Reiventar la democracia, reiventar el Estado. Madrid: Ediciones Sequitur, 1999, p.40.

44 RUIZ-RICO-RUIZ, Gerardo et al. Estado democrático y constitución: balance y perspectivas de futuro. In: LA DEMOCR ACLA en debate. Madrid: Dykinson, 2002, p.179.

45 GUÉHENNO, Jean-Marie. El fin de la democracia: la crisis política y las nuevas reglas del juego. Barcelona: Paidós, 1995. p.63.

46 É o que Boaventura chama de apoliticismo desterritorializado. 
estrutura de poder anacrônica por sua hierarquização paquidérmica, distante e pouco controlável como a que proporciona o Estado Constitucional Moderno.

Os estados estão perdendo poder, força e influência tanto em âmbito interno como no externo. No âmbito externo, estão cedendo parcelas de prerrogativas a atores surgidos do processo de globalização, em setores como o meio ambiente, as tecnologias de informação, as imigrações, o terrorismo internacional e o crime organizado, para citar alguns exemplos.

Todos esses novos atores e atividades estão provocando um profundo impacto "desterritorializador" com efeitos ainda incertos, mas que já estão gerando uma visão da vida cada vez mais universal e, portanto, menos ligada às pautas específicas de cada estado. Essa transferência de identidades está sendo fundamental na erosão dos estados nacionais. O cidadão peregrino continua pagando impostos e viajando com o passaporte expedido por um governo territorial, mas seus sonhos e projetos estão em qualquer outro lugar ${ }^{47}$. Fazem parte dessa viagem ao futuro, empreendida cada vez mais por pessoas sem problemas de raça, classe social ou nacionalidade.

Outra parcela inquietante, sobre a qual o Estado Constitucional Moderno está perdendo sua capacidade de atuação, é a do controle da criminalidade organizada e o terrorismo. O Estado Constitucional Moderno está se vendo cada vez mais incapaz para responder aos crescentes desafios colocados pelas grandes máfias do contrabando, a droga, a prostituição, os crimes de informática, o tráfico de armas e, mais recentemente, materiais radioativos, engenharia genética, entre outros. Estas e novas formas de criminalidade global exigem a adoção de medidas que superem o âmbito territorial restrito e típico do Estado Constitucional Moderno.

Por um lado, porque as instituições estatais nacionais resultam insuficientes para conjurar a visível capacidade de manobra de vários poderes privados que se movem com muita velocidade, de uma fronteira à outra, desvinculando seus benefícios econômicos de suas obrigações fiscais, ecológicas, sanitárias, laborais, enfim, de sua obrigação para com a humanidade. ${ }^{48}$

Não se trata, é claro, de um mero cosmopolitismo fugidio, destinado a liquidar as diferenças nacionais ou os elementos clássicos do Poder Público. Mas sim do encaminhamento de uma nova ideia de organização político-jurídica, que permita, como já frisado anteriormente, a possibilidade de interações entre diversos sistemas jurídicos, sem que isso suponha, necessariamente, subordinação de uns frente a outros, como aponta Del Cabo ${ }^{49}$. Esse autor espanhol aponta a existência de poderes de mercado que não podem ser controlados, o que conflita com qualquer modelo de organização político-jurídica destinada a garantir os direitos mínimos dos cidadãos.

A superação dessa situação de desencanto e frustração só parece possível caso sejam colocadas em prática duas exigências. De uma parte, o desempenho de uma dissidência ativa, que vá engajando um número cada vez maior de cidadãos na luta pela efetiva aplicação dos direitos fundamentais. De outra, a reconstrução de um sistema político e institucional capaz de processar as demandas dos cidadãos e de controlar a atividade e o poder dos protagonistas da nova economia global. Como já dito antes, uma espécie de "republicanização da globalização".

Esse Estado de base constitucional, que surgiu na Idade Moderna, apesar de transfigurado, perdura até os dias de hoje. Contudo, a partir dele, com base nele, mas em superação a ele, ao longo da Idade Contemporânea, se desenvolveu uma progressiva relativização da soberania, que possibilitou uma união de países acreditada por poucos, quando foi proposta, na Europa, cuja força cultural ainda é a locomotiva da civilização ocidental. Assim como os feudos se globalizaram em estados nacionais, agora, na evolução europeia, o processo de união continua pela globalização dos estados nacionais em comunidade transnacional.

47 FALK, Richard Antony. On buman governance: towards a new global politics. Cambridge: Polity Press, 2004. p.212.

48 DEL CABO, Antonio. Constitucionalismo, mundialização e crise del concepto de soberania: algunos efectos em América Latina y e Europa. Alicante: Publicaciones Universidad de Alicante, 2000. p.34.

49 DEL CABO, Antonio. Constitucionalismo, mundialização e crise del concepto de soberania: algunos efectos em América Latina y e Europa. Alicante: Publicaciones Universidad de Alicante, 2000. p.35. 
Esse processo se desenvolveu tendo origem e base na formação de um mercado comum, antes suprafeudal e agora transnacional, mas, partindo desse fundamento econômico, tem por sequência e consequência a constituição de nova sociedade política por coligação e relativização, antes dos domínios feudais e agora das soberanias nacionais.

\section{A SUPERAÇÃo do ESTAdo CONSTITUCIONAL}

Atualmente, a espécie humana está organizada em todas as suas esferas de reprodução essenciais e, em nível mundial, em estruturas de poder hierárquicas e oligopolistas, sem que a esses políticos e intelectuais orgânicos do "Mundo Livre" ocorra pedir a democratização dessas estruturas de poder construídas e mantidas pelas elites. Somente com um amplo movimento para a superação do Estado Constitucional, poder-se-á ter alguma perspectiva nesse sentido, como prescreve Noam Chomsky ${ }^{50}$.

Do ponto de vista dos atores sociais, elucidar as ideias de globalização, pós-modernidade e mutação significa elaborar instrumentos para compreender a história que estamos vivendo. Isso sugere a busca de uma teoria de transformação do mundo e de uma consciência histórica adequada.

O crescimento estrutural da exclusão social, pela via do pré-contratualismo ou do pós-contratualismo e a conseguinte extensão dos estados de natureza - que não oferecem opções, individuais ou coletivas, para superá-los - implicam uma crise do tipo paradigmático, um câmbio de época, que alguns autores denominaram "desmodernização" ou "contramodernização" ${ }^{51}$. Trata-se, portanto, de uma situação de muito risco. A questão que deve ser levantada é se, apesar de tudo, tem-se a capacidade para substituir o velho contrato social da modernidade por outro capaz de se contrapor e superar efetivamente à lógica da exclusão.

A mundialização capitalista do fim do Século XX engendrou condições de opressão e exploração sem precedentes na idade moderna e sua substituição assimétrica ${ }^{52}$ é fundamental para a sobrevivência da espécie humana ${ }^{53}$. Assim, se poderia ativar a gestão de uma série de condições objetivas e subjetivas que permitiriam a superação do estado atual de coisas numa direção de emancipação para o conjunto da humanidade.

Por isso, em consequência, ao debilitar as bases do Estado Constitucional Moderno, se corre o risco de dissolver algo mais profundo e estável, como é a comunidade política, na mesma linha de raciocínio de Ayuso Torres ${ }^{54}$. Novamente, como em tantos campos do conhecimento, nos movemos entre as contradições da pós-modernidade.

Em nossos tempos, a globalização tem ensejado uma questão atinente a uma alternativa, quase um dilema impossível de ser decifrado: ou caminhamos para a superação do Estado Constitucional Moderno, pelo seu próprio enfraquecimento, ensejando organizações transnacionais; ou cairemos em uma hegemonia de algum Estado ou grupo de Estados.

Ante essa situação, autores como Hobsbawm ${ }^{55}$ mostram que os estados de diversas zonas do planeta tentaram - ou tentam - uma dupla estratégica (que, paradoxalmente, não faz mais que acelerar o declínio do Estado Constitucional Moderno):

50 CHOMSKY, Noam; DIETERICH, Heinz. A sociedade global: educação, mercado e democracia. Blumenau: FURB, 1999 . p.113. 51 Sobre isso ver: CRUZ, Paulo Márcio; BODNAR, Zenildo. O novo paradigma de Direito na pós-modernidade. Revista de Estudos Constitucionais, Hermenêtica e Teoria do Direito, Porto Alegre, v. 3, p. 75-83, 2011.

52 Sobre isso ver CRUZ, Paulo Márcio; REAL FERRER, Gabriel. Los nuevos escenarios transnacionales y la democracia asimétrica. Jurídicas, Colômbia, v. 7, p. 12-17, 2010.

53 DEL CABO, Antonio. Constitucionalismo, mundialização e crise del concepto de soberania: algunos efectos en América Latina y en Europa. Alicante: Publicaciones Universidad de Alicante, 2000. p.46.

54 AYUSO TORRES, Miguel. Después del Levitán? sobre el estado y su signo. Madrid: Dykinson, 1998, p.185.

55 HOBSBAWM, Eric. Globalização, democracia e terrorismo. São Paulo: Companhia das Letras, 2007. 
a) a primeira consiste em integrar-se em unidades mais amplas, supraestatais, que acumulam competências econômicas, sociais ou militares cedidas pelos estados integrantes. Essas unidades regionais integradas exercem um novo tipo de governabilidade mundial em certos setores, como segurança, tecnologia e economia e contam com o apoio das tradicionais organizações internacionais.

b) a segunda estratégia é aquela voltada à descentralização política por meio da federalização ou outras formas de desconcentração do poder estatal. Com isso, a pretensão seria aproximar o poder do cidadão, introduzindo a Democracia no âmbito da estruturação territorial do Estado Constitucional Moderno e revalorizando as unidades políticas autônomas. Desse modo, a descentralização política faz com que, na prática, surja uma espécie de "soberania compartilhada". O Estado Constitucional Moderno revela, também, sua insuficiência quando cede capacidade de governo a cidadãos, grupos sociais, e coletivos territoriais que não se sentem suficientemente reconhecidos nem atendidos numa estrutura de poder demasiado hierárquica, muito distante e pouco controlável como é o Estado Constitucional Moderno.

Além disso, é importante citar a existência de solidariedades por identidade, que coloca em risco a identidade nacional "oficial" dos estados. Assim, no âmbito interno do Estado Constitucional Moderno, assiste-se o despertar da consciência coletiva que se manifesta em sua forma mais visível, o nacionalismo, em grande parte como reação de defesa contra a massificação homogeneizante resultante da globalização cultural e dos meios de comunicação. Esse ressurgimento mostra a existência de importantes comunidades, com consciência política própria e que não estão suficientemente reconhecidas pelo Estado Constitucional Moderno.

Deve-se ter em conta que, também, no âmbito interno, a atividade reguladora do Estado Constitucional Moderno se vê submetida a restrições cada vez mais importantes e frequentes. Na verdade, pode-se concordar com Paolo Grossi que, quando alerta que o que o Estado moderno assegura aos cidadãos, é somente um complexo de garantias formais, referindo-se a questões muito mais abstratas que efetivamente concretas ${ }^{56}$.

Seja pela complexidade da própria máquina estatal, seja pela progressiva tendência a estruturar o sistema de representação por meio de organizações especializadas ou corporações estruturadas em torno de critérios setoriais. O que obriga o Estado Constitucional Moderno a assumir complexas pautas de negociação. Tudo isso implica um importante retrocesso de seu poder e controle hierárquico.

Definitivamente, ao mesmo tempo em que se percebe a clara tendência à integração dos estados em estruturas transnacionais, observa-se, também, o surgimento de processos no sentido inverso, nos quais são produzidos uma intensa dispersão de competências entre grupos ou instituições.

O declínio político da velha ordem estatal que dividia o mundo em estados nacionais coloca sobre a mesa a necessidade de se estabelecer, primeiramente, novos modelos teóricos e, depois, a gradual efetivação destes modelos na prática.

\section{UM NOVO SISTEMA POLÍTICO GLOBAL E A IMPORTÂNCIA NODAL DA DEMOCRACIA}

É importante que novas propostas teóricas sejam discutidas na direção de um novo sistema político global que não esteja a serviço do mercado global.

Um novo conjunto teórico com relação ao poder público poderia estruturar-se em torno de quatro grandes objetivos: $1^{\circ}$ - a organização do desarme mundial para níveis que não ameacem existência da vida no planeta; $2^{\circ}$ - a organização do acesso aos recursos naturais do planeta de maneira igualitária e rigidamente sob os princípios do desenvolvimento sustentado, de forma a diminuir gradativamente as desigualdades; $3^{\circ}$ - a negociação de relações econômicas abertas e flexíveis entre as principais regiões do mundo, que na atua-

56 GROSSI, Paolo. Mitologias jurídicas da modernidade. Florianópolis: Fundação Boiteux, 2004. p. 24. 
lidade encontram-se desigualmente desenvolvidas ${ }^{57} ;$ e, $4^{\circ}$ - o início de negociações para a correta gestão da dialética mundial/nacional nas áreas das comunicações, cultura e política. Pode-se pensar até em gestão da distribuição de competências entre o plano transnacional e os planos regionais e nacionais.

Dito de outro modo, o que é realmente importante na configuração de um novo conjunto teórico sobre o tema é a Democracia como valor de civilização e não o Estado.

Mas deve-se voltar à questão sobre qual será o futuro do Estado! Nesse sentido pode-se refletir sobre três possibilidades. A primeira delas seria a volta de um Estado forte e autônomo, capaz de manter o controle do poder perante os novos organismos e entes transnacionais. Esta é uma alternativa pouco realista pelas razões já indicadas em outras partes desse artigo. Cabe uma segunda possibilidade, que consistiria em confiar na capacidade autorregulatória do emergente sistema global e reduzir, em consequência, a presença e ação dos estados até que sejam reduzidos a meros coadjuvantes de uma Sociedade em rede, multicêntrica e com poderes compartilhados em diversos níveis. É uma alternativa não só possível, mas também realista considerado o cenário mundial atual e suas projeções. O problema está em que se trata de uma alternativa demasiado realista e, portanto, extraordinariamente perigosa. A referência é à confusão usual entre mundialização e neoliberalismo ou, se preferir, à distinção entre a ideia da globalização assentada no dogma de que toda atividade humana atual deve estar sujeita ao primado da economia global.

Outra coisa, bem diferente, é a globalidade, ou seja, a existência de uma Sociedade mundial multidimensional, policêntrica, contingente e política, capaz de resolver de modo aceitável os grandes desafios de sustentabilidade sociais, econômicos, político e ambientais que enfrenta o mundo atual.

Diante dessas duas alternativas extremas, cabe uma posição intermediária, embasada na construção teórica de um Estado adaptado à nova situação, uma alternativa que permitisse a vigência de um poder público estatal, mas construído com base na nova realidade mundial e capaz de ser uma peça na engrenagem pública global.

O novo estado estaria encaixado numa rede de compartilhamento de funções públicas, interagindo com as organizações públicas transnacionais, tanto governamentais como não governamentais, por um lado, e com as regiões, comunidades, estados federados e entidades locais, por outro lado. Um novo estado que tenha como paradigma a Sustentabilidade ${ }^{58}$.

Dito de outra maneira, os novos estados exerceriam sua atividade não como entidade soberana, mas como parte componente de uma ordem política internacional mais ampla e complexa ${ }^{59}$. Assim, o Estado tende a extinguir-se como estrutura de soberania - um dos motivos para a superação do Estado Constitucional Moderno - e como coordenador de uma hierarquia piramida ${ }^{60}$. O novo estado não seria mais um pretenso gestor de uma hierarquia soberana, mas sim um potencial negociador e integrador de sua comunidade no concerto transnacional.

A criação de instituições intermediárias, capazes de não só assegurar a necessária transparência, mas também um grau mínimo de legitimidade, é, portanto, essencial. Isso supõe que, no lugar de se imaginar uma "comunidade mundial", seria resultado direto da eleição de milhões de indivíduos abstratos, se está trabalhando na construção de uma comunidade de comunidades, estabelecida sobre a base da negociação. E, entre diferentes comunidades políticas que compartilham os mesmos princípios comuns, fazendo-as compatíveis entre si e substituindo o conflito pela cooperação e o enfrentamento entre soberanias pela autonomia e independência organizadas ${ }^{61}$.

57 HÄBERLE, Peter. Estado constitucional cooperativo. Rio de Janeiro: Renovar, 2007. p.56.

58 CRUZ, Paulo Márcio; REAL FERRER, Gabriel. Direito, sustentabilidade e a premissa tecnológica como ampliação de seus fundamentos. Sequência, Santa Catarina, v. 36, p. 239, 2015.

59 CRUZ, Paulo Márcio. Repensar a democracia. Revista da Faculdade de Direito da UFG, Goiânia, v. 33, p. 22-41, 2010.

60 FERRAJOLI, Luigi. A soberania no mundo moderno: nascimento e crise do estado nacional. São Paulo: Martins Fontes, 2002.

61 HABERMAS, Jürgen. O ocidente dividido. Rio de Janeiro: Tempo Brasileiro, 2006. p.158. 
Isso está proposto assim porque pressupõe a construção de instituições políticas de intermediação, capazes de ter em consideração as duas lógicas, tanto a da concentração do poder como a da descentralização. E de organizar, por conta da mediação das instituições políticas, a passagem da primeira para a segunda, o que é, talvez, a principal tarefa política na pós-modernidade. O futuro da humanidade talvez dependa muito disso.

\section{Considerações finais}

Apesar das diversas teses apresentadas quanto à formação de uma comunidade mundial de autonomias independentes, o grande desafio, de verdade, será a nova conformação a ser dada ao Estado. Aí reside o grande esforço teórico que deve ser feito. Desde que o instrumento "de ligação", que historicamente viveu e conviveu com os princípios da Soberania moderna, possa estar apto e desempenhar sua função, tem-se a impressão que o restante do processo será mera consequência. Assim, o Estado que for teorizado e concretizado para substituir o Estado Constitucional Moderno deverá trazer em sua filosofia e em sua estrutura concreta a capacidade para ser "endógeno" e "exógeno" ao mesmo tempo.

Ainda é preciso registrar que a nova estrutura do Estado provavelmente vai se descolar completamente dos elementos teóricos que orientaram a criação do Estado Constitucional Moderno. Por isso urge que se inicie um decidido e consequente processo de teorização que possa sustentar essa nova estrutura.

É o mais longe que a prudência permite ir-se em termos propositivos. Além disso, corre-se o risco - se já não se avançou demais - de ser comparado com os visionários românticos e outros tantos que tiveram a pretensão de ter achado a fórmula mágica para a organização política da humanidade pós-moderna.

O objetivo de textos científicos como o presente é colaborar com as discussões sobre a necessidade de se teorizar o novo papel do Estado nesse ambiente transnacional complexo e cada vez mais rápido e digital. É ajudar a "desgrudar" alguns de nossos mais brilhantes pensadores do Estado Constitucional Moderno, convencê-los que haverá outra concepção para o Estado e que o concurso teórico deles é e sempre será indispensável.

\section{REFERÊNCIAS BIBLIOGRÁFICAS}

ARMADA, Charles Alexandre Souza. O estado transnacional ambiental como futuro possível para o estado e para a efetivação do direito ambiental no século XXI. In: CAMPELLO, Livia Gaigher Bósio; SOUZA, Maria Cláudia da Silva Antunes de; PADILHA, Norma Sueli (Coords.). Direito ambiental no século XXI: efetividade e desafios. Curitiba: Clássica, 2013. v.2. p.149-173.

AYUSO TORRES, Miguel. Después del Levitán?: sobre el estado y su signo. Madrid: Dykinson, 1998.

BECK, Ulrich. Qué es la globalización? Barcelona: Paidós, 1998.

CANOTILHO, J. J. Gomes. Direito constitucional e teoria da constituição. 7. ed. 8. reimp. Coimbra: Almedina, 2003.

CHOMSKY, Noam; DIETERICH, Heinz. A sociedade global: educação, mercado e democracia. Blumenau: FURB, 1999.

CRUZ, Paulo Márcio. Da soberania à transnacionalidade: democracia, direito e estado no século XXI. 2. ed. Itajaí: Univali, 2014. v.1. 
CRUZ, Paulo Márcio. Repensar a democracia. Revista da Faculdade de Direito da UFG, Goiânia, v.33, p.22-41, 2010.

CRUZ, Paulo Márcio. Soberanía y transnacionalidad: antagonismos y consecuencias. Jurídicas, Colômbia, v.7, p.13-36, 2010.

CRUZ, Paulo Márcio; BODNAR, Zenildo. O novo paradigma de Direito na pós-modernidade. Revista de Estudos Constitucionais, Hermenêutica e Teoria do Direito, Porto Alegre, v.3, p.75-83, 2011.

CRUZ, Paulo Márcio; OLIVIERO, Maurizio. (Org.) As trajetórias multidimensionais da Globalização. Itajaí: Univali, 2014. v.1.

CRUZ, Paulo Márcio; OLIVIERO, Maurizio. Reflexões sobre a crise financeira internacional e o Estado de bem estar. Jurídicas, Colômbia v.10, p.56-70, 2013.

CRUZ, Paulo Márcio; PASOLD, Cesar Luiz. Norberto Bobbio e a democracia. Revista da Faculdade de Direito, Uberlândia, v.38, p.1-23, 2010.

CRUZ, Paulo Márcio; REAL FERRER, Gabriel. A crise financeira mundial, o estado e a democracia econômica. Revista da Faculdade de Direito da UERJ, Rio de Janeiro, v. 1, p. 1-23, 2011.

CRUZ, PAULO MÁRCIO; Real Ferrer, Gabriel. Direito, sustentabilidade e a premissa tecnológica como ampliação de seus fundamentos. Sequência, Santa Catarina, v.36, p.239, 2015.

CRUZ, Paulo Márcio; REAL FERRER, Gabriel. Los nuevos escenarios transnacionales y la democracia asimétrica. Juridicas, Colômbia, v.7, p.12-17, 2010.

CRUZ, Paulo Márcio; SIRVENT, José Francisco Chofre. Ensaio sobre a necessidade de uma teoria para a superação democrática do Estado constitucional moderno. Disponível em: < https://jus.com.br/artigos/8276/ensaio-sobre-anecessidade-de-uma-teoria-para-a-superacao-democratica-do-estado-constitucional-moderno/3->. Acesso em: 20 dez. 15.

DALLARI, Dalmo de Abreu. O futuro do Estado. São Paulo: Saraiva, 2001.

DEL CABO, Antonio. Constitucionalismo, mundialização e crise del concepto de soberania: algunos efectos em América Latina y e Europa. Alicante: Publicaciones Universidad de Alicante, 2000.

FALK, Richard Antony. On human governance: towards a new global politics. Cambridge: Polity Press, 2004.

FERRAJOLI, Luigi. A soberania no mundo moderno: nascimento e crise do estado nacional. São Paulo: Martins Fontes, 2002.

GRAU, Eros Roberto. O direito posto e o direito pressuposto. 8. ed. rev. amp. São Paulo: Malheiros, 2011.

GRAZIANO SOBRINHO, Sérgio Francisco Carlos. Globalização e sociedade de controle: a cultura do medo e o mercado da violência. Rio de Janeiro: Lumen Juris, 2010.

GROSSI, Paulo. Mitologias jurídicas da modernidade. Florianópolis: Fundação Boiteux, 2004.

GUÉHENNO, Jean Marie. El porvenir de la libertad: la democratización en la época de la globalización. Barcelona: Paidós, 2000.

GUÉHENNO, Jean-Marie. El fin de la democracia: la crisis política y las nuevas reglas del juego. Barcelona: Paidós, 1995.

HÄBERLE, Peter. Estado constitucional cooperativo. Rio de Janeiro: Renovar, 2007.

HABERMAS, Jürgen. O Ocidente dividido. Rio de Janeiro: Tempo Brasileiro, 2006.

HELLER, Hermann. Teoria do Estado. São Paulo: Mestre Jou, 1968. 
HESPANHA, António Manuel. Cultura jurídica europeia: síntese de um milênio. Florianópolis: Fundação Boiteux, 2005.

HOBSBAWM, Eric. Globalização, democracia e terrorismo. São Paulo: Companhia das Letras, 2007.

LEBRET, L. J. O drama do século XX: miséria, sudesenvolvimento, inconsciência, esperança. São Paulo: Livraria Duas Cidades, 1962.

MARITAIN, Jacques. El hombre y el estado. Madrid: Ediciones Encuentro, 1983.

OLIVIERO, Maurizio; CRUZ, Paulo Márcio. Reflexões sobre o direito transnacional. In: SANTO, Davi do Espirito; PASOLD, Cesar Luiz (Orgs.) Reflexões sobre teoria da constituição e do Estado. Florianópolis: Insular, 2013.

OLIVO, Luis Carlos Cancellier de; PASOLD, Cesar Luiz (Orgs). Duas teses de Telmo Vieira Ribeiro. Joaçaba: UNOESC, 2015.

OLLER I SALA, M. Dolors. Un futuro para la democracia: una democracia para la gobernabilidad mundial. Barcelona: Cristianisme I Justícia, 2002.

PASOLD, Cesar Luiz. Função social do estado contemporâneo. 4 ed. rev. amp. Itajaí: UNVALI, 2013.

PASOLD, Cesar Luiz. Reflexões sobre o poder e o direito. 2 ed. Florianópolis: Estudantil, 1988.

PASOLD, Cesar Luiz. Teoria da constituição e do Estado: uma pauta para o tempo XXI. In: SANTO, Davi do Espirito; PASOLD, Cesar Luiz (Orgs.). Reflexões sobre teoria da constituição e do Estado. Florianópolis: Insular, 2013.

PEREZ LUÑO, Antonio Henrique. Perspectivas e tendências atuais do estado constitucional. Porto Alegre: Livraria do Advogado, 2012.

RUIZ-RICO-RUIZ, Gerardo et al. Estado democrático y constitución: balance y perspectivas de futuro, in La democracia en debate. Madrid: Dykinson, 2002.

SANTOS, Boaventura de Souza. Reiventar la democracia, reiventar el estado. Madrid: Ediciones Sequitur, 1999.

STELZER, Joana; CRUZ, Paulo Márcio. Direito e transnacionalidade. Curitiba: Juruá, 2009.

VARELA, Raquel. O modelo que fundamenta a socialdemocracia se esvaiu. Carta Capital. n. 879. Disponível em: $\quad<$ http://www.cartacapital.com.br/revista/879/todo-poder-real-aos-cidadaos-1218.html?utm_ content=buffer21d78\&utm_medium $=$ social\&utm_source $=$ twitter.com\&utm_campaign=buffer $>$. Acesso em: 20 dez.15.

VICO, Giambattista. Oraciones inaugurales \& la antiquísima sabiduría de los italianos. Barcelona: Anthropos, 2002. 


\title{
Contratos públicos y mercado global: un abordaje desde el derecho administrativo del siglo XXI*
}

\author{
Public contracts and global market: an \\ approach from the XXI century administrative \\ law
}

Bruno Ariel Rezzoagli**

\section{Resumen}

En el presente escrito se plantea la necesidad de propiciar un nuevo abordaje doctrinal de la contratación pública a partir de los principios emanados del incipiente orden jurídico administrativo global; el cual impacta, cada vez con mayor intensidad, en las regulaciones nacionales sobre la materia. El Derecho administrativo también ha sido alcanzado por la globalización, que rompe con los viejos esquemas de la contratación administrativa con un carácter estrictamente doméstico en pos de una innegable tendencia hacia la conformación un Derecho global de los contratos públicos.

Palabras claves: Contratos públicos. Globalización. Derecho administrativo. Potestades. Tradición continental.

\section{Abstract}

In this article there is a need to foster a new doctrinal approach to procurement from the principles enshrined in the emerging global administrative legal order; which strikes, with increasing intensity, national regulations on the subject. The administrative law also has been hit by globalization, which breaks the old schemes of government contracting with a purely domestic nature after an undeniable trend towards shaping a comprehensive law on public contracts.

Keywords: Procurement. Globalization. Administrative law. Powers. Continental tradition.

* Recebido em 21/01/2016 Aprovado em 05/06/2016

** Pós-doutorado em Finanças Públicas pelo Consejo Nacional de Investigaciones Científicas y Técnicas (Argentina). Doutor pela Universidade de Salamanca (Espanha). Professor da Universidad Nacional del Litoral. E-mail: brezzoagli@hotmail.com

\section{INTRODUCCIÓN}

Uno de los temas más importantes del Derecho administrativo es, sin lugar a dudas, la contratación pública. En efecto, en la actividad administrativa, junto con las manifestaciones de carácter unilateral se desarrollan acciones bilaterales en las que la Administración Pública entabla relaciones con otros 
sujetos; destacando, en el marco de este tipo de relaciones, la figura del contrato administrativo por su importancia jurídico-económica ${ }^{1}$.

Sin embargo, el tradicional entendimiento del Derecho administrativo se ve afectado por el surgimiento de un espacio jurídico-administrativo global, en el que habita toda una serie de regulaciones de tal carácter. Estamos, pues, frente a una realidad distinta que hay que analizar y comprender con una perspectiva diferente, con una mentalidad más abierta y plural porque, de lo contrario, quedaremos atrapados en aquellos prejuicios que atentan contra la evolución social ${ }^{2}$.

Es un gran error considerar que la enseñanza y aprendizaje del Derecho es un tema del pasado que poco importa frente a la tecnología moderna y las necesidades actuales; nada más importante que brindar la seguridad necesaria para crecer, que la presencia de la justicia y el Estado de Derecho, puesto que de ello depende el desarrollo de toda disciplina ${ }^{3}$.

Por ello, en la actualidad cuando nos referimos a la contratación pública, tenemos que hacerlo desde la perspectiva del Derecho administrativo del siglo XXI, que es fruto de participación, pluralismo y respeto a la dignidad humana ${ }^{4}$.

Cabe aclarar que los contratos del Estado se rigen por distintos regímenes jurídicos en los diferentes ordenamientos domésticos. Efectivamente, en unos países, por influencia del Derecho francés, se admite la figura del contrato administrativo, con la que se definen los contratos más frecuentemente celebrados por sus Administraciones (obras, suministros y servicios públicos) y cuya regulación se entiende objeto del Derecho administrativo sustantivo (sistema jurídico-administrativo continental); mientras que en la mayoría de los otros ordenamientos, los contratos que celebran las Administraciones públicas se consideran contratos privados sujetos a las normas comunes del Derecho civil y mercantil (sistema jurídico-administrativo de inspiración anglosajona) 5 .

En cualquier caso, tanto los unos como los otros tienen que ajustarse a este nuevo escenario que estamos comentando, que afecta más, como veremos a continuación, al sistema jurídico continental -de origen francés- (donde se ha desarrollado la teoría clásica de la noción de cláusula exorbitante que ba configurado la esencia del contrato administrativo) que al de inspiración anglosajona. Es por ello que en el presente artículo ahondaremos en el estudio de este emergente Derecho administrativo global -concretamente sobre el sector de la contratación pública-, de los denominados órganos administrativos globales, de los principios de este nuevo espacio jurídico, para luego reflexionar sobre su impacto en los ordenamientos domésticos sobre contratos públicos de los países con tradición jurídico-administrativa europeo continental.

\section{Globalización y Derecho administrativo}

El estudioso de la administración pública debe tener presente esta realidad en la que sectores de la actividad administrativa están sometidos a normas de carácter transnacional o intergubernamental, como es

1 NEVADO BATALLA, Pedro. Notas sobre derecho administrativo II. Salamanca: Ratio Legis, 2002. p. 123.

2 RODRÍGUEZ ARANA, Jaime et al. Derecho internacional de las contrataciones públicas. San José: Guayacán, 2011. p. 21.

3 GÓMEZ PALACIO, Ignacio. Enseñar, aprender y ejercer el Derecho ante los retos del cambio: evolución ineludible. En: ROJAS, Víctor Manuel (Coord.). La enseñanz̧a del Derecho en la Universidad Iberoamericana. México: Universidad Iberoamericana, 2002. p. 119. En este sentido el Profesor Rodríguez Arana señala que "ahora que percibimos la emergencia de este nuevo Derecho Administrativo en el que existe, todavía "in fieri”, una nueva Administración global que opera en el nuevo espacio jurídico global, es fundamental desde ya que los principios sobre los que va a descansar esta nueva realidad jurídico público se inscriban claramente en los postulados del Estado de Derecho”. Vid. RODRÍGUEZ ARANA, Jaime. El derecho administrativo global: un derecho principal. Administración de Andalucía: Revista Andaluza de Administración Pública, Sebilla, n. 76, ene./abr. 2010. p. 7.

4 PENAGOS, Gustavo. Nuevas tendencias del derecho administrativo a principios del siglo XXI. Revista Universitas, Bogotá, n. 106. p. 387, dic. 2003. p. 387.

5 MORENO MOLINA, José Antonio. El proceso de formación de un derecho global de la contratación pública. Revista DIXI, v. 14, n. 15 , p. 8-15, ene./jun. 2012. p. 12. 
el caso de la seguridad pública, la regulación de la energía, las telecomunicaciones, la inmigración, el medio ambiente, la llamada ayuda al desarrollo y muy especialmente, la contratación pública ${ }^{6}$.

Nuestros maestros nos enseñaban -me refiero principalmente a quienes nos formamos siguiendo una tradición juridica europeo continental- las notas distintivas de los contratos administrativos en torno al concepto de servicio público, cuya noción surgió en Francia caracterizada como actividad de determinado tipo realizada por la Administración en forma directa, o indirectamente a través de concesionarios, y fue el concepto que sirvió para la elaboración del viejo Derecho administrativo?

La relación con el servicio público era lo que justificaba la competencia de los tribunales llamados contencioso-administrativos, la naturaleza de contrato administrativo que asumían ciertos convenios con la Administración, el régimen jurídico del dominio público, la monopolización del servicio o falta de libre competencia, etc ${ }^{8}$. No obstante, la de "servicio público" es una noción que se revisa constantemente a fin de adecuar a ella las acciones que actualmente realiza la Administración pública; dado que la sociedad actual y, por consiguiente, sus necesidades, nada tienen que ver con el concepto de servicio público que vio la luz en el siglo XIX. Efectivamente, se trata de la institución jurídica más discutida y menos precisa en sus perfiles y en su determinación material y objetiva ${ }^{9}$.

En el ámbito contractual, la idea de lo público se vincula, por una parte, con el Estado como sujeto contratante pero, fundamentalmente, su principal conexión es con el interés general o bien común que persiguen, de manera relevante e inmediata, los órganos estatales al ejercer la función administrativa ${ }^{10}$.

En este sentido se expresa el Profesor de la Universidad de Salamanca Miguel Ángel González Iglesias al afirmar que "el contrato se nos presenta como uno de los instrumentos de la Administración para la consecución de sus fines", por lo tanto "es claro que la celebración de los mismos es parte integrante del elenco de potestades que las leyes le confieren a la misma para alcanzarlos. Potestad y contrato, por lo tanto, no son conceptos reñidos, sino que, por el contrario, el segundo se nos presenta como una aplicación de la primera"11.

Este fenómeno - el de la contratación pública- fue descripto, en la etapa de mayor auge de la tesis "ius administrativa" del contrato, como un sistema antagónico al de la contratación privada ${ }^{12}$. Las Administraciones públicas disfrutan de unas facultades exorbitantes en los contratos administrativos, tales como el poder de dirección, inspección y control de las obras, el poder de interpretación unilateral del contrato, la potestad de modificar el contrato por razón de interés público (potestas variandi), la potestad de suspender las obras por motivos de interés colectivo, la inaplicación general de las excepciones de incumplimiento administrativo, el régimen especial de mora administrativa, potestad de resolución unilateral del contrato y del principio de ejecutividad de los acuerdos ${ }^{13}$. Dichas prerrogativas traen su causa, desde otro plano, no del contrato, sino

6 RODRÍGUEZ ARANA, Jaime et al. Derecho internacional de las contrataciones públicas. San José: Guayacán, 2011. p. 20.

7 GORDILLO, Agustín. Tratado de derecho administrativo. 9. ed. Buenos Aires: Fundación de Derecho Administrativo, 2009 . p. VI-1.

8 GORDILLO, Agustín. Tratado de derecho administrativo. 9. ed. Buenos Aires: Fundación de Derecho Administrativo, 2009. . p. VI-1.

9 Vid. CHUAYFFET CHEMOR, Emilio. Derecho Administrativo. México: UNAM, 1983. (Introducción al Derecho mexicano, 4). p. 317; GARCÉS SANAGUSTÍN, Mario. La acción de fomento ante la nueva tipología de entes públicos. Presupuesto y Gasto Público, Madrid, n. 60, p. 7-23, 2010. p. 8; PONCE GÓMEZ, Francisco; PONCE CASTILLO, Rodolfo. Derecho fiscal. 11. ed. México: Limusa, 2007. p. 53; TRUCHET, Didier. Label de service public et statut du service public. Actualité Juridique-Droit Administratif, v. 1, 1982. p. 427-439.

10 CASSAGNE, Juan Carlos. El Derecho administrativo argentino: el derecho administrativo iberoamericano. Granada: INAP -UIM, 2005. p. 60 .

11 GONZÁLEZ IGLESIAS, Miguel Ángel. El contrato administrativo de consultoría y assistência. Madrid: Marcial Pons, 2002. p. 21.

12 CASSAGNE, Juan Carlos. Características principales del régimen de contrataciones de la Administración Nacional. Disponible en: < http:/ / www.cassagne.com.ar/publicaciones/Cassagne/CASSAGNE $\% 20-\% 20$ Caracteristicas $\% 20$ principales $\% 20 \mathrm{del} \% 20 \mathrm{RCAN}$.pdf>. Consultado el: 15 ago. 2012.

13 RODRÍGUEZ ARANA, Jaime. Las prerrogativas de la administración en los contratos de las administraciones Públicas. Anuario da Facultade de Dereito da Universidade da Coruña, n. 12, 2008. p. 801. Como ha señalado el profesor Ariño Ortiz "los "privilegios" 0 "prerrogativas de la Administración en la contratación son consecuencia obligada de dos factores: 1) la posición jurídica general de la Administración en el Estado moderno y 2) la tutela que el Derecho presta a los intereses públicos". Vid. ARIÑO ORTÍZ, Gaspar. La reforma de la ley de contratos del estado. Madris: Unión, 1984. p. 95. 
de la ley, no son expresión de un derecho subjetivo, sino de una potestad atribuida "ex lege" para atender los intereses públicos”"14.

Como se puede apreciar, la Administración pública históricamente ha sido concebida, en aquellos países con tradición administrativa de origen francés, como el poder a través del cual el Estado entra en contacto con los ciudadanos; siendo aquélla el centro de un Derecho administrativo autónomo, especial y exorbitan$\mathrm{te}^{15}$.

Sin embargo, la globalización no sólo ha propiciado la creación de órganos administrativos globales, que no realizan su actividad dentro de un Estado sino en el ámbito global (incluyendo los ordenamientos jurídicos supranacionales), también ha impuesto determinadas exigencias sobre las Administraciones domésticas, propendiendo a que su actuación sea racional, eficiente, transparente y con pleno sometimiento a la ley, como condiciones básicas para facilitar el libre tránsito de bienes y servicios ${ }^{16}$. En consecuencia, la mundialización del Derecho ha provocado un cambio de paradigma, donde la Administración es definida a partir del propio ciudadano y sus libertades, y no desde el poder o la prerrogativa ${ }^{17}$.

Hasta hace muy poco, a nadie se le ocurría dudar siquiera que el Derecho aplicable a la contratación administrativa era el ordenamiento jurídico doméstico y que, para el caso de que surgiera alguna disputa al respecto, la única jurisdicción competente sería la nacional, en concreto la contencioso-administrativa" ${ }^{18}$. No obstante, en una economía global donde predomina la inversión extranjera y el financiamiento multilateral para la ejecución de grandes obras, concesión de servicios públicos, etc., debemos reconocer junto al contrato administrativo regido por el derecho doméstico, la presencia de otras especies contractuales en las que se aplica preponderantemente el Derecho internacional y, en menor medida, el régimen jurídico administrativo doméstico (con la posibilidad de aplicación analógica del derecho privado) ${ }^{19}$.

Atendiendo a tal consideración, es común encontrarnos en las distintas legislaciones domésticas con la exclusión de determinados contratos (los contratos celebrados con Estados extranjeros, con entidades de derecho público internacional, con instituciones multilaterales de crédito, los que se financien, total o parcialmente, con recursos provenientes de esos organismos así como los comprendidos en operaciones de crédito público") del régimen general aplicable a la contratación administrativa ${ }^{20}$.

Como se puede apreciar, las Administraciones de los países con tradición administrativa inspiradas en el régimen francés también resultan alcanzadas por los controles propios del orden jurídico-administrativo global a través de principios que propenden a la racionalización de su actividad en beneficio de la gobernanza democrática, reduciendo el significativo ámbito de apreciación que deriva del sistema conceptual basado en

14 RODRÍGUEZ ARANA, Jaime. Las prerrogativas de la administración en los contratos de las administraciones Públicas. Anuario da Facultade de Dereito da Universidade da Coruña, n. 12, 2008. p. 803. Dicho autor aclara que tanto la operatividad del Estado social de Derecho como la esencia "vicarial” de la Administración, aconsejan (más allá de los presupuestos históricos que han configurado la esencia del Derecho Administrativo) el uso del término "potestad", en lugar de las expresiones "privilegios" o "prerrogativas".

15 HERNÁNDEZ G., José Ignacio. El concepto de administración pública desde la buena gobernanza y el derecho administrativo global: su impacto en los sistemas de derecho administrativo de la América española. Anuario da Facultade de Dereito da Universidade da Coruña, n. 16, p. 197-223, 2012. p. 201

16 HERNÁNDEZ G., José Ignacio. El concepto de administración pública desde la buena gobernanza y el derecho administrativo global: su impacto en los sistemas de derecho administrativo de la América española. Anuario da Facultade de Dereito da Universidade da Coruña, n. 16, p. 197-223, 2012. p. 201.

17 HERNÁNDEZ G., José Ignacio. El concepto de administración pública desde la buena gobernanza y el derecho administrativo global: su impacto en los sistemas de derecho administrativo de la América española. Anuario da Facultade de Dereito da Universidade da Coruña, n. 16, p. 197-223, 2012. p. 201.

18 CREMADES, Bernardo. La participación de los estados en el arbitraje internacional. Disponible en: < http://www.ohadac. com/labores-otras-contribuciones/items/la-participacion-de-los-estados-en-el-arbitraje-internacional.html>. Consultado el: 10 ago. 2012.

19 CASSAGNE, Juan Carlos. El Derecho administrativo argentino: el derecho administrativo iberoamericano. Granada: INAP -UIM, 2005. p. 60-61.

20 CASSAGNE, Juan Carlos. El Derecho administrativo argentino: el derecho administrativo iberoamericano. Granada: INAP -UIM, 2005. p. 61. 
la prerrogativa y el servicio público ${ }^{21}$. Principios que, en palabras de Rodríguez Arana, suponen una evidente limitación a una interpretación expansiva de lo que en materia de contratación pública se conoce como prerrogativas o privilegios de la Administración ${ }^{22}$.

Efectivamente, en el actual contexto económico mundial las famosas cláusulas exorbitantes, en cuanto prerrogativas de la Administración por razones de interés público, deben entenderse no como privilegios (ello obedece a una vieja concepción administrativa) sino como poderes cuyo ejercicio debe ser oportuno y respetar los parámetros de proporcionalidad y racionalidad ${ }^{23}$. Por lo tanto, no nos referimos a la supresión de las mismas, solamente a que su ejercicio esté de acuerdo con los citados principios; siendo éste, el principal reto del Derecho administrativo del siglo XXI.

\section{La tendencia hacia un Derecho administrativo global de la contratación pública}

En este nuevo escenario mundial comienzan a presentarse, para Meilán Gil, manifestaciones de la existencia de un Derecho administrativo global ${ }^{24}$, el cual resulta una consecuencia lógica del auge de sistemas transnacionales de regulación o cooperación regulatoria que se producen a través de tratados internacionales y redes intergubernamentales de cooperación más informales ${ }^{25}$. En tal sentido, muchos detalles de la implementación de dicha regulación corresponde a los denominados órganos globales que desarrollan funciones administrativas pero que no están sujetos directamente al control de los gobiernos nacionales o a los sistemas domésticos o, en el caso de los regímenes basados en tratados, a los Estados parte del mimo ${ }^{26}$.

Los órganos globales administrativos incluyen, conforme lo expresan los profesores Kingsbury, Krisch y Stewart ${ }^{27}$, organizaciones internacionales formales ${ }^{28}$, redes regulatorias informales intergubernamentales y arreglos de cooperación ${ }^{29}$, órganos regulatorios nacionales que operan en relación a un régimen internacional intergubernamental, órganos regulatorios híbridos público-privados ${ }^{30}$, y algunos órganos regulatorios privados que ejercen funciones de gobernanza transnacional de importancia pública específica ${ }^{31}$.

Respecto a la acción administrativa a nivel global, ésta incorpora la reglamentación administrativa ${ }^{32}$, el procedimiento administrativo que dirime intereses contrapuestos, y otras formas de decisiones y gestión regulatoria y administrativa. En definitiva, la acción administrativa global tiene, al igual que la doméstica, elementos tanto normativos como de carácter jurisdiccional ${ }^{33}$.

21 HERNÁNDEZ G., José Ignacio. El concepto de administración pública desde la buena gobernanza y el derecho administrativo global: su impacto en los sistemas de derecho administrativo de la América española. Anuario da Facultade de Dereito da Universidade da Coruña, n. 16, p. 197-223, 2012. p. 203.

22 RODRÍGUEZ ARANA, Jaime. Los principios del derecho global de la contratación pública. Derecho PUCP, n. 66, 2011 . p. 51.

23 RODRÍGUEZ ARANA, Jaime. Las prerrogativas de la administración en los contratos de las administraciones Públicas. Anuario da Facultade de Dereito da Universidade da Coruña, n. 12, 2008. p. 812.

24 MEILÁN GIL, José Luis. Una aproximación al derecho administrativo global. Sevilla: Derecho Global, 2011. p. 13.

25 RODRÍGUEZ ARANA, Jaime et al. Derecho internacional de las contrataciones públicas. San José: Guayacán, 2011. p. 26.

26 KINGSBURY, Benedict; KRISCH, Nico; STEWART, Richard. El surgimiento del Derecho Administrativo Global. Revista de Derecho Público, n. 24, Universidad de los Andes, mar. 2010. p. 6.

27 KINGSBURY, Benedict; KRISCH, Nico; STEWART, Richard. El surgimiento del Derecho Administrativo Global. Revista de Derecho Público, n. 24, Universidad de los Andes, mar. 2010. p. 7.

28 Basta con mencionar al Consejo de Seguridad de la ONU y comités derivados, el Alto Comisionado de las Naciones Unidas para los refugiados, la Organización Mundial de la salud, el Banco Mundial o Grupo de Acción Financiera Internacional.

29 Por ejemplo, el Comité de Supervisión Bancaria de Basilea.

30 Encuadran dentro de esta categoría: Comisión del Codex Alimentarius, Corporación de Internet para la Asignación de Nombres y Números (ICANN, por sus siglas en inglés).

31 Podemos citar, a modo de ejemplo, a la Organización Internacional de Normalización (ISO).

32 No en forma de tratados negociados por los Estados, pero sí de estándares y de reglas de aplicación general adoptadas por órganos subsidiarios. Efectivamente, ejercen funciones regulatorias de supervisión aquellos órganos cuasi-judiciales tales como el Órgano de Apelación del Órgano de Solución de Controversias de la OMC.

33 KINGSBURY, Benedict; KRISCH, Nico; STEWART, Richard. El surgimiento del Derecho Administrativo Global. Revista de 
Sin embargo, tal como expresa Rodríguez Arana, "ciertamente, esta cuestión es polémica, puesto que no toda la doctrina, ni muchos menos, admite que pueda haber regulación administrativa emanada más allá de órganos o estructuras no formalmente administrativas del nivel estatal o nacional, regional o subestatal' ${ }^{34}$.

Por otra parte, este proceso de formación del denominado Derecho administrativo global se ve reflejado con mayor nitidez en el terreno de los contratos públicos, puesto que éstos han sido objeto en las últimas décadas de importante legislación y acuerdos internacionales, como de jurisprudencia de órganos con jurisdicción internacional que han fijado principios generales, y de actuaciones administrativas, entre otras, de solución de controversias entre Estados u otras partes en disputa ${ }^{35}$.

Finalmente, Moreno Molina sostiene que el "Derecho administrativo global de los contratos públicos" es una noción que admite dos interpretaciones distintas, una restrictiva y otra en sentido amplio. En sentido estricto, este Derecho comprendería las normas y los principios que disciplinan la acción administrativa de las instituciones internacionales y de las administraciones nacionales como ejecutoras de esas decisiones; mientras que en un sentido más amplio, dicha noción describiría el proceso de desarrollo de un Derecho administrativo común en esta materia ${ }^{36}$.

\section{NoRMAS JURÍDICAS DE CARÁCTER INTERNACIONAL EN MATERIA DE CONTRATACIÓN PÚBLICA}

En el terreno internacional, debemos destacar los Acuerdos de contratación pública de la Organización Mundial de Comercio (OMC), las Normas de contratación pública del Tratado de Libre Comercio de América del Norte (TLCAN), el Protocolo sobre contrataciones públicas del Mercado Común del Sur (Mercosur), la llamada Ley modelo de contratación pública de Naciones Unidas (ONU), etc.

La mundialización de la economía, con la consecuente liberalización del comercio e innovación tecnológica, ha propiciado la celebración de acuerdos para estimular la inversión extranjera en los diferentes países; lo cual ha tenido una particular incidencia en materia de contratación pública dado que dichos acuerdos de inversión proporcionan el marco legal para que a su amparo se susciten los contratos con las entidades del sector público ${ }^{37}$.

Como se verá a continuación, los principales instrumentos jurídicos internacionales en materia de contratación se han construido sobre la base de los principios de no discriminación, de publicidad, de libre concurrencia, etc.; siendo expresión de la obligatoriedad que tienen las entidades gubernamentales y los entes del sector público, al gestionar fondos públicos, de actuar con transparencia y objetividad a los fines de adjudicar el contrato a la mejor oferta con miras al interés general ${ }^{38}$.

\subsection{El Acuerdo Plurilateral de Contratación Pública de la Organización Mundial de Comercio}

En el ámbito de las normas del comercio internacional, las contrataciones y adquisiciones públicas han sido históricamente omitidas ${ }^{39}$. En el Acuerdo General sobre Aranceles Aduaneros y Comercio (GATT)

Derecho Público, n. 24, Universidad de los Andes, mar. 2010. p. 7.

34 RODRÍGUEZ ARANA, Jaime. El derecho administrativo global: un derecho principal. Administración de Andalucía: Revista Andaluza de Administración Pública, Sebilla, n. 76, ene./abr. 2010. p. 22

35 MORENO MOLINA, José Antonio. La importante evolución hacia un Derecho Global de la Contratación Pública. En: PERNAS GARCÍA, J. José; MARTÍN RETORTILLO, María del Carmen Rodríguez (Coord.). La reforma de las Administraciones públicas. Madrid: Bubok, 2014. p. 499-516. p. 500.

36 MORENO MOLINA, José Antonio. El proceso de formación de un derecho global de la contratación pública. Revista DIXI, v. 14, n. 15 , p. 8-15, ene./jun. 2012. p. 10.

37 MEILÁN GIL, José Luis. Una aproximación al derecho administrativo global. Sevilla: Derecho Global, 2011. p. 60-61.

38 RODRÍGUEZ ARANA, Jaime. Los principios del derecho global de la contratación pública. Derecho PUCP, n. 66, 2011 . p. 31.

39 Vid. CONFERENCIA INTERNACIONAL DEL TRABAJO. Cláusulas de trabajo en los contratos celebrados por las autoridades 
de 1947, las compras públicas quedaron excluidas de forma explícita de la obligación fundamental de conceder trato nacional. Fue recién en 1979 cuando se firmó el primer Acuerdo sobre Compras del Sector Público, producto de las negociaciones comerciales de la Ronda de Tokio, que entró en vigencia en 1981 y se modificó en 1987 y cuya versión enmendada entró en vigor en 1988. Posteriormente, las Partes en el Acuerdo celebraron negociaciones para ampliar su alcance y aplicación, y cuyo resultado se ve reflejado en el Acuerdo sobre Contratación Pública que se firmó en Marrakech el 15 de abril de 1994, al mismo tiempo que el Acuerdo por el que se establece la OMC. El nuevo Acuerdo entró en vigor el $1^{\circ}$ de enero de $1996^{40}$.

Dicho acuerdo previó su propia revisión en los apartados b) y c) del párrafo 7 del artículo XXIV. El proceso para su reforma ha tenido dos momentos de gran relevancia, al llegarse a un primer acuerdo en el 2006 y culminar las negociaciones el 15 de diciembre del $2011^{41}$.

Se trata de un acuerdo plurilateral de compras públicas ${ }^{42}$ que supuso un hito fundamental en la liberalización en este sector, y que tiene por objetivo abrir a la competencia internacional la contratación de los gobiernos de sus paises signatarios, que se comprometen a aplicar procedimientos más transparentes y a asegurar un trato no discriminatorio a los bienes y servicios ofrecidos por empresas de cualquiera de ellos" ${ }^{33}$.

Además del principio de no discriminación ${ }^{44}$, el citado acuerdo establece procedimientos específicos a los que habrán de ajustarse los concursos públicos en relación a un amplio abanico de empresas públicas en los sectores del agua, la electricidad, los transportes urbanos, los puertos y aeropuertos ${ }^{45}$.

\subsection{Normas de contratación pública del Tratado de Libre Comercio de América del Norte}

El capítulo X del Tratado de Libre Comercio de América del Norte (en adelante, TLCAN), denominado "compras del sector público", tiene como objetivo principal la apertura de los mercados de adquisiciones y contrataciones públicas de Canadá, Estados Unidos y México a través de procedimientos de adjudicación claros, transparentes y predecibles, que garanticen un trato justo y no discriminatorio a todos los proveedores de la zona de libre comercio de América del Norte y, por ende, unas condiciones de igualdad en lo que respecta al acceso a la contratación pública de distintas áreas compradoras de los países suscriptores del citado tratado ${ }^{46}$.

Efectivamente, en dicho capítulo se establece que los países otorgarán a los bienes de otra parte, a los proveedores de dichos bienes y a los proveedores de servicios de otra parte, un trato no menos favorable que el más favorable otorgado a: a) sus propios bienes y proveedores, y b) los bienes y proveedores de otra parte. Además, el tratado prevé que ninguno de los miembros podrá: a) dar a un proveedor establecido localmente un trato menos

públicas. Genebra: OIT, 2008.

40 MORENO MOLINA, José Antonio. El proceso de formación de un derecho global de la contratación pública. Revista DIXI, v. 14, n. 15 , p. 8-15, ene./jun. 2012. p. 12; 13.

41 MORENO MOLINA, José Antonio. El proceso de formación de un derecho global de la contratación pública. Revista DIXI, v. 14 , n. 15 , p. 8-15, ene./jun. 2012. p. 16.

42 Es importante aclarar que los acuerdos de carácter plurilateral son aquéllos cuya aplicación únicamente recae sobre los miembros de la Organización Mundial de Comercio que hayan sido signatarios de los mismos; a diferencia de los que poseen carácter "multilateral", los cuales se aplican a todos los miembros de la citada Organización por el simple hecho de ser parte en el acuerdo por el que se crea la misma.

43 BONET BAIGET, Alfredo. Nuevas oportunidades en la contratación pública internacional. Boletín Económico de ICE, n. 3025 , abr. 2012. p. 1.

44 Conforme el párrafo 1, apartado a) del artículo III del acuerdo, las partes tienen que conceder a los productos, servicios y proveedores de las demás partes en el Acuerdo, un trato "no menos favorable" que el otorgado a sus productos, servicios y proveedores nacionales.

45 MONTAÑÁ I MORA, Miquel. Posibles modelos para la regulación de la competencia en la organización mundial del comercio. Revista Electrónica de Estudios Internacionales, n. 2, 2001. p. 5.

46 JIMÉNEZ VÁZQUEZ, Raúl. Consideraciones en torno al capítulo de compras del TLCAN y su eventual impacto en el Derecho mexicano. En: EL TRATADO de Libre Comercio de América del Norte: Análisis, diagnóstico y propuestas jurídicos, México: Instituto de Investigaciones Jurídicas; UNAM, 1993. p. 261. 
favorable que el otorgado a otro proveedor establecido localmente, en razón del grado de afiliación o de propiedad extranjeras; o b) discriminar contra un proveedor establecido localmente en razón de que los bienes o servicios ofrecidos por ese proveedor para una compra particular, sean bienes o servicios de otra parte ${ }^{47}$.

\subsection{El Protocolo de Contrataciones Públicas del Mercado Común del Sur}

En el ámbito del Mercado Común del Sur (fundado el 26 de marzo de 1991 como un espacio de integración intergubernamental mediante el tratado de Asunción suscrito por los representantes de Argentina, Brasil, Paraguay y Uruguay ${ }^{48}$ ) se adoptó, el 9 de diciembre de 2004, el Protocolo de contrataciones públicas del Mercosur mediante la Decisión del Consejo del Mercado Común No 27/04.

Los Estados Miembros del Mercosur adoptaron dicho protocolo con miras a extender gradualmente la transparencia en las contrataciones efectuadas por las entidades públicas ${ }^{49}$ y proporcionar a los proveedores y prestadores establecidos en los Estados partes y a los bienes, servicios y obras públicas originarios de esos Estados partes un tratamiento no discriminatorio en los procesos contractuales llevados a cabo por las entidades del sector público. En tal sentido, el art. 1 inc. 2 del citado protocolo, se establece que "Los procesos de contrataciones públicas de bienes, servicios y obras públicas deberán ser realizados de forma transparente, observando los principios básicos de legalidad, objetividad, imparcialidad, igualdad, debido proceso, publicidad, vinculación al instrumento de la convocatoria, concurrencia y los que concuerden con ellos".

En cuanto a su ámbito de aplicación, el art. $2^{\circ}$ dispone que "El Protocolo se aplica a las contrataciones públicas que las entidades de todos los niveles de gobierno federales y subfederales celebren para la adquisición de bienes y servicios, cualquiera sea su combinación, incluidas las obras públicas mediante cualquier método contractual', incluyendo en el Anexo I las entidades comprendidas en la norma.

En definitiva, este protocolo establece una mayor transparencia para las compras gubernamentales en base a la cláusula de la "Nación más favorecida" y el otorgamiento del "trato nacional" en buena parte de las licitaciones respectivas referidas a bienes, servicios y obra pública ${ }^{50}$. En efecto, ningún Estado parte podrá: a) discriminar a un proveedor o prestador establecido en cualquiera de los Estados Partes por motivo de uma afiliación o propiedad extranjera o, b) discriminar a um provedor o prestador estabelecido em su territorio em razón de que los bienes o servicios u obras públicas ofrecidos por ese proveedor o prestador, para una contratación en particular, sean de otro Estado Parte (art. 5 inc. 2).

\subsection{La Ley Modelo sobre Contratación Pública de Naciones Unidas}

La Comisión de Naciones Unidas para el Derecho Mercantil Internacional (CNUDMI) aprobó el 15 de junio de 1994 la denominada Ley Modelo sobre Contratación Pública, la cual se bien carece de valor normativo constituye una técnica indirecta para el desarrollo de relaciones económicas internacionales armonizadas entre los Estados, con diferentes sistemas jurídicos, sociales y económicos, en la medida que sus términos puedan considerarse favorablemente por sus Estados al promulgar o revisar las legislaciones sobre contratación pública ${ }^{51}$.

Esta ley modelo tiene como propósito central la promoción de la objetividad, la equidad y la participación en los procedimientos de adjudicación de los contratos públicos, así como la competencia empresarial y la transparencia, para alcanzar un uso óptimo de los recursos involucrados en la misma.

47 Vid. art. 1003 TLCAN.

48 GROS ESPIELL, Héctor et al. El derecho de la integración del Mercosur. Montevideo: U.M., 1999. p. 35 y ss.

49 Vid. CONFERENCIA INTERNACIONAL DEL TRABAJO. Cláusulas de trabajo en los contratos celebrados por las autoridades públicas. Genebra: OIT, 2008.

50 LUCÁNGELI, Jorge; SANGUINETTI, Mariana; ZAMORANO, Ana. Mercosur: la consolidación de la expansión de la economía del Bloque. Revista del CEI, n. 18, ago. 2010.

51 ESCRIHUELA MORALES, Francisco. La contratación del sector público: especial referencia a los contratos de suministro y de servicios. Madrid: La Ley, 2007. 
De conformidad con lo establecido en sus considerandos ${ }^{52}$, son objetivos de la misma los siguientes:

Alcanzar una máxima economía y eficiencia en la contratación pública;

Fomentar y alentar la participación de proveedores y contratistas en el proceso de contratación pública, sin hacer distinciones por concepto de nacionalidad, a fin de promover así el comercio internacional;

Promover la competencia entre proveedores o contratistas en orden al suministro del objeto del contrato adjudicable;

Garantizar un trato justo, igual y equitativo a todos los proveedores y contratistas;

Promover la rectitud y la equidad en el proceso de contratación, para que dicho proceso goce de la confianza pública; $y$

Dotar de transparencia a los procedimientos previstos para la contratación pública.

Sin lugar a dudas, se busca facilitar la armonización de la normativa internacional en una materia de gran importancia económica, y la de mayor interacción entre el sector público y los operados privados, como es la contratación pública. Efectivamente, nos referimos a las normas mencionadas anteriormente, y a otras, tales como por ejemplo las disposiciones de la Convención de las Naciones Unidas contra la Corrupción que trataremos a continuación.

\section{LA NORMATIVA COMUNITARIA EUROPEA SOBRE CONTRATOS PÚBLICOS}

Hemos decidido dedicar un apartado específico a la normativa comunitaria europea sobre contratación pública, dado que ésta constituye, en palabras del profesor Moreno Molina, "uno de los sectores en que el desarrollo del Derecho comunitario ha llegado más lejos y, consiguientemente, donde la armonización de los ordenamientos de los Estados miembros de la Comunidad se está produciendo con mayor intensidad"53.

La regulación de los contratos públicos es parte esencial de la política identificada por la Comisión y el Consejo de la Comunidad como necesaria para realizar el mercado interior ${ }^{54}$, el cual implica un espacio sin fronteras interiores, en el que esté garantizada la libre circulación de mercancías, personas, servicios y capitales $^{55}$.

Por lo tanto, el hacer efectivas las libertades fundamentales comunitarias necesarias para crear un mercado común (libertad de establecimiento, libre prestación de servicios, libre circulación de mercancías) constituye el fundamento legal de la acción comunitaria en el campo de la contratación pública; por lo que resulta inadmisible la existencia de reglamentaciones nacionales discriminatorias para empresas no nacionales, de normas que exigen la utilización de productos o bienes nacionales, el favorecimiento sistemático de las empresas nacionales, como de cualquier otra medida exclusionaria de la concurrencia intracomunitaria ${ }^{56}$.

Además, la política comunitaria europea para la apertura de los llamados mercados públicos ${ }^{57}$ a las reglas

52 Vid. Ley modelo sobre Contratación Pública.

53 MORENO MOLINA, José Antonio. El derecho de la Unión Europea en materia de contratación pública, organismo supervisor de las contrataciones del estado (OSCE). Lima, Perú. Disponible en: <http://www.osce.gob.pe/consucode/userfiles/image/moreno.pdf>.p. 11. 54 GIL ANTÓN, A. La aplicación del derecho comunitario y la repercusión en el ámbito territorial de la contratación pública de servicios financeiros. Noticias de la Unión Europea, v. 10, n. 119, p. 79-114, 1994. p. 71.

55 El Libro Blanco de la Comisión preveía, para la consecución de un mercado interior único, la desaparición de las fronteras físicas, técnicas y fiscales. Por lo que, este Libro contenía, dentro de su parte II que dedicaba a la supresión de las barreras técnicas, un apartado relativo a los contratos públicos, puesto que dicha eliminación se alcanzaría mediante la apertura del sistema interno de contratación pública a la concurrencia intracomunitaria.

56 JIMÉNEZ DE LAIGLESIA, José María. Adjudicaciones directas de contratos públicos y Derecho Comunitario. Comunidad Europea Aranzadi, Madrid, v.21, n. 7-8, p. 39-45, jul./ago. 1994. p. 39.

57 Vid. SAMANIEGO BORDIÚ, Gonzalo. La apertura de los contratos públicos en la Comunidad Europea: situación actual y 
efectivas de la competencia está basada en la idea de que esa apertura provoca significativos ahorros a las autoridades públicas intervinientes (reducción del gasto público), así como un beneficio sustancial al mercado en su conjunto ${ }^{58}$, en función a los estudios realizados a iniciativa de la Comisión sobre el Costo de la no Europa $^{59}$. En efecto, cuanto más numerosas sean las alternativas de elección mayores serán las posibilidades de beneficio entre las partes contratantes, ya que los oferentes se verán incentivados por la competencia a mejorar sus propuestas, y los demandantes podrán conocer y valorar un mayor número de ofertas en orden a seleccionar aquella que mejor satisfaga la ecuación precio-calidad ${ }^{60}$.

De cualquier manera, más allá de los beneficios que origina la apertura de mercado, como hemos señalado anteriormente, existe una tendencia a «comprar nacional», entendiendo por tal la decisión habitual de seleccionar casi siempre un proveedor nacional a pesar de que otro proveedor extranjero ofreciese mejores condiciones $^{61}$. Tendencia ésta que puede explicarse por el hecho de que los poderes públicos persiguen, a través de la contratación pública, no sólo comprar o realizar sus tareas más económicamente, sino también intervenir en la vida económica, social y política de su país ${ }^{62}$.

Por esta razón, la Unión Europea ha llevado a cabo un intenso programa legislativo tendiente a crear reglas que garanticen la apertura de ese sector comercial, reforzando la competencia y la transparencia, y suprimiendo todo obstáculo interpuesto por los operadores económicos ${ }^{63}$. Fruto de esta actividad normativa, han sido, entre otras, las directivas: 92/50/CEE, 93/36/CEE y 93/37/CEE, sobre coordinación de los procedimientos de adjudicación de los contratos públicos de servicios, de los contratos públicos de suministro y de los contratos públicos de obras, respectivamente; la Directiva 97/52/CE por las que se modifican las anteriores; las directivas 2004/17/CE y 2004/18/CE; así como las directivas 2014/23/UE, relativa a la adjudicación de contratos de concesión; 2014/24/UE, sobre contratación pública y por la que se deroga la directiva 2004/18/CE; y 2014/25/UE, relativa a la contratación por entidades que operan en los sectores del agua, la energía, los transportes y los servicios postales y por la que se deroga la directiva 2004/17/CE.

Estas directivas persiguen fundamentalmente la coordinación de los procedimientos de adjudicación de contratos públicos garantizando la publicidad adecuada de las ofertas, la libre concurrencia a los mismos y la supresión de toda medida discriminatoria ${ }^{64}$. Finalmente, uno de los objetivos principales de las nuevas directivas comunitarias del año 2014 es facilitar el acceso de las PYMEs a la contratación pública, mediante la reducción del "papeleo" para contratar, la incorporación de las nuevas tecnologías (contratación electrónica) a los fines de propiciar un fácil acceso a las licitaciones convocadas en cualquier lugar de Europa sin necesidad de contar con una gran estructura empresarial.

perspectivas. Noticias CEE, v. 8, n. 88, 1992. p. 103-106.

58 LOS CONTRATOS públicos en un Espacio Económico Único. Luxemburgo: Documentación europea, Oficina de Publicaciones Europeas, 1988. p. 11; GIL ANTÓN, A. La aplicación del derecho comunitario y la repercusión en el ámbito territorial de la contratación pública de servicios financeiros. Noticias de la Unión Europea, v. 10, n. 119, p. 79-114, 1994. p. 71.

59 El "Informe sobre el coste de la no Europa", realizado por la Comisión bajo la dirección de Paolo Cecchini, señalaba que debido a los sistemas proteccionistas de compras impuestos por los distintos Estados miembros, las autoridades públicas pagan más de lo que debieran en la adquisición de los bienes y servicios que necesitan, apoyando de esta forma a empresas subóptimas de la Comunidad (CECCHINI, P. Europa 1992: Una apuesta de futuro. Madrid: Alianza, 1988. p. 50 y ss).

60 OJEDA MARÍN, A. La Comunidad Europea y el GATT en el moderno sistema de contratación pública, RAP, n. 116, Madrid, 1988. p. 413.

61 SAMANIEGO BORDIÚ, Gonzalo. La normativa comunitaria de los contratos de las empresas que actúan en los sectores del agua, la energía, los transportes y las comunicaciones. REDA, n. 71, 1991. p. 358.

62 MATTERA, ALFONSO. EL Mercado Único Europeo: sus reglas, su funcionamento. Madrid: Civitas, 1991. p. 386.

63 SAMANIEGO BORDIÚ, Gonzalo. La apertura de los contratos públicos en la Comunidad Europea: situación actual y perspectivas. Noticias CEE, v. 8, n. 88, 1992. p. 103.

64 JIMÉNEZ DE LAIGLESIA, José María. Adjudicaciones directas de contratos públicos y Derecho Comunitario. Comunidad Europea Aranzadi, Madrid, v.21, n. 7-8, p. 39-45, jul./ago. 1994. p. 40. 


\section{A MODO DE REFLEXIÓN FINAL}

El recorrido realizado en estas páginas nos permite afirmar que estamos siendo verdaderos testigos del surgimiento y formación de un orden jurídico administrativo global, que provoca, particularmente en el ámbito de los contratos públicos, un significativo cambio de paradigma. Este replanteamiento de la contratación pública obedece al resquebrajamiento de la concepción exclusivamente doméstica de aquélla, dado que también comienza a ser alcanzada por los principios y controles propios de dicho Derecho global.

Efectivamente, este emergente orden jurídico global ha impactado y sigue impactando, incluso cada vez con mayor intensidad, en las regulaciones domésticas sobre contratación pública, propiciando que las organizaciones gubernamentales y demás entes del sector público respeten en su actuación contractual los principios de competencia, igualdad de trato, racionalidad, proporcionalidad, participación, transparencia y rendición de cuentas; los cuales modulan el ejercicio de los poderes o prerrogativas de la Administración en los países con tradición administrativa inspirada en el régimen francés.

\section{REFERENCIAS BIBLIOGRÁFICAS}

ARIÑO ORTÍZ, Gaspar. La reforma de la ley de contratos del estado. Madris: Unión, 1984.

BONET BAIGET, Alfredo. Nuevas oportunidades en la contratación pública internacional. Boletín Económico de ICE, n. 3025, abr. 2012.

CASSAGNE, Juan Carlos. Características principales del régimen de contrataciones de la administración nacional. Disponible en: <http://www.cassagne.com.ar/publicaciones/Cassagne/CASSAGNE\%20-\%20 Caracteristicas $\% 20$ principales $\% 20 \mathrm{del} \% 20 \mathrm{RCAN}$.pdf $>$.

CASSAGNE, Juan Carlos. El Derecho administrativo argentino: el derecho administrativo iberoamericano. Granada: INAP -UIM, 2005.

CECCHINI, P. Europa 1992: Una apuesta de futuro. Madrid: Alianza, 1988.

CHUAYFFET CHEMOR, Emilio. Derecho Administrativo. México: UNAM, 1983. (Introducción al Derecho mexicano, 4).

CREMADES, Bernardo. La participación de los estados en el arbitraje internacional. Disponible en: $<$ http://www.ohadac.com/labores-otras-contribuciones/items/la-participacion-de-los-estados-en-el-arbitraje-internacional.html>.

CONFERENCIA INTERNACIONAL DEL TRABAJO. Cláusulas de trabajo en los contratos celebrados por las autoridades públicas. Genebra: OIT, 2008.

ESCRIHUELA MORALES, Francisco. La contratación del sector público: especial referencia a los contratos de suministro y de servicios. Madrid: La Ley, 2007.

GARCÉS SANAGUSTÍN, Mario. La acción de fomento ante la nueva tipología de entes públicos. Presupuesto y Gasto Público, Madrid, n. 60, p. 7-23, 2010.

GIL ANTÓN, A. La aplicación del derecho comunitario y la repercusión en el ámbito territorial de la contratación pública de servicios financeiros. Noticias de la Unión Europea, v. 10, n. 119, p. 79-114, 1994.

GÓMEZ PALACIO, Ignacio. Enseñar, aprender y ejercer el Derecho ante los retos del cambio: evolución ineludible. En: ROJAS, Víctor Manuel (Coord.). La enseñanz̧a del Derecho en la Universidad Iberoamericana. México: Universidad Iberoamericana, 2002. 
GONZÁLEZ IGLESIAS, Miguel Ángel. El contrato administrativo de consultoría y assistência. Madrid: Marcial Pons, 2002.

GONZÁLEZ-VARAS IBÁÑEZ, Santiago. El contrato administrativo. Madrid: Civitas, 2003.

GONZÁLEZ-VARAS IBÁÑEZ, Santiago. El control sobre la adjudicación mediante concurso y el Derecho Comunitario europeo: Sentencias del Tribunal de Justicia de las Comunidades Europeas de 17 de septiembre de 2002 (Asunto c-513/99) y de 18 de junio de 2002 (Asunto c-92/00). Noticias de la Unión Europea, n. 219, p. 21-25, 2003.

GONZÁLEZ-VARAS IBÁÑEZ, Santiago. La Administración y las nuevas tecnologías. Asamblea: Revista Parlamentaria de la Asamblea de Madrid, n. 7, p. 215-240, 2002.

GORDILLO, Agustín. Tratado de derecho administrativo. 9. ed. Buenos Aires: Fundación de Derecho Administrativo, 2009.

GROS ESPIELL, Héctor et al. El derecho de la integración del Mercosur. Montevideo: U.M., 1999.

HERNÁNDEZ G., José Ignacio. El concepto de administración pública desde la buena gobernanza y el derecho administrativo global: su impacto en los sistemas de derecho administrativo de la América española. Anuario da Facultade de Dereito da Universidade da Coruña, n. 16, p. 197-223, 2012.

JIMÉNEZ DE LAIGLESIA, José María. Adjudicaciones directas de contratos públicos y Derecho Comunitario. Comunidad Europea Aranz̧adi, Madrid, v.21, n. 7-8, p. 39-45, jul./ago. 1994.

JIMÉNEZ VÁZQUEZ, Raúl. Consideraciones en torno al capítulo de compras del TLCAN y su eventual impacto en el Derecho mexicano. En: EL TRATADO de Libre Comercio de América del Norte: Análisis, diagnóstico y propuestas jurídicos, México: Instituto de Investigaciones Jurídicas; UNAM, 1993.

KINGSBURY, Benedict; KRISCH, Nico; STEWART, Richard. El surgimiento del derecho administrativo global. Revista de Derecho Público, n. 24, mar. 2010.

LOS CONTRATOS públicos en un Espacio Económico Único. Luxemburgo: Documentación europea, Oficina de Publicaciones Europeas, 1988.

LÓPEZ-FONT MÁRQUEZ, José Francisco. La apertura de los procedimientos nacionales de adjudicación de los contratos públicos a las empresas de otros Estados miembros de la Unión Europea. RAP, Madrid, n. 133, 1994.

LUCÁNGELI, Jorge; SANGUINETTTI, Mariana; ZAMORANO, Ana. Mercosur: la consolidación de la expansión de la economía del Bloque. Revista del CEI, n. 18, ago. 2010.

MATTERA, ALFONSO. EL Mercado Único Europeo: sus reglas, su funcionamento. Madrid: Civitas, 1991.

MEILÁN GIL, José Luis. Una aproximación al derecho administrativo global. Sevilla: Derecho Global, 2011.

MONEDERO GIL, José Ignacio. Doctrina del contrato del estado. Madrid: IEF, 1977.

MONTAÑÁ I MORA, Miquel. Posibles modelos para la regulación de la competencia en la organización mundial del comercio. Revista Electrónica de Estudios Internacionales, n. 2, 2001.

MORENO MOLINA, José Antonio. El derecho de la Unión Europea en materia de contratación pública, organismo supervisor de las contrataciones del estado (OSCE). Lima, Perú. Disponible en: < http://www.osce.gob.pe/consucode/userfiles/image/moreno.pdf>.

MORENO MOLINA, José Antonio. El nuevo derecho de la contratación pública: de las prerrogativas de la administración a la garantía de los principios generales. Madrid: INAP, 2010. (La Administración Pública entre dos siglos). 
MORENO MOLINA, José Antonio. El proceso de formación de un derecho global de la contratación pública. Revista DIXI, v. 14, n. 15, p. 8-15, ene./jun. 2012.

MORENO MOLINA, José Antonio. La importante evolución hacia un Derecho Global de la Contratación Pública. En: PERNAS GARCÍA, J. José; MARTÍN RETORTILLO, María del Carmen Rodríguez (Coord.). La reforma de las Administraciones públicas. Madrid: Bubok, 2014. p. 499-516.

NEVADO BATALLA, Pedro. Notas sobre derecho administrativo II. Salamanca: Ratio Legis, 2002.

NOGUERA DE LA MUELA, Belén. Las directivas comunitarias de los sectores excluidos y la ley 48/98, de 30 de diciembre: ámbito de aplicación y procedimientos de conciliación. Noticias de la Unión Europea, n. 205, 2002.

OJEDA MARÍN, A. La Comunidad Europea y el GATTT en el moderno sistema de contratación pública, RAP, n. 116, Madrid, 1988.

PENAGOS, Gustavo. Nuevas tendencias del derecho administrativo a principios del siglo XXI. Revista Universitas, Bogotá, n. 106, p. 387, dic. 2003.

PONCE GÓMEZ, Francisco; PONCE CASTILLO, Rodolfo. Derecho fiscal. 11. ed. México: Limusa, 2007. RODRÍGUEZ ARANA, Jaime. El derecho administrativo global: un derecho principal. Administración de Andalucía: Revista Andaluza de Administración Pública, Sebilla, n. 76, ene./abr. 2010.

RODRÍGUEZ ARANA, Jaime et al. Derecho internacional de las contrataciones públicas. San José: Guayacán, 2011.

RODRÍGUEZ ARANA, Jaime. Las prerrogativas de la administración en los contratos de las administraciones Públicas. Anuario da Facultade de Dereito da Universidade da Coruña, n. 12, 2008.

RODRÍGUEZ ARANA, Jaime. Los principios del derecho global de la contratación pública. Derecho PUCP, n. 66, 2011.

SAMANIEGO BORDIÚ, Gonzalo. La apertura de los contratos públicos en la Comunidad Europea: situación actual y perspectivas. Noticias CEE, v. 8, n. 88, 1992.

SAMANIEGO BORDIÚ, Gonzalo. La normativa comunitaria de los contratos de las empresas que actúan en los sectores del agua, la energía, los transportes y las comunicaciones. REDA, n. 71, 1991.

SANTAMARÍA PASTOR, José Antonio. Principios de derecho administrativo. Madrid: Centro de Estudios Ramón Areces, 1990. v. 2.

TRUCHET, Didier. Label de service public et statut du service public. Actualité Juridique-Droit Administratif, v. 1,1982 . 


\section{REVISTA BRASILEIRA DE POLÍTICAS PÚBLICAS BRAZILIAN JOURNAL OF PUBLIC POLICY}

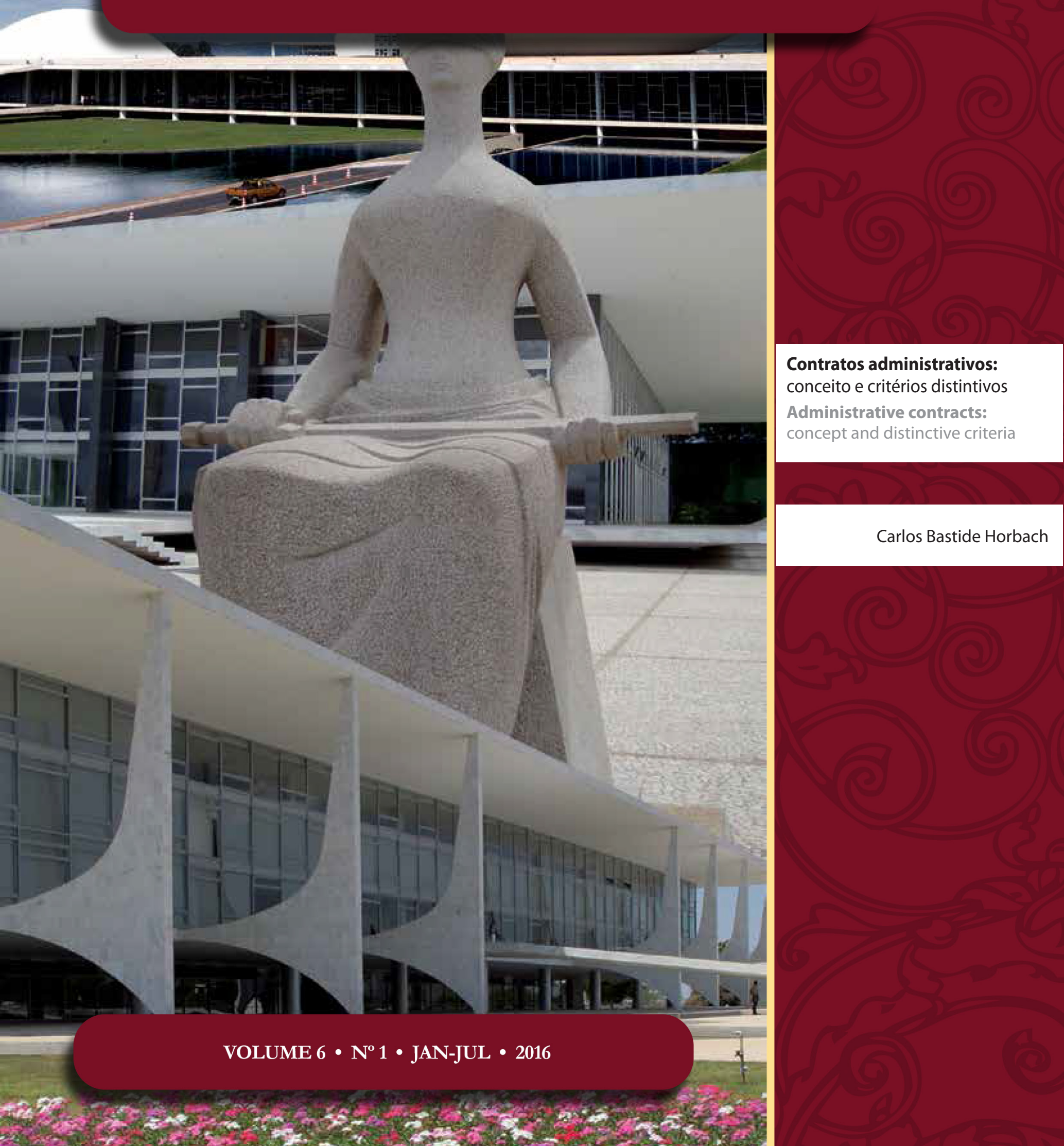




\section{Contratos administrativos: conceito e critérios distintivos*}

\section{Administrative contracts: concept and distinctive criteria}

Carlos Bastide Horbach**

\section{Resumo}

O presente trabalho busca conceituar os contratos administrativos, especialmente por meio da análise de seus critérios distintivos.

Palavras-chave: Direito administrativo. Contratos administrativos. Critérios distintivos.

\section{Abstract}

This paper intends to conceptualize the administrative contracts, specially by the analysis of its distinctive criteria.

Keywords: Administrative law. Administrative contracts. Distinctive criteria.

\section{INTRODUÇÃo}

A Teoria da Ação Administrativa ${ }^{1}$, ao longo de aproximadamente 200 anos de dogmática administrativista, aprofundou o estudo de duas formas centrais de estruturação jurídica do agir administrativo: os atos administrativos, tradicionalmente apresentados como o principal meio de expressão da função administrativa do Estado e os contratos administrativos.

Da mesma forma que os atos administrativos são uma adaptação da teoria civilista dos atos e negócios jurídicos às peculiaridades do direito púbi$\mathrm{co}^{2}$, a construção da doutrina administrativista dos contratos administrativos

* Recebido em 23/10/2015 Aprovado em 16/05/2016

** Professor Doutor de Direito Constitucional da Faculdade de Direito da Universidade de São Paulo (USP), Professor do Programa de Mestrado e Doutorado em Direito do Centro Universitário de Brasília (UniCEUB), Doutor em Direito do Estado pela USP, Mestre em Direito do Estado e Teoria do Direito pela UFRGS e Advogado. E-mail: carlos.horbach@ usp.br
1 Como ensina Eberhard Schmitd-Assmann, "A Administração pública se encarna e se expressa por meio de suas ações, qualquer que seja a forma que possam revestir: atos jurídicos e atuações materiais, planos e instrumentos acessórios, atuações preparatórias e atuações executivas, atuações dirigidas à obtenção de informações e a sua divulgação, medidas unilaterais, por um lado, e convênios e acordos, por outro, atuações da Administração com forma jurídica e atuações informais. Esse conjunto de figuras formam a 'ação administrativa prática', composta por todas as atuações imputáveis à Administração, não só as resoluções que a Administração dita unilateralmente, mas também a ação administrativa cooperativa e consensuada e sua participação nas atividades de terceiros. É tarefa do direito administrativo sistematizar essa ação administrativa prática para estruturá-la juridicamente" (cf. SCHMITDASSMANN, Eberhard. La teoría general del derecho administrativo como sistema. Madrid: Marcial Pons, 2003. p. 287. Tradução livre).

2 HORBACH, Carlos Bastide. Teoria das nulidades do ato administrativo. 2. ed. São Paulo: RT, 2010. p. 27: "A base dessa formação, portanto, é a teoria dos atos jurídicos lentamente de- 
também tem sua matriz no longo e tradicional desenvolvimento da noção dos contratos no direito privado.

Por isso, é imprescindível retomar alguns conceitos básicos do direito civil, para que, a partir desse referencial, o exame dos contratos administrativos seja mais bem fundamentado.

Já no direito romano surge a figura do acordo entre duas ou mais pessoas que pretendem um determinado efeito jurídico, ainda que não houvesse para essa fonte de obrigação um nome técnico ou uma doutrina específica, sendo a questão comumente tratada pelos jurisconsultos de Roma sob a denominação de pactum, conventio ou contractus ${ }^{3}$.

Foi Gaio, porém, que estabeleceu a divisão clássica das obrigações entre ex contractu - as obrigações derivadas de um contrato e que, em relação à Administração Pública, são objeto deste estudo - e ex delicto - extracontratuais oriundas de uma conduta antijurídica e que, projetadas sobre a função administrativa, formam o instituto da responsabilidade extracontratual do Estado. Ulpiano, por sua vez, citando Pedius, fixou a ideia de contractus habeat in se conventionem, fazendo com que o contrato não fosse somente uma colaboração exterior entre as partes contratantes, mas também - e principalmente - um acordo de vontades tendente a um fim jurídico. ${ }^{4}$

Nesse quadro, em que os contratos eram uma fonte das obrigações caracterizada por um acordo de vontades tendente a um fim jurídico manifestado numa colaboração exterior, os romanos, no seu pragmatismo jurídico, desenvolveram ainda a noção dos contratos consensuais, nos quais, independentemente de qualquer manifestação exterior - ou seja, sem nenhuma forma previamente estabelecida - o consentimento gerava a obrigação, num movimento que Max Kaser classificou um dos "contributos mais grandiosos e eficazes para a evolução futura do Direito". Tal evolução fez com que, já no período pós-clássico do direito romano, o consentimento, de acordo com a doutrina oriental, fosse a única causa contratual de obrigações. ${ }^{5}$

Foi a partir dessa concepção romana que o direito ocidental construiu a moderna Teoria dos Contratos, que se reflete no direito civil brasileiro, como é possível verificar na obra de dois de seus autores clássicos Clovis Bevilaqua ${ }^{6}$ e Washington de Barros Monteiro ${ }^{7}$ - que, de modo simples, definem contrato como sendo o acordo de vontades que tem por finalidade criar, modificar ou extinguir direitos.

Tal visão do fenômeno contratual pode ser percebida, também, nas disposições do Código Civil brasileiro de 2002, ainda que temperada - como registra Miguel Reale em sua exposição de motivos como supervisor da comissão redatora do código - por elementos como o fim social dos contratos e os valores primordiais da probidade e da boa-fé.

É exatamente tomando como base essa elementar compreensão dos contratos na doutrina civilista acordo de vontades voltado à realização de um fim jurídico - que será analisada neste artigo a questão do conceito de contrato administrativo, o que se fará com base nas origens da noção e dos critérios distintivos e tendo em vista os mais diferentes aspectos de sua disciplina normativa, como as características consagradas pelo direito administrativo brasileiro.

O pressuposto primeiro para o desenvolvimento de um conceito de contrato administrativo é a constatação - já prenunciada na abertura deste estudo - de que, muitas vezes, em vez de em vez de tomar decisões unilaterais impostas por sua autoridade, no que se caracteriza como sendo o ato administrativo, a Administração atua de forma distinta, buscando a colaboração dos particulares ou mesmo de outras pes-

senvolvida pela Teoria Geral do Direito Civil, desde os primórdios do direito romano até a era das codificações. As ideias são as mesmas, mas, com o influxo dos princípios do direito público, são conformadas às necessidades típicas da relação de administração, também essa uma mutação da ideia de relação desenvolvida no direito civil, na linha exposta por Ruy Cirne Lima".

3 KASER, Max. Direito privado romano. Lisboa: Fundação Calouste Gulbenkian, 2011. p. 61.

4 KASER, Max. Direito privado romano. Lisboa: Fundação Calouste Gulbenkian, 2011. p. 224-225.

5 KASER, Max. Direito privado romano. Lisboa: Fundação Calouste Gulbenkian, 2011. p. 227.

6 BEVILAQUA, Clovis. Código civil dos Estados Unidos do Brasil: commentado. Rio de Janeiro: Francisco Alves, 1926. v. 4. p. 245.

7 MONTEIRO, Washington de Barros. Curso de direito civil: direito das obrigações. 7. ed. São Paulo: Saraiva, 1967. p. 5. 
soas administrativas, por meio de vias bilaterais - ou multilaterais - para a consecução do interesse público. Como anota Diogo Freitas do Amaral, "isso significa que, nesses casos, a Administração Pública, em vez de definir unilateralmente a sua vontade, necessita de chegar a acordo com aqueles para constituir, modificar ou extinguir relações jurídicas administrativas". ${ }^{8}$

A obtenção de um conceito adequado de contrato administrativo - entendido como importante forma de exercício da função administrativa do Estado - não pode prescindir de um exame do movimento específico pelo qual, com base na experiência civilista, o direito administrativo foi delineando a disciplina jurídica dos contratos celebrados pela Administração Pública, indicando suas diferenças em relação ao direito civil.

Novamente se verifica, nessa matéria, o mesmo procedimento de busca de autonomia científica para o direito administrativo verificado na origem e na formação do conceito de ato administrativo, procedimento que pretende demonstrar as razões justificadoras de um tratamento jurídico diferenciado, ou - para utilizar uma expressão típica do estudo dos contratos administrativos - um tratamento exorbitante do direito comum, qual seja, o direito civil.

\section{ORIGENS dA Noção de CONTRATO ADMinistrativo}

Tradicionalmente, como ocorre com outros institutos do direito administrativo, o surgimento da noção de contrato administrativo é associado à inovadora jurisprudência do Conselho de Estado, que atingiu seu ápice criativo entre 1870 e meados dos anos 1920.

Entretanto, mesmo antes da moderna doutrina dos contratos administrativos, é possível encontrar exemplos, na Antiguidade até de contratos celebrados entre particulares e o poder público, buscando a realização de um fim coletivo. Já na Babilônia do século XIX a.C. e no antigo Egito, era comum a celebração de espécies de contratos de arrendamento de terras públicas com particulares que, como ensina Jean-Paul Valette, tinham a obrigação de satisfazer determinadas necessidades coletivas. ${ }^{9}$

Era assim, também, com os contratos que, no direito romano, visavam à criação de receitas para o erário e à atribuição do exercício de funções públicas por particulares, havendo multiplicação, já no período da República, das societas publicanorum, que atuavam como concessionárias de portos, aquedutos, estradas e outras obras públicas, bem como arrecadavam impostos. ${ }^{10}$

Em Roma, podem ainda ser apontados como precursores dos contratos administrativos os pactos celebrados entre a civitas romana e os particulares para arrendamento de terras situadas às margens das estradas e próximas de aquedutos, que eram consideradas de domínio do populus romanus tais contratos - considerados como origem do moderno direito de superfície - revertiam em favor da coletividade, uma vez que, mesmo sendo voltados à satisfação de uma necessidade do particular, impunham aos superficiários o cumprimento de obrigações para com o poder público. ${ }^{11}$

Almiro do Couto e Silva mencionam, igualmente, os chamados contratos censórios, por meio dos quais importantes atividades materialmente administrativas eram delegadas, na Roma antiga, aos particulares. Assim, além da arrecadação de impostos antes mencionada, havia, por exemplo, contratos sobre arrendamento de bens públicos, execução de obras públicas ou, ainda, de venda de bens públicos. E registra Couto e Silve que:

Aos contratos que o censor realizava nós hoje os chamaríamos de direito público, porquanto sujeitos a regime totalmente distinto dos contratos de direito privado, sendo ainda as controvérsias porventura

8 AMARAL, Diogo Freitas do. Curso de direito administrativo. Coimbra: Almedina, 2001. v. 2. p. 497.

9 VALETTE, Jean-Paul. Service public à la française. Paris: Ellipses, 2000. p. 10-11.

10 AMARAL, Diogo Freitas do. Curso de direito administrativo. Coimbra: Almedina, 2001. v. 2. p. 499.

11 PUGLIESE, Giovanni. Istituquioni di Diritto Romano. 3. ed. Torino: Giappichelli, 1991. p. 493. 
deles decorrentes resolvidas, via de regra, pela mesma autoridade que os celebrara: o censor, no uso da sua cognitio. ${ }^{12}$

Essa tendência pode igualmente ser observada - como indica Diogo Freitas do Amaral - na Idade Média, quando essas mesmas tarefas públicas eram desempenhadas, em alguns países como a França, pelos particulares, chegando-se até mesmo à execução privada da guerra por empresários nela especializados, os chamados condottieri, na Itália. ${ }^{13}$

No Antigo Regime francês, já era possível notar, nos séculos XVII e XVIII, contratos que transferiam para particulares atividades que originariamente pertenciam à Coroa, num processo que, com a Revolução de 1789, ganha novos contornos. ${ }^{14}$

O Estado Liberal que surge no final do século XVIII e no início do século XIX é um Estado mínimo, que reúne funções essenciais, como a garantia da ordem interna, a defesa externa e o desenvolvimento de uma infraestrutura básica. Assim, quando as inovações tecnológicas impõem ao poder público a necessidade do desenvolvimento de grandes obras de infraestrutura - tais como estradas de ferro, iluminação ou transportes coletivos - o Estado, desprovido dos meios materiais para tanto, busca na iniciativa privada, por meio dos contratos de concessão, a consecução dos fins de interesse público que originalmente lhe cabiam.

Espelhando esse movimento, são incontáveis os contratos de concessão, de empreitada e de fornecimento celebrados, no início do século XX, entre a Administração Pública e empresas privadas, que ficaram, desse modo, associadas ao desempenho de funções administrativas. Tais contratos eram regidos pelo direito civil, partindo-se, então, da crença de que particulares e Estado, na sua celebração, colocavam-se em posição de igualdade. ${ }^{15}$

Essa vinculação dos contratos celebrados pelo poder público à doutrina civilista e às normas do direito civil, todavia, começou a ser quebrada por uma série de julgados do Conselho de Estado francês, que identificou nesses pactos traços característicos que os distinguiriam, fazendo com que apresentassem um regime jurídico próprio. Nessa série de julgamentos, podem ser mencionados o arrêt Compagnie Nouvelle du Gaz de Deville-lès-Rouen, CE 10.01.1902; o arrêt Terrier, CE 6.02.1903; o arrêt Thérond, CE 4.03.1910; o arrêt Compagnie Générale Française des Tramways, CE 11.03.1910; o arrêt Société des Granits Porphyroüdes des Vosges, CE 31.07.1912; e, finalmente, o arrêt Compagnie Générale d'Éclairage de Bordeaux, CE 30.03.1916.

Esses acórdãos assentaram as diferenças entre os contratos privados e os contratos administrativos, firmando a competência da jurisdição especializada administrativa - tendo em vista a adoção em França do modelo do contencioso administrativo - para a apreciação das controvérsias relacionadas aos últimos.

Os efeitos dessas decisões - que repercutiram enormemente na Europa e nos países latino-americanos, formando uma teoria dos contratos administrativos, apartada do direito civil - foram assim sintetizados por Diogo Freitas do Amaral: a) a Administração Pública celebra, com os particulares, contratos regidos pelo direito civil e outros que são regulados pelo direito público, os contratos administrativos; $b$ ) esses contratos administrativos têm como diferencial a possibilidade de o conteúdo de suas prestações ser alterado em nome do interesse público; e c) essas alterações geram para o contratado a necessidade de manutenção do equilíbrio financeiro do contrato, sob pena de impor ao particular o ônus de realização do interesse coletivo. ${ }^{16}$

Desse modo, a doutrina tradicional do direito administrativo indica que a noção de contrato administrativo surgiu na França, por meio da atividade jurisdicional do Conselho de Estado, que levou em consideração a ideia de que tais contratos eram substancialmente diferentes dos contratos civis, o que justificava a sua

12 SILVA, Almiro do Couto e. Os indivíduos e o Estado na realização de tarefas públicas. Revista de Direito Administrativo, Rio de Janeiro, v. 209, p. 43-70, jul./set. 1997. p. 50.

13 AMARAL, Diogo Freitas do. Curso de direito administrativo. Coimbra: Almedina, 2001. v. 2. p. 500.

14 VALETTE, Jean-Paul. Service public à la française. Paris: Ellipses, 2000. p. 21.

15 AMARAL, Diogo Freitas do. Curso de direito administrativo. Coimbra: Almedina, 2001. v. 2. p. 501.

16 AMARAL, Diogo Freitas do. Curso de direito administrativo. Coimbra: Almedina, 2001. v. 2. p. 504. 
apreciação pelo contencioso administrativo. Ou seja, a autonomia substancial da matéria ensejou seu tratamento processual diferenciado, retirando-a da órbita de competências dos Tribunais comuns e submetendo-a ao contencioso administrativo, no que se poderia denominar de autonomia processual dos contratos administrativos.

No entanto, é necessário mencionar - ainda que em breves considerações - a teoria apresentada por Maria João Estorninho, para quem o movimento de gênese da noção de contrato administrativo foi exatamente a inversa, com a autonomia processual precedendo a autonomia substancial. Nessa perspectiva, a construção teórica do contrato administrativo e sua caracterização jurídica não passam de uma consequência justificadora de uma atribuição de competência baseada em um acaso qualquer. ${ }^{17}$

Esta é, também, a análise efetuada por Eduardo García de Enterría e Tomás-Ramón Fernández, para os quais "a distinção contratos administrativos - contratos privados é, pois, exclusivamente em sua origem uma distinção para efeitos jurisdicionais e não substantivos". ${ }^{18}$

Para a Estorninho, a competência do contencioso administrativo para apreciar as controvérsias envolvendo alguns dos contratos celebrados pela Administração Pública - sua autonomia processual, em outras palavras - tinha justificativas baseadas em referências puramente empíricas, até que ocorreu o que Eduardo García de Enterría chamou de "salto dogmático", quando a doutrina passou a buscar um critério que embasasse a substantivização jurídico-material da contratação administrativa. Nesse momento, iniciou-se um processo no qual, ao longo de aproximadamente de cem anos, a Teoria do Contrato Administrativo teria estado a procurar um "critério mágico" que permitiria a inequívoca distinção dos contratos administrativos ante os privados. ${ }^{19}$

Muitos foram os critérios fixados para justificar a existência autônoma dos contratos administrativos, podendo ser enquadrados em dois grandes grupos: a) critérios substanciais, que indicariam as características intrínsecas do contrato, determinando sua natureza jurídica e, consequentemente, o regime jurídico aplicável, civil ou administrativo; e b) critérios formais, segundo os quais o elemento fundamental para a qualificação é a norma jurídica aplicável. ${ }^{20}$

Os traços marcantes do regime jurídico dos contratos administrativos, apontados no trecho antes citado de Diogo Freitas do Amaral, são realçados por esses diferentes critérios adotados pela doutrina e pelos ordenamentos jurídicos para o reconhecimento de sua autonomia em relação aos contratos disciplinados pelo direito civil. O exame de tais critérios, pois, tem importância significativa para a conceituação dos contratos administrativos.

\section{Critérios distintivos}

Os critérios distintivos dos contratos administrativos são os elementos de sua conformação jurídica que ensejam um tratamento normativo diferenciado em relação aos contratos privados; ou, em outras palavras, tais critérios são a razão de ser de uma categoria jurídica autônoma denominada "contrato administrativo".

Maria Sylvia Zanella Di Pietro, assim, sistematiza os critérios normalmente apontados para distinguir os contratos administrativos dos contratos de direito privado; a) critério subjetivo ou orgânico, segundo o qual o contrato administrativo seria aquele formado numa relação de subordinação, isto é, numa relação jurídica na qual a Administração Pública se apresenta com poder de império, com autoridade em relação ao contratado,

17 ESTORNINHO, Maria João. Requiem pelo contrato administrativo. Coimbra: Almedina, 1990. p. 23.

18 GARCÍA DE ENTERRÍA, Eduardo; FERNÁNDEZ, Tomás-Ramón. Curso de derecho administrativo. 8. ed. Madrid: Civitas, 1998. v. 1.p. 676.

19 ESTORNINHO, Maria João. Requiem pelo contrato administrativo. Coimbra: Almedina, 1990. p. 35; 37.

20 ESTORNINHO, Maria João. Requiem pelo contrato administrativo. Coimbra: Almedina, 1990. p. 74. 
deixando de lado a igualdade típica das contratações privadas - é o que a doutrina estrangeira chama de critério da sujeição, reservando a expressão "critério orgânico" para indicar a necessidade de estar presente, na relação contratual, a Administração Pública; b) critério do objeto, que estabelece serem administrativos os contratos voltados à organização e ao funcionamento de serviços públicos, de atividades típicas da Administração Pública; c) critério da finalidade, pelo qual os contratos celebrados com uma finalidade de interesse público são administrativos; d) critério do procedimento, que faz com que sejam administrativos os contratos para cuja celebração é necessária a observância de determinadas formalidades, não verificadas nos contratos privados; e) critério das cláusulas exorbitantes do direito comum, para o qual as estipulações de poderes especiais na relação contratual, em favor da Administração Pública, são o traço caracterizador do contrato administrativo. ${ }^{21}$

Desses referenciais distintivos, para fazer uso da classificação proposta por Maria João Estorninho entre formais e substanciais, os critérios subjetivos, da sujeição, do objeto, da finalidade são substanciais; enquanto os critérios do procedimento e das cláusulas exorbitantes são formais, ainda que, inicialmente, esse último tenha pretendido expressar elementos intrínsecos da contratação administrativa. ${ }^{22}$

É importante registrar, ainda, que existe uma relação direta e necessária entre os critérios de autonomia do contrato administrativo e os elementos caracterizadores do próprio direito administrativo, como sublinha Sérvulo Correia ${ }^{23}$ :

Esse critério de fundo não pode ser outro além daquele que sirva para identificar os institutos e as normas do próprio Direito Administrativo, já que a natureza administrativa do contrato advém da virtualidade que este possua de criar, modificar ou extinguir relações jurídicas de direito administrativo. Não é, pois fruto de coincidência a correlação que se pode constatar entre os polos das várias doutrinas que pretendem encontrar o fundamento da especificidade do contrato administrativo e os critérios usados para singularizar o Direito Administrativo: a sujeição do particular, o objeto, o fim e o estatuto privativo da Administração Pública.

Esses critérios serão a seguir analisados, para que se possam fixar, com clareza, quais são os traços marcantes que devem, necessariamente, constar de uma conceituação de contrato administrativo.

\subsection{Critério subjetivo ou orgânico}

Será analisado neste artigo o critério subjetivo ou orgânico como sendo aquele que determina serem administrativos os contratos em que figurar como parte da Administração Pública, analisando-se o que Maria Sylvia Zanella Di Pietro denomina como o critério subjetivo ou orgânico no próximo item, no qual será examinado o critério da sujeição.

A adoção do critério subjetivo leva à conclusão de que basta a presença da Administração Pública num dos polos da relação jurídica contratual para que seja o contrato dela decorrente um contrato administrativo. O contrato é, portanto, administrativo se uma das partes for uma pessoa coletiva pública no exercício da função administrativa do Estado. ${ }^{24}$

Esse referencial caracterizador dos contratos administrativos nega uma distinção amplamente aceita pela doutrina brasileira, qual seja, aquela que separa os contratos privados da Administração Pública dos contratos administrativos propriamente ditos, sendo essas duas modalidades contratuais espécies do gênero contratos da Administração.

Essa distinção, aliás, está - como anteriormente visto - na gênese da noção de contrato administrativo, que se separou, num lento processo, dos contratos privados celebrados pela Administração Pública. O

21 DI PIETRO, Maria Sylvia Zanella. Direito administrativo. 20. ed. São Paulo: Atlas, 2007. p. 235.

22 ESTORNINHO, Maria João. Requiem pelo contrato administrativo. Coimbra: Almedina, 1990. p. 75.

23 CORREIA, José Manuel Sérvulo. Legalidade e autonomia contratual nos contratos administrativos. Coimbra: Almedina, 1987. p. 362.

24 RIVERO, Jean. Direito administrativo. Coimbra: Almedina, 1981. p. 133. 
módulo contratual da Administração Pública - como denomina Odete Medauar - compreende os contratos administrativos clássicos, regidos pelo direito público, e os contratos regidos parcialmente pelo direito privado, como a locação em que o poder público é o locatário, os quais não são administrativos, apesar de contarem com a Administração como sujeito da relação jurídica. ${ }^{25}$ Exposições semelhantes fazem José dos Santos Carvalho Filho ${ }^{26}$, Celso Antônio Bandeira de Mello ${ }^{27}$ e Maria Sylvia Zanella Di Pietro. ${ }^{28}$

Ou seja, a simples presença da Administração Pública num dos polos da relação contratual não é elemento suficiente para estabelecer a existência de um contrato administrativo, uma vez que contratos há em que o poder público se submete ao regime contratual comum, disciplinado pelo direito civil.

O critério subjetivo ou orgânico, entretanto, tem se apresentado em diversos ordenamentos como uma conditio sine qua non da existência de um contrato administrativo; isto é, ainda que necessários outros elementos para fixar a natureza administrativa de um contrato, a presença da Administração Pública - em suas mais diferentes conformações jurídicas - na relação é o traço sem o qual não se tem um contrato administrativo.

É isso que se dá na Espanha, como anotam Eduardo García de Enterría e Tomás-Ramón Fernández ${ }^{29}$ e na França, onde o Conselho de Estado entende que a presença da Administração é condição necessária para a caracterização da natureza administrativa de um contrato, ainda que a jurisprudência reconheça, excepcionalmente, com base na ideia de mandato, a possibilidade de contratos administrativos celebrados exclusivamente entre privados, um dos quais mandatário da Administração Pública, como decidido no arrêt Société Ansaldo Industria et S A Bouggues - CE 17.12.1999. ${ }^{30}$

No Brasil, como será adiante estudado com maior vagar, o critério subjetivo também atua como requisito necessário e primeiro, ainda que não exclusivo, para a identificação dos contratos administrativos, como parece exsurgir do regime fixado pela Lei $n^{\circ} 8.666 / 93$.

\subsection{Critério da sujeição}

O critério da sujeição ressalta a posição de subordinação em que se encontra o contratado na relação jurídica em que figura a Administração Pública. O contratado, portanto, apesar de colaborador na consecução do interesse público, encontra-se numa relação especial de sujeição. Como registra Marcello Caetano, ainda

Que a relação jurídica nasça de um acordo, trata-se de criar uma relação de subordinação cuja sequência depende da vontade preponderante de um dos sujeitos que pode modificar substancialmente o respectivo objeto. ${ }^{31}$

Ao contrário do que se poderia de início imaginar "o critério da sujeição não é uma nova versão do critério dos sujeitos mas sim, pelo contrário, é um critério que parte do objeto do contrato para efeitos de sua qualificação". 32

O objeto do contrato administrativo seria a associação duradoura entre Administração e contratado para a realização do interesse público, o que faz com que o particular a ele se sujeite como se um ente administrativo fosse. E, como o poder público não pode por meio do contrato desonerar-se do dever de buscar a realização do interesse público, impõe-se o reconhecimento de uma sujeição do particular em relação à Administração Pública para que ela possa continuar a zelar pelo interesse público,

25 MEDAUAR, Odete. Direito administrativo moderno. 11. ed. São Paulo: RT, 2007. p. 208.

26 CARVALHO FILHO, José dos Santos. Manual de direito administrativo. 17. ed. Rio de Janeiro: Lumen Iuris, 2007. p. 159-160.

27 MELLO, Celso Antônio Bandeira de. Curso de direito administrativo. 11. ed. São Paulo: Malheiros, 1999. p. 439-440.

28 CORREIA, José Manuel Sérvulo. Legalidade e autonomia contratual nos contratos administrativos. Coimbra: Almedina, 1987. p. 233.

29 GARCÍA DE ENTERRÍA, Eduardo; FERNÁNDEZ, Tomás-Ramón. Curso de derecho administrativo. 8. ed. Madrid: Civitas, 1998. v. 1. p. 687.

30 LONG, Marceau et al. Les grands arrêts de la jurisprudence administrative. 15. ed. Paris: Dalloz, 2005. p. 569.

31 CAETANO, Marcello. Manual de direito administrativo. 10. ed. Coimbra: Almedina, 1997. t. 1. p. 576.

32 ESTORNINHO, Maria João. Requiem pelo contrato administrativo. Coimbra: Almedina, 1990. p. 91. 
[...] vigiando a execução do contrato, não com a simples preocupação de salvaguardar um interesse pessoal mas com empenho de que se satisfaçam os interesses transpessoais que a lei a incumbiu. ${ }^{33}$

Em outras palavras, se - de acordo com o critério da sujeição - a Administração Pública se apresenta perante o contratado com autoridade, com o chamado poder de império, isto ocorre por força do interesse público em cujo influxo se estrutura a relação de administração materializada no contrato administrativo.

Entretanto, como assevera José Manuel Sérvulo Correia, "o critério da sujeição não basta para qualificar os contratos porque o Direito Administrativo se não esgota em relações de sujeição"; e continua afirmando que

Nos nossos tempos, não envolve o exercício de poderes de autoridade sobre os administrados o desempenho de muitas tarefas da administração de prestação, mesmo quando se processa no âmbito de normas jurídicas distintas daquelas que regem as relações indiferenciadas. ${ }^{34}$

As modernas alterações sofridas na própria concepção da função e da atividade administrativa - abertas que estão à consensualidade - tornam inadequado o critério da sujeição. ${ }^{35}$

\subsection{Critério do objeto}

Trata-se de critério tradicional na jurisprudência e, em relação às doutrinas francesas, utilizado, por exemplo, no arrêt Terrier, de 1903, que é considerado por Eduardo García de Enterría e Tomás-Ramón Fernández como o marco criador da figura dos contratos administrativos. ${ }^{36}$ Segundo tal critério, o contrato é administrativo quando tem por objeto ajudar no funcionamento de um serviço público, como resume Jean Rivero. ${ }^{37}$

Por meio desse precedente, o Conselho de Estado francês passou a incorporar a suas competências o contencioso contratual das administrações locais, sob o seguinte argumento:

[...] tudo o que concerne à organização e ao funcionamento dos serviços públicos propriamente ditos, gerais ou locais, constitui uma operação administrativa, que é, por sua natureza, do domínio da jurisdição administrativa [...] Todas as ações entre pessoas públicas e terceiros ou entre essas pessoas públicas entre si, e fundadas na execução, na inexecução ou na má execução de um serviço público são da competência administrativa. ${ }^{38}$

Desse modo, como o contrato submetido à apreciação do Conselho dizia com a execução de um serviço público, era um contrato administrativo.

Entretanto, nesse julgado, ainda há relação com o critério da sujeição, uma vez que é o arrêt Terrier que consagra modernamente na jurisprudência do Conselho de Estado a distinção entre atos de gestão e atos de autoridade, sendo estes a regra e aqueles a exceção e estando respectivamente submetidos aos regimes de direito privado e direito público. ${ }^{39}$

É com o arrêt Thérond, de 1910, que o critério do objeto de serviço público vai se apresentar como exclusivo, independentemente da ideia de atos de autoridade: todo o ato editado com um objetivo de interesse geral é de competência administrativa, em especial, todos os contratos celebrados pela Administração Pública com tal objetivo são contratos administrativos. E o aresto é claro nesse sentido:

[...] a cidade de Montpellier agiu em vista da higiene e da segurança da população e pelo objetivo de assegurar a prestação de um serviço público; assim, as possíveis dificuldades resultantes da inexecução

33 CAETANO, Marcello. Manual de direito administrativo. 10. ed. Coimbra: Almedina, 1997. t. 1. p. 183.

34 CORREIA, José Manuel Sérvulo. Legalidade e autonomia contratual nos contratos administrativos. Coimbra: Almedina, 1987. p. 365-366.

35 ESTORNINHO, Maria João. Requiem pelo contrato administrativo. Coimbra: Almedina, 1990. p. 93.

36 GARCÍA DE ENTERRÍA, Eduardo; FERNÁNDEZ, Tomás-Ramón. Curso de derecho administrativo. 8. ed. Madrid: Civitas, 1998. v. 1. p. 677.

37 RIVERO, Jean. Direito administrativo. Coimbra: Almedina, 1981. p. 135.

38 LONG, Marceau et al. Les grands arrêts de la jurisprudence administrative. 15. ed. Paris: Dalloz, 2005. p. 73-74.

39 LONG, Marceau et al. Les grands arrêts de la jurisprudence administrative. 15. ed. Paris: Dalloz, 2005. p. 75. 
ou da má execução desse serviço são de competência do Conselho de Estado. ${ }^{40}$

Tal como se dava com o conceito de direito administrativo da Escola do Serviço Público, que padecia com a imprecisão da própria noção de serviço público, esse critério para a identificação dos contratos administrativos sofre do mesmo mal.

Há muito se afastou a doutrina do compreensivo conceito de serviço público que se depreendia da obra de Leon Duguit, para quem essa categoria do direito administrativo englobava as atividades estatais como um todo. ${ }^{41}$ Atualmente, com a redução do alcance desse conceito, a moderna jurisprudência dos ordenamentos que adotam tal critério - em especial a França - tornou-se casuística, determinando, de forma empírica, o que é e o que não é serviço público e, em consequência, que matérias são objeto de contratos administrativos ou de contratos privados da Administração Pública. ${ }^{42}$

Esse movimento é descrito com precisão por José Manuel Sérvulo Correia:

[...] [embora] a ideia de "serviço público" tenha desempenhado um papel historicamente relevante como noção explicativa em torno da qual se pôde ordenar um Direito Administrativo apropriado à intervenção do Estado nos domínios econômico e social, a sua fragilidade não tardou em revelar-se, demonstrando os riscos de procurar delimitar o âmbito do Direito Administrativo com recurso a uma base material e orgânica de evolução imparável. O esclerosamento do critério desamparou a jurisprudência, que, em muitos casos, passou a usá-lo, mais como fórmula ritual do que como juízo lógico, ou a substituí-lo pela constatação da vigência de um regime administrativo desacompanhado de razão justificativa. A isso se reduz afinal o emprego do critério das "cláusulas exorbitantes". ${ }^{43}$

Esse critério das cláusulas exorbitantes será adiante analisado.

\subsection{Critério da finalidade de interesse público}

Segundo o critério da finalidade de interesse público, um contrato será administrativo sempre que tiver como fim a realização de uma necessidade coletiva, cuja concreção esteja a cargo da Administração Pública. Cuida-se, aqui, de uma extensão do critério do objeto de serviço público, que igualmente pretende se afastar da polêmica conceitual que assola essa tradicional noção do direito administrativo francês. ${ }^{44}$

A crítica que normalmente faz a doutrina a esse critério liga-se ao fato de que a função administrativa do Estado sempre deve buscar o interesse público, como fixa o próprio princípio da finalidade antes estudado. O exercício da função administrativa pressupõe, pois, a realização concreta do interesse público.

Dessa constatação duas consequências podem surgir: ou todos os contratos celebrados pela Administração Pública são administrativos, porque sempre deverá ela buscar o interesse público - e aqui este critério enfrentaria as mesmas objeções que o critério orgânico ou subjetivo; ou então este critério não é idôneo para a caracterização definitiva dos contratos administrativos, como parece acreditar Maria Sylvia Zanella Di Pietro. ${ }^{45}$

Todavia, a doutrina portuguesa - de que é exemplo Sérvulo Correia - assinala que esse fim de interesse público que caracteriza os contratos administrativos deve ser a consequência imediata, atual e necessária da execução do pactuado, caso contrário estar-se-ia diante de um contrato privado. "As prestações a que o contrato obriga deverão possuir", portanto,

40 LONG, Marceau et al. Les grands arrêts de la jurisprudence administrative. 15. ed. Paris: Dalloz, 2005. p. 128.

41 DUGUIT, Léon. Manual de derecho constitucional: teoria general del estado, el derecho y el estado, las libertades publicas. Granada: Comares, 2007. p. 64.

42 ESTORNINHO, Maria João. Requiem pelo contrato administrativo. Coimbra: Almedina, 1990. p. 90.

43 CORREIA, José Manuel Sérvulo. Legalidade e autonomia contratual nos contratos administrativos. Coimbra: Almedina, 1987. p. 359.

44 ESTORNINHO, Maria João. Requiem pelo contrato administrativo. Coimbra: Almedina, 1990. p. 83.

45 DI PIETRO, Maria Sylvia Zanella. Direito administrativo. 20. ed. São Paulo: Atlas, 2007. p. 235. 
[...] aptidão ou capacidade para satisfazerem imediatamente necessidades colectivas determinadas. A expressão contém uma ideia de proximidade finalística e não de proximidade cronológica. Haverá utilidade imediata quando a comunidade possa se beneficiar diretamente dos serviços prestados. ${ }^{46}$

Ocorre, porém, que mais uma vez a aplicação exclusiva desse critério não permite uma configuração definitiva da natureza dos contratos administrativos e de sua autonomia em relação aos contratos privados, de modo que se pode aceitar a necessidade de realização de um interesse público como mais um elemento no processo de conceituação de tais fenômenos jurídicos.

\subsection{Critério do procedimento}

Por esse critério, o traço distintivo dos contratos administrativos é a necessidade de observância de determinadas formalidades - como a necessidade de licitação, por exemplo - que não são exigidas nos contratos privados. Os procedimentos contratuais, assim, indicariam a diferença entre um e outro tipo de contratação.

Esse padrão distintivo, porém, além de ressaltar característica que não está na essência dos contratos administrativos, mas sim numa exigência que lhes é exterior, não pode ser aceito por duas razões básicas, quais sejam: a) a aceitação de que a ausência de certas formalidades não retira do contrato sua natureza administrativa, se foi celebrado como tal; b) a verificação que também muitos dos contratos típicos do direito civil exigem formalidades previstas em lei, o que não os transforma em administrativos. ${ }^{47}$

Ademais, a casuística da jurisprudência do Conselho de Estado - berço da noção de contrato administrativo, como antes visto - admite a existência de contratos administrativos verbais, como assentado no importante arrêt Epoux Bertin - CE 20.04.1956, por mais "insólita” que possa parecer essa hipótese, como registrado por Marceau Long. ${ }^{48}$

Os contratos administrativos seguem, sim, formalidades especiais, mas não são essas formalidades que moldam sua natureza especial. Na verdade, elas se impõem exatamente porque são administrativos os contratos e a ação da Administração Pública deve seguir determinadas exigências para a realização dos princípios do direito administrativo, como a legalidade e a impessoalidade, entre outros.

\subsection{Critério das cláusulas exorbitantes do direito comum}

O critério das cláusulas exorbitantes leva em consideração o regime jurídico aplicável à contratação levada a cabo pela Administração Pública. Se o contrato se dá seguindo as normas comuns do direito privado, sem nenhum traço discrepante na sua disciplina jurídica, o contrato é privado. Se o regime jurídico apresenta um conteúdo que extrapola o comum - tal como regido pelo direito civil -, o contrato é administrativo.

Esse critério é, na verdade, um desdobramento de outros já examinados, como o critério da sujeição e o critério do objeto de serviço público. Isto porque, na evolução da Escola de Bordeaux, Gaston Jèze, seguindo os passos de Duguit, desenvolveu a Teoria do Regime Jurídico de serviço público, que seria a essência do direito administrativo.

Nessa perspectiva, o direito administrativo se caracteriza como sendo o direito especial do serviço público. Um direito composto por regras exorbitantes do direito comum, o direito civil, que surgem e se impõem por e para a gestão dos serviços públicos. Os contratos celebrados com o intuito de promover a gestão desses serviços - fundamentais para o desenvolvimento da interdependência social - afastariam a igualdade típica dos contratos privados, já que a Administração, na busca do interesse público, adquiriria uma posição

46 CORREIA, José Manuel Sérvulo. Legalidade e autonomia contratual nos contratos administrativos. Coimbra: Almedina, 1987. p. 382.

47 ESTORNINHO, Maria João. Requiem pelo contrato administrativo. Coimbra: Almedina, 1990. p. 80.

48 LONG, Marceau et al. Les grands arrêts de la jurisprudence administrative. 15. ed. Paris: Dalloz, 2005. p. 485. 
de supremacia na relação contratual; posição que se expressa concretamente por meio das cláusulas exorbitantes.

A singularidade do contrato administrativo - como asseveram Eduardo García de Enterría e Tomás-Ramón Fernández - seria definida exatamente pela extrapolação dos modos contratuais privados, no que se chama de "cláusula exorbitante". "O contrato administrativo seria um contrato em que estão presentes cláusulas ou conteúdos contratuais dessa natureza, não explicáveis a partir do direito comum das obrigações". ${ }^{49}$

O critério em questão foi reconhecido pelo Conselho de Estado francês no arrêt Société des Granits Porphyrö̈des des Vosges - CE 31.07.1912, que - superando o já mencionado arrêt Thérond e em parte retornando à distinção entre gestão pública e privada referida no arrêt Terrier - assentou não ser necessário para a caracterização de um contrato como administrativo o objeto de serviço público, mas sim a existência de uma natureza própria, expressa por meio das cláusulas exorbitantes. ${ }^{50}$

Exemplos de cláusulas exorbitantes - que podem constar cumuladas ou isoladas num contrato administrativo - são dados pela jurisprudência administrativa francesa, como a que confere o poder de rescisão unilateral em favor da Administração Pública, ou a que lhe dá a faculdade de controle sobre a execução do contrato; e também cláusulas que dão poderes especiais ao contratado, como o de cobrar, dos administrados, determinadas tarifas ou taxas. ${ }^{51}$

A primeira questão que exsurge da aplicação do critério das cláusulas exorbitantes é exatamente a de como identificá-las: quando, afinal, uma cláusula é derrogatória do direito comum? Essa pergunta - como confessa Rivero - é de difícil resposta, já que:

[...] o direito civil consagra o princípio da liberdade contratual, autorizando as partes a adoptar as cláusulas mais variadas. São certamente derrogatórias as cláusulas que excedem essa liberdade e que por isso mesmo são insusceptíveis de figurar num contrato entre particulares, por contrárias à ordem pública. Por vezes consideram-se como tais as quem na prática, não são normais nas relações privadas, porque respondem a preocupações de interesse geral, estranhas aos particulares. ${ }^{52}$

Todavia, não se pode negar que essa identificação formulada por Rivero é bastante ampla, pouco esclarecendo, de modo objetivo, quais são as cláusulas exorbitantes. Essa dificuldade na definição das cláusulas exorbitantes é o principal fator de desprestígio desse critério a elas vinculado, como registra Maria João Estorninho. ${ }^{53}$

A evolução natural desse critério foi a consagração, pelo Conselho de Estado, do chamado regime jurídico exorbitante, pelo arrêt Socièté d'exploitation électrique de la rivière du Sant-CE 19.01.1973. sse julgado alarga consideravelmente o critério das cláusulas exorbitantes para realçar o regime exorbitante no qual o contrato é celebrado. ${ }^{54}$

Esse regime exorbitante, que pode decorrer tanto das próprias cláusulas derrogatórias do direito comum, como de regras estabelecidas nos textos legais ou mesmo ainda de orientações depreendidas da jurisprudência; é caracterizado por dois traços essenciais: a) a existência de prerrogativas, em favor da Administração, ligadas ao interesse público, que quebram a igualdade natural dos contratos privados; e b) a verificação de limitações à liberdade contratual, que limitam a atuação do poder público.

O regime dos contratos administrativos afasta-se pois do regime comum dos contratos, tanto pelas prerrogativas que consagra em benefício da Administração, como pelas sujeições que lhe impõe. ${ }^{55}$

49 GARCÍA DE ENTERRÍA, Eduardo; FERNÁNDEZ, Tomás-Ramón. Curso de derecho administrativo. 8. ed. Madrid: Civitas, 1998. v. 1. p. 677-678.

50 LONG, Marceau et al. Les grands arrêts de la jurisprudence administrative. 15. ed. Paris: Dalloz, 2005. p. 152.

51 LONG, Marceau et al. Les grands arrêts de la jurisprudence administrative. 15. ed. Paris: Dalloz, 2005. p. 153.

52 RIVERO, Jean. Direito administrativo. Coimbra: Almedina, 1981. p. 136.

53 ESTORNINHO, Maria João. Requiem pelo contrato administrativo. Coimbra: Almedina, 1990. p. 94.

54 LONG, Marceau et al. Les grands arrêts de la jurisprudence administrative. 15. ed. Paris: Dalloz, 2005. p. 153.

55 RIVERO, Jean. Direito administrativo. Coimbra: Almedina, 1981. p. 137-138. 
A adoção desse critério do regime exorbitante - e mesmo de sua versão mais abstrata, o critério do ambiente exorbitante - leva, segundo Maria João Estorninho, ao necessário reconhecimento de que a determinação da natureza administrativa de um contrato se dá por meio de aspectos que lhe são exteriores, num movimento que acaba por se resumir à determinação legal:

[...] existe uma mudança radical de perspectiva, pois o contrato deixa de ser considerado administrativo devido à natureza jurídica dos seus elementos essenciais - sujeitos, fim ou objeto - mas sim porque o legislador o sujeita a um regime jurídico especial. ${ }^{56}$

\section{O CRITÉRIO DISTINTIVO NO DIREITO ADMINISTRATIVO BRASILEIRO}

Inicialmente, é importante ressaltar que nenhum desses critérios, por si só, tem se mostrado suficiente para a caracterização definitiva da natureza jurídica dos contratos administrativos e para explicar, de modo cabal, suas diferenças em relação aos contratos privados.

Os ordenamentos normalmente recorrem a uma soma de critérios para indicar quando se está diante de um contrato administrativo e quando não se está. É assim, por exemplo, na França, onde há a soma do critério subjetivo com o critério do objeto ou com o objeto das cláusulas exorbitantes. Como registra Jean Rivero, o ordenamento francês encontrou uma solução para o problema da identificação dos contratos administrativos pela soma de três elementos: a) as partes do contrato - "um contrato só é administrativo se uma das partes for uma pessoa colectiva de direito público"; b) o objeto do contrato - "todo o contrato cujo objecto se liga à própria execução do serviço"; e c) as cláusulas exorbintes - "quando um contrato não tem por objecto confiar a execução de um serviço a um particular, só é administrativo se contiver uma cláusula exorbitante do direito comum". O primeiro elemento é necessário e os dois outros são alternativos, fazendo que a soma do primeiro com um dos outros caracterize um contrato administrativo. ${ }^{57}$

No Brasil não é diferente. Nenhum dos critérios, isoladamente, permite uma compreensão plena do fenômeno dos contratos administrativo. Entretanto, ao contrário do que ocorre na França, cujo tratamento jurídico dos contratos administrativos é preponderantemente jurisprudencial, o ordenamento brasileiro tem uma disciplina legal dos contratos celebrados pela Administração Pública, cristalizada na Lei no 8.666/93.

A identificação dos contratos administrativos não levanta grandes dificuldades quando a própria lei, de forma expressa, enumera quais são os acordos submetidos ao regime próprio da Administração Pública, quando se tem, portanto, contratos administrativos por determinação legal. As questões polêmicas que podem surgir num modelo com expressa disciplina legal dos contratos administrativos - e que, portanto, não dão espaço à criação jurisprudencial - dizem com a observância, numa determinada avença, das condições de conclusão do pacto e dos critérios gerais impostos pelo ordenamento jurídico; ou, ainda, com a aplicação do regime geral previsto em lei a um tipo marginal de contrato, que poderá, ou não, ser administrativo. ${ }^{58}$

Ou seja, a polêmica do critério distintivo dos contratos administrativos tem, no ordenamento brasileiro, por força da Lei no $8.666 / 93$, uma importância menor do que a verificada em países sem uma normatização pretensamente exaustiva sobre a matéria.

Desse modo, o que importa na dinâmica do regime brasileiro dos contratos administrativos é identificar quais os critérios que informaram a atividade do legislador quando da elaboração da Lei de Licitações e Contratos Administrativos.

56 ESTORNINHO, Maria João. Requiem pelo contrato administrativo. Coimbra: Almedina, 1990. p. 98-99.

57 RIVERO, Jean. Direito administrativo. Coimbra: Almedina, 1981. p. 133.

58 CORREIA, José Manuel Sérvulo. Legalidade e autonomia contratual nos contratos administrativos. Coimbra: Almedina, 1987. p. 354. 
$\mathrm{Na}$ doutrina brasileira, há certo consenso na adoção do critério da sujeição. Tal como pregava Hely Lopes Meirelles,

[...] o que tipifica o contrato administrativo e o distingue do contrato privado é a participação da Administração na relação jurídica bilateral com supremacia de poder para fixar as condições iniciais do ajuste. ${ }^{59}$

Todavia, outras características - reconhecia o autor - podem ocorrer no contrato, reforçando sua natureza administrativa, marcando o privilégio administrativo na relação contratual. Dessa posição privilegiada surgem as cláusulas exorbitantes do direito comum, que dão ao contrato a sua submissão a um regime de direito público. ${ }^{60}$

Pode-se perceber do entendimento de Hely Lopes Meirelles que, apesar da alegada vinculação ao critério da sujeição - que ele chama de supremacia do interesse público -, outros elementos se somam à orientação prevalecente no Brasil, o que é confirmado pela exegese da Lei 8.666/93.

De início, deve-se tomar como referência primeira para a caracterização da contratação administrativa no Direito brasileiro o disposto no artigo 54, caput, da Lei nº 8.666/93, segundo a qual

[...] os contratos administrativos de que trata esta Lei regulam-se pelas suas cláusulas e pelos preceitos de direito público, aplicando-se-lhes, supletivamente, os princípios da teoria geral dos contratos e as disposições de direito privado. ${ }^{61}$

Há, portanto, desde logo, a fixação de um regime jurídico apartado do direito civil; ainda que não completamente, tendo em vista a aplicação supletiva da teoria geral dos contratos nele desenvolvida. Assim, é possível verificar a aplicação do critério do regime jurídico exorbitante, como, aliás, ressalta José dos Santos Carvalho Filho. ${ }^{62}$

Esse regime diferenciado, expresso por meio de "cláusulas" e "preceitos" de direito público é o fixado pela lei, seja a Lei $\mathrm{n}^{\circ}$ 8.666/93 ou mesmo outras leis que regulem contratos administrativos específicos, como a Lei no $8.987 / 95$, que cuida dos contratos de concessão e permissão de serviço público.

Em relação à Lei no 8.666/93, o mais característico dispositivo desse regime jurídico derrogatório do direito civil $^{63}$ é o artigo 58, que estabelece as prerrogativas da Administração Pública na relação contratual, ou seja, fixa as cláusulas exorbitantes dos contratos administrativos no direito brasileiro.

Entretanto, o transcrito artigo 54 menciona um regime diferenciado de direito público "para os contratos administrativos de que trata esta Lei". Resta saber, então, quais são os contratos de que trata a Lei $n^{\circ}$ 8.666/93.

A Lei 8.666/93 é uma lei nacional, no sentido exposto por Geraldo Ataliba, isto é, uma lei aplicável a todos os entes federados. ${ }^{64}$ Isso, aliás, é o que se depreende do próprio artigo $1^{\circ}$ da lei em questão.

A Lei 8.666/93, na dicção desse dispositivo, regula os "contratos administrativos pertinentes a obras, serviços, inclusive de publicidade, compras, alienações e locações no âmbito dos Poderes da União, dos Estados, do Distrito Federal e dos Municípios"; incluindo, "além dos órgãos da administração direta, os fundos especiais, as autarquias, as fundações públicas, as empresas públicas, as sociedades de economia mista e

59 MEIRELLES, Hely Lopes. Licitações e contratos administrativos. 14. ed. São Paulo: Malheiros, 2006. p. 174.

60 MEIRELLES, Hely Lopes. Licitações e contratos administrativos. 14. ed. São Paulo: Malheiros, 2006. p. 158.

61 BRASIL. Lei n. 8.666, de 21 de junho de 1993. Brasília, 1993.

62 CARVALHO FILHO, José dos Santos. Manual de direito administrativo. 17. ed. Rio de Janeiro: Lumen Iuris, 2007. p. 160.

63 É verdade que autores criticam a utilização da expressão "regime derrogatório", como faz, por exemplo, Diogo de Figueiredo Moreira Neto (MOREIRA NETO, Diogo de Figueiredo. Curso de direito administrativo. 14. ed. Rio de Janeiro: Forense, 2006. p. 163). Entretanto, o seu cunho tradicional no direito administrativo e a compreensão imediata de seu significado - o que acaba por indicar seu valor didático - permitem sua manutenção no presente estudo.

64 ATALIBA, Geraldo. Regime constitucional e leis nacionais e federais. Revista de Direito Público, São Paulo, v. 13, v. 53-54, jan./ jun. 1980. p. 62. 
demais entidades controladas direta ou indiretamente" por esses mesmos entes federados, como expresso no parágrafo único desse artigo $1^{\circ}$.

Fica evidente a delimitação, pela lei, de um critério orgânico para a caracterização dos contratos administrativos no Brasil, o que fica ainda mais claro com a definição que o artigo $6^{\circ}$, inciso XIV, da Lei 8.666/93 dá de contratante, que "é o órgão ou entidade signatária do instrumento contratual”. Órgão e entidade, por sua vez, são termos vinculados ao conceito de Administração Pública, fixado no inciso XI do mesmo artigo $6^{\circ}$ em paralelo com o disposto no artigo $1^{\circ}$ :

Administração Pública - a administração direta e indireta da União, dos Estados, do Distrito Federal e dos Municípios, abrangendo, inclusive, as entidades com personalidade jurídica de direito privado sob controle do poder público e das fundações por ele instituídas ou mantidas.

Ou seja, do ponto de vista das partes envolvidas, os contratos administrativos no ordenamento brasileiro terão a presença da Administração Pública - tomada na sua acepção mais ampla - como contratante. Trata-se, assim, de um critério orgânico e subjetivo, que se soma ao do regime exorbitante.

Por fim, ainda é possível agregar um último critério que forma a configuração normativa dos contratos administrativos no Brasil, qual seja, o da finalidade. É fato que esse critério - como anteriormente anotado - isoladamente não tem o condão de caracterizar um contrato administrativo, tendo em vista que toda a atuação administrativa deve ser baseada na consecução do interesse público.

Todavia, é possível aplicar a distinção entre finalidade imediata e mediata de interesse público. Isso porque, se analisados os contratos aos quais a legislação brasileira atribui o caráter administrativo, é possível verificar que todos eles realizam - numa perspectiva de proximidade finalística - imediatamente uma necessidade coletiva, gerando um benefício direto para a Administração Pública ou para os administrados. Na linha do sustentado por Diogo de Figueiredo Moreira Neto, o que importa é o

[...] interesse público específico, que se reconhece como aquele que, sendo definido em lei, deverá ser imediatamente atendido pela prestação que, no contrato administrativo, incumbe ao contratante privado. ${ }^{65}$

Somados esses critérios - da sujeição, das cláusulas exorbitantes, subjetivo e da finalidade de interesse público - tem-se, no ordenamento jurídico brasileiro, a síntese da natureza dos contratos administrativos, que informa a atuação do legislador na disciplina dessa matéria e serve de referência primeira para a sua conceituação.

\section{Considerações finais: FormUlaçÃo de UM CONCEITO}

A doutrina brasileira apresenta variados conceitos de contrato administrativo, enfatizando diferentes aspectos de seu regime jurídico. Para Celso Antônio Bandeira de Mello, por exemplo, contrato administrativo:

[...] é um tipo de avença travada entre a Administração e terceiros na qual, por força de lei, de cláusulas pactuadas ou do tipo de objeto, a permanência do vínculo e as condições preestabelecidas assujeitamse a cambiáveis imposições de interesse público, ressalvados os interesses patrimoniais do contratante privado. $^{66}$

Já para Maria Sylvia Zanella Di Pietro, os contratos administrativos seriam, em síntese, "os ajustes que a Administração, nessa qualidade, celebra [...], para a consecução de fins públicos, segundo regime jurídico de direito público". ${ }^{67}$

Diogo de Figueiredo Moreira Neto, por sua vez, ensina que os contratos administrativos são

65 MOREIRA NETO, Diogo de Figueiredo. Curso de direito administrativo. 14. ed. Rio de Janeiro: Forense, 2006. p. 163.

66 MELLO, Celso Antônio Bandeira de. Curso de direito administrativo. 11. ed. São Paulo: Malheiros, 1999. p. 445.

67 DI PIETRO, Maria Sylvia Zanella. Direito administrativo. 20. ed. São Paulo: Atlas, 2007. p. 233. 
manifestações de vontades recíprocas, sendo uma delas da Administração Pública, que, integradas pelo consenso, têm por objeto a constituição de uma relação jurídica obrigacional, visando a atender, com prestações comutativas, a interesses distintos, um dos quais é público. ${ }^{68}$

Esses conceitos exemplificativamente apresentados podem servir de referência para a construção - a partir da própria Lei no 8.666/93 - de uma conceituação que leve em consideração os diferentes critérios identificados no regime jurídico dos contratos administrativos no Brasil.

Tal conceito deve, portanto, expressar os seguintes aspectos: a) a Administração Pública - em sua mais ampla caracterização - deve necessariamente figurar como contratante; b) a Administração Pública participa da relação contratual com autoridade, com poder de império; c) as prerrogativas de império da Administração Pública são cristalizadas num regime jurídico de direito público, dito exorbitante, que contém cláusulas derrogatórias do direito comum; e d) a contratação administrativa busca a realização de um interesse público imediato.

A esses aspectos deve-se somar a noção de contrato consagrada no parágrafo único do artigo $2^{\circ}$ da Lei 8.666, que tem a seguinte redação:

[...] considera-se contrato todo e qualquer ajuste entre órgãos ou entidades da Administração Pública e particulares, em que haja um acordo de vontades para a formação de vínculo e a estipulação de obrigações recíprocas, seja qual for a denominação utilizada.

Nesse quadro, é possível formular o seguinte conceito, como síntese final do presente estudo: contrato administrativo é todo e qualquer ajuste celebrado pela administração direta e indireta da União, dos Estados, do Distrito Federal e dos Municípios - abrangendo inclusive as entidades com personalidade jurídica de direito privado sob controle do poder público e das fundações por ele instituídas ou mantidas - com terceiros, em que haja um acordo de vontades para a formação de vínculo e a estipulação de obrigações recíprocas, submetido a um regime de direito público que garanta prerrogativas para a Administração e voltado à realização de um interesse público.

\section{REFERÊNCIAS BIBLIOGRÁFICAS}

AMARAL, Diogo Freitas do. Curso de direito administrativo. Coimbra: Almedina, 2001. v. 2.

ATALIBA, Geraldo. Regime constitucional e leis nacionais e federais. Revista de Direito Público, São Paulo, v. 13, v. 53-54, jan./jun. 1980.

BEVILAQUA, Clovis. Código civil dos Estados Unidos do Brasil: commentado. Rio de Janeiro: Francisco Alves, 1926. v. 4.

CAETANO, Marcello. Manual de direito administrativo. 10. ed. Coimbra: Almedina, 1997. t. 1.

CARVALHO FILHO, José dos Santos. Manual de direito administrativo. 17. ed. Rio de Janeiro: Lumen Iuris, 2007.

CORREIA, José Manuel Sérvulo. Legalidade e autonomia contratual nos contratos administrativos. Coimbra: Almedina, 1987.

DI PIETRO, Maria Sylvia Zanella. Direito administrativo. 20. ed. São Paulo: Atlas, 2007.

DUGUIT, Léon. Manual de derecho constitucional: teoria general del estado, el derecho y el estado, las libertades publicas. Granada: Comares, 2007.

ESTORNINHO, Maria João. Requiem pelo contrato administrativo. Coimbra: Almedina, 1990.

68 MOREIRA NETO, Diogo de Figueiredo. Curso de direito administrativo. 14. ed. Rio de Janeiro: Forense, 2006. p. 163. 
GARCÍA DE ENTERRÍA, Eduardo; FERNÁNDEZ, Tomás-Ramón. Curso de derecho administrativo. 8. ed. Madrid: Civitas, 1998. v. 1.

HORBACH, Carlos Bastide. Teoria das nulidades do ato administrativo. 2. ed. São Paulo: RT, 2010.

KASER, Max. Direito privado romano. Lisboa: Fundação Calouste Gulbenkian, 2011.

LONG, Marceau et al. Les grands arrêts de la jurisprudence administrative. 15. ed. Paris: Dalloz, 2005.

MEDAUAR, Odete. Direito administrativo moderno. 11. ed. São Paulo: RT, 2007.

MEIRELLES, Hely Lopes. Licitações e contratos administrativos. 14. ed. São Paulo: Malheiros, 2006.

MELLO, Celso Antônio Bandeira de. Curso de direito administrativo. 11. ed. São Paulo: Malheiros, 1999.

MONTEIRO, Washington de Barros. Curso de direito civil: direito das obrigações. 7. ed. São Paulo: Saraiva, 1967.

MOREIRA NETO, Diogo de Figueiredo. Curso de direito administrativo. 14. ed. Rio de Janeiro: Forense, 2006.

PUGLIESE, Giovanni. Istituzioni di Diritto Romano. 3. ed. Torino: Giappichelli, 1991.

RIVERO, Jean. Direito administrativo. Coimbra: Almedina, 1981.

SCHMITD-ASSMANN, Eberhard. La teoría general del derecho administrativo como sistema. Madrid: Marcial Pons, 2003.

SILVA, Almiro do Couto e. Os indivíduos e o Estado na realização de tarefas públicas. Revista de Direito Administrativo, Rio de Janeiro, v. 209, p. 43-70, jul./set. 1997.

VALETTE, Jean-Paul. Service public à la française. Paris: Ellipses, 2000. 


\section{REVISTA BRASILEIRA DE POLÍTICAS PÚBLICAS BRAZILIAN JOURNAL OF PUBLIC POLICY}
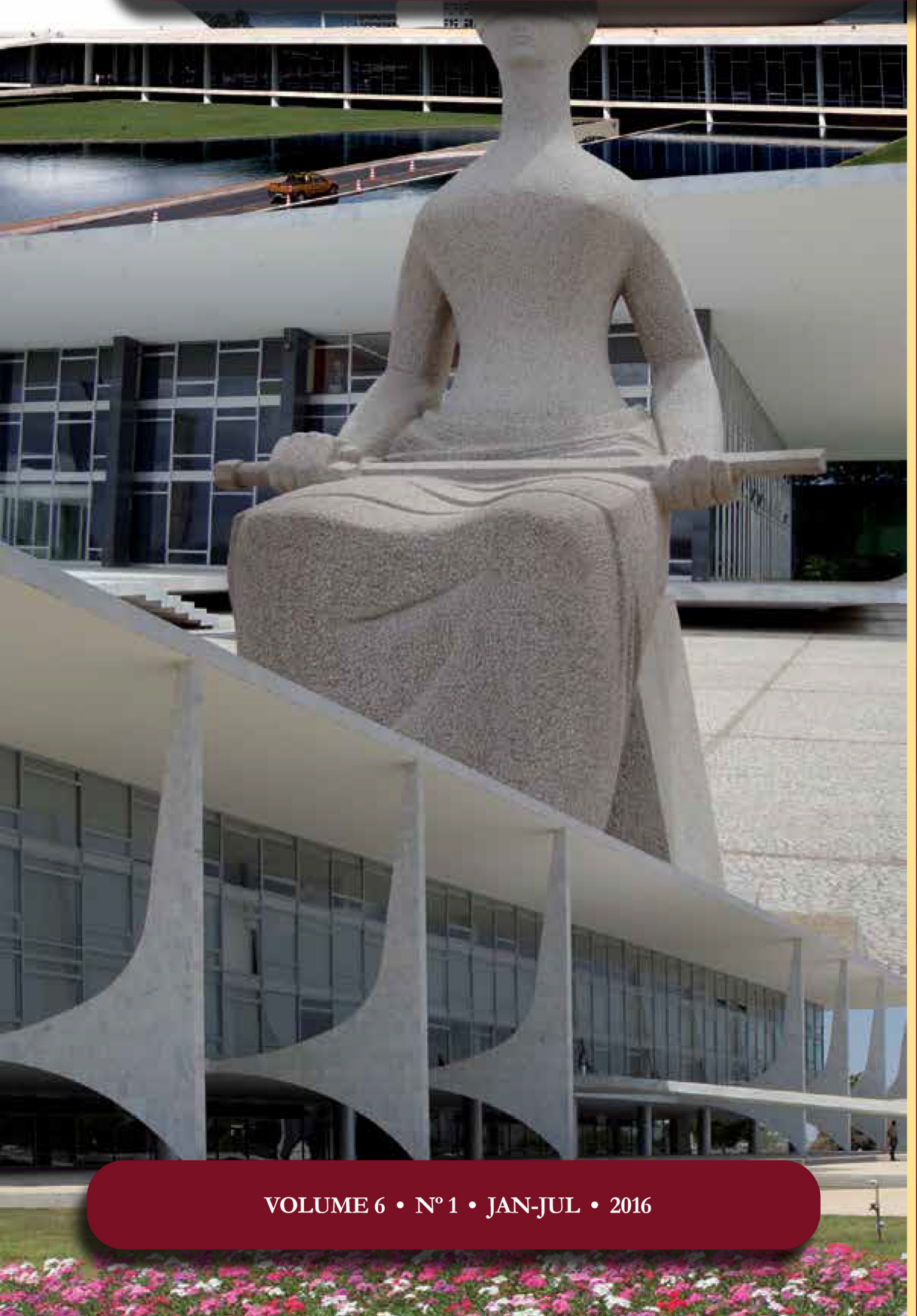

Os incentivos econômicos à compra de colhedoras pelo Pronaf-Mais alimentos para os produtores de arroz irrigado do Rio Grande do Sul

The economic incentives for purchasing harvester combine via Pronaf-Mais alimentos for irrigated rice farmers in Rio Grande do Sul

João Mairton Moura de Araújo Mário Conill Gomes André Carraro 


\title{
Os incentivos econômicos à compra de colhedoras pelo Pronaf-Mais alimentos para os produtores de arroz irrigado do Rio Grande do Sul*
}

\author{
The economic incentives for purchasing \\ harvester combine via Pronaf-Mais alimentos \\ for irrigated rice farmers in Rio Grande do \\ Sul
}

\author{
João Mairton Moura de Araújo** \\ Mário Conill Gomes*** \\ André Carraro****
}

\section{Resumo}

A inclusão de colhedoras como itens financiáveis pelo Pronaf-Mais Alimentos se apresenta como uma oportunidade para a difusão de tal tecnologia entre os agricultores familiares do Brasil. Todavia, os dados de vendas de máquinas não evidenciam um processo de difusão acelerado. Uma vez que a dependência de incentivos econômicos para os processos de difusão tecnológica são bem estabelecidos, o presente estudo avalia os impactos da compra de colhedoras pelas regras do financiamento do Programa Mais Alimentos para os agricultores a partir da modelagem dos custos do investimento. Com a análise focada nos produtores familiares de arroz irrigado do Rio Grande do Sul, estima-se que os custos provenientes da compra de máquinas são inferiores aos custos de contratação de colhedoras terceirizadas. Portanto, os termos do programa são adequados à difusão de tal tecnologia nas pequenas propriedades arrozeiras do estado. Entre as configurações de máquinas, as colhedoras de maiores capacidade operacionais se revelaram as menos custosas.

* Recebido em 20/08/2015

Aprovado em 09/01/2016

** Possui graduação em Ciências Econômicas pela Universidade Federal do Ceará (2013). Mestre em Organizações e Mercados pela Universidade Federal de Pelotas (2015). E-mail: joaomairton@gmail.com

*** Possui doutorado em Engenharia de Produção pela Universidade Federal de Santa Catarina (2001). Professor da Universidade Federal de Pelotas. E-mail: mconill@gmail.com

**** Possui doutorado em Economia pela Universidade Federal do Rio Grande do Sul (2003). Professor da Universidade Federal de Pelotas. E-mail: andre.carraro@gmail.com
Palavras-Chave: Agricultura familiar. Mecanização da agricultura. Modelo de custos.

\section{Abstract}

The inclusion of combine harvesters as a fundable asset under Pronaf-Mais Alimentos presents as an opportunity for that technology's diffusion among family farmers in Brazil. However, the machinery's sells data does not point an accelerated diffusion process. Once the technology diffusion process dependency of economics incentives is settled, this research aims evaluating the impacts of a harvester combine financing via "Mais Alimentos" program for farmers based in a costs model of the investiment. Being 
the analyses focused on irrigated rice farmers in Rio Grande do Sul, it is estimated that the costs of the machinery purchasing are lower than the alternative costs of service hiring, therefore the financing program terms are suitable to that technology's diffusion process among small irrigated rice farms of the state. Among the machinery settings, the harvester combine of highest operating capacity tend to have the lowest costs.

Keywords: Family farming. Agricultural mechanization. Costs models.

\section{INTRODUÇÃO}

A mecanização da produção agrícola é um fator importante para o aumento da produtividade da agricultura. Com o objetivo de fomentar a atividade de agricultores familiares, o governo federal criou um programa de financiamento subsidiado de máquinas para tal público, o Pronaf-Mais Alimentos. A importância do acesso ao crédito foi recentemente avaliada por Obrimah et al, evidenciando um impacto positivo na adoção de tecnologias de produção por agricultores familiares na Nigéria1.

Porém, o programa de financiamento Mais Alimentos conta com uma série de regras dotadas de discricionariedade que direcionam para públicos e ativos específicos. Assim, espera-se que o sucesso do avanço da mecanização entre os agricultores familiares seja condicionado à adequação dos termos do programa às demandas dos produtores.

Em estudo recente, Manuelli e Seshadri apontam a coerência entre o processo de difusão de tratores nos Estados Unidos e as previsões advindas das teorias clássicas do comportamento da firma². Naquele trabalho, foi evidenciado que as demandas dos agricultores por tecnologias concorrentes são bem explicadas pelas diferenças dos custos de operá-las. Por outro lado, Takeshima et al apontam que, mesmo quando os custos das tecnologias se revelam adequados, problemas como a deficiência de oferta podem travar o processo de difusão em localidades especificas ${ }^{3}$.

A adição no ano de 2010 de colhedoras de grão como item financiável pelo Mais Alimentos constituiu uma oportunidade de se intensificar a difusão de colhedoras de menor porte entre agricultores familiares no Brasil. A intenção dos termos do financiamento consiste em incentivar a organização de grupos de agricultores para adquirir colhedoras de características especificas.

Dados da Federação Nacional da Distribuição de Veículos Automotores apontam que em 2013 a venda de colhedoras de grãos no Brasil atingiu seu pico histórico. Por outro lado, no estado do Rio Grande do Sul, os dados sobre financiamento de colhedoras não evidenciam uma aceleração no processo de difusão desta tecnologia. A quantidade total de contratos de financiamentos de colhedoras automotrizes nacionais no estado em 2012 foi 966 enquanto em 2008, quando colhedoras não podiam ser financiadas pelo Mais Alimentos, foi de 949. O estado do Rio Grande do Sul concentra aproximadamente $67 \%$ da produção de arroz do Brasil ${ }^{4}$ e a maioria dos estabelecimentos são de caráter familiar 5 .

\footnotetext{
1 OBRIMAH, O. A.; ABIMIKU, F.; BRIGGS, P. B. Peasant farming in emerging countries: does agricultural financing really have an impact? Disponível em: <http://ssrn.com/abstract=2483849>. Acesso em: 1 fev. 2015.

2 MANUELLI, R. E.; SESHADRI, A. Frictionless technology diffusion: the case of tractors. American Economic Review, v. 104, n. 4, p. 1368-1391, 2014.

3 TAKESHIMA, H.; NIN--PRATT, A.; DIAO, X. Mechanization and agricultural technology evolution, agricultural intensification in Sub-Saharan Africa: typology of agricultural mechanization in Nigeria. American Journal of Agricultural Economics, v. 95, n. 5, p. 1230-1236, 2013. Disponível em: <http://ajae.oxfordjournals.org/cgi/doi/10.1093/ajae/aat045>. Acesso em: 3 dez. 2014. 4 COMPANHIA NACIONAL DE ABASTECIMENTO. Estudos de prospecção de mercado, safra 2012-2013. Disponível em: < http:// www.conab.gov.br/OlalaCMS/uploads/arquivos/12_09_11_16_41_03_prospeccao_12_13.pdf>. Acesso em: 1 nov. 2014. 5 INSTITUTO BRASILEIRO DE GEOGRAFIA E ESTATÍSTICA. Censo agropecuário 2006. Disponível em: <http://www.ibge. gov.br/home/estatistica/economia/agropecuaria/censoagro>. Acesso em: 27 fev. 2015.
} 
Nesse contexto, justifica-se uma investigação quanto à atratividade das colhedoras para os produtores de arroz no estado, dadas às regras do programa de fomento quanto ao financiamento em grupo e às características das máquinas.

Assim, o objetivo deste estudo consiste em detalhar os custos das colhedoras financiáveis pela agricultura familiar do Rio Grande do Sul nos termos do Mais Alimentos e a partir disso avaliar se estes custos favorecem a difusão da tecnologia.

\section{MÉTOdO}

Para avaliar a adequabilidade dos termos do programa de financiamento, foi utilizada modelagem de custos multiperíodos, os quais podem ser consolidados em valor presente para uma análise comparativa. Tal modelagem é amplamente utilizada na literatura que investiga estratégias de decisões de investimento e gerenciamento de ativos na agricultura. Assim, tendo em vista o investimento específico, foi adaptada a abordagem de Reid e Bradford ${ }^{6}$ a qual, além dos fluxos financeiros genéricos ${ }^{7}$, considera os custos de uma capacidade operacional inadequada.

Como o objetivo da modelagem consiste em avaliar a atratividade da compra de colhedoras nos termos do Mais Alimentos, alguns pontos merecem ser detalhados no método de avaliação.

O primeiro ponto se refere à unicidade temporal das condições do investimento. A análise de custos se limita à situação de compra no período atual, não considerando possibilidades de estratégias minimizadoras de custos que posterguem o investimento, uma vez que o comportamento dos termos do programa bem como o dos parâmetros-chaves são pouco previsíveis em períodos futuros. Com isso, foram excluídas as possiblidades de qualquer implicação quanto à substituição do equipamento. Ou seja, a modelagem se refere aos custos da compra da máquina no período atual e à posterior alienação em um período futuro, quando se enceram todos os fluxos financeiros do investimento. Com isso, não se definiu um horizonte de planejamento fixo, mas sim os custos relacionados ao investimento com qualquer duração razoável. Dadas as diferentes idades do investimento, a minimização de custos é feita com base no valor anual equivalente dos custos simulados.

Postas as devidas considerações, os componentes genéricos do modelo de custos para colhedoras de arroz é apresentado como segue.

Sobre o capital próprio:

$K=P F-F$

em que,

$\mathrm{K}$ - Capital próprio, valor que deve ser desembolsado no momento $\mathrm{N}=0$ proveniente de recursos próprios ( $\mathrm{R} \$$ correntes).

$\mathrm{PF}$ - Preço de face da colhedora à vista $(\mathrm{R} \$$ correntes $)$.

F - Valor de face do financiamento para aquisição da máquina ( $\mathrm{R}$ correntes).

6 REID, D. W.; BRADFORD, G. L. A farm firm model of machinery investment decisions. American Journal of Agricultural Economics, v. 69, n. 1, p. 64-77, 1987.

7 GRANT, E. L.; IRESON, W. G.; LEAVENWORTH, R. S. Principles of engineering economy. 7th ed. Nova Jersey: J. Wiley and Sons, 1982. 
Sobre o Financiamento:

$P M T_{N}=\left\{\begin{array}{c}F * \frac{(1+j)^{m-1} * j}{1-(1+j)^{-(n-m+1)}} ; \text { se } m<N \leq n \\ 0 ; \text { se } m \geq N \text { ou } N>n\end{array}\right.$

$I_{N}=S F_{N-1} * j$

$S F_{N}=\left\{\begin{array}{c}J_{N}+S F_{N-1}-P M T_{N} ; \text { se } N>0 \\ F ; \text { se } N=0\end{array}\right.$

em que,

$\mathrm{N}$ - período especifico no horizonte de planejamento (ano).

$\mathrm{n}$ - prazo total do financiamento (anos).

$\mathrm{m}$ - período de carência do financiamento (anos) somado de um (carêcia+1).

$j-$ taxa de juros $(\%)$.

$\mathrm{PMT}_{\mathrm{N}}$ - Valor da prestação do financiamento devido no período $\mathrm{N}$ (R $\$$ correntes).

$\mathrm{J}_{\mathrm{N}}$-Valor dos juros do financiamento referente ao período $\mathrm{N}$ ( $\mathrm{R} \$$ correntes).

$\mathrm{SF}_{\mathrm{N}}$ - Saldo final do financiamento no período $\mathrm{N}$ (R $\$$ correntes).

Sobre os custos de manutenção e reparação:

$M_{N}=P F * \mu_{N}$

em que,

$\mu_{N}$ - Coeficiente de custos de manutenção e reparação, $\left(0 \leq \mu_{N}\right)$.

$\mathrm{M}_{\mathrm{N}}$ - Custos com manutenção e reparação no período $\mathrm{N}$ (R\$ correntes).

Sobre os custos operacionais:

$O_{N}=\left\{\begin{array}{c}\left(d_{N} * k_{N}+y_{N}\right) * T_{N} ; \text { se } N>0 \\ 0 ; \text { se } N=0\end{array}\right.$

$T_{N}=\left(\frac{D}{V_{N}}\right) * u^{-1}$

$D=\frac{A * 0,01}{l * 0,0003048}$ 
$V_{N}=\left\{\begin{array}{l}\frac{D}{t_{N}} ; \text { se } t_{N} \leq \frac{D}{w(Z)} \\ w(Z) ; \text { se } t_{N}>\frac{D}{w(Z)}\end{array}\right.$

em que,

$\mathrm{O}_{\mathrm{N}}$-Custos operacionais no período $\mathrm{N}(\mathrm{R} \$$ correntes $)$.

$\mathrm{d}_{\mathrm{N}}$ - Preço do litro de díesel no período $\mathrm{N}$ (R $\$$ correntes).

$\mathrm{k}_{\mathrm{N}}$ - Consumo horário médio de diesel no período $\mathrm{N}$ (litros/hora).

$\mathrm{y}_{\mathrm{N}}$ - Custos com o operador da colhedora por hora, salários + encargos trabalhistas ( $\mathrm{R} \$$ correntes $/$ hora).

$\mathrm{u}$ - Coeficiente de eficiência de tempo da colhedora $(1 \geq \mathrm{u}>0)$.

1 - Largura da plataforma de corte da colhedora (em pés).

$\mathrm{t}_{\mathrm{N}}$ - Tempo máximo disponível para colheita no período $\mathrm{N}$ (horas).

A - Área total percorrida na lavoura (em ha).

D - Deslocamento linear total dentro da lavoura $(\mathrm{km})$.

$\mathrm{V}_{\mathrm{N}}$ - Velocidade de deslocamento durante a operação de colheita no período $\mathrm{N}$ (km/hora).

$\mathrm{T}_{\mathrm{N}}$ - Tempo total de uso da colhedora no período $\mathrm{N}$ (horas).

$\mathrm{w}(\mathrm{Z})$ - velocidade de deslocamento compatível com um nível de perda mínimo $\varphi$ (km/hora), dependente do conjunto de características Z.

Sobre o capital recuperável:

$V R_{N}=V N_{N}(X) * a_{N}(N, X)$

em que,

$V_{\mathrm{N}}$ - Valor residual da colhedora quando vendida no período $\mathrm{N}$ (R $\$$ correntes).

$\mathrm{VN}_{\mathrm{N}}$ - Valor de uma colhedora similar nova no período $\mathrm{N}(\mathrm{R} \$$ correntes).

$a_{N}$ - Coeficiente de depreciação da colhedora no período N (R\$ correntes).

$\mathrm{X}$ - conjunto de características relevantes para diferenciar o preço das colhedoras.

Sobre o progresso tecnológico:

$G_{N}=\left(R G_{N}-R_{N}\right) *(1-r)$

$R G_{N}=R P_{N} *\left(1-g_{n}\right)$

$R_{N}=R P_{N} *\left(1-p_{n}\right)$

$R P_{N}=\frac{\left(A * Q_{N} * \rho_{N}\right)}{\left(1-p_{0}\right)}$ 
$p_{N}=\varphi *\left(1+\left(\left(\frac{V_{N}-w(Z)}{w(Z)}\right)\right)\right)$

$g_{N}=p_{N} *(1-s)^{N}$

em que,

$\mathrm{G}_{\mathrm{N}}$ - Custos do progresso tecnológico consideradas as colhedoras futuras no período $\mathrm{N}$ ( $\mathrm{R} \$$ correntes).

$\mathrm{R}_{\mathrm{N}}$ - Receita da colheita usando a colhedora atual no período $\mathrm{N}$ (R $\$$ correntes).

$R G_{N}$ - Receita da colheita se fossem usadas as colhedoras futuras no período $N$ ( $R \$$ correntes).

$\mathrm{RP}_{\mathrm{N}}$ - Receita potencial da lavoura com nível $0 \%$ de perdas no período $\mathrm{N}$ ( $\mathrm{R} \$$ correntes)

$\mathrm{P}_{\mathrm{N}}$ - nível de perdas da colheita no período $\mathrm{N}(\%)$.

$\mathrm{g}_{\mathrm{N}}$ - nível de perdas da colheita das colhedoras futuras no período $\mathrm{N}(\%)$.

$\varrho_{\mathrm{N}}$ - preço do arroz no período $\mathrm{N}(\mathrm{R} \$$ correntes).

$\mathrm{Q}_{\mathrm{N}}$ - Quantidade de arroz produzida por ha no período $\mathrm{N}$.

r - Alíquota dos impostos sobre o lucro líquido.

$\varphi$ - Nível de perdas da colheita em condições ideais (\%).

$\mathrm{s}$ - taxa anual de redução de perda das colhedoras futuras $(1>\mathrm{n} \geq 0)$.

Sobre os custos do dimensionamento da máquina:

$C_{N}=R P_{N} *\left(p_{n}-\varphi\right) *(1-r)$

em que,

$\mathrm{C}_{\mathrm{N}}$ - Custos do distanciamento entre as condições de uso reais e as ideais da colhedora no período $\mathrm{N}$ ( $\mathrm{R} \$$ correntes).

Sobre a tributação sobre o lucro líquido:

$I_{N}=\left(D C_{N}+J_{N}+M_{N}+O_{N}\right) * r$

$B_{N}=\left\{\begin{array}{c}\left(V R_{N}-\left(P F *\left(1-\frac{N}{v c}\right)\right)\right) * r ; \text { se } V R_{N} \geq P F *\left(1-\frac{N}{v c}\right) \\ 0 ; \text { se } V R_{N} \leq P F *\left(1-\frac{N}{v c}\right)\end{array}\right.$

$D C_{N}=\left\{\begin{array}{c}\frac{p F}{v c} ; \text { se } 0<N \leq v c \\ 0 ; \text { se } N>v \text { c ou } N=0\end{array}\right.$

em que,

$\mathrm{I}_{\mathrm{N}}$ - Redução de custos pela redução do lucro líquido ( $\mathrm{R}$ \$ correntes)

$\mathrm{DC}_{\mathrm{N}}$ - Depreciação contábil anual no período N (R\$ correntes).

$\mathrm{B}_{\mathrm{N}}$ - Imposto incidente sobre os ganhos de capital ( $\mathrm{R} \$$ correntes)

vc - tempo de vida útil para fins contábeis (anos). 
O custo anual uniforme equivalente:

Com base nas relações que compõem os custos em cada período do horizonte de planejamento, a análise econômica é feita sobre o custo anual uniforme equivalente $\left(\mathrm{CAUE}_{\mathrm{N}}\right)$ da soma de todos os custos e descontos em determinado período para cada uma das opções de máquinas.

Assim, o cálculo dos custos relevantes incorridos pela aquisição da colhedora no período 0 e posterior alienação no período $\pi$ é realizado com base na equação 21 .

$$
C A U E_{\pi}=\left(K+\left(\frac{S F_{N}+B_{N}-V R_{N}}{(1+t m a)^{N}}\right)+\sum_{N=0}^{N=\pi}\left(\frac{P M T_{N}+M_{N}+O_{N}+G_{N}+C_{N}-I_{N}}{(1+t m a)^{N}}\right)\right) * \frac{(1+t m a)^{N} * t m a}{(1+t m a)^{N}-1}
$$

em que,

$\mathrm{CAUE}_{\pi}$ - Custo Anual Uniforme Equivalente da soma de todos os custos e descontos até o período $\pi$. tma - Taxa mínima de atratividade do investimento (\%).

\section{Resultados}

Adquirir uma colhedora nova pelo Mais alimentos surge como uma alternativa não apenas para aqueles produtores que possuem colhedoras velhas, mas também àqueles que dependem da contratação de serviços de colheita terceirizados.

O programa de financiamento aparece como uma oportunidade de substituição da colheita terceirizada por uma operação de colhedora própria. Assim, devem-se conhecer quais os custos de cada uma destas opções para um produtor individualmente.

O problema da colheita terceirizada pode ser descrito pelo modelo de custos desenvolvido anteriormente. Com base nele, pode-se modelar o comportamento do fornecedor do serviço e com isso têm-se as condições das operações que se traduzirão em custos para o agricultor. Análise similar pode ser encontrada em recente estudo de Houssou et $\mathrm{al}^{8}$, para serviços terceirizados de tratores. A simulação dos custos aplicando a modelagem anteriormente apresentada foi baseada em suposições e fontes diversas sobre elementos importantates observados na produção do arroz irrigado no Rio Grande do Sul, os quais estão explicitados na Tabela 1.

Tabela 1 - Especificação do ambiente de escolha de colhedoras, alguns parâmetros

\begin{tabular}{|l|l|l|}
\hline Parâmetro & Valor/ lei de movimento & Fonte \\
\hline $\mathrm{N}=0$ & Ano de 2013 & Suposição \\
\hline $\mathrm{PFm}$ & $\mathrm{RS} 322.596$ & MDA $^{1}$ \\
\hline $\mathrm{Fi}$ & $\mathrm{R} \$ 150.000$ & MDA \\
\hline $\mathrm{Rb}$ & $\mathrm{R} \$ 360.000$ a.a & MDA \\
\hline$\varrho_{0}$ & $\mathrm{R} \$ 32,9$ pelo saco de $50 \mathrm{~kg}$ & IRGA $^{2}$ \\
\hline $\mathrm{Q}_{0}$ & 150,7 sacos de $50 \mathrm{~kg}$ por ha & IRGA \\
\hline $\mathrm{Ag}$ & 3 & Solução eq. 23 \\
\hline $\mathrm{A}$ & 217,83 há & Solução eq. 22 \\
\hline
\end{tabular}

8 HOUSSOU, N. et al. Agricultural mechanization in Ghana: is specialized agricultural mechanization service provision a viable business model? American Journal of Agricultural Economics, v. 95, n. 5, p. 1237-1244, 2013. Disponível em: <http://ajae.oxfordjournals.org/cgi/doi/10.1093/ajae/aat026>. Acesso em: 28 fev. 2015. 


\begin{tabular}{|l|l|l|}
\hline Parâmetro & Valor/ lei de movimento & Fonte \\
\hline $\operatorname{Pr}$ & 0,01 & Suposição \\
\hline $\mathrm{P}_{0}$ & $6 \%$ & Suposição \\
\hline $\mathrm{S}$ & $5 \%$ a.a & Suposição \\
\hline$\Phi$ & $3,5 \%$ & Suposição \\
\hline $\mathrm{t}_{\mathrm{N}}$ & 300 horas & Suposição \\
\hline $\mathrm{U}$ & 0,6 & Suposição \\
\hline $\mathrm{k}_{0}$ & 12,88 litros/hora & Coletado \\
\hline $\mathrm{d}_{\mathrm{N}}$ & $\mathrm{R} \$ 2,46$ por litro & Coletado \\
\hline $\mathrm{w}(\mathrm{cv}=150)$ & $2 \mathrm{~km} / \mathrm{h}$ & Suposição \\
\hline $\mathrm{L}$ & Em pés & Depende da colhedora \\
\hline $\mathrm{CV}$ & Em cv & Depende da colhedora \\
\hline PF & Em R $\$$ corrente & Depende da colhedora \\
\hline $\mathrm{t}_{\mathrm{N}}$ & 300 horas & Suposição \\
\hline $\mathrm{R}$ & $24 \%$ & Alíquotas médias coletadas \\
\hline PIB & $3 \%$ & Suposição \\
\hline $\mathrm{IPCA}$ & $4,5 \%$. & Suposição \\
\hline $\mathrm{M}$ & $3+1$ & MDA \\
\hline $\mathrm{N}$ & 10 anos & MDA \\
\hline $\mathrm{J}$ & $2 \%$ a.a. & MDA \\
\hline $\mathrm{Im}$ & $4,5 \%$ a.a & Suposição \\
\hline Tma & $10 \%$ a.a. & Suposição \\
\hline & & \\
\hline
\end{tabular}

Fonte: Dos autores

Quem compra uma colhedora com fins de ofertar serviços de colheita tem nesse ativo um item gerador de fluxos de caixa tanto negativos (custos) quanto positivos (receita), diferenciando-se do agricultor, o qual não pode atribuir a receita gerada pela operação de colheita individualmente à colhedora.

A receita do ofertante de serviços de colheita no estado é baseada em uma porcentagem (b) da quantidade de grãos colhida $\left(\mathrm{R}_{\mathrm{N}}\right)$, equação 33. Tal percentual gira em torno de $10 \%$. Assim, é de interesse do ofertante que se colha uma grande quantidade, pois suas receitas são proporcionais. Por outro lado, os custos do proprietário de uma colhedora para tais fins são praticamente os mesmos dos agricultores que possuem colhedoras, havendo apenas pequenas modificações na maneira como as perdas se convertem em custos.

A primeira modificação deve ser feita na equação dos custos do dimensionamento (equação 17). Como o produtor tem receita equivalente $\mathrm{a} b$ da quantidade total colhida $\left(\mathrm{R}_{\mathrm{N}}\right)$, qualquer quantidade não colhida se converte em perdas do fornecedor do serviço na proporção b. Então para a colheita terceirizada a equação 17 foi substituída pela equação 23. A modificação adicional segue a mesma lógica quanto aos custos associado ao progresso tecnológico, substituindo a equação 11 pela equação 24 .

$$
\begin{aligned}
& R T_{N}=\left(R_{N}\right) *(1-r) * b \\
& C_{N}=R P_{N} *\left(p_{n}-\varphi\right) *(1-r) * b \\
& G_{N}=\left(R G_{N}-R_{N}\right) *(1-r) * b
\end{aligned}
$$


em que,

b - proporção da receita colhida que se converte em receita do fornecedor de serviços de colheita terceirizada.

$\mathrm{RT}_{\mathrm{N}}-$ Receita do fornecedor de serviços de colheita terceirizada no período $\mathrm{N}$.

As demais alterações se referem ao fato de que proprietários de colhedoras para tal fim não são público alvo do programa Mais Alimentos. Portanto, as colhedoras de categorias III ou IV não possuem descontos de $18 \%$ e não podem ser financiadas nos termos do programa para esse público.

Uma vez que as colhedoras de classes III e IV são em geral consideradas tecnicamente adequadas à colheita de arroz do público-alvo do programa de financiamento, a presente simulação considera que as colhedoras que um fornecedor de serviços terceirizados pode adquirir são as mesmas consideradas anteriormente. Para efeito de simplificação, considera-se que o fornecedor não utiliza capital de terceiros para a aquisição da máquina, $(\mathrm{F}=0)$.

Especificado dessa forma, tem-se, para cada período N, uma série de custos e receitas que podem ter seus valores presentes acumulados e transformados em séries anuais uniformes. O valor da série anual uniforme das receitas menos os custos, equação 25, pode ser analisado como uma medida de lucro liquido.

$$
L L_{\pi}=\left(\left(\sum_{N=0}^{N=\pi} \frac{R T_{N}}{(1+t m a)^{N}}\right) * \frac{(1+t m a)^{N} * t m a}{(1+t m a)^{N-1}}\right)-C A U E_{\pi}
$$

em que

LL $\pi$ - Lucro líquido anual uniforme do fornecedor de serviços de colheita terceirizada até o período $\pi$.

Como uma firma convencional, espera-se que as decisões de produção do ofertante de colheita terceirizada objetive a maximização de seu lucro, dadas as suas restrições. Para a presente análise, considera-se que o produtor dispõe de $\mathrm{K}$ unidades monetárias no período $\mathrm{N}=0$, suficiente para adquirir apenas uma das colhedoras. Assim, a restrição que age ativamente no problema do produtor é o tempo disponível para as operações de colheita no estado $\left(t_{\mathrm{N}}=300\right.$ horas).

O produtor deve escolher qual colhedora e a quantidade de serviços oferecida, equivalente à área total colhida, no tempo disponível. Os custos do produtor não sofrem grandes influências das perdas enquanto ele não cobre áreas suficientemente grandes que esgotem as 300 horas da colheita disponíveis. Em relação a esse limite, o aumento dos custos operacionais é a principal fonte de variação.

A partir da área que é suficientemente grande para demandar mais de 300 horas de operação em condições de perdas mínimas, os custos com as perdas decorrentes do aumento da velocidade de operação começam a ser positivos, enquanto os custos operacionais ficam fixos, pois não se aumentam as horas trabalhadas.

Já a receita é crescente para as primeiras quantidades adicionais de área colhida, mas, devido às perdas geradas pela restrição de tempo, a receita diminui quando a área colhida é muito grande.

Normalizando a área total colhida pela quantidade de agricultores público-alvo do programa Mais Alimentos, considerando que cada um teria 72,6 ha de lavoura de arroz irrigado a serem colhidos. A figura 1 apresenta o comportamento do lucro liquido máximo do fornecer de serviço terceirizado para cada quanti- 
dade de agricultores que ele escolha atender (Agt) e o nível de perdas da operação $\left(\mathrm{p}_{\mathrm{N}}\right)$.

Figura 1 - Gráfico do Lucro líquido máximo da colheita terceirizada e nível de perdas da operação $\left(\mathrm{p}_{\mathrm{N}}\right)$ utilizando-se cada colhedora (classe III ou IV) por quantidade de agricultores atendidos

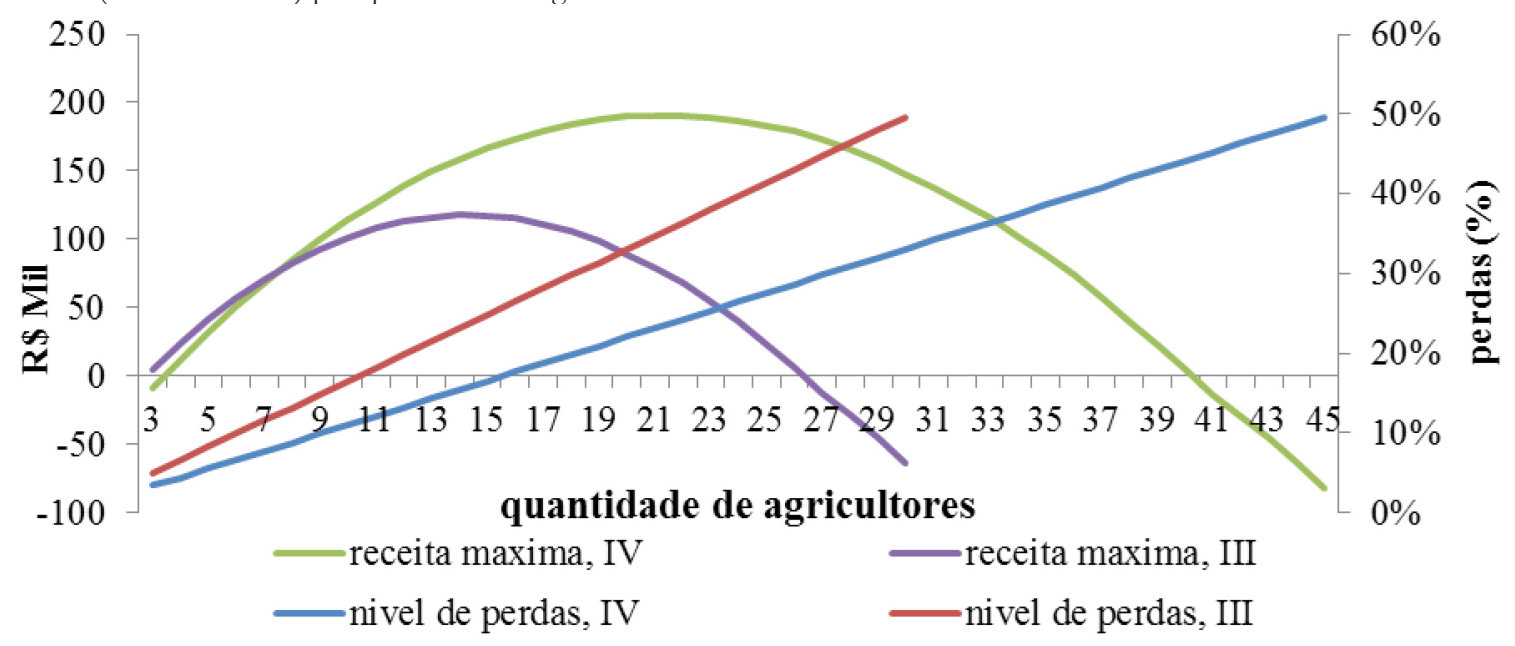

Fonte: elaboração própria

Pela figura 1, identifica-se que a colhedora da categoria IV tem o potencial de gerar maior lucro para o fornecedor de serviços de colheita terceirizada. A combinação dessa colhedora atendendo um público de 21 agricultores geraria um lucro anual equivalente máximo de $\mathrm{R} \$ 225.093$, operando a um nível de perdas de $23 \%\left(\mathrm{p}_{\mathrm{N}}\right)$, em um horizonte de planejamento de nove anos. A colhedora de categoria III seria preferível apenas se não houvesse expectativas de atender mais do que cinco agricultores.

A figura 1 explica em parte as queixas dos agricultores quanto à terceirização da colheita. De fato, os fornecedores de serviços de colheita terceirizados têm incentivos para aumentar a velocidade de operação, deteriorando a qualidade dos serviços prestados. Além disso, qualquer atraso na operação de uma lavoura pode deixar outra sem o serviço.

O nível desejável de perdas $\mathrm{p}_{\mathrm{N}}=23 \%$ pelo fornecedores do serviço dificilmente seria tolerado pelos agricultores em condições normais, exceto quando as condições climáticas apresentem a perspectiva de perda total da lavoura. De fato, os produtores rurais monitoram a qualidade do serviço prestado e pressionam para que não se atinjam tais níveis de perdas. Entretanto, a operação terceirizada conta com um nível muito menor de controle do agricultor quando comparada à operação de uma colhedora própria. Para a comparação entre os custos das duas opções, considere-se que os agricultores limitem em $\mathrm{p}_{\mathrm{N}}=10 \%$ o nível de perdas máximo admissível. Assim, operações que atinjam níveis superiores seriam totalmente rejeitadas por esses.

Sendo 10\% o nível máximo de perdas $\left(\mathrm{p}_{N}\right)$, os fornecedores de serviços terceirizados maximizariam seus lucros individuais adquirindo colhedoras da categoria IV e atenderiam a nove agricultores (Agt=9), tendo um lucro anual equivalente de $\mathrm{R} \$ 132.736 \mathrm{em}$ um horizonte de planejamento de nove anos $(\pi=9)$.

Os custos individuais dos agricultores que contratarem estes serviços seriam formados pela soma de dois componentes. O primeiro é a proporção $\mathrm{b}$ da quantidade colhida, que é igual à receita do fornecedor de serviços de colheita terceirizada $\left(\mathrm{RT}_{\mathrm{N}}\right)$. O segundo é a diferença entre as perdas da colheita terceirizada e as perdas que poderiam ser alcançadas em uma operação de perdas mínimas. A equação 26 apresenta tais custos em termos de série anual uniforme equivalente.

$$
\operatorname{CAUETI}_{\pi}=\left(\sum_{N=0}^{N=\pi} \frac{R T_{N}+\left(R P_{N} *\left(p_{n^{-}}-\varphi\right) *(1-r) *(1-b)\right) * A g t^{-1}}{(1+t m a)^{N}}\right) * \frac{(1+t m a)^{N} * t m a}{(1+t m a)^{N}-1}
$$


em que,

Agt - Quantidade de agricultores atendidos pela mesmo colhedora terceirizada

$\mathrm{CAUETI}_{\pi}$ - Custos individuais de cada agricultor atendido pela mesma colhedora terceirizada no período $\pi$.

Dividindo a série de CAUE's da colhedora da categoria IV pela quantidade de agricultores utilizada na simulação $(\mathrm{Ag}=3)$, pode-se compará-los com os valores da equação 37. $\mathrm{Na}$ figura 5 , são apresentados os custos anuais individuais de ambas as opções, colhedora própria adquirida em grupo de três agricultores, nove agricultores e contratação de colhedora terceirizada.

Figura 2- Gráfico dos CAUE's individuais por idade do investimento: colhedora própria (Classe IV) e terceirizada
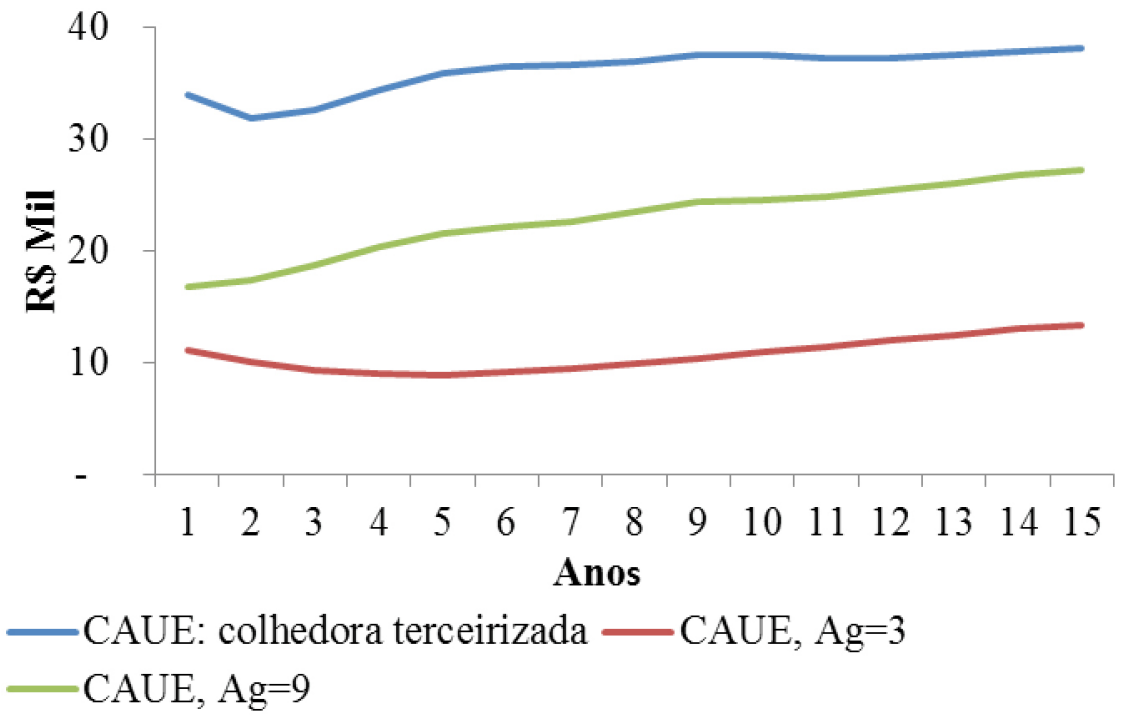

Fonte: elaboração própria

Embora as vidas econômicas das opções sejam diferentes, percebe-se que os custos associados à contratação de serviços de colheita de terceiros é uma opção mais custosa do que as opções de associação em grupos para financiar uma colhedora nova pelo programa Mais Alimentos. A proporção $b=10 \%$ e o elevado nível de perdas $\mathrm{p}_{\mathrm{N}}=10 \%$ põem a opção de colheita terceirizada em uma posição pouco competitiva em relação à aquisição de máquinas em grupo. Embora o nível de perdas $\mathrm{p}_{\mathrm{N}}=10 \%$ desfavoreça a opção por terceirização, quando se igualam as condições de colheita da colheita terceirizada com a máquina própria $\left(\mathrm{Ag}=\mathrm{Agt}=9, \mathrm{p}_{\mathrm{N}}=10 \%\right)$ a terceirização ainda se releva mais custosa, como destaca a figura 2.

Embora $\mathrm{Ag}=3$ tenha sido escolhido pela capacidade de escolha entre qualquer das máquinas financiáveis em 100\% do seus preços, este tamanho do grupo de agricultores escolhendo uma colhedora de classe IV compõe a configuração de menor CAUE individual entre as demais combinações de máquinas e tamanho dos grupos, figura 2. Enfatiza-se que obetendo-se menores custos individuais ao se formarem grupos corrobora a relação entre maiores efeciências técnicas e a participação em agrupamento de produtores de arroz irrigado descrita por Gedara et al'.

9 GEDARA, K. M. et al. Factors affecting technical efficiency of rice farmers in village reservoir irrigation systems of Sri Lanka. Journal of Agricultural Economics, v. 63, n. 3, p. 627-638, 2012. Disponível em: <http://doi.wiley.com/10.1111/j.1477-9552.2012.00343. x>. Acesso em: 28 fev. 2015. 


\section{Considerações finais}

Para o sucesso de politicas que tenham por objetivo a difusão de tecnologias de produção, é crucial que se conheçam os custos dos produtores. A adição das colhedoras como item financiável pelo Mais Alimentos foi feita de forma que criou incentivos econômicos que justificam a compra desta máquinas por pequenos produtores. Os resultados deste artigo apontam, portanto, que as condições de demanda, baseada nos custos dos produtores, estão favoráveis à decisão por financiamentos destes ativos.

\section{REFERÊNCIAS BIBLIOGRÁFICAS}

COMPANHIA NACIONAL DE ABASTECIMENTO. Estudos de prospecção de mercado, safra 2012-2013. Disponível em: < http://www.conab.gov.br/OlalaCMS/uploads/arquivos/12_09_11_16_41_03_prospeccao_12_13.pdf >. Acesso em: 1 nov. 2014.

GEDARA, K. M. et al. Factors affecting technical efficiency of rice farmers in village reservoir irrigation systems of Sri Lanka. Journal of Agricultural Economics, v. 63, n. 3, p. 627-638, 2012. Disponível em: < http:// doi.wiley.com/10.1111/j.1477-9552.2012.00343.x>. Acesso em: 28 fev. 2015.

GRANT, E. L.; IRESON, W. G.; LEAVENWORTH, R. S. Principles of engineering economy. 7th ed. Nova Jersey: J. Wiley and Sons, 1982.

HOUSSOU, N. et al. Agricultural mechanization in Ghana: is specialized agricultural mechanization service provision a viable business model? American Journal of Agricultural Economics, v. 95, n. 5, p. 1237-1244, 2013. Disponível em: <http://ajae.oxfordjournals.org/cgi/doi/10.1093/ajae/aat026>. Acesso em: 28 fev. 2015.

INSTITUTO BRASILEIRO DE GEOGRAFIA E ESTATÍSTICA. Censo agropecuário 2006. Disponível em: <http://www.ibge.gov.br/home/estatistica/economia/agropecuaria/censoagro>. Acesso em: 27 fev. 2015.

INSTITUTO RIO GRANDENSE DO ARROZ. Custo de producão do arroz irrigado médio ponderado no Rio Grande do Sul, sistema de cultivo minimo, estimativa da safra 2013/14. Disponível em: < http://www.irga.rs.gov. br/upload/20140318133121custo_de_producao_medio_ponderado_arroz_irrigado_2013_14.pdf>. Acesso em: 1 nov. 2014

MANUELLI, R. E.; SESHADRI, A. Frictionless technology diffusion: the case of tractors. American Economic Review, v. 104, n. 4, p. 1368-1391, 2014.

BRASIL. Ministério do Desenvolvimento Agrário. Pronaf-Mais alimentos. Disponível em: <http://portal. mda.gov.br/portal/saf/maisalimentos/>. Acesso em: 8 jan. 2015.

OBRIMAH, O. A.; ABIMIKU, F.; BRIGGS, P. B. Peasant farming in emerging countries: does agricultural financing really have an impact? Disponível em: <http://ssrn.com/abstract=2483849>. Acesso em: 1 fev. 2015.

REID, D. W.; BRADFORD, G. L. A farm firm model of machinery investment decisions. American Journal of Agricultural Economics, v. 69, n. 1, p. 64-77, 1987.

TAKESHIMA, H.; NIN--PRATT, A.; DIAO, X. Mechanization and agricultural technology evolution, agricultural intensification in Sub-Saharan Africa: typology of agricultural mechanization in Nigeria. American Journal of Agricultural Economics, v. 95, n. 5, p. 1230-1236, 2013. Disponível em: < http:/ / ajae.oxfordjournals. org/cgi/doi/10.1093/ajae/aat045>. Acesso em: 3 dez. 2014. 
(Notas)

1 BRASIL. Ministério do Desenvolvimento Agrário. Pronaf-Mais alimentos. Disponível em: <http://portal. mda.gov.br/portal/saf/maisalimentos/>. Acesso em: 8 jan. 2015.

2 INSTITUTO RIO GRANDENSE DO ARROZ. Custo de produção do arroz irrigado médio ponderado no Rio Grande do Sul, sistema de cultivo minimo, estimativa da safra 2013/14. Disponível em: <http://www.irga.rs.gov. br/upload/20140318133121custo_de_producao_medio_ponderado_arroz_irrigado_2013_14.pdf>. Acesso em: 1 nov. 2014. 


\section{REVISTA BRASILEIRA DE POLÍTICAS PÚBLICAS BRAZILIAN JOURNAL OF PUBLIC POLICY}

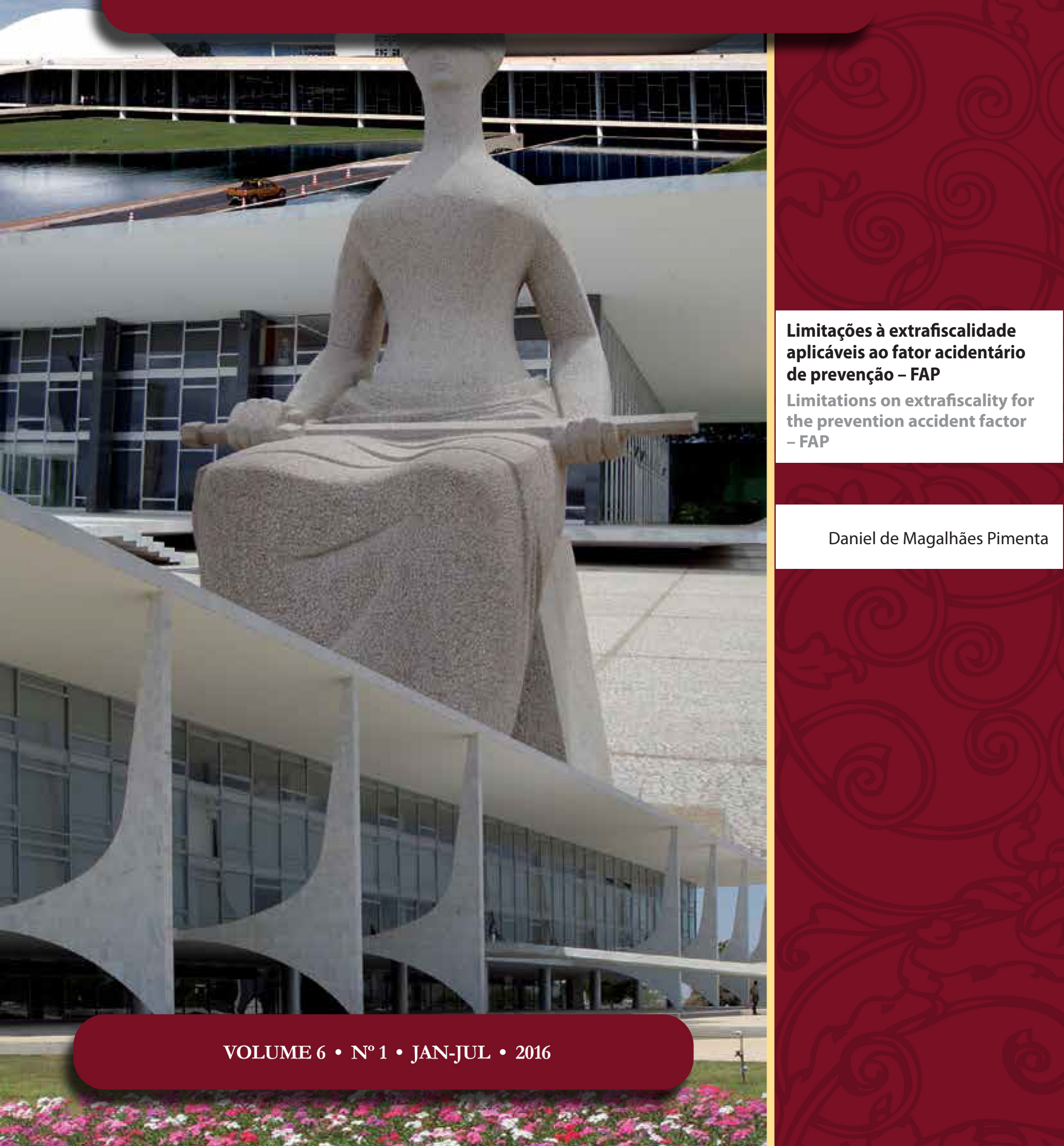




\title{
Limitações à extrafiscalidade aplicáveis ao fator acidentário de prevenção - FAP*
}

\author{
Limitations on extrafiscality for the \\ prevention accident factor - FAP
}

Daniel de Magalhães Pimenta**

\begin{abstract}
Resumo
A determinação de um mecanismo como o FAP, que impõe alíquotas individuais majoradas da contribuição previdenciária a contribuintes que apresentam maiores índices de frequência de acidentes de trabalho e de concessão de benefícios previdenciários de ordem acidentária, desafia o intérprete a buscar suas conclusões nos pilares teóricos da extrafiscalidade, dada a enorme complexidade e riqueza do tema. O presente estudo procura analisar alguns aspectos atinentes à matéria, demonstrando em que peso os limites à extrafiscalidade podem interferir na sistemática implementada pelo poder tributante e sob qual ótica o FAP, tal qual delimitado pelo legislador e pelas normativas reguladoras atuais sobre a matéria, pode representar riscos às garantias constitucionais definidas na ordem econômica e nas limitações ao poder de tributar.
\end{abstract}

Palavras-chave: FAP. Extrafiscalidade. Tributação. Economia.

\section{Abstract}

The determination of a mechanism such as FAP, which imposes higher individual tax rates of social security contributions to taxpayers who have higher numbers of labour accidents and granting of accident pension benefits, challenges the interpreter to pursue its conclusions on the theoretical pillars of extrafiscality, given the enormous complexity and theme of wealth. This study seeks to analyze certain aspects of the matter, demonstrating that limits on extrafiscality can interfere with the systematic implemented by the taxing power, and how FAP, like delimited by the legislature and by current regulatory norms on the matter, may impose risks to constitutional guarantees defined in the economic order and in the limitations on constitutional the power to tax.

Keywords: FAP. Extrafiscality. Taxation. Economy.

* Recebido em 10/03/2016 Aprovado em 05/06/2016

** Mestrando em Direito Empresarial pelas Faculdades Milton Campos. Advogado. Professor. E-mail: daniel@sgarbimagalhaes.com.br

\section{INTRODUÇão: FAP E SUAS RAÍZES EXTRAFISCAIS}

Analisando as raízes históricas do FATOR ACIDENTÁRIO DE PREVENÇÃO - FAP, constatamos que sua criação se deu em um contexto de 
desequilíbrio fiscal verificado no Brasil desde o final do século XX. Naquele momento o governo federal, preocupado com o aumento das despesas previdenciárias decorrentes de benefícios concedidos em função de acidentes de trabalho e de aposentadorias especiais ${ }^{1}$, instituiu a contribuição ao SAT, inserindo, no ordenamento tributário nacional, o art. 22, II da lei 8.212/91 ${ }^{2}$, que passou a prever a cobrança de contribuição social para o financiamento dos benefícios previdenciários de risco definidos nos arts. 57 e 58 da lei $8.213 / 91^{3}$ e daqueles concedidos em razão da incapacidade laborativa decorrente dos riscos ambientais do trabalho.

Além dessa importante inovação trazida a partir de 1998, que contemplava o custeio das despesas adicionais com esses benefícios especiais, o Executivo, também, procurou criar uma solução para a redução os gastos públicos realizados sob essa rubrica.

Efetivamente, o Executivo Federal tentou buscar soluções não somente para os efeitos do aumento dos gastos públicos, por meio da instituição de uma fonte fiscal de custeio complementar, mas também para as causas dessas despesas, quais sejam os riscos e condições de trabalho severas até então verificadas no ambiente de trabalho das empresas.

O pensamento silogístico do Executivo era de que, com a redução dos acidentes de trabalho e dos riscos ambientais laborais, menor seria a incidência de benefícios previdenciários dessa natureza, gerando-se, por consequência, o desejado equilíbrio das contas públicas.

Nesse contexto, surgiu, no ano de 2002, em reflexo à necessidade de redução de gastos previdenciários e do desenvolvimento das políticas públicas de proteção da saúde, higiene e segurança do trabalhador, a medida provisória n. $83^{4}$, de 12 de Dezembro de 2002, posteriormente convertida na lei federal 10.666, de 8 de maio de $2003^{5}$, que, pela primeira vez, previu o mecanismo extrafiscal que pouco mais tarde seria intitulado FAP - Fator Acidentário de Prevenção.

Segundo o art. $10^{6}$ da MPv 83/2002, convertida posteriormente na lei 10.666/2003, as alíquotas de 1\%, $2 \%$ e 3\% da contribuição ao SAT poderão ser reduzidas em até 50\% (cinquenta por cento) ou majoradas em até cem por cento, dependendo do desempenho de cada empresa em relação ao grau de incidência de incapacidade laborativa decorrente dos riscos verificados em seu ambiente de trabalho.

Esse novo elemento trouxe profundas alterações na sistemática de apuração da contribuição ao SAT, pois, além da majoração ou redução das alíquotas efetivas anteriormente existentes, instituiu-se a aplicação de alíquota específica e individual para cada contribuinte, e criou-se, ainda, sistemática de apuração complexa e que leva em consideração ranking de empresas elaborado segundo metodologia específica definida em regulamento.

1 As aposentadorias especiais, segundo a lei 8213/91, são aquelas concedidas pelo desempenho de atividades sujeitas a riscos e condições de trabalho especialmente severas.

2 BRASIL. Lei ordinária n. 8.212, de 24 de julho de 1991. Brasília, 1991. Disponível em:<http://www.planalto.gov.br/ccivil_03/leis/ L8212cons.htm>. Acesso em: 15 jul. 2015.

3 BRASIL. Lei ordinária n. 8.213, de 24 de julho de 1991. Brasília, 1991. Disponível em: < http://www.planalto.gov.br/CCIVIL_03/ leis/L8213cons.htm>. Acesso em: 15 jul. 2015.

4 BRASIL. Medida provisória n. 83, de 12 de dezembro de 2002. Brasília, 2002. Disponível em:< http://www.planalto.gov.br/ccivil_03/mpv/Antigas_2002/83.htm>. Acesso em: 15 jul. 2015.

5 BRASIL. Lei ordinária n. 10.666, de 8 de maio de 2003. Brasília, 2003. Disponível em: <http://www.planalto.gov.br/ccivil_03/ leis/2003/L10.666.htm>. Acesso em: 15 jul. 2015.

6 Cite-se, nesse sentido, a redação da medida provisória em comento:

[...] Art. 10. A alíquota de contribuição de um, dois ou três por cento, destinada ao financiamento do benefício de aposentadoria especial ou daqueles concedidos em razão do grau de incidência de incapacidade laborativa decorrente dos riscos ambientais do trabalho, poderá ser reduzida, em até cinqüenta por cento, ou aumentada, em até cem por cento, conforme dispuser o regulamento, em razão do desempenho da empresa em relação à respectiva atividade econômica, apurado em conformidade com os resultados obtidos a partir dos índices de freqüência, gravidade e custo, calculados segundo metodologia aprovada pelo Conselho Nacional de Previdência Social. BRASIL. Medida provisória n. 83, de 12 de dezembro de 2002. Brasília, 2002. Disponível em: <http://www.planalto. gov.br/ccivil_03/mpv/Antigas_2002/83.htm>. Acesso em: 15 jul. 2015. 
Outrossim, verificou-se, a partir do art.10 da lei 10.666/2003, a aplicação de uma evidente função extrafiscal da contribuição ao SAT, pois a União, por meio do Decreto Regulamentar posterior, elegeria um standard de comportamento a ser alcançado pelas empresas em relação às melhorias das condições da saúde e de ambiente de trabalho, e ofereceria a estas um prêmio ou uma punição pelos resultados decorrentes dos investimentos nessa área, por meio da flexibilização das alíquotas básicas da contribuição de acordo com o desempenho da empresa em cálculos realizados mediante metodologia aprovada pelo Conselho Nacional de Previdência Social.

A exposição de motivos da MPv 83/2002 retrata, claramente, a intenção extrafiscal do governo federal com a adoção dessa nova metodologia. Vejamos:

$[\ldots]$

31. No art. 10, faz-se proposta de flexibilização de alíquotas de contribuição em razão dos desempenhos das empresas na prevenção dos acidentes de trabalho. A preocupação com a saúde e segurança dos trabalhadores constitui-se em um dos temas de mais elevado poder aglutinador. Mesmo reconhecendo que a necessidade de proteger o trabalhador que trabalha em ambiente ou serviço perigoso, insalubre ou penoso é da empresa que assume o risco da atividade econômica e deve responsabilizar-se pelas consequências das enfermidades contraídas e acidentes do trabalho sofridos pelos empregados, na prática que as suporta é o Governo, por meio do Ministério da Saúde em relação às despesas médicas e hospitalares e do INSS em relação às incapacidades laborativas, temporárias ou permanentes e às mortes.

32. A proposta visa introduzir mecanismos que estimulem os empresários a investirem em prevenção e melhoria das condições do ambiente de trabalho, mediante a redução, em até $50 \%$, ou acréscimo, em até $100 \%$, da alíquota de contribuição destinada ao financiamento das aposentadorias especiais ou dos benefícios concedidos em razão de acidentes ou de doenças ocupacionais, conforme a sua posição da empresa na classificação geral apurada em conformidade com os índices de frequência, gravidade e custo das ocorrências de acidentes, medidas segundo metodologia aprovada pelo Conselho Nacional de Previdência Social - CNPS. A participação do CNPS na validação desta metodologia é de fundamental importância devido ao caráter quadripartite (governo, aposentados, trabalhadores e empregadores) da sua composição.

Com efeito, mais do que, simplesmente, arrecadar fundos para o custeio da máquina previdenciária, a contribuição ao SAT passava a exercer papel fundamental no estímulo de investimentos em prevenção e melhoria das condições do ambiente de trabalho, à medida que quanto maior os investimentos, em tese seriam menores as alíquotas aplicáveis aos contribuintes.

A nova função extrafiscal da contribuição ao SAT era, então, inequívoca com a edição da MPv 83/2002 e da lei 10.666/2003, mas pairava, ainda, no ordenamento dúvida sobre o formato a ser adotado pelo Executivo para cumprir com essa finalidade.

Visando responder a esse questionamento, o Decreto 6.042/2007 ${ }^{8}$, alterado pelo Decreto 6.957/2009 $\mathrm{e}$ instruído por portarias e outros atos normativos, instituiu o que hoje se conhece como FAP - Fator Acidentário de Prevenção, que nada mais é do um multiplicador que, aplicado à alíquota inicial do SAT (1\%,2\% ou 3\%), gerará o valor da alíquota efetiva a ser recolhida mensalmente pelo contribuinte durante o exercício fiscal subsequente. É o que dispõe o art. 202-A do Decreto 6042/2007, verbis:

Art. 202-A. As alíquotas constantes nos incisos I a III do art. 202 serão reduzidas em até cinquenta por cento ou aumentadas em até cem por cento, em razão do desempenho da empresa em relação à sua respecti-

7 BRASIL. Medida provisória n. 83, de 12 de dezembro de 2002. Brasília, 2002. Disponível em:< http://www.planalto.gov.br/ccivil_03/mpv/Antigas_2002/83.htm>. Acesso em: 15 jul. 2015.

8 BRASIL. Decreto $n$. 6.042, de 12 de fevereiro de 2007. Brasília, 2007. Disponível em:<http://www.planalto.gov.br/ccivil_03/_ ato2007-2010/2007/decreto/d6042.htm>. Acesso em: 15 jul. 2015.

9 BRASIL. Decreto n. 6.957, de 9 de setembro de 2009. Brasília, 2009. Disponível em:< http://www.planalto.gov.br/ccivil_03/_ ato2007-2010/2009/decreto/d6957.htm>. Acesso em: 15 jul. 2015. 
va atividade, aferido pelo Fator Acidentário de Prevenção - FAP. (Incluído pelo Decreto nº 6.042, de 2007) ${ }^{10}$.

\10 O FAP consiste num multiplicador variável num intervalo contínuo de cinco décimos $(0,5000)$ a dois inteiros $(2,0000)$, aplicado com quatro casas decimais, considerado o critério de arredondamento na quarta casa decimal, a ser aplicado à respectiva alíquota. (Redação dada pelo Decreto no 6.957 , de $2009)^{11}$.

Do ponto de vista meramente técnico-procedimental, o multiplicador que constitui o FAP seria, então, o resultado da aplicação da metodologia aprovada pelo CNPS que, aplicado à alíquota básica definida pelos critérios do RAT, geraria a alíquota efetiva da contribuição ao SAT a ser recolhida pelo contribuinte.

Já do ponto de vista jurídico, que constitui o ponto de interesse do presente estudo, o FAP se revelaria como principal instrumento de aplicação da função indutora extrafiscal em relação à contribuição ao SAT.

Evidentemente, a norma contida no artigo 10 da lei 10.666/2003 e regulamentada pelos decretos governamentais posteriores induz o contribuinte a comportamentos desejados pelo legislador.

Entretanto, a extrafiscalidade, ainda que seja hoje elemento central do FAP, deve se balizar sob os fundamentos próprios aplicáveis a esse tipo de norma. Com efeito, toda a teoria constitucional contemporânea baseia-se no reconhecimento de garantias fundamentais da sociedade frente ao poder regulamentador Estatal e não será diferente em relação às normas tributárias indutoras.

Dentro desse espectro é que se centra a presente pesquisa, pois, se não há dúvidas quanto à possibilidade de instituição de normas extrafiscais indutoras de comportamento tais como a prevista no Decreto 6042/2007, é importante constatar se estas estão adequadas aos limites, tributários ou não, que percorrem o ordenamento constitucional pátrio.

Assim, o presente artigo se imiscui no estudo dos limites da extrafiscalidade para chegar a algumas das conclusões sobre a validade do FAP perante o ordenamento jurídico brasileiro.

Para tanto, serão abordadas as limitações ao poder extrafiscal delimitadas pela doutrina, e apresentados aspectos da ordem constitucional econômica e tributária que, aplicados ao FAP, podem gerar discussões sobre a compatibilidade dessa sistemática no ordenamento Brasileiro.

\section{LIMITAÇõES À EXTRAFISCALIDADE SEGUNDO À DOUTRINA}

Iniciando as discussões propostas, importante se mostra adotar uma definição de extrafiscalidade em direito tributário que melhor se adapte aos objetivos do presente estudo, posto que a doutrina revela conceitos e definições distintas para os mais diversos fins e extensões.

Para tanto, definimos a extrafiscalidade como o fenômeno jurídico no qual o Estado, por meio da imposição de uma obrigação tributária, procura realizar finalidade constitucional diversa da mera arrecadação para o custeio de suas atividades.

Apurada a definição de extrafiscalidade a ser utilizada no presente ensaio, passemos a demonstrar os limites teóricos e práticos para a imposição desse fenômeno no Estado Brasileiro, segundo a doutrina pátria mais abalizada sobre o tema.

10 BRASIL. Decreto n. 6.042, de 12 de fevereiro de 2007. Brasília, 2007. Disponível em: < http://www.planalto.gov.br/ccivil_03/_ ato2007-2010/2007/decreto/d6042.htm>. Acesso em: 15 jul. 2015.

11 BRASIL. Decreto n. 6.957, de 9 de setembro de 2009. Brasília, 2009. Disponível em: <http://www.planalto.gov.br/ccivil_03/_ ato2007-2010/2009/decreto/d6957.htm>. Acesso em: 15 jul. 2015. 


\subsection{A classificação dos limites por Marciano Seabra de Godoi}

A maioria dos doutrinadores aborda os limites da prática extrafiscal com base aos nos dispositivos constitucionais que a fundamentam. Para esses autores, a norma extrafiscal, além da necessária vinculação aos fundamentos aplicáveis ao Direito Tributário brasileiro, também deverá atender às determinações constitucionais relativas à finalidade pela qual foi aplicada ${ }^{12}$.

Nesse norte, muito válidas para a definição das limitações constitucionais da extrafiscalidade são as digressões promovidas por Godoi ${ }^{13}$ sobre o tema. Para o festejado autor, a norma extrafiscal não poderá ser realizada se violar pelo menos um dos limites a seguir.

- Aqueles relacionados aos direitos fundamentais

- Aqueles relacionados a direitos de propriedade

- Aqueles relacionados ao dever de contribuir com os gastos públicos

- Aqueles relacionados à competência tributária material e legislativa

- Aqueles relacionados à capacidade contributiva

\section{Limites relacionados aos direitos fundamentais}

A limitação da extrafiscalidade pelos direitos fundamentais impõe o respeito, pelo legislador extrafiscal, aquela série de direitos individuais e sociais dispostos explicita e implicitamente na constituição de 1988. Assim, não seria possível a instituição de uma medida extrafiscal como uma taxa judiciária por demais majorada que limitasse, por exemplo, o acesso das pessoas à Justiça.

\section{Limites relacionados a direitos de propriedade}

Da mesma forma, outro limite à extrafiscalidade, para o autor mineiro, seriam os direitos de propriedade, e nesse ponto não se estaria diante somente dos princípios da vedação ao confisco, mas, também, aqueles relativos ao exercício dos direitos sobre a propriedade, sendo vedada, portanto, qualquer medida de objetivo extrafiscal que limitasse o exercício desse direito, e nesse ponto se incluiria inclusive a vedação ao exercício da livre iniciativa, também referido no presente estudo.

\section{Limites relacionados ao dever de contribuir com os gastos públicos}

No que tange ao dever fundamental de pagar impostos e contribuir com os gastos públicos, tão celebremente festejado por Nabais ${ }^{14}$, o professor Marciano Seabra Godoi chama atenção para a dimensão material do tributo, demonstrando a impossibilidade de medida tributária extrafiscal em situações em que não houver a representação de riqueza, pois o tributo não pode ser dissociado da fiscalidade e do conceito de tributo, conforme já delineado nos tópicos anteriores.

12 Schoueri, ao delimitar os limites das normas tributárias indutoras, estabelece a necessária revisão das limitações constitucionais ao poder de tributar juntamente com os princípios que norteiam a ordem econômica nacional, uma vez que, se a extrafiscalidade se manifesta por meio de uma intervenção do Estado no Domínio Econômico, os pressupostos econômicos definidos na Constituição deverão ser obedecidos. SCHOUERI, Luis Eduardo. Normas tributárias indutoras e intervenção econômica. Rio de Janeiro: Forense, 2005. 13 GODOI, Marciano Seabra. Extrafiscalidad y sus limites constitucionales. Revista Internacional de Direito Tributário da Associação Brasileira de Direito Tributário, Belo Horizonte, v.1, n.1, p.219-262, 2004.

14 NABAIS, José Casalta. O dever fundamental de pagar impostos: contributo para a compreensão do estado fiscal contemporâneo. Coimbra: Almedina, 1988. 


\section{Limites relacionados à competência tributária material e legislativa}

Sobre os limites relacionados à competência tributária, o professor mineiro repete a lógica de que somente o ente dotado de capacidade tributária pode realizar medidas extrafiscais relativas a tributos de sua competência. Isso impede, por consequência, a realização do famoso brocado "fazer cortesia com o chapéu dos outros", sob pena de usurpação da competência constitucionalmente definida.

Importante, ainda, nesse diapasão rever lição de Schoueri1 ${ }^{15}$, que, interpretando o posicionamento de vários doutrinadores respeitados em nosso ordenado, entre eles Ataliba e Ruy Barbosa Nogueira, reconhece a necessidade de observância cumulativa das competências tributária e material para a edição de normas extrafiscais de natureza indutora. Vejamos:

Para a solução da questão, importa que se reafirme, neste passo, que as normas tributárias indutoras são reflexo do poder de regular, não do poder de tributar. Não obstante se insiram no ordenamento por meio de tributos que lhes servem de veículos, são elas instrumentos de que se vale o legislador para conduzir, por indução, o comportamento dos contribuintes, gerando estímulos positivos e negativos, conforme o contribuinte incorra, ou não, na hipótese prevista em lei. Ora, se a competência legislativa está regulada pelos artigos 22 e ss. Da Constituição Federal e sendo as normas tributárias indutoras forma de legislação sobre aquelas matérias, conclui-se estarem elas sujeitas àqueles preceitos constitucionais.

Assim é que as normas tributárias indutoras sujeitam-se: I) por força do veículo pelo qual se introduzem no mundo jurídico, às regras de repartição de competências tributárias; II) por força da matéria que regulam, às regras de competência legislativa. Conclui-se, portanto, pela necessária concomitância de competências, para que se introduzam normas tributárias indutoras válidas no ordenamento brasileiro. ${ }^{16}$

\section{Limites relacionados à capacidade contributiva}

Por fim, ligando a extrafiscalidade à ideia de justiça fiscal, sempre presente no capítulo tributário da carta constitucional brasileira, o professor Godoi repele a existência de medidas com objetivos extrafiscais que, por sua natureza, não contemplem a capacidade contributiva econômica, no que é seguido por grandes expoentes da literatura jurídica, como o professor Schoueri ${ }^{17}$, que, em sua já clássica obra sobre as normas indutoras tributárias, trata da capacidade contributiva como um norte a ser respeitado na instituição daquelas normas.

Nabais ${ }^{18}$, por seu turno, sustenta que os limites da extrafiscalidade repousam em princípios gerais de direito tributário e administrativo, tais como a proibição de excesso, a proporcionalidade e a igualdade, bem como devem ser adequados e mais necessários para a realização dos objetivos para os quais foram instituídos do que outras medidas extrafiscais de caráter não tributário, tais como as subvenções.

Assim, segundo a doutrina a prática extrafiscal deverá respeitar, a nível constitucional, os princípios limitadores do poder de tributar, que poderiam inclusive, em alguns casos excepcionais, ser mitigados, mas não desrespeitados. ${ }^{19} \mathrm{Da}$ mesma forma, tendo em vista que as normas tributárias extrafiscais revelam tentativa de regulação da atividade econômica, os princípios aplicáveis à ordem econômica deverão, também, ser observados, inclusive a livre iniciativa, a busca pelo pleno emprego, o desenvolvimento do mercado nacional e a redução das desigualdades regionais.

15 SCHOUERI, Luis Eduardo. Normas tributárias indutoras e intervenção econômica. Rio de Janeiro: Forense, 2005.

16 SCHOUERI, Luis Eduardo. Normas tributárias indutoras e intervenção econômica. Rio de Janeiro: Forense, 2005. p. 251.

17 SCHOUERI, Luis Eduardo. Normas tributárias indutoras e intervenção econômica. Rio de Janeiro: Forense, 2005.

18 NABAIS, José Casalta. O dever fundamental de pagar impostos: contributo para a compreensão do estado fiscal contemporâneo. Coimbra: Almedina, 1988.

19 Caso, por exemplo, da mitigação do princípio da legalidade estrita na instituição de tributos de natureza extrafiscal, que se observou válida no julgamento do RE 343.446/RS, no qual o Supremo Tribunal Federal julgou que os critérios definidores básicas do RAT, que distingue as alíquotas aplicáveis à contribuição ao SAT, poderiam ser criados por meio de Decreto, se a lei estipulasse um mínimo teórico para isso. 
Interessante, nesse ponto, é verificar que tais princípios não tributários se aplicam tanto como mola propulsora da extrafiscalidade, quanto como limitadores de sua aplicação. Com efeito, por vezes uma determinada medida tributária poderá ser utilizada com a finalidade de fomentar a melhoria das condições do ambiente de trabalho — caso do Fator acidentário de Prevenção - FAP, instituído pela lei 10.666/2003 —, porém não poderá violar a livre iniciativa, punindo o contribuinte pelo risco normal da realização de uma atividade lícita ${ }^{20}$.

À evidência, esse aspecto jurídico-normativo de controle das normas tributárias extrafiscais é essencial para enxergar os limites da atuação do Estado.

\subsection{A classificação abrangente de Marcus de Freitas Gouvêa}

Digna de nota é também a abrangente classificação trazida pelo pesquisador Marcus de Freitas Gouvêa ${ }^{21}$, que reconhece não somente limites jurídicos internos à instituição da extrafiscalidade, mas também forças econômicas e sociais que exercem papel significante na tomada de medidas extrafiscais.

A classificação proposta pelo referido autor aponta para a existência de quatro grandes limites à aplicação da extrafiscalidade na contemporaneidade, quais sejam os limites jurídico-principiológicos, os limites jurídico-normativos, os limites lógicos e os limites socioeconômicos.

\section{Limites jurídico-principiológicos}

Por limites jurídico-principiológicos o autor sustenta que a extrafiscalidade, enquanto princípio epistemológico da Ciência do Direito e ontológico, da Tributação, deve seguir os princípios que a fundamentam, mais especificamente os princípios informadores do direito tributário e que limitam o poder de tributar, e aqueles que orientam a atividade econômica, social e cultural do Estado, que se deseja valorizar por meio da medida extrafiscal. Defende o autor:

Com isso, seja qual for o instrumento utilizado pelas ações tributárias (apesar das peculiaridades quanto às regras) não poderá desrespeitar os princípios de Direito Tributário, assim como a capacidade contributiva, o princípio da não surpresa, o princípio da legalidade tributária (que não tem a mesma conotação no Direito Econômico) e o princípio do não confisco.

\section{$[\ldots]$}

Em linhas gerais, quanto aos princípios que guardam valores constitucionais não tributários, é lícito dizer que devem ser observados pela tributação extrafiscal, pois esta não pode almejar finalidade vedada pela Carta ou contrária a seus ditames, mesmo que o proibitivo seja implícito. ${ }^{22}$

Com razão o autor, pois, a nosso ver, a visão restritiva de $\mathrm{Nabais}^{23}$ sobre a aplicação dos princípios do Direito tributário à extrafiscalidade não encontra guarida no Direito Brasileiro, à medida que a norma extrafiscal sempre preserva sua natureza tributária, não podendo ser afastada a observância dos caracteres próprios desse ramo do Direito. Da mesma forma, entendemos que a norma extrafiscal deve acompanhar os princípios e diretrizes constitucionais relacionados à finalidade extrafiscal que a fundamenta, não podendo haver norma extrafiscal que vise objetivo não compreendido na constituição.

Importante ainda ressaltar a visão abrangente do autor ao delimitar que, dentre os princípios não tributários a serem seguidos pela norma extrafiscal, devem ser respeitados não somente os princípios da ordem

20 Sobre o tema específico da extrafiscalidade no FAP, recomendamos a leitura de outros estudos mais aprofundados por nós produzidos, tais como: PIMENTA, D. M. FAP: questões polêmicas. Disponível em: <http://jus.com.br/artigos/41410/fap-questoes-polemicas>. Acesso em: 31 jul. 2015.

21 GOUVÊA, Marcus de Freitas. A extrafiscalidade no direito tributária. Belo Horizonte: Del Rey, 2006.

22 GOUVÊA, Marcus de Freitas. A extrafiscalidade no direito tributária. Belo Horizonte: Del Rey, 2006. P. 254-255.

23 NABAIS, José Casalta. O dever fundamental de pagar impostos: contributo para a compreensão do estado fiscal contemporâneo. Coimbra: Almedina, 1988. 
econômica, como disposto por parte da doutrina, mas também todas as diretrizes políticas e sociais que permeiam o objetivo extrafiscal, devendo haver a necessária ponderação de princípios quando houver dois ou mais princípios que possam, no caso concreto, ser antagônicos ou conflitantes.

\section{Limites jurídico-normativos}

Se existem limites principiológicos, consequentemente, haverá, também, limites jurídico-normativos da extrafiscalidade, representados, na visão de Gouvêa, por regras jurídicas que impedem de modo objetivo a aplicação da extrafiscalidade.

Chama atenção o referido autor que, por se tratar de princípio, a extrafiscalidade apenas sofre limitações igualmente principiológicas. Entretanto, os tributos e demais instrumentos de aplicação da extrafiscalidade estão sujeitos aos limites das regras jurídicas. Nesses casos, apesar de uma principiologia adequada, pode haver vedação expressa pelo ordenamento jurídico.

Sendo assim, se houver alguma regra objetiva ou relativa que impeça a adoção da extrafiscalidade em casos específicos, logicamente esse fenômeno não poderá ser realizado pelo ente tributante.

Nesse campo de limites, são identificadas quatro situações em que regras jurídicas poderiam impossibilitar a edição de efeitos extrafiscais à norma tributária: a) os limites objetivos relativos, que se verificam quando uma norma próba a utilização de determinado expediente tributário para realizar um valor específico; b) os limites objetivos absolutos, representados por normas que não proíbam a extrafiscalidade, mas sim a instituição de determinado tributo ou medida tributária; c) os limites subjetivos, que são relacionados a situações em que o ente tributante não detém competência tributária para instituir a medida extrafiscal; e d) os limites normativos formais, que se revelam pela imposição do meio legal adequado para se determinar a medida extrafiscal.

Em todas as situações acima, a extrafiscalidade, ainda que adequada, principiologicamente, poderia ser vedada por regras jurídicas, justificando, pois, a classificação adotada.

\section{Limites lógicos}

O prof. Marcus Gouvêa aponta, ainda, para existência de situações em que, apesar da existência de principiologia e normas que permitam a instituição de medida extrafiscal, esta não se concretiza por razões lógicas, decorrentes da imprestabilidade da medida para a efetivação do objetivo extrafiscal.

Dentre os exemplos citados pelo autor em sua obra, aquele que nos parece mais palatável para demonstrar a existência de um limite lógico é a imprestabilidade da adoção de medidas extrafiscal em tributos indiretos incidentes sobre o consumo, como tentativa de melhorar a distribuição de renda e de riqueza e na repartição do custeio das atividades estatais. Tendo em vista que os referidos tributos afetam somente preços relativos, a prática demonstra que a instituição eventuais medidas extrafiscais não terão o condão de realizar os fins supostamente pretendidos pelo ente tributante.

Para evitar a usurpação de limites lógicos, adverte Gouvêa que há de se verificar a natureza dos institutos jurídicos, porquanto, por razões lógicas, alguns são capazes de promover determinadas consequências e incapazes de promover outras, variando, assim, os efeitos extrafiscais decorrentes de cada um destes institutos..$^{24}$

Em outras palavras, é necessário que se observem, para a instituição de medidas extrafiscais, critérios de eficácia do instituto a ser adotado, sob pena de não se promover a finalidade adjacente desejada pelo Estado.

24 GOUVÊA, Marcus de Freitas. A extrafiscalidade no direito tributária. Belo Horizonte: Del Rey, 2006. p. 263. 


\section{Limites socioeconômicos}

Talvez a maior contribuição de Gouvêa ao presente estudo se revele no reconhecimento das forças externas ao direito como limitadoras da atividade extrafiscal do Estado.

De toda a construção histórica trazida nessa parte de sua obra, extrai-se a importante consideração de que $a$ extrafiscalidade respeita as forças do mercado e reconhece que, excepcionalmente, as ações tributárias podem ficar destituídas de efeito, seja por má elaboração ou por implementação inadequada ${ }^{25}$.

E não somente os agentes e elementos econômicos interfeririam na instituição de medidas extrafiscais. Também medidas social ou politicamente indesejadas podem funcionar como limitador da atividade extrafiscal do Estado.

Sendo assim, arremata o autor a nosso ver com peculiar brilhantismo, que a extrafiscalidade permitida pelo ordenamento e principiologicamente admitida pode ser inviabilizada pelo mercado e pela realidade social.

Efetivamente, alguns instrumentos tributários extrafiscais, apesar de, juridicamente, legítimos, tendem a ser repelidos pelos destinatários da norma extrafiscal - agentes econômicos, contribuintes e sociedade -, se se revelarem contrários à realidade social e econômica que se desenha em determinado momento histórico. Não se trata, aqui, de primazia da ordem econômica sobre a jurídica, tese essa que há muito já foi superada pela doutrina e pela jurisprudência. Na verdade, trata-se de reconhecer que esses elementos acabam por interferir tanto na adoção quanto na eficácia de medidas extrafiscais, afinal de contas o Direito não deve ser amorfo e desconhecer os elementos e a realidade que o circunda.

Utilizando a teoria sistêmica explicada por Lobato ${ }^{26}$, os limites acima dispostos seriam identificados como elementos que se encontram no entorno do sistema jurídico, e que são observados de dentro do sistema (hetero-observação) para a construção das normas a partir de suas referências próprias (autopoiese), e que serão destinadas a cumprir a função do sistema. Em outras palavras, o sistema jurídico, fechado enquanto sistema, não se submete ou se confunde com os caracteres dos sistemas econômicos e sociais, mas observa-os por meio de sua necessária abertura cognitiva, para processar e assimilar, internamente, essas informações externas e criar condições de cumprir sua função própria, por meio da geração das normas convenientes e permitidas pelo sistema.

O reconhecimento das forças sociais e econômicas como possíveis interferências da atividade extrafiscal é de relevante importância, pois abre a possibilidade do contínuo desenvolvimento dinâmico da extrafiscalidade enquanto fenômeno jurídico que sempre existirá nos sistemas jurídicos contemporâneos.

\section{Conclusões sobre o capítulo}

Concluindo a presente seção, apresentam-se, então, classificações que, apesar de distintas em relação à amplitude dos limites da extrafiscalidade, apresentam convergências quanto à necessidade de observância cumulativa das normas, princípios e regras aplicáveis ao ordenamento constitucional tributário e à ordem constitucional ao qual se liga à finalidade extrafiscal da norma indutora.

O núcleo duro da norma extrafiscal será, portanto, compreendido pelas diretrizes constitucionais próprias que regem a instituição e cobrança de tributos, acrescidas, de forma inseparável, dos fundamentos ligados ao objetivo constitucional extratributário para o qual o tributo foi instituído, conforme já alertava lição de Moschetti27.

25 GOUVÊA, Marcus de Freitas. A extrafiscalidade no direito tributária. Belo Horizonte: Del Rey, 2006. p. 263.

26 LOBATO, Valter de Souza. O princípio da confiança retratado no código tributário nacional: a aplicação dos artigos 100 e 146 do CTN: a análise de casos concretos. Disponível em:<http://sachacalmon.com.br/wp-content/uploads/2012/09/Artigo-Misabel-analisedos-arts-100-e-146-do-CTN-final.pdf>. Acesso em: 02 ago. 2015.

27 MOSCHETTI, Francesco. Elprincipio de capacidade contributiva. Madrid: Instituto de Estudos Fiscales, 1980. 
Especificamente em relação ao FAP, tendo em vista que, segundo o próprio legislador, o referido instituto visa estimular investimentos em prevenção e melhoria das condições do ambiente de trabalho dentro do ambiente corporativo, resta claro que o ramo constitucional, cujos princípios e normas constitucionais devem ser analisados em integração com o arcabouço tributário nacional, será o da ordem econômica. Nesse sentido, além de o art. 170 caput da CR/88 definir a valorização do trabalho humano fundamento da ordem econômica brasileira, a busca da realização dos princípios da função social da propriedade, da busca do pleno emprego e da redução das desigualdades sociais, definidos nos incisos do mesmo dispositivo, são a nosso ver o combustível constitucional que moveu a máquina tributária do Estado para a instituição da metodologia FAP.

Definidos os marcos normativos a serem utilizados na análise dos limites à extrafiscalidade, fica agora menos árdua a tarefa de identificar como o FAP seria afetado por tais limitações.

\section{FAP EM FACE DOS LIMITES EXTRAFISCAIS DEFINIDOS NA ORDEM CONSTITUCIONAL ECONÔMICA E TRIBUTÁRIA}

Iniciando o principal tópico do presente estudo, ressaltamos que nosso interesse foi o de trazer novas perspectivas relativas a alguns elementos do FAP que, a nosso ver, constituem discussões atuais vinculadas à extrafiscalidade. Dessa forma, não foi possível, até pela limitação de escopo, abordar todos os aspectos jurídicos que são apresentados pela doutrina e jurisprudência pátrias. Nosso objetivo, como acima disposto, foi focar nos aspectos da limitação da atividade estatal, e, em relação a esse espetro, apontar novos caminhos para enriquecer a discussão dobre o tema.

\subsection{Limites da ordem tributária relevantes}

\section{Legalidade}

Como disposto no tópico anterior, a instituição de tributos de caráter extrafiscal deverá observar as limitações do poder de tributar que se relacionem à garantia dos direitos fundamentais previstos na carta constitucional, tendo em vista configurarem aqueles como normas tributárias por natureza.

Dentre esses direitos, a proibição de ofensa à legalidade tributária foi, historicamente, um dos primeiros temas abordados em relação ao FAP. Argumenta parte da doutrina, baseada nas regras de competência tributária legislativa, que a definição dos elementos centrais da contribuição ao SAT pelo FAP, dentre eles as alíquotas efetivas e critérios de apuração e mensuração do tributo, não poderia ser realizada por meio de Decreto, sob pena de usurpação da competência formal do legislativo prevista no art. 146, II c/c art. 150, I da $\mathrm{CR} / 88^{28}$. Não se trataria, pois, de um vício material, mas sim formal da norma extrafiscal.

No mesmo ínterim, argumenta-se que a norma constitucional permissiva do FAP em sua atual redação, qual seja o $₫ 9^{\circ}$ do art. 195 da CR/88 alterado pela EC 47/200529, foi promulgada posteriormente ao art. $10 \mathrm{da}$ lei 10.666/2003, não podendo a União pretender conceder constitucionalidade superveniente a essa legislação.

Para essa parte da doutrina, como o atual FAP regulamentado pelo Decreto 6.042/2007 e normas posteriores preveem o porte da empresa e a condição estrutural do mercado de trabalho como critérios de

28 BRASIL. Constituição (1988). Constituição da República Federativa do Brasil. Brasília: Senado Federal, 2010. Disponível em: <http://www.planalto.gov.br/ccivil_03/constituicao/constituicao.htm>. Acesso em: 01 ago. 2015.

29 BRASIL. Emenda constitucional n. 47, de 5 de julho de 2005. Brasília, 2005. Disponível em: < http://www.planalto.gov.br/ccivil_03/ Constituicao/Emendas/Emc/emc47.htm>. Acesso em: 01 ago. 2015. 
definição da alíquota efetiva, esses critérios já deveriam estar previsto na legislação tributária de regência.

Ocorre que, apesar dessa possibilidade estar prevista na emenda constitucional 47/2005, que alterou a redação do $\$ 9^{\circ}$ do art. 195 da CR/88, a legislação que instituiu a sistemática do FAP, qual seja o art. 10.666/2003, foi editada antes da promulgação da referida emenda constitucional, não se podendo aplicar validade retroativa à norma de 2003, quando não havia a previsão de diferenciação de alíquotas pelo porte das empresas e condição estrutural do mercado de trabalho.

Para solução das questões acima, os tribunais brasileiros, sobretudo o Supremo Tribunal Federal, ainda não se posicionaram, definitivamente, em relação aos critérios definidos ao FAP. Entretanto, a maioria dos julgados produzidos a partir de 2010, data de início da vigência efetiva da metodologia que gera o FAP, aponta para a possibilidade de instituição de critérios técnicos de aplicação da norma tributário por meio de decreto, especificamente a alteração dos critérios de definição do RAT. Para tanto, se baseiam em precedente do STF, que, na suposta esteira da mais hodierna doutrina sobre a matéria, reconhece que a legalidade definida no sistema tributário brasileiro admite a fixação de aspectos da norma que possam ser definidos pelo intérprete, no caso o ente tributante, por meio de atos normativos.

Segundo a doutrina adotada pelo Supremo, desde que a interpretação esteja dentro dos limites do tipo definido pela legislação, não há impossibilidade da definição de critérios e aspectos da norma tributária pela norma infralegal, posto que ao legislador não é dado esmiuçar todas as hipóteses possíveis de incidência da norma tributária, como acreditavam os defensores das teorias que defendem a 'tipicidade cerrada' ou os conceitos fechados e imutáveis dentro do direito tributário. ${ }^{30}$

Como se pode verificar no bojo do voto condutor do referido precedente jurisprudencial emitido pelo Supremo Tribunal Federal ${ }^{31}$, o constituinte, ao determinar ao poder público a necessidade de observância ao princípio da legalidade na instituição de tributos, define que os elementos centrais dos tributos devem ser fixados em lei, citando nobre lição do saudoso professor Geraldo Ataliba.

Em certos casos, entretanto, - dispõe o relator - a aplicação da lei, no caso concreto, exige a aferição de dados e elementos. Nesses casos, a lei, fixando parâmetros e padrões, comete ao regulamento essa aferição. Não há falar, em casos assim, em delegação pura, que é ofensiva ao princípio da legalidade genéricas (C.F, art. $5^{\circ}$, II) e da legalidade tributária. (C.F., art. 150, I)..$^{32}$

Ao assim dispor, o i. julgador admite a existência de tipos e conceitos indeterminados em direito tributário, que podem exigir a complementação de sua extensão através de atos interpretativos, tais como os decretos normativos.

Por essa necessária abertura, que acompanha a evolução da própria doutrina acerca da legalidade tributária, entende o Supremo Tribunal Federal que as alterações promovidas por meio de decreto, desde que estejam dentro do escopo definido pelo legislador e sejam advindos de uma delegação derivada, não usurpam a legalidade tributária definida na constituição. ${ }^{33}$

30 Nesse sentido, vale a leitura das lições emanadas pela em. prof. Misabel Machado de Abreu Derzi e pelo prof. Schoueri sobre a matéria.

31 BRASIL. Supremo Tribunal Federal. Recurso Extraordinário. RE 343.446/RS. Relator: Ministro Carlos Velloso. Brasília, 04 de abril de 2003. Disponível em: <http://www.stf.jus.br/portal/diarioJustica/verDiarioProcesso.asp? numDj=65\&dataPublicacaoDj= 04/04/2003\&incidente $=2013286 \&$ codCapitulo $=5 \&$ numMateria $=9 \& \operatorname{codMateria}=1>$. Acesso em: 30 jun. 2015.

32 BRASIL. Supremo Tribunal Federal. Recurso Extraordinário. RE 343.446/RS. Relator: Ministro Carlos Velloso. Brasília, 04 de abril de 2003. Disponível em: <http://www.stf.jus.br/portal/diarioJustica/verDiarioProcesso.asp? numDj=65\&dataPublicacaoDj= 04/04/2003\&incidente $=2013286 \& \operatorname{codCapitulo}=5 \&$ numMateria $=9 \& \operatorname{codMateria}=1>$. Acesso em: 30 jun. 2015.

33 Contra essa posição, Lobato, ao qual nos afiliamos, entende haver deturpação da teoria da legalidade tributária, ressaltando que em Direito Tributário vige o princípio da não surpresa, não podendo o contribuinte ser tributado nos moldes do FAP, pois não possui prévia informação de qual será a alíquota definitiva a ele aplicável. Cite-se: [...]Estamos diante de um tipo incompleto, posto que somente pelo art. 10 da Lei 10.666/2003 é impossível fixar a alíquota à qual o contribuinte estará sujeito para pagar o RAT; não se sabe a metodologia a ser aplicada; não se tem idéia dos fatores que irão compor cada um dos índices (freqüência, gravidade e custo). Aliás, há expressa confissão de ferimento à legalidade quando o $\$ 10$ do art. 202-A do RPS determina que "a metodologia aprovada pelo Conselho Nacional de Previdência Social indicará a sistemática de cálculo e a forma de aplicação de índices e critérios acessórios à composição do índice composto do FAP”. 
Sendo assim, o referido tema central que atualmente vem sendo discutido nos tribunais, e que se remete à possibilidade de regulamentação do FAP por meio de Decreto Legislativo, a princípio deverá ter o mesmo deslinde da discussão posta no precedente definido pelo Supremo, à medida que, além de terem fundamentos semelhantes, seguem a linha contemporânea acerca da observância do princípio da legalidade em matéria tributária.

Entretanto, no que tange aos demais aspectos da legalidade que ainda não foram objeto de detida análise pelos tribunais, ainda não houve qualquer definição por parte da jurisprudência pátria, até porque poucos são os julgados que chegam a abordar a constitucionalidade superveniente enquanto tese. Advoga, entretanto, em favor dos defensores dessas teses, precedente do Supremo Tribunal Federal ${ }^{34}$, que, em caso semelhante referente ao alargamento da base de cálculo do PIS e da COFINS, definiu que a edição da EC 20/98 não concedeu, constitucionalidade, superveniente às leis 9.715/98 e 9.718/98, que, por essa razão, foram declaradas inconstitucionais.

No caso do FAP, a redação anterior do $₫ 9^{\circ}$ do art. $195^{35}$ da CR/88 permitia somente a flutuação das alíquotas e bases de cálculo em razão da atividade econômica e a utilização intensiva da mão de obra, que configuravam exatamente o escopo do RAT. Para viabilizar o FAP tal como disposto na lei 10.666/2003, que prevê alíquota específica em razão da posição da empresa dentro de seu setor econômico (condição estrutural do mercado de trabalho), era necessário algo mais, contudo esse acréscimo somente foi integrado ao ordenamento no ano de 2005. Ainda que o FAP tenha ficado no âmbito de estudos técnicos durante anos, tendo sido regulamentado por meio de Decreto somente em 2007, seria necessária legislação atual, posterior à Emenda Constitucional 47/2005, para instituí-lo de acordo com o novo arcabouço trazido pelo constituinte derivado. Entretanto, até a presente data, não há notícia da existência de legislação formal posterior que convalidasse o modelo constitucional posterior a 2005, podendo, efetivamente, haver uma inconstitucionalidade que, segundo o Supremo Tribunal Federal, não pode ser sanada por uma integração integrativa entre a lei 10666/2003 e a EC47/2005, posto que a competência tributária legislativa positiva exige prévio poder tributar ao ente público (art. 150, I da CR/88).

Assim, acreditamos que os próximos capítulos dessa discussão podem reservar um novo panorama que represente efetiva proteção aos direitos do contribuinte, cabendo, logicamente, uma análise mais detida da matéria por parte do judiciário para que se possa ultrapassar as ainda rasas discussões que hoje são travadas nos tribunais de revisão.

\section{Competência tributária material, isonomia, universalidade e capacidade contributiva}

Outra limitação constitucional à extrafiscalidade que pode ser visualizada na discussão relativa ao FAP se revela na medida em que as normas tributárias indutoras devem guardar relação com a isonomia e a compe-

O Poder Executivo tem ampla discricionariedade em alterar e majorar o RAT, escolhendo ao seu alvedrio os pesos e os dados que irão compor os índices de freqüência, gravidade e custo, o que torna o instituto incompatível com os ditames constitucionais. Portanto, salvo as exceções constitucionais segundo as quais a lei estabelecerá os limites dentro dos quais o Poder Executivo poderá alterar as alíquotas de tributos (CF; art. 153, $\$ 1^{\circ}$; e art. 177, $\$ 4^{\circ}, \mathrm{I}$, , , uma reserva absoluta de lei para majoração de tributos pelo aumento da alíquota, uma vez que esta é elemento inexorável da quantificação da obrigação tributária. Explicitando de forma não exaustiva o art. 150, I da Constituição, o art. 97, IV do CTN, com fulcro no art. 146, II da Constituição, dispõe que "somente a lei pode estabelecer a fixação da alíquota do tributo". LOBATO, Valter de Souza. O custeio da seguridade social e os beneficios de risco: os princípios aplicáveis e os limites ao poder de tributar. <http://sachacalmon.com.br/wp-content/ uploads/2010/12/Artigo-FAPSATRAT-Valter-Lobato.pdf>. Acesso em: 02 ago. 2015.

34 Nesse sentido, recomenda-se a leitura do acórdão 346.084/PR, de relatoria do Ministro Ilmar Galvão. BRASIL. Supremo Tribunal Federal. Recurso Extraordinário. RE 346.084/PR. Relator: Ministro Ilmar Galvão. Brasília, 09 de novembro de 2005. Disponível em: < http://www.stf.jus.br/portal/jurisprudencia/listarJurisprudencia.asp?s1=\%28RE $\% 24 \% 2 \mathrm{ESCLA} \% 2 \mathrm{E}+\mathrm{E}+3460$ 84\%2ENUME $\% 2 \mathrm{E} \% 29+\mathrm{OU}+\% 28 \mathrm{RE} \% 2 \mathrm{EACMS} \% 2 \mathrm{E}+\mathrm{ADJ} 2+346084 \% 2 \mathrm{EACMS} \% 2 \mathrm{E} \% 29 \&$ base=baseAcordaos\&url=http: / / tinyurl.com/b83jq44> Acesso em: 15 ago. 2015.

$35 \int 9^{\circ}$ As contribuições sociais previstas no inciso I deste artigo poderão ter alíquotas ou bases de cálculo diferenciadas, em razão da atividade econômica ou da utilização intensiva de mão-de-obra. (Incluído pela Emenda Constitucional no 20, de 1998) BRASIL. Constituição (1988). Constituição da República Federativa do Brasil. Brasília: Senado Federal, 2010. Disponível em: <http://www.planalto.gov.br/ccivil_03/constituicao/constituicao.htm>. Acesso em: 01 ago. 2015. 
tência tributária material para definição da hipótese de incidência do tributo extrafiscal.

Nesse sentido, quando o constituinte outorga competência positiva para a instituição de tributo extrafiscal, chegamos ao limite jurídico-normativo positivo apontado pela doutrina de Gouvêa ${ }^{36}$, mais especificamente os limites subjetivos, que dizem respeito a situações em que o ente tributante não detém competência tributária para instituir a medida extrafiscal, e os limites normativos formais, que se revelam pela imposição do meio legal adequado para se determinar a medida extrafiscal. Mais clara ainda é a lição de Godoi ${ }^{37}$, para quem a extrafiscalidade não pode estar presente quando houver limitações relacionadas à competência material tributária.

Ou seja, a competência tributária material positiva revela um dever negativo que impede a instituição do referente tributo em critérios distintos daqueles definidos no imperativo constitucional. E, infelizmente, é isso o que parecer ocorrer em relação ao FAP, posto que os critérios materiais parecem ter sido extrapolados pelo executivo.

Nesse passo, o já citado $\$ 9^{\circ}$ do art. 195, I da CR/88 define a competência tributária positiva do legislador para instituição das bases de cálculo e tarifas diferenciadas, vedando, por interpretação exclusiva, qualquer outro critério de diferenciação não previsto na carta constitucional. Tais critérios materiais de definição das bases de cálculo, como se viu, são: a) a atividade econômica; b) a utilização intensiva de mão de obra; c) o porte da empresa e; d) a condição estrutural do mercado de trabalho.

Note-se que, na realização deste imperativo constitucional, o legislador da contribuição ao SAT, já qualificado pela lei 10.666/2003 e atos normativos próprios emitidos pelo Executivo, estabelece os seguintes critérios de diferenciação de alíquota: a) Atividade Econômica (critério definidor do RAT); b) utilização intensiva da mão de obra (critério definidor do RAT); c) porte da empresa (critério definidor do FAP, presentes nos índices de massa salarial e número de vínculos definidos nos Decretos 6042/2007 e seguintes); d) condição estrutural do mercado de trabalho (critério definidor do RAT, que é diferenciado pelo CNAE do setor econômico); e e) condição individual da empresa dentro do setor (critério definidor do FAP.

Vê-se que, em relação aos critérios apontados, sobra aquele que leva exatamente a uma alíquota mais do que diferenciada e na verdade individualizada para cada contribuinte, qual seja a situação da empresa dentro do seu setor.

Em virtude da limitação de competência material negativa supracitada, o legislador não lançou mão do critério relativo à condição individual da empresa dentro do setor.

E nem poderia, pois a instituição de alíquotas individualíssimas como as propostas pelo FAP levam necessariamente a uma discussão da aplicação integrada de outros dois sobreprincípios da ordem tributária constitucional, quais sejam a universalidade e a isonomia.

O constituinte, sabiamente, deixou de conceder expressa competência ao legislador para a instituição de tributo que levasse em consideração características personalíssimas de cada contribuinte, posto que tal atividade, ainda que desejada do ponto de vista da ordem econômica, violaria as garantias fundamentais à universalidade, a capacidade contributiva e à isonomia tributárias.

Quais seriam os pressupostos de ausência de isonomia que pudessem justificar alíquotas díspares para cada contribuinte inserido no ordenamento tributário nacional? No caso do FAP, esses critérios remontam ao número de acidentes de trabalho e o valor dos benefícios concedidos em face desses eventos? Qual a relação guardada nesses critérios que possa gerar uma objetiva situação em que não há isonomia, permitindo a diferenciação de alíquotas? Da mesma forma, existe nesses critérios distinção da capacidade econômica dos contribuintes que pudesse gerar tratamento tributário diferenciado? Por fim, se várias das empresas não

36 GOUVÊA, Marcus de Freitas. A extrafiscalidade no direito tributária. Belo Horizonte: Del Rey, 2006.

37 GODOI, Marciano Seabra. Extrafiscalidad y sus limites constitucionales. Revista Internacional de Direito Tributário da Associação Brasileira de Direito Tributário, Belo Horizonte, v.1, n.1, p.219-262, 2004. 
apresentam os critérios necessários para a aplicação do FAP, em que estaria presente a universalidade material que deve guardar relação com todas as normas tributárias?

Para todas as perguntas acima, a resposta encontrada até o momento não é satisfatória, pois, se a competência material negativa impedia a utilização de outros critérios justamente para evitar a violação dos princípios tributários supracitados, a nosso ver, a União, ao propor e fazer aprovar um critério inovador, acabou por violar garantias constitucionais do contribuinte e que advêm da própria relação desproporcional de forças entre o cidadão e o fisco.

Como há muito disposto pela doutrina, desequilíbrio claro entre Estado e cidadão nas relações realizadas no ambiente constitucional faz com que sejam reiterados os mecanismos que os possam colocar em situação de igualdade, ainda que de forma ideal. Justamente por esse motivo, são ressaltadas as garantias individuais fundamentais e que, no direito tributário, se revelam pelas limitações constitucionais ao poder de tributar.

Ao defender a utilização de critério não previsto na constituição, o Estado recorre ao seu poderio coercitivo e legitimação pela autoridade para impor ao contribuinte, data vênia de forma indevida, uma exação que, segundo o constituinte, não deveria existir, justamente, para evitar essa sobreposição estatal frente ao indivíduo.

A legalidade estrita, aclamada por todos os defensores do estado de direito, demanda o respeito absoluto à ficção jurídica das garantias individuais fundamentais, justamente para reafirmar o pacto que legitima a existência do próprio Estado.

Ora, se a competência para instituição dos critérios ora discutidos visa justamente afirmar a isonomia, por meio da aplicação de alíquotas diferenciadas a contribuintes que se encontrem em situações jurídicas distintas, evidentemente as condições individuais do ambiente de trabalho representam violação do princípio tributário que justifica essa diferenciação determinada pela sistemática do FAP.

A essa discussão podemos, ainda, agregar uma possível violação ao princípio da capacidade contributiva, pois se esta deve representar a exata medida da tributação, não se verifica como critério de distinção adequado o número de acidentes de trabalho e investimentos realizados pelo empresário. Evidentemente, esse critério de distinção não se liga à capacidade contributiva do contribuinte, não constituindo, a nosso ver, critério passível para distinção de alíquotas e base de cálculo de tributos.

Se o tributo deve incidir na medida da representação de riqueza observada e tomada pelo legislador como critério de distinção, onde estaria resguardada a capacidade contributiva em um critério que leva em consideração somente eventos tratados como ilícito e que não representam qualquer representação de riqueza. À evidencia, esta é a nosso ver uma falha a ser corrigida na metodologia FAP, que estabelece critérios não condizentes com algumas das diretrizes aplicáveis ao ordenamento constitucional vigente.

Sendo assim, pelas limitações da ordem tributária supracitadas, verificam-se possíveis inconstitucionalidades no modelo imposto de forma unilateral pelo ente tributante, sendo dever da academia se aprofundar no tema para determinar a revisão dos princípios para afastar as irregularidades da norma extrafiscal que, a nosso ver, se acha em contraponto com o sistema tributário nacional.

\section{A aplicação dos limites objetivos absolutos da extrafiscalidade ao FAP}

Remontando à doutrina de GOUVEA ${ }^{38}$, dentro dos limites jurídico-normativos da extrafiscalidade, encontram-se os limites objetivos absolutos, representados por normas que não proíbem a extrafiscalidade, mas sim a instituição de determinado tributo ou medida tributária.

Analisando o FAP sob esse prisma, constatamos a existência de outra possível discussão que, inclusive, abrirá, também, o tópico a seguir, relativo à aplicação de limitações constitucionais da ordem econômica

38 GOUVÊA, Marcus de Freitas. A extrafiscalidade no direito tributária. Belo Horizonte: Del Rey, 2006. 
para a instituição da medida extrafiscal do FAP.

Nesse passo, apesar de o constituinte, expressamente, permitir a extrafiscalidade nas contribuições sociais definidas no inciso I do art. 195 da CR/88, delimitando a competência material desse ato extrafiscal, fica claro, conforme já delimitado ao longo de todo o presente ensaio, que os caracteres da norma extrafiscal que aplica o desiderato do contribuinte não poderá violar o núcleo duro aplicável aos tributos, representado pelas normas e regras que delimitam a atividade fiscal do ente tributante.

Dentre tais normas, a observância o conceito de tributo é de vital importância para a existência do fenômeno extrafiscal no direito tributário, posto que a natureza da norma tributária indutora, principalmente quando se reportar a critérios definidores de bases de cálculo e alíquotas, será, evidentemente, tributária.

Tendo esse entendimento como premissa maior, todos os caracteres do conceito de tributo ${ }^{39}$ deverão ser mantidos e observados na norma fiscal, dentre eles a ausência de configuração da figura tributária como sanção decorrente de ato ilícito. Sem a configuração desses critérios, não deverá haver norma extrafiscal, ainda que a extrafiscalidade material seja permitida.

Trazendo a assertiva acima disposta à realidade do FAP, a atribuição de alíquotas diferenciadas de acordo com os investimentos em saúde e segurança do trabalho evidentemente possui a nobre função extrafiscal de promover a valorização do trabalho, enquanto fundamento da ordem econômica constitucional.

Contudo, ao instituir a extrafiscalidade por meio de regras e critérios que acabam por penalizar o contribuinte pela ocorrência de ilícitos e não se diga que os acidentes de trabalho não são ilícitos trabalhistas, posto que, se assim não fossem, não gerariam indenizações nas demais esferas do direito, evidentemente se estaria promovendo uma norma tributária inconstitucional para a realização de um fim constitucional, o que é há muito vedado por nosso ordenamento.

Os fins não justificam os meios escolhidos pela administração e nesse sentido a nobreza do ato extrafiscal não se sustenta, por si só, sem os caracteres tributários que são utilizados como meio para a sua consecução. Concordando com esse entendimento, a i. pesquisadora Marta Toríbio Leao ${ }^{40}$, defende que as normas tributárias indutoras somente serão viáveis na medida em que não imponham ao contribuinte uma sanção pela prática do ato lícito que não é querido pelo estado.

Além de ser vedada a determinação de um ato ilícito como hipótese de incidência tributária, pelo conceito legal de tributo, também é vedada distinção do valor do tributo em face da ocorrência fatos caracterizados como ilícitos. Seria o mesmo que instituir uma alíquota adicional de contribuição social, incidente sobre a receita, contra empresas que fossem, comprovadamente, condenadas pelo crime de lavagem de dinheiro.

39 Art. $3^{\circ}$ Tributo é toda prestação pecuniária compulsória, em moeda ou cujo valor nela se possa exprimir, que não constitua sanção de ato ilícito, instituída em lei e cobrada mediante atividade administrativa plenamente vinculada. BRASIL. Lei n. 5172 , de 25 de outubro de 1966. Código Tributário Nacional. Brasília, 1966. Disponível em:< http://www.planalto.gov.br/ccivil_03/leis/L5172. htm>. Acesso em: 01 jul. 2015.

40 Cite-se, por oportuno, a posição da D. pesquisadora sobre a questão: [...] Em segundo lugar, também cabe uma advertência no sentido de que as normas tributárias desestimuladoras de determinados comportamentos podem acabar transformando o tributo numa espécie de "multa disfarçada". Vejamos o exemplo dos tributos ecológicos, que oneram às empresas mais poluidoras. Nesse caso, é possível que para a empresa seja mais lucrativo pagar o preço e manter o comportamento, isto é, talvez seja mais vantajoso pagar para poluir, do que aceitar os incentivos para adotar um novo comportamento, assumindo também os riscos não tributários que a conduta possa gerar. Ocorre que, com isto, o tributo acaba se aproximando de uma espécie de "multa", que se paga por adotar a conduta indesejada pelo Estado. Trata-se de uma aproximação, já que a multa incide sobre atividade ilícita, enquanto o tributo incide necessariamente sobre uma atividade lícita, que, porém, pode ser tão indesejada do ponto de vista político e social que se aproxime de uma ilicitude.[...]Se, no entanto, as normas tributárias indutoras passarem a ser utilizadas também como forma de desestímulo de condutas proibidas pelo Estado, surgirão dois problemas: o primeiro, a institucionalização da possibilidade de "comprar" a conduta proibida e, segundo, a transformação do tributo numa multa. No sistema brasileiro, isto seria contrário ao conceito de tributo adotado pelo Código Tributário Nacional e, por essa razão, não há como se admitir em nosso sistema um tributo indutor tendo como fato gerador atividade ilícita. LEÃO, Martha Toribio. Critérios para o controle das normas tributárias indutoras: uma análise pautada no princípio da igualdade e na importância dos efeitos. 2014. Dissertação (Mestrado) - Programa de Pós-Graduação em Direito, Universidade de São Paulo, São Paulo, 2014. p 16. 
No caso hipotético acima, apesar de o fato gerador e a hipótese de incidência não terem correlação com o ilícito, o agravamento da obrigação tributária, que passaria a constituir sanção indireta, seria, evidentemente, contrário às diretrizes e normas constitucionais tributárias.

Voltando ao FAP, uma leitura atenta da exposição de motivos da MPv 83/2002 revela a intenção do Estado de utilizar a majoração da alíquota base como forma de punição aos contribuintes que mais cometem os ilícitos trabalhistas verificados na empresa. Ainda que a contribuição ao SAT tenha como base imponível manifestação de riqueza representada pela folha de pagamento das empresas, resta claro que os demais elementos definidores do tributo.

Tal constatação, nos exatos termos dispostos na classificação de GOUVEA ${ }^{41}$, coloca em xeque a utilização do FAP com tributo extrafiscal, pois ultrapassa os limites objetivos absolutos da fiscalidade. A ausência de preocupação ou investimentos em segurança e saúde do trabalho deveriam gerar multas administrativas, mas nunca adicional de alíquota, na exata e precisa dicção de Lobato ${ }^{42}$.

Cabe, ainda, demonstrar que a imposição de condutas por meio de normas tributárias não pode travestir uma sanção contra o contribuinte sob a forma de tributo, até mesmo pela liberdade de iniciativa definida no art. 170 da CR.88. A ordem econômica constitucional designa outras medidas para esse forma de coerção por parte do Estado, não podendo ser o tributo servir de instrumento sancionador do Estado, que já possui o domínio penal e das sanções administrativas à sua disposição.

A liberdade iniciativa, inclusive, está disposta nas nossas discussões acerca da aplicação dos limites da ordem constitucional econômica aplicáveis à extrafiscalidade do FAP, conforme se verifica no tópico seguinte.

\subsection{Limites da ordem econômica e demais ramos relevantes}

Chegamos, enfim, à análise das limitações da extrafiscalidade do FAP em face das diretrizes e normas atinentes ao ramo constitucional que se pretendeu valorizar com a instituição do FAP, na esteira de toda a construção doutrinária citada nos tópicos anteriores.

Inicialmente, resta claro que um limite lógico à extrafiscalidade do FAP, nas palavras de Gouvea ${ }^{43}$, seria o cumprimento da finalidade definida no art. $7^{\circ}$, XXXVIII ${ }^{44} \mathrm{da} C R / 88$, que disciplina o seguro contra acidentes de trabalho como garantia fundamental do trabalhador.

Com efeito, se a contribuição ao SAT pretende efetivar o Seguro contra acidentes de trabalho, a cargo do empregador, a norma que estabelece o FAP não poderá, por uma finalidade extrafiscal, desviar a finalidade ou mesmo recursos da contribuição para outros fins desejados pelo Estado. Na exata esteira do pensamento do professor Godoi ${ }^{45}$, a extrafiscalidade não pode pretender violar, ainda que indiretamente, garantias fundamentais do cidadão. Sendo assim, até mesmo pela natureza finalística das contribuições sociais, qualquer desvio causado pela norma extrafiscal seria, a princípio, inconstitucional.

41 GOUVÊA, Marcus de Freitas. A extrafiscalidade no direito tributária. Belo Horizonte: Del Rey, 2006.

42 Cite-se, nesse sentido, magistério do professor Valter de Souza Lobato sobre a limitação à imposição do FAP: [...] Existindo ou não os instrumentos de gestão do ambiente laboral, cabe a Fiscalização acionar médicos e engenheiros de segurança dos quadros da Fiscalização para verificação do ambiente laboral. A ausência dos instrumentos de gestão pode gerar multas administrativas, mas jamais serão hipótese de incidência do adicional ora analisado.[...] LOBATO, Valter de Souza. O custeio da seguridade social e os benefícios de risco: os princípios aplicáveis e os limites ao poder de tributar. <http://sachacalmon.com.br/wp-content/uploads/2010/12/ Artigo-FAPSATRAT-Valter-Lobato.pdf>. Acesso em: 02 ago. 2015.

43 GOUVÊA, Marcus de Freitas. A extrafiscalidade no direito tributária. Belo Horizonte: Del Rey, 2006.

44 Art. $7^{\circ}$ São direitos dos trabalhadores urbanos e rurais, além de outros que visem à melhoria de sua condição social:[...] XXVIII - seguro contra acidentes de trabalho, a cargo do empregador, sem excluir a indenização a que este está obrigado, quando incorrer em dolo ou culpa; BRASIL. Constituição (1988). Constituição da República Federativa do Brasil. Brasília: Senado Federal, 2010. Disponível em: <http://www.planalto.gov. br/ccivil_03/constituicao/constituicao.htm>. Acesso em: 01 ago. 2015.

45 GODOI, Marciano Seabra. Extrafiscalidad y sus limites constitucionales. Revista Internacional de Direito Tributário da Associação Brasileira de Direito Tributário, Belo Horizonte, v.1, n.1, p.219-262, 2004. 
Analisando a estrutura atual da metodologia do FAP, uma crítica concreta que poderia ser feita à sistemática seria a de que a redução das alíquotas básicas, por meio da imposição de FAP menor do que 1 (hum), reduziria a extensão do seguro contra acidentes do trabalho, na medida em que reduziria a participação da empresa nesse instituto e diminuiria as fontes de custeio da atividade estatal definida pelo constituinte.

Entretanto, a realidade fática contradiz essa alegação, uma vez que a fórmula paramétrica que fundamenta do FAP, além de não prever queda na receita da contribuição, gera na prática um incremento na arrecadação, à medida que a redução máxima da alíquota base (de 50\%) não se dá na mesma proporção da majoração permitida (100\% da alíquota base). Da mesma forma, considerando-se, ainda, que, normalmente, as maiores e mais organizadas empresas acabam tendo as maiores alíquotas majoradas pelo FAP, por conta da alta massa salarial e pelo alto nível de formalização dos eventos trabalhistas, não se nota perda de arrecadação que pudesse fundamentar a alegação de que o FAP reduziria o alcance do SAT ${ }^{46}$. Esse tipo de análise, em verdade, seria mais factível quando relacionada à necessária solidariedade do sistema previdenciário, que, conforme discussões definidas no tópico anterior, se ligaria ao ideal de isonomia e universalidade do tributo em si.

Assim, a princípio não há notícias de redução da receita de custeio ao SAT que pudesse justificar a alegação de que o FAP violaria a finalidade social delimitada no inciso XXVIII do art. $7^{\circ}$ da CR/88.

Ademais, temos de considerar que a metodologia do FAP, ao buscar o aumento dos investimentos na melhoria das condições do ambiente de trabalho, busca a melhoria da condição social definida pelo constituinte no caput do art. $7^{\circ}$ da CR/88 e da mesma forma vislumbra a proteção do trabalhador, que é, também, buscada por meio do seguro contra acidentes de trabalho.

Assim, em relação à garantia fundamental prevista no art. $7^{\circ} \mathrm{da} C R / 88$, não se verifica, a princípio, violação pela norma extrafiscal que define o FAP. Entretanto, caso a prática do sistema demonstre a violação a esse direito que o fundamenta, estaremos efetivamente diante de uma prática extrafiscal que extrapola os limites delimitados pela doutrina e pelo constituinte.

Além do capítulo constitucional relativo aos direitos sociais do trabalhador, outros limites à instituição do FAP serão diretrizes da ordem econômica constitucional. Como já disposto, tendo em vista a finalidade precípua da melhoria das condições do ambiente de trabalho, reflexo do fundamento da valorização do trabalho definida no art. 170 da CR/ $88^{47}$ e a existência de intervenção estatal no domínio empresarial com regras que estimulam melhorias no ambiente laboral interno das companhias, fica claro que a extrafiscalidade do FAP, também, deve passar pelo crivo das limitações impostas pela ordem constitucional econômica.

Volvendo à lição de Schoueri, ao dispor sobre a necessidade de observância dos princípios da Ordem Econômica, observamos o seguinte:

É no delicado equilíbrio entre segurança jurídica e os princípios da Ordem Econômica, demandando agilidade e versatilidade, que se encontrará o espaço para as cláusulas gerais e para os conceitos indeterminados, enquanto instrumentos de adaptação da própria lei. ${ }^{48}$

46 Essa conclusão é referendada por Lobato, que abalizado por parecer do Conselho Federal de Estatística, atesta o viés de aumento de arrecadação pela implementação do FAP. Vejamos: [...]Contudo, tal forma de comparação entre as empresas, pela utilização de percentis, acaba por gerar graves distorções, denunciadas em parecer do Conselho Federal de Estatística - CONFE, pois tal metodologia (a) privilegia somente a ordenação dos valores, sem considerar a grandeza das acidentalidades, (b) havendo empates na classificação das empresas, as distorções são ainda mais agravadas. E assim conclui o parecer: "Por todo o exposto, dúvidas não remanescem acerca da imprestabilidade do método previsto pelas Resoluções no 1.308/09 e n $n^{\circ} 1.309 / 09$ para o cálculo do FAP (utilização de percentis), restando inconteste o objetivo arrecadatório na sua eleição; sendo esta, inclusive, uma das conclusões do parecer do CONFE, ao afirmar-se que "o método gera aumento indevido das alíquotas, portanto a metodologia incorpora fatalmente viés de aumento de arrecadação” LOBATO, Valter de Souza. O custeio da seguridade social e os benefícios de risco: os princípios aplicáveis e os limites ao poder de tributar. <http://sachacalmon.com.br/wp-content/uploads/2010/12/Artigo-FAPSATRATValter-Lobato.pdf>. Acesso em: 02 ago. 2015.

47 BRASIL. Constituição (1988). Constituição da República Federativa do Brasil. Brasília: Senado Federal, 2010. Disponível em: <http://www.planalto.gov.br/ccivil_03/constituicao/constituicao.htm>. Acesso em: 01 ago. 2015.

48 SCHOUERI, Luis Eduardo. Normas tributárias indutoras e intervenção econômica. Rio de Janeiro: Forense, 2005. p. 321. 
Com razão o d. autor paulista, pois essa necessidade de observância interativa e integrativa entre a competência reguladora da economia e a competência tributária é que dá legitimidade às normas tributárias extrafiscais.

Isso posto, iniciamos a análise do FAP à luz do principal fundamento econômico constitucional para a sua instituição, qual seja a valorização do trabalho definida no art. 170 da CR/88.

Evidentemente, estamos diante de um limite jurídico-principiológico de extrafiscalidade, posto que a melhoria das condições de saúde e segurança do ambiente laboral é reflexo direto da valorização do trabalho como gerador de riqueza para o desenvolvimento econômico do Estado.

Não há como negar que a metodologia FAP, ao estimular investimentos por meio de alíquotas minoradas da contribuição SAT, busca promover o princípio constitucional acima citado. Contudo, não pode, na busca desse objetivo, se esquecer de outros que integram a ordem econômica nacional, inclusive a função social da propriedade e a liberdade de iniciativa.

O fundamento constitucional da função social da propriedade, que ainda tem seu alcance muito discutido no ordenamento, pressupõe que o agente econômico, no exercício dos direitos sobre o seu patrimônio, deve direcionar sua atuação também ao cumprimento das diretrizes sociais definidas pelo constituinte. Nesse caso, a princípio o FAP parece cumprir esta função social, na medida em que direciona a atividade do empresário ao cumprimento de um objetivo social definido pelo Estado, inclusive cumprindo com o art. $174 \mathrm{da} C R / 88$, que outorga ao legislador a competência para estabelecer e bases para o planejamento do desenvolvimento nacional equilibrado. Entretanto, caso em algum momento se verifique que o FAP ou a legislação do SAT deixem de privilegiar esse aspecto, majorando ou reduzindo, injustificadamente, as alíquotas flutuantes ou básicas da contribuição (como pareceu ocorrer em relação a algumas atividades elencadas no Decreto 6957/2009, que alterou os critérios do RAT), evidentemente estaremos em situação que viola os limites de atuação do legislador extrafiscal.

No nosso entender, se a norma tributária extrafiscal torna tão onerosa a atividade que a relega a uma marginalidade quase que ilegal, não estaremos diante de uma figura tributária extrafiscal que promove a justiça social da propriedade, mas sim a uma sanção que acaba por inibir a prática regular de uma atividade lícita.

Trazendo a assertiva acima ao âmbito do FAP, notamos, claramente, uma tentativa de punir contribuintes que não realizam investimentos em saúde e segurança no ambiente de trabalho, por meio da imposição de alíquotas maiores que as fixadas por lei. Ao contrário das sanções meramente premiais, nas quais o contribuinte, ciente da alíquota máxima a que é sujeito, realiza investimentos para realizar a finalidade extrafiscal e reduzir sua carga tributária, com o FAP o empresário tem como primeira previsão uma alíquota média, que será majorada caso ele realize o malfeito, ainda que involuntariamente.

Some-se a isso o fato de que o seguro, pela sua própria natureza, se institui para custear indenizações de situações indesejáveis, imprevistas e imprevisíveis que geram dano ao segurado. No caso específico do SAT, as empresas custeiam o seguro por estarem sujeitas à ocorrência de eventos previdenciários e acidentes laborais causados, na maioria das vezes, pelo risco natural da atividade. A ocorrência desses eventos, na maioria das vezes, não é desejada pela empresa, que não pode ser penalizada por meio de tributação maior do que a normalmente prevista. $\mathrm{Na}$ sistemática atual, o empresário é punido, com uma alíquota maior do que a por ele esperada na realização normal e lídima de sua atividade econômica (alíquotas básicas definidas pelas alíneas a, b e c do art. 22, II da lei 8.212/91), Há, em certo grau, uma punição pelo exercício da livre iniciativa em um ambiente laboral que, para possuir licença de funcionamento, já deve a priori possuir a mínimas condições exigidas em lei.

Ora, se o contribuinte cumpre com as exigências legais para a abertura e funcionamento de seu negócio, inclusive adotando as medidas legais necessárias para obtenção de alvarás, e ainda por cima contribui para um seguro estatal que cobre riscos normais da atividade, é certo que a tributação adicional e, em valor acima 
do legalmente esperado, constitui sanção pelo mero exercício legal da atividade econômica.

Lembramos que não estamos aqui negando o valor nobre da extrafiscalidade do FAP, porém punir o contribuinte aplicando sanções que majoram, sem qualquer previsibilidade, as alíquotas decorrentes do exercício normal da atividade econômica, nos parece desarrazoado e incompatível com a liberdade iniciativa. Caso haja faltas na conduta do contribuinte, deve a administração instituir os meios adequados para puni-lo pelo descumprimento de suas obrigações, através de sanções administrativas, civis e penais. Mas tomar fato alheio à vontade e inerente ao risco comum como forma de tributação para atingimento de um fim extrafiscal, ao nosso ver, não se coaduna com as diretrizes da livre iniciativa.

\section{Considerações finais}

Diante das discussões acima propostas, acreditamos que avançamos na análise do tema proposto, expondo as limitações do FAP enquanto norma tributária de caráter extrafiscal.

Dentre os achados relevantes do presente estudo, constatamos, inicialmente, a necessidade de se adequar o FAP às diretrizes aplicáveis às ordens constitucionais tributária e econômica, além da necessária correspondência com as garantias fundamentais ao Seguro de Acidente de Trabalho definidas pelo constituinte.

Ademais, verificamos que, em relação à ordem tributária, há possíveis inconstitucionalidades e ilegalidades da metodologia FAP ligadas aos limites jurídico-normativos e jurídico-principiológicos da extrafiscalidade, na medida em que a legalidade, a competência formal e material e os princípios da isonomia, da universalidade e da capacidade contributiva parecem estar sendo vilipendiados pelo Estado.

Nesse passo, a adoção de alíquotas delimitadas por meio de Decretos, aliadas a uma tentativa de constitucionalizar de forma superveniente a sistemática do FAP podem por em cheque a viabilidade do instituto. Da mesma forma, a extrapolação da competência material constitucional para instituição da extrafiscalidade, com a imposição de critérios de distinção não permitidos pelo constituinte, nos parece ultrapassar os limites extrafiscais da competência material da norma extrafiscal, o que impõe por consequência violações à isonomia e à universalidade. Ainda em relação à ordem tributária, demonstramos que a deturpação dos métodos extrafiscais leva à violação da capacidade contributiva, na medida em que são criados critérios de distinção que não correspondem a efetiva uma distinção do critério econômico que leva à distinção de alíquotas e bases de cálculo. Por fim, questionamos, ainda, o fato de a legislação do FAP não seguir a natureza própria dos tributos, impondo obrigações de caráter pecuniário como punição pela prática de atividade indesejada pelo Estado.

Nos demais campos constitucionais, melhor sorte, a nosso ver, não assiste ao legislador da sistemática do FAP, posto que parece-nos haver uma patente violação à livre iniciativa, por meio da imposição de sanções de natureza tributária por fatos alheios ao previsível exercício lícito da atividade econômica, em um exercício indevido do princípio da função social da propriedade.

\section{REFERÊNCIAS BIBLIOGRÁFICAS}

BRASIL. Constituição (1988). Constituição da República Federativa do Brasil. Brasilia: Senado Federal, 2010. Disponível em: <http://www.planalto.gov.br/ccivil_03/constituicao/constituicao.htm>. Acesso em: 01 ago. 2015.

BRASIL. Lei n. 5172, de 25 de outubro de 1966. Código Tributário Nacional. Brasília, 1966. Disponível em: <http://www.planalto.gov.br/ccivil_03/leis/L5172.htm>. Acesso em: 01 jul. 2015. 
BRASIL. Decreto n. 6.042, de 12 de fevereiro de 2007. Brasília, 2007. Disponível em: < http://www.planalto.gov. br/ccivil_03/_ato2007-2010/2007/decreto/d6042.htm>. Acesso em: 15 jul. 2015.

BRASIL. Decreto n. 6.957, de 9 de setembro de 2009. Brasília, 2009. Disponível em: <http://www.planalto.gov. br/ccivil_03/_ato2007-2010/2009/decreto/d6957.htm>. Acesso em: 15 jul. 2015.

BRASIL. Emenda constitucional n. 47, de 5 de julbo de 2005. Brasilia, 2005. Disponível em: < http:/ / www.planalto.gov.br/ccivil_03/Constituicao/Emendas/Emc/emc47.htm>. Acesso em: 01 ago. 2015.

BRASIL. Lei ordinária n. 8.212, de 24 de julho de 1991. Brasília, 1991. Disponível em: < http://www.planalto. gov.br/ccivil_03/leis/L8212cons.htm>. Acesso em: 15 jul. 2015.

BRASIL. Lei ordinária n. 8.213, de 24 de julbo de 1991. Brasília, 1991. Disponível em:<http://www.planalto. gov.br/CCIVIL_03/leis/L8213cons.htm>. Acesso em: 15 jul. 2015.

BRASIL. Lei ordinária n. 10.666, de 8 de maio de 2003. Brasilia, 2003. Disponível em: < http://www.planalto. gov.br/ccivil_03/leis/2003/L10.666.htm>. Acesso em: 15 jul. 2015.

BRASIL. Medida provisória n. 83, de 12 de dezembro de 2002. Brasília, 2002. Disponível em: < http://www.planalto.gov.br/ccivil_03/mpv/Antigas_2002/83.htm>. Acesso em: 15 jul. 2015.

BRASIL. Supremo Tribunal Federal. Recurso Extraordinário. RE 343.446/RS. Relator: Ministro Carlos Velloso. Brasília, 04 de abril de 2003. Disponível em: < http://www.stf.jus.br/portal/diarioJustica/verDiarioProcesso.asp? numDj $=65 \&$ dataPublicacaoDj $=04 / 04 / 2003 \&$ incidente $=2013286 \&$ codCapitulo $=5 \&$ num Materia $=9 \& \operatorname{codMateria}=1>$. Acesso em: 30 jun. 2015.

BRASIL. Supremo Tribunal Federal. Recurso Extraordinário. RE 346.084/PR. Relator: Ministro Ilmar Galvão. Brasília, 09 de novembro de 2005. Disponível em: < http://www.stf.jus.br/portal/jurisprudencia/ listarJurisprudencia.asp?s1 $=\% 28 \mathrm{RE} \% 24 \% 2 \mathrm{ESCLA} \% 2 \mathrm{E}+\mathrm{E}+346084 \% 2 \mathrm{ENUME} \% 2 \mathrm{E} \% 29+\mathrm{OU}+\% 28 \mathrm{R}$ E\%2EACMS\%2E+ADJ2+346084\%2EACMS\%2E\%29\&base=baseAcordaos\&url=http: / / tinyurl.com/ b83jq44>. Acesso em: 15 ago. 2015.

DERZI, Misabel Abreu Machado. Modificações da jurisprudência: proteção da confiança, boa-fé objetiva e irretroatividade como limitadores constitucionais ao poder judicial de tributar. São Paulo: Noeses, 2009.

GODOI, Marciano Seabra. Extrafiscalidad y sus limites constitucionales. Revista Internacional de Direito Tributário da Associação Brasileira de Direito Tributário, Belo Horizonte, v.1, n.1, p.219-262, 2004.

GOUVÊA, Marcus de Freitas. A extrafiscalidade no direito tributária. Belo Horizonte: Del Rey, 2006.

LEÃO, Martha Toribio. Critérios para o controle das normas tributárias indutoras: uma análise pautada no princípio da igualdade e na importância dos efeitos. 2014. ?f. Dissertação (Mestrado) - Programa de Pós-Graduação em Direito, Universidade de São Paulo, São Paulo, 2014.

LOBATO, Valter de Souza. O custeio da seguridade social e os benefócios de risco: os princípios aplicáveis e os limites ao poder de tributar. <http://sachacalmon.com.br/wp-content/uploads/2010/12/Artigo-FAPSATRATValter-Lobato.pdf > . Acesso em: 02 ago.2015

LOBATO, Valter de Souza. O princípio da confiança retratado no código tributário nacional: a aplicação dos artigos 100 e 146 do CTN: a análise de casos concretos. Disponível em: <http://sachacalmon.com.br/wp-content/uploads/2012/09/Artigo-Misabel-analise-dos-arts-100-e-146-do-CTN-final.pdf>. Acesso em: 02 ago. 2015.

MOSCHETTI, Francesco. El principio de capacidade contributiva. Madrid: Instituto de Estudos Fiscales, 1980.

NABAIS, José Casalta. O dever fundamental de pagar impostos: contributo para a compreensão do estado fiscal contemporâneo. Coimbra: Almedina, 1988. 
PIMENTA, D. M. FAP: questões polêmicas. Disponível em: <http://jus.com.br/artigos/41410/fap-questoes-polemicas>. Acesso em: 31 jul. 2015.

SILVA, José Afonso da. Curso de direito constitucional positivo. 19. ed. São Paulo: Malheiros, 2001.

SCHOUERI, Luis Eduardo. Normas tributárias indutoras e intervenção econômica. Rio de Janeiro: Forense, 2005. 


\section{REVISTA BRASILEIRA DE POLÍTICAS PÚBLICAS BRAZILIAN JOURNAL OF PUBLIC POLICY}
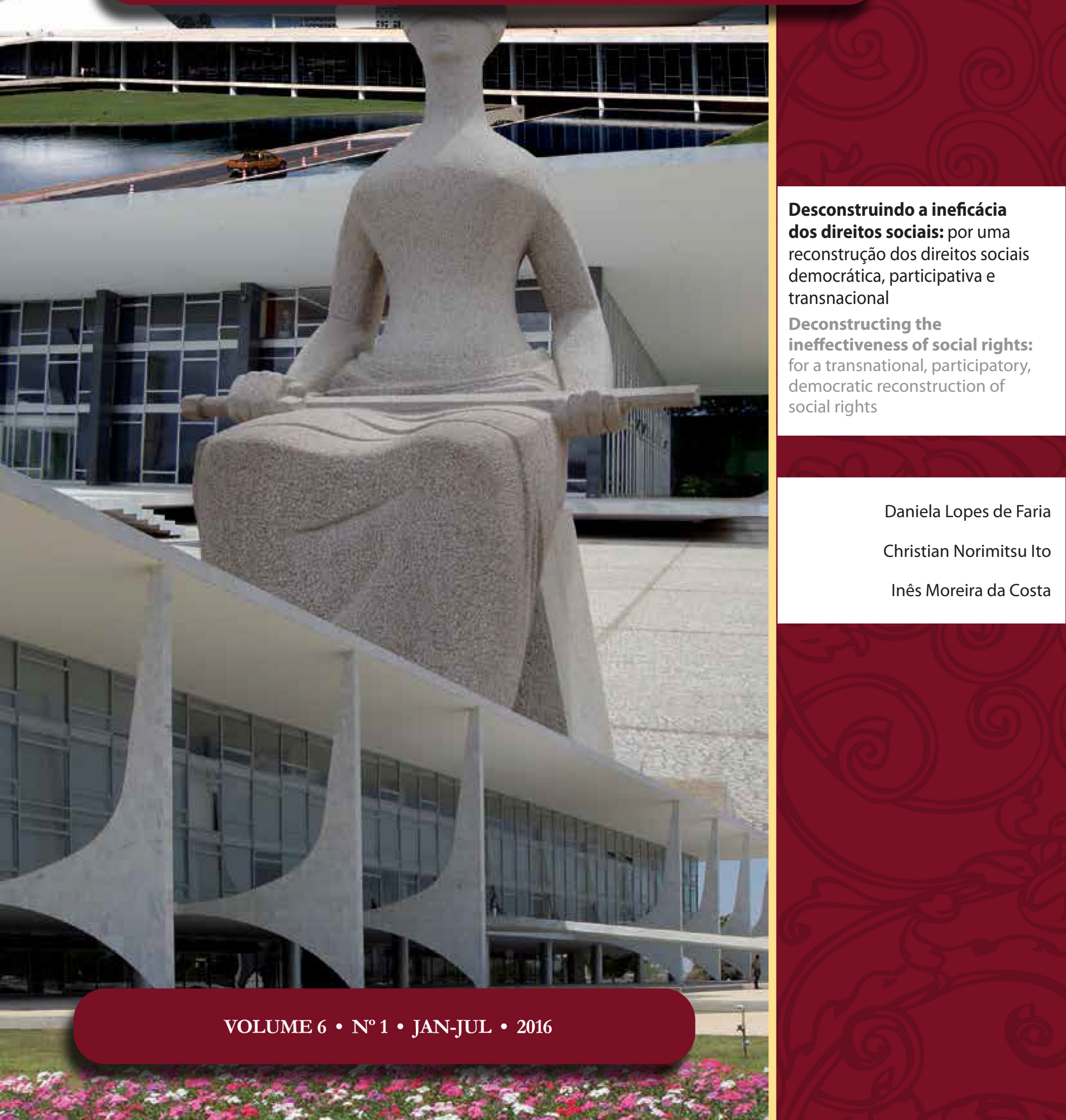

dos direitos sociais: por uma reconstrução dos direitos sociais democrática, participativa e transnacional

Deconstructing the ineffectiveness of social rights: for a transnational, participatory democratic reconstruction of social rights 


\section{Desconstruindo a ineficácia dos direitos sociais: por uma reconstrução dos direitos sociais democrática, participativa e transnacional*}

\section{Deconstructing the ineffectiveness of social rights: for a transnational, participatory, democratic reconstruction of social rights}

\author{
Daniela Lopes de Faria** \\ Christian Norimitsu Ito*** \\ Inês Moreira da Costa****
}

* Recebido em 24/11/2015

Aprovado em 27/02/2016

** Doutoranda em Ciências Jurídicas pela Universidade do Vale do Itajaí. Mestre em Direito Econômico e Socioambiental pela Pontifícia Universidade Católica do Paraná. Graduada em Direito na Pontifícia Universidade Católica do Paraná. Advogada. E-mail: danielalopesdefaria@hotmail.com.

*** Doutorando em Ciência Jurídica pela Universidade do Vale do Itajaí. Mestre em Administração pela Universidade Federal de Rondônia. Graduado em Direito pela Universidade Federal de Rondônia. Analista do Ministério Público do Estado de Rondônia. E-mail: christian_ito@hotmail.com.

**** Doutoranda em Ciência Jurídica pela Universidade do Vale do Itajaí. Mestre em Poder Judiciário pela Fundação Getúlio Vargas. Graduada em Direito pela Universidade Federal de Rondônia. Juíza de Direito do Tribunal de Justiça do Estado de Rondônia. E-mail: ines@ tjro.jus.br.

\section{Resumo}

O presente artigo tem por objetivo apresentar uma tese de desconstrução dos direitos sociais, sob a premissa de que as teorias tradicionais de origem e evolução destes possuem falhas e deficiências quanto ao seu posicionamento frente aos direitos fundamentais. Na proposta apresentada, a percepção dogmática se apresenta como a melhor medida para uma reconstrução dos direitos sociais sob uma democrática, participativa e transnacional, a fim de garantir a sua integração e alcance para uma maior parcela da sociedade, em especial, àquela mais fragilizada, mesmo que seja necessário recorrer à jurisdicionalização dos direitos garantidos nas cartas constitucionais existentes, sob o fundamento do mínimo existencial e do impedimento do retrocesso social.

Palavras-chave: Direitos sociais. Direitos fundamentais. Reconstrução. Eficácia.

\section{Abstract}

This article aims to present a deconstruction thesis of social rights under the premise that the traditional theories of the origin and evolution of these have failings and shortcomings as to its position relative to fundamental rights. In the the proposal presented, the dogmatic perception is presented as the best measure for a reconstruction of social rights under a democratic, participative and transnational vision, in order to ensure their integration and to reach a larger portion of society, especially at that most fragile, even having to resort to the judicial nature of the rights guaranteed in the existing constitutions, on the grounds of the existential minimum and preventing the social regression.

Key-words: Social rights. Fundamental rights. Reconstruction. Eficiency. 


\section{INTRODUÇÃO}

Há tempos, a sociedade moderna tenta acompanhar o dinamismo social implementado pelo desenvolvimento econômico a partir da Revolução Industrial e que deu origem ao liberalismo. É fato que, desde então, os Estados Democráticos de Direito têm enfrentado diversos paradigmas, visando equacionar os problemas sociais surgidos com base nessa nova realidade.

Para tanto e ao longo de sua história, tentam minimizar os efeitos devastadores da desigualdade econômica e social provocadas pelo crescente desenvolvimento da economia e da força liberal do capital privado. A face liberalista dos textos constitucionais edificados a partir do século XVIII começa a ceder espaço para a previsão positiva das garantias sociais necessárias para diminuir o abismo crescente entre os diversos níveis da sociedade ${ }^{1}$.

Assim, os direitos sociais estão diretamente relacionados às expectativas da sociedade quanto ao atendimento de suas necessidades básicas, também compreendidas como o mínimo existencial, em geral ligadas ao trabalho, saúde, educação, moradia e alimentação ${ }^{2}$. Dessa forma, o atual texto constitucional brasileiro resguarda, em seu artigo $6^{\circ}$, a garantia a tais direitos na qualidade de direitos sociais.

Pela própria natureza de tais direitos e da vitalidade de suas garantias, estes são requeridos pela parcela mais frágil da sociedade, o que exige dos Estados modernos a existência de uma sociedade que demonstre real sensibilidade igualitária para com o próximo.

No entanto, para Pisarello ${ }^{3}$, as políticas sociais advindas após a crise dos Estados Sociais Tradicionais acabaram se afastando da busca pela disseminação de concessão das garantias sociais e se tornaram na aplicação seletiva de políticas que, em vez de igualar as desiguais, acabam por adotar concessões revogáveis e discricionárias, já que, pela ineficiência na acessibilidade de tais direitos, somente alcançam os seus benefícios aqueles que possuem maiores condições de acesso à informação e buscam, por fim, métodos jurisdicionais para seu gozo e garantia.

O que se averigua atualmente é que os direitos sociais constitucionais estão relegados em segundo plano, face à implementação de políticas neoliberais, e dessa forma, nem mesmo a positivação de tais direitos são suficientes para garantir o seu cumprimento. Portanto, são tidas como previsões meramente programáticas das constituições.

\section{Análise crítica Às teorias de construção dos Direitos Sociais}

Em sua obra "Los derechos sociales y sus garantias. Elementos para uma reconstrucción”, Pisarello4 verifica a existência de 4 teorias para a análise dos direitos sociais, denominando-as como: Histórica, Normativa (filosófica), Teórica e Dogmática.

De uma perspectiva histórica, os direitos sociais são classificados diante da evolução histórica dos Direitos Fundamentais, assim, têm-se os direitos civis como de primeira geração, os políticos como de segunda geração e os sociais sendo os de terceira geração ${ }^{5}$.

os direitos do homem, por mais fundamentais que sejam, são direitos históricos, ou seja, nascidos em certas circunstâncias, caracterizadas por lutas em defesa de novas liberdades contra velhos poderes,

1 SARLET, Ingo Wolfgang. A eficácia dos direitos fundamentais: uma teoria geral dos direitos fundamentais na perspectiva constitucional. 12. ed. Porto Alegre: Livraria do Advogado, 2015.

2 FIORILLO. Celso Antonio Pacheco. Estatuto da cidade comentado. 2. ed. São Paulo: Revista dos Tribunais, 2005.

3 PISARELLO, Gerardo. Los derechos sociales y sus garantias: elementos para una reconstrucción. Madrid: Trotta, 2007. p. 12.

4 PISARELLO, Gerardo. Los derechos sociales y sus garantias: elementos para una reconstrucción. Madrid: Trotta, 2007. p. 17.

5 BOBBIO, Noberto. A Era dos direitos. São Paulo: Saraiva, 2007. 
e nascidos de modo gradual, não todos de uma vez e nem de uma vez por todas. [...] o que parece fundamental numa época histórica e numa determinada civilização não é fundamental em outras épocas e em outras culturas.

Como já ressaltado, os direitos sociais se impuseram nos textos constitucionais devido ao cenário político-econômico apresentado no mundo desde o século XVIII. Ademais, como bem lembra Pisarello ${ }^{6}$, caso não existissem tais condições, não se teria ambiente favorável à concessão dos direitos sociais, que antes se confundiam até mesmo como medidas de caridade governamental, sendo, sempre, insuficientes para atendimento das necessidades dos setores mais populares da sociedade.

Assim, a partir das últimas décadas do século XIX até a metade do século seguinte, constatou-se um processo de "socialização" em alguns países europeus, onde se pode verificar alterações em várias áreas do Direito. Assim surgiu o ramo autônomo do Direito do trabalho, promovendo o acesso à sindicalização e à negociação coletiva. Esse cenário finalmente se consolida após a segunda guerra mundial, claramente influenciados pelo pensamento Keynesiano do Wellfare State ou Estado de Bem Estar?

Portanto, não há como se assumir que os direitos sociais foram reconhecidos apenas e tão somente após o processo de consolidação dos direitos civis e políticos. A tese geracional peca no fato de não reconhecer que a inclusão de direitos sociais nas Constituições dos Estados Modernos ocorreu de forma complementar à conquista e ampliação dos direitos civis e políticos.

Outro ponto de desatenção da tese geracional é o reconhecimento linear e universal dos direitos sociais. Até onde se verifica, os Estados onde foram concedidas garantias sociais não universalizaram o seu acesso. Em alguns casos, se deu até mesmo o contrário, ou seja, ao resguardar o gozo e a garantia a bens vitais a toda sociedade, acabou por criar e, assim, expor, regras discriminatórias ou excludentes. São os casos das minorias de migrantes, étnicas, sociais e mesmo sexuais, no caso particular das mulheres em relação aos homens, que até hoje não alcançaram igual tratamento no mercado formal de trabalho.

O que a tese geracional esconde é que a concessão de direitos sociais ocorreu por meio de situações de conflito e não de forma harmônica, algumas foram obtidas por meio da persuasão de certos grupos por meio de reformas jurídicas, mediante rupturas e processos de autotutela, em que se obteve a abolição de privilégios e a transferência do poder e recursos de alguns setores da sociedade para outros ${ }^{8}$.

Diferentemente das tese geracional dos Direitos Sociais, há uma análise normativa-filosófica, que estabelece uma hierarquia, em termos axiológicos, dos direitos fundamentais. Assim, os direitos sociais posicionam-se de maneira subalterna em relação aos direitos civis e políticos, sob o argumento de que estes estariam mais estreitamente vinculados ao princípio da dignidade da pessoa, enquanto os direitos sociais estariam ligados, apenas, de maneira indireta e atemperada, a esse valor, o que justificaria a sua tutela debilitada.

Geralmente associada a essa visão também estaria a falsa disjunção consistente em que a implementação dos direitos fundamentais pressuporia uma opção: ou se está com direitos civis e políticos, em detrimento dos direitos sociais; ou se está com os direitos sociais, em detrimento dos direitos individuais, dessa forma, ou se está com igualdade ou com seguridade; igualdade ou liberdade; igualdade ou diversidade.

Sob essa ótica, Pisarello ${ }^{9}$ propõe forte crítica a essa percepção, inicialmente por acreditar ser impossível assegurar a garantia dos direitos civis e políticos sem o atendimento aos direitos sociais, para tanto, exemplifica essa questão ao afirmar que a dignidade e liberdade não serão atendidas se não houver igualdade de tratamento entre as pessoas. Assim, todas essas garantias estariam estreitamente relacionadas, em que o atendimento de uma só será plenamente possível mediante a concretização da outra.

6 PISARELLO, Gerardo. Los derechos sociales y sus garantías: elementos para una reconstrucción. Madrid: Trotta, 2007. p. 20.

7 GENRO, Tarso et al. O mundo real: socialismo na era pós-neoliberal. Apresentação de Mário Soares e introdução de Fernando Haddad.

Porto Alegre: L\&PM, 2008.

8 PISARELLO, Gerardo. Los derechos sociales y sus garantías: elementos para una reconstrucción. Madrid: Trotta, 2007. p. 24.

9 PISARELLO, Gerardo. Los derechos sociales y sus garantías: elementos para una reconstrucción. Madrid: Trotta, 2007. p. 25. 
Portanto, eventual dicotomia existente entre a garantia aos direitos civis e políticos em detrimento dos direitos sociais, ainda que decorrentes de um momento histórico, em que, no auge da Guerra Fria, foram assinados dois pactos internacionais junto às Nações Unidas: Pacto Internacional do Direitos Civis e Políticos (PIDCP) e o Pacto Internacional dos Direitos Econômicos, Sociais e Culturais (PIDESC), o que representa, claramente, a interpretação de que, naquela época, os direitos civis e políticos estavam desassociados dos sociais. No entanto, após o fim da Guerra Fria e a crise dos estados sociais tradicionais, o que se confirma é que não existe uma contraposição entre o princípio da liberdade e o da igualdade, mas sim que a liberdade civil e patrimonial se contrapunha a igualdade social ${ }^{10}$.

Dessa forma, não existe uma diferença axiológica entre os direitos civis e políticos e os direitos sociais, o que na realidade se verifica é que os direitos fundamentais são realmente indivisíveis e interdependentes, porém, possuem a mesma base valorativa fundada em princípios, tais como os da solidariedade, dignidade, liberdade, seguridade e pluralismo.

13. Como os direitos humanos e as liberdades fundamentais são indivisíveis, a realização dos direitos civis e políticos sem o gozo dos direitos econômicos, sociais e culturais resulta impossível. A realização de um progresso duradouro na aplicação dos direitos humanos depende de boas e eficientes políticas internacionais de desenvolvimento econômico e social; ${ }^{11}$

Já sob perspectiva teórica, dentro de um plano de maior abstração, tem-se que os direitos sociais teriam em relação aos direitos civis e políticos uma insuperável diferença estrutural da qual resultaria, naturalmente, a debilidade dos primeiros.

Por essa perspectiva, os direitos individuais se apresentariam como direitos negativos, não onerosos e de fácil proteção, enquanto os direitos sociais carregam em seu código genético, a natureza prestacional e, portanto, seriam direitos positivos, custosos, de incidência coletiva e sempre condicionados às reservas orçamentárias ${ }^{12}$.

Pisarello ${ }^{13}$ contesta tal afirmação, relatando que a bem da verdade, apesar dos direitos sociais exigirem uma série de condutas positivas do Estado, há uma grande parte deles que podem ser atendidos mediante comportamentos negativos, como o direito a uma moradia que pode ser contemplado mediante o direito a não ser desalojado de maneira arbitrária, inclusive em casos que envolvam contratos de locação.

Ademais, a atenção à garantia dos direitos fundamentais, sejam eles civis, políticos ou sociais, pode ser prestada mediante a edição de leis, regulamentos ou mesmo por meio da edição de marcos regulatórios, capazes de assegurar a garantia necessárias àqueles que usufruirão de tais direitos.

Um outro grande exemplo de que os direitos sociais podem ser assegurados mediante atitudes negativas é a máxima da não regressividade dos direitos sociais, tal como afirmado no Pacto Internacional do Comitê de Direitos econômicos, sociais e culturais (PDESC), que proíbe os poderes públicos em adotarem medidas e políticas que piorem a garantia aos direitos sociais já assegurados, sem que haja a devida e justificável motivação ${ }^{14}$.

Para avaliar se uma mudança redundaria em regressividade dos direitos sociais, sugere-se a adoção de

10 ARAUJO, J. A. Estevez. La constitución como processo y ladesobediencia civil. Madrid: Trotta, 1994.

11 ORGANIZAÇÃO DAS NAÇÕES UNIDAS. Proclamação de Teerã-1968. Disponível em: < http://www.direitoshumanos.usp. br/index.php/Confer $\%$ C3\%AAncias-de-C $\%$ C3\%BApula-das-Na $\%$ C3\%A7\%C3\%B5es-Unidas-sobre-Direitos-Humanos/proclamacao-de-teera.html>. Acesso em: 09 jul. 2015.

12 HOLMES, Stephen; SUNSTEIN, Cass. The cost of rights, why liberty depends on taxes. New York: Norton, 2000. p. 94.

13 PISARELLO, Gerardo. Los derechos sociales y sus garantías: elementos para una reconstrucción. Madrid: Trotta, 2007. p. 60-61.

14 Nesse sentido se fala também de cláusulas de proibição de evolução reaccionária ou de retrocesso social (ex. consagradas legalmente as prestações de assistência social, o legislador não pode eliminá-las posteriormente sem alternativas ou compensações reconhecidas, através de lei, o subsídio de desemprego como dimensão do direito ao trabalho, não pode o legislador extinguir este direito, violando o núcleo essencial do direito social constitucionalmente protegido). CANOTILHO, José Joaquim Gomes. Constituição dirigente e vinculação do legislador: contributo para a compreensão das normas constitucionais programáticas. 2. ed. Coimbra: Coimbra, 2001. 
critérios, os quais foram replicados por meio de decisão do Tribunal Constitucional Espanhol, em que elenca: 1) a legitimidade da medida a ser adotada e sua vinculação ao ordenamento jurídico; 2) a idoneidade caracterizada no caráter da medida, congruente e adequada aos fins a que se propõe; 3) a necessidade, representada pelo seu caráter indispensável e imprescindível, sobretudo ante a ausência de outras medidas; 4) a proporcionalidade, deve ser uma medida equilibrada e proporcional, averiguada através do alcance de mais benefícios e vantagens para o interesse público frente a outros bens juridicamente protegidos ${ }^{15}$.

Irrestrita também é a relação entre o princípio da não regressividade e o princípio da obrigação de progressividade, que autoriza aos poderes públicos o desenvolvimento do conteúdo dos direitos sociais no tempo e a fazê-lo de maneira gradual na medida em que se disponibilizem os recursos necessários. Dessa forma, traduz-se em um princípio de obrigações positivas, destinadas à satisfação das necessidades dos grupos em maior situação de vulnerabilidade.

A perspectiva teórica ainda aponta que os direitos sociais apresentam direitos vagos e indeterminados. Ora, não apenas esses mas todos os demais direitos fundamentais são previstos de maneira vaga, sem que necessariamente haja a preocupação com os meios que serão utilizados para o seu alcance, afinal, tratam-se de normas programáticas ${ }^{16}$ previstas nos textos constitucionais. Sejam direitos civis, políticos ou sociais, todos apresentam uma zona de penumbra e um núcleo de certeza. E este é determinado por técnicas hermenêuticas, podendo desenvolver-se ao longo do tempo com base no desenvolvimento de novas interpretações.

Outra crítica que pode ser facilmente refutada reside no fato de distinguir os direitos sociais dos direitos civis e políticas em virtude de estes serem de natureza individual e aqueles de natureza coletiva. Os direitos sociais podem ser concebidos tanto de maneira coletiva como também individual, é assim que se trata por exemplo o direito ao meio ambiente sadio, cujos reparos e proteções podem ser contemplados em ambas as formas. Assim, também se comportam os direitos civis e políticos, como no direito de associação, que se infringido pode ser tutelado não apenas por aquele que teve sua esfera jurídica atingida, mas também por órgãos de representação coletiva.

Dessa forma, temos que os direitos fundamentais são direitos de cunho complexo, que podem ser ora positivos, ora negativos; ora custosos, ora não custosos; ora individuais, ora coletivos.

Finalmente, com base em uma ótica dogmática, verifica-se que esta é fortemente influenciada pelas teses anteriores, em que inicialmente temos que seriam direitos secundários, tal como defende a linha filosófica, ou então, que apresentariam uma suposta diferença estrutural junto aos direitos civis e políticos, o que por lógica, leva a maioria dos ordenamentos jurídicos contemporâneos a reservar-lhes uma proteção mais debilitada.

Portanto, os direitos sociais não seriam autênticos direitos fundamentais, pois desprovidos das mesmas garantias reservadas aos direitos individuais, o que lhes reserva apenas a característica de serem princípios programáticos, cuja exigência seria de livre configuração pelo legislador o que acarreta em uma fragilizada proteção jurisdicional.

A vulneração dos direitos sociais está diretamente relacionada às desigualdades materiais de poder existentes nas sociedades atuais, para tanto, uma alternativa à vontade dos poderes dominantes em sobrejulgar os direitos sociais só seria possível mediante a remoção de obstáculos, tais como a condução do poder, em especial a exercida sobre a propriedade privada e na força da mídia.

Assim, Pisarello ${ }^{17}$ defende a necessidade de uma reconstrução dos direitos sociais perante uma dupla

15 PULIDO, Bernal C. El principio de proporcionalidade y los derechos fundamentales. Madrid: Centro de Estudios Constitucionales, 2013. 16 PIMENTA, Paulo Roberto Lyrio. Eficácia e aplicabilidade das normas constitucionais programáticas. São Paulo: M. Limonad, 1999. p. 150.

17 PISARELLO, Gerardo. Los derechos sociales y sus garantías: elementos para una reconstrucción. Madrid: Trotta, 2007. p. 111-114. 
perspectiva, a primeira sob um ponto de vista garantista, pois se o direito pode expressar o direito dos mais fortes, também pode se traduzir num instrumento de serviços aos sujeitos pertencentes às camadas mais frágeis da sociedade. Contudo, essa lógica garantista não assegura, por si só, o alcance dos direitos sociais, uma vez que possibilita a discussão jurídica, política, capaz de deslegitimar as múltiplas formas de poder arbitrário, que podem bloquear o acesso às necessidades mais básicas da sociedade.

A segunda está em uma perspectiva democrática participativa ou então democrática deliberativa. Conforme essa aproximação, a democracia apareceria como um processo sempre aberto e não como um regime acabado ao que se pode alcançar. Assim, a garantia dos direitos sociais deve ser efetivado mediante um processo constante de democratização e, para o autor, essa reconstrução somente seria adquirida mediante a concessão de melhores garantias e de mais democratização.

\section{A CRÍtICA À PERSPECTIVA DOGMÁtICA DOS DiREITOS SOCIAIS E A SUA RECONSTRUÇÃo}

Pisarello ${ }^{18}$ faz crítica à percepção dogmática, sobre três teses: na primeira, defende que os direitos sociais reconhecidos em constituições e tratados internacionais são tão fundamentais quanto os direitos civis e políticos e gozam, em consequência, de mecanismos potencialmente equivalentes de tutela, incluídos os de tipo jurisdicional e estabelece uma distinção de visão dos direitos sociais no plano axiológico e no plano dogmático. No plano axiológico, o que indica o caráter fundamental de um direito é sua pretensão de tutela de interesses ou necessidades vitais ligados ao princípio da igualdade. No plano dogmático, direitos fundamentais são aqueles interesses ou necessidades aos quais se atribui maior relevância dentro de um ordenamento jurídico, de modo que a ausência de garantias legislativas ou jurisdicionais de um direito constitucional não pode se equiparar a ausência de fundamentalidade, muito menos se pode falar em inutilidade da norma que reconhecesse o direito.

Paulo Bonavides ${ }^{19}$ sustenta que não existe distinção de grau nem de valor entre os direitos sociais e individuais, porquanto ambos são elementos de um bem maior, sem o qual não se torna efetiva a proteção constitucional: a dignidade da pessoa humana.

Estamos aqui, em presença do mais alto valor incorporado à Constituição, como fórmula universal de um novo Estado social de Direito. É por essa ótica - a dignidade da pessoa humana — que se guia a diligência interpretativa das presentes reflexões. Garantias sociais são, no melhor sentido, garantias individuais, garantias do indivíduo em sua projeção moral de ente representativo do gênero humano, compêndio da personalidade, onde se congregam os componentes éticos superiores mediante os quais a razão qualifica o homem nos distritos da liberdade, traçando-lhe uma circunstância de livre arbítrio que é o espaço de sua vivência existencial.

A segunda crítica ${ }^{20}$ refuta a tese de que a realização dos direitos sociais dependem exclusivamente de iniciativa do legislador: todos os direitos, não apenas os sociais, dependem de uma intervenção legislativa para sua plena eficácia, com diferente alcance.

Efetivamente, compete ao legislador decidir sobre a positivação de determinados direitos e sobre a aplicação dos recursos para sua implementação. No entanto, a maior ou menor regulação legal poderá reforçar ou debilitar as possibilidades de exigibilidade judicial, mas não impedirá que os tribunais analisem o caso concreto, determinando que o poder público preste ou não determinado serviço de natureza social.

A terceira crítica ${ }^{21}$ se manifesta contra a tese de que os direitos sociais não seriam justiciáveis, porque faltaria legitimidade democrática dos órgãos jurisdicionais, que não são eleitos, e idoneidade técnica dos juízes

18 PISARELLO, Gerardo. Los derechos sociales y sus garantías: elementos para una reconstrucción. Madrid: Trotta, 2007. p. 79-81.

19 BONAVIDES, Paulo. Curso de direito constitucional. 26. ed. São Paulo: Malheiros, 2011. p. 658.

20 PISARELLO, Gerardo. Los derechos sociales y sus garantías: elementos para una reconstrucción. Madrid: Trotta, 2007. p. 83-87.

21 PISARELLO, Gerardo. Los derechos sociales y sus garantías: elementos para una reconstrucción. Madrid: Trotta, 2007. p. 87-90. 
para lidar com questões econômicas e sociais.

O argumento de ausência de legitimidade democrática não se sustenta porque os tribunais, ao controlar e sancionar a administração por atuações indevidas ou omissões arbitrárias que vulneram direitos sociais não interferem no princípio democrático, ao contrário, o reforçam, ao assegurar o cumprimento das leis e normas constitucionais. Além disso, a tutela desses direitos não pode ser realizada exclusivamente por órgãos legislativos, que ficam muito à mercê do jogo político, no sentido de terem interesse em projetos que lhes tragam benefícios eleitorais imediatos, ou que tenham a ver com as prioridades de determinado partido.

Alexy ${ }^{22}$ sustenta que a necessária colisão entre o princípio democrático e os direitos fundamentais significa que o problema de divisão de competências entre o legislador com legitimação democrática direta e responsabilidade e o tribunal constitucional apenas indiretamente legitimado democraticamente, e não destituível eleitoralmente, é um problema inevitável e permanente, e denomina isso de "paradoxo da democracia".

Assim, a justiça constitucional é o instrumento mais idôneo para garantir o correto funcionamento dos procedimentos democráticos.

Quanto à ausência de idoneidade técnica dos juízes em matéria econômica e social, e ausência de comprometimento com as consequências financeiras de suas decisões, por não serem os responsáveis pela arrecadação de impostos, podem ser superadas. Em relação às questões técnicas, pelo auxílio de peritos, e em relação às consequências econômicas, é inevitável que as decisões judiciais causem impacto financeiro, e é recomendável que se tenha em conta essas consequências, não apenas orçamentárias, mas também politicas e sociais. No entanto, conforme Pisarello ${ }^{23}$, isso não pode ser confundido com o pragmatismo consequencialista segundo o qual toda intervenção judicial com repercussões econômicas colocaria em perigo o equilíbrio orçamentário ou constituiria uma intromissão ilegítima no âmbito reservado à esfera política.

\section{TeORIA dos Custos, mínimo eXISTENCIAL e ReSERVA do possível}

Mesmo reconhecendo a justiciabilidade dos direitos sociais, uma das maiores dificuldades na concretização desses direitos reside no aspecto econômico, ou seja, todos os direitos representam custos e deve haver uma rubrica para tanto. Os direitos de liberdade não são tão onerosos, de modo que podem ser garantidos a todos os cidadãos sem sobrecarregar os cofres públicos. Já os direitos sociais, pela natureza das prestações, exigem, em geral, grandes recursos. Como compatibilizar a escassez de recursos com a potencialização da efetividade dos direitos sociais?

Partindo dessa visão sobre os custos dos direitos, parte da doutrina procura delimitar a exigibilidade dos direitos (fundamentais e sociais) com base em critérios jurídicos e econômicos.

A Teoria dos Custos dos Juristas norte-americanos Stephen Holmes e Cass Sunstein ${ }^{24}$ propõe que o Estado, para se manter, precisa da receita dos tributos e, como há uma extensa lista de atividades a implementar, nem sempre o quantum apurado será suficiente para tudo e procuram demonstrar todas as dificuldades que a escassez dos recursos leva para concretizar os direitos sociais, de modo que o Estado não é absolutamente obrigado a fornecer algo que está além de sua capacidade orçamentária, não importando a natureza do pleito do demandante.

Essa concepção do custo dos direitos também é defendida por Flávio Galdino ${ }^{25}$, para quem a própria justificabilidade de um direito fundamental depende da aferição das possibilidades orçamentárias, e que levar

22 ALEXY, Robert. Teoria dos direitos fundamentais. 2. ed. São Paulo: Malheiros, 2015. p. 447.

23 PISARELLO, Gerardo. Los derechos sociales y sus garantías: elementos para una reconstrucción. Madrid: Trotta, 2007. p. 96.

24 HOLMES, Stephen; SUNSTEIN, Cass. The cost of rights, why liberty depends on taxes. New York: Norton, 2000. p. 35.

25 GALDINO, Flávio. Introducão à teoria dos custos dos direitos: direitos não nascem em árvores. Rio de Janeiro: Renovar, 2005. p. 343. 
os direitos a sério é, dentre outras coisas, incluir pragmaticamente no rol das trágicas escolhas que são feitas todos os dias pelas pessoas os custos dos direitos:

deste modo, só se reconhecerá uma alegado direito subjetivo como sendo um direito subjetivo fundamental quando, dentre outras condições, houver possibilidade real de torná-lo efetivo, ou seja, quando a análise dos respectivos custos e benefícios autorizar o reconhecimento dos direitos em questão. [...] A existência de um determinado direito fundamental, contudo, depende também e principalmente da verificação, dentre muitas outras condicionantes fáticas e jurídicas, das possibilidades financeiras para realizá-lo em um determinado momento e da justificação em termos de custo-benefício. [...] No mais das vezes, é imprescindível a análise sistêmica e não individualizada dos direitos, pois, como visto, no plano da escassez, a alocação justa de direitos deve colocar na balança as trágicas escolhas possíveis e não apenas as (eventualmente pródigas) opções axiológicas do legislador eventual ou do administrador da hora.

Assim, a implementação dos direitos fundamentais, incluídos os sociais (com sua força cogente) neste artigo, deve levar em consideração o custo e a existência de recursos. A limitação de recursos do Estado envolve escolhas alocativas, ou seja, compete-lhe a opção pela destinação dos recursos, o que importará sacrifícios de uma situação em detrimento de outra. É o que originou o termo "escolhas trágicas", no sentido de que pode privar uma pessoa de bens jurídicos extremamente relevantes, ou pode alijar a população da participação ou acesso a serviços de socialização indispensáveis à sua formação plena enquanto cidadã.

Daniel Sarmento ${ }^{26}$ discorre sobre o tema no seguinte sentido:

a escassez obriga o Estado em muitos casos a confrontar-se com verdadeiras "escolhas trágicas", pois, diante da limitação de recursos, vê-se forçado a eleger prioridades dentre várias demandas igualmente legítimas. Melhorar a merenda escolar ou ampliar o número de leitos na rede pública? Estender o saneamento básico para comunidades carentes ou adquirir medicamentos de última geração para o tratamento de alguma doença rara? Aumentar o valor do salário-mínimo ou expandir o programa de habitação popular? Infelizmente, no mundo real nem sempre é possível ter tudo ao mesmo tempo.

Essas limitações orçamentárias levaram à construção dogmática da reserva do possível, para indicar que os direitos sociais só podem ser garantidos quando houver recursos para tanto.

Essa teoria teve origem em 1972, no Tribunal Constitucional Alemão, em decisão conhecida como numerus clausus (número restrito), na qual foi analisada demanda judicial proposta por estudantes que não haviam sido admitidos nas escolas de Medicina de Hamburgo e Munique, em face da limitação do número de vagas em cursos superiores adotada pelo país em 1960, com fundamento no art. 12 da lei fundamental alemã, que garantia a livre escolha de trabalho, ofício ou profissão.

Ao decidir a questão, a corte alemã entendeu que o direito pleiteado, qual seja, o aumento do número de vagas na universidade, encontrava limitação na reserva do possível, conceituada como o que o indivíduo pode razoavelmente exigir da sociedade, sob pena de, em virtude das limitações de ordem econômica, comprometer a plena efetivação dos direitos sociais ${ }^{27}$.

Para Ingo Sarlet ${ }^{28}$, a reserva do possível deve ser analisada em três dimensões: a) a efetiva disponibilidade fática dos recursos para a efetivação dos direitos fundamentais; b) a disponibilidade jurídica dos recursos materiais e humanos, que guarda íntima conexão com a distribuição das receitas e competências tributárias, orçamentárias, legislativas e administrativas e; c) proporcionalidade da prestação, em especial no tocante à sua exigibilidade e também da razoabilidade.

A reserva do possível só pode ser invocada quando restar objetivamente comprovada a inexistência

26 SARMENTO, Daniel. A proteção judicial dos direitos sociais: alguns parâmetros ético-jurídicos. In: NOVELINO, Marcelo (Org.). Leituras complementares de constitucional: direitos humanos e direitos fundamentais. 4. ed. Salvador: JusPodivm, 2010. p. $389-427$.

27 SARMENTO, Daniel. A proteção judicial dos direitos sociais: alguns parâmetros ético-jurídicos. In: NOVELINO, Marcelo (Org.). Leituras complementares de constitucional: direitos humanos e direitos fundamentais. 4. ed. Salvador: JusPodivm, 2010. p. $389-427$.

28 SARLET, Ingo Wolfgang. A eficácia dos direitos fundamentais: uma teoria geral dos direitos fundamentais na perspectiva constitucional. 12. ed. Porto Alegre: Livraria do Advogado, 2015. p. 296. 
de recursos financeiros para a realização de determinado fim, sob pena de ser utilizada pelo Estado como forma de se exonerar dolosamente do cumprimento de suas obrigações delineadas constitucionalmente. E, para tanto, Pisarello ${ }^{29}$ sugere que sejam demonstrados, pelos órgãos estatais a) o emprego do máximo esforço no âmbito do máximo dos recursos disponíveis para satisfazer os direitos em questão; b) a coleta e difusão suficiente a respeito das necessidades existentes; c) a supervisão efetiva do cumprimento das metas já estabelecidas e do estabelecimento de metas futuras adequadas (direito ao atendimento progressivo); d) e que tais planos contemplem adequadamente soluções eficientes para os grupos mais necessitados.

De outro lado, deve-se considerar que, nos ordenamentos jurídicos atuais, o simples reconhecimento de um direito como fundamental comporta atribuição de um conteúdo mínimo e com ele a imposição de certos deveres elementares para os poderes públicos.

Canotilho ${ }^{30}$ acentua que um direito social sob 'reserva dos cofres cheios' equivale, na verdade, a nenhuma vinculação jurídica, e, para atenuar essa desoladora constatação, adianta-se, por vezes, que a única vinculação razoável e possível se reconduz à garantia do mínimo social. No entanto, "esta garantia do mínimo social resulta já do dever indeclinável dos poderes públicos de garantir a dignidade da pessoa humana e não de qualquer densificação jurídico-constitucional dos direitos sociais".

Os elementos que configuram o conteúdo mínimo não são rígidos, variando conforme o direito pretendido, fatores pessoais, contexto social ou histórico. Segundo Sarlet ${ }^{31}$, o conteúdo do mínimo existencial abrange: a) um mínimo fisiológico; b) um mínimo sociocultural (direito à educação e acesso a bens culturais) e até mesmo c) um mínimo ecológico.

Ocorre que a efetividade desses direitos não pode ficar dissociada das previsões orçamentárias do Estado, ainda mais quando se cuida de comunidades que demandam uma grande quantidade de atividades prestacionais, como acontece no Brasil. Como diz Paulo Bonavides ${ }^{32}$, "quanto mais desfalcada de bens ou mais débil a ordem econômica de um país constitucional, mais vulnerável e frágil nele a proteção efetiva dos sobreditos direitos; em outros termos, mais programaticidade e menos juridicidade ostentam".

Isso não significa, por outro lado, que o atendimento de outros direitos prestacionais, que não exclusivamente aqueles reconhecidos na esfera do mínimo existencial, devam ser recusados pelo poder público.

Ainda no que diz aos direitos sociais a prestações como direitos subjetivos, notadamente no que diz com a sua condição de direitos originários a prestações, convém repisar e melhor explicitar que ao advogarmos o entendimento de que na esfera da garantia do mínimo existencial (que não poderá ser reduzido ao nível de um mero mínimo vital), ou, em outras palavras, a uma estrita garantia da sobrevivência física) há que reconhecer a exigibilidade (inclusive judicial!) da prestação em face do Estado,não estamos - enfatize-se esse ponto - afastando a possibilidade de direitos subjetivos a prestações que ultrapassem estes parâmetros mínimos, mas apenas afirmando que neste plano (de direitos subjetivos para além do mínimo existencial) o impacto dos diversos limites e objeções que se opõe ao reconhecimento destes direitos (especialmente o comprometimento de outros bens fundamentais) poderá, a depender das circunstâncias do caso, prevalecer ${ }^{33}$

Assim, a solução mais viável, para compatibilizar a efetivação desses direitos e a limitação orçamentária estatal, ou como diz Jorge Miranda ${ }^{34}$, "no ajustamento do socialmente desejável ao economicamente possivvel, é reconhecer que o Estado Social destina-se a proporcionar condições para uma existência digna, e não um padrão ótimo de bem-estar social e, portanto, estaria vinculado ao adimplemento das condições mínimas de existência digna do ser humano e não à totalidade de suas necessidades.

29 PISARELLO, Gerardo. Los derechos sociales y sus garantias: elementos para una reconstrucción. Madrid: Trotta, 2007. p. 102.

30 CANOTILHO, José Joaquim. Direito constitucional e teoria da constituição. 3. ed. Coimbra: Almedina, 1999. p. 451.

31 SARLET, Ingo Wolfgang. A eficácia dos direitos fundamentais: uma teoria geral dos direitos fundamentais na perspectiva constitucional. 12. ed. Porto Alegre: Livraria do Advogado, 2015. p. 329.

32 BONAVIDES, Paulo. Curso de direito constitucional. 26. ed. São Paulo: Malheiros, 2011. p. 659.

33 SARLET, Ingo Wolfgang. A eficácia dos direitos fundamentais: uma teoria geral dos direitos fundamentais na perspectiva constitucional. 12. ed. Porto Alegre: Livraria do Advogado, 2015. p. 366.

34 MIRANDA, Jorge. Manual de direito constitucional. Rio de Janeiro: Coimbra, 2000. t. 4. p. 392. 
Aliado a essa alternativa, pode-se buscar aplicar com mais rigor os princípios da proporcionalidade e da razoabilidade, indagando se as políticas públicas oferecem respostas de curto, médio e longo prazo, ao menos para os mais vulneráveis, promovendo-se o controle judicial das opções orçamentárias e da legislação relativa aos gastos públicos (inclusive sobre a que dispõe acerca da responsabilidade fiscal) e também no controle (jurisdicional) das decisões políticas acerca da alocação de recursos, principalmente no tocante à transparência das decisões e a viabilização do controle social sobre a aplicação dos recursos alocados no âmbito do processo político (ex: necessidade de uso de recursos para propaganda institucional, aumento do número de servidores comissionados etc).

\section{Proibição de PROTEÇÃo INSUFiCIeNTE E de Retrocesso SOCIAL}

Cabe ao Estado a obrigação de criar os pressupostos fáticos indispensáveis aos exercícios dos direitos fundamentais em geral, assim como a obrigação de concretizar os direitos sociais em particular, evitando que a omissão ou ação precária do poder público venha a caracterizar uma hipótese de proteção insuficiente que resulte em violação a esses direitos, pelo fato de não atingidos os mínimos exigíveis de satisfação de determinadas prestações.

A proibição de insuficiência seria, assim, forma de aplicação da proporcionalidade quando o direito envolvido tem função protetiva (positiva), no sentido de não fixar mais do que um mínimo de proteção (efetiva e adequada).

A primeira decisão empregando a "proibição de insuficiência" de que se tem notícias é também de origem alemã: em 1993, ao revisar o entendimento esposado 18 anos antes, o Tribunal Constitucional alemão decidiu pela inconstitucionalidade da regulação dada por lei que descriminalizava o aborto realizado em até doze semanas da concepção, porquanto a legislação alemã obrigava o Estado a proteger a vida humana intrauterina, assegurando, assim, a proteção jurídica do nascituro, também perante sua mãe, proibindo-lhe a interrupção da gestação ${ }^{35}$.

Conforme esclarece Jürgen Schwabe:

a extensão do dever de tutela da vida humana intrauterina deve ser determinada visando, de um lado, o significado e a necessidade de proteção do bem a ser protegido, e, de outro lado, os bens jurídicos que com ele entrem em conflito. Como bens jurídicos atingidos pelo direito à vida do nascituro - partindose da pretensão jurídica da mulher gestante à proteção e observância de sua dignidade humana (Art. 1 I GG) — vêm à pauta, sobretudo, seu direito à vida e à incolumidade física (Art. 2 II GG), bem como seu direito da personalidade (Art. 2 I GG). Ao contrário, não pode a mulher gestante, que com o aborto mata o nascituro, valer-se da posição jurídica protegida pelo direito fundamental do Art. 4 I GG.

O Estado deve adotar medidas normativas e fáticas suficientes para cumprir seu dever de tutela, que levem — considerando os bens conflitantes — ao alcance de uma proteção adequada e, como tal, efetiva (proibição de insuficiência). Para tanto, é necessário um projeto de proteção que combine elementos de proteção preventiva e repressiva ${ }^{36}$.

No caso, afirmou-se, que não se poderia cogitar da prevalência do direito de defesa da mãe (livre disposição do corpo), sob o risco de o Estado não cumprir efetiva e adequadamente um dever a ele imposto — constitucionalmente deduzido.

No Brasil, o STF aplicou esse princípio ao apreciar uma ação declaratória que tinha por objeto condicionar a permissão da pesquisa e terapia com células-tronco embrionárias (por fertilização in vitro) somente

35 Conforme BverfGE88, 203. In: SCHWABE, Jürgen. Cinquenta anos de jurisprudência do Tribunal Constitucional Federal Alemão. Tradução Beatriz Hennig et al. Montevideo: Fundação Konrad-Adenauer, 2005. p. 273-294. Disponível em: < http://biblio.juridicas. unam.mx/libros/libro.htm?l=2241>. Acesso em: 20 jul. 2015.

36 SCHWABE, Jürgen. Cinquenta anos de jurisprudência do Tribunal Constitucional Federal Alemão. Tradução Beatriz Hennig et al. Montevideo: Fundação Konrad-Adenauer, 2005. p. 276 
após a prévia aprovação e autorização por Comitê Central de Ética e Pesquisa, vinculado ao Ministério da Saúde ${ }^{37}$, bem como em casos mais recentes ${ }^{38}$.

Ao lado do princípio da proteção insuficiente há um outro princípio correlato: o da vedação do retrocesso social. Para Sarlet ${ }^{39}$, a ideia nuclear é a de que eventuais medidas supressivas ou restritivas de prestações sociais implementadas (e, portanto, retrocessivas em matéria de conquistas sociais) pelo legislador devem ser consideradas inconstitucionais por violação do por violação do princípio da proibição de retrocesso, sempre que com isso restar afetado o núcleo essencial legislativamente concretizado dos direitos fundamentais, especialmente nas hipóteses em que resultar uma afetação da dignidade da pessoa humana, no contexto do que tem sido batizado como mínimo existencial.

Conforme Canotilho ${ }^{40}$, o núcleo essencial dos direitos sociais já realizado e efetivado por meio de medidas legislativas deve considerar-se constitucionalmente garantido, sendo inconstitucionais quaisquer medidas estaduais que, sem a criação de meios alternativos ou compensatórios, se traduzam, na prática numa anulação, revogação ou aniquilação pura e simples desse núcleo essencial:

a proibição de retrocesso social nada pode fazer contra as recessões e crises econômicas (reversibilidade fática), mas o princípio em análise limita a reversibilidade dos direitos adquiridos(ex: segurança social, subsídio de desemprego, prestações de saúde), em clara violação do princípio da proteção da confiança e da segurança dos cidadãos no âmbito económico, social e cultural,e do núcleo essencial da existência mínima inerente ao respeito pela dignidade da pessoa humana. O reconhecimento desta proteção de 'direitos prestacionais de propriedade', subjetivamente adquiridos, constitui um limite jurídico do legislador e, ao mesmo tempo, uma obrigação de prossecução de uma política congruente com os direitos concretos e as expectativas subjectivamente alicerçadas.

Assim, cada nova conquista impede que se retorne às condições primitivas. Essa proibição ganha relevo justamente nos períodos de crise, pois é nas dificuldades e na fragilização individual em que mais se exige a intervenção estatal. No entanto esse não pode ser considerado um direito absoluto. O que se veda ao legislador é a possibilidade de, sem justificativa razoável, eliminar ou reduzir o nível de concretização alcançado por um determinado direito fundamental social.

\section{Dimensão objetiva dos diReitos SOCiais}

Os direitos sociais exigem uma miríade de normas organizacionais, que geram uma multiplicidade de obrigações jurídicas de distintos sujeitos, cujo cumprimento conjunto é necessário para que o Estado realize as prestações dos direitos sociais de forma integral. ${ }^{41}$ Para Luis Pietro Sanchís, por essa necessidade de um

37 BRASIL. Supremo Tribunal Federal. Ação declaratória de constitucionalidade. ADC 3510. Relator: Min. Carlos Ayres Brito. Publicado no DOU de 30 de maio de 2005.

38 BRASIL. Supremo Tribunal Federal. Ag .Reg. no Recurso Extraordinário com Agravo. ARE 745745 AgR. Segunda Turma. Relator: Min. Celso de Mello, Brasília, 02 de dezembro de 2014. Disponível em: < http://redir.stf.jus.br/paginadorpub/paginador. jsp?docTP=TP\&docID=7516923>. Acesso em: 20 abr. 2016. Assunto: manutenção de rede de assistência à saúde da criança e do adolescente; e no BRASIL. Supremo Tribunal Federal. Agravo de Instrumento. AI 598212. Segunda Turma. Relator: Min. Celso de Mello, Brasília, 25 de março de 2014. Disponível em: <http://www.stf.jus.br/arquivo/cms/noticianoticiastf/anexo/ai598212cm. pdf>. Acesso em: 20 abr. 2016. Assunto: criação, implantação e estruturação da Defensoria Pública da Comarca de Apucarana. O STF também já aplicou esse princípio, ao analisar sentença que obrigava o Município de São Paulo a matricular crianças em unidades de ensino infantil próximas de sua residência ou do endereço de trabalho de seus responsáveis legais (BRASIL. Supremo Tribunal Federal. Ag .Reg. no Recurso Extraordinário com Agravo. ARE 639337. Segunda Turma. Relator: Min. Celso de Mello, Brasília, 23 de agosto de 2011. Disponível em: <http://redir.stf.jus.br/paginadorpub/paginador.jsp?docTP=AC\&docID=627428>. Acesso em: 20 abr. 2016).

39 SARLET, Ingo Wolfgang. Dignidade da pessoa bumana e direitos fundamentais na Constituição Federal de 1988. 4. ed. Porto Alegre: Livraria do Advogado, 2006. p. 121.

40 CANOTILHO, José Joaquim Gomes. Direito constitucional e teoria da constituição. 3. ed. Coimbra: Almedina, 1999. p. $326-327$. 41 SANCHÍS, Luis Pietro. Los derechos sociales y el principio de igualdad sustancial. Disponível em: < dialnet.unirioja.es/descarga/articulo/1065762.pdf>. Acesso em: 13 jul. 2015. 
aparato administrativo para cumprimento das prestações relacionadas aos direitos sociais, poder-se-ia afirmar que há uma predominância da dimensão objetiva dos direitos sociais em relação à dimensão subjetiva.

Segundo Sanchís todos os direitos fundamentais apresentam esse aspecto objetivo, que "son elementos esenciales de un ordenamiento objetivo de la comunidad nacional, y de ahí la función preferente que desempeñan en lai nterpretación del Derecho y el interés público que existe en su protección”. ${ }^{2}$

Dimitri Dimoulis aduz que a dimensão subjetiva (ou clássica) corresponde no aspecto negativo, ao direito de resistir à intervenção estatal (liberdades) e no seu aspecto positivo, ao direito de exigir do Estado uma prestação/ação estatal (direitos sociais). Por sua vez, a dimensão objetiva independe dos titulares do direito, dos sujeitos, oferecendo critérios de controle da ação estatal, os quais devem ser aplicados independentemente de intervenções/violações de direitos fundamentais de determinada pessoa. ${ }^{43}$

Segundo Dimoulis, a dimensão objetiva possui 3 aspectos fundamentais.

Em primeiro lugar, os direitos fundamentais apresentam normas de competência negativa, no sentido de que o que está sendo outorgado ao indivíduo, em termo de liberdade, está sendo objetivamente retirado da esfera de atuação do Estado. Dentro desse aspecto se estabelece o controle abstrato de constitucionalidade, no qual o Estado realiza um autocontrole em função dos direitos fundamentais, tendo dentre os legitimados várias autoridades estatais. ${ }^{44}$

Um segundo aspecto da dimensão objetiva dos direitos fundamentais é o seu funcionamento como critério de interpretação e conformação do direito infraconstitucional, por meio do fenômeno da irradiação dos direitos fundamentais. Acerca desse fenômeno, Riccardo Guastini esclarece que a constitucionalização do ordenamento jurídico é o processo de transformação de um ordenamento em que ao seu término o ordenamento em questão resulta totalmente impregnado pelas normas constitucionais. Um ordenamento jurídico constitucionalizado se caracteriza por uma Constituição extremamente invasiva, capaz de condicionar tanto a legislação quanto a jurisprudência, tanto a doutrina quanto a atuação dos atores políticos, assim como as relações sociais. ${ }^{45}$

O terceiro aspecto da dimensão objetiva é o dever estatal de tutela dos direitos fundamentais, que é "o dever do Estado de proteger ativamente o direito fundamental contra ameaças de violação provenientes, sobretudo de particulares". ${ }^{46}$

Diante disso, nota-se a relevância da dimensão objetiva dos direitos sociais, pois o Estado, para conseguir prestá-los adequadamente, deve se estruturar com órgãos e agentes administrativos e planejar suas políticas públicas para atender aos direitos sociais com efetividade.

\section{As garantias dos direitos Socials como instrumento para sUa ReConstrução DEMOCRÁTICA, PARTICIPATIVA E TRANSNACIONAL}

Com base na desconstrução dos mitos que possibilitaram a contínua inefetividade dos direitos sociais, Gerardo Pisarello propõe uma reconstrução dos direitos sociais com base em alguns elementos. Em primeiro lugar, alerta para a necessidade de uma reconstrução unitária, que reconheça a interdependência e

42 SANCHÍS, Luis Pietro. Los derechos sociales y el principio de igualdad sustancial. Disponível em: < dialnet.unirioja.es/descarga/articulo/1065762.pdf>. Acesso em: 13 jul. 2015.

43 DIMOULIS, Dimitri. Teoria geral dos direitos fundamentais. São Paulo: RT, 2008. p. 117-119.

44 DIMOULIS, Dimitri. Teoria geral dos direitos fundamentais. São Paulo: RT, 2008. p. 119.

45 GUASTINI, Riccardo.La “constitucionalización” delordenamiento jurídico: el caso italiano. In: CARBONELL, Miguel (Ed.). Neoconstitucionalismo(s). 2. ed. Madrid: Trotta, 2005. p. 49.

46 DIMOULIS, Dimitri. Teoria geral dos direitos fundamentais. p. 119. 
a indivisibilidade dos direitos civis, políticos e sociais ${ }^{47}$, consoante esclarece a Declaração sobre o Direito ao Desenvolvimento de 1986, reconhecendo-se, assim, que as gerações de direitos fundamentais refletem aspectos que compõem a dignidade da pessoa humana, formando um sistema integrado, sem prevalência de alguns direitos sobre outros. ${ }^{48}$

Além disso, urge reconhecer o caráter poliédrico dos direitos fundamentais, que igualmente assumem dimensões positivas e negativas; são custosos e ao mesmo tempo não são custosos; são determinados, e igualmente indeterminados; possuem dimensão objetiva (mandatos e princípios reitores) e subjetiva (justiciáveis); e que todos dispõem dos mesmos mecanismos de proteção. ${ }^{49}$

Outro aspecto relevante dessa reconstrução diz respeito à complexidade das garantias dos direitos no que diz respeito aos sujeitos encarregados de protegê-los (executivo, legislativo, judiciário, órgãos externos de controle, tribunal de contas, e defensorias do povo). As vias jurisdicionais não podem ser a única nem a principal via de satisfação dos direitos sociais. Deve-se buscar um caráter multi-institucional de tutela dos direitos fundamentais. ${ }^{50}$

A reconstrução das garantias dos direitos também é complexa no que diz respeito às escalas de proteção, infraestatal, supraestatal, que compreenda diversos âmbitos como o municipal, sub-estatal e estatal, até o plano regional e internacional. Assim, Pisarello destaca a importância da descentralização para os Municípios, em razão da proximidade das necessidades sociais das pessoas, desde que haja suficiência financeira para arcar com os custos. ${ }^{51}$ No Brasil, por exemplo, em julgamento da ADI 2922/RJ proposta em face de lei estadual, o STF ressaltou que a competência legislativa concorrente (art. 24, Constituição Federal) teria o condão de transformar os Estados-membros em verdadeiros laboratórios legislativos, a permitir que novas e exitosas experiências fossem formuladas e eventualmente adotadas pelos demais.

$\mathrm{Na}$ escala supraestatal, o fenômeno da globalização impulsionou a "desterritorialização do poder" minuindo a importância das fronteiras políticas e retirando do controle dos Estados questões como mercado financeiro, comunicações, especialmente pela internet, e problemas ambientais. Conforme expôs Cruz e Bodnar "na atualidade, nenhuma democracia pode isolar-se dos efeitos do que acontece além de suas fronteiras" 53.

Assim, ganha destaque a ideia de Marcelo Neves de transconstitucionalismo, na qual se analisa o convívio e as influências recíprocas entre ordens jurídicas distintas, como a constitucional-estatal, a regional, as locais extraestatais, a internacional e a supranacional, sem atribuir de forma prima facie superioridade absoluta de qualquer dessas ordens.

O transcontitucionalismo não toma uma única ordem jurídica ou um tipo determinado de ordem como ponto de partida ou ultimaratio. Rejeita tanto o estatalismo quanto o internacionalismo, o supranacionalismo, o transnacionalismo e o localismo como espaço de solução privilegiado dos problemas constitucionais. Aponta, antes, para a necessidade de construção de 'pontes de transição', da promoção de 'conversações constitucionais', do fortalecimento de entrelaçamentos constitucionais entre diversas ordens jurídicas: estatais, internacionais, supranacionais e locais [...] As ordens envolvidas na solução do problema constitucional específico, no plano de sua própria autofundamentação, reconstroem continuamente a sua identidade, mediante o entrelaçamento constitucional com a(s) outra(s): a identidade é rearticulada através da alteridade..$^{54}$

47 PISARELLO, Gerardo. Los derechos sociales y sus garantías: elementos para una reconstrucción. Madrid: Trotta, 2007. p. 111.

48 SARLET, Ingo Wolfgang; FENSTERSEIFER, Tiago. Direito constitucional ambiental: estudos sobre a Constituição, os direitos fundamentais e a proteção do ambiente. São Paulo: Revista dos Tribunais, 2011. p. 45-46.

49 PISARELLO, Gerardo. Los derechos sociales y sus garantías: elementos para una reconstrucción. Madrid: Trotta, 2007. p. 111-112.

50 PISARELLO, Gerardo. Los derechos sociales y sus garantías: elementos para una reconstrucción. Madrid: Trotta, 2007 . p.112.

51 PISARELLO, Gerardo. Los derechos sociales y sus garantías: elementos para una reconstrucción. Madrid: Trotta, 2007. p. 130-131

52 SOUZA NETO, Cláudio Pereira de; SARMENTO, Daniel. Direito constitucional: teoria, história e métodos de trabalho. Belo Horizonte: Fórum, 2014. p. 88

53 CRUZ, Paulo Márcio; BODNAR, Zenildo (Org.). Globalização, transnacionalidade e sustentabilidade. Itajaí: UNIVALI, 2012. Disponível em: <http://siaiapp28.univali.br/LstFree.aspx>. Acesso em: 15 maio 2015

54 NEVES, Marcelo. Transconstitucionalismo. São Paulo: M. Fontes, 2009. p. 18. 
Portanto, cada vez mais se nota um entrelaçamento entre as ordens constitucional e internacional, formando o que Jurgen Habermas denomina de Constelação Pós-Nacional. ${ }^{55}$ Assim, consoante assevera Marcos Leite Garcia, "com a transnacionalização dos direitos fundamentais, o compromisso de um país periférico passaria a ser com toda a comunidade transnacional a que pertence, e não mais somente com seu (des) enganado povo." 56

Por outro lado, faz-se necessária uma reconstrução democrática e participativa, menos institucionalista. Há necessidade de criar espaços em que os destinatários dos direitos possam ser ouvidos na construção do conteúdo do direito.

Essa reconstrução parte das distinções conceituais entre as garantias institucionais e as garantias extrainstitucionais. Garantias institucionais são aqueles mecanismos de proteção dirigidos pelo Poder Público, por meio de seus Poderes Legislativo, Executivo e Judiciário, bem como pelo Ministério Público e Tribunais de Contas. $^{57}$

Já as garantias extrainstitucionais ou garantias sociais são aquelas em que o resguardo dos direitos se coloca nas mãos dos próprios titulares. São precisamente o exercício dos direitos civis e políticos de participação destinados a reclamar a satisfação dos direitos. São garantias sociais indiretas os instrumentos que permitem a participação institucional, política e jurisdicional das garantias dos direitos, como, por exemplo, possibilidade de eleger ou destituir órgãos encarregados de tutelá-los (Assembleia constituinte, Assembleia ordinária, poder executivo). Trata-se do direito de sufrágio ativo e passivo. ${ }^{58}$

Todavia, a noção de cidadania deve ir além da noção de que somente exige do cidadão "sua participação política na forma simplista, voluntária e periódica do sufrágio" ${ }^{59}$.Contudo, na Constituição existem instrumentos que possibilitam uma comunicação permanente da vontade pública, são eles o plebiscito, o referendo, a iniciativa popular de lei, os conselhos gestores de políticas públicas e o orçamento participativo. Assim, embora se reconheça a importância da representação, esta não deve ser a única forma de participação do cidadão na vida pública, deve-se incentivar a construção de espaços nos quais há uma deliberação pública e uma efetiva participação social na política do Estado, para uma realização da democracia de forma mais profunda. ${ }^{60}$

A participação popular é essencial em todas as fases do ciclo das políticas públicas (da sua formulação à sua implementação) para dar maior legitimidade ao processo, visto que "deve ser expressão de um processo público, no sentido de abertura à participação de todos os interessados, diretos e indiretos, para a manifestação clara dos interesses em jogo" ${ }^{\prime 1}$, assim como amplia a cidadania, desenvolvendo a responsabilidade das pessoas.

A participação social na administração pública contribui, também, para uma maior eficiência na gestão pública, bem como uma contenção de abusos e ilegalidades, além de haver um grau maior de consensualidade e aceitação da população das decisões estatais, pois estavam envolvidas no processo decisório ${ }^{62}$. Consoante Wallace Martins Júnior são pressupostos da participação o acesso à informação, uma maior abertura

55 HABERMAS, Jurgen. A constelação pós-nacional: ensaios políticos. Tradução de Márcio Seligmann-Silva. São Paulo: LitteraMundi, 2001.

56 GARCIA, Marcos Leite. Reflexões sobre os fenômenos dos novos direitos fundamentais e as demandas transnacionais. Revista de Direito da UNISC. Santa Cruz do Sul, n. 33, p. 103-129, jan./jun. 2010.

57 PISARELLO, Gerardo. Los derechos sociales y sus garantías: elementos para una reconstrucción. Madrid: Trotta, 2007. p. 113.

58 PISARELLO, Gerardo. Los derechos sociales y sus garantías: elementos para una reconstrucción. Madrid: Trotta, 2007. p. 123.

59 LOPES, Ana Maria D’Ávila. A participação política das minorias no estado democrático de direito brasileiro. In: ALBUQUERQUE, Paulo Antonio de Menezes; LIMA, Martonio Mont'Alverne Barreto (Org.) Democracia, direito e politica: estudos internacionais em homenagem a Friedrich Muller. Florianópolis: Conceito, 2006. p. 85

60 MENDES, Denise Cristina Vitale Ramos. Representação política e participação: reflexões sobre o déficit democrático. Disponível em: <http://www.scielo.br/pdf/rk/v10n2/a02v10n2.pdf>. Acesso em: 01 set. 2011. p. 143-153

61 BUCCI, Maria Paula Dallari. Direito administrativo e políticas públicas. São Paulo: Saraiva 2002. p. 269.

62 MARTINS JÚNIOR, Wallace Paiva. Transparência administrativa: publicidade, motivação e participação popular. São Paulo: Saraiva, 2004. p. 298. 
à participação e a superação da noção de que o interesse público é monopólio estatal, especialmente ante a aproximação entre os interesses difusos e públicos. ${ }^{63}$

Bernardo Kliksberg afirma que "a gestão participativa, no campo social, traz resultados muito superiores a outros modelos organizacionais de caráter tradicional, como os burocráticos e os paternalistas". ${ }^{64}$ Ademais, verifica-se, também, como consequência da participação, um empoderamento da comunidade e um fortalecimento da organização comunitária. ${ }^{65}$

Assim, Kliksberg destaca a importância da democracia participativa, afirmando que:

aspira-se substituir a 'democracia passiva' por uma 'democracia inteligente', onde o cidadão esteja amplamente informado, disponha de múltiplos canais para transmitir seus pontos de vista - e não através da eleição das autoridades máximas, cada tantos anos - e exerçam uma influência real e constante sobre a gestão dos assuntos públicos. ${ }^{66}$

Nesse contexto que surge a noção de accountability, que consiste em "processos de avaliação e responsabilização permanente dos agentes públicos que permitam ao cidadão controlar o exercício do poder concedido aos seus representantes." ${ }^{97}$

Ser cidadão num regime democrático significa possuir uma série de direitos, entre os quais a prerrogativa de participar da escolha de seus governantes e influir nas suas decisões, mas significa, também, uma série de obrigações sociais, entre as quais a de participar daquelas atividades diretamente vinculadas à seleção dos governantes e da vigilância sobre as suas ações. No entanto, a participação, para ser efetiva, demanda informações precisas e confiáveis que permitam ao cidadão construir um quadro referencial da atuação do governo e, a partir daí, atuar no sentido de exigir que os representantes expliquem as suas ações, mudem sua forma de agir ou mesmo alterem os objetivos das políticas públicas.

A accountability como forma de cobrar respostas dos governantes ocorre exatamente porque existem deficiências nas informações que são passadas ao público. Nesse caso, a accountability como answerability pretende criar mais transparência em relação ao exercício do poder. ${ }^{68}$

Segundo Arlindo Rocha, existem duas formas de accountability, o horizontal ou institucional e o vertical ou social. No accountability vertical ou social, a sociedade exerce seu poder de premiar ou punir seus governantes e representantes mediante a manutenção ou retirada do poder por intermédio do voto direto em eleições livres, entre outros mecanismos de pressão política, ou seja, é produto da ação política do cidadão e entidades da sociedade civil, inclusive imprensa. ${ }^{69}$

Já o accountability horizontal ou institucional se efetiva mediante a mútua fiscalização entre os poderes (checks and balances), por meio de órgãos governamentais que controlam a atividade pública e, principalmente, pela existência de agências estatais com poder, vontade e capacitação para supervisionar, avaliar e punir, se for o caso, agentes ou agências governamentais, ou seja, é produto das agências internas ao estado. ${ }^{70}$

63 KLIKSBERG, Bernardo. Como por em prática a participação? Algumas questões estratégicas. In: GESTÃO pública e participação. Salvador: Fundação Luis Eduardo Magalhães, 2005. p. 301-303.

64 KLIKSBERG, Bernardo. Como por em prática a participação? Algumas questões estratégicas. In: GESTÃO pública e participação. Salvador: Fundação Luis Eduardo Magalhães, 2005. p. 67-68.

65 KLIKSBERG, Bernardo. Como por em prática a participação? Algumas questões estratégicas. In: GESTÃO pública e participação. Salvador: Fundação Luis Eduardo Magalhães, 2005 p. 68-70.

66 KLIKSBERG, Bernardo. Como por em prática a participação? Algumas questões estratégicas. In: GESTÃO pública e participação. Salvador: Fundação Luis Eduardo Magalhães, 2005. p. 92.

67 ROCHA, Arlindo Carvalho. Accountability na Administração Pública: modelos teóricos e abordagens. Contabilidade, Gestão e Governança, Brasília, v. 14, n. 2, p. 82 -97, maio/ago. 2011.

68 ROCHA, Arlindo Carvalho. Accountability na Administração Pública: modelos teóricos e abordagens. Contabilidade, Gestão e Governança, Brasília, v. 14, n. 2, p. 82 -97, maio/ago. 2011.

69 ROCHA, Arlindo Carvalho. Accountability na Administração Pública: modelos teóricos e abordagens. Contabilidade, Gestão e Governança, Brasília, v. 14, n. 2, p. 82 -97, maio/ago. 2011.

70 ROCHA, Arlindo Carvalho. Accountability na administração pública: modelos teóricos e abordagens. Contabilidade, Gestão e Governança, Brasília, v. 14, n. 2, p. 82 -97, maio/ago. 2011. 
Portanto, a reconstrução dos direitos sociais depende necessariamente de uma participação popular nas políticas públicas sociais, de modo a atender de forma mais eficiente aos anseios da população, sem descurar da accountability como instrumento de fiscalização e controle dos poderes constituídos.

\section{Conclusão}

Com base dessa pesquisa conclui-se que, por razões políticas e econômicas os direitos sociais foram teorizados ao longo do tempo de forma a lhes atribuir mínima ou pouca efetividade. Eram considerados normas programáticas, sem eficácia imediata, ou dependentes da malfadada reserva do possível.

Diante dessas justificações para assegurar a inefetividade dos direitos sociais, a presente pesquisa propôs-se a desconstruir essas falácias, desde as perspectivas histórica, filosófico-normativa, teórica e dogmática para posteriormente propor uma reconstrução dos direitos sociais, a partir das ideias de democracia participativa e dos diálogos entre as diversas escalas de proteção dos direitos fundamentais, da local, nacional à internacional.

Destaca-se a importância da participação popular na conquista dos direitos sociais, que acabou alavancada pelos históricos de decadência dos Estados Sociais, baseados no Wellfare State, porém, dificultados em virtude das políticas neoliberais adotadas nas maiores economias.

Propõe-se neste artigo uma constelação multi-institucional, participativa, transnacional e integral de garantias dos direitos civis, políticos e sociais, a fim de garantir a sua jurisdicionalização e assegurar o alcance de seus fins às camadas mais fragilizadas da sociedade, como forma de um Estado mais voltado ao atendimento do mínimo existencial necessário para uma vida mais digna à maior parcela da sociedade, com o claro objetivo de garantir uma maior eficácia aos direitos sociais assegurados nos textos constitucionais, ante a premissa de que a atual conjuntura mundial exige uma interpretação transconstitucional, sem barreiras fronteiriças, exigindo-se um comportamento solidário frente às mazelas sociais.

\section{REFERENCIAS BIBLIOGRÁFICAS}

ALEXY, Robert. Teoria dos direitos fundamentais. 2. ed. São Paulo: Malheiros, 2015.

ARAUJO, J. A. Estevez. La constitución como processo y ladesobediencia civil. Madrid: Trotta, 1994.

BOBBIO, Noberto. A era dos direitos. São Paulo: Saraiva, 2007.

BONAVIDES, Paulo. Curso de direito constitucional. 26. ed. São Paulo: Malheiros, 2011.

BRASIL. Supremo Tribunal Federal. Ag .Reg. no Recurso Extraordinário com Agravo. ARE 745745 AgR. Segunda Turma. Relator: Min. Celso de Mello, Brasília, 02 de dezembro de 2014. Disponível em: < http:// redir.stf.jus.br/paginadorpub/paginador.jsp?docTP=TP\&docID=7516923>. Acesso em: 20 abr. 2016.

BRASIL. Supremo Tribunal Federal. Ag .Reg. no Recurso Extraordinário com Agravo. ARE 639337. Segunda Turma. Relator: Min. Celso de Mello, Brasília, 23 de agosto de 2011. Disponível em: < http:/ / redir. stf.jus.br/paginadorpub/paginador.jsp?docTP=AC\&docID=627428>. Acesso em: 20 abr. 2016

BRASIL. Supremo Tribunal Federal. Agravo de Instrumento. AI 598212. Segunda Turma. Relator: Min. Celso de Mello, Brasilia, 25 de março de 2014. Disponível em: < http://www.stf.jus.br/arquivo/cms/noticianoticiastf/anexo/ai598212cm.pdf>. Acesso em: 20 abr. 2016.

BUCCI, Maria Paula Dallari. Direito administrativo e politicas públicas. São Paulo: Saraiva 2002. 
CANOTILHO, José Joaquim Gomes. Direito constitucional e teoria da constituição. 3. ed. Coimbra: Almedina, 1999.

CRUZ, Paulo Márcio; BODNAR, Zenildo (Org.). Globalização, transnacionalidade e sustentabilidade. Itajaí : UNIVALI, 2012. Disponível em: <http://siaiapp28.univali.br/LstFree.aspx>. Acesso em: 15 maio 2015.

FIORILLO. Celso Antonio Pacheco. Estatuto da cidade comentado. 2. ed. São Paulo: Revista dos Tribunais, 2005.

GALDINO, Flávio. Introdução à teoria dos custos dos direitos: direitos não nascem em árvores. Rio de Janeiro: Renovar, 2005.

GARCIA, Marcos Leite. Reflexões sobre os fenômenos dos novos direitos fundamentais e as demandas transnacionais. Revista de Direito da UNISC. Santa Cruz do Sul, n. 33, p. 103-129, jan./ jun. 2010.

GENRO, Tarso et al. O mundo real: socialismo na era pós-neoliberal. Apresentação de Mário Soares e introdução de Fernando Haddad. Porto Alegre: L\&PM, 2008.

GUASTINI, Riccardo. La "constitucionalización” delordenamiento jurídico: el caso italiano. In: CARBONELL, Miguel (Ed.). Neoconstitucionalismo(s). 2. ed. Madrid: Trotta, 2005.

HABERMAS, Jurgen. A constelação pós-nacional: ensaios políticos. Tradução de Márcio Seligmann-Silva. São Paulo: LitteraMundi, 2001.

HOLMES, Stephen; SUNSTEIN, Cass. The cost of rights, why liberty depends on taxes. New York: Norton, 2000.

KLIKSBERG, Bernardo. Como por em prática a participação? Algumas questões estratégicas. In: GESTÃO pública e participação. Salvador: Fundação Luis Eduardo Magalhães, 2005.

LOPES, Ana Maria D’Ávila. A participação política das minorias no estado democrático de direito brasileiro. In: ALBUQUERQUE, Paulo Antonio de Menezes; LIMA, Martonio Mont'Alverne Barreto (Org.). Democracia, direito e politica: estudos internacionais em homenagem a Friedrich Muller. Florianópolis: Conceito, 2006. p. 85

MARTINS JÚNIOR, Wallace Paiva. Transparência administrativa: publicidade, motivação e participação popular. São Paulo: Saraiva, 2004.

MENDES, Denise Cristina Vitale Ramos. Representação política e participação: reflexões sobre o déficit democrático. Disponível em: <http://www.scielo.br/pdf/rk/v10n2/a02v10n2.pdf>. Acesso em: 01 set. 2011.

MIRANDA, Jorge. Manual de direito constitucional. Rio de Janeiro: Coimbra, 2000. t. 4.

ORGANIZAÇÃO DAS NAÇÕES UNIDAS. Declaração Universal dos Direitos Humanos. Disponível em: <http://unesdoc.unesco.org/images/0013/001394/139423por.pdf>. Acesso em: 07 jul. 2015.

ORGANIZAÇÃO DAS NAÇÕES UNIDAS. Proclamação de Teerã-1968. Disponível em: < http://www.direitoshumanos.usp.br/index.php/Confer\%C3\%AAncias-de-C \%C3\%BApula-das-Na\%C3\%A7\%C3\%B5esUnidas-sobre-Direitos-Humanos/proclamacao-de-teera.html>. Acesso em: 09 jul. 2015.

PISARELLO, Gerardo. Los derechos sociales y sus garantias: elementos para una reconstrucción. Madrid: Trotta, 2007.

ROCHA, Arlindo Carvalho. Accountability na administração pública: modelos teóricos e abordagens. Contabilidade, Gestão e Governança, Brasília, v. 14, n. 2, p. 82 -97, maio/ago. 2011.

SANCHÍS, Luis Pietro. Los derechos sociales y el principio de igualdad sustancial. Disponível em: < dialnet.unirioja. es/descarga/articulo/1065762.pdf>. Acesso em: 13 jul. 2015.

SARLET, Ingo Wolfgang. A eficácia dos direitos fundamentais: uma teoria geral dos direitos fundamentais na perspectiva constitucional. 12. ed. Porto Alegre: Livraria do Advogado, 2015. 
SARLET, Ingo Wolfgang; FENSTERSEIFER, Tiago. Direito constitucional ambiental: estudos sobre a constituição, os direitos fundamentais e a proteção do ambiente. São Paulo: Revista dos Tribunais, 2011.

SARMENTO, Daniel. A proteção judicial dos direitos sociais: alguns parâmetros ético-jurídicos. In: NOVELINO, Marcelo (Org.). Leituras complementares de constitucional: direitos humanos e direitos fundamentais. 4. ed. Salvador: JusPodivm, 2010. p. 389-427.

SOUZA NETO, Cláudio Pereira de; SARMENTO, Daniel. Direito constitucional: teoria, história e métodos de trabalho. Belo Horizonte: Fórum, 2014. 


\section{REVISTA BRASILEIRA DE POLÍTICAS PÚBLICAS BRAZILIAN JOURNAL OF PUBLIC POLICY}

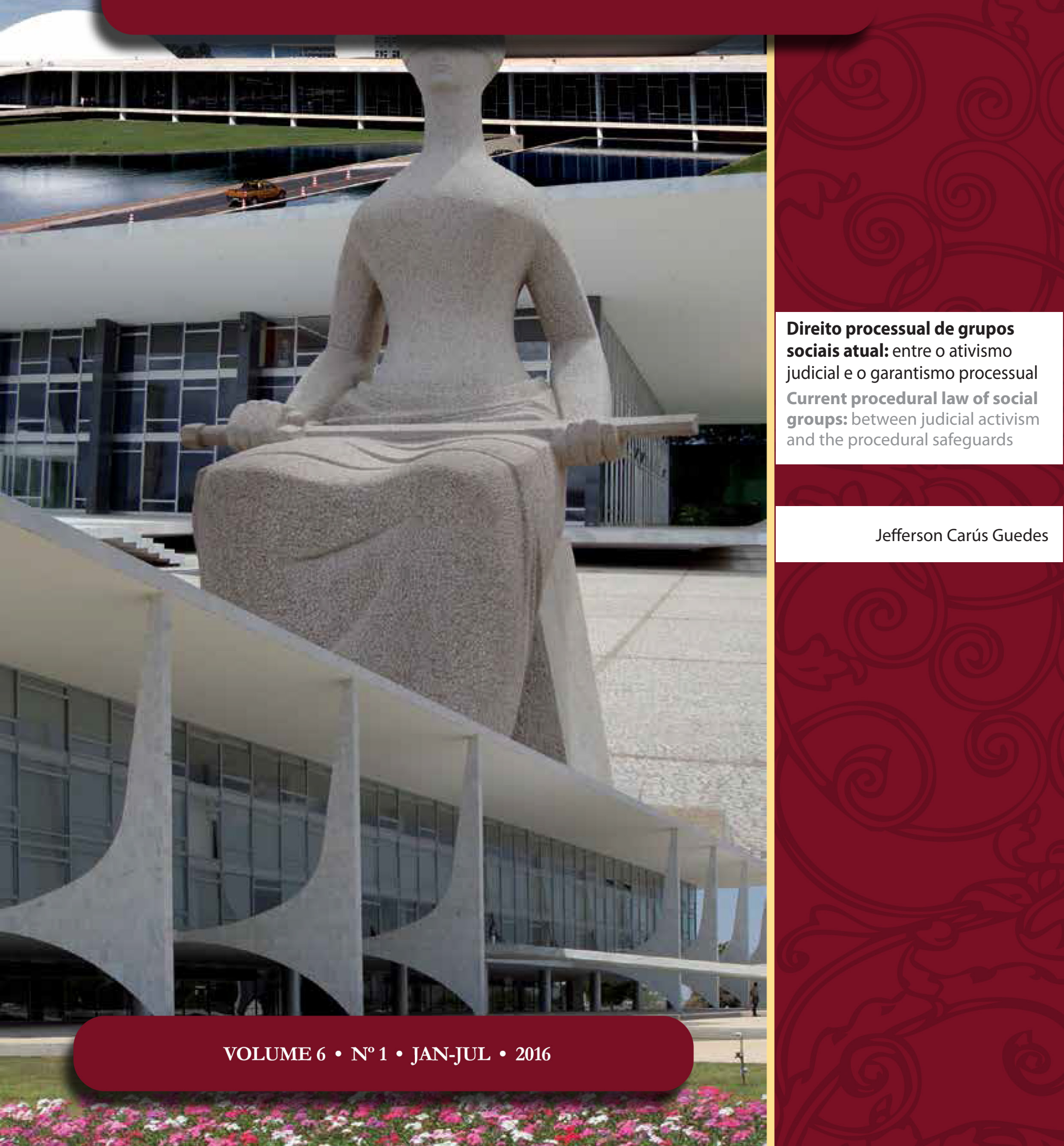




\title{
Direito processual de grupos sociais atual: entre o ativismo judicial e o garantismo processual* $^{*}$
}

\author{
Current procedural law of social groups: \\ between judicial activism and the procedural \\ safeguards
}

Jefferson Carús Guedes**

\section{Resumo}

O presente artigo busca discutir o chamado direito processual de grupos sociais, especialmente sua categorização entre o ativismo judicial e o garantismo processual. Em 2006 já havíamos tratado da existência de um "direito processual social" ou "direito processual de grupos sociais" ao repor o debate sobre certas áreas do processo civil que podem ou devem merecer tratamento diferenciado das regras processuais e, de modo geral, apenas, como um reflexo de diferenciações originadas do direito material. O que nos parece, às vezes, é que ressuscitamos velhos temas ao debater o atual garantismo processual e o ativismo judicial. Entende-se ser possível que haja normas autoritárias em regimes democráticos e normas democráticas em regimes autoritários. Pensar-se em regras universais não faz mais muito sentido no Brasil, hoje, quando se quer um processo cada vez mais "customizado" ou adequado à tutela desejada pela parte. Reequilibrar partes com regras do processo, quando e se necessário, pode ser tarefa estatal, seja pela outorga de direitos, seja pela compensação processual, sejam aos pobres ou desassistidos, negros, beneficiários de seguro social, adolescentes em condição de risco, indígenas, mulheres, agricultores, desabrigados de catástrofes, homossexuais e outras minorias, refugiados, detentos, imigrantes, desempregados, doentes, acidentados, microempresários; sem-terra, deficientes. Mas, além disso, tutelar não mais ou não apenas os direitos desses indivíduos ou grupos de indivíduos, mas as pessoas e como pessoas, assim reconhecidas pela técnica processual.

Palavras-chaves: Ativismo judicial; Garantismo processual; Direito processual de grupos sociais;

* Artigo convidado.

** Professor da Graduação, Especialização, Mestrado e Doutorado do UniCEUB. Doutor e Mestre em Direito Processual Civil (PUCSP). Advogado da União. E-mail: Professor. carusguedes@gmail.com

\section{Abstract}

This article seeks to discuss the so-called procedural law of social groups, especially its categorization between judicial activism and procedural safegurads. In 2006 we had already dealt with the existence of a "social procedural law" or "procedural law of social groups" to guide the debate over certain areas of civil procedure that can or should be given differential treatment 
of procedural rules and, in general, only as a reflection of differences arising from the substantial law. What seems sometimes that it is a kind of resurrected old themes, discussing the current procedural safeguards and judicial activism. It is understood that there may be authoritarian norms in democratic regimes, and democratic norms in authoritarian regimes. Think about universal rules does not make much sense in Brazil anymore, today, when we want an ever more "customized" or proper guardianship process desired by the people. Rebalance the litigants with procedural rules, when (and if needed), can be a state task to grant civil rights, whether by procedural compensation to some kind of litigants: poor or disadvantaged, black, beneficiaries of social insurance, adolescents in risk situation, indigenous, women, farmers, displaced by disasters, homosexuals and other minorities, refugees, prisoners, immigrants, unemployed, sick people, injured, microentrepreneurs; landless poor. But beyond that, no more safeguard the rights of these individuals or groups of individuals, but as people and people as well recognized by the procedural technique.

Keywords: Judicial Activism; Procedural Safeguards; Procedural Law of Social Groups;

\section{INTRODUÇÃo}

Este texto, escrito originalmente a convite do caríssimo amigo de mais de uma década, Prof. GLAUCO Gumerato Ramos, para coletânea brasileira organizada pelo prof. José RenAto NALini em homenagem ao Prof. Juan Montero Aroca, possuía no título original ${ }^{1}$ uma evidente provocação ao opor como contrários perfeitos o Garantismo Processual e o, assim dito, Direito Processual de Grupos Sociais.

Dessa feita, são realizadas pequenas adaptações para a publicação em Coletânea sobre o ativismo judicial do Centro Brasileiro de estudos Constitucionais - CBEC, dirigido pelo professor Carlos Ayres Britto, no Centro Universitário de Brasília - UniCEUB.

Em texto publicado pelo professor Montero Aroca na obra Proceso civil e ideología: un prefacio, una sentencia, dos cartas y quince ensayos, ${ }^{2}$ - obra que a esta altura estamos traduzindo para o português em conjunto com o próprio Glauco Gumerato Ramos e Fauzi Hassan ChOucr —, o estimado catedrático valenciano faz várias associações entre autoritarismo processual e o processo civil social, para, ao fim, reafirmar suas convicções garantistas. Para além desse texto autoral, o prof. Montero Aroca conseguiu reunir em torno de si um grupo de processualistas de vários países dispostos a rediscutir velhas e renovadas posturas estatais relacionadas, principalmente, à tendência de desequilíbrio entre direito processual e política legislativa processual associada à sua notável capacidade de, às vezes, deixar-se influenciar pela ideologia.

Essa atividade de militância democrática e doutrinária do prof. MONTERO Aroca ultrapassou as fronteiras espanholas em várias direções, produzindo seus reflexos além da Espanha, na Itália, Portugal, Argentina, Peru, Colômbia, Chile e também no Brasil.

Por aqui, em profissão de fé, nos últimos anos, mas também em outras plagas da América Latina (do México à Patagônia Argentina) o Prof. Glauco Gumerato Ramos tem escrito e divulgado as ideias e as obras dos professores Juan Montero Aroca e Adolfo Alvarado Velloso, ${ }^{3}$ afirmando sua convicção em prol do garantismo processual.

1 O título original seria: “Ainda e mutto ‘A favor’ do Direito Processual Social ou 'Contra' o garantismo processual univerSAL". Melhor será posicionar o Direito Processual de Grupos Sociais entre o Ativismo e o Garantismo, em homenagem à trova quinhentista portuguesa de Francisco Sá DE Miranda: "Pouco por força podemos,/ isso que é, por saber veio,/ todo o mal jaz nos extremos,/ o bem todo jaz no meio."

2 MONTERO AROCA, Juan. Proceso civil e ideología: un prefacio, una sentencia, dos cartas y quince ensayos. Valencia: Tirant lo Blanch, 2006. Essa obra reúne trabalhos de Adolfo Alvarado Velloso, Eugenia Ariano Deho, José Carlos Barbosa Moreira, Franco Cipriani, Ignazio Díez-Picazo, Federico G. Dominguez, Luís Correia de Mendonça, Girolamo Monteleone, Joan Picó i Junoy, Giovanni Verde e do próprio coordenador, Juan Montero Aroca.

3 ALVARADO VELLOSO, Adolfo. Garantismo procesal contra actuación judicial de oficio. Valencia: Tirant lo Blanch, 2005. 
De outro lado, quase por acidente, tratamos no ano de 2006 da existência de um possível Direito Processual Sociatt ou Direito Processual de Grupos Sociais ao repor o debate sobre certas áreas do processo civil que podem ou devem merecer tratamento diferenciado das regras processuais e, de modo geral, apenas, como um reflexo de diferenciações originadas do direito material. Não há e nem houve na proposição apresentada nesse trabalho um sentido original e pré-ordenado de opor-nos às afirmações garantistas do prof. MONTERO Aroca ou de Alvarado Velloso, ideia que somente mais tarde se afigurou possível, com os debates feitos com o amigo Glauco Gumerato Ramos.

Por isso e só por isso é que este artigo pode ser considerado, em pálida medida, uma réplica tardia das afirmações feitas pelo meu querido contendor brasileiro e, em escala ainda menor, aos trabalhos dos professores espanhol e argentino.

\section{Contornos VelHos E NOVOS de UM BinÔMIO APARENTEMENTE INCONCILIÁVEL: ${ }^{5}$ A) SOCIALISMO E INDIVIDUALISMO; B) AUTORITARISMO E LIBERALISMO C) PUBLICISMO E PRIVATISMO; D) ATIVISMO (JUDICIAL) E GARANTISMO (PROCESSUAL)}

O que se nos parece, às vezes, é que ressuscitamos velhos temas ao debater o atual garantismo e tanto é assim que Montero Aroca nos traz como exemplo em seu texto o Codice de Procedura Civile italiano de 1940, com sua carga caricatural de ser norma criada pelos fascistas, como se fosse possível às normas processuais corresponderem em exata medida à presença ou não de democracia em determinada nação a certo tempo, como se fossem a imagem espectral de seus propositores.

Nem sempre isso ocorre. É possível que haja normas autoritárias em regimes democráticos e normas democráticas em regimes autoritários. BARBOSA MOREIRA adverte que a disciplina processual sofre influência das características do regime político, ${ }^{6}$ sem dizer que essa influência seja sempre perniciosa ou irreversível. JOAN PiCó I JUNOY tem a mesma opinião, discordando da relação direta entre concessão de poderes instrutórios ao juiz e o caráter fascista e autoritário ou mesmo totalitário do processo civil. ${ }^{7}$

No caso dessa polêmica, mudam-se os nomes e os fenômenos mantêm-se próximos, permitindo dizer que o antagonismo hoje evidente entre ativismo e garantismo já foi visto outrora entre socialismo e liberalismo, autoritarismo e liberalismo e entre publicismo e privatismo. Esse seria um binômio aparentemente inconciliável, desde muito aparentemente contraditório.

Essas denominações historicamente se posicionam em certa ordem, conforme se propõe abaixo:

a) socialismo e individualismo - Atribui-se essa primeira divisão dupla de denominações dada aos debates originais surgidos logo após a edição das normas processuais que no final do século XIX aparece-

$4 \mathrm{O}$ artigo se denomina Direito Processual Social no Brasil: as primeiras linhas e a acidentalidade se deve à pesquisa sobre igualdade e desigualdade processual, por nós desenvolvida, sob a generosa orientação do prof. ARRUDA ALVIM, para a tese de doutoramento (PUCSP/2008), que possuía o desafio inicial de definir uma "área" do Direito Processual Civil que contemplasse as "diferenciações" entre partes e interesses merecedores de compensações processuais. O desafio original ficou resumido a esse artigo publicado em 2006, na Revista Latinoamericana de Derecho Social, n. 2, (México: UNAM) e na Revista de Processo, n. 142, (São Paulo: Revista dos Tribunais).

5 ALCALÁ-ZAMORA Y CASTILLO, Niceto. Liberalismo y autoritarismo en el proceso. In: ___. Estudios de Teoría General e Historia del Proceso. Ciudad de México: UNAM, 1974. v. 2. p. 285. Dirá que não há incompatibilidade alguma entre liberalismo e autoritarismo no processo. Por essa razão nominamos e 'aparentemente' inconciliável o binômio.

6 MOREIRA, José Carlos Barbosa. Neoprivatismo no processo civil. In: ___ Temas de direito processual. 9. ed. São Paulo: Saraiva, 2007. p. 87-102. p. 88. O autor cita como exemplos leis que considera insuspeitas de autoritarismo, tais como a Lei da Ação popular (Lei n. 4.717/1965) e Lei da Ação Civil Pública (Lei n. 7.347/1985), editadas durante os governos militares (1964-185). Contudo, ao argumento de Montero Aroca essas também seriam, provavelmente, leis autoritárias, pois outorgam excessivos poderes aos juízes, e não democráticas, como imagina Barbosa Moreira.

7 PICÓ I JUNOY, Joan. El derecho procesal entre el garantismo y la eficacia: un debate mal planteado, Revista de Processo, n. 197, p. 193-210, jun. 2011. p. 117. 
ram na Prússia e na Áustria, e principalmente à anterior "militância" socialista de ANTON MENGER.

A obra mais referida de Anton Menger é Das Büergerliche Recht und die besitzlosen Volksklassen. Eine Kritik des Entwurfs eines Buergerlichen Gesetzbuches fuer das deutsche Reich, Tübingen, 1890, ${ }^{8}$ composto de estudos críticos sobre o Projeto do Código Civil do Império alemão, publicados nos Archiv für sociale Gesetzgebung und Statistk, edições $1^{\mathrm{a}}$ a $3^{\mathrm{a}} / 1889$ e 1ª $/ 1890$, traduzido e publicado em espanhol em duas ocasiões, em 1898 e em 1998 com o título El Derecho Civil y los pobres.

As observações sobre o processo civil contidas na obra podem ser sintetizadas na seguinte crítica:

A extraordinária diferença segundo a qual os que têm e os que não têm bens podem perseguir seu direito tem sido até agora esquecida pelos jurisconsultos. O motivo disto consiste, sem dúvida, em que, por causa de sua educação e de seus interesses, os jurisconsultos de todos os países se sentem inclinados a considerar-se exclusivamente como servidores e representantes das classes abastadas. ${ }^{9}$

E acrescentava, referindo-se ao Direito de Família:

[...] Não posso dar por terminada essa crítica sobre as disposições legais relativas aos filhos ilegítimos, sem antes considerar o lado processual desta questão. [...] o procedimento civil é prejudicial aos interesses das classes pobres, na medida em que exclui, ordinariamente, a intervenção autônoma do juiz. Este defeito geral da administração da justiça civil influi em nossos casos, pesando duplamente sobre as costas dos pobres. Este defeito geral da administração da justiça civil influi em nossos casos, pesando duplamente sobre as costas dos pobres, porque a mulher mãe fora do casamento põe-se, com seu filho, em estado desesperado. Diante de uma necessidade urgentíssima seria desejável que se autorizasse o juiz a obrigar o pai do filho ilegítimo, ainda antes que se desse por concluído o processo acerca da paternidade, prévio exame sumário, a pagar os gastos do parto e da alimentação. ${ }^{10}$

Mais que a proteção de um ou de outro possível litigante, com características que o enfraquecem, a ideologia autoritária que confere excessivos poderes ao juiz se espalha por toda a legislação, como dizem seus críticos, dando um poder amplo ao juiz no processo, em detrimento do protagonismo das partes.

Essa “fórmula” foi adotada na Zivilprocessordnung de 1895, projetado por FrANZ KLEIN para a Áustria e no Relatório Chiovenda, de 1920, para a reforma processual italiana. ${ }^{11}$

Contudo, no mundo jurídico neolatino, deve-se a Giuseppe Chiovenda a disseminação na Itália, desde a oportunidade em que apresentou em 1906 a conferência Le reforme processuale e le corrente del pensiero moderno, a reproposição principalmente dos pontos referentes à reforma social do processo e à "desconfiança da classe operária nos juízes burgueses", idéia contida na obra de Anton Menger. ${ }^{12}$

Em oposição haveria um processo civil representado por normas processuais vinculadas a um individualismo no qual o papel do juiz estaria vinculado à provocação das partes, à iniciativa destas, tanto para a definição do objeto do processo, suas delimitações, da prova e as atividades para a sua obtenção e, por fim, a contenção da decisão ao que foi requerido pelas partes, sendo exemplo desse modelo a legislação francesa. ${ }^{13}$

8 Há um exemplar da edição original alemã na Biblioteca do Supremo Tribunal Federal, em Brasília, doada pela família de PONTES de Miranda. Há uma edição argentina, da mesma tradução de Adolfo G. Posada e introdução de Diego Lamas; Buenos Aires: Atalaya, 1947.

9 MENGER, Anton. El Derecho Civily los pobres. Granada: Comares, 1998. p. 134-135.

10 MENGER, Anton. El Derecho Civily los pobres. Granada: Comares, 1998. p. 213. Estão aqui presentes, sem dúvida, os elementos do que hoje conhecemos como de antecipação de tutela dos alimentos ou mesmo dos alimentos gravídicos.

11 Essa denominação é atribuída por Luiz Machado Guimarães a Eduardo Couture, quando descreve a autoridade do juiz segundo a fórmula de Franz KLeIn, no século XIX, e de Giuseppe Chiovenda, no século XX. Ver: COUTURE, Eduardo. Oralidade e regra moral no processo civil. In: PROCESSO Oral: coletânea de estudos de juristas nacionais e estrangeiros. Rio de Janeiro: Forense, 1940. p. 99-110.

12 CHIOVENDA, Giuseppe. Le riforme processuali e le correnti del pensiero moderno. In: Civile. Milano: Giuffré, 1993. p. 379-394. p. 391, onde afirma que o principal problema da justiça civil é a relação entre iniciativa da parte e iniciativa do juiz, chave das reformas processuais para a adaptação do processo às necessidades sociais.

13 KELLY, John M. Storia del pensiero giuridico occidentale. Bologna: Mulino, 1996. p. 388, onde esclarece que "a ideia fundamental dos legisladores franceses era excluir a incerteza e a arbitrariedade na aplicação da lei e com este fim trataram de reduzir o quanto possível a função interpretativa e de criação do direito pelo juiz, em quem não se confiava." 
Desde então se atribui a essa dupla influência a disseminação do processo autoritário no processo civil nas nações continentais europeias e latino-americanas.

b) autoritarismo e liberalismo - Fora do Brasil, como dito, essa disputa entre o binômio aparentemente inconciliável se deu em muitos países, revelando e ocultando as posturas políticas supostamente escondidas sob esse manto.

O que ocorreu na Itália e principalmente o que restou dos debates em torno do CPC italiano é que passou ao futuro como uma disputa para a recuperação da autoridade do juiz, inexistente ou tênue no processo civil que correspondia a esse país, antes da reforma. Giuseppe Chiovenda afirmava que "o conceito renovado da justiça como função do Estado (...) restitui ao juiz no processo moderno uma posição central de órgão público interessado em distribuir justiça da melhor e mais rápida forma possível”. (\$S 47-47 do Relatório). O próprio Piero Calamandrei concordava que o Projeto

propõe introduzir no processo civil aquela restauração de princípio de autoridade, que foi introduzida ou está em vias de introdução em todas as esferas da vida nacional". ${ }^{14}$ Não é de se estranhar, portanto, que esse processo que recupera a autoridade do juiz é em processo autoritário. ${ }^{15}$

Mas essa é apenas uma face. Há outras, certamente.

Nesse sentido, autoritário é o processo que concentra poderes no juiz e o faz o centro do debate; liberalé o processo que atribui às partes essa centralidade e a disposição de atos e de fases processuais.

No Brasil os debates que revelaram as posições dominantes para a elaboração do CPC unitário que viria a público em 1939 expunham mais uma disputa entre forma de realização dos atos: escrita ou oral do que uma oposição entre autoritarismo e liberalismo. É certo, entretanto, que atrás dessa cortina existe sempre o debate sobre a prova e sua realização, que se coliga com o tema da autoridade.

A Exposição de Motivos do CPC de 1939, da redação do intrépido Ministro da Justiça de Getúlio Vargas, Prof. Francisco Campos, era clara em dizer que o processo tradicional serviu de "instrumento de dominação política", pois "formalista e bizantino, tendo sido apenas um instrumento das classes privilegiadas, que tinham lazer e recursos suficientes para acompanhar os jogos e cerimônias da justiça, complicados nas suas regras, artificiosos na sua composição e, sobretudo demorado nos seus desenlaces." ${ }^{\text {"16 }}$ Nos títulos seguintes, o Ministro argumentava ainda o caráter popular do Estado varguista e a restauração de sua autoridade, além do papel de direção a ser exercido pelo juiz no processo, que lhe confere "poderes largos", para "investigar os fatos" e "descobrir a verdade". Tudo isso revelava a "concepção publicística do processo", com inspiração confessada em Giuseppe ChIOvenda. ${ }^{17}$

Luiz Machado Guimarães no ensaio Processo autoritário e regime liberal, republicado em seus Estudos de Direito Processual Civil já apontava para a tendência de ampliação dos poderes do juiz e para o "processo autoritário", como reação ao "absenteísmo característico do Estado liberal”, que gerara o desenvolvimento do processo liberal, com juiz inerte e passivo e por tudo isso um processo inconveniente. Essa tendência, segundo o autor, já ocorria inclusive em estados liberais e, no Brasil, não coincidia exclusivamente com o Estado Novo e seu reconhecido autoritarismo, pois antes mesmo, em 1915, o Código de Processo da Babia (art. 127) já trazia dispositivo similar àquele que depois se consagraria como expressão do processo autoritário, no art. 117 do CPC de $1939 .{ }^{18}$

14 CALAMANDREI, Piero. Premissas políticas do Projeto do Código de Processo Civil italiano. In: PROCESSO oral: coletânea de estudos de juristas nacionais e estrangeiros. Rio de Janeiro: Forense, 1940. p. 201-213. p. 166. Esse trabalho foi apresentado como Parecer ao texto do Projeto Preliminar de CPC (1937).

15 BÖHN, Peter. Processo civile e ideologia nello stato nazisocialista. Rivista Trimestrale de Diritto e Procedura Civile, Milano, ano 58, n. 2, p. 1-35, jun. 2004. Sobre a influência da ideologia nazisocialista no processo civil; sobre a influência de Franz KLEIN, item n. 3 , p. 640; sobre o uso do judiciário como instrumento político e ideológico, item n. 4, p. 641-647.

16 CAMPOS, Francisco. Exposição de Motivos. In: BRASIL. Código de Processo Civil. 3. ed. São Paulo: Saraiva, 1969. p. 1-24. p. 2.

17 CAMPOS, Francisco. Exposição de Motivos. In: BRASIL. Código de Processo Civil. 3. ed. São Paulo: Saraiva, 1969. p. 1-24. p. 5-7.

18 GUIMARÃES, Luiz Machado. Processo autoritário e regime liberal, In: GUIMARÃES, Luiz Machado. Estudos de Direito Proces- 
Mas esses exemplos citados por MACHAdo Guimarães não são os únicos, pois os códigos estaduais de Minas Gerais em 1922 (art. 262) e da Parabyba em 1930 (art. 263) também conferiam os mesmos poderes instrutórios ao juiz, para a apuração da verdade. ${ }^{19}$

E mesmo antes, no Regulamento 737/1850, norma processual comercial do Império do Brasil — 45 anos antes da Zivilprocessordun de 1895, austríaca, de Franz KLEIN — já havia a possibilidade do juiz ordenar diligências independentemente do requerimento das partes, sem que se considerasse esse um processo autoritário.

Art. 230. Se, examinados os autos, o juiz entender necessária, para julgar afinal, alguma diligência, ainda que lhe não tenha sido requerida nas allegações finaes, a poderá ordenar, marcando para isso o prazo conveniente.

Com todos esses precedentes resta muito estranho, no Brasil, associar-se integral e diretamente o processo autoritário aos governos e fases autoritárias. ${ }^{20}$

Depois disso, Moacyr Amaral Santos, em aula proferida na abertura do ano letivo de 1959, sob o título Contra o processo autoritário, dizia que "um processo é do tipo autoritário, e desse tipo será consequentemente o juiz, pela predominância do princípio inquisitivo sobre o dispositivo, da autoridade sobre a liberdade." Contudo, considerava que as várias mudanças havidas entre o anteprojeto e a lei (CPC/1939), "de algum modo desmancharam cientificamente essa feição, que o legislador, politicamente, pretendia aparentar à sua obra." 21 Por fim, em proposta intermediária o autor defende a "concepção publicística do processo", com certas limitações aos poderes do juiz.

No CPC de 1939 destacavam-se os arts. 112 e 117, referentes aos poderes do juiz na instrução:22

Art. 112. O juiz dirigirá o processo por forma que assegure à causa andamento rápido, sem prejuízo da defesa dos interessados."

\section{$[\ldots]$}

Art. 117. A requerimento, ou ex-offcicio, o juiz poderá, em despacho motivado, ordenar as diligências necessárias à instrução do processo e indeferir as inúteis em relação a seu objeto, ou requeridas com propósitos manifestamente protelatórios.

De outra parte, com outro espírito, havia normas inseridas no CPC de 1939 que aparentemente iam em sentido contrário ao propalado autoritarismo, como o art. $4^{\circ}$ :

Art. $4^{\circ}$. O juiz não poderá pronunciar-se sobre o que não constitua objeto do pedido, nem considerar exceções não propostas para as quais seja por lei reclamada a iniciativa da parte.

Em razão dessas contradições é que Frederico Marques considerava que o processo do Código era "sem sistema e sem coerência" e AlfREDO BUZAID via nele "duas almas". ${ }^{23}$

c) publicismo e privatismo - Sob a nova denominação de publicismo e privatismo aparecem uma série de trabalhos, principalmente a partir da década de 1970, na Itália, e de 1980, no Brasil, renovando a afirmação de que o processo civil é o instrumento de natureza pública, informado pelos princípios do Direito

sual Civil. Rio de Janeiro: Jurídica Universitária, 1969. p. 128-136. p. 128-130.

19 Com redação idêntica, esses códigos previam no art. 262 da Lei n. 830, de 7/09/1922 (CPC de Minas Gerais) e no art. 263 do Dec. 28, de 2/12/1930 (CPC da Parahyba) que: “O juizpóde ordenar 'ex officio' as diligencias que julgar necessárias para se apurar a verdade dos factos allegados, depois de realizadas as que forem requeridas pelas partes."

20 GUEDES, Jefferson Carús. O princípio da oralidade: procedimento por audiências no Direito Processual Civil brasileiro. São Paulo: Revista dos Tribunais, 2003. p. 23-25, nas quais são feitas referências ao processo romano-canônico e a concessão de poderes instrutórios ao juiz pela Clementia Saepe, ano 1306 d.C., do Papa Clemente V.

21 Aula proferida na Faculdade de Direito da Universidade de São Paulo (USP). SANTOS, Moacyr Amaral. Contra o processo autoritário, Revista da Faculdade de Direito da Universidade de São Paulo, v. 54, n.2, p. 30-44, 1959. p. 37.

22 Outros dispositivos conferiam poderes instrutórios ao juiz, como o art. 224 (requisição de certidões às repartições públicas); art. 210 (oitiva pelo juiz de testemunha referida).

23 SANTOS, Moacyr Amaral. Contra o processo autoritário. Revista da Faculdade de Direito da Universidade de São Paulo, v. 54, n.2, p. 30-44, 1959. p. 39. 
Público, que limita o princípio dispositivo, de natureza liberal e individualista. ${ }^{24}$ MAuro CAPPELLETTI não vê incompatibilidade entre o princípio dispositivo e o caráter público e indisponível do processo, porquanto seu andamento e o seu resultado também sejam do interesse desse ente; a liberdade das partes quanto ao objeto material do processo não se estende ao processo em si, não podendo as partes determinar como esse instrumento se desenvolverá. ${ }^{25}$

Barbosa Moreira, revisando o binômio aparentemente inconciliável já observou em tom jocoso as inúmeras contradições da hipótese levantada de correspondência entre Estados autoritários e normas processuais inquisitivas ou autoritárias e vice-versa. Em tom mais sério, examina a questão central trazida, da liberdade ou não do juiz em adentrar no campo aparentemente reservado às partes de busca da prova para proferir a sua decisão. E conclui:

quem quer o fim, quer os meios. Se a lei quer que o juiz julgue, não pode deixar de querer que ele julgue, tanto quanto possível, bem informado; logo, não deve impedi-lo de informar-se, pelos meios que tenha à mão. ${ }^{26}$

Confirma sua proposição inicial de que a concessão dos poderes instrutórios não desrespeita garantias das partes.

CÂndido R. Dinamarco, ao descrever a influência no Brasil de Enrico T. LieBMan — chegado em pleno momento de início de vigência do CPC de 1939 — manifesta-se sobre a natureza pública do processo, que marcha em:

direção ao alargamento dos poderes do juiz e do reforço da autoridade deste, notadamente no que diz respeito à antecipação e à efetivação da tutela jurisdicional. ${ }^{27}$

Luiz Guilherme Marinoni, ainda na década de 1990, indicava como essencial a participação efetiva do juiz ativo no processo, característica de um processo democrático, capaz de manter incólume o contraditório, pois inútil a igualdade de oportunidades sem paridade de armas. Contudo sugeria que a atuação instrutória do juiz não se vinculasse à natureza do direito litigado, se disponível ou indisponível, mas ao que se busca, que é a instrução para o exercício do poder estatal de decidir sobre o direito. ${ }^{28}$

LeONARdo GreCo também dedicou-se ao exame das sucessivas modificações nominais do binômio aparentemente inconciliável em seu artigo Publicismo e privatismo no processo civil, descrevendo os contrastes entre juiz inerte e ativo, o modelo processual oral e concentrado, a finalidade do processo equilibrada entre busca da verdade e da justiça, o impulso oficial, boa-fé e a compensação de desigualdades. O autor isola os fenômenos político-institucional e político-processual, quando critica a posição de MontERo Aroca e repropõe a “intervenção assistencial subsidiária do juiz para suprir a dificuldade de uma das partes ou de ambas no exercício da sua defesa, a fim de assegurar em plenitude o seu direito de acesso à justiça e a paridade de armas”, denominando-a como compensação processual. ${ }^{29}$

24 JARDIM, Afrânio Silva. A publicização do processo civil. Rio de Janeiro: Líber Juris, 1982. p. 87-91 e p. 107-109.

25 CAPPELLETTI, Mauro. Publicización, oralidad, socialización. In: __. El processo civil en el Derecho Comparado. Buenos Aires: EJEA, 1973. p. 44-45. O autor associa a publicização do processo à oralidade, também identificada ao uso dos poderes de direção e de controle pelo juiz.

26 MOREIRA, José Carlos Barbosa. Neoprivatismo no processo civil. In:

Temas de direito processual. 9. ed. São Paulo: Saraiva, 2007. p. 87-102. p. 88-95. Em estudo anterior, publicado em 1984, o professor destacava que: "confiar ao juiz papel mais ativo na direção e na instrução do feito, ao contrário do que parecem recear alguns, não implica forçosamente instaurar no processo civil o domínio do 'autoritarismo' ou do 'paternalismo'." (...) “A ampliação dos poderes do órgão judicial não tem como contrapartida necessária o amesquinhamento do papel das partes, nem a eliminação, ou sequer a redução, das garantias a que fazem jus e tampouco da responsabilidade a que fazem jus.” MOREIRA, José Carlos Barbosa. Neoprivatismo no processo civil. In:

Temas de direito processual. 9. ed. São Paulo: Saraiva, 2007. p. 87-102. p. 54.

27 DINAMARCO, Cândido R. Liebman e a cultura processual brasileira. Revista de Processo, São Paulo, n. 119, p. 259-284, 2005. p. 1-2 e p. 5-6. Essa posição depois seria consagrada em outros autores italianos: CAPPELLETTI, Mauro. Publicización, oralidad, socialización. In: ___ El _ Erocesso civil en el Derecho Comparado. Buenos Aires: EJEA, 1973. p. 43-79. No mesmo sentido: CABRAL, Antônio do Passo. O processo como superego social: um estudo sobre os fins sociais da jurisdição. Revista de Processo, São Paulo, n. 115, p. 345-389, 2004. p. 345.

28 MARINONI, Luiz Guilherme. Novas linhas do processo civil: o acesso à Justiça e os institutos fundamentais do Direito Processual. São Paulo: Revista dos Tribunais, 1993. p. 71-74.

29 GRECO, Leonardo. Publicismo e privatismo no processo civil. Revista de Processo, São Paulo, n. 164, p. 29-56, 2008. 
Em conclusão reafirma nossa tradição liberal e a luta que por ele devemos manter, mas visando um novo ideal ajustado ao Estado Democrático de Direito:

que não apenas respeita o livre arbítrio dos cidadãos na tomada de decisões relativas à sua esfera privada, mas que, no momento em que estes recorrem ao Estado para a tutela dos seus direitos, este, através dos juízes, controla vigilantemente se aqueles estão em condições de se autotutelarem e, em caso negativo, supre moderada e parcimoniosamente as suas insuficiências para, sem comprometer a sua imparcialidade, assegurar-lhes o acesso efetivo ao gozo dos seus direitos, tendo em vista que as posições de dominação que prevalecem na sociedade precisam ser neutralizadas, sob pena de entregarem os mais fracos ao jugo incontrastável dos mais fortes, em total desrespeito às promessas de construção de uma sociedade erigida sob a égide da dignidade humana e do pleno respeito aos direitos fundamentais. ${ }^{30}$

Por todos se vê que as mudanças de denominação correspondem a determinados períodos principalmente no século XX, para indicar um fenômeno provavelmente único e comum a todos eles, qual seja, a disputa entre duas posições políticas e ideológicas, identificada cada uma com a menor ou maior presença e força do Estado e de seus agentes (juízes) no exercício da atividade jurisdicional.

d) ativismo (judicial) e garantismo (processual) - pode-se dizer que a retomada dessa discussão surge outra vez entre Espanha e Itália e daí se projeta para a América Latina, onde tem tido repercussão no Brasil, Argentina, Peru, Colômbia, Chile e outros países.

A nova roupagem da discussão foi notada recentemente por Barbosa Moreira, LeOnARdo Greco e pelo próprio Juan Montero Aroca, quando afirma que "estamos sempre voltando sobre o mesmo [tema], sobre o papel do Estado na sociedade e sobre o [papel] do juiz no processo". ${ }^{31}$

Glauco Gumerato Ramos tem sido, dentre nós, o autor que melhor tem destacado essa nova roupagem do debate crítico sobre a posição do juiz como figura central do processo, sobre a tendência de publicização do processo e a mitigação do princípio dispositivo. Seu texto original, Ativismo e garantismo no processo civil: apresentação do debate, ${ }^{32}$ depois de traçar um relato do ressurgimento da polêmica, aponta para as linhas centrais da postura ativista. Posicionaram-se ao lado de Montero Aroca os processualistas italianos Franco Cipriani e Girolamo Monteleone, autores de parte dos textos publicados na obra coletiva editada na Espanha e na própria Itália. ${ }^{33}$ Esse ressurgimento da disputa se ampara muito nas discussões feitas por FRANCO CiPRIANi, a partir do ano de 1991-1992, nas quais afirmava o caráter autoritário do CPC italiano de 1942 e a partir da criação em 2006 da revista Il Giusto Processo Civile, dedicada ao debate dos temas do garantismo processual civil. ${ }^{34}$

A crítica à publicização do processo se encontra nos textos mais recentes de JuAn MONTERo ArocA, mas também em sua obra publicada logo após a edição da Nueva LEC espanhola, em $1999 .{ }^{35} \mathrm{O}$ ativismo proces-

30 GRECO, Leonardo. Publicismo e privatismo no processo civil. Revista de Processo, São Paulo, n. 164, p. 29-56, 2008. Conclusão. A proposta de assistência do juiz à parte mais frágil se encontra também em: CALAMANDREI, Piero. Instituciones de Derecho Procesal Civil: según el nuevo Código. Buenos Aires: Depalma, 1943. p. 342-345. DENTI, Vittorio. Il processo come strumento di politica sociale: processo civile e giustizia sociale. Milano: Comunità, 1971. p. 53-55.

31 MONTERO AROCA, Juan. El proceso civil llamado "social” como instrumento de "justicia" autoritaria. In: civil e ideologia: un prefacio, una sentencia, dos cartas y quince ensayos. Valencia: Tirant lo Blanch, 2006. p. 130-166. p. 164.

32 RAMOS, Glauco Gumerato. Ativismo e garantismo no processo civil: apresentação de debate. Revista Brasileira de Direito Processual, Belo Horizonte, n. 70, p. 83-102, 2010. p. 83-102.

33 CIPRIANI, Franco. El proceso civil italiano entre revisionistas e negacionistas. In: MONTERO AROCA. Juan. Proceso civil e ideología: un prefacio, una sentencia, dos cartas y quince ensayos. Valencia: Tirant lo Blanch, 2006. p. 81-96. CIPRIANI, Franco. El proceso civil entre viejas ideologías y nuevos eslóganes. In: MONTERO AROCA. Juan. Proceso civil e ideología: un prefacio, una sentencia, dos cartas y quince ensayos. Valencia: Tirant lo Blanch, 2006. p. 37-42. MONTELEONE, Girolamo. Principios y ideologías del proceso civil: impresiones de un 'revisionista. In: MONTERO AROCA. Juan. Proceso civil e ideología: un prefacio, una sentencia, dos cartas y quince ensayos. Valencia: Tirant lo Blanch, 2006. p. 97-108. MONTELEONE, Girolamo. El actual debate sobre las 'orientaciones publicísticas' del proceso civil. In: MONTERO AROCA, Juan. Proceso civil e ideología: un prefacio, una sentencia, dos cartas y quince ensayos. Valencia: Tirant lo Blanch, 2006.. p. 97-108.

34 PISANI, Andrea Proto. Pubblico e privato nel processo civile. Revista de Processo, São Paulo, n. 207, p. 281-302, 2012. p. $295-301$. 35 MONTERO AROCA, Juan. El Derecho Procesal en el siglo XX. Valencia: Tirant lo Blanch, 2000. p. 71. Essa obra editada em 2000 traça um panorama crítico do processo civil europeu, influenciado por FrANZ KLEIN, que segue a tendência de publicização, 
sual é, para essa corrente, esse conjunto todo de fenômenos que vão se conformando a partir do final do século XIX e início do século XX, sintetizados pela ampliação dos poderes instrutórios do juiz. De outro lado, o garantismo seria o inverso, caracterizado pela posição moderada do juiz, com seus poderes limitados na atividade probatória e no impulso processual, com a revalorização do princípio dispositivo.

Outro é, por certo, o ativismo constitucional, como bem destacou o próprio prof. Glauco Gumerato Ramos em debate no UniCEUB (Centro Universitário de Brasília) em reunião de nosso Grupo de Pesquisa $=$ ISO Justiça Processual e Desigualdade..$^{36}$ Esse outro ativismo dos Tribunais Constitucionais vem sendo definido pela doutrina e pelos próprios tribunais, mas ainda pende de completa delimitação. ${ }^{37}$

Em todas essas variações de denominações o que se nota é uma discussão entre duas formas aproximadas de ver o processo, que se isolam uma da outra por motivos político-processuais como: a) a vedação ou autorização ao juiz decidir além das alegações das partes; b) vedação ou autorização para o juiz determinar de ofício a realização de provas; c) vedação ou autorização a impulsionar o processo.

\subsection{O debate menos importante: II Codice de Processo Civile Italiano de 1940}

Debater sobre o texto do CPC italiano de 1940 é valioso, mas estranho a alguns dos nossos processualistas, muitas vezes desatentos até mesmo às normas processuais vigentes na década de 1950/1960/1970, no Brasil.

Muito se escreveu sobre esse assunto e há variadas posições sobre essa lei italiana, com o propósito de contornar aquilo que não se lhe pode retirar, ou seja, o fato de ter sido editada por fascistas em pleno ano de 1940. Seu nascimento sob o patrocínio de um governo que é hoje execrado por todos (ou quase todos) permite que se lhe oponham ressalvas. ${ }^{38}$

Quem se posiciona neste sentido Franco Cipriani, opinião confirmada por Juan montero Aroca, Girolamo Monteleone e Alvarado Velloso, mas que encontra concordância total ou parcial em outros doutrinadores. $^{39}$

De outro lado, respeitados doutrinadores já argumentaram que a referida lei não é exatamente autoritária porque editada por um Estado fascista.

Giovanni Verde sugere que se trata

de ver se há disposições do código que seguem uma linha de características autoritárias e se estas disposições são de tal importância que permitem qualificar o código como autoritário.

com função social, como fenômeno de massas, com a ampliação dos poderes do juiz e mitigação do princípio dispositivo. PICÓ I JUNOY, Joan. El derecho procesal entre el garantismo y la eficacia: un debate mal planteado, Revista de Processo, n. 197, p. 193-210, jun. 2011. Considera como sinônimas as expressões ‘publicização' e ‘socialização do processo' que possui como virtude a ampliação dos poderes do juiz.

36 Nessa oportunidade o professor afirmou que o ativismo pode ser vislumbrado numa dupla perspectiva: a) aquela praticada pelo STF, sob inspiração da Suprema Corte Americana (Common Law), na qual o juiz pode criar o direito, sendo assim no Brasil, na qual o juiz interpreta a lei estabelecida pelo Legislador e b) praticado pelas instâncias inferiores, posição criticada pelo professor, na qual a figura do juiz é excessivamente valorizada e onde se exacerba o seu poder, interferindo na matéria que deveria ser das partes e influenciando a decisão. (Reunião de 14/09/2011 do Grupo de Pesquisa =ISO Justiça Processual e Desigualdade, UniCEUB, Brasília-DF). 37 Sobre o conceito de ativismo constitucional ver: BRANCO, Paulo Gustavo Gonet. Em busca de um conceito fugidio: o ativismo judicial. In: FELLET, André; GIOTTI, Daniel de Paula; NOVELINO, Marcelo (Org.). As novas faces do ativismo judicial. Salvador: Juspodivm, 2011. p. 387-401. A obra coletiva reúne mais de 20 textos sobre o tema.

38 A primeira edição do ano 1941 da Rivista di Diritto Processuale Civile, v. 18, Parte I, traz uma série de artigos que apontam progressos e elogiam o CPC italiano de 1940, tendo como autores, entre outros: CARNELUTTI, Francesco. Carattere del nuovo Codice di Procedura Civile; REDENTI, Enrico. L'umanità nel nuovo processo civile; CONFORTI, Leopoldo. Codice rivoluzionario; D'AMELIO, Mariano. Le tendenze sociali del nuovo Codice di Procedura Civile.

39 RICCI, Gian Franco. Il processo civile fra ideologie e quotidianità. Rivista Trimestrale di Diritto e Procedura Civile, Milano, ano 59, p. $77-103$, mar. 2005. p. 86. concordando parcialmente. 
E acrescenta que esse código autoritário e fascista tornou possível a formação de uma jurisprudência respeitosa em relação ao princípio da congruência entre pedido e sentença, não sendo diferente daquela ideologia liberal pretendida por Montero Aroca. ${ }^{40}$

Michelle TARufFo, autor de uma das mais consagradas obras sobre a história do processo civil italiano medieval, moderno e contemporâneo, ao tratar do CPC de 1940 sintetiza quanto à matriz ideológica do código que: "com toda probabilidade, na verdade, o Relatório Grandi foi considerado como fascista, mas não o código.” E mais, finaliza dizendo que se se tem em conta tudo o que foi dito, então é lícito afirmar que aparte as tentativas de "fascistizar" o código completo em qualquer parte do Relatório Grandi - isso não pode ser considerado o fruto da ideologia fascista nem de modo geral, nem nas suas disposições individuais. É verdade, em substância, que as conexões entre o código e o fascismo são principalmente cronológicas [...]" ${ }^{41}$

Barbosa Moreira, de outra parte, observa que o CPC italiano de 1940 tem sido alvo de críticas por ser produto do fascismo, embora a melhor razão esteja com os que divergem dessa posição, citando com exemplo Michele TARuffo, que afirmava ser a Relazione del Ministro Grandi uma "cláusula de estilo acrescentada pela exigência política contingente." ${ }^{42}$

Mas a fogueira segue acesa, pois recentemente Andrea Proto PisAni a ela voltou-se para dizer que

a polêmica sobre se o código de 1940 era ou não fascista, era ou não autoritário seria progressivamente atenuada e os processualistas civis, recuperada a sua tranqüilidade, teriam podido voltar ainda dedicar-se ao estudo do processo acentuando o componente publicista. ${ }^{43}$

De um ponto de vista mais amplo, Alessandro Somma, com base em extensa bibliografia, relativiza a influência do fascismo sobre o direito, restringindo-a a aspectos principalmente formais. E acrescenta

à luz do que aqui se observou não me parece que o Código Civil italiano [1942] — como o recurso formal dos modelos mutuais da história — possa ser considerado fascista ou antifascista. ${ }^{44}$

Entretanto, deve-se destacar o mais detalhado exame que se dispõe sobre a Relazione Grandi, feito pelo processualista colombiano JAIRO PARRA QuJjANO, na obra Racionalidad e ideología en las pruebas de oficio, na qual assegura, em síntese, que:

Mediante a leitura cuidadosa do Relatório deixamos claro que, ao contrário do sustentado pelo então ministro da Justiça em seu Relatório, não é possível identificar fisionomia alguma da ideologia fascista no Codice di Procedura Civile de 1940, máxime se se leva em consideração que o fascismo não realizou, nem poderia ter realizado contribuição ideológica qualquer ao direito processual (...), pois seu discurso foi simples retórica. ${ }^{45}$

Essa posição se alinha com a postura ideológica adotada na obra, que considera necessária a concessão de poderes ao juiz como forma de permitir que ele "conheça a verdade", essencial para decidir de forma justa.

40 VERDE, Giovanni. Las ideologías Del proceso en un reciente ensayo, In: MONTERO AROCA, Juan. Proceso civil e ideología: un prefacio, una sentencia, dos cartas y quince ensayos. Valencia: Tirant lo Blanch, 2006. p. 67-80. p. 72-74.

41 TARUFFO, Michele. La giustiz̧ia civile in Italia dal '700 a oggi. Bologna: Mulino, 1980. p. 286. Essa é também a posição firme de: ALCALÁ-ZAMORA Y CASTILLO, Niceto. Liberalismo y autoritarismo en el proceso. In: ___. Estudios de Teoría General e Historia del Proceso. Ciudad de México: UNAM, 1974. v. 2. p. 245-289. p. 260, ao afirmar que o código "não tem nada de fascista, se se excetuam algumas tão explosivas como circunstanciais frases de sua exposição de motivos."

42 MOREIRA, José Carlos Barbosa. Neoprivatismo no processo civil. In: Temas de direito processual. 9. ed. São Paulo: Saraiva, 2007. p. 87-102. p. 89.

43 PISANI, Andrea Proto. Pubblico e privato nel processo civile. Revista de Processo, São Paulo, n. 207, p. 281-302, 2012. p. 292. O texto corresponde à palestra proferida em Cagliari, em julho de 2011, em homenagem a Franco Cipriani. De outra parte, considerando relativa e inútil a discussão, ver: RICCI, Gian Franco. Il processo civile fra ideologie e quotidianità. Rivista Trimestrale di Diritto e Procedura Civile, ano 59, n. 6, p. 87. 2005.

44 SOMMA, Alessandro. Fascismo e diritto. Rivista Trimestrale di Diritto e Procedura Civile, Milano, ano 55, n. 3, p. 597-663, set. 2001. p. 643.

45 PARRA QUIJANO, Jairo. Racionalidad e ideología en las pruebas de oficio. Bogotá: Themis, 2001. p. 55. Ao fim da obra há o texto integral da Relazione Grandi, traduzida para o espanhol. 
Luiz Machado Guimarães, em 1940, tratando do CPC brasileiro, antes mesmo da leitura na Itália do Relatório Grandi, elogiava a corajosa adoção brasileira do processo inquisitório, "cedendo ao juiz, amplos poderes de iniciativa não só na direção do processo, como também na respectiva instrução."

A pergunta que pode ser feita é: a norma processual italiana de 1940 é autoritária por que confere poderes excessivos ao juiz ou por que foi feita pelos fascistas? Provavelmente pelas duas razões ou ainda por outras. Ou não! Provavelmente não era apenas isso: uma norma feita pelos fascistas, que conferia poderes excessivos ao juiz. Por certo, também, a mesma regra processual pode ter aplicação democrática e antidemocrática, conforme o período e os componentes ideológicos ou históricos de sua aplicação. Essa última hipótese torna ainda menos importante esse debate, em vista de sua relatividade.

\section{O DEBATE ESTRANGEIRO E BRASILEIRO ATUAL: TALVEZ O MAIS IMPORTANTE}

Em atenção à História das leis ou História do Processo Civil, deve-se dizer que a visão sobre o direito e o processo só pode existir a partir de um olhar mais amplo, mais amplo, que considere suas razões gerais, sejam políticas ou não. Explico: nem todos os atos da Colônia eram coloniais e assim por diante, no Império, na Monarquia e na República.

Para situar o Brasil, olhemos inicialmente os nossos dois CPCs e o terceiro que assim quer ser chamado e que está em fase final de redação legislativa: o CPC de 1939, o CPC de 1973 e o CPC Novo, de 2013 ou 2014, como o chamaremos. Os dois primeiros correspondem a dois graves períodos de exceção democrática, editados o primeiro na Ditadura de Vargas (1930-1945) e o segundo em plena Ditadura Militar (1964-1985), ao contrário do terceiro que se aproxima e nascerá em um momento de vigor ou de revigoramento democrático. Por curiosidade, muitos dizem tratar-se, este último, de um "belo monumento ao processo autoritário", sem que se diga o mesmo dos anteriores.

O centro desse debate, referente aos poderes instrutórios do juiz e ao controle formal do processo, à altura da entrada em vigência do CPC de 1973 (1\%/1/1974) já se encontrava estabilizada na legislação processual brasileira, pois até mesmo alguns CPCs Estaduais ${ }^{47}$ haviam previsto o instituto, como o CPC de $1939^{48}$ e o CPC de $1973,{ }^{49}$ assim como vem reafirmado no Projeto do Novo CPC. ${ }^{50} \mathrm{Na}$ doutrina se destaca desde alguns anos os trabalhos de João Batista Lopes e de José Roberto dos Santos Bedaque, sintetizando a posição dominante sobre o tema, ${ }^{51}$ mas não pacífica. ${ }^{52}$

46 GUIMARÃES, Luiz Machado. Processo autoritário e regime liberal, In: GUIMARÃES, Luiz Machado. Estudos de Direito Processual Civil. Rio de Janeiro: Jurídica Universitária, 1969. p. 128-136. p. 131-132.

47 São lembrados pelo próprio Luiz Machado GuIMARÃes, como exemplos de Códigos Estaduais que previram os poderes instrutórios do juiz, o Código do Processo Civil, Commercial, Penal e Orphanologico do Estado da Babia (Lei n. 1.121, de 21.08.1915) e o Código do Processo Civil e Commercial do Estado do São Paulo (Lei n. 2.421, de 14.01.1930). Mas pode-se identificar outros dois casos além dos citados acima: o Código do Processo Civil do Estado de Minas Gerais (Lei n. 830, de 07.09.1922), e o Código do Processo Civil e Commercial do Estado da Parabyba (Dec. n. 28, de 02.12.1930).

48 “Art. 117. A requerimento, ou ex-officio, o juiz poderá, em despacho motivado, ordenar as diligências necessárias à instrução do processo e indeferir as inúteis em relação a seu objeto, ou requeridas com propósitos manifestamente protelatórios."

49 "Art. 130. Caberá ao juiz, de ofício ou a requerimento da parte, determinar as provas necessárias à instrução do processo, indeferindo as diligências inúteis ou meramente protelatórias."

50 "Art. 354. Caberá ao juiz, de ofício ou a requerimento da parte, determinar as provas necessárias ao julgamento da lide. Parágrafo único. O juiz indeferirá, em decisão fundamentada, as diligências inúteis ou meramente protelatórias. (Anteprojeto, art. 258; PL 166/2010 do Senado, art. 354).

51 LOPES, João Batista. Os poderes do juiz no aprimoramento da prestação jurisdicional. Revista de Processo, São Paulo, n. 35, p. 24-67, 1984. BEDAQUE. José Roberto dos Santos. Poderes instrutórios do juiz. 3. ed. São Paulo: Revista dos Tribunais, 2001. p. 74157. (especialmente itens 3-3.8). Ver textos precedentes a esses que são ilustrativos: no Brasil, NAVES, Candido. Impulso, processual e poderes do juiæ. Belo Horizonte: Santa Maria, 1949. p. 53-57; na Itália, CAPPELLETTI, Mauro. Publicización, oralidad, socialización. In: _. El processo civil en el Derecho Comparado. Buenos Aires: EJEA, 1973. p. 60-62.

52 CÂMARA, Alexandre Freitas. Poderes instrutórios do juiz e processo civil democrático. Revista de Processo, São Paulo, n. 153, p. 1-11 (eletrônica), 2007. observa que a “a doutrina brasileira não é pacífica a respeito do alcance deste poder do juiz”, item n. 2 , p. 2. 
Alexandre Freitas Câmara, ao tratar dos Poderes instrutórios do juiz e processo civil democrático, após um extenso reexame das posições políticas dos grupos que se opõem, alguns considerando-se democráticos e outros autoritários o processo, assegura a legitimidade democrática do art. 130 do CPC atual, no qual "impõe-se o reconhecimento de amplos poderes de iniciativa probatória ao juiz, permitindo-se que este agente estatal cumpra sua missão constitucional: fazer justiça." 53

Outro exemplo, anterior ao CPC de 1973, é a Lei n. 5.478/1968, Lei de Alimentos, que prevê, por exemplo, no art. 19 que:

o juiz, para instrução da causa ou na execução da sentença ou do acordo, poderá tomar todas as providências necessárias para seu esclarecimento ou para o cumprimento do julgado ou do acordo, inclusive a decretação de prisão do devedor até 60 (sessenta) dias. ${ }^{54}$

O Projeto do Novo CPC, depois da apresentação do Anteprojeto (2009), da tramitação no Senado Federal (PL 166/2010), que a esta altura está na Câmara de Deputados (Projeto de Lei n. $\left.{ }^{\circ} 8.046 / 2010\right)$, possui outros tantos exemplos de força que também poderiam ser considerados autoritários, tal como o art. $118^{55}$ e, especialmente, o inc. III, que autoriza ao juiz: "determinar todas as medidas indutivas, coercitivas, mandamentais ou sub-rogatórias necessárias para assegurar o cumprimento de ordem judicial, inclusive nas ações que tenham por objeto prestação pecuniária”.

Mas devemos observar que o processo civil brasileiro não vem sendo regulado exclusivamente no CPC, mas também recebe a normatização de inúmeras leis especiais ou esparsas. Nessas normas especiais, que regulam, por exemplo, mais da metade dos processos da União e de seus entes, na Justiça Federal, tramitam pelo procedimento dos Juizados Especiais Federais (JEF), com uma grande variedade de regras compensatórias.

Mas há outros exemplos nos quase 100 (cem) procedimentos especiais existentes nessas leis esparsas, no CPC de 1973 e até no CPC 1939, ainda parcialmente vigente. Isto é uma parte do Direito Processual de Grupos Sociais atual. Embora velho nas suas concepções, ele é novo e variável quanto aos grupos de destinatários, quanto às matérias e mesmo quanto aos seus fundamentos ideológicos.

É insuficiente hoje tratar-se de Direito Processual de Grupos Sociais pensando apenas em regras compensatórias para os pobres, como pensavam os socialistas do final do século XIX e até a metade do século XX. As desigualdades encontradas atualmente nas sociedades se pulverizam em inúmeras formas, como será exposto a seguir no item n. 4.2 deste texto.

Nele virão listadas as: a) Desigualdades sociais (individuais e de grupos); b) Desigualdades econômicas; c) Desigualdades educacionais ou instrucionais gerais; d) Desigualdades técnicas-jurídicas e gerais; e) Desigualdades culturais (étnicas, linguísticas etc.); f) Desigualdades político-institucionais (Estado e seus órgãos) e as desigualdades político-ideológicas de grupo (Partidos Políticos, Associações, Organizações Sociais e Sindicatos).

53 CÂMARA, Alexandre Freitas. Poderes instrutórios do juiz e processo civil democrático. Revista de Processo, São Paulo, n. 153, p. 1-11 (eletrônica), 2007. p. 5-8.

54 Poucos dirão tratar-se de uma lei autoritária, embora tenha sido publicada em plena fase crítica da Ditadura Militar, em vista da natureza dos direitos em disputa na ação de alimentos e o possível desequilíbrio entre as partes, a justificar esta e outras tantas diferenciações procedimentais ali previstas.

55 "Art. 118. O juiz dirigirá o processo conforme as disposições deste Código, incumbindo-lhe: I - promover o andamento célere da causa; II - prevenir ou reprimir qualquer ato contrário à dignidade da justiça e indeferir postulações impertinentes ou meramente protelatórias, aplicando de ofício as medidas e as sanções previstas em lei; III - determinar todas as medidas indutivas, coercitivas, mandamentais ou sub-rogatórias necessárias para assegurar o cumprimento de ordem judicial, inclusive nas ações que tenham por objeto prestação pecuniária; IV - tentar, prioritariamente e a qualquer tempo, compor amigavelmente as partes, preferencialmente com auxílio de conciliadores e mediadores judiciais; V - dilatar os prazos processuais e alterar a ordem de produção dos meios de prova adequando-os às necessidades do conflito, de modo a conferir maior efetividade à tutela do bem jurídico; VI - determinar o pagamento ou o depósito da multa cominada liminarmente, desde o dia em que se configure o descumprimento de ordem judicial; VII - exercer o poder de polícia, requisitando, quando necessário, força policial, além da segurança interna dos fóruns e tribunais; VIII - determinar, a qualquer tempo, o comparecimento pessoal das partes, para ouvi-las sobre os fatos da causa, caso em que não incidirá a pena de confesso; IX - determinar o suprimento de pressupostos processuais e o saneamento de outras nulidades processuais." (Anteprojeto, art. 107; PL 166 do Senado, art. 118). 
Parte dessas desigualações criam desníveis que recebem ou mereceriam receber tratamento processual diferenciado, sem que, em todas elas, se encontre uma diferença de riqueza ou de capacidade financeira, um desequilíbrio de corte exclusivamente econômico.

Em outro trabalho, mas recente, escrito em coautoria com Eliana Pires Rocha, intitulado Derechos Fundamentales y Proceso Civil en el Brasil: algunas técnicas procesales compensatorias de desigualdades sociales y la protección judicial de los derechos fundamentales — publicado no Anuario de Derechos Humanos, n. 11, da Universidad Complutense de Madrid $^{56}$ — foi apontada uma série de grupos sociais que merecem proteção processual ou tratamento processual diferenciado, em razão das suas diversas características:

São técnicas previstas no Código de Processo Civil ou em leis especiais brasileiras, que se destinam ao reequilíbrio da desigualdade social:

a) Criancas e adolescentes - Ademais das prerrogativas contidas no Código de Processo Civil, as crianças e os adolescentes possuem, em sua defesa, as normas do Estatuto da Criança e do Adolescente (ECA), Lei n. 8.069/1990. Entre os benefícios processuais constam regras especiais, como a gratuidade de justiça e a assistência jurídica, a dispensa de pagamento de despesas recursais (preparo), a intimação direta e pessoal do advogado e dos responsáveis nas comunicações, a simplificação e a celeridade, a preferência no julgamento de recursos aos tribunais, recursos com efeito apenas devolutivo, bem como a legitimação do Ministério Público, tanto para propor ações, como para interpor recursos. O Estatuto estabeleceu, pioneiramente, a concessão de tutelas de urgência como formas de proteção desse grupo especial e diferenciado de pessoas, que, em vista de sua fragilidade, não se submete às regras gerais.

b) Idosos - Os idosos também integram grupo distinto, sendo parte processual contemplada com uma desigualdade de tratamento por compensação, de acordo com o Estatuto do Idoso (EI), Lei n. 10.741/2003, no qual consta título próprio sobre o acesso à Justiça. A compensação é garantia mediante a observância do procedimento sumário às suas causas, a criação de varas especializadas em idosos e prioridade na tramitação de processos e nas diligências processuais. A tramitação prioritária dos processos de idosos já fora prevista no Código de Processo Civil desde 2001, quando a doutrina apresentou clara defesa em seu favor, ao argumentar que: "[...] é de absoluta legitimidade constitucional a lei que manda dar prioridade, nos juízos inferiores e nos tribunais, às causas de interesse de pessoas com idade igual ou superior a sessenta-e-cinco anos (Lei n. 10.173/2003); toma-se em consideração que as partes idosas têm menor expectativa de sobrevida e, na maioria dos casos, mais necessitam da tutela jurisdicional." Desde 2003, o Estatuto do Idoso considera como tal os maiores de 60 anos, criando uma duplicidade de normas, uma prevendo 60 anos e outra 65 anos. A ambigüidade foi resolvida recentemente, mediante alterações promovidas no CPC, que previu, de modo uniforme ao Estatuto do Idoso, a prioridade processual aos maiores de 60 anos. O benefício, aplicado em todos os graus de jurisdição, permite a aceleração processual, em vista da notória expectativa de vida menor que os beneficiários possuem. As regras relativas ao processo coletivo permitem que várias entidades estatais, para-estatais e privadas representem os idosos em juízo, as quais poderão contar com medida concessivas de tutelas de urgência e específica (ordens para fazer ou não-fazer), sem a antecipação de despesas processuais.

c) Portadores de deficiência física on mental e de doenças graves- A prioridade na tramitação de processos administrativos, prevista originalmente para maiores de 65 anos, mais tarde reduzida a idade para 60 anos, beneficia também, desde meados de 2009, as pessoas portadoras de deficiência física e mental e os portadores de doenças consideradas graves. Nos processos judiciais, o benefício se estende somente aos portadores de doenças graves, pois, o art. 1211-A, desde a Lei n. 12.008/2009, que altera o CPC, prevê que: Os procedimentos judiciais em que figure como parte ou interessado pessoa com idade igual ou superior a 60 (sessenta) anos, ou portadora de doença grave, terão prioridade de tramitação em todas as instâncias. Também há regras especiais para o processo coletivo que envolva interesse desigual na relação processual.

d) Acidentados em trabalho - Por meio da ação acidentária, prevista na Lei n. 6.376/1976, os feridos em acidentes de trabalho têm em seu favor uma série de distinções processuais, tais como: a modificação da competência do juízo para o local do fato, a competência da justiça estadual, ainda que o réu seja autarquia federal (Instituto Nacional de Seguro Social), a presença do Ministério Público como fiscal

56 ROCHA, Eliana Pires; GUEDES, Jefferson Carús. Derechos Fundamentales y Proceso Civil en el Brasil: algunas técnicas procesales compensatorias de desigualdades sociales y la protección judicial de los derechos fundamentales. Anuario de Derechos Humanos, Madrid, v. 11, 2010. p. 478-484. 
da lei, a concessão de jus postulandi à parte ou ao representante não-advogado (dispensa do advogado), o princípio da verdade real, que dá ao juiz maiores poderes, a mitigação do princípio dispositivo e do princípio da demanda, a celeridade e a simplificação pela adoção do procedimento sumário, a gratuidade de justiça, a valorização da conciliação e a transigibilidade dos interesses. São vantagens que garantem proteção à parte considerada mais fraca da relação processual.

e) Consumidores - Os consumidores de bens e serviços, públicos ou privados, podem ir a juízo, utilizando todos os meios e espécies de ações (art. 83 do CDC). O Código de Defesa do Consumidor (CDC), Lei n. 8.078/1990, prevê regras processuais especiais e estabelece princípios que autorizam a sua conformação autônoma. Essa conformação se dá, em sua maior parte, por meio das ações coletivas, que estão cercadas por peculiaridades que esse sistema possui. Mas tais ações não excluem o processo individual de consumo, que preserva singularidades, embora seja regido pelas normas gerais de processo (CPC) e por leis extravagantes. Dentre alguns benefícios processuais está a inversão do ônus da prova.

f) Beneficiários da previdência e assistência social - Os assistidos pela Previdência Social têm a seu favor, no plano processual, a Lei dos Juizados Especiais Federais (Lei n. 10.259/2001), que, combinada com a Lei dos Juizados Especiais Cíveis e Criminais (Lei n. 9.099/1995), oferece vantagens em relação aos juízos comuns. Esse novo modelo judicial se baseia na ampliação do acesso à Justiça por meio de um modelo consensual, econômico e simplificado, oral e concentrado, informal e célere. Caracteriza-se também pela ampliação dos poderes do juiz (art. $4^{\circ}$ ), isonomia total entre Administração e administrado, com redução de prerrogativas da Fazenda Pública, possibilidade de transação de Direito Público, fim da apelação ex officio e recorribilidade somente quanto ao direito material. Nesses juizados, os pedidos não podem ultrapassar 60 salários mínimos (17 mil US\$) e o pagamento das condenações é feito pelo Tesouro, mediante requisição e não pelo sistema vinculado ao orçamento do ano seguinte (precatório).

g) Agricultores e camponeses - Em alguns poucos casos, os camponeses contam com regras especiais para a aquisição da propriedade. Ela pode se dar por meio do usucapião especial agrário (Lei n. 6.969/1981), da ação discriminatória de terras públicas (Lei n. 6.383/1976) e das imissões possessórias agrárias. São tipicamente agrárias as demandas de cumprimento, de despejo, de consignação, de rescisão e de indenização em contratos agrários, de preferência, de divisão, demarcação e extinção de condomínio agrário, usucapião especial e nunciação de obras rurais, além da desapropriação para fins de reforma agrária. No processo agrário adotam-se, sem exceção, os princípios constitucionais processuais, tais como contraditório, ampla defesa, duplo grau, isonomia, publicidade etc.; os princípios gerais do processo, como princípio dispositivo e da demanda, lealdade processual e boa-fé, e, também, princípios especiais ou próprios, dentre os quais podem ser arrolados os princípios da simplificação e da oralidade, com identidade física e concentração de atos, o princípio da gratuidade de justiça, o princípio da indisponibilidade das regras e da fixação da competência segundo o local dos bens litigados.

h) Beneficiários do meio ambiente sadio - Este grupo, titular de direito difusos, que, às vezes, congrega toda a sociedade, tem a seu dispor meios eficientes de atuação, principalmente a ação civil pública (Lei n. 7.347/1985) e a ação popular (Lei n. 4.717/1965). Estas não são vistas como típicas ações, mas como técnicas que ensejam procedimentos, métodos de cognição e provimentos diferenciados para a obtenção da tutela do meio ambiente, para o que se aplica subsidiariamente os dispositivos do Código de Processo Civil. As regras do "processo civil ambiental” se ampliam cada vez mais, de forma a privilegiar a preservação do meio ambiente. Mais notável, contudo, são as prerrogativas do processo coletivo e a possibilidade de concessão de tutela preventiva dos ilícitos ambientais.

h) Mulher 'casada'- O gênero feminino é contemplado com o foro privilegiado em ações de divórcio e de alimentos. Essas leis processuais brasileiras (CPC, Lei do Divórcio e Lei de Alimentos) existiam antes da Constituição de 1988 e persistem como normas conformes à Carta. Nessas hipóteses, há o deslocamento de competência como forma de compensação por desigualdades, permitindo que a mulher ajuíze a ação de seu interesse no local que lhe é mais favorável. (Ver no STF o RE 227.114/SP)

Esses são sujeitos processuais que podem em maior ou menor escala necessitar ou depender da atividade instrutória do juiz, da elasticidade de seus poderes na busca da prova. São pessoas e as pessoas é que merecem tutela, não apenas os direitos. ${ }^{57}$

57 CABRAL, Antônio do Passo. O processo como superego social: um estudo sobre os fins sociais da jurisdição. Revista de Processo, São Paulo, n. 115, p. 345-389, 2004. p. 347, referindo CÂNDIDO R. DinAMARCO. 
Atenta à realidade dos nossos dias, tratando de iniciativa probatória do juiz, a profa. AdA PeLLEgRINI Grinover destaca que: “a visão do Estado social não admite a posição passiva e conformista do juiz, pautada por princípios especialmente individualistas. O processo não é um jogo, em que pode vencer o mais poderoso ou o mais astucioso, mas um instrumento de justiça, pelo qual se pretende encontrar o verdadeiro titular do direito. A pacificação social almejada pela jurisdição sofre sério risco quando o juiz permanece inerte, aguardando passivamente a iniciativa instrutória da parte." 58

\subsection{O que se pode denominar como ativismo (processual civil) e como garantismo processual civil atualmente}

Para se chegar a esse conceito, tem-se de passar os olhos sobre as obras mencionadas ao longo deste artigo. Para Juan Montero Aroca, Adolfo Alvarado Velloso, Glauco Gumerato Ramos e outros, o ativismo processual civil é o excessivo papel do juiz no processo que, principalmente, determina a realização de provas, além de intervir em outras atividades típicas das partes.

Basicamente, o juiz ativista viola o conhecido axioma latino iudex debet judicare secundum allegata et probata a partibus, identificado com a proibição de o juiz de ir além das alegações das partes e a proibição de o juiz de determinar a realização de provas de ofício ou sem requerimento dos interessados.

Além disso, Juan Montero Aroca arrola manifestações que se alinham com o ativismo, embora não se refiram estritamente à atividade do juiz, tais como o não reconhecimento pelas partes de ser o juiz um terceiro e a classificação da "luta processual" das partes como má-fé ou improbidade processual.

O garantismo processual civil - e diga-se 'processual civil' porque o garantismo processual penal pode e deve ter outro sentido - está posto como o inverso do ativismo, devendo o juiz que se manter alheio à delimitação do objeto do processo e na definição do âmbito da prova como um espectador, sem interferir nessas atividades.

Com isso o juiz preserva sua independência e a essencial imparcialidade.

Como dito acima, o garantismo seria caracterizado pela posição moderada do juiz, com seus poderes limitados na atividade probatória e no impulso processual, com a revalorização do princípio dispositivo.

O garantismo, na palavra final do artigo do professor JuAn Montero Aroca é a luta contra a publicização, nome que se dá ao fenômeno do século XX que se caracteriza pelo favorecimento extremo do coletivismo a ponto de se suprimirem direitos fundamentais das pessoas. ${ }^{59}$

\section{A favor ou Contra o garantismo? oU a FaVor da terceira Via da COOPERAÇÃo E DA DEMOCRACIA?}

Não há pecado antidemocrático em alguém se posicionar contrariamente à universalização da visão garantista no processo civil.

Do mesmo modo, não há perigo em outrem se opor à orientação social do processo ou ao Direito Processual de Grupos Sociais.

Uma e outra são visões parciais; uma e outra estão revestidas de nuances políticas; uma e outra posição têm componentes ideológicos, de grupo ou grupos, de categorias profissionais, estamentos ou até de classes

58 GRINOVER, Ada Pellegrini. A iniciativa instrutória do juiz no processo penal acusatório. In: A marcha do processo. Rio de Janeiro: Forense Universitária, 2000. p. 77-86. p. 81.

59 MONTERO AROCA, Juan. El proceso civil llamado "social" como instrumento de "justicia" autoritaria. In: civil e ideología: un prefacio, una sentencia, dos cartas y quince ensayos. Valencia: Tirant lo Blanch, 2006. p. 165. Proceso 
sociais. O que se deseja é um debate público que esclareça o mais que possa, expondo quais são e de quem são os interesses que acompanham uma ou outra posição.

Como alertou Nicolò Trocker, a escolha somente deve ocorrer quando nos colocamos diante da "estreita perspectiva de uma rígida alternativa entre autoritarismo e liberalismo", ${ }^{60}$ que a rigor nem sempre existe. Em algumas situações processuais se evidencia a possibilidade de coexistência das duas correntes ideológicas. Noutras é possível dizer-se que o processo pode ser garantista, como nos litígios privados entre partes equilibradas e direitos disponíveis e que admitam transação. Numa sociedade complexa e em 'tempos difíceis' as alternativas processuais ou procedimentais não podem ser rígidas.

Há novas propostas teóricas em autores que identificam o 'processo autoritário' com o inquisitorial e o 'processo garantista' com o adversarial, aproximação considerada imperfeita ou simplista, mas possível. Como alternativa intermediária, diante da incapacidade de solução dos modelos extremos, surge a proposta de uma terceira via, pelo processo cooperativo, baseado nos princípios da boa-fé processual, do devido processo e do contraditório, reexaminados e revalorizados. Nesse modelo o órgão jurisdicional assume dupla posição, ora paritária, ora assimétrica. ${ }^{11}$ De modo similar, propõe-se um processo civil cooperativo, que sucede ao isonômico e ao assimétrico, baseado o primeiro em uma "dupla posição do juiz (paritária no diálogo, assimétrica na decisão) e o reforço das posições jurídicas das partes conferem marca ao processo civil cooperativo, manifestando-se ao longo de todo o formalismo processual." ${ }^{2}$ Também há quem defenda um processo civil democrático, justificado a partir da necessidade de o processo se abrir a novos conteúdos e novos desafios, diante da premissa de que:

os macro-modelos de estruturação do processualismo científico (liberalismo processual e socialização processual), centrados em dogmas do protagonismo (das partes e advogados ou dos juízes), não conseguem resolver os problemas de eficiência e de legitimidade dos sistemas normativos (extremamente complexos) da atualidade. ${ }^{63}$

Essas novas propostas revelam a incapacidade do processo tradicional de resolver os novos desafios processuais, que não se restringe ao binômio aparentemente inconciliável: autoritário x liberal. Deve-se, contudo, voltar ao garantismo.

\subsection{Mas por que ser contrário a um garantismo processual universal?}

Universalizar uma ou outra posição não é mais compatível com a fase atual das nossas sociedades multifacetadas, complexas, multiculturais, multiétnicas. Se no passado os socialistas diziam que as regras do direito eram incompreensíveis para os pobres e para os operários, hoje as limitações são outras, hoje as incompreensões são para outros.

Há áreas do processo em que as desigualdades entre os sujeitos parciais são de menor expressão ou não interferem no resultado processual, podendo ser desprezadas. Em outras as diferenças são mais aparentes, não devendo ser negligenciadas.

Propusemos uma reclassificação na Teoria Geral do Processo que observasse essas diferenças, considerando a maior ou menor necessidade de intervenção da força do juiz-Estado;

60 TROCKER, Nicolò. Il processo civile tedesco e quello italiano: loro basi storico-ideologiche. In: Processo civile e Costituzione: problemi de diritto tedesco e italiano. Milano: Giuffrè, 1974. p. 8-9, especialmente a nota 11, na qual destaca a posição de R. Schmidt, Prozessrecht und Staatsrecht. Noutra passagem o autor denomina o binômio aparentemente inconciliável de "rígido dualismo". 61 DIDIER JUNIOR, Fredie. Os três modelos de direito processual: inquisitivo, dispositivo e cooperativo. In: LEITE, George Salomão; SARLET, Ingo Wolfgang; CARBONELL, Miguel (Coord.). Direitos, deveres e garantias fundamentais. Salvador: JusPodivm, 2011. p. 427-439. p. 431-434.

62 MITIDIERO, Daniel. Colaboração no processo civil: pressupostos sociais, lógicos e éticos. São Paulo: Revista dos Tribunais, 2009. p. 101-103.

63 NUNES, Dierle José Coelho; BAHIA, Alexandre G. M. F. Processo, jurisdição e processualismo constitucional democrático na América Latina: alguns apontamentos. Revista Brasileira de Estudos Políticos, Belo Horizonte, v. 10, p. 61-94, 2010. p. 92. Ver também: NUNES, Dierle José Coelho. Processo liberale, sociale e democrático. Disponível em: <http://www.diritto.it>. 
a) Processo para defesa dos interesses públicos ou do Patrimônio Público: a1) Direito Processual Constitucional; a-2) Direito Processual Eleitoral; a3) Direito Processual Ambiental; a-4) Direito Processual Administrativo (Direito Processual Público); a-5) Direito Processual Tributário;

b) Processo para defesa de interesses individuais privados: b-1) Direito Processual Civil; b-2) Direito Processual Comercial ou Empresarial;

c) Processo para defesa de interesses individuais privados especiais (Direito Processual de Grupos Sociais): c-1) Direito Processual do Trabalho; c-2) Direito Processual Agrário; c-3) Direito Processual Previdenciário e Assistencial Social; c-4) Direito Processual do Consumidor; c-5) Direito Processual da Infância e Adolescência; c-6) Direito Processual dos Idosos; c-7) Direito Processual Acidentário e de Portadores de Deficiência.

O grupo do Processo para defesa dos interesses públicos ou do Patrimônio Público, o Direito Processual Civil serve de instrumento ao exercício da jurisdição civil em toda a sua extensão, seja para defesa do patrimônio do Estado, seja para defesa de interesses gerais, neles incluídos o ramo constitucional, o administrativo, o tributário etc. Contudo, tem-se nesse ramo do direito processual uma postura diferenciada para aplicação das regras processuais; orienta-se por princípios influenciados pelo direito público e a atuação das partes e do juiz sofre influência da natureza dos direitos litigados. Assim: ora "protege" o patrimônio estatal que deve ser de todos, ora "defende" a cidadania contra o gigantismo da força processual estatal.

O grupo do Processo para defesa de interesses individuais privados, que se caracteriza pela transigibilidade dos interesses materiais litigados, que influenciam as leis de processo, trazendo a elas uma maior disponibilidade das regras, desde a demanda, o impulso oficial, a iniciativa probatória, a amplitude do objeto de prova, as regras e a extensão dos recursos. ${ }^{64}$ Nesse sentido, o processo pode ser garantista, no sentido reclamado por Montero Aroca, pois está diante de partes que, em geral, são equiparadas, assim como diante de direitos disponíveis.

O grupo do Processo para defesa de interesses individuais privados especiais (Direito Processual de Grupos Sociais) caracteriza o Direito Processual de Grupos Sociais pela presença de interesses privados diferenciados, amparados por regras materiais e, também, protegidos pelas regras processuais especiais. Nesses casos o juiz amplia seus poderes, tanto para a busca de provas, quanto para a concessão de medidas urgentes de ofício.

Por tal razão, essas distinções entre partes e situações jurídicas distintas, não se pode pretender uma regra universal que imobilize o juiz sempre, em todos os casos e pelos mesmos meios. Encontrada essa contradição deve ser feita uma distinção necessária.

Universalizar o garantismo corresponderia, a essa altura, a permitir uma aplicação plena do princípio dispositivo e a mitigação do princípio inquisitivo, que não tem precedente conhecido. ${ }^{65}$ DEvIS ECHANDíA, ao tratar do tema sob a ótica da legislação colombiana, afirma que podem harmonizar-se o critério liberal com as convicções sociais e, com igual razão pode ter-se um processo civil também social, que cumpra a função do interesse público. ${ }^{66}$

\subsection{E por que se dizer a favor do direito processual de grupos sociais em sociedades com desigualdades complexas e multidimensionais?}

A possibilidade de manter uma posição própria e nacional sobre o Direito Processual de Grupos Sociais se deve à existência de grupos ou conjuntos sociais que mereçam atenção diferenciada da lei processual (e

64 GUEDES, Jefferson Carús. Direito Processual Social no Brasil: as primeiras linhas. Revista Latinoamericana de Derecho Social, México, v. 2, p. 55-91, 2006. p. 67-81. Revista de Processo, n. 142, p. 148-160, ano.

65 Ver: CAPPELLETTI, Mauro. Iniciativas probatorias del juez y bases pré-jurídicas de la estructura del proceso. In: . La oralidad de las pruebas en el proceso civil. Buenos Aires: Ejea, 1972. p. 111-135.

66 DEVIS ECHANDÍA, Hernando. Política social en la justicia civil. In: valia, 1985. p. 201-213. p. 213. Estudios de Derecho Procesal. Buenos Aires: Za- 
material). Os pobres da Europa dos anos 1940 não são mais os únicos merecedores de atenção especial do direito; os frágeis de então não são os frágeis de agora, aqui!

Os tempos já são outros, mas as desigualdades se mantêm, tendo se tornado desigualdades complexas e multidimensionais. ${ }^{67}$ São variadas as suas desigualdades e elas são capazes de influenciar o processo. $\mathrm{Na}$ tese antes indicada ${ }^{68}$, classificamos as desigualdades em várias categorias, que superam a exclusividade da desigualdade econômica:

a) Desigualdades sociais (individuais e de grupos) - as desigualdades sociais podem englobar as demais desigualdades ou delas serem resultado, pois os reflexos nas posições sociais decorrem da riqueza, da capacidade, do conhecimento, sendo difícil a sua separação das demais. ${ }^{69}$ Tende-se a associar o conceito de desigualdade ao de pobreza, com conotação mais próxima à economia. Mas pobreza é conceito teórico relacionado aos níveis e profundidade da carência nas sociedades ocidentais modernas, de cunho econômico mais que sociológico, mesmo que seja usado por igual e quase sem distinções entre economistas, sociólogos e antropólogos. ${ }^{70}$ Sabe-se também que a desigualdade é um fenômeno sociológico universal ${ }^{71}$ que pode atingir um indivíduo, alguns indivíduos ou grupos. ${ }^{72}$

b) Desigualdades econômicas - a pobreza é conceito teórico do século XIX que se transferiu à teoria da carência, vista como insuficiente à definição dos desequilíbrios em sociedades complexas, nas quais a avaliação da pobreza passou a ser medida por índices que não expressam a existência de grupos excluídos, tais como desempregados ou outros grupos, de diferentes raças ou etnias, de diferentes idades, de diferentes classes etc. ${ }^{73}$

c) Desigualdades educacionais ou instrucionais gerais - os desequilíbrios na educação formal, na instrução elementar ou na própria instrução geral criam desníveis que se refletem no direito. A dificuldade de comunicação oral ou escrita, o analfabetismo, a distância dos meios de comunicação e a incapacidade de plena troca comunicacional é também decorrente da instrução deficitária ou ausente.

d) Desigualdades técnicas-jurídicas e gerais - é a desigualdade ou déficit técnico associado a uma vulnerabilidade decorrente da carência ou ausência de conhecimentos de certa área do saber humano. O desconhecimento técnico do direito, das leis, pode servir de exemplo. Anton Menger descrevia prejuízos próprios dos pobres pela ignorância de seus direitos, por motivos óbvios de terem os de melhor posse maior interesse pelo direito, além de cultura mais elevada; de modo geral os pobres sabem pouquíssimo de seus direitos. ${ }^{74}$

67 "As desigualdades complexas ou multidimensionais de modo geral estão associadas à pobreza, que cria desnível ou déficit nos demais campos ou atividades vitais, atrasando a saúde, a educação, o conhecimento cultural, a comunicação, a instrução técnica etc. Exemplos podem ser muitos, mas um é a feminilização da pobreza, que associa a liderança doméstica de lares pobres àqueles conduzidos por mulheres, fazendo convergir duas condições de trato desigual e merecedoras de compensação: a condição feminina e a pobreza. Mas há muitos outros que podem associar múltiplas condições de déficit como a baixa instrução escolar, a pobreza, a integração de minorias indígenas ou de imigrantes, comuns em agricultores latino-americanos, por exemplo. O acesso ao crédito, a participação política, a luta processual por direitos é obturada se não forem criados pelo Estado mecanismos de equiparação para essas pessoas ou grupos sociais." GUEDES, Jefferson Carús. Igualdade e desigualdade no processo civil: o processo como técnica compensatória de desigualdades sociais. 2008. Tese (Doutorado em Direito)- Pontifícia Universidade Católica, São Paulo, 2008. (Versão adaptada para livro "A", inédito)

68 GUEDES, Jefferson Carús. Igualdade e desigualdade no processo civil: o processo como técnica compensatória de desigualdades sociais. 2008. Tese (Doutorado em Direito)- Pontifícia Universidade Católica, São Paulo, 2008. (Versão adaptada para livro "A").

69 SEN, Amartya. Desigualdade reexaminada. Rio de Janeiro: Record, 2001. p. 147, neste ponto o autor expõe a relação existente entre os diferentes tipos de desigualdade.

70 ARZATE SALGADO, Jorge G. Elementos conceituais para a construção de uma teoria sociológica da carência. In: CATTANI, Antonio David; DIAZ, Laura Mota (Org.). Desigualdades na América Latina: novas perspectivas analíticas. Porto Alegre: UFRGS, 2005. p. 235-252. p. 236.

71 RODRIGUEZ SOLERA, Carlos Rafael. Sete grandes debates sobre a desigualdade social. In: CATTANI, Antonio David; DIAZ, Laura Mota (Org.). Desigualdades na América Latina: novas perspectivas analíticas. Porto Alegre: UFRGS, 2005. p. 207-233. p. 218.

72 FISS, Owen. Grupos y cláusula de igual protección. In: GARGARELLA, Roberto. Derecho y grupos desavantajados. Barcelona: Gedisa, 1999. p. 145-146.

73 ARZATE SALGADO, Jorge G. Elementos conceituais para a construção de uma teoria sociológica da carência. In: CATTANI, Antonio David; DIAZ, Laura Mota (Org.). Desigualdades na América Latina: novas perspectivas analíticas. Porto Alegre: UFRGS, 2005. p. 235-252. p. 237-239.

74 MENGER, Anton. El Derecho Civily los pobres. Granada: Comares, 1998. p. 137-139. 
e) Desigualdades culturais (étnicas, lingüísticas etc.) - as desigualdade culturais podem manifestar-se de diversas formas. Will Kymlicka ao tratar do multiculturalismo sugere que "precisamos ir além do nível dos pronunciamentos retóricos, e examinar a forma como o multiculturalismo realmente funciona, i.e, que tipo de demandas estão sendo feitas por grupos minoritários; [...] como elas causam impacto nos direitos e nos recursos de diferentes pessoas dentro e fora do grupo, e assim por diante. ${ }^{75}$

f) Desigualdades político-institucionais (Estado e seus órgãos) e as desigualdades político-ideológicas de grupo (Partidos Políticos, Associações e Sindicatos) - são dadas em função do interesse público ou dos interesses sociais protegidos por determinadas instituições públicas e identificados os elementos aos quais se atribui relevância. Embora algumas instituições públicas ou privadas não sejam econômica ou culturalmente frágeis, concede-se a elas diferenciados poderes, isenções, benefícios ou direitos de modo a estender, indiretamente, a certos sujeitos sociais por elas representados, alguns privilégios compensatórios.

Por certo outras desigualdades podem ser acrescentadas, desdobradas ou detalhadas para melhor compreender as situações múltiplas que disso decorre. Por razões variadas, essas desigualdades apresentam-se com denominações diversas, tais como: pobreza, miserabilidade, exclusão, vulnerabilidade, desvantagem, déficit, deficiência, desequilibrio, assimetria, desproporcionalidade, inequitatividade, discriminação, desequiparação, desfavorecimento, marginalização, diferença, multiculturalidade etc.

Todas querem dizer, em toda ou em alguma medida, desigualdade.

\subsection{Escalas e tons de um direito processual de grupos sociais no Brasil, nestes tempos}

Há variadas escalas de dispositivos que permitem tratamento diferenciado a partes menos ou mais favorecidas, por um ou por outro componente natural, cultural ou social.

Niceto Alcalá-Zamora y Castillo, em trabalho republicado em seus Estudios de Teoría General e Historia del Proceso, afirma que seria fácil mostrar uma série importante e variada de dispositivos postos a serviço da finalidade de proteção dos fracos em sentido jurídico. ${ }^{76}$ Deve ser verdade para outras legislações, mas esse não é o objeto dessa exposição.

Piero Calamandrei, em seu Instituciones de Derecho Procesal Civil destacava o "caráter social do novo processo e o novo significado do princípio da igualdade das partes", que, segundo o Relatório Grandi, baseava-se na aproximação do povo da Justiça, de um processo mais popular e acessível às pessoas humildes, características consideradas indeterminadas ou genéricas. Para o autor, as características mais díspares eram a tendência de simplificação das formas, a concentração, a clareza das disposições, a imediatidade entre juiz e partes, e a nova concepção da igualdade das partes, que no modelo anterior não passava de um enunciado teórico. ${ }^{77}$

$\mathrm{Na}$ legislação brasileira atual, são muitas as situações "postas a serviço de atenuação das desigualdades processuais". Exemplos dessa natureza estão perdidos em normas de maior ou menor impacto, de variadas épocas, com valor geral ou especial, subsumidas em regras de direito material civil, trabalhista, ambiental ou agrária.

Tudo revela a força assistemática das proposições e o caráter somente conceitual e político que as classifica como normas de um pretenso Direito Processual de Grupos Sociais.

Em tese de doutoramento, na qual foi tratado o tema da Igualdade e desigualdade no Processo Civil: o processo como técnica compensatória de desigualdades sociais, ${ }^{78}$ foi feita uma tentativa de classificação desses instrumentos,

75 KYMLICKA, Will. Multiculturalismo liberal e Direitos Humanos. In: SARMENTO, Daniel; IKAWA, Daniela; PIOVESAN, Flavia. (coord.). Igualdade, diferença e Direitos Humanos. Rio de Janeiro: Lumen Juris, 2008. p. 217-243. p. 220.

76 ALCALÁ-ZAMORA Y CASTILLO, Niceto. Causas y efectos sociales del Derecho Procesal. In: Estudios de Teoría

General e Historia del Proceso. Ciudad de México: UNAM, 1974, v. 2. p. 245-289. p. 145.

77 CALAMANDREI, Piero. Instituciones de Derecho Procesal Civil: según el nuevo Código. Buenos Aires: Depalma, 1943. p. 342.

78 GUEDES, Jefferson Carús. Igualdade e desigualdade no processo civil: o processo como técnica compensatória de desigualdades 
nas leis processuais brasileiras, dividindo-os em três técnicas ou formas: a) técnicas ou institutos compensatórios; b) procedimentos especiais [compensatórios]; c) juizados especiais [compensatório]:

As técnicas ou institutos processuais possuem natureza compensatória de desigualdades, mas encerram-se em si, sem serem capazes de influenciar ou modificar integralmente um procedimento.

Por razões lógicas, foram divididas em técnica propriamente compensatória, por servirem exclusivamente à finalidade original de regra de compensação de desigualdades, e técnica excepcionalmente compensatória por servirem ordinariamente a uma finalidade original sem ser regra de compensação de desigualdades, mas que se podem tornar técnicas compensatórias de desigualdades.

São compensatórias para os fins deste trabalho: a) a assistência judiciária gratuita (assistência jurídica, assistência judiciária e a gratuidade de Justiça); b) as alterações da distribuição e inversão do ônus da prova; c) concessão de poderes dirigentes ao juiz; d) concessão de poderes instrutórios ao juiz; e) legitimação extraordinária; f) modificações de competência; e g) eqüidade. São técnicas excepcionalmente compensatórias para os fins deste trabalho: a) tutelas diferenciadas; b) tutelas de urgência (antecipada e cautelar); c) tutela específica; d) simplificação do processo e do procedimento (sumarização ou abreviação, limitação ao formalismo e ao "excesso de rito"); e) redução e simplificação ou alteração do sistema recursal (efeitos); f) oralidade, imediatidade e conciliação; e g) controle da moralidade, do abuso do processo e da má-fé e do comportamento processual indevido.

Os procedimentos especiais têm a característica de somarem técnicas isoladas e transformarem por inteiro um procedimento especial em uma técnica compensatória. Por esse procedimento dá-se tratamento diferenciado a pessoas ou grupos, com a finalidade de atender à peculiaridade do direito litigado ou a singularidades dos sujeitos sociais envolvidos.

São procedimentos especiais de natureza compensatória: b1) procedimentos dos juizados especiais (JECC e JEF); b2) procedimentos compensatórios em favor da Fazenda Pública; b3) outros procedimentos especiais com natureza compensatória de desigualdades; b4) procedimentos especiais coletivos como sistema compensatório de desigualdades.

A natureza peculiar dos Juizados Especiais como sistema especial na Justiça Comum e de procedimento especializado é expressão orgânica e funcional da natureza compensatória de desigualdades dessa nova estrutura judicial brasileira. Cria-se para o trato de questões simplificadas uma verdadeira justiça à parte, com juízes, servidores, equipamentos, prédios, sistemas diferenciados. ${ }^{79}$

Em síntese, afirmou-se que existem: a) técnicas processuais compensatórias isoladas; b) procedimentos especiais compensatórios e; c) órgãos jurisdicionais compensatórios (JECC, JEF, JEFP).

O que se nota é que tais normas protetoras ou compensatórias de desigualdades se espalham por leis especiais, sem um tratamento orgânico ou sistemático e só assim permitindo que se atribua, apenas como uma provocação acadêmica, a denominação de Direito Processual de Grupos Sociais.

De forma pontual, alguns exemplos possuem maior organicidade, como é o caso do "Sistema dos Juizados Especiais", agora completo com a edição da terceira e provavelmente última norma desse conjunto. Esses juizados são organizados nas três leis conhecidas: a) Lei n. 9.099/1995, Juizados Especiais Cíveis e Criminais (JECC); ${ }^{80}$ Lei n. 10.259/2001, Juizados Especiais Federais (JEF) ${ }^{81}$ e c) Lei n. 12.153/2009, Juizados Especiais da Fazenda Pública (JEFP). ${ }^{82}$ Por vários critérios e princípios essas normas especiais, às quais correspondem

sociais. 2008. Tese (Doutorado em Direito)- Pontifícia Universidade Católica, São Paulo, 2008.

79 GUEDES, Jefferson Carús. Igualdade e desigualdade no processo civil: o processo como técnica compensatória de desigualdades sociais. 2008. Tese (Doutorado em Direito)- Pontifícia Universidade Católica, São Paulo, 2008.

80 Órgãos da Justiça Comum dos Estados e do Distrito Federal (DF) criados para a conciliação de matérias de menor complexidade e valor igual ou inferior a 40 salários mínimos (SM), entre particulares.

81 Órgãos da Justiça Comum Federal para a conciliação de matérias de menor complexidade e valor igual ou inferior a 60 salários mínimos (SM) entre particulares e a União e alguns de seus entes de administração indireta (autarquias, fundações e empresas públicas).

82 Órgãos da Justiça Comum dos Estados e do DF para a conciliação de matérias de menor complexidade e valor de até 20 ou 60 salários mínimos (SM) a depender do ente federativo, entre particulares e Estado, DF e Municípios ou alguns de seus entes de administração indireta (autarquias, fundações e empresas públicas). 
curiosamente também unidades jurisdicionais próprias vinculadas, além dos procedimentos. Os Juizados Especiais são também objeto de crítica em artigo recente do Prof. Glauco Gumerato Ramos, por afrontarem na sua "praxe local" as garantias do devido processo, por ser "antirrepublicano, antidemocrático, um não processo". ${ }^{83}$ Além de impedir a uniformização própria das matérias examinadas pelos Tribunais Estaduais, Tribunal do Distrito Federal e Tribunais Regionais Federais, as decisões dos Juizados Especiais.

Nessa perspectiva, de adaptação e diferenciação procedimental às demandas específicas de certos grupos sociais, tem-se de concordar com a criação de procedimentos especiais que levem em consideração tais desigualdades, de modo a atender com tutela adequada às necessidades processuais de tais sujeitos ou de seus coletivos organizados ou não.

Ainda assim devemos lembrar sempre a observação de Niceto Alcalá-Zamora y Castillo quando estabelece como critério a definição das características do processo liberal e do processo autoritário, mais que suas vantagens, por considerar esse passo inicial essencial à valoração de um ou de outro modelo. ${ }^{84}$

\section{Considerações finais}

Pensar-se em regras universais não faz mais muito sentido no Brasil, hoje, quando se quer um processo cada vez mais "customizado" ou adequado à tutela desejada pela parte. As razões podem ser muitas, mas aponto três genéricas.

Há um imenso campo de atuação do Processo Coletivo, no qual as regras e princípios, tais como o princípio dispositivo e seus dois aspectos não possuem ressonância tão alta, sendo guiado por outros princípios e para proteção de outros interesses. ${ }^{85}$

Há uma extensa atuação processual do Estado, ${ }^{86}$ desconhecido e sem correspondência na maioria dos países europeus continentais ou de tradição anglo-saxônica, que permitem o reconhecimento de um campo próprio do Direito Processual Administrativo, como Direito Processual Público, ora com outorga de poderes mais amplos ao juiz, ora com mitigação de garantias processuais estatais, ora privilegiando o Estado, ora protegendo o cidadão da excessiva força processual estatal. ${ }^{87}$

Não há mais o velho Direito Processual de Grupos Sociais dos pobres do século XIX e do século XX, havendo sim novas e complexas dificuldades que mais exigem do Estado e de seus agentes, sejam administradores ou juízes.

Reequilibrar partes com regras do processo, quando e se necessário, pode ser tarefa estatal, seja pela outorga de direitos, seja pela compensação processual, ${ }^{88}$ sejam aos pobres ou desassistidos, negros, benefi-

83 RAMOS, Glauco Gumerato. O processo civil gatopardista dos Juizados Especiais. Revista Brasileira de Direito Processual, Belo Horizonte, n. 77, p. 37-42, 2012. p. 37.

84 ALCALÁ-ZAMORA Y CASTILLO, Niceto. Liberalismo y autoritarismo en el proceso. In: Estudios de Teoría General e Historia del Proceso. Ciudad de México: UNAM, 1974, v. 2. p. 245-289. p. 252.

85 ALMEIDA, Gregório Assagra de. Direito Processual Coletivo brasileiro. São Paulo: Saraiva, 2003. p. 560-579, especialmente o princípio da máxima efetividade do processo coletivo, que corresponde à ampliação dos poderes do juiz (item 11.7.7, p. 576-577), baseado na opinião de Ada Pellegrini Grinover. Também: MACEDO JUNIOR, Ronaldo Porto. Ação civil pública, o direito social e os princípios. In: YARSHELL, Flávio Luiz; MORAIS, Maurício Zanoide de (Coord.). Estudos em homenagem à professora Ada Pellegrini Grinover. São Paulo: DPJ, 2005. p. 290-299. p. 294-296.

86 Diferentemente de outras repúblicas federativas (México e Argentina) temos apenas uma lei processual 'nacional', que se aplica, a todos os litígios, sejam entre sujeitos privados ou entre estes e o Estado (União, Estados, Distrito Federal, Municípios e os entes de cada um desses entes federativos), ao lado de inúmeras leis esparsas que tratam de procedimentos especiais ou de incidentes processuais.

87 SUNDFELD, Carlos Ari. O direito processual e o direito administrativo. In:

Direito processual público: a fazenda pública em juízo. São Paulo: Malheiros, 2000. p. 15-30, nas quais aponta as razões de conexão entre o Direito Administrativo e o Direito Processual. 88 COUTURE, Eduardo J. Algunas nociones fundamentales sobre Derecho Procesal del Trabajo. In: Estudios de Derecho Procesal Civil, 3. ed. Buenos Aires: Depalma, 1989. p. 271-288. p. 275-276, onde descreve a sua ideia de igualdade por compensação, feita por meio da criação de outras desigualdades. 
ciários de seguro social, adolescentes em condição de risco, indígenas, mulheres, agricultores, desabrigados de catástrofes, homossexuais e outras minorias, refugiados, detentos, imigrantes, desempregados, doentes, acidentados, microempresários; sem-terra, deficientes etc.

Mas, além disso, tutelar não mais ou não apenas os direitos desses indivíduos ou grupos de indivíduos, mas as pessoas e como pessoas, assim reconhecidas pela técnica processual.

\section{REFERÊNCIAS BIBLIOGRÁFICAS}

ALCALÁ-ZAMORA Y CASTILLO, Niceto. Liberalismo y autoritarismo en el proceso. In: Estudios de Teoría General e Historia del Proceso. Ciudad de México: UNAM, 1974, v. 2. p. 245-289.

ALMEIDA, Gregório Assagra de. Direito processual coletivo brasileiro. São Paulo: Saraiva, 2003.

ALVARADO VELLOSO, Adolfo. Garantismo procesal contra actuación judicial de oficio. Valencia: Tirant lo Blanch, 2005.

ARZATE SALGADO, Jorge G. Elementos conceituais para a construção de uma teoria sociológica da carência. In: CATTANI, Antonio David; DIAZ, Laura Mota (Org.). Desigualdades na América Latina: novas perspectivas analíticas. Porto Alegre: UFRGS, 2005. p. 235-252.

BEDAQUE. José Roberto dos Santos. Poderes instrutórios do juiz: 3. ed. São Paulo: Revista dos Tribunais, 2001.

BÖHN, Peter. Processo civile e ideologia nello stato nazisocialista. Rivista Trimestrale de Diritto e Procedura Civile, Milano, ano 58, n. 2, p. 1-35, jun. 2004.

BRANCO, Paulo Gustavo Gonet. Em busca de um conceito fugidio: o ativismo judicial. In: FELLET, André Fernandes; DE PAULA, Daniel Giotti; NOVELINO, Marcelo (Org.). As novas faces do ativismo judicial. Salvador: JusPodivum, 2011. p. 387-401.

CABRAL, Antônio do Passo. Imparcialidade e impartialidade: por uma teoria sobre a repartição e incompatibilidade de funções nos processos civil e penal. In: DIDIER JUNIOR, Fredie. Teoria do Processo: panorama doutrinário mundial. Salvador: JusPodivm, 2008. p. 99-124.

CABRAL, Antônio do Passo. O processo como superego social: um estudo sobre os fins sociais da jurisdição. Revista de Processo, São Paulo, n. 115, p. 345-389, 2004.

CALAMANDREI, Piero. Instituciones de Derecho Procesal Civil: según el nuevo código. Buenos Aires: Depalma, 1943.

CALAmANDREI, Piero. Premissas políticas do Projeto do Código de Processo Civil italiano. In: Processo Oral: coletânea de estudos de juristas nacionais e estrangeiros. Rio de Janeiro: Forense, 1940. p. 165-170.

CÂMARA, Alexandre Freitas. Poderes instrutórios do juiz e processo civil democrático. Revista de Processo, São Paulo, n. 153, p. 1-11 (eletrônica), 2007.

CAMPOS, Francisco. Exposição de Motivos. In: . Código de Processo Civil. 3. ed. São Paulo: Saraiva, 1969. p. 1-26.

CAPPELLETTT, Mauro. Iniciativas probatorias del juez y bases pré-jurídicas de la estructura del proceso. In: La oralidad de las pruebas en el proceso civil. Buenos Aires: Ejea, 1972. p. 111-135.

CAPPELLETTI, Mauro. Publicización, oralidad, socialización. In: Elprocesso civil en el Derecho Comparado. Buenos Aires: EJEA, 1973. p. 43-80.

COUTURE, Eduardo J. Algunas nociones fundamentales sobre Derecho Procesal del Trabajo. In: Estudios de Derecho Procesal Civil. 3. ed. Buenos Aires: Depalma, 1989. p. 271-288. 
COUTURE, Eduardo J. Oralidade e regra moral no processo civil. In: PROCESSO oral: coletânea de estudos de juristas nacionais e estrangeiros. Rio de Janeiro: Forense, 1940.

CHIOVENDA, Giuseppe. Le riforme processuali e le correnti del pensiero moderno. In: Saggi di

Diritto Processuale Civile. Milano: Giuffré, 1993. p. 379-394.

DENTI, Vittorio. Il processo come strumento di politica sociale, processo civile e giustizia sociale. Milano: Comunità, 1971.

DEVIS ECHANDÍA, Hernando. Política social en la justicia civil. In: Estudios de Derecho Procesal. Buenos Aires: Zavalia, 1985. p. 201-213.

DIDIER JR., Fredie. Os três modelos de direito processual: inquisitivo, dispositivo e cooperativo. In: LEITE, George Salomão; SARLET, Ingo Wolfgang; CARBONELL, Miguel (Coord.). Direitos, deveres e garantias fundamentais. Salvador: JusPodivm, 2011. p. 427-439.

DINAMARCO, Cândido R. Revista de Processo, São Paulo, n. 119, p. 259-284, 2005.

FISS, Owen. Grupos y cláusula de igual protección. In: GARGARELLA, Roberto. Derecho y grupos desavantajados. Barcelona: Gedisa, 1999. p. 137-168.

GRECO, Leonardo. Publicismo e privatismo no processo civil. Revista de Processo, São Paulo, n. 164, p. 29-56, 2008.

GRINOVER, Ada Pellegrini. A iniciativa instrutória do juiz no processo penal acusatório. In: . $A$ marcha do processo. Rio de Janeiro: Forense Universitária, 2000. p. 77-86.

GUEDES, Jefferson Carús. Direito Processual Social no Brasil: as primeiras linhas. Revista Latinoamericana de Derecho Social, México, v. 2, p. 55-91, 2006.

GUEDES, Jefferson Carús. Igualdade e desigualdade no processo civil: o processo como técnica compensatória de desigualdades sociais. 2008. Tese (Doutorado em Direito)-Pontifícia Universidade Católica, São Paulo, 2008 .

GUEDES, Jefferson Carús. O princípio da oralidade: procedimento por audiências no Direito Processual Civil brasileiro. São Paulo: Revista dos Tribunais, 2003.

GUIMARÃES, Luiz Machado. Processo autoritário e regime liberal. In: GUIMARÃES, Luiz Machado. Estudos de Direito Processual Civil. Rio de Janeiro: Jurídica Universitária, 1969. p. 128-136.

JARDIM, Afrânio Silva. A publicização do processo civil. Rio de Janeiro: Liber Juris, 1982.

KELLY, John M. Storia del pensiero giuridico occidentale. Bologna: Mulino, 1996.

KYMLICKA, Will. Multiculturalismo liberal e Direitos Humanos. In: SARMENTO, Daniel; IKAWA, Daniela; PIOVESAN, Flavia. (Coord.). Igualdade, diferença e Direitos Humanos. Rio de Janeiro: Lumen Juris, 2008. p. 217-243.

LOPES, João Batista. Os poderes do juiz no aprimoramento da prestação jurisdicional. Revista de Processo, São Paulo, n. 35, p. 24-67, 1984.

MACEDO JUNIOR, Ronaldo Porto. Ação civil pública, o direito social e os princípios, In: YARSHELL, Flávio Luiz; MORAIS, Maurício Zanoide de (Coord.). Estudos em homenagem à professora Ada Pellegrini Grinover. São Paulo: DPJ, 2005. p. 290-299.

MARINONI, Luiz Guilherme. Novas linhas do processo civil: o acesso à Justiça e os institutos fundamentais do Direito Processual. São Paulo: Revista dos Tribunais, 1993.

MENGER, Anton. El Derecho Civily los pobres. Granada: Comares, 1998. 
MITIDIERO, Daniel. Colaboração no processo civil: pressupostos sociais, lógicos e éticos. São Paulo: Revista dos Tribunais, 2009.

MONTELEONE, Girolamo. Principios y ideologías del proceso civil: impresiones de un 'revisionista. In: MONTERO AROCA. Juan. Proceso civil e ideologia: un prefacio, una sentencia, dos cartas y quince ensayos. Valencia: Tirant lo Blanch, 2006. p. 97-108.

MONTERO AROCA, Juan. El proceso civil llamado "social" como instrumento de "justicia" autoritaria. In: _. Proceso civil e ideología: un prefacio, una sentencia, dos cartas y quince ensayos. Valencia: Tirant lo Blanch, 2006. p. 130-166.

MONTERO AROCA, Juan. El Derecho Procesal en el siglo XX. Valencia: Tirant lo Blanch, 2000.

MONTERO AROCA, Juan. Proceso civil e ideología: un prefacio, una sentencia, dos cartas y quince ensayos. Valencia: Tirant lo Blanch, 2006.

MOREIRA, José Carlos Barbosa. A função social do processo civil moderno e o papel do juiz e das partes na direção e na instrução do processo. In: Temas de Direito Processual: terceira série. São Paulo: Saraiva, 1984. p. 43-56.

MOREIRA, José Carlos Barbosa. Neoprivatismo no processo civil. In: . Temas de direito processual. 9. ed. São Paulo: Saraiva, 2007. p. 87-102.

NAVES, Candido. Impulso, processual e poderes do juir. Belo Horizonte: Santa Maria, 1949.

NUNES, Dierle José Coelho. Processo Jurisdicional democrático: uma análise crítica das reformas processuais. Curitiba: Juruá, 2008.

NUNES, Dierle José Coelho; BAHIA, Alexandre G. M. F. Processo, jurisdição e processualismo constitucional democrático na América Latina: alguns apontamentos. Revista Brasileira de Estudos Políticos, Belo Horizonte, v. 10, p. 61-94, 2010.

PARRA QUIJANO, Jairo. Racionalidad e ideología en las pruebas de oficio. Bogotá: Themis, 2001.

PICÓ I JUNOY, Joan. El derecho procesal entre el garantismo y la eficacia: un debate mal planteado, Revista de Processo, n. 197, p. 193-210, jun. 2011.

PISANI, Andrea Proto. Pubblico e privato nel processo civile. Revista de Processo, São Paulo, n. 207, p. 281302, 2012.

RAMOS, Glauco Gumerato. Ativismo e garantismo no processo civil: apresentação de debate. Revista Brasileira de Direito Processual, Belo Horizonte, n. 70, p. 83-102, 2010.

RAMOS, Glauco Gumerato. O processo civil gatopardista dos Juizados Especiais. Revista Brasileira de Direito Processual, Belo Horizonte, n. 77, p. 37-42, 2012.

RICCI, Gian Franco. Il processo civile fra ideologie e quotidianità. Rivista Trimestrale di Diritto e Procedura Civile, Milano, ano 59, p. 77-103, mar/2005.

ROCHA, Eliana Pires; GUEDES, Jefferson Carús. Derechos Fundamentales y Proceso Civil en el Brasil: algunas técnicas procesales compensatorias de desigualdades sociales y la protección judicial de los derechos fundamentales. Anuario de Derechos Humanos, Madrid, v. 11, p. 451-492, 2010.

RODRIGUEZ SOLERA, Carlos Rafael. Sete grandes debates sobre a desigualdade social. In: CATTANI, Antonio David; DIAZ, Laura Mota (Org.). Desigualdades na América Latina: novas perspectivas analíticas. Porto Alegre: UFRGS, 2005. p. 207-233.

SANTOS, Moacyr Amaral. Contra o processo autoritário, Revista da Faculdade de Direito da Universidade de São Paulo, v. 54, n. 2, p. 30-44, 1959. 
SEN, Amartya. Desigualdade reexaminada. Rio de Janeiro: Record, 2001.

SOMMA, Alessandro. Fascismo e diritto. Rivista Trimestrale di Diritto e Procedura Civile, Milano, ano 55, n. 3, p. 597-663, set. 2001.

SUNDFELD, Carlos Ari. O direito processual e o direito administrativo. In: Direito processual público: a fazenda pública em juízo. São Paulo: Malheiros, 2000. p. 15-30.

TARUFFO, Michele. La giustizia civile in Italia dal '700 a oggi. Bologna: Mulino, 1980.

TROCKER, Nicolò. Il processo civile tedesco e quello italiano: loro basi storico-ideologiche. In: Processo civile e Costiturione: Problemi de diritto tedesco e italiano. Milano: Giuffrè, 1974. p. 3-90.

VERDE, Giovanni. Las ideologías del proceso en un reciente ensayo. In: MONTERO AROCA, Juan. Proceso civil e ideología: un prefacio, una sentencia, dos cartas y quince ensayos. Valencia: Tirant lo Blanch, 2006. 


\title{
Políticas públicas, mínimo existencial e Poder Judiciário: a questão do direito à moradia*
}

\author{
Public policy, existential minimum and \\ Judiciary: matter of the right to housing
}

Diogo de Calasans Melo Andrade**

\section{Resumo}

O programa minha casa minha vida (PMCMV) é uma política púbica de moradia que dá impulso às ações do Estado no sentido de concretizar o direito à moradia. Ocorre que, segundo pesquisas trazidas no decorrer deste artigo, nem sempre se concede uma moradia digna para todos, não se chegando a cidadania plena. Assim, resta a seguinte indagação: pode o Poder Judiciário interferir nas políticas públicas de moradia? Por outro lado, o Estado/ Poder Executivo traz como limite a não interferência o mínimo existencial, a reserva do possível e a separação dos poderes, a tese que, como será demonstrado, não parece razoável e apropriada. Defende-se, aqui, que a moradia é o núcleo essencial de um direito fundamental, ou seja, o mínimo existencial que deve ser realizado pelo Estado. Por fim, argumenta-se que, na falta de programas de governo ou políticas públicas de moradia eficazes, por parte do Poder Executivo, resta ao Poder Judiciário intervir em tais políticas, com as funções de controle e de fiscalização, com um único fim: concretizar o direito social à moradia.

Palavras-chaves: Políticas públicas. Moradia. Poder Judiciário.

\section{Abstract}

The Minha casa Minha vida program (MCMV) is a pubic housing policy that propels the State's actions in order to realize the right to housing. It turns out that, according to surveys brought within that article, if not always provides decent housing for everyone, not reaching full citizenship. Thus, there remains the following question: can the judiciary interfere in public housing policies? On the other hand, the State/ Executive Branch, brings as limit the non interference in the minimum existencial, the booking of possible and the separation of powers, thesis that, as will be demonstrated, do not seem reasonable or appropriate. It is argued, here, that housing is the essential core of a fundamental right, that means, the existential minimum that must be done by the state. Finally, it is argued that in the absence of public governmental or public policy programs of effective housing, by the Executive Branch, left to the courts intervene in such policies, controlling

** Bacharel em Direito pela Universidade Tiradentes (2002). Mestre em Direito pela Universidade Federal de Sergipe (2013). Doutorando em Direito na Universidade Presbiteriana Mackenzie.E-mail:contato@diogocalasans.com

Recebido em 07/12/2015

Aprovado em 14/12/2015 and supervising, with a sole purpose: achieving the social right to housing. 
Keywords: Public policy. Housing. Executive branch.

\section{As políticas públicas de moradia No Brasil}

O CNPq junto com o Ministério das Cidades, lançou em 2012, edital de pesquisa para avaliar o Programa Minha Casa Minha Vida (PMCMV), do qual resultaram 11 equipes contempladas que formaram a "Rede Cidade e Moradia" e avaliaram empreendimentos de 22 municípios em 6 estado: Pará, Ceará, Rio Grande do Norte, Minas Gerais, Rio de Janeiro e São Paulo, e concluíram que: a) como são as construtoras - em sua relação com a Caixa - que definem o projeto e sua localização, tem prevalecido no programa padrão de produção com fortíssima homogeneização das soluções de projeto arquitetônico e urbanístico e das técnicas construtivas, independentemente das características físicas dos terrenos ou das condições bioclimáticas locais; b) os Municípios permitem a construção dos empreendimentos em localizações mais baratas, como em zonas rurais englobadas por alterações nos perímetros urbanos, que reproduzem padrão de cidade segregada e sem urbanidade, pois são mal servidas por transporte, infraestrutura ou oferta de serviços urbanos adequados ao desenvolvimento econômico e humano; c) os processos de seleção da demanda feito por meio de cadastro das prefeituras nem sempre são transparentes; d) programa habitacional que atende, prioritariamente, aos interesses do setor privado, sem vínculos necessários com uma política urbana e fundiária, que estima o aumento dos preços dos imóveis na cidade e tem gerado péssimas inserções urbanas e segregação social, e) o programa baseia-se numa produção padronizada e em larga escala, desarticulada das realizadas locais, mal inserida e isolada da cidade, com base em modelo de propriedade privada condominial ${ }^{1}$.

Assim, percebe-se que o PMCMV possui série de problemas e mesmo concedendo grande número de habitações, segundo a citada pesquisa, essas moradias não são dignas, o que gera a falta de uma cidadania plena, uma vez que, sem moradia, não se pode falar em cidadania. Esse PMCMV possui sérios problemas e não atinge toda a população sem moradia do Brasil, sendo necessário, em primeiro lugar, análise das políticas públicas de moradia, pois, para a efetivação da cidadania e dos direitos sociais, é necessário que o Estado, juntamente com a sociedade civil organizada, realize políticas públicas eficazes e esses direitos sociais possuem enfoque prestacional, uma obrigação de fazer do Estado.

Ainda sobre o tema habitação, existem dois grandes problemas quando analisamos os casos práticos, um em relação à falta de clareza e informação do governo a respeito dos programas de habitação, que se limita a dizer o custo, sem fiscalização; o outro é a perda do controle da situação para que não haja caos. Assim, percebe-se que temos processos, mas não se tem a continuidade da melhoria e acompanhamento dos projetos implementados².

O tema políticas públicas é, inicialmente, da ciência política e da administração pública. Mas, para estudar as políticas públicas, faz-se essencial estudar as instituições jurídicas, o processo político de tomada de decisões e a legitimidade. Assim, para uma política pública ser considerada legítima, esta deve fundar-se na lei. Os desafios para implementação das políticas públicas são jurídicos, econômicos e, principalmente, polí-

1 RUfINO, Maria Beatriz Cruz; SHIMBO, Lúcia Zanin; AMORE, Caio Santo (Org.). Minha casa... e a cidade? Avaliação do programa minha casa minha vida em seis estados brasileiros. Rio de Janeiro: Letra capital, 2015. p. 419-422.

2 Para isso, o senado investiga, periodicamente, o impacto dos programas governamentais em relação aos objetos para os quais eles foram criados, criando resolução que procura: contrastar o que aconteceu após a intervenção (ou a omissão) do Poder Público com o que teria ocorrido em um cenário contrafatual. Qualquer é a essência da atividade de avaliação, que tem, basicamente, três finalidades não excludentes entre si: a) identificar os resultados que podem ser atribuídos à intervenção; b) compreender os mecanismos que determinam seu sucesso (ou fracasso), em relação aos objetivos preestabelecidos; e c) investigar a eficiência da intervenção. Na dimensão resultado, o enfoque consiste em medir os efeitos da intervenção. FREITAS, Igor Vilas Boas. Avaliação de politica pública no Senado Federal: proposta de abordagem. Brasília: Senado Federal, 2013. Disponível em: < https://www12.senado. leg.br/publicacoes/estudos-legislativos/tipos-de-estudos/outras-publicacoes/avppsf/avaliacao-de-politicas-publicas-no-senadofederal-1>. Acesso em 10 set. 2015. 
ticos. As decisões do Estado sobre Políticas Públicas, a depender da hipótese, são exercidas e realizadas por meio do Direito. Já o alcance de uma política pública é supraindividual, uma vez que envolve a coletividade, com demandas expectativas comuns.

Diferentemente das leis, as políticas públicas não são gerais e abstratas, são específicas e buscam a realização de objetivos determinados. Elas atuam de forma complementar, preenchendo os espaços normativos e concretizando os princípios e regras, com vista a objetivos determinados. Correspondem, no plano jurídico, as diretrizes, normas de um tipo especial, rompendo as amarras dos atributos de generalidade e abstração - que extremam as normas dos atos jurídicos, estes concretos, para dispor sobre matérias contingentes 3 .

O estado da arte na área de políticas públicas significa o mapa de como a literatura clássica resume a política pública como o campo do conhecimento que busca, ao mesmo tempo, "colocar o governo em ação" e/ou analisar essa ação (variável independente) e, quando necessário, propor mudança no rumo ou curso dessas ações (variável dependente). A formulação de políticas públicas constitui-se no estágio em que os governos democráticos traduzem seus propósitos e plataformas eleitorais em programas e ações que produzirão resultados ou mudanças no mundo real ${ }^{4}$.

Sobre a definição de políticas públicas, Bucci ${ }^{5}$ conceitua esse termo como um programa ou quadro de ação governamental, porque consiste em conjunto de medidas articuladas (coordenadas) cujo escopo é dar impulso, isto é, movimento à máquina do governo, no sentido de realizar algum objetivo de ordem pública ou na ótica dos juristas, concretizar o direito. A doutrina traz outros conceitos para políticas públicas ${ }^{6}$

Assim, as políticas públicas partem do Estado e têm como finalidade a concretização de um direito. Outro ponto importante consiste em analisar quais são os elementos e as etapas que compõem o ciclo das políticas públicas e a forma como estão sendo ou não articulados. Para o processo de definição e implementação das políticas públicas, é necessário analisar uma série de atividade e etapas distintas, dentre as quais podemos destacar: (a) identificação dos problemas e demandas a serem atacadas para a definição das prioridades a serem decididas junto aos formuladores de políticas públicas; (b) formulação de propostas concretas entre diferentes opções de programas a serem adotados; (c) implementação propriamente dita da política, com a criação da estrutura necessária e observância da burocracia existência, gasto de recurso e aprovação de leis; (d) avaliação de recursos da política por meio da verificação do resultado e impactos da política, para que se possa aferir se ela realmente funciona ou não; (e) fiscalização e controle da execução da política por meio da atuação da sociedade civil, dos Tribunais de Contas e do Ministério Público?

De mais a mais, Bucci, em outra obra, propôs examinar o fenômeno governamental, enquanto manifestação juridicamente disciplinada, em três planos de aproximação: macro, meso e micro institucional. Há, no plano macroinstitucional, as decisões políticas fundamentais, a "grande política", bem como os rumos do

3 BUCCI, Maria Paula Dallari. O conceito de política pública em direito. In: (Org.). Politicas Públicas: reflexões sobre o conceito jurídico. São Paulo: Saraiva, 2006. p. 25-27.

4 SOUZA, Celina. Políticas públicas: uma revisão da literatura. Revista Sociologias, Porto Alegre, v. 8, n. 16, p. 20-45, jul./dez. 2006 . p. 26 5 BUCCI, Maria Paula Dallari. O conceito de política pública em direito. In: conceito jurídico. São Paulo: Saraiva, 2006. p. 14.

6 Política como uma atividade, isto é, conjunto organizado de normas e atos tendentes à realização de objetivo determinado. COMPARATO, Fábio Konder. Ensaio sobre o juízo de constitucionalidade de políticas públicas. In: MELLO, Celso Antonio Bandeira de (Org.). Estudos em homenagem a Geraldo Ataliba. São Paulo: Malheiros, 1997. p. 39-48. p. 97. Compreende políticas públicas como uma atuação do Estado no sentido de reduzir os efeitos negativos da descontinuidade administrativa, assim como para potencializar os recursos disponíveis. MATSUMOTO, Meggie Iara; BARBOSA, Claudia Maria. A legitimidade do poder judiciário na condução de políticas públicas para a realização de direito fundamentais. In: PAMPLONA, Danielle Anne (Coord). Politicas públicas: elementos para alcance do desenvolvimento sustentável. Curitiba: Juruá, 2012. Concluímos, portanto, que as políticas públicas constituem os mecanismos estatais de efetivação dos direitos fundamentais, mediante a satisfação espontânea dos bens da vida por eles protegidos. O Estado, como sujeito passivo da obrigação, as satisfaz por meio da atuação concreta das formas de expressão do poder estatal. CANELA JUNIOR, Osvaldo. Controle judicial de politicas públicas. São Paulo: Saraiva, 2011. p. 59.

7 DUARTE, Clarice Seixas. Para além da judicialização: a necessidade de uma nova forma de abordagem das políticas públicas. In: SMANIO, Gianpaolo Poggio; BERTOLIN, Patrícia Tuma Martins; BRASIL, Patrícia Cristina (Org.). O direito na fronteira das políticas públicas. São Paulo: Páginas e Letras, 2015. p. 26. 
planejamento de longo prazo. No plano meso institucional, da "média política", os arranjos institucionais, que desenham a ação governamental racionalizada, agregando e compondo os elementos disponíveis, em uma direção determinada, tornada previsível, com base em regra e institucionalização jurídica, que define as situações a serem experimentadas em operações futuras, resultando na reiteração da ação. Finalmente, há a ação governamental, nas suas menores unidades, microinstitucional, a chamada "pequena política" no desenrolar do processo político que leva a formação e o desenvolvimento das políticas públicas, a decisão e as iniciativas pertinentes, além das decisões judiciais, nas hipóteses de conflito. Essa dimensão é aquela que sobressai o papel dos indivíduos ${ }^{8}$.

Por outro lado, é importante diferenciar planejamento do plano, uma vez que o planejamento coordena, racionaliza e dá unidade de fins à atuação do Estado, diferenciando-se de uma intervenção conjuntural ou casuística. O plano é a expressão da política geral do Estado, é mais que um programa, é um ato de direção política, pois determina a vontade estatal por meio de um conjunto de medidas coordenadas, não podendo limitar-se à mera enumeração de reivindicações. O planejamento, embora possua conteúdo técnico, é um processo político, especialmente nas sociedades que buscam a transformação das estruturas econômicas e sociais. Surgem planos, mas não há planejamento. Um plano de desenvolvimento requer o planejamento da Administração Pública. O plano sem planejamento é uma formulação racional de ideias, mas sem nenhuma efetividade prática. O planejamento é o processo e o plano é a concretização9. Assim, para que exista a efetividade prática de um direito, faz-se necessário plano com o seu respectivo planejamento.

Existe diferença entre política de Estado e política de Governo. Na primeira o horizonte temporal é medido em décadas, políticas constitucionalizadas e, em relação à segunda, as políticas se realizam como parte de um programa maior, com suporte infralegais ${ }^{10}$. Para a referida autora, não se reconhece à noção de política pública o sentido de uma categoria nova no direito.

Por fim, Bucci traz o quadro referência que sintetiza o caráter sistemático que articula os elementos mais importantes que integram a política pública e indica os seguintes elementos: 1) Nome oficial do programa de ação; 2) Gestão governamental; 3) Base normativa; 4) Desenho jurídico-institucional; 5) Agentes governamentais; 6) Agentes não governamentais; 7) Mecanismos jurídicos de articulação; 8) Escala e público-alvo; 9) Dimensão econômico-financeira do programa; 10) Estratégica de implantação; 11) Funcionamento efetivo do programa e 12) Aspectos do desenho jurídico-institucional ${ }^{11}$.

Em relação ao nosso tema moradia, aplicando o quadro de referência ao PMCMV temos os seguintes elementos que integram a política pública: 1) a nome oficial do programa é Programa Minha Casa Minha Vida (PMCMV), 2) a gestão é da União, 3) a base normativa é a Lei 11.977/09, 4) Programa Nacional de Habitação Urbana e Rural, 5) os agentes governamentais são a União, Estados, Municípios e Distrito Federal, 6) os agentes não governamentais são os beneficiários, cooperativas habitacionais, associações de moradores, fundações, organizações da sociedade civil, 7) mecanismos jurídicos de articulação, 8) famílias com renda de até $\mathrm{R} \$ 4.650,00,9)$ a dimensão econômico-financeira é de $\mathrm{R} \$ 16.500 .000 .000$,00 para o fundo de arrendamento residencial-FAR e $\mathrm{R} \$ 500.000 .000,00$ para o fundo de desenvolvimento social-FDS, 10) estratégia de implantação, 11) funcionamento efetivo do programa e 12) desenho jurídico-institucional.

Não é o objetivo deste artigo analisar, profundamente, o PMCMV, uma vez que, para isso, faz-se necessário trabalho com pesquisa de dados estatísticos, pesquisa de campo, revisão da literatura e, provavaelmente,

8 BUCCI, Maria Paula Dallari. Fundamentos para uma teoria jurídica de politicas públicas. São Paulo: Saraiva, 2013. p. 43.

9 BERCOVICI, Gilberto. Planejamento e políticas públicas: por uma nova compreensão do papel do Estado. In: BUCCI, Maria Paula Dallri (Org.). Políticas Públicas: reflexões sobre um conceito jurídico. São Paulo: Saraiva, 2006. p. 143-161. p. 145-148.

10 BUCCI, Maria Paula Dallari. O conceito de política pública em direito. In: (Org.). Políticas Públicas: reflexões sobre o conceito jurídico. São Paulo: Saraiva, 2006. p. 12.

11 BUCCI, Maria Paula Dallari. Quadro de referência de uma política pública: primeiras linhas de uma visão jurídico-institucional. In: SMANIO, Gianpaolo Poggio; BERTOLIN, Patrícia Tuma Mantins; BRASIL, Patricia Cristina (Org.). O direito na fronteira das políticas públicas. São Paulo: Páginas e Letras, 2015. p. 9-11. 
anos de pesquisa para que se possa detectar a situação concreta do programa. No presente artigo científico, o método escolhido foi o sintético ${ }^{12}$, além da revisão bibliográfica descritiva, exploratória em que serão analisados leis e normas, relatórios técnicos, livros, artigos, teses e dissertações, além da busca em sites do Governo e do Poder Judiciário.

Assim, após a análise das políticas públicas voltadas à moradia no Brasil, podemos perceber que nem sempre esse direito é concretizado, o que faz surgir o seguinte questionamento: quais são os limites para o Poder Judiciário interferir nas políticas públicas criadas pelo Executivo? Esses limites são o mínimo existencial, a reserva do possível e a separação dos poderes, objetos do próximo tópico desde artigo.

\section{Limites À INTERVEnÇÃo do Poder JudiciáRIO: O MíNIMO EXISTENCIAL, A RESERVA do POSSÍVEL E A SEPARAÇÃo dOS PODERES}

O que podemos fazer para mudar esse quadro relacionado à falta de habitação? Esse direito fundamental à moradia é uma necessidade humana vital, biológica e indispensável para uma vida digna. Não existe vida digna sem moradia também digna. Uma das funções da propriedade urbana é a consecução da moradia, pois o direito à moradia é um direito ao acesso à propriedade da habitação, que, por meio do mercado imobiliário, chegamos à propriedade.

Os constitucionalistas tratam esse direito como um direito humano, de segunda geração ou dimensão e como um direito fundamental social, já os civilistas como um direito real de conteúdo patrimonial, é o que diz Milagres ${ }^{13}$ quando entende que: "na visão constitucional, o direito à moradia configura direito fundamental de segunda geração ou dimensão, de conteúdo mínimo, objeto de implementação gradativa mediante a realização de políticas públicas".

Já Souza defende ser o direito à moradia um exercício que deve ser protegido e efetivado pelo Estado:

O direito à moradia torna-se um exercício que deve ser naturalmente protegido e efetivado pelo Estado, independentemente de norma infraconstitucional ou constitucional, já que decorre de um estado de necessidade do indivíduo e, em contrapartida, de um dever legal assumido pelo Estado Brasil, inclusive perante organizações internacionais ${ }^{14}$.

O direito à moradia não se resume a programas habitacionais, mas às condições de habitabilidade proporcionadas pelos centros urbanos e que a impossibilidade de um pleno exercício deste impõe custo muito elevado para a sociedade e, por conseguinte, demanda efetiva sobre o Poder Público ${ }^{15}$.

Assim, surge como primeiro limite à intervenção do judiciário nas políticas públicas a garantia do mínimo existencial ${ }^{16}$, considerado um direito às condições mínimas de existência humana digna que exige prestações positivas por parte do Estado; o segundo limite é a razoabilidade, que mede-se pela aplicação do princípio da proporcionalidade, que significa a busca do justo equilíbrio entre os meios empregados e os fins a serem alcançados; e o terceiro limite é a reserva do possível, conhecida como disponibilidade financeira,

12 Sintetizar os argumentos implica construir o sumário, ou melhor, dividir as partes de um todo com o espírito de resumi-las. Se apoia na ideia de uma divisão lógica dos argumentos ao apresentar e construir um texto jurídico. MONEBHURRUN, Nitish. Manual de metodologia jurídica: técnicas para argumentar em textos jurídicos. São Paulo: Saraiva, 2015.

13 MILAGRES, Marcelo de Oliveira. Direito à moradia. São Paulo: Atlas, 2011. p. 63.

14 SOUZA, Sergio Iglesias Nunes de. Direito à moradia e de habilitação: análise comparativo e seu aspecto teórico e prático com os direitos da personalidade. 3. ed. São Paulo: Revista dos Tribunais, 2013. p. 213.

15 MUKAI, Toshio. Temas de direito urbanistico e ambiental. Belo Horizonte: Fórum, 2007. p. 66.

16 Compreendamos como núcleo essencial de um direito fundamental o mínimo necessário a ser realizado pelo Estado para o reconhecimento do próprio valor que se almejou resguardar juridicamente. Em suma, a Administração não pode — porque sequer é facultado ao Legislativo - deixar de cumprir o núcleo essencial de um direito à prestação se este direito qualifica-se como direito fundamental. PIRES, Luis Manuel Fonseca. Controle judicial da discricionariedade administrativa: dos conceitos jurídicos indeterminados às políticas públicas. 2. ed. Belo Horizonte: Fórum, 2013. p. 268 -270. 
que deverá ser comprovada pela administração, aplicando, inclusive, a inversão do ônus da prova e, sendo comprovada a falta de previsão orçamentária, o Poder Judiciário faz constar, na próxima proposta orçamentária, verba necessária à implementação da política pública ${ }^{17}$.

É sabido que, com o elevado número de pessoas nas cidades, surgem os problemas, dentre eles a violência, malhas viárias estreitas, o desemprego em massa, o trabalho informal e a falta de moradia. Assim, não se pode imaginar a dignidade de uma pessoa que sequer tenha acesso a um lar digno, como forma de garantir o mínimo existencial, esse é entendimento de Roguet:

[...] não basta que o Estado propicie o simples habitar ao cidadão, devendo estruturar uma moradia que possibilite o desenvolvimento dos atos básicos de higiene pessoal, acesso às redes de esgoto e saneamento, área não isoladas e acessíveis com transporte público, contando com escolas e postos de saúde, como forma de garantir o mínimo existencia ${ }^{18}$.

Considerar que a moradia é um mínimo existencial, apesar de ser adequado, não é unânime, mas o teórico Marshall entendeu que o direito à moradia é mínimo Marshall:

Mas o direito básico de ter o cidadão uma moradia, seja lá qual for, é mínimo. Ele não pode reivindicar mais do que um teto sobre sua cabeça, e sua reivindicação poder ser atendida, como vimos nos últimos anos, por um cômodo num cinema abandonado transformado num centro de recuperação ${ }^{19}$.

Parte da doutrina entende que a moradia não seria um direito que pudesse ser exigido em face do Estado, ou seja, não autoriza dizer que a norma reconhece a obrigação do Estado dar uma casa a cada ser humano, esse é o pensar de Mattos:

Importa destacar, entretanto, que tal entendimento não autoriza dizer que a norma reconhece a obrigação do Estado de dar uma casa para cada indivíduo, assim como a norma estabelecida no artigo $7^{\circ}$ da Constituição não reconhece o direito subjetivo a um emprego e, sim, a criação genérica de oportunidades de trabalho e proteção ao trabalhador ${ }^{20}$.

Com o mesmo pensar, entende Souza ${ }^{21}$ que o direito de moradia não guarda relação obrigatória com o direito de propriedade, não podendo exigir do Estado um imóvel para todos:

o fato de todos terem o direito à moradia, portanto, não significa que têm o direito de exigir que o Estado dê um imóvel para todos. Não podemos jamais fazer tal afirmação. Pois o direito à moradia não guarda relação obrigatória com o direito de propriedade ${ }^{22}$

Para essa parte da doutrina, o segundo limite à interferência do Poder Judiciário é a reserva do possível como argumento contrário à concretização dos direitos fundamentais, exigindo que as pretensões formuladas em face do Estado sejam analisadas com a devida razoabilidade. Dentre as várias acepções da razoabilidade, Ávila destaca três, a primeira como equidade, a segunda similar à congruência e a terceira equiparada à equivalência:

primeiro, a razoabilidade é utilizada como diretriz que exige relação das normas gerais com as individuais do caso concreto, quer mostrando sob a qual perspectiva a norma deve ser aplicada, quer indicando em quais hipóteses o caso individual, em virtude de suas especificidades, deixa de se enquadrar na

17 GRINOVER, Ada Pellegrini. O controle das políticas públicas pelo poder judiciário. Revista do Curso de Direito da Faculdade de Humanidades e Direito, v. 7, n. 7, p. 9-37, 2010. p. 18-26.

18 ROQUET, Patrícia; CHOHFI, Roberta Dib. Políticas públicas e moradia: rumo a concretização do direito à cidade. In: SMANIO, Gianpaolo Poggio; BERTOLIN, Patrícia Tuma Mantins (Org.). O direito e as políticas públicas no Brasil. São Paulo: Atlas, 2013. p. 302-322. p. 310.

19 MARSHALL, Thomaz Humphrey. Cidadania, classe social e status. Rio de Janeiro: Zahar, 1967. p. 97.

20 MATTOS, Liana Portilho. Nova ordem jurídica-urbanística: função social da propriedade na prática dos tribunais. Rio de Janeiro: Lumen Juris, 2006. p. 79.

21 SOUZA, Sergio Iglesias Nunes de. Direito à moradia e de habilitação: análise comparativo e seu aspecto teórico e prático com os direitos da personalidade. 3. ed. São Paulo: Revista dos Tribunais, 2013. p. 165.

22 SOUZA, Sergio Iglesias Nunes de. Direito à moradia e de habilitação: análise comparativo e seu aspecto teórico e prático com os direitos da personalidade. 3. ed. São Paulo: Revista dos Tribunais, 2013. p. 165. 
norma geral. Segundo, a razoabilidade é empregada como diretriz que exige uma vinculação das normas jurídicas com o mundo ao qual se faz referência, seja reclamando a existência de um suporte empírico e adequado a qualquer ato jurídico, seja demandando uma relação congruente entre a medida adotada e o fim que ela pretende atingir. Terceiro, a razoabilidade é utilizada como diretriz que exige a relação de equivalência entre duas grandezas. ${ }^{23}$

$\mathrm{Na}$ equidade deve-se analisar o que normalmente acontece, verificando as circunstâncias do fato e o aspecto individual do caso. Já na congruência, utilizaremos o suporte empírico e a relação congruente entre o critério de diferenciação escolhido e a medida adotada. Por fim, na equivalência, utiliza-se da equivalência entre a medida adotada e o critério que a dimensiona.

Interessante é o pensar de Fonte em relação à reserva do possível, quando defende que se pode condicionar a existência de previsão orçamentária futura, incluídos na lista de precatórios:

assim, seria interessante e justo que as sentenças nesta matéria reconhecessem o direito prestacional pretendido na demanda, mesmo que fosse para condicioná-lo à existência de previsão orçamentária futura, quem sabe até incluí-los na lista de precatórios alimentares prevista no art. 100 da Constituição Federal de $1988 .^{24}$

Nessa linha de pensamento, constata-se que o fenômeno econômico tem sido invocado para impedir a concessão de direitos fundamentais sociais pelo Poder Judiciário. Alega-se, em geral, que o Poder Judiciário não pode conceder direitos cuja satisfação demandará receitas não disponíveis pelo Estado. Tal fundamento, contudo, traz em si a desconsideração de que o Estado brasileiro possui objetivos a serem, efetivamente, atendidos, de tal forma que o orçamento há de servir como instrumento para a respectiva realização e não como óbice. ${ }^{25}$

Já Pires defende que o argumento do afastamento do controle judicial com fundamento na legislação orçamentária cai por terra uma vez que a administração possuiu mais de uma opção de ação, pois sua competência não é vinculada:

não há amaras à Administração com rubricas detalhadas e minimamente precisas sobre o emprego do dinheiro público, o que representa, inclusive, a espargida liberdade discricionária de que goza o Executivo na escolha das políticas públicas e a respectiva definição dos meios.

Por isso, diante da pluralidade de opções padece o argumento que pretende afastar o controle judicial com fundamento na legislação orçamentária como se à Administração fosse conferida apenas uma única opção de ação, como se fosse uma competência vinculada. ${ }^{26}$

Para Liberati, defende-se a reserva do financeiramente possível, uma vez que não é o Estado que fixa o montante de recursos disponíveis para a concretização das ações, mas sim o legislador:

[..] no sentido de que ao estado somente poderia ser exigida a execução dos direitos sociais, se tivesse efetiva capacidade financeira para isso. Todavia, não é o Estado que fixa o montante de recursos disponíveis para a concretização das ações. Tal dever compete ao legislador, que ajusta o orçamento pretendido pelo Estado, configurando uma reserva constitucional da efetiva capacidade de prestação do Estado

\section{$[\ldots]^{27}$}

Esse argumento usado pelo Poder Público que a falta de dinheiro é um dos entraves à aplicação do direito fundamental à moradia não é adequado, uma vez que, segundo Milagres a insuficiência de fundos não pode ser causa da não efetividade desse direito:

23 ÁVILA, Humberto. Teoria dos princípios da definição à aplicaşão dos princípios jurídicos. 13. ed. São Paulo: Malheiros, 2012. p. 173.

24 FONTE, Felipe de Melo. Políticas públicas e direitos fundamentais. São Paulo: Saraiva, 2013. p. 147.

25 CANELA JUNIOR, Osvaldo. Controle judicial de políticas públicas. São Paulo: Saraiva, 2011. p. 102.

26 PIRES, Luis Manuel Fonseca. Controle judicial da discricionariedade administrativa: dos conceitos jurídicos indeterminados às políticas públicas. 2. ed. Belo Horizonte: Fórum, 2013. p. 261.

27 LIBERATI, Wilson Donizeti. Políticas públicas no estado constitucional. São Paulo: Atlas, 2013. p. 119. 
é preciso vencer essas limitações ou restrições. A ausência ou insuficiência de recursos estatais não pode ser causa da não efetividade do direito à moradia, que, pela sua essencialidade e pelo seu caráter existencial, pode ir muito além de uma concepção de direito fundamental social. ${ }^{28}$

Por outro lado, o terceiro limite à interferência do Poder Judiciário nas políticas públicas de moradia é a teoria da separação dos poderes. Ocorre que essa teoria não é absoluta, nem no que se refere ao aspecto filosófico nem em sua positivação jurídica. Assim, sobre o tema Pires entende que é possível o Judiciário intervir para recompor a ordem jurídica toda vez que for violada por ação ou omissão do Poder Público:

em suma, a divisão das funções e a distribuição destas aos diferentes órgãos nunca foi absoluta e estanque, e mesmo ao se partir da realidade positiva do nosso sistema jurídico, a independência dos Poderes reclama, em igual passo, a harmonia entre si (art. $2^{\circ}$ da Constituição Federal), o que caracteriza, nos moldes delineados pela ordem constitucional, a realização do chamado sistema de "freios e contrapesos" - isto é, e em análise do presente tema, a indiscutível possibilidade, o dever, de o Judiciário intervir para recompor a ordem jurídica toda vez que esta for violada por ação ou omissão do Executivo ${ }^{29}$.

Notamos, portanto, nova conformação do Estado por via de consectário lógico da teoria da separação dos poderes. Essa teoria não pode, evidentemente, ser um fim em si mesma e deve estar estritamente ligada às finalidades do Estado. Por conseguinte, com a alteração das finalidades estatais, altera-se igualmente a concepção da Teoria da Separação dos Poderes. A estabilidade objetiva no Estado liberal é substituída pelo dirigismo estatal, alterando-se, de forma profunda, a concepção da teoria da separação dos poderes. Dentro desse quadro, o Estado existe para atender ao bem comum, o que representa a satisfação espontânea dos direitos fundamentais. Não é possível a invocação do princípio da separação dos poderes para a não apreciação da pretensão do titular do direito fundamental social ${ }^{30}$.

Assim, detecta-se que os três limites à atuação do Poder Judiciário sobre as políticas públicas de moradia não são razoáveis, tampouco adequados, tratando-se de retórica, uma vez que, considerando que a moradia é núcleo essencial do direito fundamental, por se tratar de mínimo existencial, não pode o Estado deixar de realizar e concretizar esse direito.

\section{Possibilidade/necessidade da interferência do Poder Judiciákio nas políticas PÚBLICAS DE MORADIA INEFICAZES}

Essas políticas públicas voltadas à habitação são realizadas pelo Poder Executivo por meio dos programas de governo. Ocorre que, na falta desse poder executivo, cabe ao Poder Judiciário atuar na concretização dessas políticas públicas (judicialização da política), com a revisão das decisões e atos omissos dos demais poderes, esse é o pensar de Matsumoto "é possível e legítimo que o Poder Judiciário atue na concretização de políticas públicas, sendo também um garantidor da eficácia constitucional [...]”31

Mesmo entendendo que é preciso descobrir alternativas para se evitar a Judicialização, sem deixar os direitos desatendidos, Duarte defende que é possível a interferência do judiciário quando houver falhas nas políticas públicas:

quando houver uma falha no cumprimento desse dever, o Executivo pode ser obrigado por uma autoridade judicial a executar o que deve? Entendemos que sim, pois no Estado Social e Democrático de Direito, as políticas públicas são o objeto primário dos direitos sociais, e, na sua ausência ou insuficiência,

28 MILAGRES, Marcelo de Oliveira. Direito à moradia. São Paulo: Atlas, 2011. p. 64

29 PIRES, Luis Manuel Fonseca. Controle judicial da discricionariedade administrativa: dos conceitos jurídicos indeterminados às políticas públicas. 2. ed. Belo Horizonte: Fórum, 2013. p. 262.

30 CANELA JUNIOR, Osvaldo. Controle judicial de politicas públicas. São Paulo: Saraiva, 2011. p. $72-94$.

31 MATSUMOTO, Meggie Iara; BARBOSA, Claudia Maria. A legitimidade do poder judiciário na condução de políticas públicas para a realização de direito fundamentais. In: PAMPLONA, Danielle Anne. (Coord.). Políticas públicas: elementos para alcance do desenvolvimento sustentável. Curitiba: Juruá, 2012. p. 170. 
os indivíduos e grupos podem compelir o Estado a executar o que deve ${ }^{32}$.

Não restam dúvidas que, para efetivar os direitos fundamentais, as instituições jurídicas, órgãos e poderes do Estado podem sofrer o controle necessário, esse é o pensar de Smanio:

essa conceituação jurídica permite que as Instituições Jurídicas e os órgãos e Poderes do Estado possam efetivar as decisões Políticas e sofrer o controle necessário de sua atuação, sobretudo para assegurar os direitos fundamentais constitucionalmente estabelecidos. ${ }^{33}$

É bom frisar que a execução das políticas públicas é uma competência discricionária da administração pública que deve realizar metas presentes da Lei Maior e nas Leis Ordinárias para que se atenda o interesse público, por isso todo ato e toda atividade do Estado relacionado às políticas públicas sujeitam-se ao controle do Poder Judiciário, senão vejamos o que entende Pires:

por isso, todo ato e toda atividade da Administração Pública que realizam - ou deveriam realizar uma política sujeitam-se ao controle judicial dos seus pressupostos e/ou elementos vinculados, como competência ou sujeito, o motivo de fato, a motivação e a finalidade - e esta última conforme a teoria da finalidade. Outrossim, o espaço legítimo da discricionariedade administrativa de uma política pública deve ser aferido no âmbito normativo e no exercício da função administrativa - neste último caso, em relação ao momento de ação, à forma, aos requisitos procedimentais, à formalização, ao objeto, ao conteúdo e ao motivo. Pois o que confirma ou infirma o espaço legítimo da discricionariedade administrativa de uma política pública é o procedimento de ponderação da teoria dos princípios. ${ }^{34}$

No mesmo sentido, é o entendimento de Barroso, quando afirma que pode o judiciário impor ou invalidar ações administrativas e políticas públicas, sempre que o judiciário estiver atuando para preservar um direito fundamental:

é nesse ambiente, é nessa dualidade presente no Estado constitucional democrático que se coloca essencial: podem juízes e tribunais interferir com as deliberações dos órgãos que representam maiorias políticas isto é, o Legislativo e o Executivo - impondo ou invalidando ações administrativas e políticas públicas? A resposta será afirmativa sempre que o Judiciário estiver atuando, inequivocamente, para preservar um direito fundamental previsto na Constituição ou para dar cumprimento a alguma lei existente. Vale dizer: para que seja legítima, a atuação não pode expressar um ato de vontade própria do órgão julgador, precisando reconduzir-se a uma prévia deliberação majoritária, seja da constituição, seja do legislador. ${ }^{35}$

O equilíbrio de constitucionalidade, pois, é atingido quando o Poder Judiciário, em atividade residual e integradora, dá completude ao sistema, mediante a prolação de sentença, na qual vincula os agentes públicos à satisfação do bem da vida protegido pelo direito fundamental social. ${ }^{36}$

O Estado Social e Democrático de Direito considera alguns direitos fundamentais como deveres de ação por parte do Poder Púbico — ou pela perspectiva do administrado, como direitos a prestações, exigindo-se prestações positivas, elucida Pires:

pois é nesta dimensão dos direitos a prestações contra o Estado, que muitas vezes decorrem de direitos sociais, e outras não poucas de direitos individuais, mas que são sempre - dos direitos sociais e os direitos individuais - verdadeiros direitos fundamentais, que se apresenta de inestimável valia a teoria do núcleo essencial dos direitos fundamentais. ${ }^{37}$

32 DUARTE, Clarice Seixas. Para além da judicialização: a necessidade de uma nova forma de abordagem das políticas públicas. In: SMANIO, Gianpaolo Poggio; BERTOLIN, Patrícia Tuma Martins; BRASIL, Patrícia Cristina (Org.). O direito na fronteira das políticas públicas. São Paulo: Páginas e Letras, 2015. p. 18.

33 SMANIO, Gianpaolo Poggio. Legitimidade jurídica das políticas públicas: a efetivação da cidanania. In: SMANIO, Gianpaolo Poggio; BERTOLIN, Patrícia Tuma Mantins (Org.). O direito e as políticas públicas no Brasil. São Paulo: Atlas, 2013. p. 3-15. p. 10.

34 PIRES, Luis Manuel Fonseca. Controle judicial da discricionariedade administrativa: dos conceitos jurídicos indeterminados às políticas públicas. 2. ed. Belo Horizonte: Fórum, 2013. p. 259.

35 BARROSO, Luis Roberto. Da falta de efetividade à judicialização excessiva: direito à saúde, fornecimento de medicamentos e parâmetros para a atuação judicial. In: SOUZA NETO, Claudio Pereira de; SARMENTO, Daniel. Direitos sociais: fundamentos, judicialização e direitos sociais em espécie. Rio de Janeiro: Lumen Juris, 2010. p. 875-904. p. 882.

36 CANELA JUNIOR, Osvaldo. Controle judicial de políticas públicas. São Paulo: Saraiva, 2011. p. 96.

37 PIRES, Luis Manuel Fonseca. Controle judicial da discricionariedade administrativa: dos conceitos jurídicos indeterminados às políti- 
Já Duarte entende que as questões referentes às políticas públicas podem chegar ao Judiciário por meio de ações individuais e este pode, no caso de falhas ou desvios, aplicar o direito:

ainda que essas questões cheguem ao Judiciário por meio de ações individuais, o que deve ser apreciado é se existe uma política pública (objeto primário dos direitos sociais) em curso; se ela é adequada e suficiente; em caso negativo, qual é a razão disso; se os recursos previstos são apropriados para obtenção dos resultados pretendidos e se está havendo correta aplicação dos mesmos. Em caso de falhas ou desvios, ainda que o pedido seja individual, não se trata de fazer realocação irracional e individualista de recursos, mas de aplicar o Direito em um caso concreto de omissão ou desvio de Poder Público, o que, nos termos do artigo $5^{\circ}$, inciso XXXV, da Constituição, constitui lesão a direito e, como tal, não pode ser excluída da apreciação do Judiciário. ${ }^{38}$

Ainda sobre a possibilidade de uma ação individual para o controle das políticas públicas, explica Grinover: "qualquer tipo de ação - coletiva, individual com efeitos coletivos ou meramente individual — pode ser utilizada para provocar o Poder Judiciário a exercer o controle e a possível intervenção em políticas públicas" 39

No mesmo sentir, Roquet defende que o Juiz deve ser coautor das políticas públicas, atuando o Poder Judiciário na sua função de controle:

diante dessa nova ordem denominada 'judicialização política', contando com o juiz como coautor das políticas públicas, fica claro que sempre que os demais poderes comprometerem a integridade e a eficácia dos fins do Estado — incluindo os dos direitos fundamentais, individuais e coletivos — o Poder Judiciário deve atuar na sua função de controle.

Com efeito, se é possível controlar cada ato estatal, deve também ser possível controlar o todo e a movimentação rumo ao todo. Assim como agredir um princípio é mais grave que transgredir uma norma, empreender uma política — que é um plexo de atos — que seja em si mesma injurídica é mais grave que praticar um simples ato contrário ao Direito. ${ }^{40}$

Diferente não é o caminho de Pontes que em sua tese de doutorado defendeu a intervenção do poder judiciário nas políticas públicas:

a utilização de certos instrumentos jurídicos, bem como a provocação do Poder Judiciário, ante as decisões que se mostrem contrárias aos preceitos constitucionais, com a respectiva publicização de tais entendimentos, força, em certa medida, a evidência das manifestações de cunho meramente proprietário ${ }^{41}$.

A figura do direito público subjetivo, quando utilizada para proteger um bem que é ao mesmo tempo individual e social, deve se prestar à exigibilidade do caráter coletivo de tais direitos, ou seja, à exigibilidade de políticas públicas. No caso do direito público subjetivo, a pretensão individual é concorrente e não substitutiva em relação à pretensão pública ${ }^{42}$.

Corroborando esses entendimentos, o Supremo Tribunal Federal decidiu que pode o Poder Judiciário, em caráter excepcional, interferir na formulação e implementação das políticas públicas, sempre que comprometer a eficácia dos direitos constitucionais:

cas públicas. 2. ed. Belo Horizonte: Fórum, 2013. p. 268.

38 DUARTE, Clarice Seixas. O Ciclo das Políticas Públicas. In: SMANIO, Gianpaolo Poggio; BERTOLIN, Patrícia Tuma Mantins (Org.). O direito e as políticas públicas no Brasil. São Paulo: Atlas, 2013. p. 16-43. p. 35.

39 GRINOVER, Ada Pellegrini. O controle das políticas públicas pelo poder judiciário. Revista do Curso de Direito da Faculdade de Humanidades e Direito, v. 7, n. 7, p. 9-37, 2010. p. 35.

40 ROQUET, Patrícia; CHOHFI, Roberta Dib. Políticas públicas e moradia: a falta de acompanhamento como óbice à concretização do direito à cidade. In: SMANIO, Gianpaolo Poggio; BERTOLIN, Patrícia Tuma Martins; BRASIL, Patrícia Cristina (Org.). O direito na fronteira das politicas públicas. São Paulo: Páginas e Letras, 2015. p. 86.

41 PONTES, Daniele Regina. Direito à moradia: entre o tempo e o espaço das apropriações. 2012. Tese (Doutorado) - Universidade Federal do Paraná, Curitiba, 2012. p. 201

42 DUARTE, Clarice Seixas. Direito público subjetivo e políticas educacionais. In: BUCCI, Maria Paula Dallari (Org.). Politicas públicas: reflexões sobre o conceito jurídico. São Paulo: Saraiva, 2004. p. 113-118. p. 116-117. 
impende assinalar, no entanto, que tal incumbência poderá atribuir-se, embora excepcionalmente, ao Poder Judiciário, se e quando os órgãos estatais competentes, por descumprirem os encargos políticosjurídicos que sobre eles incidem em caráter mandatário, vierem a comprometer, com tal comportamento, a eficácia e a integridade de direitos individuais e/ou coletivos impregnados de estatura constitucional, como sucede na espécie em exame (STF, Agravo Regimental no Recurso Extraordinário n. ${ }^{\circ}$ 410.715-5)

Quanto à legitimidade para propor ação de inconstitucionalidade de políticas públicas explica Comparato:

[...] ser atribuída não apenas a órgãos estatais, como o Ministério Público e as Mesas Diretoras das Câmaras Legislativas, mas também a partidos políticos, ainda que não representados no órgão legislativo, a sindicatos ou entidades de classe, à Ordem dos Advogados do Brasil e mesmo, analogamente ao que ocorre em matéria de defesa do consumidor, a quaisquer outras organizações não-governamentais, constituídas e em funcionamento há pelo menos um ano. ${ }^{43}$

Já Barcellos defende que as políticas públicas sofrem limitações jurídicas genéricas que decorre do Estado republicano:

se a Constituição contém normas nas quais estabelecem fins públicos prioritários, e se tais disposições são normas jurídicas, dotadas de superioridade hierárquica e de centralidade no sistema, não haveria sentido em concluir que a atividade de definição das políticas públicas — que irá, ou não, realizar esses fins — deve estar totalmente infensa ao controle jurídico. Em suma: não se trata da absorção do político pelo jurídico, mas apenas da limitação do primeiro pelo segundo. E com isto chega-se à última a fazer neste ponto. (grifo no autor) ${ }^{44}$

\section{$[\ldots]$}

Assim, além da vinculação específica aos fins prioritários contidos no texto constitucional, a definição das políticas públicas e, consequentemente, do destino a ser dado aos recursos públicos, sofre limitação jurídica genérica que decorre do próprio Estado republicano. ${ }^{45}$

Por outro lado, esse pensar não é unânime, uma vez que Virgílio Afonso da Silva possui entendimento contrário, quando afirma que não podem os juízes ignorar as políticas públicas existentes, concedendo, de forma irracional e individual, medicamentos ou tratamentos:

não é possível, devido a razões que serão analisadas mais adiante, que os direitos sociais sejam tratados como se tivessem a mesma estrutura que têm os chamados direitos individuais (civis e políticos), ou seja, juízes não podem ignorar as políticas públicas já existentes nessas áreas, concedendo, de forma irracional e individualista, medicamentos, tratamentos de saúde ou vagas em sala de aula a todo aquele que recorrer ao Judiciário. ${ }^{46}$

Com o mesmo sentir, Appio, em sua tese de doutorado, posicionou-se contra a interferência do Poder Judiciário nas políticas públicas por entender que é incompatível com a democracia, uma vez que repele a atuação de instâncias não eleitas que pretendem promover seus programas próprios:

nesse sentido, o processo de formulação das políticas públicas não pode ser decorrência da vontade dos legitimados ativos para ações de controle concentrado de constitucionalidade ou ações coletivas. Aceitar que instituições específicas da comunidade organizada - em favor das quais o legislador autorizou a promoção de ações que visam proteger bens coletivos — detenham legitimidade para formular políticas públicas que vinculem os governos eleitos se revela incompatível com a concepção de democracia constitucional, a qual repele a atuação direta de instâncias não eleitas que pretendem promover seus programas próprios de ação estatal sem qualquer vinculação com a sociedade. ${ }^{47}$

43 COMPARATO, Fábio Konder. Ensaio sobre o juízo de constitucionalidade de políticas públicas. In: MELLO, Celso Antonio Bandeira de (Org.). Estudos em homenagem a Geraldo Ataliba. São Paulo: Malheiros, 1997. p. 39-48. p. 47.

44 BARCELLOS, Ana Paula. Neoconstitucionalismo, direitos fundamentais e controle das políticas públicas. Cadernos da Escola de Direito e Relações Internacionais, v. 1, n. 5, p. 125-135, jan./dez. 2005. p. 135.

45 BARCELLOS, Ana Paula. Neoconstitucionalismo, direitos fundamentais e controle das políticas públicas. Cadernos da Escola de Direito e Relações Internacionais, v. 1, n. 5, p. 125-135, jan./dez. 2005. p.135.

46 SILVA, Virgílio Afonso da. O judiciário e as políticas públicas: entre a transformação social e obstáculo à realização dos direitos sociais: In: SOUZA NETO, Claudio Pereira de; SARMENTO, Daniel (Org). Direitos sociais: fundamentos, judicialização e direitos sociais em espécie. Rio de Janeiro: Lumen Juris, 2010. p. 595.

47 APPIO, Eduardo Fernando. O controle judicial das politicas públicas no Brasil. 2004. 473 f. Tese (Doutorado) - Programa de Pós- 
Cumpre frisar que as garantias processuais — remédios jurídicos a serem exercidos perante os Tribunais — são importantes, mas não são suficientes para a satisfação dos direitos fundamentais que têm como objeto as políticas públicas. Afinal, a satisfação de uma demanda individual não resolve o problema do ponto de vista macro, levando em conta uma dimensão inerente às políticas públicas: a resolução de problemas em grande escala ${ }^{48}$.

Pelo exposto, pode-se concluir que é dever do Poder Executivo criar programas de governo para efetivar as políticas públicas de moradia, mas, no caso de omissão, não restam dúvidas que cabe ao Poder Judiciário intervir em tais políticas com o fim de concretizar esse direito fundamental.

\section{Considerações finais}

Pelo exposto, percebe-se que uma das funções do princípio da função social da propriedade urbana é se chegar à moradia, com o acesso à habitação e um lar digno, uma vez que não existe vida digna sem moradia. Para isso, um dos caminhos para a efetivação desse princípio social são as políticas públicas de moradia criadas pelo Executivo, que, quando omissas ou ineficazes, resta a atuação do Poder Judiciário, seja por meio de ações individuais ou coletivas, controlando e fiscalizando o Poder Executivo, no que se refere às políticas públicas de moradia, com o objetivo de concretizar o direito social à moradia e chegarmos a cidadania plena.

\section{REFERÊNCIAS BIBLIOGRÁfICAS}

ALEXY, Robert. Teoria dos direitos fundamentais. 2. ed. Tradução Virgílio Afonso da Silva. São Paulo: Malheiros, 2012.

ALMEIDA, Rafael Alves de. Gestão democrática na formatação de políticas públicas. 2015. 257 f. Tese (Doutorado) - Programa de Pós-Graduação em Políticas Públicas, Estratégias e Desenvolvimento, Instituto de Economia, Universidade Federal do Rio de Janeiro, Rio de Janeiro, 2015.

APPIO, Eduardo Fernando. O controle judicial das políticas públicas no Brasil. 2004. 473 f. Tese (Doutorado) Programa de Pós-Graduação em Direito, Universidade Federal de Santa Catarina, Florianópolis, 2004.

ÁVILA, Humberto. Teoria dos princípios da definição à aplicação dos princípios jurídicos. 13. ed. São Paulo: Malheiros, 2012.

BARCELLOS, Ana Paula. Neoconstitucionalismo, direitos fundamentais e controle das políticas públicas. Cadernos da Escola de Direito e Relações Internacionais, v. 1, n. 5, p. 125-135, jan./ dez. 2005.

BARROSO, Luis Roberto. Da falta de efetividade à judicialização excessiva: direito à saúde, fornecimento de medicamentos e parâmetros para a atuação judicial. In: SOUZA NETO, Claudio Pereira de; SARMENTO, Daniel. Direitos sociais: fundamentos, judicialização e direitos sociais em espécie. Rio de Janeiro: Lumen Juris, 2010. p. 875-904.

BERCOVICI, Gilberto. Planejamento e políticas públicas: por uma nova compreensão do papel do Estado. In: BUCCI, Maria Paula Dallri (Org.). Politicas Públicas: reflexões sobre um conceito jurídico. São Paulo: Saraiva, 2006. p. 143-161.

Graduação em Direito, Universidade Federal de Santa Catarina, Florianópolis, 2004. p. 421-422.

48 DUARTE, Clarice Seixas. Para além da judicialização: a necessidade de uma nova forma de abordagem das políticas públicas. In: SMANIO, Gianpaolo Poggio; BERTOLIN, Patrícia Tuma Martins; BRASIL, Patrícia Cristina (Org.). O direito na fronteira das políticas públicas. São Paulo: Páginas e Letras, 2015. p. 16. 
BONIZZATO, Luigi. Propriedade urbana privada e direitos sociais. Curitiba: Juruá, 2007.

BUCCI, Maria Paula Dallari. Fundamentos para uma teoria jurídica de políticas públicas. São Paulo: Saraiva, 2013.

BUCCI, Maria Paula Dallari. O conceito de política pública em direito. In: (Org.). Politicas Públicas: reflexões sobre o conceito jurídico. São Paulo: Saraiva, 2006. p. 25-27.

BUCCI, Maria Paula Dallari. Quadro de referência de uma política pública: primeiras linhas de uma visão jurídico-institucional. In: SMANIO, Gianpaolo Poggio; BERTOLIN, Patrícia Tuma Mantins; BRASIL, Patricia Cristina (Org.). O direito na fronteira das políticas públicas. São Paulo: Páginas e Letras, 2015.

CAFRUNE, Eibs Marcelo. Mediação de conflitos fundiários urbanos: do debate teórico à construção política. Revista da Faculdade de Direito da UniRitter, Porto Alegre, n. 11, p. 197-217, 2010.

CANELA JUNIOR, Osvaldo. Controle judicial de políticas públicas. São Paulo: Saraiva, 2011.

CARVALHO, José Murilo de. Cidadania no Brasil: o longo caminho. 3. ed. Rio de Janeiro: Civilização Brasileira, 2002.

COMPARATO, Fábio Konder. Ensaio sobre o juízo de constitucionalidade de políticas públicas. In: MELLO, Celso Antonio Bandeira de (Org.). Estudos em homenagem a Geraldo Ataliba. São Paulo: Malheiros, 1997. p. 39-48.

COMPARATO, Fábio Konder. Estado, reforma e desenvolvimento: a nova cidadania. Lua Nova: Revista de Cultura e Política, São Paulo, n. 28-29, p. 1-11, abr. 2008.

DIMOULIS, Dimitri; MARTINS, Leonardo. Teoria geral dos direitos fundamentais. 4. ed. São Paulo: Atlas, 2012.

DUARTE, Clarice Seixas. Direito público subjetivo e políticas educacionais. In: BUCCI, Maria Paula Dallari (Org.). Políticas públicas: reflexões sobre o conceito jurídico. São Paulo: Saraiva, 2004. p. 113-118.

DUARTE, Clarice Seixas. O Ciclo das Políticas Públicas. In: SMANIO, Gianpaolo Poggio; BERTOLIN, Patrícia Tuma Mantins (Org.). O direito e as políticas públicas no Brasil. São Paulo: Atlas, 2013. p. 16-43.

DUARTE, Clarice Seixas. Para além da judicialização: a necessidade de uma nova forma de abordagem das políticas públicas. In: SMANIO, Gianpaolo Poggio; BERTOLIN, Patrícia Tuma Martins; BRASIL, Patrícia Cristina (Org.). O direito na fronteira das políticas públicas. São Paulo: Páginas e Letras, 2015.

ECO, Humberto. Como se faz uma tese. 14. ed. São Paulo: Perspectiva, 1998.

FIGUEIREDO, Leonardo Vizeu. Lições de direito econômico. 7. ed. Rio de Janeiro, 2014.

FONTE, Felipe de Melo. Políticas públicas e direitos fundamentais. São Paulo: Saraiva, 2013.

FREITAS, Igor Vilas Boas. Avaliação de política pública no Senado Federal: proposta de abordagem. Brasília: Senado Federal, 2013. Disponível em: <https://www12.senado.leg.br/publicacoes/estudos-legislativos/ tipos-de-estudos/outras-publicacoes/avppsf/avaliacao-de-politicas-publicas-no-senado-federal-1>. Acesso em 10 set. 2015.

FUNDAÇÃO JOÃO PINHEIRO. Déficit Habitacional no Brasil: 2011-2012. Belo Horizonte, 2015.

GRINOVER, Ada Pellegrini. O controle das políticas públicas pelo poder judiciário. Revista do Curso de Direito da Faculdade de Humanidades e Direito, v. 7, n. 7, p. 9-37, 2010.

HERRERA, Carlos Miguel. Estado, constitución y derechos sociales. Revista Derecho del Estado, n. 15, p. 7592, dic. 2003.

LIBERATI, Wilson Donizeti. Políticas públicas no estado constitucional. São Paulo: Atlas, 2013. 
LOPES, Ana Maria D’Ávila. A cidadania na constituição brasileira de 1988: redefinindo a participação política. In: BONAVIDES, Paulo; LIMA, Francisco Gérson Marques; BEDÊ, Faya Silveira (Org.). Constituição e processo: estudos em homenagem a Prof. J. J. Canotinho. São Paulo: Malheiros, 2006. p. 21-33.

MACEDO FILHO, Renato. Onde mora a cidadania? Visibilizando a participação das mulheres no movimento sem teto. 2010. Tese (Doutorado) - Universidade Federal de Salvador, Salvador, 2010.

MARMELSTEIN, George. Curso de direitos fundamentais. 3. ed. São Paulo: Atlas, 2011.

MARSHALL, Thomaz Humphrey. Cidadania, classe social e status. Rio de Janeiro: Zahar, 1967.

MASCARO, Alysson Leandro. Crítica da legalidade e do direito brasileiro. 2. ed. São Paulo: Quartier Latin, 2008.

MATSUMOTO, Meggie Iara; BARBOSA, Claudia Maria. A legitimidade do poder judiciário na condução de políticas públicas para a realização de direito fundamentais. In: PAMPLONA, Danielle Anne (Coord.). Políticas públicas: elementos para alcance do desenvolvimento sustentável. Curitiba: Juruá, 2012.

MATTOS, Liana Portilho. Nova ordem jurídica-urbanistica: função social da propriedade na prática dos tribunais. Rio de Janeiro: Lumen Juris, 2006.

MILAGRES, Marcelo de Oliveira. Direito à moradia. São Paulo: Atlas, 2011.

MONEBHURRUN, Nitish. Manual de metodologia jurídica: técnicas para argumentar em textos jurídicos. São Paulo: Saraiva, 2015.

MUKAI, Toshio. Temas de direito urbanistico e ambiental. Belo Horizonte: Fórum, 2007.

PIRES, Luis Manuel Fonseca. Controle judicial da discricionariedade administrativa: dos conceitos jurídicos indeterminados às políticas públicas. 2. ed. Belo Horizonte: Fórum, 2013.

PONTES, Daniele Regina. Direito à moradia: entre o tempo e o espaço das apropriações. 2012. Tese (Doutorado) - Universidade Federal do Paraná, Curitiba, 2012.

RIBEIRO, Hélcio. Constituição, Participação e Políticas Públicas. In: SMANIO, Gianpaolo Poggio; BERTOLIN, Patrícia Tuma Mantins (Org.). O direito e as políticas públicas no Brasil. São Paulo: Atlas, 2013. p. 44-62.

RIZZO JUNIOR, Ovidio. Controle social de políticas públicas. 2009. Tese (Doutorado) - Faculdade de Direito da USP, São Paulo, 2009.

ROQUET, Patrícia; CHOHFI, Roberta Dib. Políticas públicas e moradia: a falta de acompanhamento como óbice à concretização do direito à cidade. In: SMANIO, Gianpaolo Poggio; BERTOLIN, Patrícia Tuma Martins; BRASIL, Patrícia Cristina (Org.). O direito na fronteira das políticas públicas. São Paulo: Páginas e Letras, 2015.

ROQUET, Patrícia; CHOHFI, Roberta Dib. Políticas públicas e moradia: rumo a concretização do direito à cidade. In: SMANIO, Gianpaolo Poggio; BERTOLIN, Patrícia Tuma Mantins (Org.). O direito e as políticas públicas no Brasil. São Paulo: Atlas, 2013. p. 302-322.

RUFINO, Maria Beatriz Cruz; SHIMBO, Lúcia Zanin; AMORE, Caio Santo (Org.). Minha casa... e a cidade? avaliação do programa minha casa minha vida em seis estados brasileiros. Rio de Janeiro: Letra capital, 2015.

SARLET, Ingo Wolfgang. A eficácia dos direitos fundamentais: uma teoria geral dos direitos fundamentais na perspectiva constitucional. 10. ed. Porto Alegre: livraria do Advogado, 2010.

SEVERINO, Antônio Joaquim. Metodologia do trabalho científico. 22. ed. São Paulo: Cortez, 2007.

SILVA, Solange Teles. Direito fundamental ao meio ecologicamente equilibrado: avanços e desafios. Revista de Direito Ambiental, v. 48, p. 224-247, 2007. 
SILVA, Virgílio Afonso da. O judiciário e as políticas públicas: entre a transformação social e obstáculo à realização dos direitos sociais: In: SOUZA NETO, Claudio Pereira de; SARMENTO, Daniel (Org). Direitos sociais: fundamentos, judicialização e direitos sociais em espécie. Rio de Janeiro: Lumen Juris, 2010. p. 875-904 SMANIO, Gianpaolo Poggio. As dimensões da cidadania. Revista da ESMP, v. 2, p. 13-23, jan./jun. 2009.

SMANIO, Gianpaolo Poggio. Cidadania e políticas públicas. In: ; BERTOLIN, Patrícia Tuma Mantins; BRASIL; Patricia Cristina (Org.). O Direito na Fronteira das Politicas Públicas. São Paulo: Páginas e Letras, 2015.

SMANIO, Gianpaolo Poggio. Legitimidade jurídica das políticas públicas: a efetivação da cidanania. In: SMANIO, Gianpaolo Poggio; BERTOLIN, Patrícia Tuma Mantins (Org.). O direito e as políticas públicas no Brasil. São Paulo: Atlas, 2013. p. 3-15.

SOUZA, Celina. Políticas públicas: uma revisão da literatura. Revista Sociologias, Porto Alegre, v. 8, n. 16, p. 20-45, jul./dez. 2006.

SOUZA, Luciane Moessa de. Meios consensuais de solução de conflitos envolvendo entes públicos e a mediação de conflitos coletivos. 2010. Tese (Doutorado) - Faculdade Federal de Santa Catarina, Florianópolis, 2010.

SOUZA, Sergio Iglesias Nunes de. Direito à moradia e de habilitação: análise comparativo e seu aspecto teórico e prático com os direitos da personalidade. 3. ed. São Paulo: Revista dos Tribunais, 2013. 


\section{REVISTA BRASILEIRA DE POLÍTICAS PÚBLICAS BRAZILIAN JOURNAL OF PUBLIC POLICY}

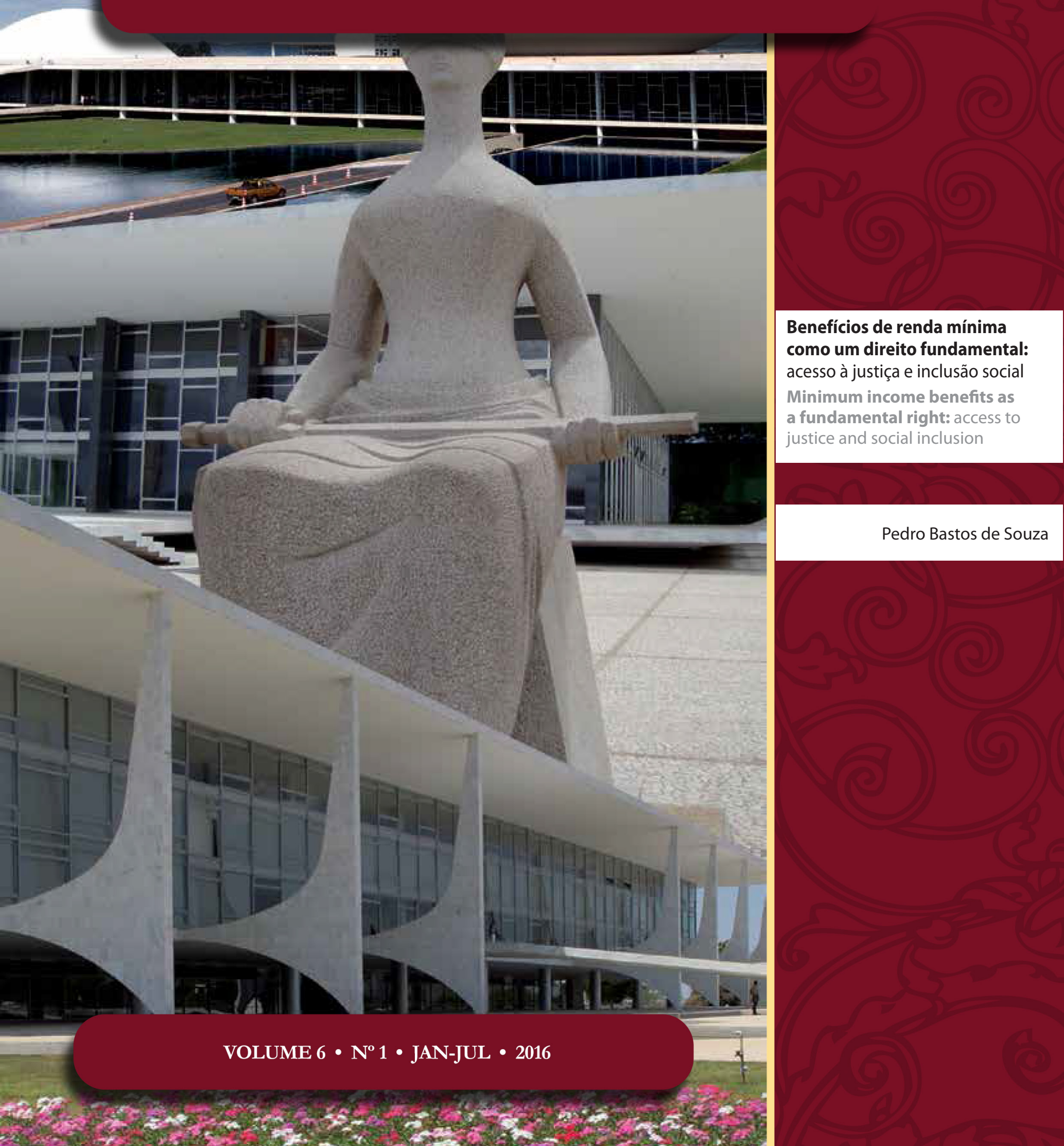




\title{
Benefícios de renda mínima como um direito fundamental: acesso à justiça e inclusão social*
}

\author{
Minimum income benefits as a fundamental \\ right: access to justice and social inclusion
}

Pedro Bastos de Souza**

\begin{abstract}
Resumo
O presente estudo debate a importância das políticas públicas de renda mínima, em especial o Bolsa Família e o Benefício de Prestação Continuada (BPC), como garantidoras do mínimo existencial. Ressalta a natureza de direito fundamental dessas prestações e sua relação de instrumentalidade para o exercício de cidadania e de outros direitos fundamentais. Aponta a exigibilidade desse direito perante o Judiciário, ainda que reconhecendo a dificuldade de acesso à justiça por parte dos cidadãos em estado de vulnerabilidade social.
\end{abstract}

Palavras-chave: Direitos fundamentais. Renda mínima. Dignidade humana.

\section{Abstract}

This study discusses the importance of minimum income benefits, especially Bolsa Família and BPC, as guarantors of a minimum survival. Underscores the nature of fundamental right of these benefits and their instrumentality relationship for the exercise of citizenship and other basic rights. Points to the enforceability of this right, while considering the difficulty of access to justice by citizens in social vulnerability condition.

Key-words: Fundamental rights. Minimum income benefits. Human dignity.

\section{INTRODUÇÃO}

Os direitos fundamentais, que, em um primário estágio, assumiram o caráter de direitos negativos, importaram uma restrição à ação do Estado. Posteriormente, passam a assumir uma postura ativa, exigindo ações positivas do Estado. Parece razoável fazer um silogismo entre os ideais de liberdade, igualdade e solidariedade e os direitos de primeira, segunda e terceira dimensões.

O Estado Constitucional estabelece metas, diretrizes ou princípios vinculados a valores e a opções políticas. No caso brasileiro, há uma preocupação normativa com a redução das desigualdades sociais com vistas à superação de um grave quadro social em que a população, em sua maioria, não consegue exercer, em plenitude, sua dignidade e sua cidadania. 
O fenômeno de constitucionalização do Direito, identificado com o Neoconstitucionalismo, representa a expansão dos valores presentes nos princípios e regras constitucionais para o restante do ordenamento jurídico. Por essa razão, a aplicabilidade direta da Constituição a um leque maior de situações, a inconstitucionalidade das normas incompatíveis com a Carta Constitucional e, o que é mais importante, a interpretação das normas infraconstitucionais de acordo com a Constituição.

Essa evolução de paradigma significa um maior apreço pelos direitos fundamentais e, principalmente, pela garantia de um mínimo existencial por meio da erradicação da pobreza. É tempo, pois, de dar maior densidade a termos que costumam aparecer nas constituições, como "sociedade livre, justa e solidária."

A efetividade da garantia de uma renda mínima também passa, inicialmente, pela própria possibilidade de acesso à justiça, pelo correto funcionamento da gestão pelo Poder Executivo e por uma atuação do Judiciário sensível à nova dogmática neoconstitucionalista. É o que se aborda no presente artigo, no qual também são analisados alguns posicionamentos-chave do Judiciário brasileiro.

O mínimo existencial pode ser considerado como o conjunto de condições materiais indispensáveis à existência humana, embora seu alcance seja variável no espaço e no tempo. Associado ao princípio da dignidade da pessoa humana, é um importante valor para a concretização dos direitos prestacionais fundamentais.

Benefícios de cunho social, como o Bolsa Família e o Benefício de Prestação Continuada exercem papel essencial tanto para a redução de desigualdades como para a eficácia do princípio da dignidade da pessoa humana. Por se tratar de indivíduos vivendo no limite ou abaixo da linha da pobreza, encontram-se em estado de vulnerabilidade social e têm dificuldade de acesso à assistência jurídica.

O presente estudo tem como objetivo evidenciar o caráter de direito fundamental dos benefícios de renda mínima como concretizadores do mínimo existencial e densificadores de princípios constitucionais expressos, como a redução das desigualdades sociais e regionais e a erradicação da pobreza.

Para atingir os objetivos propostos, apresentou-se revisão de literatura em que se relaciona a exclusão social com o acesso à justiça. Ainda em perspectiva teórica, buscou-se destacar a natureza de direito fundamental dos benefícios de renda mínima. Por fim, traçou-se um panorama do tratamento às questões envolvendo políticas de alívio à pobreza em nível micro por parte do Poder Judiciário.

\section{EXCLUSÃO SOCIAL E O ACESSO À JUSTIÇA}

A necessidade contemporânea da efetividade do processo, ao temperar a absoluta procura pela segurança jurídica racionalista, obriga que os princípios processuais constitucionais tenham nova roupagem, com vista a garantir ao titular do direito material instrumentos adequados a assegurar a realização plena de seu direito à luz dos direitos fundamentais do processo. O direito é, antes, uma categoria ética a exigir uma realização adequada e justa, ou seja, materialmente correta e normativamente plausível da juridicidade. Há, portanto, que se transformar o direito em um saber prático, rompendo com a objetificação dos textos legais. ${ }^{1}$

Conforme destacado por Cambi, ${ }^{2}$ a supremacia da Constituição sobre a lei e a repulsa à neutralidade da lei e da jurisdição encontram, no artigo $5^{\circ}$, inciso XXXV, da Constituição Federal um importante alicerce teórico. Ao se prever no rol do artigo $5^{\circ}$ da CF a impossibilidade de a lei excluir da apreciação do Poder Judiciário lesão ou ameaça ao direito, consagrou-se não apenas a garantia de inafastabilidade da jurisdição

1 ESPÍNDOLA, Angela Araujo da Silveira; CUNHA, Guilherme Cardoso Antunes da. O processo, os direitos fundamentais e a transição do estado liberal clássico para o Estado contemporâneo. Revista de Estudos Constitucionais, Hermenêutica e Teoria do Direito (RECHTD), v. 3, n. 1, p. 93, jan./jun. 2011.

2 CAMBI, Eduardo. Neoconstitucionalismo e Neoprocessualismo. Revista do Programa de Pós-Graduação em Direito da Universidade Federal da Babia, Salvador, ano 2, n. 17, p. 115-129, 2008. 
(acesso à justiça), mas um verdadeiro direito fundamental à tutela jurisdicional efetiva, célere e adequada (acesso à ordem jurídica justa).

As garantias constitucionais processuais, encaradas no Estado Liberal Clássico como defesas do cidadão contra o Estado, passam a ser encaradas, no Estado Contemporâneo, como direitos fundamentais, com eficácia plena e aplicação imediata, possibilitando ao cidadão o direito a uma tutela jurisdicional adequada e efetiva, haja vista a obrigação deste Estado em realizar os direitos fundamentais, tudo com vistas a obter a justiça no caso concreto. ${ }^{3}$

Necessidades sociais nunca antes sentidas ou reivindicadas passaram a reclamar ações do poder público, muitas de natureza prestacional, atingindo áreas da vida pessoal e social que estavam fora do âmbito da política.

O direito fundamental de acesso à justiça, previsto no artigo $5^{\circ}$, inciso XXXV, da $\mathrm{CF}$, significa o direito à ordem jurídica justa. Assim, conforme destaca Eduardo Cambi, ${ }^{4}$ a designação acesso à justiça não se limita, apenas, à mera admissão ao processo ou à possibilidade de ingresso em juízo, mas, ao contrário, essa expressão deve ser interpretada extensivamente, compreendendo a noção ampla do acesso à ordem jurídica justa, que abrange: i) o ingresso em juízo; ii) a observância das garantias compreendidas na cláusula do devido processo legal; iii) a participação dialética na formação do convencimento do juiz, que irá julgar a causa (efetividade do contraditório); iv) a adequada e tempestiva análise, pelo juiz, natural e imparcial, das questões discutidas no processo (decisão justa e motivada); v) a construção de técnicas processuais adequadas à tutela dos direitos materiais (instrumentalidade do processo e efetividade dos direitos).

Os fins públicos buscados pelo processo, como instrumento democrático do poder jurisdicional, transcendem os interesses individuais das partes na solução do litígio. Essa visão publicística, imposta pela constitucionalização dos direitos e garantias processuais (neoprocessualismo), não se esgota na sujeição das partes ao processo. De acordo com Eduardo Cambi, o Neoconstitucionalismo e o neoprocessualismo servem de suporte crítico para a construção não somente de "novas" teorias e práticas, mas sobretudo para a construção. ${ }^{5}$

Assim, o que se observa é uma grande evolução no plano teórico no que diz respeito ao direito ao procedimento como uma garantia fundamental para o exercício dos demais direitos e a realização de justiça social.

Porém, há um severo descompasso entre as proposições teóricas e realidade prática no Brasil. O Poder Judiciário não apenas funciona de forma lenta, morosa e burocrática, mas apresenta-se, institucionalmente, muito distante do cidadão comum.

Estamos tratando neste estudo de direito a um mínimo existencial, sob um enfoque constitucional. Não podemos, contudo, deixar de alertar para o fato de que, caso o cidadão não o tenha garantido nas vias administrativas, o caminho por meio do Judiciário é extremamente tormentoso.

O perfil dos cidadãos potenciais beneficiários dos programas de renda mínima indica que são pessoas de baixa escolaridade, vivendo no limite ou abaixo da linha da pobreza. Possuem, assim, uma inerente dificuldade de mobilização para buscar assistência judiciária. Não têm consciência de seus próprios direitos e, quando têm, não sabem a quem recorrer.

Buscando arrefecer esse cenário, a Constituição de 1988, no art. 5, LXXIV, trouxe não só a promessa do acesso universal à Justiça, mas também a ordem para a institucionalização da Defensoria Pública em todo o Estado Brasileiro. Reconhecendo a importância da concessão de assistência jurídica integral, estendeu a atuação do Defensor Público ao âmbito extrajudicial e a todas as instâncias do Poder Judiciário.

3 OLIVEIRA, C. A. A. de. Teoria e prática da tutela jurisdicional. Rio de Janeiro: Forense, 2008.

4 CAMBI, Eduardo. Neoconstitucionalismo e Neoprocessualismo. Revista do Programa de Pós-Graduação em Direito da Universidade Federal da Babia, Salvador, ano 2, n. 17, p. 115-129, 2008.

5 CAMBI, Eduardo. Neoconstitucionalismo e Neoprocessualismo. Revista do Programa de Pós-Graduação em Direito da Universidade Federal da Babia, Salvador, ano 2, n. 17, p. 115-129, 2008. 
O contexto socioeconômico de extrema desigualdade social, aliado ao aumento da complexidade das relações jurídicas geradora de hipossuficiência organizacional, representa, ao mesmo tempo, um cenário de valorização do papel da Defensoria Pública, não apenas como função essencial à justiça, mas, em tempos de pós-positivismo, como instituição essencial do Estado Democrático de Direito.

De acordo com Sales, ${ }^{6}$ ter acesso ao Judiciário é ter também acesso à justiça; mas o acesso à justiça é mais abrangente por englobar o acesso a conhecimentos de direito e meios de garanti-los. Inclui o direito a ter os conflitos solucionados de forma célere, entre outros meios que garantam uma justiça social efetiva.

Assim, a atuação da Defensoria Pública na defesa dos grupos vulneráveis não mais se limita a intervenções judiciais. Ao contrário, a orientação extrajudicial reflete um essencial escopo do sistema normativo constitucional, pois possibilita a prevenção de litígios, além de educar os grupos vulneráveis na consolidação de seus direitos e garantias fundamentais.?

Assim, talvez o papel mais importante de atores jurídicos como os da Defensoria Pública seja a atuação preventiva, fora do processo jurisdicional, orientando o cidadão carente sobre como requerer determinados benefícios, como o Bolsa Família e o Benefício de Prestação Continuada.

Esse relacionamento mais próximo com o cidadão já começa a acontecer, ainda que de forma tímida. A Defensoria Pública de São Paulo, por exemplo, disponibiliza uma cartilha "Benefício de Prestação Continuada - Conheça o que é e como funciona este direito socioassistencial", ${ }^{8}$ destinada a esclarecer o cidadão sobre as características dos benefícios, as condições de elegibilidade e os documentos necessários. O Ministério do Desenvolvimento Social também desenvolveu material educativo neste sentido. ${ }^{9}$

\section{Políticas públicas de aLívio À POBReza e diReitos fundamentais}

$\mathrm{Na}$ linha que vem sendo construída nesta pesquisa, os benefícios de renda mínima constituem elemento essencial para a garantia do mínimo existencial. Celso Bastos ${ }^{10}$ destaca que o Direito brasileiro considera a desigualdade social como um problema de relevância constitucional (art. $3^{\circ}$, III, da Constituição Federal de 1988). É preciso, pois, buscar formas de combater a pobreza e assegurar condições mínimas para o indivíduo, não se concebendo que a riqueza sirva apenas para alguns, enquanto outra grande parte da população careça de condições mínimas de sobrevivência.

Como bem frisado por Matheus Bezerra, ${ }^{11}$ a aproximação do indivíduo com os seus direitos não deve ser buscada apenas por construções meramente textuais, de preceitos normativos no bojo de uma Carta Política, ou por construções científicas abstratas; é preciso que a ciência jurídica, através dos seus institutos, utilize com maior veemência seu poder de transformação da realidade existente, para que sejam estabelecidas condições socioeconômicas favoráveis ao florescimento dos direitos fundamentais estabelecidos, para

6 SALES, Lília Maia de Morais. Assessoria jurídica gratuita como forma de acesso à justiça e inclusão social, 2007. Disponível em: <www. mediacaobrasil.org.br/artigos_pdf/3.pdf>. Acesso em: 10 set. 2014.

7 ROCHA, Paulo Osório Gomes. Concretização de Direitos Fundamentais na perspectiva jurídico-constitucional da Defensoria Pública: um caminho “ainda” a ser trilhado. Revista Direito Público, n. 17, p. 144, jul./ago./set. 2007.

8 DEFENSORIA PÚBLICA DO ESTADO DE SÃO PAULO. Cartilha Benefício de Prestação Continuada: conheça o que é e como funciona este direito socioassistencial, 2011. Disponível em: <http:// www.defensoria.sp.gov.br/dpesp/repositorio/33/documentos/bpc_leitura.pdf>. Acesso em: 01 dez. 2015.

9 BRASIL. Ministério do Desenvolvimento Social. Cartilha BPC, 2012. Disponível em: < http://www.mds.gov.br/webarquivos/ publicacao/assistencia_social/cartilhas/cartilha-bpc-final.pdf>. Acesso em: 01 dez. 2015.

10 BASTOS, Celso Ribeiro; MARTINS, Ives Gandra. Comentários à Constituição do Brasil: promulgada em 5 de outubro de 1988. São Paulo: Saraiva, 1988.

11 BEZERRA, Matheus Ferreira. A utilização dos instrumentos jurídicos brasileiros para diminuição da desigualdade social e promoção dos direitos fundamentais. Revista do Programa de Pós-Graduação em Direito da Universidade Federal da Bahia, Salvador, ano 2 , n. 17, p. 115-1289, 2008. 
que se alcance a sua maior promoção e exigibilidade.

A efetividade de uma política pública, de qualquer natureza, está relacionada com a qualidade do processo administrativo que precede a sua realização e que a implementa. As informações sobre a realidade a transformar, a capacidade técnica e a vinculação profissional dos servidores públicos, a disciplina jurídica dos serviços públicos determinarão, em concreto, os resultados da política pública como instrumento de desenvolvimento. ${ }^{12}$ De certa forma, o Poder Judiciário acaba atuando como "bombeiro", quando esse processo se apresenta falho.

É verdade que o conceito de "mínimo existencial" é indeterminado, dotado de certa plasticidade. Assim, os julgadores atribuem conteúdo às prestações mínimas, estabelecendo a norma a ser aplicada a determinado caso e tomam decisão de política pública ao definirem prioridades na alocação dos recursos escassos. Conforme Honório, ${ }^{13}$ o Judiciário pode controlar a atuação do administrador e do legislador ao analisar a razoabilidade do conteúdo conferido ao mínimo existencial. Desse modo, o Judiciário interfere nas atividades legislativas e administrativas.

Ainda de acordo com Honório, ${ }^{14}$ quando uma condição indispensável à vida estiver em risco, a intervenção do Judiciário será mais do que possível; será obrigatória. Trata-se de atuar para possibilitar a própria democracia e a cooperação social. A não atuação do Judiciário no campo do mínimo existencial é que seria absurda. A proteção do mínimo existencial está na esfera legítima de atuação do Poder Judiciário. Trata-se de concretização da eficácia mínima dos direitos fundamentais.

Sustenta-se a opinião de que a assistência social prestada para uma garantia das condições mínimas existenciais não se limita ao mínimo no sentido econômico. De acordo com Ingo Sarlet ${ }^{15}$, deve alcançar também um mínimo na acepção sociocultural, ainda que a determinação do valor da prestação assecuratória deste mínimo existencial não tenha sido consensualmente obtida, não se podendo falar, até o presente momento, de uma solução uniforme no que diz com este aspecto.

Argumenta Andréas Krell ${ }^{16}$ que:

é obrigação de um Estado Social controlar os riscos resultantes do problema da pobreza que não podem ser atribuídos aos próprios indivíduos, e restituir um status mínimo de satisfação das necessidades pessoais. Assim, numa sociedade onde existe a possibilidade fática da cura de uma doença, o seu impedimento significa uma violência contra a pessoa doente que é diretamente prejudicada na sua vida e integridade.

Não se pode submeter a Administração apenas à lei formal, mas sim a todo o ordenamento e seu poder normativo, que contempla a democracia, a soberania, a dignidade da pessoa humana, os valores sociais do trabalho e da livre iniciativa, o pluralismo político, com vistas a construir uma sociedade melhor e mais justa, um Estado de Direito Material, isto é, um Estado Constitucional, pelo que passa a ser chamado também como princípio da juridicidade. ${ }^{17}$

12 BREUS, Thiago Lima. Políticas Públicas no Estado Constitucional: a problemática da concretização dos direitos fundamentais sociais pela administração pública brasileira contemporânea.2006. Dissertação (Mestrado) -- Universidade Federal do Paraná, Curitiba, 2006.

13 HONORIO, Cláudia. Olhares sobre o minimo existencial em julgados brasileiros. 2009. Dissertação (Mestrado)- Universidade Federal do Paraná, Curitiba, 2009.

14 HONORIO, Cláudia. Olhares sobre o minimo existencial em julgados brasileiros. 2009. Dissertação (Mestrado)- Universidade Federal do Paraná, Curitiba, 2009.

15 SARLET, Wolfgang Ingo. Dignidade da pessoa bumana e direitos fundamentais na Constituição da República de 1988. Porto Alegre: Livraria do Advogado, 2002.

16 KRELL, Andreas J. Controle judicial dos serviços públicos básicos na base dos direitos fundamentais sociais. In: SARLET, Ingo Wolfgang (Org.). A Constituição Concretizada: construindo pontes entre o público e o privado. Porto Alegre: Livraria do Advogado, 2000. p. 42.

17 BREUS, Thiago Lima. Políticas Públicas no Estado Constitucional: a problemática da concretização dos direitos fundamentais sociais pela administração pública brasileira contemporânea. 2006. Dissertação (Mestrado) - Universidade Federal do Paraná, Curitiba, 2006. 
As políticas públicas estão submetidas ao princípio da legalidade, no sentido de que, tanto em relação aos meios, quanto aos fins, a inobservância do princípio da legalidade pode gerar a invalidação da política pública, por meio da declaração de nulidade dos atos que lhe dão substrato. ${ }^{18}$

Assim, os princípios constitucionais previstos no art. 37 (legalidade, impessoalidade, moralidade, publicidade e eficiência) se aplicam a todas as atividades da Administração e, necessariamente, funcionam como vetores axiológicos das políticas públicas e devem balizar toda a análise referente aos benefícios de renda mínima.

É importante compreender que existem dois campos de análise: o individual, que poderíamos chamar de microjustiça e o difuso, que poderíamos chamar de macrojustiça.

Os estudos sobre atuação do Judiciário em relação a políticas públicas têm sido enfocados sob ângulo predominante individual. A atenção é dada ao atendimento ou não de determinado direito subjetivo. Assim se tem discutido, por exemplo, o direito ao fornecimento gratuito de medicamentos. Esta é a discussão, também, quanto aos parâmetros para concessão do Benefício de Prestação Continuada: análise de casos concretos.

Embora a presente pesquisa não perca de vista esse enfoque do direito subjetivo, é preciso ir além para verificar uma série de questões que perpassam o âmbito individual e estão ligadas ao atendimento dos princípios constitucionais que regem a Administração Pública. A questão do controle sobre as macropolíticas é uma delas. Não estamos falando, ainda, de influir nas próprias linhas mestras dos programas, mas de verificar aspectos ligados à legalidade, impessoalidade e moralidade na concessão de benefícios e na condução dos programas.

Muito se divulga sobre a ocorrência de fraudes na concessão de benefícios sociais. Divulga-se na imprensa a existência de beneficiários-fantasma, cumulação indevida de benefícios e seu uso como forma de pressão eleitoreira.

Tais práticas ferem de morte os princípios da moralidade e da impessoalidade. Em razão disso, deve ser valorizado o papel do Ministério Público, como instituição apropriada para, na tutela do interesse coletivo, atuar na defesa do interesse público.

Existem, no direito processual brasileiro, diversos mecanismos de proteção que podem ser manejados para o caso de desvio de finalidade na gestão dos benefícios de renda mínima: cite-se a Ação Civil Pública, a Ação Popular e a Ação de Improbidade.

$\mathrm{Na}$ mesma trilha de expansão das funções judiciárias, outros instrumentos foram criados ou aprimorados pela Constituição, como por exemplo, o mandado de segurança coletivo e o mandado de injunção. $\mathrm{Na}$ mesma linha tem seguido a Ação Civil Pública, que tem produzido bons efeitos no controle da conduta comissiva ou omissiva da Administração. ${ }^{19}$

Trata-se de instrumento para proteger o patrimônio público e social e outros interesses difusos e coletivos (art. 129, III, da Constituição). Flávio Dino Costa lembra que, em muitos casos, o manejo da ação civil pública resultou na implementação de políticas públicas, como no caso do fornecimento de medicamentos anti-HIV. ${ }^{20}$

Também a Advocacia-Geral da União deve atuar no sentido de zelar pela higidez e bom funcionamento dos programas da União Federal. Essa fiscalização se torna mais eficaz na medida em que o próprio Poder Executivo adota critérios de transparência na divulgação de dados, cadastros e resultados.

18 BREUS, Thiago Lima. Políticas Públicas no Estado Constitucional: a problemática da concretização dos direitos fundamentais sociais pela administração pública brasileira contemporânea. 2006. Dissertação (Mestrado) - Universidade Federal do Paraná, Curitiba, 2006. 19 COSTA, Flávio Dino de Castro e. A função realizadora do Judiciário e as políticas públicas no Brasil. R. CEJ, n. 28, p. 40-53, jan./mar. 2005.

20 COSTA, Flávio Dino de Castro e. A função realizadora do Judiciário e as políticas públicas no Brasil. R. CEJ, n. 28, p. 40-53, jan./mar. 2005. 
Um bom exemplo é o programa Bolsa Família, que possui uma base de dados na qual qualquer cidadão pode acessar as informações sobre os benefícios por município, com menção a todas as famílias cadastradas. Há, assim, um esforço de colaboração do Poder Executivo em cumprir o princípio da publicidade.

Breus $^{21}$ comenta, nesse sentido, a importância do acesso a informações:

Derivado do princípio da publicidade que requer a atuação transparente dos poderes públicos, o acesso à informação acerca da arrecadação e da receita dos entes estatais e o seu dispêndio, relativo às despesas planejadas, impõe-se para que se possa efetuar um controle social eficaz das políticas públicas.

Embora não seja o foco central deste trabalho, é importante citar, ainda, o papel do Tribunal de Contas da União e da Controladoria da União, como órgãos de controle capazes de fiscalizar o uso do dinheiro público e a eficiência dos programas governamentais.

Parte do receio da doutrina jurídica de que o Judiciário estaria invadindo a discricionariedade do administrador e se imiscuindo em questões de natureza técnico-gerencial se resolve a partir do momento em que o TCU e a CGU passam a atuar de forma mais consistente, em sintonia com o Poder Judiciário.

Esses órgãos não possuem poder judicante em sentido estrito, mas seus pareceres, decisões e recomendações possuem, cada vez mais, legitimidade democrática no cenário jurídico e político brasileiro. Com base nos trabalhos do TCU e da CGU o Judiciário pode - ou melhor, deve - agir para cumprir a Constituição, com base em subsídios de natureza técnica, que já foram analisados por outras instâncias competentes.

Se o TCU declara que o Executivo está em mora ou que há alguma atuação irregular nos programas de renda mínima, caberia ao Judiciário dar executoriedade, na prática, àquilo que foi propugnado pela corte de contas.

Enfim, a tese que se sustenta neste artigo é que a participação de atores sociais, como o Ministério Público, o TCU e a CGU, serve para dar legitimidade à atuação do Poder Judiciário quando se fala em programas de renda mínima, especialmente quando se trata de corrigir ou punir a atuação irregular dos administradores públicos.

Garantia de acesso à informação e sistemas de controle são, assim, pontos nodais para garantir a exigibilidade dos benefícios de renda mínima. Nessa linha, em relação a uma dogmática jurídica das políticas públicas, Ana Paula de Barcellos indica que, para que se torne minimamente consistente, ela deveria ser estruturada sobre, pelo menos, três temas: a identificação dos parâmetros de controle; a garantia de acesso à informação e a elaboração dos sistemas de controle. ${ }^{22}$

A garantia de acesso à informação é essencial para que haja qualquer parâmetro de controle, seja pela sociedade civil como um todo, seja pelo Judiciário, seja pelos demais órgãos estatais de controle. Barcellos ${ }^{23}$ ressalta a gravidade do problema:

se os parâmetros de controle objetivos já previstos no texto constitucional, e.g., para investimentos mínimos em saúde e educação, devem ser calculados com base em um combinado de receitas oriundas de tributos específicos, a ignorância acerca de tais informações dificulta a aplicação do parâmetro.

Os cidadãos têm direito subjetivo de dispor de informação sobre a receita pública existente e as despesas planejadas e realizadas pelos órgãos estatais. A sonegação dos dados sobre receitas e despesas jurídicas inviabiliza os controles jurídico e político e essa medida poderá exigir soluções jurídicas que assegurem, coativamente se necessário, $\mathrm{o}$ acesso à informação. ${ }^{24}$

21 BREUS, Thiago Lima. Políticas Públicas no Estado Constitucional: a problemática da concretização dos direitos fundamentais sociais pela administração pública brasileira contemporânea. 2006. Dissertação (Mestrado) - Universidade Federal do Paraná, Curitiba, 2006. p. 219.

22 BARCELLOS, Ana Paula de. A eficácia jurídica dos princípios constitucionais: o princípio da dignidade da pessoa humana. Rio de Janeiro: Renovar, 2002.

23 BARCELLOS, Ana Paula de. Neoconstitucionalismo, direitos fundamentais e controle das políticas públicas. Revista de Direito Administrativo, Rio de Janeiro, n. 240, abr./jun. 2005. p. 99.

24 BARCELLOS, Ana Paula de. Neoconstitucionalismo, direitos fundamentais e controle das políticas públicas. Revista de Direito 
Já há alguns instrumentos de controle, como a possibilidade de intervenção federal quando do não investimento mínimo em educação e saúde (art. 34, VII e 35, III), a Lei de Responsabilidade Fiscal (LC 101/00) e a Lei 8429/92.

A tutela de interesses coletivos, difusos e individuais homogêneos, por sua vez, permitiu que as questões sociais juridicamente relevantes fossem resolvidas de forma mais adequada e rápida. Não obstante as resistências governamentais, legislativas, judiciais e doutrinárias, provenientes dos pensamentos jurídicos mais retrógrados - que insistentemente procuram minimizar esta importante onda trazida pelo movimento de acesso à justiça -- essas demandas coletivas têm proporcionado a possibilidade de o Judiciário, nos últimos anos, dar efetividade aos direitos fundamentais -- sobretudo os de caráter social (previstos no artigo $6^{\circ}$, da CF) -- o que coloca o Poder Judiciário, hoje, no centro das atenções e das perspectivas da sociedade. ${ }^{25}$

Como se vê, a atuação do Judiciário é importante, mas a efetivação dos direitos sociais depende especialmente de um atuar efetivo e dinâmico dos demais atores institucionais e da própria sociedade civil organizada.

Quanto às normas que versam sobre direitos fundamentais, sua exigibilidade deve ser a maior possível. Se o novo constitucionalismo valoriza os princípios e visa dar maior eficácia às normas constitucionais, não se poderá mais defender que o Estado não pode prestar assistência social em razão da ausência de recursos.

Se o indivíduo se encontra em situação de miséria, não possuindo condições de prover seu próprio sustento, o Estado deve fornecer, liminarmente, o mínimo para que se garanta sua sobrevivência.

Por isso, os parâmetros de renda familiar per capita - utilizados para critério de concessão de benefícios - não podem ser aplicados de forma automática, à moda do velho positivismo normativista. Por vezes, o parâmetro estabelecido na lei, em razão das vicissitudes do caso concreto, não será suficiente para garantir a mínima eficácia ao comando constitucional. Há necessidade de se temperar a regra fria das leis com a força progressista dos princípios.

\section{DiReITO À RENDA MÍNIMA: ANÁLISE CRÍtICA DA ATUAÇÃo do PODER JUDICIÁRIO}

Um dos pontos de difícil equacionamento é o fato de que o juiz normalmente está preparado para realizar a justiça no caso concreto, a chamada microjustiça. De acordo com Barroso, ${ }^{26}$ o magistrado nem sempre dispõe das informações, do tempo e mesmo do conhecimento para avaliar o impacto de determinadas decisões, proferidas em processos individuais, sobre a realidade de um segmento econômico ou sobre a prestação de um serviço público.

Além disso, o juiz é tecnicamente qualificado, mas sociopoliticamente muito distante das relações sociais que ensejam as decisões. A sensibilidade social não pode ser auferida apenas quando da realização de um concurso de provas e títulos. É de se questionar se o fato de os membros da magistratura fazerem parte de uma elite intelectual e econômica não dificultaria as fundamentações em prol de justiça social e das classes menos favorecidas da população.

Trata-se de questão que vai muito além da dogmática jurídica. O magistrado que recebe quase 40 salários mínimos mensais provavelmente terá dificuldade para mensurar a importância que um acréscimo de $1 / 4$ de salário mínimo pode ter para a dignidade de uma família. Mesmo o defensor público, tradicionalmente

Administrativo, Rio de Janeiro, n. 240, abr./jun. 2005.

25 CAMBI, Eduardo. Neoconstitucionalismo e Neoprocessualismo. Revista do Programa de Pós-Graduação em Direito da Universidade Federal da Babia, Salvador, ano 2, n. 17, 2008.

26 BARROSO, Luis Roberto. Novos paradigmas e categorias da interpretação constitucional. Revista da Ordem dos Advogados do Brasil, v. 24, p. 201-260, 2008. 
considerado mais "próximo do povo", também está sujeito a esta limitação, que é de natureza cognitiva. Ao mesmo tempo em que vivencia mais de perto a realidade da população, também faz parte de uma elite jurídica e econômica.

Corroborando tal premissa, há que se mencionar pesquisa realizada pelo Instituto de Estudos Econômicos, Sociais e Políticos de São Paulo (IDESP, 1993) e citada por Flávio Dino, ${ }^{27}$ indicando que apenas 37\% dos juízes paulistas concordavam com a assertiva " $O$ compromisso com a justiça social deve preponderar sobre a estrita aplicaşão da lei”. O dado indica a postura normativista e formalista vigente na magistratura brasileira.

É interessante observar certa incoerência dos tribunais brasileiros em relação a questões ligadas aos programas de transferência de renda. Quando se trata da esfera penal, com ações delituosas ligadas à recepção fraudulenta de benefícios, o Judiciário tem exaltado o papel de programas como o Bolsa Família na erradicação da pobreza e como vetor do mínimo existencial.

Um exemplo claro é a condenação por crime de estelionato, quando do cadastro / dados falsos para inclusão no benefício. Mesmo que o "beneficiário" receba um valor pequeno, não estará abrangido pelo princípio da insignificância. Cite-se, por exemplo, o Habeas Corpus nº 86957- PR (STJ), que, não obstante o valor de R \$900,00, considerou não estar presente o princípio da insignificância.

O valor em si do prejuízo não é tão relevante quando se trata de crime envolvendo o Bolsa Família. Afasta-se, assim, a incidência do princípio da insignificância: PENAL E PROCESSO PENAL. BOLSA FAMÍLIA. PRINCÍPIO DA INSIGNIFICÂNCIA. NÃO
CABIMENTO. SUPORTE PROBATÓRIO MÍNIMO. RECEBIMENTO DA DENÚNCIA.

1. Princípio da insignificância. $O$ aspecto patrimonial torna-se menos relevante, ao se levar em consideração que o objetivo primordial é a tutela do Programa Bolsa Família, cuja finalidade é eminentemente social. (STJ, RSE 200850050005978 RJ, 01/02/2011). ${ }^{28}$

Assim, a danosidade social, nesse caso, é analisada sob o ângulo difuso. A dogmática penal, nesse caso, volta-se à criação de tipos penais que tutelam os chamados "bens supraindividuais", como a saúde pública, a ordem econômica, o meio ambiente, o sistema previdenciário, entre outros. Numa sociedade constitucionalmente fundada, como observa Gilberto Pinheiro Júnior: ${ }^{29}$

onde o social é erigido ao patamar de fundamento constitucional, o que implica necessariamente o controle da economia para sua consecução, a luta para esse controle exigirá a intervenção do Direito Penal, por meio do Direito Penal Econômico, que tipificará novos delitos protetores desses novos bens jurídicos não tão definidos. Nesse campo, então, não há que se falar em descriminalização ou intervenção mínima, como se vem fazendo na criminalidade clássica, muito pelo contrário.

Em relação ao cumprimento das prestações de caráter público de que depende o indivíduo no quadro da assistência social por parte do Estado, ressalte-se o entendimento de Luiz Regis Prado: ${ }^{30}$

[...] o Direito Penal realiza uma das mais importantes e numerosas tarefas do Estado, na medida em que apenas a proteção dos bens jurídicos constitutivos da sociedade e a garantia das prestações públicas necessárias para a existência possibilitam ao cidadão o livre desenvolvimento da sua personalidade, que nossa Constituição considera como pressuposto de uma condição digna.

Ainda de acordo com Regis Prado: ${ }^{31}$

O penalista progressista moderno está na defesa de uma intervenção mínima do Estado; contudo entendemos que em algumas áreas como a da criminalidade econômica se faz necessário uma

27 COSTA, Flávio Dino de Castro e. A função realizadora do Judiciário e as políticas públicas no Brasil. R.CEJ, n. 28, p. 40-53, jan./mar. 2005. p. 47.

28 BRASIL. Superior Tribunal de Justiça. RSE 200850050005978 RJ. Rio de Janeiro, 01 de fevereiro de 2011.

29 PINHEIRO JUNIOR, Gilberto José. Crimes econômicos: as limitações do direito penal. Campinas: Edicamp, 2003. p. 56.

30 PRADO, Luiz Régis. Bem jurídico penal e Constituição. São Paulo: Revista dos Tribunais, 1997. p. 58.

31 PRADO, Luiz Regis. Direito penal econômico. São Paulo: Revista dos Tribunais, 2004. p. 54. 
penalização mais gravosa face aos efeitos muitas vezes imperceptíveis para a população, mas que causam à coletividade grandes prejuízos na realização por parte do Estado na prestação de serviços típicos de um Estado Social.

Os bens supraindividuais não estão diretamente ligados à pessoa, mas vinculados ao funcionamento do sistema. Tal é o caso da proteção à higidez dos benefícios de natureza assistencial, que assume caráter macrossocial. Para Régis Prado ${ }^{32}$ o macrossocial deve estar subordinado ao microssocial.

Considerável parte dos crimes relacionados com o Bolsa Família dizem respeito a estelionato, mas também há casos de furto qualificado (art. 155, \ $4^{\circ}$ do Código Penal), quando se realizam saques fraudulentos em conta de beneficiário. Nesse caso, também é afastado o princípio da insignificância. Assim:

ESPECIAL. PENAL. ARTS. 71 E 155, S 4º, CP. FURTO QUALIFICADO. CONTINUIDADE DELITIVA. BOLSA FAMÍLIA.SAQUESFRAUDULENTOS. PRINCÍPIODAINSIGNIFICÂNCIA. INAPLICABILIDADE CONDUTA TÍPICA PERPETRADA CONTRA PROGRAMA ESTATAL QUEBUSCA RESGATARDA MISERABILIDADE PARCELASIGNIFICATIVADA POPULAÇÃO. MAIOR REPROVAÇÃO. CONTINUIDADE DELITIVA. NÚMERO DE INFRAÇÕES IMPLICA MAIOR EXASPERAÇÃO DE PENA. AUSÊNCIA DE PREQUESTIONAMENTO. SÚMULA 211/STJ.

[...] 3. Indevida a incidência do princípio da insignificância em decorrência de duplo fundamento: primeiro, o quantum subtraído, qual seja, $\mathrm{R} \$ 2.130,00$ (dois mil, cento e trinta reais), não pode ser considerado irrisório; e, segundo, além de atentar contra a Administração Pública, o delito foi praticado em desfavor de programa de transferência de renda direta - Programa Bolsa Família - que busca resgatar da miserabilidade parcela significativa da população do País, a tornar mais desabonadora a conduta típica. (REsp 1303748 AC 2012/0021034-2, STJ, Julgado em 25/06/2012. Rel Sebastião Reis Júnior). ${ }^{33}$

A jurisprudência entende incabível a aplicação do princípio da bagatela no caso de fraude contra o sistema de bolsa-família, por ser um benefício que transcende a questão patrimonial. Neste sentido, conforme entendeu-se no julgamento do RSE 200950050001916 RJ (TRF2), em 16/11/2010:

a teoria da insignificância vincula-se à lesividade ao bem jurídico, devendo ser analisado o desvalor da conduta do agente. De fato, se na hipótese de estelionato relativo a seguro-desemprego ou a Bolsa Família, considerarmos o montante, todas as fraudes seriam insignificantes, colocando em risco o programa social. $^{34}$

Uma das maneiras mais simples de burlar o sistema é omitir a existência de Carteira de Trabalho onde está registrada a renda de um dos membros da família, bem como a omissão de outras fontes de renda. Nesse sentido:

A sistemática prestação de informação inverídica e a apresentação de CTPS diversa da que o marido utilizava, em que constava o emprego como eletricista, não apenas no requerimento do benefício, como também quando da visita da assistente social, demonstram pleno conhecimento de que a denunciada não fazia jus ao bolsa família e dolosamente ocultou os verdadeiros rendimentos de sua família, a fim de induzir e manter em erro a Administração pública. (ACR 1431 SP 2008.61.13.001431-0, TRF-3, de $14 / 07 / 2009 .^{35}$

Outra questão enfrentada é o cometimento de crimes pelos próprios membros da Administração Pública, que desviam o valor dos benefícios, configurando o crime de peculato. Assim:

PENAL. PECULATO. ART. 312, $\mathbb{S} 1^{\circ}$, DO CP. SUBTRAÇÃO DE VALORES ORIGINÁRIOS DE PROGRAMA SOCIAL FEDERAL. AUTORIA E MATERIALIDADE COMPROVADAS. DOSIMETRIA DA PENA. REDUÇÃO.

1. Devidamente configurado o delito de peculato (art. 312, $\sqrt{ } 1^{\circ}$, do CP, uma vez que os acusados

32 PRADO, Luiz Regis. Direito penal econômico. São Paulo: Revista dos Tribunais, 2004. p. 54.

33 BRASIL. Superior Tribunal de Justiça. REsp 1303748 AC 2012/0021034-2. Relator: Sebastião Reis Júnior. 25 de junho de 2012.

34 BRASIL. Tribunal Regional Federal da Segunda Região. RSE 200950050001916 RJ. Rio de Janeiro, 16 de novembro de 2010.

35 BRASIL. Tribunal Regional Federal da Terceira Região. TACR 1431 SP 2008.61.13.001431-0. São Paulo, 14 de julho de 2009. 
valeram-se da facilidade proporcionada pela qualidade de funcionário público de um dos agentes, para obter cartões e senhas de beneficiários de programas sociais federais (bolsa escola, auxílio gás e bolsa família), subtraindo em proveito próprio recursos públicos que não lhes pertenciam, mediante saques bancários (Apelação Criminal 2131/PR - TRF4 - 09/09/2010). ${ }^{36}$

Enfim, os delitos em tela não atingem somente o erário, mas também colocam em risco a higidez de um programa social destinado ao auxílio de famílias carentes, sendo impossível falar em bagatela. O Programa Bolsa Familia tem sido considerado tão importante pelo Judiciário no combate à miséria que tem sido utilizado como instrumento de presunção de hipossuficiência dos jurisdicionados em uma série de hipóteses. Não se considera o Bolsa Família como condição sine qua non para demonstrar pobreza, mas, na análise da hipossuficiência, há uma forte tendência de considerar o recebimento do benefício como uma prova praticamente cabal. Neste sentido:

Assistência Judiciária. Locação. Impugnação ao pedido de justiça gratuita. Alegação de que inexiste prova documental que comprove a condição de pobreza da autora. Impugnação rejeitada. Declaração feita pelo interessado. Impugnada recebedora de benefício financeiro. Inscrição nos programas sociais Bolsa Família e Renda Mínima. Impugnação não acolhida. TJSP - Impugnação de Assistência Judiciária: 2100005212008826 SP 2100005-21.2008.8.26.0000. Julgado em 15/12/2011, 32 ${ }^{\text {a }}$ Câmara Cível. ${ }^{37}$

Também, no Agravo de Instrumento AI 70039996194 RS, julgado em 22/11/2010, tem-se exatamente o mesmo entendimento. Destaca-se, apenas, a parte final da ementa do acórdão, que é bem clara: "Sendo beneficiária do programa assistencial do governo federal chamado Bolsa Família, é lógico que a parte agravante não possui rendimentos[...]".

Mesmo para garantia de outros benefícios ou auxílios de natureza assistencial/social, o recebimento do Programa Bolsa Família tem sido reconhecido como um argumento em prol de se reforçar a necessidade de proteção ao indivíduo. Foi o caso, por exemplo, do deferimento de “tarifa social de água”, em um programa social de tarifas reduzidas no Rio Grande do Sul. O Julgado 71003036183 RS, da $3^{\text {a }}$ Turma Recursal, com base nos princípios da razoabilidade, da dignidade da pessoa humana e da equidade, utilizou como um dos fundamentos para garantir a tarifa social de água o fato de o cidadão ser beneficiário do Programa Bolsa Família.

Ressalte-se, aliás, que ser inscrito no Programa Bolsa Família permite ao beneficiário acesso a outros benefícios, como a utilização de carta social nos Correios (cartas enviadas a $\mathrm{R} \$ 0,01$ ) e atendimento prioritário no Programa Saúde da Família.

Em que pese essa boa deferência do Poder Judiciário ao papel dos programas de renda mínima, o fato é que a visão em defesa de um "bem social", fundamentada na necessidade de se garantir um mínimo existencial, nem sempre se verifica quando se trata da discussão sobre a própria concessão dos benefícios.

A atuação do Judiciário, nesse ponto, pode ser considerada frustrante se cotejada com os novos paradigmas do Direito Constitucional, ventilados no presente estudo. A posição do Judiciário tem se mostrado por vezes legalista e positivista, aplicando a letra fria da lei de modo automático.

Um dos empecilhos para análise por parte dos tribunais superiores (STF e STJ) tem sido a alegação de ser "impossível revolver a análise probatória" (Súmula 279, STF) ${ }^{38}$ O que é mais preocupante é o entendimento de que eventual descumprimento do dever do Estado em prestar o benefício seria, no máximo, uma afronta indireta à Constituição.

Se há o cumprimento aos requisitos para receber o benefício, a afronta à Constituição é direta, pois se está negando um direito fundamental ao mínimo existencial. Em síntese, no Recurso Extraordinário

36 BRASIL. Tribunal Regional Federal da Quarta Região. Apelação Criminal 2131 PR. Paraná, 09 de setembro de 2010.

37 SÃO PAULO. Tribunal de Justiça do Estado de São Paulo. Impugnação de Assistência Judiciária: 2100005212008826 SP $2100005-$ 21.2008.8.26.0000. 32 Câmara Cível. São Paulo, 15 de dezembro de 2011.

38 BRASIL. Supremo Tribunal Federal. Súmula 279, de 13 de dezembro de 1963. Disponível em: <http://www.stf.jus.br/portal/ jurisprudencia/listarJurisprudencia.asp?s1=279.NUME.\%20NAO\%20S.FLSV.\&base=baseSumulas>. Acesso em: 03 dez. 2015. 
628231/AM (Relator Ricardo Lewandowski, 13/09/2010), entendeu-se, equivocadamente, que:

o mero preenchimento do Cadastro Único para Programas Sociais (CadÚnico) não gera direito adquirido à concessão do benefício Bolsa Família; a afronta à Constituição, se ocorrente, seria indireta no caso (Lei 10.836/2004 e Decreto 5.209/2004); para se verificar se a recorrente preenche os requisitos para a concessão do benefício seria necessário o revolvimento das provas constantes dos autos, o que inviabiliza o recurso extraordinário.

Essa decisão deixa de considerar a força irradiante da Constituição, a centralidade dos direitos fundamentais e a ideia de filtragem constitucional. Mostra-se, assim, retrógrada e em desalinho com a dogmática constitucional contemporânea.

Não parece ser razoável ignorar a relevância de princípios e valores constitucionais (como dignidade da pessoa humana e erradicação da pobreza) para a aplicação de um dogma (não tratar matéria fática em recursos de natureza especial) cuja função é, apenas, utilitarista: diminuir o número de processos nos tribunais superiores.

Quando a questão se tratar do caso do Benefício de Prestação Continuada, há polêmica quanto aos limites do art. 20, $\$ 3^{\circ}$ da Lei 8742/93 (Lei da LOAS). Três seriam as possibilidades:

a) O critério da lei $(1 / 4$ do salário) é rígido e apenas os que comprovem estar aquém deste limite terão direito ao benefício.

b) O critério da lei é apenas um standard, no qual se garante a presunção de miséria. Pretendentes ao benefício com renda maior do que tal valor poderão comprovar, no caso concreto, a condição de miséria (idéia de interpretação conforme).

c) O dispositivo é, desde logo, inconstitucional, pois restringe um direito social fundamental. A lei só poderia estabelecer procedimentos ou trâmites, mas não estabelecer um valor, se a própria Constituição não o fez.

O Supremo Tribunal Federal confirmou a constitucionalidade da exigência da renda mínima per capita de $1 / 4$ do salário mínimo em sede da ADIn 1232/DF, entendendo que deve ela ser considerada como um parâmetro para a aferição da necessidade, mas não impedindo, peremptoriamente, que outros fatores sejam utilizados para comprovar a carência de condições de sobrevivência digna.

Reproduz-se aqui a ementa:

CONSTITUCIONAL. IMPUGNA DISPOSITIVO DE LEI FEDERAL QUE ESTABELECE O CRITÉRIO PARA RECEBER O BENEFÍCIO DO INCISO V DO ART. 203, DA CF. INEXISTE A RESTRIÇÃO ALEGADA EM FACE AO PRÓPRIO DISPOSITIVO CONSTITUCIONAL QUE REPORTA À LEI PARA FIXAR OS CRITÉRIOS DE GARANTIA DO BENEFÍCIO DE SALÁRIO-MÍNIMO À PESSOA PORTADORA DE DEFICIÊNCIA FÍSICA E AO IDOSO. ESTA LEI TRAZ HIPÓTESE OBJETIVA DE PRESTAÇÃO ASSISTENCIAL DO ESTADO. AÇÃO JULGADA IMPROCEDENTE (ADIn 1.232/DF, Rel. Ilmar Galvão, 1998). ${ }^{39}$

O julgamento da ADIN não foi suficientemente claro para afastar de vez o entendimento de que o limite de $1 / 4$ salário é insuperável. Assim, os tribunais em segunda instância, o Superior Tribunal de Justiça e a Turma Nacional de Unificação continuaram a decidir pela possibilidade de se entender miserável mesmo aquele cuja renda ultrapasse $1 / 4$ do salário mínimo. Nesse sentido:

A família com renda mensal per capita inferior a $1 \frac{1}{4}$ do salário-mínimo não é capaz de prover de forma digna a manutenção do membro idoso ou portador de deficiência física $\left(\mathbb{S} 3^{\circ}\right.$, art. 20, Lei 8.742/93). Contudo, o legislador não excluiu outras formas de verificação da condição de miserabilidade. Precedentes do STJ, da TNU e desta Corte (AC 4827 BA 0004827-55.2006.4.01.3306, TRF-1, AC-4827, BA, de 27/09/2012). ${ }^{40}$

39 BRASIL. Supremo Tribunal Federal. ADIn 1.232/DF. Relator: Ilmar Galvão. Brasília, 1998.

40 BRASIL. Tribunal Regional Federal da Primeira Região. AC 4827 BA 0004827-55.2006.4.01.3306. TRF-1, AC-4827. Bahia, 27 
Por incrível que pareça, outros Tribunais Federais continuam deixando de conceder o benefício, tratando a questão como simples cálculo matemático e mecânico, mesmo quando a renda ultrapassa em porção ínfima o limite da lei.

Em um caso julgado pelo TRF-3 (AC 31398 SP, julgada em 13/06/2011), não apenas foram considerados os R \$ 90,00 como renda, a título de Bolsa Família e Programa Ação Jovem, como se negou o benefício por que a renda per capita da família era de míseros $\mathrm{R} \$ 225,00$, já que um dos filhos trabalhava informalmente e recebia $R \$ 300,00$ por mês (menos de $1 / 2$ salário mínimo à época). Considerou-se, ainda, que a família vivia "em habitação adequada", e por isso o membro da família deficiente não faria jus ao benefício. ${ }^{41}$

Uma decisão como esta acaba funcionando como um desestímulo à inserção dos demais membros da família no mercado de trabalho. O julgado não levou em conta o esforço do irmão não-deficiente, que recebia $\mathrm{R}$ \$300,00 mensais como auxiliar de eletricista, e, possivelmente, ajudava, mesmo com esse baixo salário, na manutenção do irmão. Nesse caso concreto, a falta de razoabilidade do julgador poderia levar a um juízo também de razoabilidade, mas por instinto de sobrevivência da própria família: se o irmão com renda para de trabalhar, o irmão deficiente passa a ter o direito de auferir uma renda duas vezes maior, e maior mesmo que a do próprio pai.

São essas peculiaridades do caso concreto, que uma interpretação constitucional mais aberta, baseada em princípios e dentro de uma lógica do razoável, deveria levar em conta, sob pena de, com um manto de um arraigado positivismo jurídico, cometer absurdos.

Há que se ressaltar, é certo, o entendimento de parte dos juízes e Tribunais Regionais Federais para a concessão do Benefício de Prestação Continuada, no sentido de prestigiar a análise do caso concreto para apuração da real necessidade do requerente. Ressalta-se que, além do preenchimento do requisito econômico, o critério da incapacidade também tem sido flexibilizado quando são verificadas implicações e/ou peculiaridades que impedem o demandante de ser reabilitado para outras funções. Nesse sentido, mencione-se entendimento do TRF-2, que considerou o valor de $1 / 2$ salário mínimo de renda familiar, levando em conta as condições da requerente:

[...] IV - Vale ressaltar que o parâmetro objetivo da renda familiar per capita $\left(\$ 3^{\circ}\right.$ do art. 20 da Lei ${ }^{\circ}$ 8.742/93), para grande parte das hipóteses, não pode derivar de uma interpretação estritamente literal do dispositivo legal, especialmente naqueles casos em que, diante de circunstâncias peculiares tal renda não assegura a efetiva sobrevivência e cuidados a que faz jus o ente familiar, em especial o pretendente ao benefício (Apelação, TRF2 2014.51.01.013742-4, 01/02/2016) 42 $^{42}$

No contexto dessa discussão, há ainda uma interpretação que, se acolhida, afetaria em termos práticos qualquer uma das opções acima. É a visão que considera, independentemente de se adotar ou não a flexibilidade, o patamar de $1 / 2$ salário mínimo, pois teriam sido estas as previsões do Estatuto do Idoso.

Fora do âmbito penal, havíamos apontado mecanismos de tutela coletiva que poderiam ser eficazes no combate a fraudes e mau gerenciamento de programas de renda mínima, como a Ação Civil Pública, a Ação Popular e a Lei de Responsabilidade Fiscal (LC 105). Só que estas questões chegam de forma rara ao Judiciário e, quando chegam, há dificuldade por parte dos tribunais em tratar a questão sob ângulo coletivo/difuso. Cite-se, como exemplo, em um caso de investigação de fraudes no Bolsa Família:

o pedido de quebra de sigilo bancário dos recorridos (Vereadora do Município e seu marido) não se enquadra nos dispositivos legais autorizadores da Lei Complementar 105, de 10/01/2001, notadamente em seus arts. $3^{\circ}, \Omega 1^{\circ}$, por não estarem os requeridos vinculados ao Poder Executivo de Caraíbas/BA, e $4^{\circ}$, $\int 1^{\circ}$, em face da ausência de instauração de Comissão Parlamentar de Inquérito, para apuração da suposta percepção irregular dos benefícios do Bolsa Família. (AC 5371 BA 0005371-98.2010.4.01.3307, TRF1) ${ }^{43}$

de setembro de 2012.

41 BRASIL. Tribunal Regional Federal da Terceira Região. AC 31398 SP. São Paulo, 13 de junho de 2011.

42 BRASIL. Tribunal Regional Federal da Segunda Região. Apelação 2014.51.01.013742-4. 01 de fevereiro de 2016.

43 BRASIL. Tribunal Regional Federal da Primeira Região. AC 5371 BA 0005371-98.2010.4.01.3307. 
Por fim, ao menos uma questão vem se encaminhando em prol da garantia do mínimo existencial. Trata-se de saber se o valor recebido por um indivíduo a título de Bolsa Família influi na renda da família para efeito de análise de renda para concessão do BPC, bem como se o próprio deferimento do BPC para um membro da família influi ou não na composição da renda.

Boa parte da Jurisprudência encaminha-se para o entendimento de que a renda oriunda do recebimento do Bolsa Família não deve entrar no cálculo. Interessante o argumento de razoabilidade e racionalidade para estas hipóteses:

Outro benefício assistencial ou previdenciário, de até um salário-mínimo, pago a idoso, ou aposentadoria por invalidez de valor mínimo paga à pessoa de qualquer idade, não deverão ser considerados para fins de renda per capita; devendo-se excluir tanto a renda quanto a pessoa do cômputo para aferição do requisito. [...] a renda auferida pelo benefício do Bolsa Família deve ser excluído. Isso porque, a uma, se deve ser excluído o benefício assistencial e a aposentadoria da renda familiar, nos termos do art. 34 da Lei do Idoso, com mais razão deve ser excluído benefício que visa atender necessidade específica da família. A duas, o benefício de prestação continuada é mais benéfico. Sendo assim, cabe ao órgão responsável a verificação da permanência da autora no programa. (AC 4827 BA 0004827-55.2006.4.01.3306, TRF-1, AC-4827, BA, de 27/09/2012) ${ }^{44}$

O próprio Supremo Tribunal Federal, por meio do Agravo de Instrumento n. ${ }^{\circ}$ 672.694, de 2010, entendeu que os rendimentos obtidos por idoso ou deficiente, seja benefício de amparo assistencial, seja aposentadoria, devem ser desconsiderados no cálculo da renda per capita quando do levantamento da situação de miserabilidade, critério exigido para concessão do benefício de amparo assistencial.

Conforme Liana Danis ${ }^{45}$, se quem pleiteia o benefício contar no meio familiar com integrante que também não reunia condições de se prover, tanto que fez jus a benefício de um salário mínimo, seja em razão da idade, seja em razão de deficiência, não é razoável exigir o sacrifício deste familiar, pois também não possui meios de prover à própria manutenção e tampouco de prover seus familiares.

Além disso, o Estatuto do Idoso, art. 34, parágrafo único, prevê que o benefício já concedido a qualquer membro da família nos termos do caput não será computado para os fins do cálculo da renda familiar per capita a que se refere a LOAS.

Por fim, é de se louvar o entendimento do Superior Tribunal de Justiça, tanto quanto ao parâmetro de $1 / 4$ apenas como limite mínimo, como quanto à cumulatividade de benefícios em uma mesma família.

PREVIDENCIÁRIO. BENEFÍCIO ASSISTENCIAL. AFERIÇÃO DA HIPOSSUFICIÊNCIA E DA DEFICIÊNCIA POR OUTROS MEIOS QUE NÃO O CRITÉRIO DE 1/4 DO SALÁRIO MÍNIMO “PER CAPITA”. POSSIBILIDADE. EXCLUSÃO DE BENEFÍCIO DE VALOR MÍNIMO PERCEBIDO POR MAIOR DE 65 ANOS. ART. 34, PARÁGRAFO ÚNICO, LEI No 10.741/2003. APLICAÇÃO ANALÓGICA. 1. Predomina no âmbito da Terceira Seção o entendimento de que o critério previsto no artigo $20, \mathbb{S} 3^{\circ}$, da Lei n. 8.742/1993 para a concessão de benefício assistencial deve ser interpretado como limite mínimo, devendo ser incluídos os segurados que comprovarem, por outros meios, a condição de hipossuficiência. Precedente prolatado em recurso especial processado como representativo da controvérsia, nos termos do art. 543-C do CPC (Resp n. 1.112.557/MG). 2. O benefício previdenciário de valor mínimo, recebido por pessoa acima de 65 anos, não deve ser considerado na composição na renda familiar, conforme preconiza o art. 34, parágrafo único, da Lei 10.741/2003 (Estatuto do Idoso). Precedente: Pet n. 7.203/PE, relatora Ministra Maria Thereza de Assis Moura. 3. Agravo regimental improvido. (RIO GRANDE DO SUL, AgRg no REsp 1247868 (2011/0077742-9), Relator Jorge Mussi, Quinta Turma, 2011) ${ }^{46}$

44 BRASIL. Tribunal Regional Federal da Primeira Região. AC 4827 BA 0004827-55.2006.4.01.3306, TRF-1, AC-4827. Bahia, 27 de setembro de 2012.

45 DANI, Liana Lidiane Pacheco. Da concessão de amparo assistencial e composição de renda per capita. Disponível em: <www.anadef.com. br>. Acesso em: 01 ago. 2015.

46 BRASIL. Superior Tribunal de Justiça. AgRg no REsp 1247868 (2011/0077742-9). Quinta turma. Relator: Jorge Mussi. Rio Grande do Sul, 2011. 


\section{Considerações Finais}

Os direitos fundamentais possuem aplicabilidade imediata e devem ser efetivados na máxima medida possível. O fato de alguns direitos demandarem complementação por meio de lei ou outro ato normativo não pode servir de escudo ao seu descumprimento, devendo, nesse caso, serem sanadas as omissões.

Especialmente no que tange aos chamados direitos de segunda dimensão, merecem destaque os direitos sociais de cunho prestacional. Nessa categoria, avulta a importância de um papel ativo do Estado na implementação de políticas públicas.

O princípio da dignidade da pessoa humana é reafirmado com o fortalecimento de uma cultura jurídica pós-positivista. A reaproximação entre o Direito e a ética torna o ordenamento jurídico mais sensível aos valores morais em países onde os direitos sociais fundamentais ainda não possuem plena concretude avulta a importância de se conferir à dignidade da pessoa humana um viés social.

A dignidade da pessoa humana, assim, tem seu âmbito amplificado. Nesse sentido, não só os juristas, mas os gestores públicos em geral devem perceber a dignidade não apenas sob o ângulo do indivíduo isolado em si mesmo, mas inserido em determinado meio social, participando de uma determinada comunidade.

O mínimo existencial, categoria de conceito jurídico indeterminado, não pode ser desenvolvido pelo Judiciário como um sistema acabado de solução, mas sim analisado nas vicissitudes de cada demanda. Permite-se, assim, a adaptação às necessidades no tempo e no espaço, em casa sociedade. A fluidez do conceito recomenda, assim, maior flexibilidade na apreciação das demandas judiciais, pois padrões rígidos (tetos e pisos avaliados em dinheiro) nem sempre serão condizentes com a realidade concreta dos cidadãos.

A ideia de mínimo existencial tem sido utilizada para contornar barreiras impostas à concretização dos direitos básicos (notadamente em sua dimensão prestacional). Ao se reconhecer que determinado direito integra o mínimo existencial, deve-se entender que se está diante de direito subjetivo, não cabendo, assim, a alegação de ausência de recursos para efetivar as prestações estatais.

Por meio de patamares satisfatórios de necessidades básicas (alimentação, água, vestuário, saúde) é que o cidadão pode começar a pensar a ter acesso aos demais direitos de natureza social (educação, cultura, trabalho, lazer). Ao atingir esse mínimo material necessário, o cidadão terá melhores condições de participar da esfera pública.

Assim, a implementação de políticas públicas pelo Estado, em especial aquelas voltadas para a garantia de um mínimo existencial (mínimo, aqui, como sinônimo de básico, e não de ínfimo), permite ao cidadão meios de considerar-se membro de um regime de fato democrático, com acesso às oportunidades e aos serviços públicos e com um mínimo de voz ativa na sociedade.

O Estado brasileiro parece realizar um sério esforço no sentido de aumentar a cobertura dos programas de transferência de renda mínima. Com isso, é natural um certo aumento da litigiosidade. A população, aos poucos, parecer tomar maior consciência de seus direitos. Com o aparelhamento das Defensorias Públicas, estas demandas reprimidas poderão ser melhor canalizadas.

A posição do Judiciário oscila, ora para encampar uma nova dogmática constitucional, com a valorização dos princípios e a ênfase na dignidade da pessoa humana, ora para se apegar (ainda) a uma postura positivista e legalista.

Em que pese essa boa deferência ao papel dos programas de renda mínima, o fato é que esta visão em defesa de um "bem social", fundamentada na necessidade de se garantir um mínimo existencial, nem sempre se verifica quando se trata da discussão sobre a própria concessão dos benefícios.

Com base no volume de demandas que chega aos tribunais, percebe-se que, se por um lado questões ligadas ao Benefício de Prestação Continuada chegam com frequência ao Judiciário, o mesmo não se pode 
dizer em relação ao Programa Bolsa Família. A maior parte da Jurisprudência coletada diz respeito à questão penal (fraude/estelionato na concessão de benefícios).

Levando-se em conta o grau de vulnerabilidade dos potenciais usuários do Programa Bolsa Família (PBF), é possível conjecturar que existe uma forte demanda reprimida quanto à judicialização do tema, uma vez que cidadãos excluídos do programa não conseguem também ter acesso a serviços públicos básicos. Possuem pouco grau de escolarização e dificilmente conseguirão acesso ao Judiciário.

\section{REFERÊNCIAS BIBLIOGRÁFICAS}

BARCELLOS, Ana Paula de. A eficácia jurídica dos princípios constitucionais: o princípio da dignidade da pessoa humana. Rio de Janeiro: Renovar, 2002.

BARCELLOS, Ana Paula de. Neoconstitucionalismo, direitos fundamentais e controle das políticas públicas. Revista de Direito Administrativo, Rio de Janeiro, n. 240, abr./jun. 2005.

BARROSO, Luís Roberto. Neoconstitucionalismo e constitucionalização do direito. Revista da Escola Nacional da Magistratura, Brasília, ano 1, n. 02, out. 2006.

BARROSO, Luis Roberto. Novos paradigmas e categorias da interpretação constitucional. Revista da Ordem dos Advogados do Brasil, v. 24, p. 201-260, 2008.

BASTOS, Celso Ribeiro; MARTINS, Ives Gandra. Comentários à Constituição do Brasil: promulgada em 5 de outubro de 1988. São Paulo: Saraiva, 1988.

BEZERRA, Matheus Ferreira. A utilização dos instrumentos jurídicos brasileiros para diminuição da desigualdade social e promoção dos direitos fundamentais. Revista do Programa de Pós-Graduação em Direito da Universidade Federal da Babia, Salvador, ano 2, n. 17, 2008.

BRASIL. Ministério do Desenvolvimento Social. Cartilha BPC, 2012. Disponível em: <http://www.mds. gov.br/webarquivos/publicacao/assistencia_social/cartilhas/cartilha-bpc-final.pdf>. Acesso em: $01 \mathrm{dez}$. 2015.

BRASIL. Superior Tribunal de Justiça. RSE 200850050005978 RJ. Rio de Janeiro, 01 de fevereiro de 2011.

BRASIL. Superior Tribunal de Justiça. REsp 1303748 AC 2012/0021034-2. Relator: Sebastião Reis Júnior. 25 de junho de 2012.

BRASIL. Tribunal Regional Federal da Segunda Região. RSE 200950050001916 RJ. Rio de Janeiro, 16 de novembro de 2010.

BRASIL. Tribunal Regional Federal da Terceira Região. TACR 1431 SP 2008.61.13.001431-0. São Paulo, 14 de julho de 2009.

BRASIL. Tribunal Regional Federal da Quarta Região. Apelação Criminal 2131 PR. Paraná, 09 de setembro de 2010.

BRASIL. Supremo Tribunal Federal. Súmula 279, de 13 de dezembro de 1963. Disponível em: <http:// www.stf.jus.br/portal/jurisprudencia/listarJurisprudencia.asp?s1=279. NUME.\%20NAO\%20S. FLSV.\&base=baseSumulas>. Acesso em: 03 dez. 2015.

BRASIL. Supremo Tribunal Federal. ADIn 1.232/DF. Relator: Ilmar Galvão. Brasília, 1998.

BRASIL. Tribunal Regional Federal da Primeira Região. AC 4827 BA 0004827-55.2006.4.01.3306. TRF-1, AC-4827. Bahia, 27 de setembro de 2012. 
BRASIL. Tribunal Regional Federal da Segunda Região. Apelação 2014.51.01.0137424. 01 de fevereiro de 2016.

BRASIL. Tribunal Regional Federal da Primeira Região. AC 5371 BA 0005371-98.2010.4.01.3307.

BRASIL. Tribunal Regional Federal da Primeira Região. AC 4827 BA 0004827-55.2006.4.01.3306, TRF-1, AC-4827. Bahia, 27 de setembro de 2012.

BRASIL. Superior Tribunal de Justiça. AgRg no REsp 1247868 (2011/0077742-9). Quinta turma. Relator: Jorge Mussi. Rio Grande do Sul, 2011.

BREUS, Thiago Lima. Politicas Públicas no Estado Constitucional: a problemática da concretização dos direitos fundamentais sociais pela administração pública brasileira contemporânea. 2006. Dissertação (Mestrado) Universidade Federal do Paraná, Curitiba, 2006.

CAMBI, Eduardo. Neoconstitucionalismo e Neoprocessualismo. Revista do Programa de Pós-Graduação em Direito da Universidade Federal da Babia, Salvador, ano 2, n. 17, 2008.

COSTA, Flávio Dino de Castro e. A função realizadora do Judiciário e as políticas públicas no Brasil. R. CEJ, n. 28, p. 40-53, jan./mar. 2005.

DANI, Liana Lidiane Pacheco. Da concessão de amparo assistencial e composição de renda per capita. Disponível em: <www.anadef.com.br>. Acesso em: 01 ago. 2015.

DEFENSORIA PÚBLICA DO ESTADO DE SÃO PAULO. Cartilha Benefício de Prestação Continuada: conheça o que é e como funciona este direito socioassistencial. 2011. Disponível em: <http:// www.defensoria.sp.gov.br/dpesp/repositorio/33/documentos/bpc_leitura.pdf>. Acesso em: 01 dez. 2015.

ESPÍNDOLA, Angela Araujo da Silveira; CUNHA, Guilherme Cardoso Antunes da. O processo, os direitos fundamentais e a transição do estado liberal clássico para o Estado contemporâneo. Revista de Estudos Constitucionais, Hermenêtica e Teoria do Direito (RECHTD), v. 3, n. 1, p. 84-94, jan./jun. 2011.

HONORIO, Cláudia. Olhares sobre o minimo existencial em julgados brasileiros. 2009. Dissertação (Mestrado)Universidade Federal do Paraná, Curitiba, 2009.

KRELL, Andreas J. Controle judicial dos serviços públicos básicos na base dos direitos fundamentais sociais. In: SARLET, Ingo Wolfgang (Org.). A Constituição Concretizada: construindo pontes entre o público e o privado. Porto Alegre: Livraria do Advogado, 2000.

OLIVEIRA, C. A. A. de. Teoria e prática da tutela jurisdicional. Rio de Janeiro: Forense, 2008.

PINHEIRO JUNIOR, Gilberto José. Crimes econômicos: as limitações do direito penal. Campinas: Edicamp, 2003.

PRADO, Luiz Régis. Bem jurídico penal e Constituição. São Paulo: Revista dos Tribunais, 1997.

PRADO, Luiz Regis. Direito penal econômico. São Paulo: Revista dos Tribunais, 2004.

ROCHA, Paulo Osório Gomes. Concretização de Direitos Fundamentais na perspectiva jurídico-constitucional da Defensoria Pública: um caminho "ainda” a ser trilhado. Revista Direito Público, n. 17, p. 144, jul./ ago./set. 2007.

SALES, Lília Maia de Morais. Assessoria jurídica gratuita como forma de acesso à justiça e inclusão social, 2007. Disponível em: <www.mediacaobrasil.org.br/artigos_pdf/3.pdf>. Acesso em: 10 set. 2014.

SARLET, Wolfgang Ingo. Dignidade da pessoa bumana e direitos fundamentais na Constituição da República de 1988. Porto Alegre: Livraria do Advogado, 2002. 


\section{REVISTA BRASILEIRA DE POLÍTICAS PÚBLICAS BRAZILIAN JOURNAL OF PUBLIC POLICY}

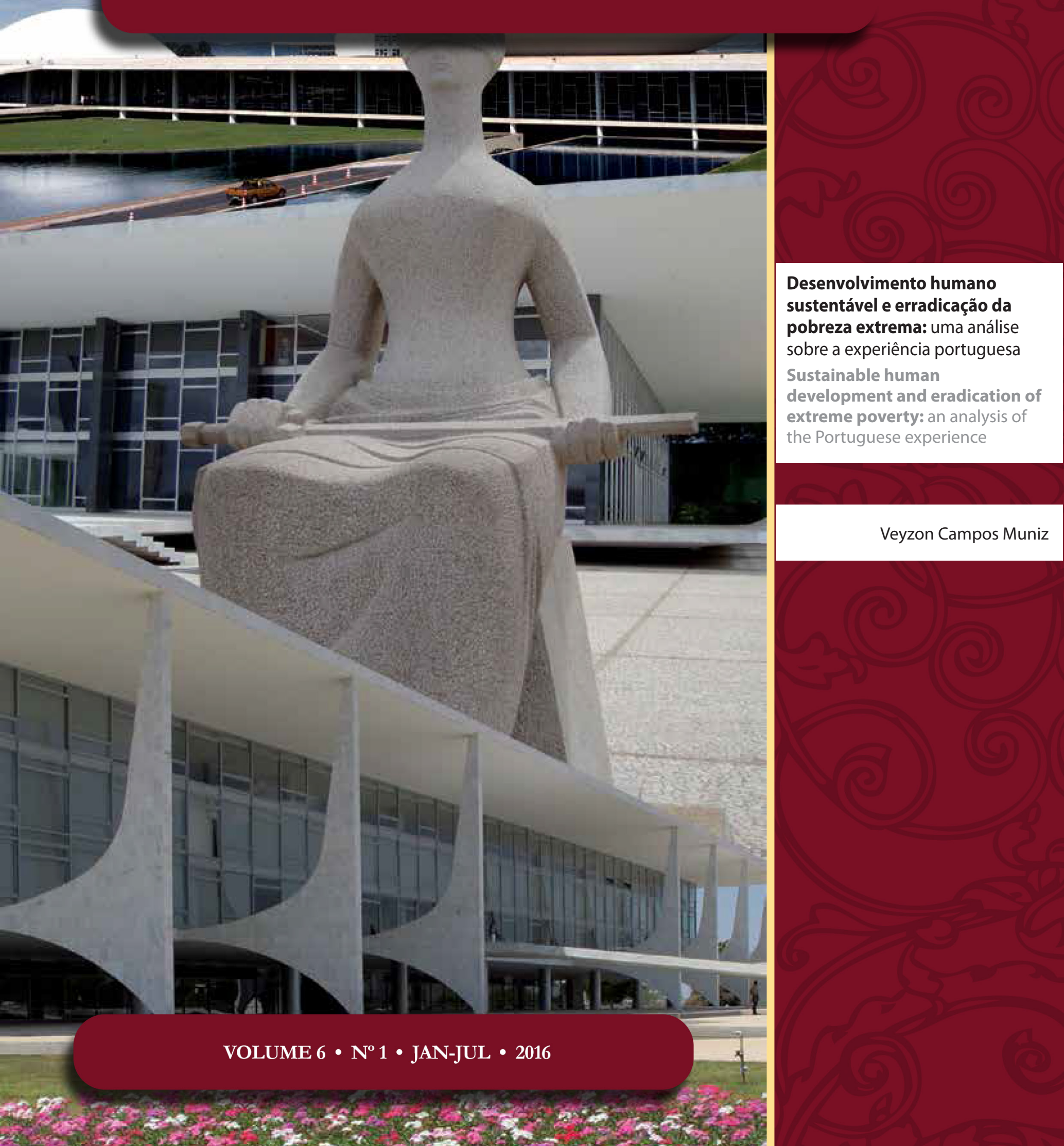




\title{
Desenvolvimento humano sustentável e erradicação da pobreza extrema: uma análise sobre a experiência portuguesa*
}

\author{
Sustainable human development and \\ eradication of extreme poverty: an analysis of \\ the Portuguese experience
}

Veyzon Campos Muniz**

\section{Resumo}

O presente artigo tem por escopo analisar a relação existente entre desenvolvimento sustentável e pobrezas. Assim, parte-se da avaliação do cumprimento dos primeiros Objetivos de Desenvolvimento do Milênio e de Desenvolvimento Sustentável (na concepção da Organização das Nações Unidas), quais sejam: erradicar a extrema pobreza e a fome e acabar com a pobreza em todas as suas formas e em todos os lugares. Objetiva-se, em primeiro momento, apresentar uma formulação teórica e propositiva acerca da matéria. Para, em um segundo segmento, centrar-se no seu enfrentamento pelo Estado Português, com fulcro na concretização das garantias de sustentabilidade social e combate à pobreza. Por conseguinte, assevera-se a emergência de se dar visibilidade à afirmação do desenvolvimento humano sustentável na consecução de políticas públicas e na efetividade de direitos fundamentais, no âmbito de um Estado Socioambiental e Democrático de Direito.

Palavras-chave: Direito e desenvolvimento. Sustentabilidade. Pobreza. Direito português.

* Recebido em 07/07/2015 Aprovado em 21/09/2015

** Doutorando junto ao Programa de Doutoramento em Direito Público - Estado Social, Constituição e Pobreza do Instituto Jurídico da Universidade de Coimbra (Portugal). Mestre em Direito, com voto de distinção e louvor, e bacharel laureado em Ciências Jurídicas e Sociais, pela PUCRS. Advogado. E-mail: veyzon_ muniz@yahoo.com.br

\section{Abstract}

This article has for scope to analyze the relationship between sustainable development and poverty. Thus, its bases on the assessment of compliance of the first Millennium Development and Sustainable Development Goals (in the design of the United Nations), namely: to eradicate extreme poverty and hunger and to end poverty in all its forms and everywhere. We present, at first, a theoretical and purposeful formulation on the subject. In a second segment, focuses in your coping by the Portuguese State with fulcrum in the implementation of the guarantees of social sustainability and poverty reduction. Therefore, it asserts to emergency of to call attention to sustainable human development in the achievement of public policies and in the effectiveness of fundamental rights, in the framework of a Environmental and Democratic State of Law.

Keywords: Law and Development. Sustainability. Poverty. Portuguese Law. 


\section{SUMÁRIO}

1 Introdução. 2 Interpretação sistemática, Direito \& Desenvolvimento. 3 Direito ao desenvolvimento e sustentabilidade social. 4 Pobrezas e socialidade. $5 \mathrm{O}$ combate à pobreza em Portugal. 6 Considerações Finais. Referências.

\section{INTRODUÇÃO}

Em junho de 1993, a Organização das Nações Unidas promoveu a II Conferência Mundial de Direitos Humanos, em Viena, no sentido de proceder avaliação dos avanços e perspectivas da prática do direito internacional dos direitos humanos. Naquela oportunidade, o debate entre as delegações governamentais de Portugal e da China ganhou destaque por demonstrar o quão frágil se mostrava o princípio da universalidade dos direitos humanos.

José Manuel Durão Barrosoํㅜㄹ Ministro dos Negócios Estrangeiros de Portugal, à época, defendeu:

Seria presunção nossa e um claro abuso pensar que, em vez de reconhecer e garantir, a comunidade dos Estados concede ou cria os direitos dos homens. Daqui deriva que o Estado [...] deve respeitar os direitos e a dignidade dos seus cidadãos e que não pode, em nome de alegados interesses coletivos econômicos, de segurança ou outros - ultrapassar a fronteira que lhe é imposta pela própria anterioridade dos direitos do homem e sua primazia relativamente a quaisquer fins ou funções do Estado.

A tese portuguesa, no sentido de se afirmar a indivisibilidade e interdependência dos direitos humanos, voltaria a ser debatida, em setembro de 2000, por ocasião da Cimeira do Milênio, pela qual se promoveu intensa reflexão acerca das necessidades básicas e das demandas sociais que não vinham sendo satisfatoriamente atendidas no âmbito das políticas públicas estaduais. Contando com 191 delegações governamentais, aprovou-se a Resolução A/RES/55/2/2000, pela qual ficaram estabelecidos objetivos concretos, mensuráveis e temporalmente delimitados, no sentido de ver-se efetivados direitos humanos e fundamentais. ${ }^{2}$

A referida Resolução ou Declaração do Milênio, como foi nomeada, reconheceu, inequivocamente, a inter-relação existente entre desenvolvimento, sustentabilidade social e erradicação da pobreza. Identificando-se, inclusive, como o primeiro dos oito Objetivos de Desenvolvimento do Milênio, a eliminação da extrema pobreza e da fome. Ao lado dessa meta, a Organização das Nações Unidas pugnou pela implementação do Projeto do Milênio, isto é, uma rede global de auxilio aos Estados na mudança do status quo tímido de combate à pobreza até então realizado, centrando-se em um planejamento estratégico de horizonte temporal a ser findado em 2015. ${ }^{3}$

Passados quinze anos, a Organização das Nações Unidas novamente se voltou ao tema do Desenvolvimento Sustentável do Milênio, assim, em Assembleia Geral, em setembro de 2014, Grupo de Trabalho Aberto elaborou uma proposta para a agenda pós-2015. ${ }^{4}$

1 BARROSO apud TRINDADE, Antonio Augusto Cançado. Tratado de direito internacional dos direitos humanos. Porto Alegre: S. A. Fabris, 1997. v. 1. p. 218.

2 ORGANIZAÇÃO DAS NAÇÕES UNIDAS. Declaração do Milênio. Nova Iorque: ONU, set. 2000. Disponível em: <http:// www.pnud.org.br/Docs/declaracao_do_milenio.pdf>. Acesso em: 09 dez. 2015.

3 Os oito objetivos gerais identificados foram: 1 - Erradicar a extrema pobreza e a fome; 2 - Atingir o ensino básico universal; 3 - Promover a igualdade de gênero e a autonomia das mulheres; 4 - Reduzir a mortalidade infantil; 5 - Melhorar a saúde materna. 6 - Combater o HIVIAIDS, a malária e outras doenças; 7 - Garantir sustentabilidade ambiental; 8 - Estabelecer uma parceria mundial para o desenvolvimento. ORGANIZAÇÃO DAS NAÇÕES UNIDAS. Declaraşão do Milênio. Nova Iorque: ONU, set. 2000. Disponível em: <http://www.pnud.org.br/Docs/ declaracao_do_milenio.pdf>. Acesso em: 09 dez. 2015

4 Por meio do Programa das Nações Unidas para o Desenvolvimento se constituiu uma articulação de envolvimento global que, aliada à visão local do desenvolvimento humano, trabalha para ajudar a coordenar os esforços de cada país no alcance dos objetivos firmados. As ações do Programa em Portugal podem ser acompanhadas pelo Centro Regional de Informação das Nações Unidas 
Nesse contexto, a presente pesquisa versa sobre o cumprimento da meta de erradicação da pobreza extrema em Portugal. Primeiro, traçando algumas proposições teóricas fundamentais para compreensão do objeto. Em seguida, desvelando como se deu o enfrentamento à pobreza nos últimos anos pelo Estado Português. Por fim, infere-se algumas perspectivas da implementação do desenvolvimento humano sustentável no país.

\section{InterpretaÇão Sistemática, Law \& DeVElopment}

Para alcançar o objetivo de demonstrar a inter-relação entre desenvolvimento sustentável e pobrezas, faz-se necessário esclarecer os fundamentos metodológicos utilizados na presente investigação, notadamente: a análise econômica empreendida e a prevalência da interpretação sistemática defendida.

I - A formulação de interpretações ou investigações, jurídicas ou econômicas, comumente desenvolvidas no âmbito da pesquisa científica, tem como objeto de estudo, essencialmente, comportamentos humanos. Amartya $\operatorname{Sen}^{5}$ explicita dialogicamente isso ao referir que, em última análise, o comportamento é uma questão social, o que acarreta reflexos no senso de identidade que encerra o reconhecimento dos objetivos de outras pessoas e das interdependências mútuas existentes em uma comunidade. Abre-se, nesses termos, a possibilidade do estudo do comportamento enquanto ação social ou mesmo prática institucional.

Interessante referir que Robert Castel $^{6}$ apresenta, oportunamente, a questão social enquanto "regulação circular" pela qual o:

estado dirige a economia. Constrói uma correspondência entre objetivos econômicos, objetivos políticos, objetivos sociais. Circularidade de uma regulação que pesa sobre o econômico para promover o social e que faz o social o meio de tirar de apuros a economia quando esta se abate.

Com efeito, direito e economia se ocupam da interpretação e da análise de comportamentos individuais ou coletivos com vista ao atendimento de demandas de interesse das ciências sociais aplicadas. Robert Cooter e Thomas Ulen ${ }^{7}$, nesse contexto, conceituam a análise econômica do direito como um assunto interdisciplinar que reúne dois grandes campos de estudo e facilitam uma maior compreensão de ambos. ${ }^{8}$

para A Europa Ocidental (ORGANIZAÇÃO DAS NAÇÕES UNIDAS. Objectivos de desenvolvimento do milénio (ODM). Bruxelas, 2015. Disponível em: <http://www.unric.org/pt/objectivos-de-desenvolvimento-do-milenio-actualidade>. Acesso em: 09 dez. 2015. Atenta-se que os dezessete Objetivos de Desenvolvimento Sustentável propostos em 2014 foram: 1 - Acabar com a pobreza em todas as suas formas, em todos os lugares; 2 - Acabar com a fome, alcançar a segurança alimentar, melhorar a nutrição; 3 - Assegurar uma vida saudável e promover o bem-estar para todos; 4 - Garantir educação inclusiva, equitativa e de qualidade; 5 - Alcançar a igualdade de gênero e empoderar todas as mulheres e meninas; 6 - Garantir disponibilidade e manejo sustentável da água; 7 - Garantir acesso à energia barata, confiável, sustentável; 8 - Promover o crescimento econômico sustentado, inclusivo e sustentável; 9 - Construir infraestrutura resiliente, promover a industrialização inclusiva; 10 - Reduæir a desigualdade entre os países e dentro deles; 11 - Tornar as cidades e os assentamentos bumanos inclusivos, seguros, resilientes; 12 - Assegurar padrões de consumo e produção sustentável; 13 - Tomar medidas urgentes para combater a mudança do clima; 14 - Conservar e promover o uso sustentável dos oceanos; 15 - Proteger, recuperar e promover o uso sustentável as florestas; 16 - Promover sociedade pacíficas e inclusivas para o desenvolvimento sustentável; 17 - Fortalecer os mecanismos de implementação e revitalizar a parcela global. ORGANIZAÇÃO DAS NAÇÕES UNIDAS. Declaração do Milênio. Nova Iorque: ONU, set. 2000. Disponível em: <http://www.pnud.org.br/Docs/declaracao_do_milenio.pdf>. Acesso em: 09 dez. 2015.

5 SEN, Amartya. Sobre ética e economia. Trad. Laura Teixeira Motta. São Paulo: Companhia das Letras, 1999. p. 101.

6 CASTEL, Robert. Metamorfoeses da questão social. Petrópolis: Vozes, 1998. p. 487.

7 COOTER, Robert; ULEN, Thomas. Direito e economia. Trad. Luis Marcos Sander, Francisco Araújo da Costa. 5. ed. Porto Alegre: Bookman, 2010. p. 33.

8 A análise econômica do direito enquanto movimento teórico contemporâneo costuma ter sua origem identificada nos artigos de Ronald Coase cf. COASE, Ronald H. The problem of social cost. The Journal of Law and Economic, Chicago, v. 3, p. 1-44, Oct. 1960; e Guido Calabresi cf. CALABRESI, Guido. Some thoughts on risk distributions and the law of torts. The Yale Law Journal. Yale, v. 70, n. 4, p. 499-553, Mar. 1961. Pedro Mercado Pacheco explicita que a Law \& Economics se trata de uma família teórica heterogênea que propugna, em linhas gerais, a (re)definição do direito com escopo nos problemas relacionados à eficiência e à viabilidade prática, custos e repercussões socioeconômicas de institutos, instrumentos e intervenções jurídicos. PACHECO, Pedro Mercado. El analisis economico del derecho. Madri: Centro de Estúdios Constitucionalies, 1994. p. 34-35. 
É, justamente, o imbricamento entre direito e economia que permite a abertura epistemológica utilizada na presente pesquisa, com o objetivo de aprofundar a reflexão acerca da erradicação da pobreza, enquanto mandamento constitucional. ${ }^{9}$

Quando tratamos de direitos fundamentais, desenvolvimento sustentável e pobrezas, é imprescindível se ter em conta que se está diante de objetos atinentes a múltiplos campos de estudo. Pode-se afirmar, assim, que ora se faz uma análise situada no âmbito específico da Law \& Development, segmento da Law \& Economics que desvela interfaces do direito e do desenvolvimento socioeconômico. ${ }^{10}$ Edifica-se, nesse sentido, uma análise de como o direito é instrumento para a promoção de desenvolvimento sustentável, políticas públicas democráticas e direitos fundamentais.

II - Outrossim, com o estreitamento das políticas econômicas, a partir do contexto de globalização, e o reconhecimento da internacionalização de matérias outrora pensadas somente em âmbito estadual, o estabelecimento de bases hermenêuticas adequadas na prática jurídica é cada vez mais relevante. José Joaquim Gomes Canotilho ${ }^{11}$, nesse contexto, alerta que "interpretar a Constituição é uma tarefa que se impõe metodicamente a todos os aplicadores das normas constitucionais (legislador, administração, tribunais)".

Pontua-se, frente a tal afirmação, que do exercício hermenêutico ${ }^{12}$ não pode se furtar, igualmente, o interlocutor de uma pesquisa acerca de um assunto sensível como a pobreza e sua repercussão no desenvolvimento sustentável. Ingo Wolfgang Sarlet, ${ }^{13}$ assim, elenca um catálogo de técnicas e diretrizes para assegurar uma metodologia "racional e controlável ao processo de interpretação (e aplicação) da Constituição e de suas normas (princípios e regras)", com forte no auxílio à formulação de respostas constitucionalmente adequadas aos problemas jurídico-constitucionais.

Valendo-se do referido rol de princípios de interpretação constitucional, desvelado pelo autor, ${ }^{14}$ apresentam-se três princípios essenciais à compreensão da garantia fundamental de erradicação da pobreza extrema:

a. Princípio da supremacia da Constituição: a interpretação deve atender uma hierarquia em que as normas constitucionais ocupam posição superior em relação às demais normas do ordenamento jurídico, ou seja, a estrutura normativa legalmente determinada não pode ignorar o que o texto constitucional estabelece, sobremaneira, a sustentabilidade como princípio estruturante;

b. Princípio da máxima eficácia e efetividade da Constituição: a interpretação deve se orientar pela busca da concretização constitucional (aproximação entre o dever-ser normativo e o ser da realidade social), isto é, a interpretação serve de instrumento para se assegurar a otimização da eficácia e efetividade da Constituição nas relações jurídico-administrativas, entre Estado e cidadãos, com escopo na redução máxima da pobreza em concreto;

9 Pontua-se que a aplicação de métodos e teorias próprias da ciência econômica na análise da formação, estrutura e impacto do direito não se confunde com uma interpretação econômica do direito. Não cabe ao operador jurídico interpretar usando métodos econômicos. Preserva-se, assim, a concepção de uma hermenêutica própria, pela qual se realizam inferências jurídicas sobre o pensamento econômico.

10 Marco Antônio Vasconcellos e Manuel Garcia, alertam que a teoria macroeconômica tradicional se preocupa com aspectos de curto prazo, notadamente, questões de desemprego e inflação. Refere que são as teorias de desenvolvimento socioeconômico, insertas na Law \& Development, que passam a incorporar questões estruturais, que envolvem políticas cujos efeitos demandam uma perspectiva intergeracional sobre os resultados. VASCONCELLOS, Marco Antônio; GARCIA, Manuel. Fundamentos de economia. 2. ed. São Paulo: Saraiva, 2004. p. 87.

11 CANOTILHO, José Joaquim Gomes. Direito constitucional e teoria da constituição. 7. ed. Coimbra: Almedina, 2010. p. 1223.

12 Na dicção de Ricardo Guastini "a atividade de averiguar ou decidir o significado de algum determinado documento ou texto jurídico", incluindo-se aí, logicamente, o texto constitucional, normas comunitárias e tratados internacionais. GUASTINI, Riccardo. Estudios sobre la interpretación jurídica. Trad. Marina Gascón e Miguel Carbonell. Cidade do México: Instituto de Investigaciones Jurídicas, 1999. p. 458.

13 SARLET, Ingo Wolfgang; MARINONI, Luiz Guilherme; MITIDIERO, Daniel. Curso de direito constitucional. São Paulo: Revista dos Tribunais, 2012. p. 207.

14 Tais princípios têm como finalidade possibilitar ao intérprete o pleno entendimento das normas constitucionais e sua significância nas relações jurídicas. Cf. SARLET, Ingo Wolfgang; MARINONI, Luiz Guilherme; MITIDIERO, Daniel. Curso de direito constitucional. São Paulo: Revista dos Tribunais, 2012. p. 207-218. 
c. Princípio da força normativa da Constituição: a interpretação frente a problemas ou deficit constitucionais deve primar por soluções que possibilitem a atualização normativa da Constituição e, ao mesmo tempo, garantam a sua eficácia e permanência, ou seja, diante da insustentável degradação do ser humano, vulnerabilizado pela pobreza, condição não adequada a quaisquer parâmetros de sustentabilidade, o intérprete deve fazer primar pelo atendimento à realização do texto constitucional na prática, sobretudo, na formulação de políticas públicas. ${ }^{15}$

Juarez Freitas ${ }^{16}$, oportunamente, aduz que a interpretação sistemática deve ser entendida como:

[...] uma operação que consiste em atribuir, topicamente, a melhor significação, dentre várias possíveis, aos princípios, às normas estritas (ou regras) e aos valores jurídicos, hierarquizáveis num todo aberto, fixando-lhes o alcance e superando antinomias em sentido amplo, tendo em vista solucionar os casos sob apreciação. Dito de outro modo, verdadeiramente a interpretação sistemática, compreendida em novas e realistas bases, é a que se realiza em consonância com aquela rede hierarquizável, máxime na Constituição, tecida junto na interação com o intérprete, positivador derradeiro.

A partir do exercício hermenêutico sistemático se dá concretude material à interpretação constitucional e à aplicação da Constituição. ${ }^{17}$ Filia-se, assim, à ideia de que a interpretação sistemática é "a interpretação jurídica, por excelência", devendo o operador "contribuir para a descoberta e para a formação tópica do sistema jurídico, em sintonia com os objetivos fundamentais do Estado Democrático."18

\section{Direito ao desenVolvimento e sustentabilidade social}

Michel Troper ${ }^{19}$ aduz que a interpretação de um sistema jurídico (ou de seu funcionamento) depende de uma escolha ontológica decorrente de uma opção epistemológica. Resta estabelecido um binômio (experiência-certeza) que permite a construção de um raciocínio sistemático, e, consequentemente, de uma interpretação que impõe ao intérprete a valoração e seleção de arquétipos estruturais. Nesse contexto, se foi opção do constituinte a concretização de um Estado Socioambiental e Democrático de Direito, é correto afirmar o desenvolvimento sustentável como um paradigma interpretativo na experiência constitucional portuguesa.

O texto constitucional elenca, expressamente, como princípio fundamental da organização econômico-social da República Federativa Portuguesa, o "planejamento democrático do desenvolvimento econômico e social" (em seu artigo $80, e$ e, como incumbência prioritária do Estado Português, a promoção do "aumento de bem-estar social e econômico e da qualidade de vida das pessoas, especial das mais desfavorecidas, no quadro de uma estratégia de desenvolvimento sustentável" (nos termos do artigo 81, a). Como muito bem explicita José Casalta Nabais, ${ }^{20}$ "O

15 Merecem destaque as proposições de Konrad Hesse no sentido de que deve haver uma conexão indissolúvel entre a ordenação jurídica e a realidade fática. Nesse mote, propugna-se que não há que se pensar em um direito fundamental sem que este tenha sede constitucional, mas também não há direito fundamental sem que haja fatos sociais que o sustentem. Nesse contexto, o objetivo fundamental de erradicação da pobreza advém da realidade de vulnerabilidade social dos pobres. HESSE, Konrad. Escritos de derecho constitucional. Trad. Pedro Cruz Villalón. Madri: Centro de Estudios Constitucionales, 1992.

16 FREITAS, Juarez. A interpretação sistemática do direito. 5. ed. São Paulo: Malheiros, 2010. p. 82-83.

17 Nessa linha de raciocínio, é nítido que a interpretação sistemática mescla elementos interpretativos sistêmicos e teológicosavaliativos. Neil MacCormick refere que: "Por trás da interpretação sistêmica repousa um princípio de racionalidade fundado no valor da coerência e da integralidade de todo o sistema jurídico. Por trás da interpretação teológico-avaliativa repousa o respeito por uma demanda de razão prática segundo a qual as atividades humanas precisam ser guiadas por algum senso de valor a ser realizado pela ação e por princípios que sejam observados nesse senso de valor". Assim, visando à materialidade da linha de argumentação ora defendida, assevera-se que interpretar sistematicamente é interpretar com base nas prescrições do sistema jurídico e na circunscrição dos valores constitucionalmente estabelecidos. MACCORMICK, Neil. Retórica e o estado de direito. Trad. Conrado Hübner Mendes. Rio de Janeiro: Elsevier, 2008. p. 185.

18 FREITAS, Juarez. A interpretação sistemática do direito. 5. ed. São Paulo: Malheiros, 2010. p. 290.

19 TROPER, Michel. A filosofia do direito. Trad. Ana Deiró. São Paulo: M. Fontes, 2008. p. 123-154.

20 CASALTA NABAIS, José. Política fiscal, desenvolvimento sustentável e luta contra a pobreza. Cadernos da Escola de Direito e Relações Internacionais da UniBrasil, Curitiba, n. 7, p. 361-378, jan./dez. 2007. p. 368. 
desenvolvimento sustentável é o desenvolvimento econômico ou crescimento do produto, [...] que esteja comprometido com o futuro, com as necessidades das futuras gerações".

Observa-se, nesses termos, que o desenvolvimento sustentável, de matriz constitucional, para além de social e econômico em sentido estrito, apresenta-se como bumano, em sentido amplo, na medida em que garante aos cidadãos que o Estado não ponha em causa os deveres e obrigações que possui com as gerações futuras. Trata-se de uma ideia de desenvolvimento delineado pela condição humana ${ }^{21}$, em perspectivas multigeracional e também transestatal.

De fato, a Organização das Nações Unidas, em 1972, quando da proclamação da Declaração sobre o Meio Ambiente Humano, afirmou essa concepção de desenvolvimento humano sustentável ao definir que o desenvolvimento impõe um processo de mudança no qual a exploração de recursos, a direção de investimentos, a orientação da produção científica e a evolução institucional devem ser feitas com vista ao atendimento de necessidades sociais presentes e futuras. ${ }^{22}$

O desenvolvimento sustentável, como aponta Juarez Freitas ${ }^{23}$, mostra-se como um verdadeiro axioma axiológico, pela qual se introduz na integralidade da sociedade - aqui incluída a cultura e o direito - um modelo de valoração interpretativa. Enquanto determinação ética e jurídico-institucional, com forte no artigo 66, 2, da Constituição da República Portuguesa, se induz uma diretriz cogente para intérpretes e aplicadores do direito, qual seja: a garantia do direito ao ambiente (não apenas ecológico), no quadro de um desenvolvimento (humano) sustentável, que enseja ao Estado, com o envolvimento e participação dos cidadãos, a promoção e integração de objetivos fundamentais atrelados à qualidade de vida.

Resta nítido que o Estado Português estabeleceu, mesmo que implicitamente, o entendimento de que o meio ambiente é um conjunto de interações de diversas ordens (ecológica, social, cultural, urbanística) cujo direito ao desenvolvimento vem respaldar como imperativo inarredável. Peter Häberle ${ }^{24}$ pontua, nesse sentir, que a sustentabilidade deve ser entendida como elemento estrutural típico dos Estados Constitucionais contemporâneos, uma vez que o seu protagonismo tópico salvaguarda a própria concepção de constituição ao longo das gerações.

Tomando-se por base um modelo multidimensional de sustentabilidade, pautado, sobretudo, na ideia de se está diante de uma imposição constitucional consistente em escolhas públicas racionais, pode-se afirmar que Estados Constitucionais devem atender as seguintes dimensões essenciais para concretizar o desenvolvimento sustentável enquanto elemento estrutural da ordenação social (e garantir a sua longevidade). Observam-se:

21 Hannah Arendt refere que a ideia sobre a condição humana "compreende algo mais que as condições nas quais a vida foi dada ao homem. Os homens são seres condicionados: tudo aquilo com o qual eles entram em contato torna-se imediatamente uma condição de sua existência." Nesse sentido, afirmar que o desenvolvimento está atrelado essencialmente à garantia de bem-estar importa no reconhecimento de um princípio constitucional implícito de vedação de retrocesso social. ARENDT, Hannah. A condição bumana. 10. ed. Rio de Janeiro: Forense Universitária, 2003. p. 17.

22 A referida Declaração proclama que: "O homem é ao mesmo tempo obra e construtor do meio ambiente que o cerca, o qual lhe dá sustento material e lhe oferece oportunidade para desenvolver-se intelectual, moral, social e espiritualmente”. ORGANIZAÇÃO DAS NAÇÕES UNIDAS. Declaração de Estocolmo sobre o ambiente humano, 1972: publicada pela Conferência das Nações Unidas sobre o meio ambiente humano em Junho de 1972. Disponível em: <http://www.direitoshumanos.usp.br/index.php/Meio-Ambiente/declaracao-de-estocolmosobre-o-ambiente-humano.html>. Acesso em: 09 dez. 2015.

23 FREITAS, Juarez. Sustentabilidade: direito ao futuro. 2. ed. Belo Horizonte: Fórum, 2012. p. 31.

24 HÄBERLE, Peter. Nachhaltigkeit und Gemeineuropäisches Verfassungsrecht. In: WOLFGANG, Kahl (Org.). Nachbaltigkeit als Verbundbegriff. Tubinga: Mohr Siebeck, 2008. p. 180-206. p. 200. 
Figura 1 - Modelo multidimensional da sustentabilidade

\begin{tabular}{|c|c|c|c|c|}
\hline $\begin{array}{c}\text { Dimensão } \\
\text { Social }\end{array}$ & $\begin{array}{c}\text { Dimensão } \\
\text { Ética }\end{array}$ & $\begin{array}{c}\text { Dimensão } \\
\text { Ambiental }\end{array}$ & $\begin{array}{c}\text { Dimensão } \\
\text { Econômica }\end{array}$ & $\begin{array}{c}\text { Dimensão } \\
\text { Política }\end{array}$ \\
\hline $\begin{array}{c}\text { Vedação de } \\
\text { desenvolvimento } \\
\text { excludente e injusto }\end{array}$ & $\begin{array}{c}\text { Reconbecimento da } \\
\text { ligação de todos os seres e } \\
\text { universalização concreta } \\
\text { do bem-estar }\end{array}$ & $\begin{array}{c}\text { Garantia intergeracional } \\
\text { ao meio ambiente } \\
\text { equilibrado }\end{array}$ & $\begin{array}{c}\text { Imposição de uma } \\
\text { avaliação de custos e } \\
\text { benefícios financeiros } \\
\text { intra e intergeracional }\end{array}$ & $\begin{array}{c}\text { Determinação de eficácia } \\
\text { da tutela jurídica de } \\
\text { direitos fundamentais }\end{array}$ \\
\hline
\end{tabular}

Fonte: Do Autor ${ }^{25}$.

Tal modelo pentapartite informa em sua dimensão ecológico-ambiental a indisponibilidade de qualidade ambiental nas ações públicas e privadas, consagrando o direito fundamental difuso ao meio ambiente, respeitados os princípios de proteção e prevenção ambientais. A dimensão econômico-financeira, ao seu turno, estabelece uma ordem econômica que, sem se desviar da meta de obtenção de prosperidade financeira, se balizada pelo respeito ao meio ambiente humano.

Por sua vez, é a dimensão ética na constituição da sustentabilidade que permite explicitar os princípios de solidariedade e igualdade comunitários, enquanto, elementos constitutivos de um mínimo ético existente em uma ordenação estadual. Integrando-se, materialmente, com a dimensão social, representativa do signo de justiça social.

Com efeito, como se depreende do texto constitucional, tem-se, com base nessas dimensões, uma determinação de realização substantiva da sustentabilidade. ${ }^{26}$ Incluindo-se, nesse particular, a erradicação da pobreza como expressão da dimensão ético-social do desenvolvimento humano sustentável português.

Por conseguinte, ganha relevo a dimensão política da sustentabilidade, por determinar mandamentalmente a aplicabilidade das normas de direitos fundamentais, no sentido se ver realizadas políticas públicas concretas de desenvolvimento sustentável. De fato, deve-se pensar a sustentabilidade como um processo de desenvolvimento voltado à garantia de bem-estar social, com forte na estabilidade intertemporal do Estado. $^{27}$

Logo, as múltiplas dimensões apresentadas determinam ao intérprete constitucional que observe a sustentabilidade enquanto princípio estruturante de um Estado Socioambiental e Democrático de Direito que pretende, por vocação e essência, se postergar no tempo. As diretrizes normativas de desenvolvimento sustentável, nesse sentido, permitirão a concretização desse objetivo, sendo oportuno referir que a Declaração sobre o Meio Ambiente Humano, em seu item 2, aduz que:

a proteção e o melhoramento do meio ambiente humano é uma questão fundamental que afeta o bemestar dos povos e o desenvolvimento econômico do mundo inteiro, um desejo urgente dos povos de todo o mundo e um dever de todos os governos. ${ }^{28}$

José Joaquim Gomes Canotilho, ${ }^{29}$ ao versar sobre o princípio-síntese do Estado Português, expõe aspectos

25 Cf. FREITAS, Juarez. Sustentabilidade: direito ao futuro. 2. ed. Belo Horizonte: Fórum, 2012.

26 José Carlos Vieira de Andrade alerta que a "constituição, enquanto estatuto jurídico do político, não fornece uma resposta concreta e determinada para o problema de como e em que medida deve o Estado prossegue essa tarefa fundamental que é a de promover a efetivação dos direitos econômicos, sociais, culturais e ambientais". ANDRADE, José Carlos Vieira de. Os direitos fundamentais na constituição portuguesa de 1976. 5. ed. Coimbra: Almedina, 2012. p. 382.

27 Suzana Tavares da Silva, ao analisar problemas metodológicos incidentes na afirmação de direitos fundamentais na seara global, refere que "a garantia de bem-estar social é um conceito cuja densificação apenas é possível em relação a um modelo econômico-social", sendo taxativa ao dizer que "as preocupações sociais do Estado consubstanciam fundamentalmente um problema político e não um problema jurídico”. SILVA, Suzana Tavares da. Direitos fundamentais na Arena Global. Coimbra: Imprensa da Universidade de Coimbra, 2011 . p. 59.

28 ORGANIZAÇÃO DAS NAÇÕES UNIDAS. Declaração de Estocolmo sobre o ambiente humano, 1972: publicada pela Conferência das Nações Unidas sobre o meio ambiente humano em Junho de 1972. Disponível em: <http://www.direitoshumanos.usp.br/ index.php/Meio-Ambiente/declaracao-de-estocolmo-sobre-o-ambiente-humano.html>. Acesso em: 09 dez. 2015.

29 CANOTILHO, José Joaquim Gomes. O princípio da sustentabilidade como princípio estruturante de direito constitucional. Tékhne: Revista de Estudos Politécnicos, Barcelos, v. 8, n. 13, p. 7-18, 2010. p. 8-9. 
estruturais da sustentabilidade, análogos aos referenciados em da referida Declaração, que merecem atenção:

Tal como outros princípios estruturantes do Estado Constitucional - democracia, liberdade, juridicidade, igualdade - o princípio da sustentabilidade é um princípio aberto carecido de concretização conformadora e que não transporta soluções prontas, [...] o imperativo categórico que está na génese do princípio da sustentabilidade e, se preferir, da evolução sustentável: os humanos devem organizar os seus comportamentos e acções de forma a não viverem: (i) à custa da natureza; (ii) à custa de outros seres humanos; (iii) à custa de outras nações; (iiii) à custa de outras gerações. Em termos mais jurídico-políticos, dir-se-á que o princípio da sustentabilidade transporta três dimensões básicas: (1) a sustentabilidade interestatal, impondo a equidade entre países pobres e países ricos; (2) a sustentabilidade geracional que aponta para a equidade entre diferentes grupos etários da mesma geração (exemplo: jovem e velho); (3) a sustentabilidade intergeracional impositiva da equidade entre pessoas vivas no presente e pessoas que nascerão no futuro.

O raciocínio desenvolvido no sentido de que os seres humanos devem organizar os seus comportamentos de forma a viverem com autonomia e de que há imposição de equidade intra e intergeracionais é fundamental para compreendermos os reflexos da sustentabilidade à erradicação da pobreza. Com efeito, a conformação da sustentabilidade aplicada à tutela dos direitos fundamentais advém, justamente, das implicações ético-sociais que ela condiciona.

Nas relações jurídico-administrativas, a irradiação da sustentabilidade indica, inequivocamente, a incumbência prioritária do Estado, nos âmbitos econômico e social, de promover o aumento de bem-estar para a população, em especial para os segmentos socais em condição de vulnerabilidade. Trata-se de uma garantia difusa, constitucionalmente assegurada, que tem por fundamento a própria sustentabilidade social.

Notadamente a dimensão social da sustentabilidade é o elemento que apoia ativamente a capacidade das gerações atuais e futuras de compartilhar interesses comuns e cooperar de modo direto para o aprimoramento estadual e comunitário. O desenvolvimento socioeconômico impõe, nesses termos, a difusão de bem-estar no futuro a partir de uma gestão pública socialmente responsável no presente. Logo, não podem ser alijados no processo de desenvolvimento os mais pobres, em plano material, sob pena de uma nítida agressão ao Estado Socioambiental e Democrático de Direito.

Com efeito, a sustentabilidade social guarda correspondência com a faceta humana de não "meramente" sobreviver, mas sim prosperar. Garante-se, com base nela, a proteção de necessidades básicas e contínuo desenvolvimento do potencial humano por meio da expansão de condições e oportunidade salutares. Ela, assim, almeja a equidade social, sobremaneira, na ofensiva contra aspectos estruturais que enriqueçam alguns em detrimento de outrem, determinando a constituição de mecanismos institucionais que assegurem compartilhamento de bens públicos e benefícios sociais, de modo equitativo para a integralidade da sociedade.

Amartya e Bernardo ${ }^{30}$, ao apresentarem a ideia de capital social, restam por formular assertivas fundamentais na afirmação da dimensão social do desenvolvimento sustentável. O capital social é composto, sinteticamente, pelo clima de confiança nas relações sociais, pela capacidade de associabilidade, pela consciência cívica e pelos valores éticos predominantes em uma determinada sociedade, ou seja, passa a ser indiciário do comportamento sustentável do Estado e demais agentes econômicos. Aplicando-se tal concepção à noção de sustentabilidade social, percebemos os seguintes vetores:

30 SEN, Amartya; KLIKSBERG, Bernardo. As pessoas em primeiro lugar: a ética do desenvolvimento e os problemas do mundo globalizado. Trad. Bernardo Azemberg. São Paulo: Companhia das Letras, 2010. p. 304-315. 
Figura 2 - Vetores capitais da sustentabilidade social

\begin{tabular}{|r|l|}
\hline Equidade & $\begin{array}{l}\text { São oferecidas condições e oportunidades equitativas para todos os membros da sociedade, em } \\
\text { particular os mais vulneráveis }\end{array}$ \\
\hline Diversidade & Há promoção, incentivo e respeito à diversidade e ao multiculturalismo \\
\hline Conectividade & $\begin{array}{l}\text { Existem processos, sistemas e estruturas que fomentam a comunicabilidade, a nivel formal, informal } \\
\text { e institucional }\end{array}$ \\
\hline Qualidade de vida & Restam asseguradas as necessidades básicas, individuais e coletivas, dos membros da sociedade \\
\hline $\begin{array}{r}\text { Democracia e } \\
\text { Governança }\end{array}$ & $\begin{array}{l}\text { São estabelecidos processos democráticos, procedimentos transparentes e estruturas políticas abertas e } \\
\text { responeis }\end{array}$ \\
\hline Maturidade & $\begin{array}{l}\text { Existe aceitação social e individual da responsabilidade no crescimento constante e consistente da } \\
\text { sociedade por meio de atributos pessoais e coletivos }\end{array}$ \\
\hline
\end{tabular}

Fonte: Do Autor ${ }^{31}$

Posto isso, é possível afirmar, com respaldo na Constituição, que o principio estruturante da sustentabilidade enseja o desenvolvimento sustentável como parâmetro teórico e prático na orientação da interpretação e análise jurídicas. No corolário, a sua dimensão ético-social repercute diretamente nas relações jurídicas, afirmando a sustentabilidade social como indutora de um desenvolvimento socioeconômico de protagonismo humano, assegurado pelo poder público. Justificando-se, ainda, a incidência da noção de capital social no cotidiano da sociedade e regulado pelo Estado Constitucional.

\section{Pobrezas e socialidade}

Subordinando-se ao conjunto de ações institucionais que objetivam garantir e aprimorar a qualidade de bem-estar, a partir do fomento ao capital social na sociedade, é possível inferir, sobretudo, dos seus vetores relativos à equidade e à maturidade, uma imposição no sentido de se diminuírem desigualdades socioeconômicas e se ampliar o acesso a bens e serviços públicos. Percebe-se, nitidamente, que, quando falamos em sustentabilidade social, estão as pessoas em primeiro lugar - como no título da obra de Amartya Sen e Bernardo Kliksberg. ${ }^{32}$

Nesse contexto, novamente, a Organização das Nações Unidas figura como fórum global de fomento ao desenvolvimento sustentável. Em 1986, quando da Declaração sobre o Direito ao Desenvolvimento, positivou-se a conceituação de socialidade como fator essencial ao direito ao desenvolvimento. $\mathrm{Na}$ dicção do parágrafo $2^{\circ}$, do artigo $2^{\circ}$ :

todos os seres humanos têm responsabilidade pelo desenvolvimento, individual e coletivamente, levandose em conta a necessidade de pleno respeito aos seus direitos humanos e liberdades fundamentais, bem como seus deveres para com a comunidade, que sozinhos podem assegurar a realização livre e completa do ser humano, e deveriam por isso promover e proteger uma ordem política, social e econômica apropriada para o desenvolvimento. ${ }^{33}$

Importante referir que, ao se reportar ao Pacto Internacional sobre Direitos Econômicos, Sociais e Culturais e ao Pacto Internacional sobre Direitos Civis e Políticos, o mesmo diploma, em seu artigo 4, impõe aos Estados signatários:

o direito e o dever de formular políticas nacionais adequadas para o desenvolvimento, que visem o constante aprimoramento do bem-estar de toda a população e de todos os indivíduos, com base em sua participação

31 Cf. SEN, Amartya; KLIKSBERG, Bernardo. As pessoas em primeiro lugar: a ética do desenvolvimento e os problemas do mundo globalizado. Trad. Bernardo Azemberg. São Paulo: Companhia das Letras, 2010.

32 SEN, Amartya; KLIKSBERG, Bernardo. As pessoas em primeiro lugar: a ética do desenvolvimento e os problemas do mundo globalizado. Trad. Bernardo Azemberg. São Paulo: Companhia das Letras, 2010.

33 ORGANIZAÇÃO DAS NAÇÕES UNIDAS. Declaração sobre o direito ao desenvolvimento: adotada pela Resolução n. ${ }^{\circ} 41 / 128 \mathrm{da}$ Assembléia Geral das Nações Unidas, de 4 de dezembro de 1986. Disponível em: <http://www.direitoshumanos.usp.br/index. php/Direito-ao-Desenvolvimento/declaracao-sobre-o-direito-ao-desenvolvimento.html>. Acesso em: 09 dez. 2015. 
ativa, livre e significativa no desenvolvimento e na distribuição equitativa dos benefícios daí resultantes. ${ }^{34}$

Entretanto, mesmo positivados, em sede da Carta Internacional de Direitos Humanos, socialidade e desenvolvimento não se tornam realidade social, sem ações individuais, coletivas e institucionais práticas. O fenômeno da pobreza é exemplificativo e contundente no sentido de provar que os Estados Socioambientais e Democráticos de Direito possuem grandes e sérios desafios na consecução de políticas públicas efetivas e na concretização fática dos direitos fundamentais.

Outrossim, ao se debruçar sobre Relatório do Desenvolvimento Humano da Organização das Nações Unidas, ${ }^{35}$ pode ser lido um relato de uma mãe solteira da Guiana que assim define: "a pobreza é a fome, a solidão, não ter lugar para ir quando o dia é longo, a privação, a discriminação, o abuso, o analfabetismo". Tal depoimento emocionado se alia a tantos outros, tornando perceptível o quão complexa é problemática da pobreza e suas implicações à socialidade.

Deepa Narayan ${ }^{36}$, por sua vez, introduz assertivas que justificam a utilização do termo pobreza no plural, as quais se destacam:

a. A pobreza é multidimensional: o fenômeno não se refere apenas ao bem-estar econômico, mas também a questões sociais, de dignidade, liberdades, democracia, igualdade, autonomia e empoderamento. Centrar a comprrensão da pobreza de modo ortodoxo, coloca as pessoas que vivem abaixo de um certo limiar de renda como pobres, ignorando outras condições específicas relvantes como p.ex. apsectos espaciais ou temporais.

b. A pobreza é dinâmica: o fenômeno corrresponde a uma situação e não a uma característica inata aos sujeitos. Percebe-se que há muito movimento para cima e para baixo quando pensamos em uma linha de pobreza. Além disso, os fatores que levam ao movimento ascendente são diferentes daquelas relacionadas com o movimento descendente; o que requer políticas públicas diferentes para cada situação concreta.

c. A pobreza é variável: o fenômeno apresenta tanto variação interna ao Estado quanto frente aos outros países. É perceptível uma variação maior dentro de um país do que entre países; revela-se assim que a mobilidade da pobreza varia mais estadualmente do que comunitariamente. O que é importante para compreender a dinâmica e a capacidade de resposta das democracias locais.

As pobrezas, assim, apresentam-se de muitos modos, sendo mais ou menos problemáticas para o Estado Constitucional na medida em que seus instrumentos democráticos estão melhor implementados, seus gestores públicos estão mais qualificados e seu nível de desenvolvimento humano sustentável é mais robusto. Contudo, a percepção da pobreza pelo sujeito é, indubitavelmente, um fator fundamental para a efetividade de qualquer política pública de combate ou erradicação - por tratar-se de uma questão de cidadania.

A mesma autora, nessa linha de raciocínio, destaca seis parâmetros de mensuração da pobreza, a partir da dicção de pessoas pobres ${ }^{37}$ :

em primeiro lugar, a pobreza é consistente em muitas dimensões interligadas. Embora a pobreza raramente seja sobre a falta de apenas uma coisa, a linha de fundo é sempre a fome, a falta de alimentos. Em segundo lugar, a pobreza tem dimensões psicológicas importantes, tais como a impotência, a falta de voz, a dependência, a vergonha e a humilhação. A manutenção da identidade cultural e as normas sociais de solidariedade ajudam as pessoas pobres a continuar a acreditar em sua própria humanidade,

34 FUNDO DE POPULAÇÃO DAS NAÇÕES UNIDAS. Pacto Internacional sobre os Direitos Econômicos, Sociais e Culturais. Disponível em: <http://www.unfpa.org.br/Arquivos/pacto_internacional.pdf>. Acesso em: 09 dez. 2015; ORGANIZAÇÃO DAS NAÇÕES UNIDAS. Pacto Internacional sobre os Direitos Civis e Políticos. Disponível em: <http://www.gddc.pt/direitos-humanos/ textos-internacionais-dh/tidhuniversais/cidh-dudh-direitos-civis.html>. Acesso em: 09 dez. 2015.

35 ORGANIZAÇÃO DAS NAÇÕES UNIDAS. Relatório do Desenvolvimento Humano 2014. Lisboa: Camões, 2014. p. 18.

36 NARAYAN, Deepa. Child poverty insights: the dynamics of poverty. In: UNITED NATIONS CHILDREN'S FUND. Social and economic policy: policy and practice. Nova Iorque: Unicef, Apr. 2010. p. 1-4.

37 NARAYAN, Deepa. Child poverty insights: the dynamics of poverty. In: UNITED NATIONS CHILDREN'S FUND. Social and economic policy: policy and practice. Nova Iorque: Unicef, Apr. 2010. p. 4-5. 
apesar das condições desumanas. Em terceiro lugar, as pessoas pobres não têm acesso à infraestrutura básica, como estradas (sobretudo, em áreas rurais), transportes e água limpa. Em quarto lugar, enquanto há uma sede generalizada pela alfabetização, a escolarização recebe pouca menção ou críticas mistas. As pessoas pobres percebem que a educação oferece uma fuga da pobreza, mas somente se o ambiente econômico na sociedade em geral é de qualidade educacional. Em quinto lugar, a carência de saúde e as doenças são temidas quase integralmente, enquanto fonte de miséria. Isto está relacionado com os custos de cuidados de saúde, bem como com a perda de rendimentos devido a doenças. Finalmente, os pobres raramente falam de renda, mas concentram-se em ativos (físicos, humanos, sociais e ambientais) que a gerem como uma maneira de lidar com sua vulnerabilidade. Em muitas áreas, nota-se que esta vulnerabilidade possui uma dimensão de gênero. ${ }^{38}$

De fato, a pobreza, enquanto fato social presente na sociedade, pode possuir o efeito consequencial de afirmar a socialidade e, por conseguinte, impulsionar a implementação de políticas públicas que visem dar concretude ao desenvolvimento humano sustentável - todavia, a mão contrária também é verdadeira, podendo dar causa a um ambiente caótico e a convulsões sociais. O pobre, enquanto sujeito de direitos, pode (e deve) deixar de ser visto como mero destinatário de assistência social, passando a ser considerado efetivamente como cidadão, respeitada a sua condição de vulnerabilidade.

Como exposto pelas Regras de Brasília sobre Acesso à Justiça das Pessoas em condição de Vulnerabilidade, aprovadas no âmbito da XIV Conferência Judicial Ibero-americana, ${ }^{39}$ desvelam-se como em condição de vulnerabilidade aquelas pessoas que, pela pobreza (enquanto circunstâncias sociais, econômicas, étnicas ou culturais), encontram especiais dificuldades em exercitar com plenitude os direitos reconhecidos pelo ordenamento jurídico. Dessa feita, fica bastante claro que quanto maior a pobreza (socioeconômica) maior é a dificuldade para exercício de direitos fundamentais.

\section{O combate À pobreza em Portugal}

A Constituição da República Portuguesa trata das tarefas fundamentais do Estado, em seu artigo $9^{\circ}$, estabelecendo na alínea $d$, a promoção do bem-estar e da qualidade de vida do povo, propugnando

A igualdade real entre os portugueses, bem como a efetivação dos direitos econômicos, sociais, culturais e ambientais, mediante a transformação e modernização das estruturas econômicas e sociais. ${ }^{40}$

Nota-se que, sendo a opção constituinte pelo desenvolvimento humano sustentável, a erradicação de entraves à sua concretização torna-se um consentâneo lógico.

A pobreza é, assim, um problema a ser enfrentado pelo Estado Constitucional. Contudo, a pobreza extrema emerge como uma dificuldade ainda maior. Segundo Jeffrey Sachs ${ }^{41}$, a pobreza absoluta refere-se:

[...] a condição em que as famílias não conseguem nem ao menos ter acesso a meios básicos de subsistência. Elas são assoladas pela fome crônica, não conseguem ter acesso a tratamento de saúde, não desfrutam de água potável segura e sistema de saneamento básico, não possuem condições de custear a educação de algumas ou de todas as suas crianças, e por vezes são desprovidas de condições elementares de moradia e itens básicos de vestimenta, como sapatos. Ao contrário da pobreza moderada e da relativa, a pobreza extrema somente é encontrada nos países em desenvolvimento.

O Banco Mundial, em seu Relatório sobre o Desenvolvimento Mundial 1990, estabeleceu liminar de

38 Tradução nossa.

39 FUNDACION INTERNACIONAL Y PARA IBEROAMÉRICA DE ADMINISTRACION Y POLITICAS PUBLICAS. Regras de Brasilia sobre acesso à Justiça das pessoas em condição de vulnerabilidade, 2008. p. 8. Disponível em: <http://www.anadep.org.br/ wtksite/100-Regras-de-Brasilia-versao-reduzida.pdf>. Acesso em: 09 dez. 2015.

40 PORTUGAL. Constituição (1976). Revisão constitucional n. 7, de 12 de agosto de 2005. Disponível em: <http://www.parlamento. pt/Legislacao/Documents/constpt2005.pdf>. Acesso em: 09 dez. 2015.

41 SACHS, Jeffrey. The end of poverty, economic possibilites for our time. New York: The Penguin, 2005. p. 20. 
pobreza, em ideia análoga, fixando o parâmetro de renda de um dólar norte-americano por dia (medido em termos de paridade de poder aquisitivo médio local) para a determinação da pobreza extrema.

Nesse contexto, Portugal que, segundo o mais recente Relatório do Desenvolvimento Humano da Organização das Nações Unidas ${ }^{42}$, figura na $41^{a}$ posição entre os países de desenvolvimento humano muito elevado, não teria, assim, pobreza extrema a ser erradicada, consoante a proposição do Sachs ${ }^{43}$. Mas esse fato retira a sociedade portuguesa da discussão acerca da erradicação da pobreza?

Acreditamos que não. Quando nos voltamos para âmbito interno de Portugal, os dados do Instituto Nacional de Estatística nos revelam uma realidade sensível ao fenômeno da pobreza. Valendo-se de uma taxa percentual, calcula-se a proporção da população cujo rendimento médio situa-se abaixo da linha de pobreza definida como $60 \%$ do rendimento mediano por adulto equivalente. ${ }^{44}$ Nesse contexto, o país que, no contexto global, não logra nível de pobreza relevante, apresenta, em âmbito intraestadual, uma tendência de agravamento do risco de pobreza de sua população. Observam-se os seguintes dados:

Figura 3 - Evolução temporal da taxa de risco de pobreza em Portugal

\begin{tabular}{|c|c|c|c|c|}
\hline \multicolumn{4}{|c|}{ Taxa percentual de risco de pobreza } & \\
\hline Anos & $\begin{array}{l}\text { Antes de qualquer } \\
\text { transferência social }\end{array}$ & $\begin{array}{l}\text { Após transferências } \\
\text { relativas a pensões }\end{array}$ & $\begin{array}{c}\text { Após transferências } \\
\text { sociais }\end{array}$ & \\
\hline 2000 & 38,0 & 27,0 & 21,0 & \\
\hline 2001 & 37,0 & 24,0 & 20,0 & \\
\hline 2002 & $\mathrm{x}$ & 26,0 & 20,0 & \\
\hline 2003 & $\mathrm{x}$ & 26,0 & 19,0 & \\
\hline 2004 & 41,3 & 26,5 & 20,4 & \\
\hline 2005 & 40,8 & 25,7 & 19,4 & \\
\hline 2006 & 40,2 & 25,1 & 18,5 & \\
\hline 2007 & 40,0 & 24,2 & 18,1 & \\
\hline 2008 & 41,5 & 24,9 & 18,5 & \\
\hline 2009 & 41,5 & 24,3 & 17,9 & \\
\hline 2010 & 43,4 & 26,4 & 17,9 & \\
\hline 2011 & 42,5 & 25,4 & 18,0 & \\
\hline 2012 & 45,4 & 25,3 & 17,9 & \\
\hline 2013 & 46,9 & 25,5 & 18,7 & \\
\hline
\end{tabular}

Fonte: Do Autor ${ }^{45}$

42 ORGANIZAÇÃO DAS NAÇÕES UNIDAS. Relatório do Desenvolvimento Humano 2014. Lisboa: Camões, 2014.

43 SACHS, Jeffrey. The end of poverty, economic possibilites for our time. New York: The Penguin, 2005.

44 OBSERVATÓRIO DAS DESIGUALDADES. Indicadores sobre Rendimento e Pobreza. Disponível em: < http://observatorio-dasdesigualdades.cies.iscte.pt/index.jsp?page=indicators\&id=113 >. Acesso em: 09 dez. 2015

45 Pesquisa realizada através do ambiente de Condições de Vida e Rendimentos das Famílias na Europa. CONDIÇÕES de vida e rendimentos das famílias na Europa. In: FUNDAÇÃO FRANCISCO MANUEL DOS SANTOS. PORDATA: Base de Dados Portugal Contemporâneo. Disponível em: <http://www.pordata.pt/Europa/ Ambiente+de+Consulta/Tabela>. Acesso em: 09 dez. 2015. 
Iniciando a análise a partir do ano 2000, no qual foram estabelecidos os Objetivos para o Desenvolvimento do Milênio, até o ano-base 2013 (último disponível), podem-se notar três conjunturas socioeconômicas distintas: há uma gradativa diminuição anual da taxa de risco de pobreza até 2003 , nova tendência de queda no triênio seguinte e, com a Crise Financeira de 2008, um crescente aumento do risco de ingresso na margem de pobreza.

Percebe-se que é com base nas transferências sociais e de políticas públicas análogas que o Estado Português vem tentando equalizar os índices de pobreza. Em sentido quantitativo, os recursos investidos parecem insuficientes para que as pessoas pobres deixarem de o ser ou para que outras não venham a se tornar. $\mathrm{O}$ manejo da política econômica, nesse condão, também repercute de modo predominantemente negativo ao desenvolvimento socioeconômico.

Sob outro aspecto, Pedro Perista e Isabel Baptista ${ }^{46}$, ainda, apontam que a população portuguesa, em linhas gerais, entende a pobreza como um fenômeno de responsabilidade das próprias pessoas pobres e de seu núcleo familiar, o que, igualmente, tem reflexos nocivos à sustentabilidade social e à socialidade.

Manuela Silva ${ }^{47}$, ainda em 2010, ano declarado de combate à pobreza e à exclusão social, em plano comunitário, atentou ao mérito de se chamar a opinião pública, a sociedade civil e os governos estaduais para o debate sobre a pobreza. Todavia, estabeleceu crítica ao modelo de ação implementado, atentando que as economias de muitos países na zona do euro, incluindo-se Portugal, atuavam "aquém das suas potencialidades e desfocadas da sua finalidade primeira: a satisfação das necessidades das pessoas em bens essenciais, o desenvolvimento socioeconômico, a coesão social e a persecução do bem comum".

Anos mais tarde, Suzana Toscano ${ }^{48}$ iria referir que os cidadãos portugueses "reconhecem a necessidade imperiosa de se gastar menos", porém “estão pouco disponíveis para enfrentar as mudanças que tal implica, resistindo à reconfiguração do estado social e exigindo do Estado que faça mais com muito menos".

Pelo exposto, no ano de avaliação do cumprimento das metas do Milênio, revela-se grande dificuldade na reversão do percentual de risco de pobreza, resultante da própria realidade social portuguesa contemporânea. Notadamente, tem-se uma evolução das exigências para a concretização da qualidade de vida e uma revisão do conceito comparativo de pobreza no contexto pós-Crise Financeira de 2008 - que, em termos mais duros, "põe Portugal na cauda dos mais pobres da UE25, sobretudo se considerarmos o fosso entre os mais ricos e os mais pobres". ${ }^{49}$

\section{Considerações finais}

Ao se encaminhar para o desfecho da presente investigação, é importante se ter em conta que os Objetivos de Desenvolvimento do Milênio, em que se insere a erradicação da pobreza, não são meras normas programáticas a serem formalmente observadas, por terem sido firmadas junto a Organização das Nações Unidas. Tratam-se, em verdade, de garantias relevantes para a concretização do desenvolvimento sustentável, tanto internamente aos Estados quanto em âmbito global.

O direito ao desenvolvimento, igualmente, não é vazio de sentido. Ele orienta e organiza comportamentos humanos (individuais, sociais e institucionais) de modo a impor de equidade intra e intergeracionais,

46 PERISTA, Pedro; BAPTISTA, Isabel. A estruturalidade da pobreza e da exclusão social na sociedade portuguesa: conceitos, dinâmicas e desafios para a acção. Fórum Sociológico, Lisboa, n. 20, p. 39-46, 2010. p. 46.

47 SILVA, Manuela. Enfrentar a crise. Erradicar a pobreza: contributo da economia social. Revista Sociedade e Trabalho, Lisboa, n. 41, p. 102-110, dez. 2010. p. 103-104.

48 TOSCANO, Suzana. Como reformar a administração pública. In: RODRIGUES, Maria de Lurdes; SILVA, Pedro Adão e. Politicas públicas em Portugal. Lisboa: Cies, 2012. p. 231-238. p. 256.

49 TOSCANO, Suzana. Como reformar a administração pública. In: RODRIGUES, Maria de Lurdes; SILVA, Pedro Adão e. Politicas públicas em Portugal. Lisboa: Cies, 2012. p. 231-238. p. 256. 
tornando claro que só pode haver sustentabilidade social em um Estado Constitucional livre de pobreza extrema, ou seja:

I - Desenvolvimento humano e sustentabilidade social possuem uma origem seminal comum, isto é, a afirmação normativa da sustentabilidade enquanto princípio estruturante do Estado Constitucional. É fácil e materialmente perceptível, quando da análise fática de situações concretas de pobreza, que o desenvolvimento humano se apresenta como objetivo e finalidade de ações políticas, bem como a sustentabilidade social se mostra como balizador normativo-axiológico de escolhas públicas e estratégias antecipatórias.

II - Há uma inter-relação entre a sustentabilidade social e a própria concepção de socialidade. Quando tratamos da luta contra a pobreza, nota-se (ao menos em plano teórico) certa coesão solidária voltada à melhoraria da qualidade de bem-estar (global). O que, através do fomento ao capital social, pode impor responsabilidades para todo o corpo social. Os cidadãos e o Estado-Gestor ${ }^{50}$ devem cooperar e adotar medidas próprias e conjuntas de implementação do desenvolvimento.

III - A consecução de políticas públicas e a concretização de direitos fundamentais correspondem ao objetivo precípuo de um Estado Socioambiental e Democrático de Direito. Por conseguinte, o cumprimento da erradicação da pobreza extrema pelo Estado Constitucional atende ao "desenvolvimento material e imaterial, socialmente inclusivo, durável e equânime, no intuito de assegurar, no presente e no futuro, o direito ao bem-estar". ${ }^{51}$

Cumpre referir que o movimento de Law \& Development instrumentaliza, o intérprete jurídico para o diagnóstico e resolução dos problemas constitucionais que se apresentam diante da busca pelo desenvolvimento sustentável, como se pode observar no caso do enfrentamento das pobrezas. Consolida-se, desse modo, a ideia de que uma ordem constitucional sustentável (justa, eficiente e coerente) se traduz em um "sistema jurídico que proporciona a estrutura de incentivos mais adequada à realização do potencial produtivo da sociedade". ${ }^{2}$

Assevera-se que é o princípio da sustentabilidade que estrutura o Estado Constitucional e que "violar um princípio é muito mais grave que transgredir uma norma qualquer" ${ }^{3}$. Assim, a agressão à sustentabilidade implica ofensa não apenas a uma norma constitucional específica, mas a todo o sistema jurídico. Impondo-se, nesse mote, que a omissão, frente à pobreza, seja encarada como uma violação à integridade essencial do ordenamento constitucional.

Ferdinand Lassale ${ }^{54}$ ensina que:

os problemas constitucionais não são problemas de direito, mas do poder; a verdadeira Constituição de um país somente tem por base os fatores reais e efetivos do poder que naquele país vigem.

Ora, mesmo com ressalvas a esse entendimento, propugna-se que a sustentabilidade é uma questão-chave do ordenamento constitucional, pela dificuldade de sua implementação política, como defende o autor, mas também, pelas implicações sociais e econômicas que possui. O fenômeno da pobreza, multidimensional, dinâmico e variável se constitui como uma problemática que, inegavelmente, desafia o Estado Constitucional, mas também extrapola as fronteiras constitucionais portuguesas.

Com efeito, a partir da irradiação subjetiva do direito ao desenvolvimento humano sustentável ${ }^{55}$, pode-se inserir o combate à pobreza extrema como uma de suas propriedades essenciais, com base no sistema

50 Bob Jessop relaciona tal modelo com o projeto sociocultural, político e econômico de Estado pelo qual o problema da questão social dialoga diretamente com a gestão governamental de políticas públicas. JESSOP, Bob. State Theory. Cambridge: Polity, 1990.

51 FREITAS, Juarez. Sustentabilidade: direito ao futuro. 2. ed. Belo Horizonte: Fórum, 2012. p. 41.

52 FLORENZANO, Vincenzo Demétrio. Sistema financeiro e responsabilidade social: uma proposta de regulação fundada na teoria da justiça e na análise econômica do direito. São Paulo: Textonovo, 2004. p. 38.

53 MELLO, Celso Antônio Bandeira de. Curso de direito administrativo. 12. ed. São Paulo: Malheiros, 2000. p. 748.

54 LASSALLE, Ferdinand. A essência da constituição. Trad. Aurélio Wander Bastos. Rio de Janeiro: Lumen Juris, 2000. p. 40.

55 Cf. MARMELSTEIN, George. Curso de direitos fundamentais. São Paulo: Atlas, 2008. p. 282. 
axiológico constitucional da República Portuguesa e aliada à base normativa da sistemática internacional de proteção aos direitos humanos. Afinal, lutar contra a pobreza é, sem dúvidas, lutar pela dignidade humana e pela integralidade do ser humano.

Como muito bem informa Robert Alexy ${ }^{56}$, a ideia geral acerca dos direitos humanos os define, "primeiro, como direitos morais, segundo, universais, terceiro, fundamentais, quarto, abstratos e, quinto, dotados de prioridade sobre as outras normas" ${ }^{57}$ Sendo assim, entende-se que há o reconhecimento da erradicação da pobreza como imposição moral, universalmente consentida, com sede constitucional, genericamente aplicável e prioritária para o desenvolvimento humano sustentável.

Destarte, ciente do contexto de austeridade enfrentado pela União Europeia e da nítida reconfiguração do Estado Português, após a Crise Financeira de 2008, pretende-se com a presente investigação fomentar a reflexão acerca da temática da eliminação da pobreza extrema ou absoluta, mas, sobremaneira, induzir o debate sobre a redução das pobrezas que impedem a concretização da qualidade de uma vida digna aos portugueses. Cumpre alertar que a situação de vulnerabilidade social pela redução de condições econômicas de subsistência e diminuição acentuada de poder aquisitivo é multifatorial, dinâmico e passível de atingir qualquer Estado diante de conjunturas de crise.

Constata-se, por derradeiro, pelas palavras do poeta Fernando Pessoa que: "Ah, como tudo é nulo e vão! A pobreza da inteligência ante a riqueza da emoção!”. Afinal, de que adianta se implementar complexos aparatos normativos não efetivos à prática se ainda milhares de pessoas passam fome e privações materiais. Por fim, almeja-se, com a presente pesquisa apresentada neste artigo, a constituição de contributo à afirmação de uma consciência coletiva voltada à socialidade e à prestação de uma boa gestão pública na execução de políticas públicas de combate às múltiplas formas de pobreza.

\section{REFERÊNCIAS BIBLIOGRÁFICAS}

ALEXY, Robert. Law, morality, and the existence of human rights. Ratio Juris, v. 25, n. 1, p. 2-14, Mar. 2012. ANDRADE, José Carlos Vieira de. Os direitos fundamentais na constituição portuguesa de 1976. 5. ed. Coimbra: Almedina, 2012.

ARENDT, Hannah. A condição bumana. 10. ed. Rio de Janeiro: Forense Universitária, 2003.

BANCO MUNDIAL. Relatório sobre o desenvolvimento mundial 1990: a pobreza. São Paulo: FGV, 1990.

CALABRESI, Guido. Some thoughts on risk distributions and the law of torts. The Yale Law Journal. Yale, v. 70, n. 4, p. 499-553, Mar. 1961.

CANOTILHO, José Joaquim Gomes. Direito constitucional e teoria da constituição. 7. ed. Coimbra: Almedina, 2010.

CANOTILHO, José Joaquim Gomes. O princípio da sustentabilidade como princípio estruturante de direito constitucional. Tékhne: Revista de Estudos Politécnicos, Barcelos, v. 8, n. 13, p. 7-18, 2010.

CASALTA NABAIS, José. Política fiscal, desenvolvimento sustentável e luta contra a pobreza. Cadernos da Escola de Direito e Relações Internacionais da UniBrasil, Curitiba, n. 7, p. 361-378, jan./dez. 2007.

CASTEL, Robert. Metamorfoeses da questão social. Petrópolis: Vozes, 1998.

COASE, Ronald H. The problem of social cost. The Journal of Law and Economic, Chicago, v. 3, p. 1-44, Oct. 1960.

56 ALEXY, Robert. Law, morality, and the existence of human rights. Ratio Juris, v. 25, n. 1, p. 2-14, Mar. 2012. p. 10.

57 Tradução do autor. 
CONDIÇÕES de vida e rendimentos das famílias na Europa. In: FUNDAÇÃO FRANCISCO MANUEL DOS SANTOS. PORDATA: Base de Dados Portugal Contemporâneo. Disponível em: <http://www.pordata.pt/Europa/ Ambiente+de+Consulta/Tabela>. Acesso em: 09 dez. 2015.

COOTER, Robert; ULEN, Thomas. Direito e economia. Trad. Luis Marcos Sander, Francisco Araújo da Costa. 5. ed. Porto Alegre: Bookman, 2010.

FLORENZANO, Vincenzo Demétrio. Sistema financeiro e responsabilidade social: uma proposta de regulação fundada na teoria da justiça e na análise econômica do direito. São Paulo: Textonovo, 2004.

FREITAS, Juarez. A interpretação sistemática do direito. 5. ed. São Paulo, Malheiros, 2010.

FREITAS, Juarez. Sustentabilidade: direito ao futuro. 2. ed. Belo Horizonte: Fórum, 2012.

FUNDACION INTERNACIONAL Y PARA IBEROAMÉRICA DE ADMINISTRACION Y POLITICAS PUBLICAS. Regras de Brasilia sobre acesso à Justiça das pessoas em condição de vulnerabilidade, 2008. Disponível em: <http://www.anadep.org.br/wtksite/100-Regras-de-Brasilia-versao-reduzida.pdf>. Acesso em: 09 dez. 2015.

FUNDO DE POPULAÇÃO DAS NAÇÕES UNIDAS. Pacto Internacional sobre os Direitos Econômicos, Sociais e Culturais. Disponível em: <http://www.unfpa.org.br/Arquivos/pacto_internacional.pdf>. Acesso em: 09 dez. 2015.

GUASTINI, Riccardo. Estudios sobre la interpretación jurídica. Trad. Marina Gascón e Miguel Carbonell. Cidade do México: Instituto de Investigaciones Jurídicas, 1999.

HÄBERLE, Peter. Nachhaltigkeit und Gemeineuropäisches Verfassungsrecht. In: WOLFGANG, Kahl (Org.). Nachhaltigkeit als Verbundbegriff. Tubinga: Mohr Siebeck, 2008. p. 180-206.

HESSE, Konrad. Escritos de derecho constitucional. Trad. Pedro Cruz Villalón. Madri: Centro de Estudios Constitucionales, 1992.

JESSOP, Bob. State Theory. Cambridge: Polity, 1990.

LASSALLE, Ferdinand. A essência da constituição. Trad. Aurélio Wander Bastos. Rio de Janeiro: Lumen Juris, 2000 .

MACCORMICK, Neil. Retórica e o estado de direito. Trad. Conrado Hübner Mendes. Rio de Janeiro: Elsevier, 2008.

MARMELSTEIN, George. Curso de direitos fundamentais. São Paulo: Atlas, 2008.

MELLO, Celso Antônio Bandeira de. Curso de direito administrativo. 12. ed. São Paulo: Malheiros, 2000.

NARAYAN, Deepa. Child poverty insights: the dynamics of poverty. In: UNITED NATIONS CHILDREN'S FUND. Social and economic policy: policy and practice. Nova Iorque: Unicef, Apr. 2010.

NARAYAN, Deepa. Voices of the poor: can anyone hear us? Washington: Oxford University Press, 2000.

OBSERVATÓRIO DAS DESIGUALDADES. Indicadores sobre Rendimento e Pobreza. Disponível em: < http:// observatorio-das-desigualdades.cies.iscte.pt/index.jsp?page=indicators\&id=113 > . Acesso em: 09 dez. 2015.

ORGANIZAÇÃO DAS NAÇÕES UNIDAS. Declaração de Estocolmo sobre o ambiente humano, 1972: publicada pela Conferência das Nações Unidas sobre o meio ambiente humano em Junho de 1972. Disponível em: <http://www.direitoshumanos.usp.br/index.php/Meio-Ambiente/declaracao-de-estocolmo-sobre-oambiente-humano.html>. Acesso em: 09 dez. 2015.

ORGANIZAÇÃO DAS NAÇÕES UNIDAS. Declaração do Milênio. Nova Iorque: ONU, set. 2000. Di- 
sponível em: <http://www.pnud.org.br/Docs/declaracao_do_milenio.pdf>. Acesso em: 09 dez. 2015.

ORGANIZAÇÃO DAS NAÇÕES UNIDAS. Declaração sobre o direito ao desenvolvimento: adotada pela Resolução n. ${ }^{\circ}$ 41/128 da Assembléia Geral das Nações Unidas, de 4 de dezembro de 1986. Disponível em: $<$ http://www.direitoshumanos.usp.br/index.php/Direito-ao-Desenvolvimento/declaracao-sobre-o-direito-ao-desenvolvimento.html>. Acesso em: 09 dez. 2015.

ORGANIZAÇÃO DAS NAÇÕES UNIDAS. Human Development Report 1997. New York: Oxford University Press, 1997.

ORGANIZAÇÃO DAS NAÇÕES UNIDAS. Objectivos de desenvolvimento do milénio (ODM). Bruxelas, 2015. Disponível em: <http://www.unric.org/pt/objectivos-de-desenvolvimento-do-milenio-actualidade>. Acesso em: 09 dez. 2015.

ORGANIZAÇÃO DAS NAÇÕES UNIDAS. Pacto Internacional sobre os Direitos Civis e Políticos. Disponível em: <http://www.gddc.pt/direitos-humanos/textos-internacionais-dh/tidhuniversais/cidh-dudh-direitoscivis.html>. Acesso em: 09 dez. 2015.

ORGANIZAÇÃO DAS NAÇÕES UNIDAS. Relatório do Desenvolvimento Humano 2014. Lisboa: Camões, 2014.

PACHECO, Pedro Mercado. El analisis economico del derecho. Madri: Centro de Estúdios Constitucionalies, 1994.

PERISTA, Pedro; BAPTISTA, Isabel. A estruturalidade da pobreza e da exclusão social na sociedade portuguesa: conceitos, dinâmicas e desafios para a acção. Fórum Sociológico, Lisboa, n. 20, p. 39-46, 2010.

PORTUGAL. Constituição (1976). Revisão constitucional n. 7, de 12 de agosto de 2005. Disponível em: <http:// www.parlamento.pt/Legislacao/Documents/constpt2005.pdf>. Acesso em: 09 dez. 2015.

SACHS, Jeffrey. The end of poverty, economic possibilites for our time. New York: The Penguin, 2005.

SARLET, Ingo Wolfgang; MARINONI, Luiz Guilherme; MITIDIERO, Daniel. Curso de direito constitucional. São Paulo: Revista dos Tribunais, 2012.

SEN, Amartya. Sobre ética e economia. Trad. Laura Teixeira Motta. São Paulo: Companhia das Letras, 1999.

SEN, Amartya; KLIKSBERG, Bernardo. As pessoas em primeiro lugar: a ética do desenvolvimento e os problemas do mundo globalizado. Trad. Bernardo Azemberg. São Paulo: Companhia das Letras, 2010.

SILVA, Manuela. Enfrentar a crise. Erradicar a pobreza: contributo da economia social. Revista Sociedade e Trabalho, Lisboa, n. 41, p. 102-110, dez. 2010.

SILVA, Suzana Tavares da. Direitos fundamentais na Arena Global. Coimbra: Imprensa da Universidade de Coimbra, 2011.

TOSCANO, Suzana. Como reformar a administração pública. In: RODRIGUES, Maria de Lurdes; SILVA, Pedro Adão e. Políticas públicas em Portugal. Lisboa: Cies, 2012. p. 231-238.

TRINDADE, Antonio Augusto Cançado. Tratado de direito internacional dos direitos humanos. Porto Alegre: S. A. Fabris, 1997. v. 1.

TROPER, Michel. A filosofia do direito. Trad. Ana Deiró. São Paulo: M. Fontes, 2008.

VASCONCELLOS, Marco Antônio; GARCIA, Manuel. Fundamentos de economia. 2. ed. São Paulo: Saraiva, 2004. 


\section{REVISTA BRASILEIRA DE POLÍTICAS PÚBLICAS BRAZILIAN JOURNAL OF PUBLIC POLICY}
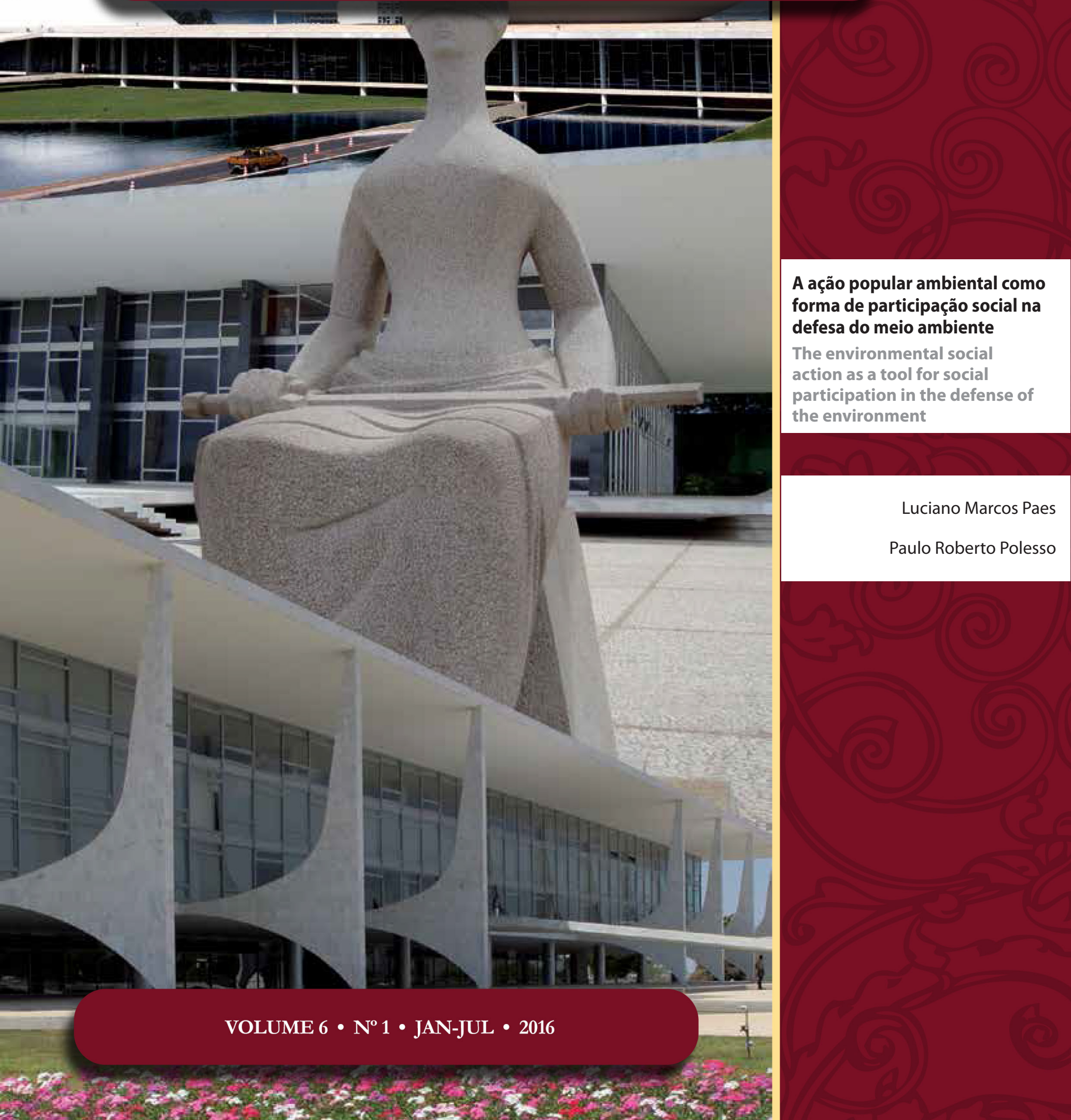


\title{
A ação popular ambiental como forma de participação social na defesa do meio ambiente*
}

\section{The environmental social action as a tool for social participation in the defense of the environment}

\author{
Luciano Marcos Paes ** \\ Paulo Roberto Polesso***
}

\section{Resumo}

O presente artigo aborda a participação popular na proteção ao meio ambiente pelo manejo da ação popular ambiental como instrumento para sua tutela. Nessa trajetória, sem a pretensão de esgotar o assunto, enfoca-se a legitimidade ativa por meio do prisma de uma concepção moderna do conceito de cidadania, circundando-se aspectos ligados aos efeitos da sentença, para, ao final, integrar o direito à informação como sustentáculo da ação popular, com vistas a estabelecer uma visão panorâmica da temática e, sobretudo, oportunizar o fomento do debate acerca do objeto do estudo.

Palavras-chave: Participação popular. Ação popular ambiental. Cidadania. Proteção ao meio ambiente. Informação.

\section{Abstract:}

This article approaches public participation towards the protection of the environment through the management of social environmental actions as a tool for its guardianship. Following this path, with no claim to exhaust the subject, active legitimacy is focused through the prism of a modern conception of citizenship, circling up aspects related to the effects of the sentence and finally integrating the right to information as the foundation of social action; seeking to establish an overview of the theme, and above all, to create opportunities that can foster debate about the object of study.

** Possui graduação em Direito pela Universidade de Caxias do Sul - UCS (2014). Agente Administrativo na Prefeitura Municipal de Montenegro, RS (1990). Mestrando em Direito pela Universidade de Caxias do Sul - UCS (2015).E-mail:1mpaes@ucs.br

*** Possui graduação em Direito pela Universidade de Caxias do Sul - UCS (1993). Procurador do SAMAE de Caxias do Sul, RS (1996). Especialista em Direito Público pela Universidade de Caxias do Sul (1999). Mestrando em Direito pela Universidade de Caxias do Sul UCS (2015).E-mail:ppolesso@hotmail.com

Keywords: Public participation. Environmental Social Action. Citizenship. Environmental Protection. Information. 


\section{INTRODUÇÃo}

A democracia ocidental teve início na Grécia e, atualmente, ganhou formas bem diferentes. No Brasil, a partir do século XVIII, com influência do Iluminismo a história política brasileira é marcada por fatos que vão desde o Brasil Colônia até golpes de estado e revoluções, como as de 1930 e 1964.

A partir da Constituição Federal Brasileira de 1988, são colocados à disposição da população mecanismos de participação para que se possa exercer a cidadania e, assim, fortalecer o regime democrático por meio da participação popular inclusive nas questões que envolvam a proteção e a preservação do meio ambiente.

Uma das melhores maneiras de tratar essas questões consiste em assegurar a participação dos cidadãos com o objetivo de preservação ambiental, seja na esfera administrativa, legislativa ou judicial.

Abordam-se como procedimentos metodológicos neste artigo o bibliográfico e o dialético. Os objetivos, geral e específico, são respectivamente: analisar, no contexto social brasileiro, a possibilidade da participação popular na tutela do meio ambiente por meio da ação popular ambiental, buscando a proteção e a preservação do meio ambiente.

\section{A participação popular na tUtela do meio ambiente}

É sabido que, em um Estado Democrático de Direito, como é o Brasil, o poder emana do povo que o exerce por meio de seus representantes ou diretamente, conforme previsão constitucional (art. $1^{\circ}$, parágrafo único da Constituição Federal de 1988), pois é esta quem diz como o povo vai participar e, assim, a participação pública ambiental ficou estabelecida pelo caput do artigo 225, uma vez que

Todos têm direito ao meio ambiente ecologicamente equilibrado, bem de uso comum do povo e essencial à sadia qualidade de vida, impondo-se ao Poder Público e a coletividade o dever de defendê-lo e preservá-lo para as presentes e futuras gerações

O que implica dizer que para a proteção do meio ambiente é fundamental o direito à participação popular.

Para Maffini " “a participação popular implica a obrigatoriedade de se oportunizar, tanto quanto seja possível, a participação dos integrantes da coletividade na construção das decisões exaradas pela Administração Pública”.

É normal a integração do homem que convive em grupo e assim também é o seu estímulo em participar das decisões coletivas já que o princípio da "participação" reflete a expansão da consciência social e o anseio das pessoas em sociedade para influenciar, de algum modo nas decisões de poder e interesses possibilitando não apenas escolher aqueles que governarão, mas também como se é governado².

De acordo com Santos ${ }^{3}$

O princípio participativo caracteriza-se pela participação direta e pessoal da cidadania na formação dos atos do governo, e integra o conceito de democracia social, ligando-se a problemática de democratização da sociedade (grifo do autor).

A democracia é o meio de realização dos valores essenciais para uma vida em sociedade em que a possibilidade de participação ativa é direito do cidadão; e, a partir da sua manifestação crítica, com a discussão

1 MAFFINI, Rafael. Direito administrativo. 3. ed. São Paulo: Revista dos Tribunais, 2009. p. 125.

2 MOREIRA NETO. Curso de direito administrativo: parte introdutória, parte geral e parte especial. 15. ed. Rio de Janeiro: Forense, 2009. p. 86.

3 SANTOS, Jair Lima dos. Tribunal de Contas da União \& controle estatal e social da Administração Pública. Curitiba: Juruá, 2004. p. 94. 
dos reais problemas, é possível a articulação de soluções que chegam até a Administração Pública para que esta eleja suas prioridades e determine a execução na medida em que se possam ver atendidos os verdadeiros anseios populares.

A ação popular ambiental também é uma forma direta na defesa do meio ambiente, por intermédio do processo jurisdicional, nos termos do art. $5^{\circ}$, LXXIII, da Constituição Federal, atribuindo a qualquer cidadão a possibilidade de ser parte legítima para propor ação popular que vise a anular ato lesivo, a diversos bens e valores, entre os quais o meio ambiente e o patrimônio histórico-cultural.

A ação popular encontra-se disciplinada pela Lei n. 4.717/1965, trazendo, como sujeito legitimado à propositura de demandas populares, o indivíduo nacional que esteja no exercício dos direitos políticos, ou seja, o cidadão que deverá fazer prova de que é eleitor demonstrando assim sua condição de cidadão.

Essa exigência vem sendo objeto de questionamentos, em face do caput do artigo 225 da Constituição Federal, uma vez que a expressão "todos" lá descrita traz o entendimento de que cidadão, no Brasil, sob a ótica da participação pública ambiental, deve ser considerado todo o indivíduo integrante da sociedade, tanto nacional quanto estrangeiros residentes no País, a quem se reconheceu, sem discriminação, a titularidade do direito ao meio ambiente ecologicamente equilibrado, independentemente da concomitante titularidade do direito de votar e ser votado ${ }^{4}$.

Ademais, não se pode conceber que o texto constitucional possa ter seu alcance limitado por norma infraconstitucional, isto é, o conceito de 'cidadão', expressão repetidas vezes utilizada na Carta Política, em nenhum momento por ela foi restrito àquela pessoa que o $\int 3^{\circ}$ do artigo $1^{\circ}$ da Lei $n^{\circ} 4.717 / 1965$ qualifica como mero portador de título eleitoral.

Importante, ainda, ter-se presente a lúcida referência realizada por Machado ${ }^{5}$, amparado na redação concedida ao inciso II do artigo 68 da Constituição Federal ${ }^{6}$, quando comenta a legitimidade ativa para a ação popular, em cujo contexto sublinha que o constituinte tratou de cidadania, direitos políticos e eleitorais como temas distintos, ou seja, assinalando que cidadão é muito mais do que o indivíduo votante, para daí concluir que todos os habitantes do país, brasileiros e estrangeiros, estão credenciados à promoção da ação popular ambiental.

De oura parte, quando o constituinte estendeu a 'todos' o direito ao meio ambiente, também atribuiu a 'todos' o direito à educação, à saúde, à cultura; vale dizer, atribuiu esses direitos a qualquer indivíduo, votante ou não.

Por isso, em outras palavras, não se pode conceber, dentro da estrutura de nosso ordenamento jurídico, que a Constituição estabeleça um direito e o seu exercício seja subtraído por norma hierarquicamente inferior.

É fato, pois, que a previsão restritiva da legitimidade ativa para a ação popular, constante do dispositivo acima citado, não foi recepcionada pelo Texto Maior, uma vez que diminui o conceito de cidadão, ou melhor, restringe a acepção da cidadania ao mero direito de votar e ser votado, olvidando-se que esse entendimento se posta muito aquém do grau de civilidade que nos dias atuais a sociedade brasileira, malgrado seus percalços, alcançou.

Afinal, quando se fala em cidadania também se deve ter em mente os direitos dos indivíduos de participação na vida social do país, dentre os quais o de fazer valer os valores constitucionais mais caros, sejam eles

4 MIRRA, Álvaro Luiz Valery. Participação, processo civil e defesa do meio ambiente no direito brasileiro. 2010. 715 folhas. Tese (Doutorado em Direito) - Universidade de São Paulo, São Paulo, 2010. p. 210-216.

5 MACHADO, Paulo Affonso Leme. Direito ambiental brasileiro. 18. ed. São Paulo: Malheiros, 2010. p. 139.

6 Art. 68. As leis delegadas serão elaboradas pelo Presidente da República, que deverá solicitar a delegação ao Congresso Nacional. $\int 1^{\circ}$ Não serão objeto de delegação os atos de competência exclusiva do Congresso Nacional, os de competência privativa da Câmara dos Deputados ou do Senado Federal, a matéria reservada à lei complementar, nem a legislação sobre:

I - organização do Poder Judiciário e do Ministério Público, a carreira e a garantia de seus membros;

II - nacionalidade, cidadania, direitos individuais, políticos e eleitorais; 
de índole individual ou de expressão coletiva.

O fato é que talvez se faça necessário, a respeito da acepção com que se devam tomar as expressões 'cidadão' e 'cidadania', dessacralizar sua interpretação, ou seja, aproximá-la do entendimento mais ligado ao senso comum, abandonando o academicismo e o juridicismo exacerbado, porquanto já advertia Warat

A solenização da palavra permite à ciência da lei mostrar-se como saber enigmático, o saber de um poder suposto como absoluto, dotado da divina capacidade de dizer indefinidamente a verdade [...] $\mathrm{O}$ juridicismo, então, legitima o discurso que contém o oráculo do poder, legitima o funcionamento social da lei, como uma palavra enigmática, que demanda a presença de glosadores sacralizados? ${ }^{7}$.

Todavia apesar dessas peculiaridades da ação popular para a defesa em juízo do meio ambiente, também merece atenção a restrição da legitimação para a causa às pessoas jurídicas, pois, conforme entendimento predominante no Supremo Tribunal Federal, expresso na Súmula no 365: "Pessoa jurídica não tem legitimidade para propor ação popular".

Ora, também não se encontra justificativa plausível ou mais veemente para se impedir o alargamento da legitimidade ativa às entidades de proteção ambiental ou classistas, como é o caso, em especial, da Ordem dos Advogados do Brasil, cuja missão institucional é defender a Constituição Federal, o Estado democrático de direito, os direitos humanos, a justiça social e zelar pela boa aplicação das leis ${ }^{8}$.

\section{A AÇÃo POPULAR AMBiENTAL}

De origem romana, as actiones populares foram concebidas num período histórico em que a noção de Estado ainda não se firmara. De fato, conquanto num primeiro momento apenas se admitisse a busca pela tutela jurídica de direitos próprios, a ideia de que, buscando a proteção de um interesse pessoal, por vezes o cidadão protegia os interesses da comunidade, ganhou aceitação e aplicabilidade.

Dentre os muitos exemplos corriqueiramente citados referem-se ações populares contra violação de sepulcros (sepulchro violato) ou contra quem mantivesse objetos nas sacadas ou abas de telhado sem os devidos cuidados para que não caíssem sobre os transeuntes (de positis et suspensas), ou seja, as matérias colacionadas denotam claro uso da ação popular como instrumento para a proteção concreta dos interesses da coletividade.

O primeiro texto constitucional brasileiro a trazer a ação popular foi a Carta Política de 1934, porém durante o período do chamado Estado Novo, em 1937, a ação popular foi suprimida.

A ação popular foi restabelecida novamente no ordenamento por disposição constitucional a partir da Constituição Federal de 1946, e assim mantida a partir de então, mesmo passando por períodos ditatoriais até chegar aos dias atuais.

A Constituição de 1988 estabelece em seu art. 5, inc. LXXIII, que

Qualquer cidadão é parte legítima para propor ação popular que vise anular ato lesivo ao patrimônio público ou entidade de que o Estado participe, à moralidade administrativa, ao meio ambiente e ao patrimônio histórico e cultural, ficando o autor, salvo comprovada má-fé, isento de custas judiciais e do ônus da sucumbência?

Para Bolzan de Morais

A ação popular é um instrumento jurídico colocado à disposição do cidadão, e só a ele, para coibir a prática de atos lesivos produzidos contra os bens especificados na norma constitucional. Tem ela

7 WARAT, Luiz Alberto. Introdução geral ao direito: a epistemologia jurídica da modernidade. Porto Alegre: Sérgio Fabris, 2002 , p. 77. 8 Lei no 8.906/94, art. 44.

9 MANCUSO, Rodolfo de Camargo. Ação popular: proteção do erário, do patrimônio público, da moralidade administrativa e do meio ambiente. São Paulo: Revista dos Tribunais, 2009. p. 64-73. 
conteúdo transindividual, embora a legitimação que atribua seja individual, uma vez que os benefícios produzidos e/ou prejuízos evitados não serão incorporados ao patrimônio do litigante com exclusividade, mas comporão como que um patrimônio comum solidariamente titularizado e usufruível pela sociedade como um todo distinto ${ }^{10}$.

A partir desse breve panorama da ação popular no Brasil, percebe-se que, após a promulgação da Constituição de 1988, a amplitude do alcance desse instrumento jurídico-popular foi estendida para possibilitar a defesa, pelo cidadão, de interesses meta ou transindividuais da mais alta valia, ou seja, representativos do próprio gênero humano, motivo pelo qual ela pode e deve ser manejada para a tutela e defesa do meio ambiente.

A legitimação para a propositura da ação popular ambiental é atribuída, em caráter concorrente e autônomo, a todos os indivíduos titulares do direito ao meio ambiente ecologicamente equilibrado. Assim, advoga-se que qualquer cidadão, com a extensão conceitual acima defendida, está autorizado a propor a demanda popular ambiental, de forma isolada ou com outros cidadãos (litisconsórcio facultativo unitário dada a indivisibilidade do direito objeto de proteção), afora intervir no processo da demanda ajuizada por outro legitimado ativo.

De fato quanto à intervenção do indivíduo igualmente legitimado, no processo instaurado por outro colegitimado, a Lei n. 4.717/1965 dispõe, no $\int 5^{\circ}$ do art. $6^{\circ}$, que a habilitação de qualquer outro cidadão poderá se dar na condição de "litisconsorte ou assistente", motivo pelo qual se está diante de exceção à regra tradicional, que não permite ao cotitular do poder de agir em juízo, escolher a maneira pela qual intervirá no processo pendente, como litisconsorte ou assistente, aliás

A possibilidade de intervenção de um ou mais cidadãos, na demanda popular ambiental proposta por outro colegitimado, seja como litisconsorte, seja como assistente (simples ou litisconsorcial), mostrase importante, como fator de ampliação da participação popular na defesa do meio ambiente por intermédio do processo jurisdicional e como mecanismo de auxílio e controle da adequação da atuação judicial do indivíduo que tomou a iniciativa de ingressar em juízo, em prol da defesa do direito de todos ao meio ambiente. Tanto quanto o é, aliás, a possibilidade aberta a qualquer outro cidadão, diverso daquele que ajuizou a demanda, de promover o prosseguimento da ação e do processo correspondente, nas hipóteses de desistência ou extinção provocada do feito sem julgamento do mérito (art. $9^{\circ}$ da Lei n. $4.717 / 1965)^{11}$.

É inegável a abertura da participação judicial direta na defesa do meio ambiente propiciada pela ação popular, tanto em função da legitimidade ativa para a causa concedida a todos os cidadãos, a partir da concepção atualizada de cidadania a que se aludiu, como ainda, em razão da legitimidade para intervir reconhecida aos demais indivíduos que não ajuizaram a demanda, inclusive a fim de assegurar o prosseguimento desta na hipótese de desistência ou extinção provocada do processo.

Nesse sentido

A posição doutrinária e jurisprudencial que reconhece a legitimidade do autor popular como extraordinária é mais consistente na medida em que coloca o mesmo como substituto da coletividade. É induvidoso que o direito a um meio ambiente equilibrado não pode ser tido como um direito material pessoal e individual do autor popular. Este direito trata-se de direito difuso, sem titular individual definido.

O caso é de substituição processual, em especial na tutela do meio ambiente, porque o cidadão ao ajuizar a referida ação popular age em nome próprio em defesa de direito que não lhe pertence diretamente, mas sim a toda a coletividade. O direito ao meio ambiente preservado é um direito que pertence a toda a sociedade e não a um indivíduo isoladamente. $\mathrm{O}$ autor popular recebe autorização para agir em defesa da coletividade do art. $1^{\circ}$ da Lei $n^{\circ}$ 4.717/1965 e, em relação ao meio ambiente, da própria Constituição

10 MORAIS, José Luis Bolzan de. Do direito social aos interesses transindividuais: o Estado e o direito na ordem contemporânea. Porto Alegre: Livraria do Advogado, 1996. p. 193.

11 MIRRA, Álvaro Luiz Valery. Participação, processo civil e defesa do meio ambiente no direito brasileiro. 2010. 715 folhas. Tese (Doutorado em Direito) - Universidade de São Paulo, São Paulo, 2010. p. 214. 
Federal de 1988, em seu art. art. $5^{\circ}$, inc. LXXIII ${ }^{12}$.

A ação popular ambiental brasileira guarda, inequivocamente, natureza corretiva da atividade da Administração Pública, sem olvidar o caráter preventivo defendido por ilustres juristas, a fim de mantê-la ou reconduzi-la à legalidade e à moralidade administrativa. Porém,

O aludido perfil da ação popular, no Brasil, não sofreu alteração com a promulgação da Constituição de 1988, ainda que esta tenha feito referência destacada à anulação de ato lesivo ao meio ambiente e ao patrimônio histórico e cultural, em acréscimo à anulação de ato lesivo ao patrimônio público ou de entidade de que o Estado participe. Mesmo em matéria ambiental a ação popular mantém a sua característica fundamental de instrumento processual destinado a provocar o controle jurisdicional de atos do Poder Público. Por via de consequência, não se presta ela à prevenção, à correção ou à reparação de lesões decorrentes de atividades ou omissões atribuídas exclusivamente aos particulares, ou à prevenção e à reparação de danos que não se vinculem à prévia invalidação de atos administrativos ${ }^{13}$.

Ademais, a análise da ação popular demonstra ser ela uma ferramenta poderosa do cidadão comum para o controle de interesses difusos na proteção ao meio ambiente, todavia

Sua prática não se dá com a frequência desejada; não porque inexistem fatos que se enquadrariam em seu objeto, mas sim, pela necessidade de contratação de um advogado para ajuizá-la. Tanto é que milhares de ações civis públicas tramitam pelo Poder Judiciário, uma vez que o cidadão prefere provocar o Ministério Público a contratar um profissional para ajuizar a ação da qual é titular por força da norma constitucional, igualando-se, na legitimidade, ao parquet na Ação Civil Pública ${ }^{14}$.

$\mathrm{Na}$ verdade, mormente quando se trata da ação popular ambiental, sua pouca utilização pela cidadania, além de marcar a característica de que ainda não logramos implementar uma autêntica cultura de atuação participativa nas questões que envolvem os direitos coletivos, também esbarra na questão da instrumentalização dos meios de prova acerca do dano ambiental combatido.

É inegável que o Ministério Público, por obra da autonomia conquistada a partir da ordem constitucional de 1988, que lhe permitiu uma gerência administrativa e orçamentária próprias, instrumentalizou-se com pessoal e recursos capazes de fazer frente, de forma muito mais efetiva, à demonstração da causa de pedir, ou seja, à demonstração do dano ambiental objetivo e, também, às informações técnicas necessárias ao entendimento dos diferentes colores que o dano ambiental pode tomar.

Afinal, mesmo que a produção de provas seja possível ao longo da instrução processual, a ação popular não pode ser proposta sem lastro algum, mormente quando se objetiva tutela antecipatória para coibir danos ambientais cujas consequências posteriores podem se mostrar extremamente gravosas. A respeito, Silva adverte:

É ônus do autor popular provar a ocorrência de ato lesivo por ele alegado como fundamento da demanda. Enfim, incumbe-lhe comprovar a efetiva verificação dos fundamentos de fato (causa petendi próxima) da demanda, para que possa obter os efeitos pretendidos ${ }^{15}$.

Em idêntico viés e a corroborar a dificuldade do autor em arcar com os quase sempre intrincados ou complexos encargos probatórios de uma demanda ambiental, a jurisprudência do Tribunal de Justiça do Estado do Rio Grande do Sul tem corriqueiramente afastado o cabimento da actio popular em situação de deficiência probatória ${ }^{16}$.

12 WEDY, Gabriel. Ação popular ambiental. RevistaProcessos Coletivos, Porto Alegre, v. 6, n. 2. Trimestral. 2015. Disponível em:< http:// www.processoscoletivos.net/index.php/revista-eletronica/66-volume-6-numero-2-trimestre-01-04-2015-a-30-06-2015/1554-acaopopular-ambiental>. Aceso em: 13 maio 2015.

13 MIRRA, Álvaro Luiz Valery. Participação, processo civil e defesa do meio ambiente no direito brasileiro. 2010. 715 folhas. Tese (Doutorado em Direito) - Universidade de São Paulo, São Paulo, 2010. p. 216-217.

14 MARIN, Jeferson Dytz Marin; BRANDELLI, Ailor Carlos Brandelli. O Controle da Administração Pública pela Ação popular: a legitimidade do cidadão para a fiscalização dos atos do governante. Revista de Informação legislativa, Brasília, a. 47, n. 185, p. 135-144, jan./mar. 2010. p. 143.

15 SILVA, José Afonso da. Ação popular constitucional: doutrina e processo. 2. ed. São Paulo: Malheiros, 2007. p. 216.

16 Reexame necessário. Direito Público não especificado. Ação popular. Suspensão e nulidade das licenças expedidas pela FEPAM para instalação de condomínios na cidade de Xangri-lá. Improcedência por ausência de comprovação dos danos alegados. Com- 
Observe-se, no entanto, que a Lei da Ação Popular ${ }^{17}$ não reconhece efeito erga omnes à decisão de improcedência fulcrada em deficiência probatória, circunstância que não inibe sua reedição, pelo mesmo fundamento, por qualquer outro cidadão, com base em novas provas. A previsão é sabia, conforme adverte Mancuso, pois é inadmissível que uma ação popular mal proposta, ou deliberadamente mal proposta por um cúmplice do autor dos danos viesse a adquirir autoridade de coisa julgada, inibindo o cidadão movido por interesses autênticos de manejá-la eficazmente ${ }^{18}$.

Importante frisar, no aspecto, que a Lei da Ação Popular (LAP) estabeleceu mecanismo diferenciado daquele estatuído no Código de Processo Civil acerca dos limites subjetivos da coisa julgada, ou seja, a autoridade da coisa julgada, nessa espécie de ação coletiva, restringe-se aos limites do objeto posto no pedido inicial, uma vez que, em se tratando de demanda na qual o interesse público prevalece, o que se busca é apuração da verdade real.

No mesmo sentido, a advertência de Marin:

As ações coletivas, notadamente aquelas que tutelam o bem ambiental, precisam de uma versão publicista da coisa julgada, firmada da concepção de que a representação do polo ativo é universal, de caráter indeterminado, tanto do ponto de vista personal quanto territorial ${ }^{19}$.

Todavia, no caso de procedência de demanda popular, os efeitos do julgado são oponíveis a todos, adquirindo força de lei entre as partes e tornando-se imutável, também, perante qualquer outro cidadão ou juízo, além de portar, segundo reconhece-lhe a doutrina, os efeitos constitutivo e condenatório.

No entanto, no que tange ao cumprimento do julgado, atentando-se às legitimações para sua execução estabelecidas nos artigos 16 e 17, da Lei $n^{\circ} 4.717 / 65^{20}$, em se tratando de tutela de bem ambiental, em que pese a legitimidade conferida também ao Ministério Público, ainda se observa a existência de um apego à feição privatista do processo, enquanto, justamente nessa etapa, da tutela executiva, a feição publicista deveria se fazer mais fortemente presente, conforme acentua Lunelli ${ }^{21}$.

Aliás, ainda a respeito da necessária efetividade da prestação da tutela jurisdicional que, mesmo na ação privada, não representa apenas um interesse dos particulares, a inserção de conteúdo mandamental à condenação que visa proteção ambiental conferiria uma feição ainda mais publicista ao processo, valorizando a jurisdição, porquanto:

A proposta de mandamentalização poderia inclusive realizar-se de ofício, independentemente do pedido do autor, produzindo a quebra da necessária identidade da natureza da ação e a respectiva sentença de

provada a ausência de obstáculo para construção dos condomínios elencados na cidade de Xangri-lá, estando as obras devidamente autorizadas pelos órgãos competentes, nem sequer se vislumbrando ocorrência de ilegalidades na emissão das licenças expedidas pela FEPAM, para efeito de suspender os empreendimentos, deve ser confirmada a sentença de improcedência da ação. Precedentes do TJRS. Sentença confirmada em reexame necessário. (Reexame necessário no 70061758371. 22a . Câmara Cível, Tribunal de Justiça do RS, Relator: Carlos Eduardo Zietlow Duro, julgado em 06/10/2014. (disponível em www.tjrs.jus.br - acesso em 27/07/2015) 17 Art. 18. A sentença terá eficácia de coisa julgada oponível "erga omnes", exceto no caso de haver sido a ação julgada improcedente por deficiência de prova; neste caso, qualquer cidadão poderá intentar outra ação com idêntico fundamento, valendo-se de nova prova.

18 MANCUSO, Rodolfo de Camargo. Ação popular: proteção do erário, do patrimônio público, da moralidade administrativa e do meio ambiente. São Paulo: Revista dos Tribunais, 2009. p. 387.

19 MARIN, Jeferson Dytz. A necessidade de superação da estandardização do processo e a coisa julgada nas ações coletivas de tutela ambiental. In: MARIN, Jefferson; LUNELLI, Carlos Alberto. (Org.) Estado, meio ambiente e jurisdição. Caxias do Sul: EDUCS, 2012. p. 51-91. p. 54.

20 Art. 16. Caso decorridos 60 (sessenta) dias da publicação da sentença condenatória de segunda instância, sem que o autor ou terceiro promova a respectiva execução o representante do Ministério Público a promoverá nos 30 (trinta) dias seguintes, sob pena de falta grave.

Art. 17. É sempre permitida às pessoas ou entidades referidas no art. $1^{\circ}$, ainda que hajam contestado a ação, promover, em qualquer tempo, e no que as beneficiar a execução da sentença contra os demais réus.

21 LUNELLI, Carlos Alberto. Por um novo paradigma processual nas ações destinadas à proteção do bem ambiental: a contribuição do contempt of court. In: LUNELLI, Carlos Alberto; MARIN, Jefferson. (Org.) Estado, meio ambiente e jurisdição. Caxias do Sul: EDUCS, 2012. p. 147-164. p. 150-151. 
procedência, porque numa ação em que o autor formulasse apenas o pedido condenatório, a sentença incluiria o comando mandamental, ordem de pagamento sob pena de caracterização do ilícito de desobediência. No entanto, tal aspecto não compromete a estruturação das ações do processo civil, ainda mais diante da crescente necessidade de publicização do processo ${ }^{22}$.

Até por consequência dessas circunstâncias, em vez de exercitar sua cidadania de forma direta, ajuizando ele próprio a ação popular, o que se verifica é que o indivíduo, até por incorporar um modelo cultural que atesta seu acomodamento e passividade, fruto do notório desencanto com as instituições que integram nossa democracia representativa, prefere se reportar às poucas instituições que ainda lhe inspiram credibilidade ou the conferem alguma esperança na consecução do bem comum, e, no caso, optam por noticiar danos ambientais ao Ministério Público. Daí a consequente grande utilização da ação civil pública para coibir atentados à higidez ambiental.

Todavia, veja-se que, acaso o cidadão opte por ele próprio promover a ação popular, o Ministério Público poderá sucedê-lo no prosseguimento da demanda, conforme estabelece o artigo $9^{\circ}$ da legislação específica ${ }^{23}$, produzindo todas as provas necessárias e adotando todas as providências pertinentes ao seu prosseguimento.

Assim, apesar de sua utilização prática abaixo da frequência desejada, o que não se pode imputar à ausência de acontecimentos passíveis de remediação por esta via processual, resta evidente que não se pode deixar de reconhecer na Ação Popular Ambiental um importante canal que viabiliza e concretiza o acesso participativo à justiça, especialmente em questões que envolvam proteção ao meio ambiente.

Importante considerar, por último e não por ser de menor relevância, que as dificuldades para a obtenção da prova apta a instruir e fundamentar a proposição da actio popularis, também passam pela penosa garimpagem das informações necessárias para tanto.

Modelar, nesse sentido, a compreensão da importância da informação ambiental na forma como é cultuada pelo direito luso, especialmente após a subscrição de Portugal à Convenção de Aarhus ${ }^{24}$, segundo esclarece Lanceiro:

A definição de 'informação em matéria de ambiente' engloba os conteúdos informativos (e.g., dados, notícias, conhecimentos), sob qualquer forma, sobre o estado do ambiente, sobre os factores, medidas ou actividades que afectam ou podem afetar o ambiente ou destinadas a protegê-lo, sobre as análises custos/benefícios e análises econômicas utilizadas no processo de tomada de decisão e igualmente informações sobre o estado da saúde e da segurança das pessoas, incluindo a contaminação da cadeia alimentar, as condições de vida, os locais de interesse cultural e as construções, na medida em que sejam ou possam ser afectados por elementos do ambiente ou por um desses factores, medidas ou atividades ${ }^{25}$.

Aliás, o acesso à informação ambiental é um caminho ainda de percurso tortuoso ao cidadão, porquanto nosso modelo social ainda não cultiva o hábito inerente à sua fácil disponibilização, dificultando o exercício de uma das expressões mais autênticas do princípio democrático.

\footnotetext{
22 LUNELLI, Carlos Alberto; MARIN, Jefferson. A preservação da tutela jurisdicional a partir da interação das eficácias mandamental e condenatória. Revista de Processo, São Paulo, v. 36, n. 195, p. 423-438, maio 2011. p. 431.

23 Art. $9^{\circ}$ Se o autor desistir da ação ou der motiva à absolvição da instância, serão publicados editais nos prazos e condições previstos no art. $7^{\circ}$, inciso II, ficando assegurado a qualquer cidadão, bem como ao representante do Ministério Público, dentro do prazo de 90 (noventa) dias da última publicação feita, promover o prosseguimento da ação.

24 A Convenção de Aarhus foi assinada na Dinamarca, na cidade do mesmo nome, em 25 de junho de 1998 e em vigor desde 30 de outubro de 2001, constituindo-se em importante mecanismo do Direito Internacional do Ambiente, objetivando alcançar o desenvolvimento sustentável pela participação dos cidadãos.

25 LANCEIRO, Rui Tavares. O direito de acesso à informação ambiental em Portugal: alguns problemas. In: GOMES, Carla Amado Gomes; ANTUNES, Tiago Antunes (Coords.). A Trilogia de Aarbus. Lisboa: Instituto de Ciências Jurídico-Políticas. Faculdade de Direito. Universidade de Lisboa, 2015. p. 29-60, p. 48.
} 


\section{Considerações finais}

A partir do exposto, observa-se que a ação popular ambiental é um dos mecanismos protetivos do meio ambiente que possibilitam a participação do cidadão de forma a intervir, senão na consecução dos processos decisórios, ao menos por meio da via de controle corretivo ou preventivo, nas ações que se consubstanciam danosas aos interesses metaindividuais ilegitimamente atingidos.

A ação popular ambiental tem abrangência para, além de servir como instrumento destinado essencialmente à impugnação de atos lesivos ao meio ambiente, praticados pelo Poder Público ou por entidade de que o Estado participe, também atingir pessoas jurídicas de direito privado que incorram nas mesmas condutas, bem como obter a reparação de danos ambientais resultantes de tais atos.

Por outro lado, a construção de um Estado Democrático de Direito só ocorre com base na mais ampla e versatilizada participação da sociedade, exercitando plenamente os instrumentos inerentes à cidadania, e a ação popular ambiental consubstancia um mecanismo que possibilita a todo cidadão buscar a discussão de qualquer ilegalidade decorrente de conduta comissiva ou omissiva do Poder Público, inclusive do ente ministerial, quando este ajuíza ou deixa de ajuizar ações civis públicas que envolvam matéria ambiental de natureza complexa e ainda pendente de estudos científicos que assegurem a prevenção e a precaução necessárias à manutenção ou recuperação do meio ambiente, patrimônio que nos incumbe garantir para uma sadia qualidade de vida à presente e às futuras gerações.

Assim, em que pese o instituto neste artigo brevemente visitado tenha sua utilização até certo ponto diminuída, ou quase menosprezada, por conta dos diferentes óbices antes passados em referência, o fato é que não se pode prescindir de qualquer aparelho útil ao exercício da democracia direta que o plexo constitucional coloca à disposição do cidadão.

Afinal, o exercício democrático é atividade que se deve manter em constância, porquanto o fortalecimento dos princípios inerentes à participação popular somente galgarão a superlativa e devida consideração quando seu recepcionamento ocorrer no cotidiano da cidadania.

\section{REFERÊNCIAS BIBLIOGRÁFICAS}

BRASIL. Constituição (1988). Constituição da República Federativa do Brasil. Brasília: Senado Federal, 1988.

BRASIL. Lei no 4717, de 29 de junho de 1965. Regula a ação popular. Brasília, [s.n], 1965.

BRASIL. Lei ñ 8906, de 4 de julho de 1994. Dispõe sobre o Estatuto da Advocacia e a Ordem dos Advogados do Brasil (OAB). Brasília, [s.n], 1994.

LANCEIRO, Rui Tavares. O direito de acesso à informação ambiental em Portugal: alguns problemas. In: GOMES, Carla Amado Gomes; ANTUNES, Tiago Antunes (Coords.). A Trilogia de Aarbus. Lisboa: Instituto de Ciências Jurídico-Políticas. Faculdade de Direito. Universidade de Lisboa, 2015. p. 29 -60.

LUNELLI, Carlos Alberto. Por um novo paradigma processual nas ações destinadas à proteção do bem ambiental. A contribuição do contempt of court. In: LUNELLI, Carlos Alberto; MARIN, Jefferson (Org.). Estado, meio ambiente e jurisdição. Caxias do Sul: EDUCS, 2012. p. 147 - 164.

LUNELLI, Carlos Alberto; MARIN, Jefferson. A preservação da tutela jurisdicional a partir da interação das eficácias mandamental e condenatória. Revista de Processo, São Paulo, v. 36, n. 195, p. 423-438, maio 2011.

MACHADO, Paulo Affonso Leme. Direito ambiental brasileiro. 18. ed. São Paulo: Malheiros, 2010.

MAFFINI, Rafael. Direito administrativo. 3. ed. São Paulo: Revista dos Tribunais, 2009. 
MANCUSO, Rodolfo de Camargo. Ação popular: proteção do erário, do patrimônio público, da moralidade administrativa e do meio ambiente. São Paulo: Revista dos Tribunais, 2009.

MARIN, Jeferson Dytz Marin; BRANDELLI, Ailor Carlos Brandelli. O Controle da Administração Pública pela ação popular: a legitimidade do cidadão para a fiscalização dos atos do governante. Revista de Informação legislativa, Brasília, a. 47, n. 185, p. 135 - 144, jan./mar. 2010.

MARIN, Jeferson Dytz Marin. A necessidade de superação da estandardização do processo e a coisa julgada nas ações coletivas de tutela ambiental. In: MARIN, Jefferson; LUNELLI, Carlos Alberto (Org.). Estado, meio ambiente e jurisdição. Caxias do Sul: EDUCS, 2012. p. 51 - 91.

MIRRA, Álvaro Luiz Valery. Participação, processo civil e defesa do meio ambiente no direito brasileiro. 2010. 715 folhas. Tese (Doutorado em Direito)- Universidade de São Paulo, São Paulo, 2010.

MORAIS, José Luis Bolzan de. Do direito social aos interesses transindividuais: o Estado e o direito na ordem contemporânea. Porto Alegre: Livraria do Advogado, 1996.

MOREIRA NETO. Curso de direito administrativo: parte introdutória, parte geral e parte especial. 15. ed. Rio de Janeiro: Forense, 2009.

SANTOS, Jair Lima dos. Tribunal de Contas da União \& controle estatal e social da administração pública. Curitiba: Juruá, 2004.

SILVA, José Afonso da. Ação popular constitucional: doutrina e processo. 2. ed. São Paulo: Malheiros, 2007.

UNIVERSIDADE DE CAXIAS DO SUL. Sistema de Bibliotecas: guia para elaboração de trabalhos acadêmicos [recurso eletrônico] SIBUCS; organização Michele Marques Batista; colaboração Marcelo Votto Teixeira, Michele Otobelli Bertéli. 3. ed. Caxias do Sul, 2015. Dados Eletrônicos (1 arquivo).

WARAT, Luiz Alberto. Introdução geral ao direito: a epistemologia jurídica da modernidade. Porto Alegre: Sérgio Fabris, 2002.

WEDY, Gabriel. Ação Popular Ambiental. Revista Processos Coletivos, Porto Alegre, v. 6, n. 2. Trimestral. 2015. Disponível em: <http://www.processoscoletivos.net/index.php/revista-eletronica/66-volume-6-numero2-trimestre-01-04-2015-a-30-06-2015/1554-acao-popular-ambiental>. Acesso em: 13 maio 2015. 


\section{Direito penal ambiental como tutela de sustentação à atuação administrativa e civil nos Estados Unidos da América e no Japão*}

\author{
Environmental criminal law as the keystone \\ to administrative and civil authority in the \\ United States and Japan
}

\author{
Luiz Gustavo Gonçalves Ribeiro** \\ Lorena Machado Rogedo Bastianetto***
}

\title{
Resumo
}

A agenda ambiental possui peculiaridades que o Direito Penal clássico não aventou enfrentar. A modernidade trouxe indefinições e inseguranças que romperam as fronteiras da subjetividade determinada, da lesividade conhecida e do dano tangível, o que constrangeu as nações a reagir e suprir lacunas dantes inexploradas. Nesse desiderato reacional estatal, eclode o Direito Penal Ambiental, esfera impetuosa que intervém ao sinal prodrômico de transgressão iterativa ao seu bem mais caro: o meio ambiente. Os Estados Unidos da América e o Japão, nações divergentes na história e desenvolvimento de suas sociedades, alargaram o influxo penal, impulsionados por fatores congêneres, mas com resultado díspar. Todavia, a precisão do Direito Penal extravasa um discernimento de educação cívica e da imperatividade de recursos hábeis a enternecer o elo coletivo entre os cidadãos. Neste artigo, a vertente metodológica jurídico-dogmática foi escolhida para que, com base no raciocínio lógico-dedutivo e na investigação legislativa e doutrinária, bem como da coleta de dados dos órgãos públicos pertinentes nos sistemas americano e japonês, o trabalho possa oportunizar reflexões a respeito do papel do Direito Penal para o fortalecimento do Direito Administrativo e do Direito Civil.

Palavras-chave: Meio ambiente. Direito penal. Estados Unidos da América. Japão. Cotejo social e jurídico.

\section{Abstract}

The environmental agenda presents challenges to old assumptions concerning Penal Law. The modern age brought indefinition and unstableness through broadened concepts of liability, damage and offensiveness. This fresh scenario required nations to provide proper response to causes never addressed before. Therefore, Environmental Criminal Law became visible, since continual transgressions and non-compliance were jeopardizing its major legal asset. The United States of America and Japan, nations with distinct social evolvement and history, employ Penal Law as the key to envi- 
ronmental violations, although peculiar outcomes have emerged in each country. Nevertheless, the demand for criminalization depicts frames of civic education and the essentiality of effective resources to strengthen collective ties among individuals. Laying the groundwork on deductive reasoning and comparative analysis of both legal systems and public data - American and Japanese -, the juridical dogmatic alignment of this paper was chosen in order to offer inputs regarding the encouragement of Administrative and Civil Law by Criminal liability.

Keywords: Criminal law. Environment. Japan. Social and juridical correlation. United States of America.

\section{INTRODUÇÃO}

A ciência jurídica penal, disciplina consagradora da responsabilidade subjetiva e imbuída em princípios e regras de núcleo duro, enfrenta, na modernidade, desafios advindos de estímulos sociais imprecisos e oscilantes, os quais se propagam em movimentos racionais descontínuos. A juridicização do fenômeno ecológico, bem como a exaltação de bens jurídicos de natureza difusa projetam esse espectro indeterminado ao Direito Penal, o qual deve atender às demandas sociais através de um sistema punitivo seguro e autolimitado por garantias materiais e processuais precisas.

A Matemática, ciência-matriz da civilização, lida com a incerteza como fenômeno atávico, isto é, de cunho natural, inato à percepção humana. Aristóteles, citando Zenão, já estruturava a premissa de que

se as coisas são muitas, as coisas existentes são infinitas, pois há sempre coisas entre as coisas existentes e, novamente, outras coisas entre essas outras. Sendo assim, as coisas existentes são infinitas. ${ }^{1}$

Com base na noção de "infinidade", aufere-se a imprecisão da percepção humana, ponto fomentador da falibilidade. O empenho social em normatizar está naturalmente atrelado àquilo de que se tem consciência. Dessa constatação, infere-se que somente se pode reger juridicamente aquilo que se conhece, mesmo que desse conhecimento derive a ignorância ou o próprio dessaber.

No Direito brasileiro, a Constituição da República de 1988 (CR/88)², em seu título II, clarifica que os direitos fundamentais estão essencialmente encetados nos bens jurídicos "vida, liberdade, igualdade, segurança e propriedade"; e em seu art. $225^{3}$, dispõe que o meio ambiente seria um bem de uso comum do povo. Dessa formatação constitucional, depreende-se que a Biota pertence ao domínio público - direito fundamental de propriedade - e tem uma destinação difusa, isto é, toda a coletividade está apta a dela usufruir.

Posto isso, vê-se que a fruição do meio ambiente revela-se um direito subjetivo de cada cidadão per sie de todos, concomitantemente. Resta aferir, por meio do sistema normativo, o que se poderia considerar como uso normal ou comum do bem "meio ambiente" e o que se conceberia como uso especial ou anormal deste.

Dessa disjunção descende a eminência do Direito Penal Ambiental, o qual integra a atuação do Direito Administrativo e Civil quanto à regulação do uso especial ou anormal da Natureza.

Grosso modo, o cenário irresoluto e abstrato gerado pelo uso especial do meio ambiente seria uma das

1 CARVALHO, Joaquim Francisco de. As origens do pensamento matemático e a crise dos fundamentos. Periódico Eletrônico Norte Ciência, Academia Paraense de Ciência, v. 1, n. 2, p. 59-60, 2010. Disponível em: < http://aparaciencias.org/vol-1.2/06_Joaquim\%20 p.\%2059-65.pdf>. Acesso em: 1 jun. 2015.

2 Art. $5^{\circ}, \mathrm{CR} / 88$ : “Todos são iguais perante a lei, sem distinção de qualquer natureza, garantindo-se aos brasileiros e aos estrangeiros residentes no País a inviolabilidade do direito à vida, à liberdade, à igualdade, à segurança e à propriedade, nos termos seguintes [...]” BRASIL. Constituição (1989). Constituição da República Federativa do Brasil. In: ANGHER, Anne Joyce (Org.). Vade mecum acadêmico de direito Rideel. 20. ed. São Paulo: Rideel, 2015. p. 19.

3 Art. 225, CR/88: “Todos têm direito ao meio ambiente ecologicamente equilibrado, bem de uso comum do povo e essencial à sadia qualidade de vida, impondo-se ao Poder Público e à coletividade o dever de defendê-lo e preservá-lo para as presentes e futuras gerações BRASIL. Constituição (1989). Constituição da República Federativa do Brasil. In: ANGHER, Anne Joyce (Org.). Vade mecum acadêmico de direito Rideel. 20. ed. São Paulo: Rideel, 2015. p. 76. 
pedras de toque para a construção criminal da responsabilidade ambiental em todos os sistemas jurídicos mundiais. Outro ponto nodal seria a identificação desse uso anormal e as limitações de ordem pública ao uso comum, as quais, uma vez não atendidas ou infringidas, transmudam-se em uso especial do Ecossistema. Dita sistemática, associada ao atributo universal ou transnacional do meio ambiente, propala uma conotação peculiar do Direito Penal Ambiental nas nações do mundo, dissociada da elaboração criminal para os delitos comuns. Essa desunião ordenatória propugna um caminhar inevitável da Ciência Jurídica rumo ao desconhecido, com uma única certeza: a consciência do dessaber denuncia a premência do regimento de ultima ratio, haja vista a inespecificidade danosa, corolário do assédio ambiental, bem como sua índole acumulativa.

À parte de o meio ambiente ser considerado explicitamente, na Constituição pátria, um bem, inegável é que, nas normatizações, seja este concebido abertamente como tal ou não, o ser humano sempre avistou a Biota com alteridade. Dita acepção desborda o porte usurário da relação entre indivíduo e natureza, mesmo que esse desfrute consista meramente em júbilo proveniente de um elo afetivo com o Ecossistema, o mais suave feitio da sua utilização.

O Direito Penal Ambiental a ser contemplado neste artigo tem como enfoque as nações norte-americana e japonesa, etnias manifestamente dessemelhantes, com o escopo de deslindar o enfrentamento singular de cada país quanto aos dilemas advindos da convivência entre o ser humano e o meio ambiente. A estruturação do sistema jurídico, o elo comunitário entre os cidadãos e a ascendência das campanhas midiáticas promovem contextos muito correlatos que se desagregam pragmaticamente pela originalidade coletiva de ambas as nações, informação que restaura o destaque ancestral dos referenciais de assimilação e confrontação de problemas por cada coletividade.

O texto traz a hipótese de que a premência do influxo penal revela-se necessária para o fortalecimento e efetividade das tutelas menos invasivas ao patrimônio jurídico do cidadão, já que traduz um modus educandi basilar para a estruturação do entendimento dos povos a respeito dos bens que unificam em si o particular e a alteridade, seja pela consagração ou não de institutos de maleabilidade na persecução penal. Em vista disso, o estudo dos sistemas americano e japonês - os quais, apesar de acolherem a indispensabilidade penal para a tutela da Biota, desjungem na expressão funcional do sistema - apresenta-se como importante ferramenta para a intelecção do verdadeiro encargo do Direito Penal, bem como de seus atributos de cooperação para com os demais ramos da Ciência Jurídica, aporte essencial para uma competência integral de institutos restauradores, reparatórios e sancionadores de grau menos intenso que a tutela penal.

A vertente metodológica contemplada foi a jurídico-dogmática e utilizado o raciocínio lógico-dedutivo para a exposição do conteúdo das premissas legais, doutrina e dados públicos da Administração em ambos os sistemas norte-americano e japonês, os quais demonstram, para a testagem da hipótese, a necessidade de coexistência da tutela penal com as demais, tanto em sede legislativa como operacional, predicado robustecedor da valência plena da atividade administrativa e civil para a consecução dos fins mais caros dos institutos restauradores, reparatórios e sancionadores ambientais de tomo primário, elemento reflexivo para o enaltecimento da índole de impregnância social que o Direito Penal goza em categoria de amplo reverenciamento dos cidadãos.

\section{TUtela PENAL AMBiental NORTE-AMERICANA}

Os Estados Unidos da América mantêm vigente em sua legislação federal suas duas mais antigas leis ambientais em ricochete, as popularmente conhecidas "Rivers and Harbors Appropriation Act of 1899",

4 UNITED STATES. Rivers and Harbors Appropriation Act. Available at: < http://uscode.house.gov/view.xhtml?req=granuleid:USCprelim-title33-section407\&num=0\&edition=prelim>. Access: 04 June 2015. 
e "Refuse Act of 1899". ${ }^{5}$ Referidas normatizações tinham por escopo a mantença da qualidade de navegabilidade nas águas norte-americanas, bem como dos seus canais portuários, por meio da criminalização de condutas de descarte de refugo e depósito de materiais em seus cursos d'água, assim como em seus terminais de embarcação. Desprovidas de pretensões ambientalistas e integralmente focadas na mercancia fluvial desembaraçada, ambas as leis preveem as sanções de encarceramento e multa para os delitos ali descritos como de menor potencial ofensivo. Hoje, ainda vigentes, nota-se uma transmudação na sua leitura, abarcando um viés biofílico e de conservação ambiental.

Entretanto, o despertar norte-americano para a pauta ecológica deu-se mais tarde, na década de 1970, com as emendas às já existentes leis federais "Clean Air Act" ${ }^{6}$ e "Clean Water Act", 7 as quais prescrevem ações de controle e prevenção de poluição advindas, tanto de fontes industriais quanto de natureza móvel, e implantam programas e ações afirmativas governamentais de natureza ambientalista. A criação da Agência Federal de Proteção Ambiental - "Environmental Protection Agency" - também foi um importante marco no caminhar norte-americano rumo à criminalização de condutas lesivas ao meio ambiente, já que inaugura a institucionalização do controle, monitoramento e vigilância de atividades potencialmente danosas.

Percebeu-se, no entanto, segundo Kondrat ${ }^{8}$, uma latência legal desses diplomas por mais de uma década, justamente pelo fato de o órgão do Poder Executivo - Environmental Protection Agency (EPA) - não dispor, até 1981, de competências investigativas de cunho penal. A partir dessa data, a EPA criou seu departamento criminal (Office of Criminal Enforcement) ${ }^{9}$, com a estreia de uma divisão especializada em crimes ambientais, Environmental Crimes Section ${ }^{10}$, na estrutura do Ministério da Justiça norte-americano. $\mathrm{Na}$ esteira de Zaffaroni et al. ${ }^{11}$, infere-se que a criminalização primária esvazia-se na ausência da criminalização secundária, ou seja, o Direito Penal concretiza sua seletividade delituosa abstrata, ex lege, por meio de uma estrutura especializada que escolhe ou elege as condutas alvo de sua atuação. A eleição descrita é condicionada às forças midiáticas, ao poder de veiculação de informações e à censura aos fatos pertinentes a essa criminalização.

Nos Estados Unidos, a influência da mídia na consternação social ganha um relevo ainda mais eminente, já que o sistema de justiça criminal norte-americano admite a transação penal, instituto substancialmente diverso do que se concebe na seara nacional. Essa negociação entre os "advogados públicos" (promotores de Justiça ou procuradores da República no sistema penal brasileiro) e os advogados da parte ré (defensores públicos ou advogados particulares) ocorre sem a participação do Poder Judiciário, o qual entra em cena apenas posteriormente para deferir ou rejeitar as tratativas entre as partes envolvidas. A transação penal

5 UNITED STATES. Refuse Act of 1899. Available at: <http://uscode.house.gov/view.xhtml?req=granuleid:USC-prelim-title33section407\&num=0\&edition=prelim>. Access: 04 June 2015. Free translation. A Lei Federal de Refugo é uma seção da Lei Federal de Domínio de Rios e Portos, ganhando luz própria apenas pela especificação dos delitos de descarte de refugos em águas e portos americanos.

6 UNITED STATES. Clean Air Act. Available at: <http://uscode.house.gov/view.xhtml?req=granuleid:USC-prelim-title42section7401\&num=0\&edition=prelim >. Access: 4 June 2015. Free translation. A Lei Federal de Ar Limpo data de 1955 sob a denominação de "Air Pollution Control Act", tendo sido revista em 1963 com determinações iniciais para o controle da poluição do ar e de ampliação de estudos para a quantificação de níveis de poluição toleráveis e qualificação de substâncias poluidoras. Em 1970, as emendas à Lei representaram grande avanço na positivação desse controle em âmbitos federal e estadual, inaugurando importantes programas ambientais do governo.

7 UNITED STATES. Clean Water Act. Available at: <http://uscode.house.gov/view.xhtml?req=granuleid:USC-prelim-title33section1251\&num=0\&edition=prelim>. Access: 4 June 2015. Free translation. A Lei Federal de Água Limpa data de 1948 sob a denominação de "Federal Water Pollution Control Act", tendo sido integralmente reformulada em 1972.

8 KONDRAT, Robert G. Punishing and preventing pollution in Japan: is American style criminal enforcement the solution? Pacific Rim Law \& Policy Journal Association, v. 9, n. 2, p. 379-414, 2000. Available at: < https://digital.lib.washington.edu/dspace-law/ bitstream/handle/1773.1/812/9PacRimLPolyJ379.pdf?sequence=1>. Access: 4 June 2015.

9 UNITED STATES. Environmental Protection Agency. Criminal enforcement. Available at: <http://www2.epa.gov/enforcement/ criminal-enforcement>. Access: 1 Feb. 2016.

10 UNITED STATES. Departamento f Justice. Environmental and Natural Resources Division. [Home]. Available at: <http:// www.justice.gov/enrd>. Access: 1 Feb. 2016.

11 ZAFFARONI, E. Raul et al. Direito penal brasileiro: teoria geral do direito penal. 2. ed. Rio de Janeiro: Revan, 2013. v. 1. 
norte-americana aplica-se, em regra, a todos os tipos de infrações penais e tem como fim último poupar o réu do julgamento e de uma possível sanção penal severa, bem como livrar os advogados representantes da sociedade ou do Estado de provar a ocorrência do crime. É um instituto pertencente ao processo penal e de natureza sancionatória, com efeitos penais prospectivos e sequelas civis, e origina-se, essencialmente, da economia na administração da Justiça e da ausência de obrigatoriedade da ação penal por parte dos advogados públicos, representantes do Estado.

Dessa arquitetura, eclode o valor da comoção social no encorajamento dos prosecutors a investirem-se na persecução penal, infirmando as tratativas interpartes, as chamadas plea bargains ou plea agreements ${ }^{12}$, de compleição privatística e esvaziadas do porte retributivo e de calmaria ou estabilização social que os julgamentos oferecem.

$\mathrm{Na}$ alçada ambiental, essa racionalização tem procedência observável. A latência legislativa superior a 10 anos das leis ambientais de grande tomo da Federação norte-americana advém de um único foco midiático ecológico durante o período em tela: o escândalo do Canal Love ${ }^{13}$. Levaria mais de duas décadas para outro desastre ambiental, largamente difundido pelos meios de comunicação, voltar a alarmar a população norte-americana - o acidente com o petroleiro Exxon Valdez ${ }^{14}$ na costa do Alaska.

O caso Exxon Valdez fez despontar um sobressalto na nação norte-americana a respeito das consequências catastróficas provenientes da poluição, fato que culminou na criação, em 1990, da Lei Federal de Persecução da Poluição ${ }^{15}$, a qual deixou límpida a concepção de que somente o Direito Penal, por intermédio das agências policiais, estaria apto a impelir corporações e pessoas a obedecerem às disposições legais ambientais. Em paralelo com os ensinamentos de $\operatorname{Neves}^{16}$, poder-se-ia inferir que a supracitada lei federal seria produto da demonstração da capacidade de ação do Estado por meio da edição de uma "legislação-álibi”, apta a exortar uma eficiente e rápida resposta governamental entremeio às grandes crises comunitárias. Todavia, entende-se que a normatização em tela detém o caráter de decreto regulamentar no sistema jurídico brasileiro, competência privativa do chefe do Poder Executivo, segundo o art. 84, inciso IV da $\mathrm{CR} / 88^{17}$, configurando-se não um diploma de tipificação penal de condutas in abstracto, mas um verdadeiro mandamento executório direcionado à Agência de Proteção Ambiental norte-americana (EPA). Dentre as determinações do Congresso norte-americano, ressaltam-se a ampliação de receitas destinadas à EPA, o alargamento progressivo dos quadros de servidores públicos policiais e o treinamento de investigadores, advogados, peritos, inspetores e demais profissionais em persecução penal ambiental.

Dessarte, desvia-se a "legislação-álibi”" de sua função hipertrófica simbólica em cotejo com a efetividade social da lei ${ }^{18}$ como proposta por Neves ${ }^{19}$, uma vez que o preceito legislativo avulta a atuação da guarda ambiental e fornece instrumentos hábeis a esse reforço interventivo. Depreende-se, assim, que o Estado agiu legislativamente, impulsionado pelo alarme ecológico selecionado pela imprensa para entorpecer a so-

12 UNITED STATES. Federal Rules of Criminal Procedure. Available at: <https://www.law.cornell.edu/rules/frcrmp>. Access: 2 June 2015.

13 Love Canal Tragedy: a empresa Hooker Electro Chemical Corporation utilizou um terreno próximo às Cataratas do Niágara/ NY para o depósito de resíduos químicos. Após o esgotamento da capacidade do aterro, uma camada de argila impermeável foi utilizada para cobrir o local. Duas décadas depois, esse mesmo terreno já se encontrava integralmente habitado, inclusive com a instalação de escolas municipais. Toneladas de compostos químicos lançaram-se à superfície devido a um aumento considerável do índice pluviométrico no ano de 1978, contaminando toda a comunidade local e destruindo as propriedades.

14 Em marco de 1989, o petroleiro pertencente à empresa Exxon Mobil lançou $120.000 \mathrm{~m}^{2}$ de petróleo na costa do Alaska, após encalhar na Prince William Sound (Enseada do Príncipe Guilherme).

15 UNITED STATES. Pollution Prosecution Act, 1990. Available at: <https://www.govtrack.us/congress/bills/101/s2176>. Access: 05 June 2015.

16 NEVES, Marcelo. A constitucionalização simbólica. São Paulo: WMF Martins Fontes, 2007. (Coleção Justiça e Direito).

17 Art. 84: "Compete privativamente ao Presidente da República: IV - sancionar, promulgar e fazer publicar as leis, bem como expedir decretos e regulamentos para sua fiel execução”. BRASIL. Constituição (1989). Constituição da República Federativa do Brasil. In: ANGHER, Anne Joyce (Org.). Vade mecum acadêmico de direito Rideel. 20. ed. São Paulo: Rideel, 2015. p. 45.

18 NEVES, Marcelo. A constitucionalização simbólica. São Paulo: WMF Martins Fontes, 2007. (Coleção Justiça e Direito). p. 1.

19 NEVES, Marcelo. A constitucionalização simbólica. São Paulo: WMF Martins Fontes, 2007. (Coleção Justiça e Direito). 
ciedade de conflituosidade. Porém, a normatização mandamental transmuda o núcleo exculpante legal para um formato de tutela específica penal, conjuntura que aperfeiçoa o sistema de persecução e sobreleva os mecanismos de busca punitiva.

Em antinomia ao proposto por Zaffaroni et $\mathrm{al}^{20}$,a rotulagem dos vulneráveis, autores de crimes no sistema penal comum, restaria desmantelada pela ascensão de uma clientela penal pujante no Direito Penal Ambiental. O estereótipo subsistiria, focado, entrementes, em pessoas resguardadas do Direito Penal ordinário, vulneráveis nessa perspectiva não pela desvalorização que a sociedade impinge a estas, mas justamente pelo calibre e projeção que destilam socialmente. Crê-se que a qualidade do dano ambiental, bem como o obscurantismo quanto ao resultado material ecológico assentam uma dinâmica penal heterogênea com a mira em uma freguesia outrora inatacável e em condutas típicas refinadas e não toscas e de fácil detecção como na seletividade criminal normal. Nesse contexto, o elixir criminal incorpora uma perspectiva subjetiva e objetiva rara, transpondo as limitações de funcionamento da armação jurídico-delituosa habitual.

Do exposto acima, verifica-se que a tipificação de condutas antijurídicas, anteriormente cuidadas pelo Direito Administrativo e Civil, assim como a operacionalização de agências policiais eficazes, aptas a causar repercussão concreta na penalização dos comportamentos ambientais contra legem, denotam a característica de assimilação inata do ser humano e o atributo visceral de obediência social: a opressividade vertical alimentada pela violência lícita.

O empirismo corrobora referida afirmação com o resultado exitoso do sistema penal ambiental norte-americano há anos, publicado pela EPA, o qual inclui, apenas no ano de 2014, um total de 155 anos de encarceramento, associados a $\$ 163$ milhões em multas penais, administrativas e civis, além de $\$ 453.7$ milhões em gastos para adequação corporativa às normas ambientais via Termos de Ajustamento de Conduta ${ }^{21}$.

Vital a menção de que o programa de persecução penal da Agência de Proteção ambiental americana ${ }^{22}$ inicia seu plano de atuação com a assertiva de que

enquanto as corporações e as pessoas naturais estão aptas a pagar multas por seus ilícitos ambientais, somente a pessoa natural pode ser encarcerada, fato que impede a transferência da 'pegada ambiental' ao consumidor americano. ${ }^{23}$

Referida afirmação sela o entendimento de que o programa penal do órgão tem como foco a pessoa natural, e não a responsabilização penal da pessoa jurídica. Com base nessa convergência, os dados estatísticos do trabalho da agência demonstram que, nos seus anos iniciais de existência, 70\% dos réus em processos criminais ambientais eram corporações, sendo os 30\% remanescentes de pessoas naturais. Atualmente, a realidade inverteu-se, apenas $20 \%$ dos réus são pessoas jurídicas, e os demais $80 \%$ são de pessoas naturais ${ }^{24}$.

O cerne do plano estratégico da agência revela que o fator inibitório de maior valor para a atuação do órgão não é a responsabilização penal das empresas - apesar de ela ser uma imputação penal de grande tomo e largamente lançada mão nas sentenças e transações penais -, mas a persecução penal individual daqueles envolvidos no crime. Nessa vertente, a estigmatização da sanção penal ganha contornos explícitos e veicula pela mídia e nos plexos sociais com grande rapidez e efetividade. Esse caráter misto de retributividade e de prevenção erga omnes através da sanção penal tem sido o eixo da persecução criminal ambiental norte-americana. Punindo-se as pessoas com encarceramento, penas restritivas de direito, e mesmo com a multa

20 ZAFFARONI, E. Raul et al. Direito penal brasileiro: teoria geral do direito penal. 2. ed. Rio de Janeiro: Revan, 2003. v. 1.

21 A respeito do tema, UNITED STATES. Environmental Protection Agency. [Enforcement annual results: fiscal year 2014]. Available at: <http:/ /www2.epa.gov/enforcement/enforcement-annual-results-fiscal-year-fy-2014>. Access: 1 Feb. 2016.

22 A respeito, UNITED STATES. Environmental Protection Agency. Criminal Enforcement Program, Oct. 2011. Available at: <http://www.epa.gov/sites/production/files/documents/oceft-overview-2011.pdf>. Access: 1 Feb. 2016. p. 1. Free translation.

23 A respeito, UNITED STATES. Environmental Protection Agency. Criminal Enforcement Program, Oct. 2011. Available at: <http://www.epa.gov/sites/production/files/documents/oceft-overview-2011.pdf>. Access: 1 Feb. 2016. p. 4. Free translation.

24 A respeito, UNITED STATES. Environmental Protection Agency. Criminal Enforcement Program, Oct. 2011. Available at: <http://www.epa.gov/sites/production/files/documents/oceft-overview-2011.pdf>. Access: 1 Feb. 2016. p. 6. 
penal individual, paralelamente, constata-seque as taxas de observância às medidas administrativas impostas pelo órgão, bem como as sanções civis e a recuperação ambiental em processos cíveis têm sido, a cada ano fiscal, mais respeitadas e honradas ${ }^{25}$. Portanto, a tipificação de condutas juridicamente ilícitas contra o bem ambiental, bem como a eficiente operacionalização da persecução penal com o desfecho penal sancionador da pessoa natural, reverberam na atuação administrativa e civil do órgão, a qual tem sido muito mais exitosa e ampla desde a incorporação da tutela penal aos ilícitos ambientais. A ação da Polícia Judiciária nas investigações de ilícitos ambientais imprime uma chaga à atividade fiscalizatória da agência, reforçando a efetividade das sanções administrativas, civis e dos termos de ajustamento de conduta para recuperação e restauração da Biota. A presença da Polícia Judiciária ambiental e a troca de informações e expertise entre as atuações civis, administrativas e penais do órgão já são bastantes para suscitar grande interesse dos envolvidos em cumprir com a Polícia Administrativa e a conformar sua atuação e de suas empresas com os regulamentos ambientais. Dessa arquitetura, o mais atraente é a constatação de que o Direito Administrativo e Civil são muito mais eficientes de mãos dadas ao Direito Penal, extenuando o axioma de que só se maneja a tutela criminal a partir da ineficiência prévia dos demais ramos jurídicos. A trajetória de persecução penal ambiental americana tem desbordado que as tutelas menos invasivas aos direitos fundamentais do cidadão operam com muito mais sucesso e alargam sua proatividade através de um Direito Penal bem estruturado para sancionar. O Direito Penal continua com seu caráter subsidiário, mas uma subsidiariedade praticável pelo Estado, o que implica dizer que a opção de persecução penal deve preexistir e estar pronta para ser acionada com competência, ou seja, o Direito Penal deve nascer, conjuntamente, com as demais sanções jurídicas e ter seu aparato de funcionamento constituído pari passu aos outros ramos do Direito. Sua onipresença e colaboração perene com a Polícia Administrativa é que imprimem às sanções extrapenais e às leis ambientais um elevado grau de compliance.

Além do mais, o caráter preventivo da sanção penal à prática de delitos ambientais, segundo a política ambiental americana, está intimamente atrelado ao acesso à informação pela população a respeito do programa penal de repressão aos ilícitos, não somente por meio da divulgação midiática das persecuções penais, mas por meio do alargamento do incremento das vias de ingresso e participação do cidadão nas investigações de viés biofílico. O sítio eletrônico da EPA permite a todos o registro de notícias de infrações ambientais, bem como o apontamento de paradeiros de fugitivos procurados pela Polícia Judiciária Ambiental ${ }^{26}$.

Como não poderia deixar de ser, a atuação do Direito Penal ambiental americano volta-se, mormente, para as ações de deliberado descumprimento da legislação ambiental por corporações e pessoas naturais, e, em acordo com os dados da EPA, mais de 90\% das denúncias criminais encerram-se com uma sentença penal condenatória ${ }^{27}$. Em 2016, a mídia americana já propagou amplamente uma sentença penal condenatória de 20 anos de reclusão a um cidadão de Nova Jersey, o qual foi o protagonista de um esquema fraudatório a programas governamentais americanos de mudança de comportamento corporativo para a ampliação do uso de combustíveis renováveis, especialmente o biodiese ${ }^{28}$. Essa nova condenação assevera a posição da Federação norte-americana de demonstração explícita da intolerabilidade quanto a infrações penais ambientais graves, e, de igual modo, promove uma mensagem educativa às corporações e à população em geral de que o aparato penal ambiental encontra-se a todo vapor, emparelhado com a Polícia Administrativa para uma repressão subsidiária, mas eficiente quanto aos ilícitos ambientais, dado estimulante para a observância das tutelas antecedentes à incidência criminal.

25 A respeito, UNITED STATES. Environmental Protection Agency. Criminal Enforcement Program, Oct. 2011. Available at: <http://www.epa.gov/sites/production/files/documents/oceft-overview-2011.pdf>. Access: 1 Feb. 2016.

26 A respeito, UNITED STATES. Environmental Protection Agency. Criminal Enforcement Program, Oct. 2011. Available at: <http://www.epa.gov/sites/production/files/documents/oceft-overview-2011.pdf>. Access: 1 Feb. 2016. p. 6-7.

27 A respeito, UNITED STATES. Environmental Protection Agency. Criminal Enforcement Program, Oct. 2011. Available at: <http://www.epa.gov/sites/production/files/documents/oceft-overview-2011.pdf>. Access: 1 Feb. 2016. p. 11.

28 A respeito, UNITED STATES. Department of Justice. Southern District of Indiana. New Jersey man sentenced in Indiana to 20 years for biodiesel fraud scheme. 8 Jan. 2016. Available at: <https://www.justice.gov/usao-sdin/pr/new-jersey-man-sentenced-indiana20-years-biodiesel-fraud-scheme>. Access: 1 fev. 2016. 


\section{Proteção penas ambiental no Japão}

A nação insular japonesa, de história díspar à norte-americana e construtora de uma cultura secular de disciplina, lealdade e de militarização governamental, aponta traçado de contexto ambiental muito similar à trajetória norte-americana.

Faz-se essencial salientar que o Japão possui uma memória enraizada quanto à lisura comportamental e ao respeito a códigos de conduta. A classe dos samurais alicerçava-se na combinação da sabedoria budista com o uso da força legítima para o alcance da subordinação social. Havia, inclusive, uma permissiva legal ${ }^{29}$, na época feudal japonesa, que concedia a estes o direito de matar membros de castas inferiores que os desrespeitassem. Essa tradição verticalizada do arquipélago reverberou na sociedade contemporânea, extremamente burocrática, estratificada e marcada pela resiliência.

Referidos atributos poderiam resultar na inferência de que a sociedade nipônica moderna usufruiria de uma estrutura normativa leniente, de visão horizontalizada, desonerando a Ciência Jurídica de regramentos extensos ou, ao menos, minorando o influxo do Direito Penal na arquitetura social. Essa assertiva não se demonstra fidedigna.

O Direito Penal japonês determina-se intensamente austero, com sanções capitais, aprisionamento permanente e de trabalhos forçados, bem como um patamar de imputabilidade penal reduzido a 14 anos de ida$\mathrm{de}^{30}$. Robustecendo essa perspectiva, vê-se um anacronismo criminal da sociedade japonesa com seu código de direito privado, anterior ao estatuto penal. A Lei no 89, de 1896 $6^{31}$, Código Civil do Japão, determina, em seu art. $4^{\circ}$, a idade de 20 anos para a aquisição da capacidade de exercício para os atos da vida civil, padrão que descerra um fosso de seis anos entre as searas jurídicas, apresentando uma lógica negativa se comparada ao Direito brasileiro.

Segundo Gomes e García-Pablos de Molina 32 “"o crime tem natureza de problema social e como tal deve ser resolvido no seio da comunidade e pela comunidade”, tendo a criminologia clássica preconizado sua decifração pelo combate entre indivíduo e Estado.

É cediço que a moderna criminologia aventa um multíplice entendimento do delito, levando em conta uma crescente responsabilidade estatal na sua prevenção, bem como a magnitude da ressocialização do autor. Na sociedade japonesa, entretanto, essa perspectiva não infirmou o caráter rigoroso da sanção penal e a eminência da violência legal para a obtenção da obediência comunitária, fato que talvez seja o fator determinante para o pioneirismo da nação nipônica na criminalização ambiental.

Essencial a anotação de que esse vanguardismo refere-se a leis de feitio biofílico, com intuito de proteção direta do meio ambiente como bem jurídico, e não em ricochete, como anteriormente verificado em referência a leis norte-americanas.

Em 1970, a "Dieta Nacional Japonesa", Poder Legislativo do país, operou agilmente em matéria ambiental, editando novos estatutos e emendando leis já existentes, a maioria delas com foco na atividade poluidora $^{33}$.

29 JAPÃO. "Kiri sute Gomen": lei japonesa concessiva do direito de eliminação de membros de castas inferiores pelos samurais na época do regime feudal japonês (1100 a 1867). Disponível em: <http://www.thejapanesepage.com>. Acesso em: 4 jun. 2015.

30 A respeito do tema, ver arts. 9 e 41 do Código Penal Japonês (Lei no 45 de 1907). JAPAN. Act n. 45, 1907. Penal code. Available at: <http:/ / www.japaneselawtranslation.go.jp/law/detail/?id=1960\&vm=04\&re=02>. Access: 4 June 2015.

31 JAPAN. Act n. 89, 1896. Civil code. Available at: <http://www.moj.go.jp/content/000056024.pdf>. Access: 4 June 2015.

32 GOMES, Luiz Flávio; GARCÍA-PABLOS DE MOLINA, Antonio. Criminologia. Trad. Luiz Flávio Gomes; Yellbin Morote; García Davi Tangerino. 8. ed. São Paulo: Revista dos Tribunais, 2012.

33 Segundo Kondrat, as leis emendadas foram: Lei Básica para o Controle da Poluição Ambiental; Lei de Controle da Poluição do Ar; Lei de Regulação de Emissão de Ruídos; Lei de Refugo; Lei do Patrimônio Natural; Lei de Controle de Substâncias Tóxicas e Perigosas; e Lei de Regulação de Insumos para a Agricultura. As novas leis foram: Lei de Controle da Poluição das Águas; Lei do Poluidor-Pagador; Lei de Crimes da Atividade Poluidora Nocivas à Saúde Humana; Lei de Prevenção da Poluição Marítima; Lei de 
A Lei no 142, de 1970, intitulada "Lei de Crimes da Atividade Poluidora Nociva à Saúde Humana", simboliza a inauguração do Princípio da Precaução no Direito insular, apresentando um novo encarte da figura danosa, carente de materialidade e assente em possíveis resultados aferidos intelectivamente ex ante a constatação do prejuízo ecológico. O Estatuto regulava as atividades de risco de cunho empresarial, dolosas e culposas, empreendendo status agressivo aos comportamentos antijurídicos, ou seja, elevando o grau da responsabilidade subjetiva ao transmudar a regência legal do âmbito civil e administrativo para o poderio do Direito Penal.

Na mesma esteira, a Lei de Controle da Poluição do Ar - Lei no 97/1968 - e a Lei de Controle da Poluição das Águas - Lei no 138/1970 (a primeira emendada em 1970 com a criminalização das condutas lá descritas e a última editada no mesmo ano também com a chaga penal) - avançam extraordinariamente, debutando a penalização de pessoas jurídicas e pessoas naturais representantes de corporações que inobservam os parâmetros administrativos de regulação da atividade poluidora, bem como normas de minimização dos riscos da atividade empresarial considerada potencialmente danosa.

Similarmente à conjuntura norte-americana, essas normatizações originaram-se da propagação midiática de conflituosidades sociais internas, advindas, no caso nipônico, do descobrimento do nexo causal entre as atividades poluidoras e patologias terríficas, como a doença ambiental de Minamata ${ }^{34}$, a doença itai-itai ${ }^{35}$ e a Yokkaichi Asthma3.

Entretanto, contrariamente à realidade da Federação norte-americana, a atividade legiferante japonesa teve um feitio de criminalização primária ${ }^{37}$, segundo nomenclatura de Zaffaroni et al ${ }^{38}$, desprovida, em grande parte, de mandados executivos para aparelhamento das agências policiais, como percebido na Lei Federal de Persecução da Poluição da nação norte-americana de 1990. Assim, a tipificação de condutas de assédio ambiental libertas de instrumentos hábeis à sua executividade endossam o porte fantasma da regulação penal ambiental, a qual foi parcamente concretizada quando em cotejo com a ordenação dos Estados Unidos da América.

Interessante a menção de que o Poder Legislativo japonês determina-se o maior poder do Estado ${ }^{39}$, em dissonância com os sistemas norte-americano e brasileiro, os quais horizontalizam a autoridade de cada alçada estatal. Além do mais, o Gabinete, órgão supremo do Poder Executivo, tem em sua composição membros pertencentes à Dieta Nacional, ou seja, há uma preponderância clara da atividade protocolar na sociedade nipônica, herança de uma biografia social de sujeição e formalidade.

Segundo Ferrajolit ${ }^{40}$ o Direito Penal ocuparia uma munus central no sistema político e normativo das nações, já que autoriza ao Estado a disposição sobre direitos alheios em seu mais elevado grau de agressão. In casu, segundo o art. $9^{\circ}$ do Código Penal Japonês, Lei no 45 de 1907, prescreve-se:

Descarte de Resíduos Sólidos e de Limpeza Urbana; e Lei de Controle da Poluição dos Solos. KONDRAT, Robert G. Punishing and preventing pollution in Japan: is American style criminal enforcement the solution? Pacific Rim Law \& Policy Journal Association, v. 9, n. 2, p. 379-414, 2000. Available at: <https://digital.lib.washington.edu/dspace-law/bitstream/handle/1773.1/812/9PacRimL PolyJ379.pdf?sequence=1>. Access: 4 June 2015.

34 Nas províncias de Kagoshima, Kumamoto e Niigata, resíduos de mercúrio orgânico vinham sendo lançados há décadas na Baía de Minamata pela Corporação Chisso (fornecedora de Cristal Líquido), ocasionando a contaminação de pessoas e animais e o desenvolvimento de uma síndrome neurológica, denominada Doença de Minamata.

35 Na província de Toyama, na bacia do rio Jinzu-gawa, a contaminação das águas proveniente do despejo de cádmio por mineradoras, iniciado por volta de 1912, contaminou em massa a população local, a qual desenvolveu a doença ambiental de itai-itai.

36 Na década de 1960, a poluição do ar por óxido sulfúrico na cidade de Yokkaichi, na província de Mie, ocasionou sérios transtornos respiratórios, fruto da atividade de petroquímicas locais.

37 ZAFFARONI, E. Raul et al. Direito penal brasileiro: teoria geral do direito penal. 2. ed. Rio de Janeiro: Revan, 2003. v. 1.

38 ZAFFARONI, E. Raul et al. Direito penal brasileiro: teoria geral do direito penal. 2. ed. Rio de Janeiro: Revan, 2003. v. 1.

39 A respeito, ver art. 41 da Constituição Japonesa. JAPÃO. Constitution (1946). Constitution of Japan. Available at: <http://japan. kantei.go.jp/constitution_and_government_of_japan/constitution_e.html>. Access: 4 June 2015.

40 FERRAJOLI, Luigi. Direito e razão: teoria do garantismo penal. 4. ed. rev. São Paulo: Revista dos Tribunais, 2014. 
As punições principais são categorizadas como pena de morte, encarceramento com trabalho forçado, encarceramento sem trabalho forçado, multa, prisão por crimes de menor potencial ofensivo sem trabalho forçado e multa de pequeno valor, com o confisco como pena suplementar ${ }^{41}$.

Isso posto, vê-se que um ente ficcional de natureza pública detém o ius vitae ac necis, direito de vida ou morte sobre os seus dependentes. A dependência cidadã consiste-se, na modernidade, em objeto de estudo da criminologia moderna.

Advirta-se para uma desarmonia entre o garantismo penal ou direito penal mínimo preconizado por Ferrajoli ${ }^{42}$ e as atuais tendências político-criminais das nações. $O$ sistema garantista imprime a ideia de um arcabouço de proteções materiais e processuais amplo e rígido, bem como a quantidade e qualidade dos tipos penais e das penas nesses descritas secundariamente. A codificação japonesa em tela, datada do início do século passado, dita punições culminantes aos perpetradores de comportamentos delituosos. Todavia, o movimento de resposta penal aos problemas ambientais, mediante a tipificação de condutas ecologicamente abusivas, não acompanha a austeridade nipônica delitual ordinária, dado que evidencia uma orientação legislativa criminal muito mais amena por parte da Dieta Nacional com o passar do tempo, consentânea à marcha penal global rumo à infirmação de penas capitais e permanentes. Além disso, segundo Foote ${ }^{43}$, a operacionalização do Direito Penal japonês, através do procedimento penal positivado, caracteriza-se bastante suave, já que concede ampla discricionariedade ao promotor de Justiça na avaliação quanto à oportunização do jus persequendi. O art. 248 do Código de Processo Penal japonês dispõe: "Quando a persecução penal for desnecessária segundo o caráter, idade, história de vida, gravidade do fato, circunstâncias ou situação pós-delitual do autor, não há obrigatoriedade nessa". ${ }^{44}$

Dessarte, como no Direito norte-americano, não há a regência geral do Princípio da Obrigatoriedade como no sistema brasileiro. O mandamento da oportunidade, instituto processual japonês, mitiga a severidade de seu direito material, concedendo supremacia ministerial na consideração dos custos-benefícios da persecução penal, bem como na avaliação da eficácia da admoestação operada entre quatro paredes pela promotoria nipônica em face do indiciado. Não há, no Japão, o instituto da transação penal norte-americano ou plea bargain, mas apenas a ampla faculdade dos promotores quanto à inação, à prerrogativa de não denunciar, lançando a possibilidade de agir nas obscuras e profundas gavetas cerradas do parquet.

Essa arquitetura penal denota uma rigidez material positivada de natureza punitiva que vai de encontro ao sistema SG de Ferrajoli ${ }^{45}$ e também uma fleuma processual bastante benéfica ao suspeito da infração e tóxica à sociedade e à vítima, aparente contradição que apenas reforça os atributos de um direito penal inseguro, incerto, lançado à sorte nas entranhas de um direito penal máximo.

Na seara ambiental, no entanto, não há essa severidade de direito material como no sistema comum, nem quanto ao encarceramento, nem quanto à pena pecuniária. $\mathrm{O}$ art. 30 da Lei de Controle da Poluição das Águas (Lei no 138/1970) ${ }^{46}$ determina pena privativa de liberdade não superior a um ano e pena de multa não

41 Act n $^{\circ} 45 / 1907 /$ 刑の種類) (Categories of Punishments) 第九条 死刑、懲役、禁錮、罰金、拘留及び科料を主刑 とし、没収を付加刑とする。Article 9: “The principal punishments are categorized as the death penalty, imprisonment with work, imprisonment without work, fine, misdemeanor imprisonment without work and petty fine, with confiscation as a supplementary punishment" JAPAN. Act n. 97, 1968. Air Pollution Control Act. Available at: <http://www.japaneselawtranslation.go.jp/ law/detail/?id=2146\&re=02>. Access: 04 June 2015. Free translation.

42 FERRAJOLI, Luigi. Direito e razão: teoria do garantismo penal. 4. ed. rev. São Paulo: Revista dos Tribunais, 2014.

43 FOOTE, Daniel H. The benevolent paternalism of Japanese criminal justice. California Law Review, v. 80, n. 2, p. 317-390, 1992. Available at: $<$ http://scholarship.law.berkeley.edu/cgi/viewcontent.cgi?article $=1784 \&$ context $=$ californialawreview $>$. Access: 4 June 2015.

44 Act no 131/1948 - Article 248: "Where prosecution is deemed unnecessary owing to the character, age, environment, gravity of the offense, circumstances or situation after the offense, prosecution need not be instituted". JAPAN. Act n. 131, 1948. The Code of Criminal Procedure. Available at: <http://www.oecd.org/site/adboecdanti-corruptioninitiative/46814489.pdf>. Access: 4 June 2015.

45 FERRAJOLI, Luigi. Direito e razão: teoria do garantismo penal. 4. ed. rev. São Paulo: Revista dos Tribunais, 2014.

46 Act no 138/1970: Any person who violates the orders issued under the provisions of Article 8, Article 8-2, Article13 Paragraph

1 or Paragraph 3, Article13-2 Paragraph 1, or Article14-3 Paragraph 1 or Paragraph 2 shall be liable to penal servitude not exceeding 
superior a 1,000,000 ienes - valor que representa aproximadamente $R \$ 25.000,00$ - como penas máximas na legislação ecológica.

Na mesma direção, a Lei de Controle da Poluição, Lei no 97, de 1968, comina, em seu art. 3347, o mesmo limite supracitado em referência à Lei de Controle da Poluição das Águas, tanto no que concerne à multa quanto à pena privativa de liberdade.

Portanto, na tutela de bens difusos, a nação japonesa tem seguido um viés mais favorável ao delinquente, tanto nas disposições positivadas de direito substantivo quanto na operacionalização do sistema penal pelas regras complacentes de direito adjetivo.

Os estudos criminológicos atuais, entrementes, identificam uma tendência comportamental dos países em apregoar uma intervenção penal da segurança cidadã ${ }^{48}$. Referida ingerência conta com a comunidade para minimizar a delinquência, mediante sua colaboração direta com a força policial. A cooperação veemente da sociedade atinge graus bastante satisfatórios, uma vez que há uma propagação do sentimento de temor em relação ao crime e à condição de vítima. Além desses atributos, essa referência penal alicerça-se na elaboração do problema social da criminalidade como produto da responsabilidade subjetiva estatal. Chama-se a atenção para o componente culposo do instituto, o qual, via omissões - mau funcionamento do serviço público, funcionamento intempestivo ou omissão integral em funcionar -, logra êxito quanto ao desfecho marginal e delinquente daqueles que do Estado dependem.

Essa construção, para muitos, fomenta grande retrocesso na compreensão do fenômeno da criminalidade, bem como na tonificação do sistema garantista, já que investe o Estado na compulsão de debelar transgressões a qualquer custo. Exige-se do ente uma atuação repressiva apaziguadora, visto que este não agiu preventivamente, momentum mais vantajoso e propício para o empreendimento de ações afirmativas visando ao estrangulamento da delinquência.

Contudo, este trabalho não assimila o retrato de Direito Penal Ambiental japonês com traços involutivos. Depreende-se que o Direito Penal abraçou o potencial ou efetivo dano ambiental com a aflitividade que lhe é peculiar, pois se faz penoso urbanizar a comunidade e deixar evidente a eminência de certos bens, que não são particularmente de ninguém e pertencem, generalizadamente, a todos. A educação familiar, muito fincada na verticalização e nos binômios erro-castigo e acerto-prêmio, ilustra que o modus rudimentar e eficiente de educação opera-se pelo constrangimento da liberdade e de direitos. O Direito Penal como ultima ratio entra em cena justamente por ser a prima ratio de elaboração do comportamento civilizado.

A estruturação jurídica das nações reflete, sem grandes pormenores, os métodos de educação formal e não formal, classicamente empreendidos em plexos diminutos de comunhão social, sendo a composição familiar por laços de parentesco, afinidade ou sentimental o mais arraigado nas coletividades.

Em sede judicial, apresenta-se a ação penal condenatória (A) 285 de $2007^{49}$, proferida pela Alta Corte de Sapporo, capital da província de Hokkaido, a qual foi apreciada em última instância recursal pela Corte Suprema do Japão, baseada em Tóquio. A ação versa sobre a culpabilidade dos diretores de uma sociedade anônima do ramo de frete e depósito portuário, os quais, mediante contrato, incumbiram um terceiro do descarte de resíduos tóxicos e perigosos depositados em suas instalações na cidade de Chiba, a $40 \mathrm{~km}$ da capital do país. A lide travou-se na discussão principal a respeito da inclusão dos diretores, juntamente com o

one year or to a fine not exceeding 1,000,000 yen. JAPAN. Act n. 138, 1970. Water Pollution Control Law. Available at: <https:// www.env.go.jp/en/laws/water/wlaw/ch6.html>. Access: 04 June 2015.

47 Act n ${ }^{\circ}$ 97/1968 - Article 33: "Any person who has violated an order issued under Article 9, Article 9-2, Article 14, paragraphs (1) or (3), Article 17-7, Article 17-10, Article 18-8, or Article 18-11 shall be punished by imprisonment with work for up to one year or a fine of up to one million yen." JAPAN. Act n. 97, 1968. Air Pollution Control Act. Available at: <http://www.japaneselawtranslation.go.jp/law/detail/?id=2146\&re=02>. Access: 04 June 2015.

48 GOMES, Luiz Flávio; GARCÍA-PABLOS DE MOLINA, Antonio. Criminologia. Trad. Luiz Flávio Gomes; Yellbin Morote; García Davi Tangerino. 8. ed. São Paulo: Revista dos Tribunais, 2012. p. 462-466.

49 A respeito, JAPAN. Courts in Japan. Home. Available at: <http://www.courts.go.jp>. Access: 1 Feb. 2016. 
subcontratado, como autores do crime de Descarte Ilegal de Lixo Tóxico, previsto no art.16 c/c art. 25, item 8 da Lei de Descarte de Produtos Tóxicos e Perigosos ${ }^{50}$ e na comprovação do dolo eventual ou da negligência comportamental empreendida por aqueles ao desonerarem-se do dever de descarte dessas substâncias. A Suprema Corte nipônica, em acórdão unânime, decidiu pela coautoria culposa dos representantes da S.A, os quais tinham o dever de fiscalização e certificação do devido destino desse material. A pena imposta ao crime em questão é a privativa de liberdade não excedente a cinco anos e multa de até 10,000,000 ienes - aproximadamente U\$80,000. Noticia-se, ainda, que no ano de 2007, segundo estatísticas da Agência de Polícia Nacional, 2.051 pessoas foram presas pelo crime de Descarte Ilegal de Lixo Tóxico de natureza industrial ${ }^{51}$.

Vê-se que o contexto nipônico de persecução penal em relação às infrações ambientais é bem mais ameno se comparado à realidade americana, entretanto, a imputação criminal não deixa de existir e de funcionar, mesmo que segundo a discricionariedade e oportunidade aferidas pelo parquet japonês. A convivência da imputação penal, mesmo em um contexto de baixa aplicação, com as sanções civis e administrativas, manifesta a contribuição da criminalização de ilícitos ambientais para o êxito de outras searas jurídicas, ainda mais em sociedade protocolares e hierarquizadas como o Japão. O parco manejo da responsabilidade penal compensa-se pela presença operante do sistema criminal associado à ampla respeitabilidade da comunidade nipônica quanto aos mandamentos legislativos.

De todo o exposto, depreende-se que a mácula penalizadora foi o mais próspero expediente encontrado por corpos sociais desiguais para responder à crise ambiental. O Direito Penal, multisortido nas nações do globo quanto a seus preceitos primários, institutos e orientação de regência entre os patamares mínimo e máximo, detém uma expressão uníssona mundial, ou seja, o influxo impactante do preceito secundário penalizador na mais cara expressão da ontologia: a liberdade, dado que revigora os demais sistemas de protetividade ecológica.

\section{Conclusão}

A história discrepante entre as nações norte-americana e nipônica, aquela sedimentada com a colonização europeia a partir do século XVI, e esta de memória longínqua, com o desenvolvimento dos povos que ali habitavam e manufaturavam a argila, denuncia tramas coletivas sui generis, além de marcas individuais singulares entre seus povos. Esses elementos oferecem sustentação à ideação política e jurídica de ambos os países, bem como ao vigor do liame social entre seus cidadãos e à postura destes perante as adversidades.

Dentre essas adversidades, a de maior tomo seria a criminalidade, fenômeno que as comunidades tentam estrangular na utopia de harmonização do corpo comum. O fracionamento do arcabouço jurídico em áreas de atuação desborda-se fundamental não só para fins acadêmicos, mas para o empreendimento de testes de investida diante de crises comunitárias. O ensaio da eficácia de institutos jurídicos pertencentes a campos de incidência heterogêneos são primaciais para estimar a empatia e a resistência das sociedades quanto à capacidade destes na resposta às agruras difusas.

Na seara ambiental, a ofensiva penal traz um desfecho mais próspero e anuente à insubmissão às prescrições jurídicas, conjuntura de alvoroço nas correntes que relacionam o desenvolvimento social ao direito penal mínimo, assim como nos estudos da criminologia moderna, os quais alevantam a imperatividade de uma proposta integradora para responder ao delito, como a reparação do dano e a conciliação entre os impactados pelo delito.

50 JAPAN. Waste Law n. 137, 1970. Disposal and Public Cleaning Act. Available at: <https://www.env.go.jp/en/laws/recycle/01. pdf>. Access: 5 Aug. 2015.

51 A respeito, JAPAN. National Police Academy. Police Policy Research Center. Crimes in Japan in 2007, 2008. Available at: < https://www.npa.go.jp/english/seisaku5/20081008.pdf>. Access: 1 Feb. 2016. 
Não obstante, acredita-se que a interferência do Direito Penal na proteção de bens jurídicos difusos, como o é o meio ambiente, remonta à incultura coletiva a respeito da preservação e tutela de coisas fundamentais a cada um e também ao outro, dentro de um contexto grupal que une não só comunidades e nações, mas a sociedade mundial.

Dessa incompreensão, surge a premência do influxo penal, o que não traduz retrocesso ou involução social, mas, sim, modus educandi basilar para a estruturação do entendimento dos povos a respeito dos bens que unificam em si o particular e a alteridade.

O preparo das populações do globo a respeito da significância de bens de titularidade propalada advirá do caminhar sem saltos pelos estágios de capacitação humana, exercendo a mídia papel medular na comoção coletiva de conscientização e internalização da crucialidade da agenda ambiental na vida de cada um, de todos e dos a nascer, seja hoje ou no futuro, aqui, ali ou acolá.

As nações norte-americana e japonesa depreenderam pela indispensabilidade penal quando se trata de regular a Biota, desjungindo-se apenas na expressão funcional do sistema penal. A consagração de institutos de maleabilidade na persecução penal, bem como o aparelhamento e especialização das agências policiais, associados ao entusiasmo da imprensa e às características de acatamento cidadão das conflituosidades internas, determinam as dissonâncias sistêmicas que desunem os resultados da terapêutica penal, o que, no entanto, não infirma a expressividade do Direito Penal para o coroamento da defesa administrativa e civil do ecossistema. Mais do que isso, a prestabilidade da custódia criminal apenas revigora e estimula a habilidade e rendimento de institutos jurídicos extrapenais que lidam com atos ilícitos, responsabilidade, perigo e dano.

$\mathrm{Na}$ realidade brasileira, na qual a reverência protocolar é quebradiça, o modelo americano de tutela ambiental ostenta-se mais propício ao sucesso, mediante a especialização da Polícia Judiciária, do Ministério Público e do Poder Judiciário não só em razão da matéria, mas por concursos públicos, academias de polícia especializadas, cursos oficiais de formação e aperfeiçoamento de magistrados e promotores de justiça, bem como a capacitação de profissionais de saúde e peritos para a boa instrução dos procedimentos administrativos e processuais. A especialização da persecução penal ambiental seria o primeiro passo para o alargamento da efetividade do sistema ambiental nacional, não só pela aplicação de sanções penais, mas para a construção de uma ideação coletiva de que as esferas administrativas e cíveis merecem um eficaz acatamento como escape da imputação criminal.

\section{REFERÊNCIAS BIBLIOGRÁFICAS}

ASSOCIATION OF STATE AND TERRITORIAL SOLID WASTE MANAGEMENT OFFICIALS. [Home]. Available at: <http://www.astswmo.org>. Access: 10 July 2015.

BRASIL. Constituição (1989). Constituição da República Federativa do Brasil. In: ANGHER, Anne Joyce (Org.). Vade mecum acadêmico de direito Rideel. 20. ed. São Paulo: Rideel, 2015.

CARVALHO, Joaquim Francisco de. As origens do pensamento matemático e a crise dos fundamentos. Periódico Eletrônico Norte Ciência, Academia Paraense de Ciência, v. 1, n. 2, p. 59-60, 2010. Disponível em: <http:// aparaciencias.org/vol-1.2/06_Joaquim\%20p.\%2059-65.pdf>. Acesso em: 1 jun. 2015.

FERRAJOLI, Luigi. Direito e razão: teoria do garantismo penal. 4. ed. rev. São Paulo: Revista dos Tribunais, 2014.

FOOTE, Daniel H. The benevolent paternalism of Japanese criminal justice. California Law Review, v. 80, n. 2, p. 317-390, 1992. Available at: <http://scholarship.law.berkeley.edu/cgi/viewcontent.cgi?article=1784\&c ontext $=$ californialawreview $>$. Access: 4 June 2015. 
GOMES, Luiz Flávio; GARCÍA-PABLOS DE MOLINA, Antonio. Criminologia. Trad. Luiz Flávio Gomes; Yellbin Morote; García Davi Tangerino. 8. ed. São Paulo: Revista dos Tribunais, 2012.

GUSTIN, Miracy Barbosa de Sousa; DIAS, Maria Tereza Fonseca. (Re)pensando a pesquisa jurídica: teoria e prática. Belo Horizonte: Del Rey, 2010.

JAPAN. Act n. 131, 1948. The Code of Criminal Procedure. Available at: <http://www.oecd.org/site/ adboecdanti-corruptioninitiative/46814489.pdf>. Access: 4 June 2015.

JAPAN. Act n. 138, 1970. Water Pollution Control Law. Available at: <https://www.env.go.jp/en/laws/ water/wlaw/ch6.html>. Access: 04 June 2015.

JAPAN. Act n. 45, 1907. Penal code. Available at: <http://www.japaneselawtranslation.go.jp/law/ detail/?id=1960\&vm=04\&re=02>. Access: 4 June 2015.

JAPAN. Actn. 89, 1896. Civil code. Available at: <http://www.moj.go.jp/content/000056024.pdf>. Access: 4 June 2015.

JAPAN. Actn. 97, 1968. Air Pollution Control Act. Available at: < http://www.japaneselawtranslation.go.jp/ law $/$ detail $/$ ?id=2146\&re=02>. Access: 04 June 2015.

JAPAN. Courts in Japan. Home. Available at: <http://www.courts.go.jp>. Access: 1 Feb. 2016.

JAPAN. National Police Academy. Police Policy Research Center. Crimes in Japan in 2007, 2008. Available at: <https://www.npa.go.jp/english/seisaku5/20081008.pdf>. Access: 1 Feb. 2016.

JAPAN. Waste Law n. 137, 1970. Disposal and Public Cleaning Act. Available at: <https://www.env.go.jp/ en/laws/recycle/01.pdf>. Access: 5 Aug. 2015.

JAPÃO. Constitution (1946). Constitution of Japan. Available at: <http://japan.kantei.go.jp/constitution_ and_government_of_japan/constitution_e.html>. Access: 4 June 2015.

KONDRAT, Robert G. Punishing and preventing pollution in Japan: is American style criminal enforcement the solution? Pacific Rim Law \& Policy Journal Association, v. 9, n. 2, p. 379-414, 2000. Available at: $<$ https:// digital.lib.washington.edu/dspace-law/bitstream/handle/1773.1/812/9PacRimLPolyJ379. pdf? sequence $=1>$. Access: 4 June 2015.

NEVES, Marcelo. A constitucionalização simbólica. São Paulo: WMF Martins Fontes, 2007. (Coleção Justiça e Direito).

UNITED STATES. Clean Air Act. Available at: < http://uscode.house.gov/view.xhtml?req=granuleid:USCprelim-title42-section7401\&num=0\&edition=prelim>. Access: 4 June 2015.

UNITEDSTATES. CleanWater Act. Availableat: <http://uscode.house.gov/view.xhtml?req=granuleid:USCprelim-title33-section1251\&num=0\&edition=prelim>. Access: 4 June 2015.

UNITED STATES. Department of Justice. Environmental and Natural Resources Division. [Home]. Available at: <http://www.justice.gov/enrd>. Access: 1 Feb. 2016.

UNITED STATES. Department of Justice. Southern District of Indiana. New Jersey man sentenced in Indiana to 20 years for biodiesel fraud scheme. 8 Jan. 2016. Available at: <https://www.justice.gov/usao-sdin/pr/newjersey-man-sentenced-indiana-20-years-biodiesel-fraud-scheme>. Access: 1 fev. 2016.

UNITED STATES. Environmental Protection Agency. [Enforcement annual results: fiscal year 2014]. Available at: <http://www2.epa.gov/enforcement/enforcement-annual-results-fiscal-year-fy-2014>. Access: 1 Feb. 2016.

UNITED STATES. Environmental Protection Agency. Criminal enforcement. Available at: < http://www2. epa.gov/enforcement/criminal-enforcement>. Access: 1 Feb. 2016. 
UNITED STATES. Environmental Protection Agency. Criminal Enforcement Program, Oct. 2011. Available at: <http://www.epa.gov/sites/production/files/documents/oceft-overview-2011.pdf>. Access: 1 fev. 2016.

UNITED STATES. Federal Rules of Criminal Procedure. Available at: < https://www.law.cornell.edu/rules/ frcrmp>. Access: 2 June 2015.

UNITED STATES. Mississippi Department of Environmental Quality. Home. Available at: < https://www. deq.state.ms.us>. Access: 01 July. 2015.

UNITED STATES. Pollution Prosecution Act, 1990. Available at: <https://www.govtrack.us/congress/ bills/101/s2176>. Access: 05 June 2015.

UNITED STATES. Refuse Act of 1899. Available at: <http://uscode.house.gov/view. xhtml?req=granuleid:USC-prelim-title33-section407\&num=0\&edition=prelim>. Access: 04 June 2015.

UNITED STATES. Rivers and Harbors Appropriation Act. Available at: <http://uscode.house.gov/view. xhtml?req=granuleid:USC-prelim-title33-section407\&num=0\&edition=prelim>. Access: 04 June 2015.

ZAFFARONI, E. Raul et al. Direito penal brasileiro: teoria geral do direito penal. 2. ed. Rio de Janeiro: Revan, 2003. v. 1.

ZAFFARONI, E.; PIERANGELI, José Henrique. Manual de direito penal brasileiro: parte geral. 10. ed. São Paulo: Revista dos Tribunais, 2013. 


\title{
Construção social do projeto polos de produção de biodiesel no contexto do PNPB: uma análise perceptiva*
}

\author{
Social construction of biodiesel production \\ project in the context of poles PNPB: an \\ analysis perceptual
}

\author{
Érika Cristine Silva** \\ Maria das Dores Saraiva de Loreto*** \\ Haudrey Germiniani Calvelli;*** \\ Ronaldo Perez ${ }^{* * * *}$
}

* Recebido em 23/02/2016

Aprovado em 09/05/2016

** Possui graduação em Economia Doméstica e atualmente é estudante do Programa de Pós-graduação em Economia Doméstica pela Universidade Federal de Viçosa. E-mail: erika. silva@ufv.br

*** Possui graduação em Economia Doméstica e em Ciências Econômicas, bem como Mestrado e Doutorado em Economia Rural, pela Universidade Federal de Viçosa, além de Pós-doutorado em Família e Meio Ambiente pela University of Guelph-Canadá. Professora Titular do Departamento de Economia Doméstica (DED), vinculado a Universidade Federal de Viçosa. E-mail: mdora@ufv.br

**** Possui graduação em Ciências Sociais, especialista em Gestão de Políticas Públicas em Gênero e Raça, mestre e doutora em Ciências Humanas pela Universidade Federal de Juiz de Fora. Pós-doutorado pelo Programa Nacional de Pós-doutores. E-mail: haudreyg@hotmail. com

***** Possui graduação em Engenharia Química, Mestrado em Engenharia Química pela Faculdade de Engenharia Química e Doutorado em Engenharia de Alimentos pela Universidade Estadual de Campinas. É professor adjunto III do Departamento de Tecnologia de Alimentos, vinculado a Universidade Federal de Viçosa. E-mail: rperez7789@gmail.com

\section{Resumo}

A pesquisa em questão buscou analisar as percepções dos representantes e idealizadores da Política Nacional de Produção e Uso de Biodiesel (PNPB), tendo como foco o processo de construção social do Projeto Polos de Biodiesel. Especificamente, objetivou-se examinar o processo de gestão social e praticas de governança desse projeto, considerando-se os espaços decisórios e relacionais. Metodologicamente, fez uso da pesquisa bibliográfica e entrevista semiestruturada, com posterior análise de conteúdo. Os resultados indicaram descompassos nas relações entre os arranjos produtivos locais e as Usinas de Biodiesel. O biodiesel brasileiro é produzido, basicamente, a partir da soja, em face à realidade dos agricultores, com baixo grau instrução, capacitação, capitalização e fragilidade institucional. Constatou-se uma coerência entre a percepção das lideranças socioinstitucionais e os dados da pesquisa bibliográfica; identificando que, apesar dos avanços do PNPB, as metas de inclusão social não foram alcançadas. Questiona-se sobre a continuidade do Projeto Polos de Biodiesel, seja por haver alcançado seus objetivos ou por limitação de recursos humanos e financeiros. Conclui-se que a construção social do projeto foi permeada por uma lógica produtiva, com limitada valorização do conhecimento e experiências dos agricultores familiares, seus recursos naturais, dimensão tecnológica, organizacional, sociopolítica e cultural.

Palavras-chave: Projeto Polos de Biodiesel. Construção social. Percepção socioinstitucional.

\section{Abstract}

The research in question sought to examine the perceptions of representatives and creators of the National Production and Use of Biodiesel Policy (PNPB), focusing on the social construction process of the Centers for Biodiesel Project. Specifically, the objective was to examine the process of 
social management and governance practices of this project, considering the decision and relational spaces. Methodically made use of literature and semi-structured interview, with subsequent analysis of content. The results indicated drift in relations between the local production arrangements and Biodiesel plants. The Brazilian biodiesel is produced mainly from soybeans, given the reality of farmers, low educational level, training, capitalization and institutional fragility. It was found consistency between the perception of socio-institutional leaders and the data from the literature; identifying that, despite the advances of PNPB, social inclusion goals were not met. wonders about the continuity of the Centers for Biodiesel Project, is for having achieved your goals or limited human and financial resources. It was concluded that the social construction of the project was permeated by a productive logic, with limited appreciation of the knowledge and experiences of farmers, their natural resources, technological, organizational, socio-political and cultural.

Keywords: Polos Biodiesel Project. Social construction. Perception institutional partner.

\section{INTRODUÇÃo}

As políticas públicas são importantes elementos de influência na definição de diferentes trajetórias econômicas, ambientais, tecnológicas e sociais. Nesse sentido, a discussão sobre a temática das políticas públicas vem ganhando espaço em diversos espaços e fóruns. Uma política que vem sendo muito discutida nos últimos tempos diz respeito às políticas públicas brasileiras para a Agricultura Familiar, instituídas a partir da década de 1990. Essas políticas se pautam na reprodução do processo histórico de desenvolvimento econômico do Brasil; ou seja, preconizam as formas de acesso à renda e oportunidades de crescimento pelo viés da reprodução do capital, uma vez que não são modificadas as suas estruturas de exploração ${ }^{1}$.

Vários programas que visam à inserção dos agricultores familiares no mercado já foram implementadas. Nesse contexto, insere-se o Programa Nacional de Produção e Uso de Biodiesel (PNPB), que é uma política pública que busca a integração e o fortalecimento da agricultura familiar brasileira, tornando-a parte do processo produtivo do biodiesel².

O biodiesel ${ }^{3}$ é considerado uma das alternativas da matriz energética brasileira mais promissora no combate da pobreza e promoção da inclusão social, por poder estar vinculada à agricultura familiar e, em particular, aos assentamentos rurais, com grande potencial de geração de empregos, melhoria da renda agrícola e redução do êxodo rural.

Outra justificativa, apresentada para o crescente interesse pela produção agroenergética ou de biodiesel, no Brasil e no $\mathrm{Mundo}^{4}$, está associado com a eminente escassez do petróleo e o grande impacto ambiental da queima de combustíveis fósseis (efeito estufa, chuva ácida). Essas preocupações levaram ao Estado brasileiro a rever o Plano Nacional de Agroenergia, em busca de uma matriz energética menos poluente e por fontes alternativas de energia, capazes de contemplar tanto a eficiência econômica quanto a responsabilidade com o meio ambiente e inclusão social. Assim, foi criado, em 2004, o Programa Nacional de Produção e Uso de Biodiesel (PNPB), que tem como princípios norteadores a segurança e soberania alimentar; sustentabilidade

1 RIBEIRO, Dinalva Donizete; DIAS, Mariza Souza. Políticas públicas para a agricultura familiar: o PAA e o PNPB. Mercator, Fortaleza, v. 12, n. 27, p. 81-91, 2013.

2 ABRAMOVAY, Ricardo; MAGALHÃES, Reginaldo. O acesso dos agricultores familiares aos mercados de biodiesel- parcerias entre grandes empresas e movimentos sociais. Textos para Discussão FIPE, São Paulo, n. 6, 2007.

3 Um combustível obtido a partir de matérias-primas vegetais, tal como soja, mamona, canola, palma, girassol, dendê, amendoim e gergelim, ou animais, tais como, sebo bovino, suíno e de aves, além de óleos utilizados em frituras, por intermédio de diferentes processos, como o craqueamento, a esterificação ou a transesterificação. GONÇALVES, M. F.; EVANGELISTA, F. R. Os descompassos do Programa Nacional de Produção e Uso de Biodiesel (PNPB) no Nordeste. In: CONGRESSO DA SOCIEDADE BRASILEIRA DE ECONOMIA, ADMINISTRAÇÃO E SOCIOLOGIA RURAL. 46., 2008, Rio Branco. Anais... Rio Branco, 2008.

4 SACHS, I. A revolução energética no Sec. XXI. Estudos Avançados, v. 21, n. 59, 2007. 
dos sistemas de produção e geração de renda e agregação de valores. Conforme Muller ${ }^{5}$, a elaboração de tais políticas públicas contribuíram para a legitimação da política rural e o reconhecimento social da importância da agricultura familiar pela sociedade brasileira.

Para alcançar o processo de inclusão social, o PNPB adotou duas importantes estratégias, que foi a Criação do selo Combustível social e implantação do Projeto Polos de Produção de Biodiesel. O Selo Combustível é um benefício de isenção fiscal concedido pelo Ministério do Desenvolvimento Agrário aos produtores de biodiesel que promovam a inclusão social e o desenvolvimento regional, por meio de geração de emprego e renda para os agricultores familiares enquadrados nos critérios do PRONAF. Por outro lado, o Projeto Polos visa promover ações relacionadas à produção de oleaginosas, além de estimular a redução nos custos da cadeia produtiva e promover políticas públicas que favoreçam aos agricultores familiares ${ }^{6}$.

Além dessas medidas, o PNPB buscou alcançar seus objetivos, combinando instrumentos regulatórios, distributivos e redistributivos, que criam um regime de incentivos e restrições ao crescimento da indústria de biodiesel, na intenção de alinhar a expansão industrial com objetivos sociais, ambientais e estratégicos do programa. Entretanto, o referido autor destaca que pressões de setores interessados na política, falhas de implementação do programa e resultados imprevistos interferiram, de certa forma, no Programa, impedindo que este alçasse suas metas, principalmente em relação ao processo de inclusão social ${ }^{7}$.

O processo de inclusão social do PNPB tem apresentado controvérsias, pelas próprias dificuldades de incluir a agricultura familiar de regiões mais vulneráveis socialmente na produção do biodiesel ${ }^{8.9}$. Nesse contexto foi estruturado o presente trabalho, que buscou responder aos seguintes questionamentos: como tem sido estruturado o processo de gestão social do Projeto Polos de Biodiesel no contexto do PNPB? Quais são suas práticas de governança, em termos de espaços decisórios, interesses, relações de poder, conflitos e consenso?

Pressupõe-se que as respostas ao questionamento em questão, que contextualizam a temática a ser pesquisada, podem contribuir para tecer algumas considerações avaliativas sobre o PNPB e sobre o Projeto Polos de Biodiesel, que é o foco do estudo em questão, uma vez que considera as percepções do público envolvido.

Desa forma, o presente artigo tem como objetivo analisar as percepções dos representantes e idealizadores do PNPB, tendo como foco o processo de construção social do Projeto Polos de Biodiesel, em termos da gestão social e práticas de governança.

\section{Metodologia}

Trata-se de uma pesquisa de natureza qualitativa, do tipo descritivo-exploratória, que teve como unidade empírica de análise o Projeto Polos de Produção e Uso de Biodiesel, com estratégia de desenvolvimento do PNPB.

5 MULLER, A. L. A construção de políticas públicas para a agricultura família do Brasil: o caso do programa de aquisição de alimentos. 2007. 139 f. Dissertação (Mestrado em Desenvolvimento Rural)-Universidade Federal do Rio Grande do Sul, Porto Alegre, 2007.

6 COSTA, Erivânia Dárcia da. Programa Nacional de Produção e Uso do Biodiesel: uma análise e reflexão dos resultados. 2014.53 f. Trabalho de Conclusão de Curso (Monografia)- Departamento de Economia, Universidade Federal do Rio Grande do Norte, Natal, 2014. 7 TIBURCIO, Breno Aragão. Atores Sociais, Agricultura Familiar e Desenvolvimento Territorial: uma análise do Programa Nacional de Produção e Uso de Biodiesel. 2011. Tese (Doutorado em Ciências Sociais)-Universidade Federal Rural do Rio de Janeiro, Rio de Janeiro, 2011.

8 PENIDO, Marina de Oliveira. O Programa Nacional de Produção e Uso de Biodiesel: alternativa ou "mais do mesmo"? Do domínio do agribusiness à inserção da agricultura familiar na cadeia produtiva do biodiesel no Norte de Minas. 2011. 334 f. Dissertação (Mestrado em Geografia)- Universidade Federal Fluminense, Rio de Janeiro, 2011.

9 LORETO, M. D. S.; CALVELli, H. G.; LIMA, M. P. Cenário do Programa Nacional de Produção e Uso de Biodiesel: uma visão sócia institucional. In: SEMINÁRIO NACIONAL DE SOCIOLOGIA \& POLÍTICA. 4., 2012, Curitiba. Anais... Curitiba: UFPR, 2012. 
Para o desenvolvimento dessa pesquisa, foi feito um levantamento para identificar os principais representantes e idealizadores do Projeto Polos de Produção e Uso de Biodiesel, constatando-se que se encontravam na cidade de Brasília - DF e de São Paulo - SP, especificamente.

Em seguida, foi aplicada entrevista uma semiestruturada por meio de um roteiro preestabelecido, juntamente a cinco representantes do MDA, que estiveram e estão até o momento a frente do processo de construção e implementação do PNPB. Além disso, foi feita entrevista com um representante da Confederação Nacional dos Trabalhadores na Agricultura (CONTAG) e com dois consultores da PLURAL ${ }^{10}$. Por meio dessas entrevistas, buscamos identificar e examinar a configuração e estrutura de governança do Projeto Polos de Produção e Uso de Biodiesel.

Após a leitura dos documentos e transcrição das entrevistas, procedeu-se a análise de conteúdo. "A análise de conteúdo é uma técnica de pesquisa que trabalha com o sentido da palavra, permitindo produzir inferências do conteúdo da comunicação de um texto replicáveis ao seu contexto social”"11.

\section{Resultados e discussões}

\subsection{Criação e Construção do Programa Nacional de Produção e Uso de Biodiesel e do Projeto Polos de Biodiesel}

O PNPB foi criado em 2004 e regulamentado em 2005, mediante Lei 11097, tem como diretrizes a implantação de um programa sustentável e de promoção da inclusão social, garantia de preços competitivos, qualidade e suprimento; produção da bioenergia, a partir de diferentes fontes oleaginosas e em regiões diversas ${ }^{12.13}$.

Para garantir e cumprir com seus objetivos, o PNPB precisou criar estratégias que se traduzissem na combinação de diversos instrumentos para inserir os agricultores familiares na cadeia do biodiesel, dentre os quais destacam-se a concessão do Selo Combustível Social a empresas produtoras de biodiesel, a partir da compra dos grãos de oleaginosas da agricultura familiar e das metas produtivas estabelecidas para as empresas vencedoras dos leilões da ANP; além da implementação pelo MDA do "Projeto Polos de Produção de Biodiesel" ${ }^{14}$.

O "Selo Combustível Social", concedido pelo Ministério do Desenvolvimento Agrário (MDA), tem como objetivo estimular parcerias entre as empresas e a agricultura familiar, o que envolve, além da garantia de compra da matéria-prima a preços previamente acordados, a prestação de serviços de assistência técnica e o apoio à organização desse segmento de agricultores ${ }^{15}$.

10 A Plural é uma sociedade cooperativa de consultoria, pesquisa e assessoria, fundada em 1998. Seus trabalhos são orientados por uma visão de desenvolvimento e de sociedade com o propósito de valorizar os princípios da sustentabilidade e da solidariedade, os processos participativos, e o fortalecimento da sociedade civil e de suas organizações. PLURAL. Nossos trabalhos. 2016. Disponível em: <http://www.pluralcooperativa.com.br/trabalhos.html>. Acesso em: 20 jan. 2016.

11 CAREgNATO, Rita Catalina Aquino; MUTTI, Regina. Pesquisa qualitativa: análise de discurso versus análise de conteúdo. Texto Contexto Enfermagem, v. 15, n. 4, p. 679-684, 2006.

12 VASCONCELOS, M. Programa Nacional de Produção e uso de Biodiesel (PNPB). Disponível em: <http://www.editoraferreira.com. br/publique/media/au_19_marcio.pdf>. Acesso em: 22 jan. 2016.

13 BUENO, O. C.; ESPERANCINI, M. S.; TAKITANE, I. C. Produção de biodiesel no Brasil: aspectos socioeconômicos e ambientais. Revista Ceres, v. 56, n. 4, p. 507-512, 2009.

14 FAVARETO, A; MAGALHÃES R; SCHRODER M. Dilemas da inovação institucional e governança nos arranjos produtivos de biodiesel. In: CONGRESSO BRASILEIRO DE ECONOMIA, ADMINISTRAÇÃO E SOCIOLOGIA RURAL. 46., 2008, Rio Branco. Anais... Rio Branco: SOBER, 2008.

15 BRASIL. Ministério do Desenvolvimento Agrário. Biodiesel conta com 100 mil agricultores familiares. 2007. Disponível em: <http:// www.mda.gov.br/sitemda/noticias/biodiesel-conta-com-100-mil-agricultores-familiares\#sthash.n0IYtGnb.dpuf $>$. Acesso em: 18 
Por outro lado, para a promoção do Programa Nacional de Produção e Uso do Biodiesel, foi implantado o Projeto Polos de Biodiesel, que colaborou para o desenvolvimento local dos municípios produtores de oleaginosas, por meio da inclusão dos agricultores familiares ${ }^{16}$.

Os Polos de Biodiesel foram criados a partir de 2006, por meio do MDA, com a participação de 30 polos em todo país, em 313 municípios. Em 2012, o Projeto Polos de Biodiesel já contava com 63 polos, em que participavam 1.091 municípios, como relatado por um dos entrevistados. [...] o primeiro projeto polos se eu não me engano foi em 2006, um ano depois da criação do programa [...] em 2012 a gente chegou a ter 63 polos de biodiesel no país, isso significava 63 grupos de trabalho (Respondente, 02).

As ações realizadas pelos polos de Biodiesel tornam-se importantes na medida em que proporcionam o avanço das áreas de produção de oleaginosas, com capacidade de reduzir os custos logísticos da cadeia produtiva e promover a inclusão da agricultura familiar, por meio das políticas públicas que favoreçam o acesso à assistência e às novas tecnologias, com reflexos na melhoria da renda dos agricultores.

Para ser criado os Polos, foram levadas em consideração diversas variáveis, entre elas a presença dos agricultores que detivessem aptidão, identidade e presença nas áreas de plantio da oleaginosa adequada ao território, conforme zoneamento agrícola do Ministério da Agricultura; além de atores sociais, políticos e econômicos interessados no desenvolvimento dessa cadeia ${ }^{17}$.

O Projeto Polos de Biodiese ${ }^{18}$ foi fomentado pela Plural Consultoria, Pesquisas e Serviços (PLUTAL) na região Sul, Sudeste e Norte e, pela Obra Kolping do Brasil ${ }^{19}$, na região Nordeste, sendo essas duas instituições responsáveis diretos pela estratégia de implantação do Selo Combustível Social no país. Essa implantação se deu por meio da constituição de fóruns de gestão compartilhada da integração dos arranjos produtivos, estruturados nas áreas de atuação das usinas de biodiesel integradas com a agricultura familiar e no entorno do Selo.

O projeto polos de biodiesel surgiu a partir da criação do Programa Nacional de Produção e Uso de biodiesel, que foi criado em 2004 e 2005, ai a primeira experiência do projeto polos ela foi mais ou menos, em 2005/2006 a partir de uma experiência com uma entidade chamada Obra Kolping do Brasil, que atuava, sobretudo no nordeste, no Ceara na Bahia eles tinham uma atuação mais regionalizada ali né? e a plural cooperativa era voltada ali mais para o sudeste com esta ideia dos Polos né (Respondente, $01)$.

A gente começou em 2006, a plural entrou neste processo por que a gente percebeu essa dinâmica do selo combustível social que está inserido aí no PNPB que foi justamente 2005/2006, e faltava uma organização que juntasse a base produtiva com as empresas, que fizesse uma ponte né? Que ajudasse a forma estes arranjos produtivos, e mais do que isso porque tinha uma carência muito grande de informações para os agricultores que eram digamos assim os beneficiários desse programa (Respondente, 06).

A equipe técnica de articulação do Projeto Polos no Brasil, composta pela Plural Consultoria e Pesquisa e pela Obra Kolping, atuava em conjunto com outros atores com o propósito de dar suporte para a criação dos Polos e de seus Núcleos de Produção (NPs) de matérias-primas para o biodiesel.

Assim o Ministério do Desenvolvimento Agrário (MDA), em parceria com a Plural Consultoria e Pesqui-

jan. 2016.

16 BRASIL. Ministério do Desenvolvimento Agrário. Programa nacional de produção e uso de biodiesel: inclusão social e desenvolvimento territorial. 2011. Disponível em: < http://www.mda.gov.br/sitemda/sites/sitemda/files/user_arquivos_64/Biodiesel_Book_final_Low_Completo.pdf $>$. Acesso em: 14 jan. 2016.

17 BRASIL. Ministério do Desenvolvimento Agrário. Anexo VII. 1. Projeto Polos de Biodiesel. 2009. Disponível em <http://portal. mda.gov.br/register/?return_url=\%2fprincipal\%2f\#>. Acesso em: 21 jan. 2016.

18 LUNARDI, José Clóvis Teles. O Campesinato Tradicional e a Indústria de Biodiesel: Integração Subordinada no Sul do Brasil 2003 - 2008. 2011. 169 f. Tese (Doutorado em Educação)- Programa de Pós Graduação em Educação, Universidade Federal do Paraná, Curitiba, 2011.

19 OBRA KOLPING. Obra Kolping do Brasil: apresentação. 2016. Disponível em: < http://kolping.org.br/site/institucional/apresentacao>. Acesso em: 17 jan. 2016. 
sa, foram os responsáveis pela formação de Grupos de Trabalho Gestores (GTGs), na Região Sudeste que se responsabilizavam pela coordenação da produção de matéria-prima e das negociações entre agricultores familiares e as empresas processadoras de biodiesel, dentro dos parâmetros do Selo Combustível Social previsto no PNPB.

Nós tínhamos um mecanismo estabelecido formalmente que ele funcionou muito bem no início, porque tinha uma supervisão geral, como que era o formato né? a gente tinha os articuladores nos polos a nível local, tinha uma figura que se chamava supervisor técnico que ele atuava ali em âmbito mais regional, então tinha o supervisor técnico da região sul, da região centro-oeste, tinha o supervisor técnico que acompanhava mais o semiárido, e a região Sudeste e também tinha uma supervisão geral [...] então cada um desses falava diretamente com MDA com a Coordenação Geral de biocombustíveis, não tinha essa hierarquia entre nós assim, o coordenador de biocombustível acessava cada um, se quisesse obter informações diretas obtinha sem problema nenhum, mas tinha uma organicidade, tinha uma organização própria do projeto polos e da própria Plural para pode entender e poder acompanhar melhor a execução dessa coisa tão grande em campo, e aí tinha esse processo de sistematização de informações que se traduziam em relatórios mensais que era passado para o MDA (Respondente, 06).

A organização proposta para os Polos de Produção do biodiesel se fez com participação de parcerias e ou convênios com sindicatos, prefeituras, empresas, bancos, ONG's, EMATERs, entre outros atores, que tinham interesse em desenvolver a região. A governança dos polos era articulada pelos Grupos de Trabalhos (GTs), que tinham como objetivo identificar os problemas, organizar a base produtiva, executar ações para solucionar os problemas, além de buscar desenvolver os arranjos produtivos locais ${ }^{20}$. No entanto, conforme relatado por um dos entrevistados o Grupos de Trabalho Gestores precisava ter uma articulação maior com os atores sociais envolvidos para alcançar os objetivos propostos:

os atores era gente ligada ao sindicato dos trabalhadores rurais, sempre chamava gente ligado a prefeitura, Governo do Estado a Bioempresa e as associações ali [...] eu acho que nesse ponto o polos não conseguia evoluir muito entendeu, porque as prefeituras os sindicatos eles iam lá muito mais no sentido de ver o que teria para ganhar do que qual seria a possibilidade de como eles poderiam estar ajudando ali também né, e isso gerava uma certa frustração também, porque ficava sempre a cargo da empresa e do Governo Federal de ter alguma ação, mais proativa para isso, isso era meio complicado, isso sempre foi bem falado porque qual a ideia do polos, justamente você criar uma gama de atores ali que a partir do momento que o articulador saísse dali continuasse tendo a organicidade de se reunir e tudo mais (Respondente, 01).

Nesse sentido, como crítica ao desenvolvimento do Projeto, está o fato de que a estrutura da governança ou o governo das ações coletivas devem ser aprimorado, por meio da multiplicidade de atores ou de agentes dos grupos de trabalhos, envolvendo um conjunto maior de parceiros ou fornecedores dos serviços essenciais. Além disso, deveria ser consolidada a capacidade de planejamento dos Grupos de Trabalho, de forma a assegurar: a) a elaboração e o monitoramento da execução de um plano estratégico no âmbito dos GTs; b) o delineamento do horizonte da sustentabilidade a partir de padrões discutidos internacionalmente; c) o estímulo e apoio à a formação de cooperativas e associações de produtores, a formação de sistemas locais de inovação tecnológica e institucional, aperfeiçoamento dos mecanismos de regulação e incentivo, tais como, zoneamentos socioambiental e agroclimático, além da adoção de novos mecanismos que fortalecessem o ambiente institucional mais amplo do mercado de biodiese ${ }^{21}$.

Um dos entrevistados ao ser indagado sobre a estrutura de governança dos Polos, em relação aos principais interesses e às relações de poder, considerou que:

20 BRASIL. Ministério do Desenvolvimento Agrário. Programa nacional de produção e uso de biodiesel: inclusão social e desenvolvimento territorial. 2011. Disponível em: < http://www.mda.gov.br/sitemda/sites/sitemda/files/user_arquivos_64/Biodiesel_Book_final_Low_Completo.pdf $>$. Acesso em: 14 jan. 2016.

21 TIBURCIO, Breno Aragão. Atores Sociais, Agricultura Familiar e Desenvolvimento Territorial: uma análise do Programa Nacional de Produção e Uso de Biodiesel. 2011. Tese (Doutorado em Ciências Sociais)-Universidade Federal Rural do Rio de Janeiro, Rio de Janeiro, 2011. 
os principais interesses dos polos era representado pela figura do articulador [...] mas com um protagonismo muito presente daquelas pessoas que estavam diretamente envolvidos no programa como: as cooperativas, os dirigentes de cooperativas, dirigente de Sindicato, dirigente de Federação e tal (Respondente, 06).

Outro entrevistado, no entanto, acreditava que o programa deveria ter tido uma preocupação maior em apoiar e organizar a base produtiva dos agricultores:

[...] porque o que aconteceu, foi se trabalhado muito nas cooperativas já existentes e não se buscou a criação de novas estruturas para você poder efetivamente está trabalhando, no sul, por exemplo, eu diria que mais de 90\% da matéria-prima ela é comercializada via as cooperativas da Agricultura Familiar porque são cooperativas que já existiu, não foram criados a partir dos polos, então como o sul está muito mais organizado com relação às cooperativas foi menos difícil de fazer, do que numa região sudeste e região Nordeste que foram, digamos meio que aproveitada as estruturas existentes e não se trabalhou na lógica de trabalhar outro, então eu acho que um pouco falhou nesse processo (Respondente, 04).

No que diz respeito à criação e formação dos polos ${ }^{22}$, destacou-se a necessidade da realização de um diagnóstico das cadeias produtivas do biodiesel, que levasse em consideração diferentes aspectos, tais como: presença de agricultores, presença de áreas consideradas próprias ao cultivas agrícola, potencialidades técnicas e efeitos secundários, como o aproveitamento dos seus subprodutos e atores sociais, políticos e econômicos interessados no desenvolvimento dessa cadeia. Em função desse diagnóstico, a produção deveria ser modelada, considerando as características dos agricultores e da regionalização, como sazonalidade e escala periódica, para definição de qual tecnologia seria aplicável, qual o tamanho das unidades produtoras e, principalmente, os aspectos relacionados à qualidade do biodiesel. Esses fatores foram, também, relatados por um dos entrevistados, como especificado:

[...] a criação do Projeto polos então se delimitava um pouco por este conjunto de fatores, tem oleaginosa, tem agricultor, ali tem um capital social interessante, tem usina perto com interesse de comprar, tem movimento social, então se criou o projeto polos e ai o projeto polos ele foi se moldando (Respondente, 01).

Outro ponto de destaque, no que se refere ao processo decisório, é que, após o diagnóstico da cadeia produtiva de cada região, os planos de ação deveriam ser definidos, envolvendo políticas de crédito, assistência técnica, capacitação e inovação tecnológica, para que as metas de produção fossem alcançadas. Além disso, as organizações reunidas nos Grupos de Trabalho deveriam monitorar a execução dos contratos e verificar eventuais descumprimentos por parte das empresas ou dos produtores ${ }^{23}$. Segundo um dos entrevistados, por muitas vezes, acontecia o descobrimento do contrato por parte dos agricultores.

A Petrobras biocombustível se queixa muito de que fecharam o contrato com os agricultores, e esse é uma das maiores vantagens do PNPB que você tem uma garantia de compra, no entanto, muita das vezes os agricultores não honram, porque passou um outro que ele chamam de intermediário e ofereceu um valor maior, então acontece as vezes um problema que é comum acontecer em mercado, mas ai merece ali um trabalho focado e o que foi que aconteceu, que aí onde entrava um pouco o pessoal do projeto polos atuando em cada situação que acontecia dessa natureza e tal( Respondente, 06).

Por outro lado, outro entrevistado acredita que esse descumprimento ocorre, às vezes, pela demora da própria empresa em fazer o recolhimento das oleaginosas, além do fato de que alguns "atravessadores" ou "intermediários" ofereciam mais pela produção do que a Petrobras Biocombustivel.

O agricultor que negociar com quem que negociar com ele, então se a Petrobras que negociar com ele, passa primeiro e tem uma proposta boa beleza, mais se passa um atravessador que é vizinho dele e tem uma proposta melhor, para ele tanto faz tanto fez, e ela começou a aprender isso, começou a aprender também que trabalhar com agricultura e muito difícil né?, e bem diferente que você chegar e abrir um poço de água profunda, que a partir do momento que você atingiu aquilo ali, vai te dar uma certa

22 ABRAMOVAY, Ricardo; MAGALHÃES, Reginaldo. O acesso dos agricultores familiares aos mercados de biodiesel- parcerias entre grandes empresas e movimentos sociais. Textos para Discussão FIPE, São Paulo, n. 6, 2007.

23 ABRAMOVAY, Ricardo; MAGALHÃES, Reginaldo. O acesso dos agricultores familiares aos mercados de biodiesel- parcerias entre grandes empresas e movimentos sociais. Textos para Discussão FIPE, São Paulo, n. 6, 2007. 
periodicidade de produção, mais na agricultura não tem isso, tem uma série de variáveis né?, e a principal dela e o ser humano, e muita gente diferente (Respondente, 01).

Pelo envolvimento de uma gama de atores envolvidos nesse programa, procurou-se indagar os entrevistados sobre os principais problemas e conflitos enfrentados por este. Os principais problemas citados foram a seca e a distância logística entre os polos.

Os principais problemas, eu acho que a dificuldade de se reunir, longa distância, [...] as vezes você tinha uma reunião em Janaúba do polo de serra geral e ai tinha gente que era de Espinosa, a gente tentava mais não tinha recurso para isso entendeu, no projeto a gente ate tinha uns dias de campo tinha recurso para chamar o pessoal mais pra reunião do polo mesmo as vezes era difícil [...] mais se fizéssemos em Espinosa o povo de Janaúba não ia, e se fizéssemos em Janaúba o povo de Espinosa não ia, a gente tentava um meio termo né Mato Verde, Porterinha, mais sempre fica ruim pra alguém, então era uma dificuldade, o problema que tinha era isso (Respondente, 01).

O Programa ate 2010 vinha numa ascensão, e desde 2010 quando surgiu a seca [...] surgiu não né, porque a seca é uma coisa recorrente, mais veio mais um período de seca e este ciclo parece que não termina nunca né? [...] todo nordeste, semiárido pegando Minas, está enfrentando o quinto ano de seca e está com uma situação complicadíssima de fornecimento de água, por que vem agravando a cada ano, isso trouxe um reflexo, porque os alimentos subiram muito de preço, então muitos deixaram de fornecer matéria-prima porque a produtividade não foi suficiente para cumprir os contratos com a Pbio" (Respondente, 06).

Em relação aos conflitos existentes, foi possível detectar, na fala dos entrevistados, que há uma divergência explícita entre os movimentos sociais e sindicais do campo representativo da agricultura familiar, que não são unânimes quanto à viabilidade da alternativa biodiesel para o desenvolvimento da agricultura familiar.

Uma coisa que sempre pegou muito foi conflito de movimento, a história dos movimentos sociais no Brasil envolvendo movimentos sindicais, ela é permeada por disputas, disputas onde um surge a partir do outro né? vão surgindo, geralmente são questões incidentes, às vezes o discurso fica muito carregado no sentido de meu movimento faz isso, porque o outro movimento não faz, se o outro movimento fala eu já não participo, então a gente tem muito isso [...] disputa entre eles, questões ligadas ao SINTRAF, ao sindicato de trabalhadores rurais, a associação de comunidade tal que não dialoga com a associação de comunidade tal (Respondente, 01).

Outro grande conflito destacado está entre a capacidade de inserção social da mamona e sua competitividade ante a soja. $\mathrm{O}$ fato de a soja apresentar mercado consolidado e maduro compromete as chances da mamona no âmbito da cadeia produtiva do biodiesel ${ }^{24}$.

Primeiro nós tínhamos na oportunidade uma única empresa chamada Brasil Ecodiesel [...] que entrou no programa com uma visão de que a mamona seria o prato do dia, o prato do biodiesel era a mamona, esqueceu-se de uma série de problemas de que a mamona teria com relação a forma de produção, ou seja, em um programa que exige um volume extraordinário de matéria prima, é produzir mamona colhendo ela a mão com uma produtividade de 300, 400 quilos por hectare o projeto teria que ter o Brasil inteiro, vamos dizer assim produzindo para dar conta de um trem desse. Mesmo assim o que é que a Brasil ecodiesel fez, bem, a Brasil ecodiesel tentou digamos assim fazer um plano nacional e nós fomos juntos, a CONTAG esteve junto nessas ações de ilusionismo né? [...], no entanto tivemos frustrações de todas as ordens, não só Nordeste como praticamente o Brasil inteiro se mostrou que não tinha, primeiro não tinha tradição, não tinha habilidade, não tinha os insumos corretos, não tinha pesquisa [...] então a alternativa foi a soja (Respondente, 04).

Portanto, a dependência da soja e as dificuldades em promover a inclusão social dos agricultores familiares são, atualmente, os principais desafios e conflitos da política de bioenergia ${ }^{25}$. Para resolver esses impasses,

24 VAZ, P. H. P. de M. et al. Análise da competitividade da mamona e da soja para a produção de biodiesel no nordeste do Brasil. Revista de Economia Agrícola, São Paulo, v. 57, n. 1, p. 35-48, jan./jun. 2010.

25 LORETO, Maria das Dôres Saraiva de; CALVELLI, Haudrey Germiniani; SILVA, Érika Cristine. Biocombustíveis no Brasil: uma política de inclusão social? In: JORNADAS INTERSDISCIPLINARIAS DE ESTUDIOS AGRARIOS Y AGROINDUSTRIALES. 8., 2013, Buenos Aires. Anais... Buenos Aires: Facultad de Ciencias Económicas de la Universidad de Buenos Aires, 2013. 
em se tratando do monopólio da soja na produção do biocombustível, o governo deveria investir em alternativas por meio do incentivo de pesquisas, que possam atenuar os gargalos tecnológicos do PNPB, como foi ressaltado pela totalidade dos entrevistados.

\subsection{Processo de Inclusão Social dos Agricultores Familiares na Cadeia de Biodiesel}

Dentre os conflitos vivenciados pelo PNPB, em seu processo de gestão social, está a limitada inclusão social da agricultura familiar na cadeia da produção agroenergética. A agricultura familiar ocupa hoje um papel de destaque no cenário brasileiro, tanto no que diz respeito à geração de postos de trabalho quanto à produção de alimentos para o consumo interno do país. Uma das metas do Programa Nacional de Produção e Uso de Biodiesel era inclusão social da agricultura familiar, por meio da geração de emprego e renda, visando estimular a permanência do agricultor no campo, e, portanto, contribuir para a redução do êxodo rural. Dessa forma, o PNPB buscava garantir essa inclusão por meio da compra de matéria prima da agricultura familiar, principalmente, daqueles que têm suas propriedades em áreas geográficas menos atraentes para outras atividades econômicas. Nesse cenário, esse modelo agrícola poderia vir a ser mais próspero e sustentável deixando de ser somente uma agricultura de autossobrevivência, para ser autossustentável economicamente, ambientalmente e socialmente ${ }^{26}$.

Entretanto, apesar de os esforços para ampliar a inserção da agricultura familiar, os resultados do PNPB, do ponto de vista distributivo e da justiça social estão longe de atingir as metas esperadas inicialmente ${ }^{27}$. Segundo dados do MDA, divulgados pela BiodieselBR ${ }^{28}$, apesar de toda a expectativa criada em torno do potencial do biodiesel para a geração de renda entre os agricultores familiares das regiões mais pobres do país, os resultados obtidos têm ficado aquém do esperado. Além dos interesses em privilegiar a oferta do biodiesel, dentro da lógica produtivista, as metas de inclusão social foram revistas para baixo e a iniciativa mais nobre do PNPB, que pretendia incluir 200 mil famílias nos primeiros anos, só alcançou a metade da meta esperada.

Ao ser indagado sobre o processo de Inclusão da agricultura familiar nas regiões produtoras de oleaginosa, um dos entrevistados coloca que se nos atentarmos aos números que o Programa pretendia atingir quando este foi criado, essa realidade ainda se encontra distante:

Se você pegar os números que se tinha em mente em 2005 e 2006, a resposta vai ser não, na verdade o programa ele caminhou para outro lugar [...] ele foi tomando outra cara durante os 10 anos dele né? ele foi tomando outro rumo completamente diferente do que foi pensado naquele momento mais eu acho que ele de certa forma também deu certo, ele chegou no patamar ai de 100 mil famílias, só que a gente precisa melhorar muito sobretudo no semiárido Brasileiro no Nordeste, e ai eu acho que é outra abordagem, não é a mesma abordagem que a gente faz no Centro-oeste no Sul do Brasil né, que ai é uma abordagem muito mais fiscalizatória, uma abordagem mais de manter as coisas nos trilhos e tudo mais, eu acho que ali é fomento, e um trabalho junto com as empresas que querem estar lá, que não e fácil estar lá né? (Respondente, 01).

Outro aspecto de destaque da inclusão social da agricultura familiar refere-se à matéria-prima, o Programa abrange diversas oleaginosas para produção de biodiesel, como mamona, canola, gergilim, girassol e soja. No entanto, em sua criação, a solução para o alcance da inclusão social estaria no desenvolvimento das regiões mais marginalizadas da agricultura familiar, como o Nordeste e Semiárido, por meio da integração dos agricultores familiares na cadeia do biodiesel, com a produção da mamona.

26 PEREIRA, Gemeriane. O Programa Nacional de Uso e Produção de Biodiesel PNPB: análise de uma relação com o agronegócio. SIMPÓSIO MINEIRO DE GEOGRAFIA - DAS DIVERSIDADES À ARTICULAÇÃO GEOGRÁFICA. 1., 2014, Alfenas. Anais... Alfenas: Universidade Federal de Alfenas, 2014. p. 754 - 768.

27 SILVA, Érika Cristine; LORETO, Maria das Dôres Saraiva de; CALVELLI, Haudrey Germiniani. A Dinâmica dos Polos de Produção de Biodiesel no Contexto do PNPB. In: CONGRESSO INTERNACIONAL INTERDISCIPLINAR EM SOCIAIS E HUMANIDADES. 2014, Salvador. Anais... Salvador: UCSal, 2014.

28 BIODIESELBR. Sem a Petrobras programa social do biodiesel é um fracasso. 2011. Disponível em: <http://www.biodieselbr.com> Acesso em: 20 jan. 2016. 
Porém, de acordo com BiodieselBr ${ }^{29}$, o óleo de soja no mix de matérias-primas da indústria brasileira continua sendo a matéria-prima mais utilizada na produção do biodiesel brasileiro (76,4\%). A mamona, por exemplo, juntamente a culturas como óleo de palma, amendoim, nabo forrageiro e girassol corresponderam com apenas $2 \%$ da produção do biodiesel ${ }^{30}$.

Esse mix de matérias primas na produção agroenergética é citado por um dos entrevistados, que ressalta a importância da soja:

As principais matérias-primas que foram de alguma maneira trabalhada em escala na agricultura familiar, nós temos aí a soja que domina desde o começou do programa e onde realmente ela se firmou, tem uma boa participação de metade a dois terços do volume, hoje ela é mais de $90 \%$ [...] mas ainda tinha Girassol, Canola alguns núcleos com Amendoim, Gergelim, Mamona basicamente Nordeste, o Dendê no Norte, e aí fora isso ensaios, experiências, aventuras com o Pinhão Manso, a Macaúba nem tanto mais e outra ótica, Nabo Forrageiro [...] tem uns outros nomes ai que apareciam no cenário (Respondente, 03).

Conforme BiodieselBR ${ }^{31}$, culturas, como a da mamona, apesar de estimulada para a produção de biodiesel por parte do governo, não é atraente para a produção de biodiesel devido à alta viscosidade apresentada no óleo produzido, o que ultrapassa especificações de alguns motores e, assim, torna mais alto o custo de produção para atendimento dessas especificações.

Um dos motivos, citados pelo entrevistado, em relação à baixa produtividade da mamona, está associado à desorganização, falta de financiamento e irregularidade das relações na cadeia, criada pela demanda de óleo para a ricinoquímica e a consequente falta de investimentos em pesquisa e em assistência técnica, apresentando assim baixo nível tecnológico, conforme relato a seguir apresentado:

Além do MDA, você só tinha na época um presidente da república saindo no Brasil e no mundo inteiro dizendo que nos íamos fazer biodiesel de mamona, outros órgãos do governo nós nunca conseguimos envolver eles concretamente dentro do programa [...] durante, pelo menos, seis anos de 2006 a 2012, o Pronaf não financiou mamona para ninguém para o biodiesel [...] então você não teve financiamento quando se fala aqui de mamona, você não teve nenhum tipo de aporte do próprio governo federal, eu não quero dizer aporte pra empresa, mas aporte, por exemplo, para as organizações nossas das cooperativas, nós tínhamos a ideia inclusive de formar um fundo, é onde desse fundo a gente faria todo o processo de organização da agricultura familiar para dentro do programa que poderíamos num sonho chegarmos, por exemplo, até o esmagamento [...] só que nos não tivemos nenhuma chance de financiamento, nenhuma chance governamental de termos algo que impulsionasse o programa para agricultura familiar (Respondente, 04).

Outro pesquisador entrevistado, no entanto, destaca que as cadeias-produtivas de algumas matérias-primas, como o caso da mamona, não se encontram ainda devidamente organizadas, ainda se tem muitas dificuldades:

"o agricultor hoje se ele quiser plantar soja, com todas as críticas que se tem a soja mais eu não estou entrando neste mérito, mais se ele quiser plantar soja ele deita na rede e descansa, lógico que eu estou exagerando, mais não é aquilo igual quando você fala eu vou plantar mamona, onde você tem mil dificuldades" (Respondente, 01).

Assim, vários fatores têm dificultado o alcance da inclusão social, como a lógica econômica da relação entre aumento da escala e redução de custos, que gera forte concentração da produção e, mesmo que mercado de biodiesel cresça, não é garantida uma maior participação da agricultura familiar. A soja, por apre-

29 BIODIESELBR. Soja teve participação de 76,4\% na produção de biodiesel em 2015, segundo dados da ANP. 2016. Disponível em: <http://www.biodieselbr.com/noticias/materia-prima/uso/soja-teve-participacao-76-4-producao-biodiesel-2015-dados-daanp-040216.htm>. Acesso em: 21 jan. 2016.

30 PENIDO, Marina de Oliveira. O Programa Nacional de Produção e Uso de Biodiesel: alternativa ou "mais do mesmo"? Do domínio do agribusiness à inserção da agricultura familiar na cadeia produtiva do biodiesel no Norte de Minas. 2011. 334 f. Dissertação (Mestrado em Geografia)- Universidade Federal Fluminense, Rio de Janeiro, 2011.

31 BIODIESELBR. A qualidade da matéria-prima para a produção de biodiesel. 2006. Disponível em: <http://www.biodieselbr.com/ noticias/colunistas/ramos/qualidade-materia-prima-producao-biodiesel-1.htm>. Acesso em: 09 jan. 2016. 
sentar menores custos de produção e maior volume de oferta, provavelmente continuará a ser a principal matéria-prima da produção do biodiesel. Esses são alguns dos fatores que impedem o PNPB de realizar o desenvolvimento regional e, consequentemente, a inclusão social ${ }^{32}$.

Nesse sentido, o PNPB, enquanto um Programa que visa inclusão social e desenvolvimento regional, não está atuando de forma significativa nas regiões do Brasil consideradas mais pobres. Ou seja, existem limitações para que o programa atue como instrumento regulatório utilizado pelo governo para promover a inclusão da agricultura familiar na cadeia de produção do combustível, por meio da adoção de medidas compensatórias que busquem conciliar o crescimento econômico e sustentabilidade social ${ }^{33}$.

Outros agravantes que levaram a não inclusão da agricultura familiar na cadeia produtiva, como era a meta inicial do PNPB, foram os ajustes realizados para garantir os empreendimentos empresariais, que acabaram privilegiando os grandes empresários da soja, sendo pequenas as melhorias na vida dos agricultores familiares, principalmente os agricultores nordestinos, por não estarem estruturados e não conseguirem produzir o necessário para competir no mercado.

Portanto, a dependência da soja e as dificuldades em promover a inclusão social dos agricultores familiares são, atualmente, os principais desafios do PNPB. Para resolver esses impasses, em se tratando do monopólio da soja na produção do biocombustível, o governo deveria investir em matérias primas alternativas, por meio do incentivo de pesquisas, que podem atenuar os gargalos tecnológicos do PNPB, como foi ressaltado pela totalidade dos entrevistados. Quanto ao problema da inclusão dos agricultores familiares nordestinos, o governo está se apoiando na capacidade operacional, logística e financeira da Petrobras Biocombustível.

\subsection{Processo de desarticulação do projeto Polos de Biodiesel}

Especificamente, no que concerne ao Projeto Polos de Biodiesel, existem controvérsias sobre seu processo de gestão e manutenção, havendo alguns entrevistados, que acreditam que sua desarticulação ou extinção deve-se ao fato de a política ter cumprido com seu objetivo.

Constatou-se, no processo de avaliação de uma política pública, que podem ocorrer diferentes alternativas:

a) continuação da política pública da forma que está nos casos em que as adversidades de implementação são pequenas; b) reestruturação marginal de aspectos práticos da política pública, nos casos em que as adversidades de implementação existem, mas não são suficientemente graves para comprometer a política pública; c) extinção da política pública, nos casos em que o problema público foi resolvido, ou quando os problemas de implementação são insuperáveis, ou quando a p política pública se torna inútil pelo natural esvaziamento do problema ${ }^{34}$.

Na visão dos entrevistados, o Projeto Polos deveria ser extinto, uma vez que cumpriu com seu papel inicial de promover o avanço das áreas de produção de oleaginosas, de forma a reduzir os custos da cadeia produtiva e alcançar a inclusão familiar, por meio do acesso à assistência e novas tecnologias, afirmando que:

Os polos eles não acabaram porque eles não funcionaram, eles acabaram por que eles cumpriram com o papel deles, não existia mais o propósito de gastar um recurso com convênio, e eu estou falando de 2006 a 2010 foram 4 anos de projeto polos (Respondente, 01).

Eu não acho que houve assim... acabou e não ficou nada, eu acho que ficou sim e muita coisa, e acabou por que exauriu esse modelinho que a gente tinha pensado lá atrás, a gente foi moldando etapas depois

32 BUENO, O. C.; ESPERANCINI, M. S.; TAKITANE, I. C. Produção de biodiesel no Brasil: aspectos socioeconômicos e ambientais. Revista Ceres, v. 56, n. 4, p. 507-512, 2009.

33 SILVA, A. C. I. M. Programa nacional de produção e uso de biodiesel e a inserção da agricultura familiar no polo agreste pesqueira de biodiesel em Pernambuco. 2012, 151 f. Dissertação (Mestrado em Administração e Desenvolvimento Rural)-Universidade Federal Rural de Pernambuco, Recife, 2012.

34 SECCHI, Leonardo. Políticas públicas: conceitos, esquemas de análise, casos práticos. São Paulo: Cengage Lerning, 2010. 
outra e exauriu, era hora de tomar uma outra forma uma outra conotação (Respondente, 06).

$\mathrm{Na}$ visão de outro entrevistado, o projeto polos poderia ter validade nos processos de fiscalização e de aferição; no entanto, era preciso que o MDA tivesse uma equipe técnica especializada para realizar o processo de fiscalização.

O projeto polos na minha concepção só continuava ter validade nos processos de fiscalização e de aferição, para isso o MDA não precisava necessariamente contratar empresas de grande magnitude, agora eu acho que é preciso ainda sim ter um corpo contratado pelo MDA para fazer os processos de fiscalização, aferição uma série de coisas que nós estamos muito dúbio [...] o MDA teria que ter esta equipe digamos mais robusta, quando se fala desse processo de fiscalização e aferição (Respondente, 04).

Entretanto, na visão de representantes dos agricultores, o motivo do Projeto não ter tido continuidade formal se deu pelo fato de o convênio com a empresa Plural ter acabado, em função da limitação de capital financeiro do Projeto: "em minha opinião, ele deu muito certo apesar das dificuldades, hoje assim a gente trabalhava com um cenário de escassez de recursos e de estratégias que se mudam né?".

Eu acho que o principal motivo foi pelo fato do convênio ter acabado, eu acho que [...] eles estão lá ainda, estão produzindo em muitos casos são os mesmos polos, mas não está formalizado, não tem mais essa figura da PLURAL por trás dando este caráter mais formal na criação do polo com os articuladores (Respondente, 05).

Nesse sentido, existe a concepção na perspectiva da Plural, de que o projeto polos deixou um legado, "o projeto ele terminou porque ele tinha que se adequar ao momento apesar das lacunas que acabou ficando". Ou seja, para a Plural, eles conseguiram, de certa forma, organizar a cadeia produtiva de oleaginosas do agricultor; no entanto, os agricultores tinham carências básicas de gestão e precisavam se qualificar para se manter nesse mercado.

Se não fosse feito algo pelo governo no sentido de apoiar e de qualificar estes empreendimentos, para eles se manterem no mercado algo terrível poderia acontecer, porque iria inviabilizar mais para frente, porque o descumprimento de um contrato no âmbito institucional tem uma série de implicações legais, então em vez de ajudar aquele grupo de agricultores a gente poderia estar prejudicando (Respondente, 06).

Foi a partir desses levantamentos que se deu início a uma discussão sobre o próximo passo do Projeto Polos, por meio da criação do Programa "Ater mais Gestão".

O projeto polos ele já estava com uma musculatura de base ali já formada e que precisava receber orientação, qualificação com relação a como gerir seus negócios, então o passo seguinte foi amadurecer o que poderia ser feito, e aí veio amadurecendo, de 2010 pra cá já vem amadurecendo e surgiu o Programa Ater Mais Gestão (Respondente, 01).

O programa “Ater Mais Gestão" foi criado em 2012/2013, com o intuito de promover o fortalecimento de cooperativas da agricultura familiar, por meio da qualificação de seus sistemas de gestão (organização, produção e comercialização), além de levar assistência técnica para cooperativas, com o objetivo de promover a inserção e qualificação dos empreendimentos coletivos da agricultura familiar para os mercados institucionais e privados ${ }^{35}$.

O Programa Ater Mais Gestão foi lançado em 2012, e vem com esta conotação, com ações que ajudam as cooperativas a qualificar a sua gestão e se manter fornecedores desse mercado, por um lado é bom para o governo porque ele tem os mercados institucionais que não é só o PNPB, tem o PNPB, tem o PNAE e o PAA, são esses os três principais mercados (Respondente, 06).

Dessa forma o Projeto Polos de Biodiesel, que tinha como objetivo a inclusão social e inserção do agricultor na cadeia de biodiesel, ganha outra conotação, por parte do PNPB, por meio do incentivo aos mercados institucionais.

35 BRASIL. Ministério do Desenvolvimento Agrário.. Vinte Anos do PRONAF, 1995-2015. Avanços e Desafios. 2015. Disponível em: <http://www.mda.gov.br/sitemda/sites/sitemda/files/ceazinepdf/PRONAF_20_ANOS_VALTER_BIANCHINI.pdf>. Acesso em: 20 jan./2016. 


\section{Considerações finais}

Apesar do discurso governamental de conjugar eficiência produtiva com inclusão social, por meio da inserção da agricultura familiar na cadeia produtiva do biodiesel, a Política de Agroenergia não atentou para as especificidades locais, em termos de recursos físicos, financeiros e socioculturais, pautando-se basicamente em uma lógica produtivista e econômica. Os impasses entre a agricultura familiar e o setor produtivo são constantes, pelo fato de os agricultores familiares possuírem limitada capitalização, capacitação e cultura organizacional, essenciais à atuação de forma competitiva no mercado do biodiesel. Ou seja, a pressão dos produtores de biodiesel e a correlação de forças econômicas e políticas envolvidas no PNPB, dentro e fora do governo, somadas às preocupações quanto à efetividade do programa, induziram a adoção de uma estratégia que priorizou a garantia da oferta do biocombustível.

O Programa Nacional de Produção de biodiesel tem tido significativos avanços em relação à capacidade operacional, mas as questões referentes ao processo de inclusão social têm sido limitadas, tornando-se necessária a implementação de políticas públicas e estratégias que levem em consideração a participação dos agricultores familiares na cadeia produtiva de biodiesel. Para tanto, considera-se necessário que o programa invista em pesquisas, a fim de aumentar a diversificação e regionalização dos arranjos produtivos bem como a institucionalização de mecanismos capazes de promover a cooperação e a formação de competências, ao nível individual e coletivo.

O Projeto Polos de Produção de Biodiesel enfrentou desafios diversos desafios, estando estes associados à construção e à consolidação do capital social e ao processo de governança, em especial pelas limitações logísticas de coordenação e de monitoramento das ações para o desenvolvimento dos polos, que levassem em consideração os aspectos culturais, econômicos, sociais e agronômicos diferenciados. Enfim é preciso que ocorra uma revalorização dos atores coletivos, em termos de possibilidades de inserção em processos decisórios e de governança, mediante processos participativos.

Existem controvérsias, sobre a sua extinção, em termos da resolução do problema público ou pelo próprio esvaziamento dos participantes, em função da limitação financeira do projeto.

\section{REFERÊNCIAS BIBLIOGRÁFICAS}

ABRAMOVAY, Ricardo; MAGALHÃES, Reginaldo. O acesso dos agricultores familiares aos mercados de biodiesel- parcerias entre grandes empresas e movimentos sociais. Textos para Discussão FIPE, São Paulo, n. 6, 2007.

BIODIESELBR. A qualidade da matéria-prima para a produção de biodiesel. 2006. Disponível em: < http://www. biodieselbr.com/noticias/colunistas/ramos/qualidade-materia-prima-producao-biodiesel-1.htm>. Acesso em: 09 jan. 2016.

BIODIESELBR. Sem a Petrobras programa social do biodiesel é um fracasso. 2011. Disponível em: <http:/ /www. biodieselbr.com> Acesso em: 20 jan. 2016.

BIODIESELBR. Soja teve participação de 76,4\% na produção de biodiesel em 2015, segundo dados da ANP. 2016. Disponível em: <http://www.biodieselbr.com/noticias/materia-prima/uso/soja-teve-participacao-76-4-producao-biodiesel-2015-dados-da-anp-040216.htm>. Acesso em: 21 jan. 2016.

BUENO, O. C.; ESPERANCINI, M. S.; TAKITANE, I. C. Produção de biodiesel no Brasil: aspectos socioeconômicos e ambientais. Revista Ceres, v. 56, n. 4, p. 507-512, 2009. 
CAREgNATO, Rita Catalina Aquino; MUTTI, Regina. Pesquisa qualitativa: análise de discurso versus análise de conteúdo. Texto Contexto Enfermagem, v. 15, n. 4, p. 679-684, 2006.

COSTA, Erivânia Dárcia da. Programa Nacional de Producão e Uso do Biodiesel: uma análise e reflexão dos resultados. 2014. 53 f. Trabalho de Conclusão de Curso (Monografia)-Departamento de Economia, Universidade Federal do Rio Grande do Norte, Natal, 2014.

FAVARETO, A; MAGALHÃES R; SCHRODER M. Dilemas da inovação institucional e governança nos arranjos produtivos de biodiesel. In: CONGRESSO BRASILEIRO DE ECONOMIA, ADMINISTRAÇÃO E SOCIOLOGIA RURAL. 46., 2008, Rio Branco. Anais... Rio Branco: SOBER, 2008.

GONÇALVES, M. F; EVANGELISTA, F. R. Os descompassos do Programa Nacional de Produção e Uso de Biodiesel (PNPB) no Nordeste. In: CONGRESSO DA SOCIEDADE BRASILEIRA DE ECONOMIA, ADMINISTRAÇÃO E SOCIOLOGIA RURAL. 46., 2008, Rio Branco. Anais... Rio Branco, 2008.

LORETO, M. D. S.; CALVELLI, H. G.; LIMA, M. P. Cenário do Programa Nacional de Produção e Uso de Biodiesel: Uma Visão Sócia Institucional. In: SEMINÁRIO NACIONAL DE SOCIOLOGIA \& POLÍTICA. 4., 2012, Curitiba. Anais... Curitiba: UFPR, 2012.

LORETO, Maria das Dôres Saraiva de; CALVELlI, Haudrey Germiniani; SILVA, Érika Cristine. Biocombustíveis no Brasil: uma política de inclusão social? In: JORNADAS INTERSDISCIPLINARIAS DE ESTUDIOS AGRARIOS Y AGROINDUSTRIALES. 8., 2013, Buenos Aires. Anais... Buenos Aires: Facultad de Ciencias Económicas de la Universidad de Buenos Aires, 2013.

LUNARDI, José Clóvis Teles. O Campesinato Tradicional e a Indústria de Biodiesel: Integração Subordinada no Sul do Brasil 2003 - 2008. 2011. 169 f. Tese (Doutorado em Educação)-Programa de Pós Graduação em Educação, Universidade Federal do Paraná, Curitiba, 2011.

BRASIL. Ministério do Desenvolvimento Agrário. Anexo VII. 1. Projeto Polos de Biodiesel. 2009. Disponível em <http://portal.mda.gov.br/register/?return_url=\%2fprincipal\%2f\#>. Acesso em: 21 jan. 2016.

BRASIL. Ministério do Desenvolvimento Agrário.. Biodiesel conta com 100 mil agricultores familiares. 2007. Disponível em: <http://www.mda.gov.br/sitemda/noticias/biodiesel-conta-com-100-mil-agricultoresfamiliares\#sthash.n0IYtGnb.dpuf>. Acesso em: 18 jan. 2016.

BRASIL. Ministério do Desenvolvimento Agrário.. Programa nacional de producão e uso de biodiesel: inclusão social e desenvolvimento territorial. 2011. Disponível em: <http://www.mda.gov.br/sitemda/sites/sitemda/ files/user_arquivos_64/Biodiesel_Book_final_Low_Completo.pdf>. Acesso em: 14 jan. 2016.

BRASIL. Ministério do Desenvolvimento Agrário.. Vinte Anos do PRONAF, 1995-2015. Avanços e Desafios. 2015. Disponível em: <http://www.mda.gov.br/sitemda/sites/sitemda/files/ceazinepdf/PRONAF_20_ ANOS_VALTER_BIANCHINI.pdf>. Acesso em: 20 jan./2016.

MULLER, A. L. A construção de políticas públicas para a agricultura família do Brasil: o caso do programa de aquisição de alimentos. 2007. 139 f. Dissertação (Mestrado em Desenvolvimento Rural)-Universidade Federal do Rio Grande do Sul, Porto Alegre, 2007.

OBRA KOLPING. Obra Kolping do Brasil: apresentação. 2016. Disponível em: < http://kolping.org.br/site/ institucional/apresentacao>. Acesso em: 17 jan. 2016.

PENIDO, Marina de Oliveira. O Programa Nacional de Produção e Uso de Biodiesel: alternativa ou "mais do mesmo"? Do domínio do agribusiness à inserção da agricultura familiar na cadeia produtiva do biodiesel no Norte de Minas. 2011. 334 f. Dissertação (Mestrado em Geografia)-Universidade Federal Fluminense, Rio de Janeiro, 2011. 
PEREIRA, Gemeriane. O Programa Nacional de Uso e Produção de Biodiesel PNPB: análise de uma relação com o agronegócio. SIMPÓSIO MINEIRO DE GEOGRAFIA - DAS DIVERSIDADES À ARTICULAÇÃO GEOGRÁFICA. 1., 2014, Alfenas. Anais... Alfenas: Universidade Federal de Alfenas, 2014.

PLURAL. Nossos trabalhos. 2016. Disponível em: <http://www.pluralcooperativa.com.br/trabalhos.html>. Acesso em: 20 jan. 2016.

RIBEIRO, Dinalva Donizete; DIAS, Mariza Souza. Políticas públicas para a agricultura familiar: o PAA e o PNPB. Mercator, Fortaleza, v. 12, n. 27, p. 81-91, 2013.

SACHS, I. A revolução energética no Sec. XXI. Estudos Avançados, v. 21, n. 59, 2007.

SECCHI, Leonardo. Políticas públicas: conceitos, esquemas de análise, casos práticos. São Paulo: Cengage Lerning, 2010.

SILVA, A. C. I. M. Programa nacional de produção e uso de biodiesel e a inserção da agricultura familiar no polo agreste pesqueira de biodiesel em Pernambuco. 2012, 151 f. Dissertação (Mestrado em Administração e Desenvolvimento Rural) Universidade Federal Rural de Pernambuco, Recife, 2012.

SILVA, Érika Cristine; LORETO, Maria das Dôres Saraiva de; CALVELLI, Haudrey Germiniani. A Dinâmica dos Polos de Produção de Biodiesel no Contexto do PNPB. In: CONGRESSO INTERNACIONAL INTERDISCIPLINAR EM SOCIAIS E HUMANIDADES. 2014, Salvador. Anais... Salvador: UCSal, 2014.

TIBURCIO, Breno Aragão. Atores Sociais, Agricultura Familiar e Desenvolvimento Territorial: uma análise do Programa Nacional de Produção e Uso de Biodiesel. 2011. Tese (Doutorado em Ciências Sociais)-Universidade Federal Rural do Rio de Janeiro, Rio de Janeiro, 2011.

VASCONCELOS, M. Programa Nacional de Produção e uso de Biodiesel (PNPB). Disponível em: < http://www. editoraferreira.com.br/publique/media/au_19_marcio.pdf>. Acesso em: 22 jan. 2016.

VAZ, P. H. P. de M. et al. Análise da competitividade da mamona e da soja para a produção de biodiesel no nordeste do Brasil. Revista de Economia Agrícola, São Paulo, v. 57, n. 1, p. 35-48, jan./jun. 2010. 


\section{REVISTA BRASILEIRA DE POLÍTICAS PÚBLICAS BRAZILIAN JOURNAL OF PUBLIC POLICY}
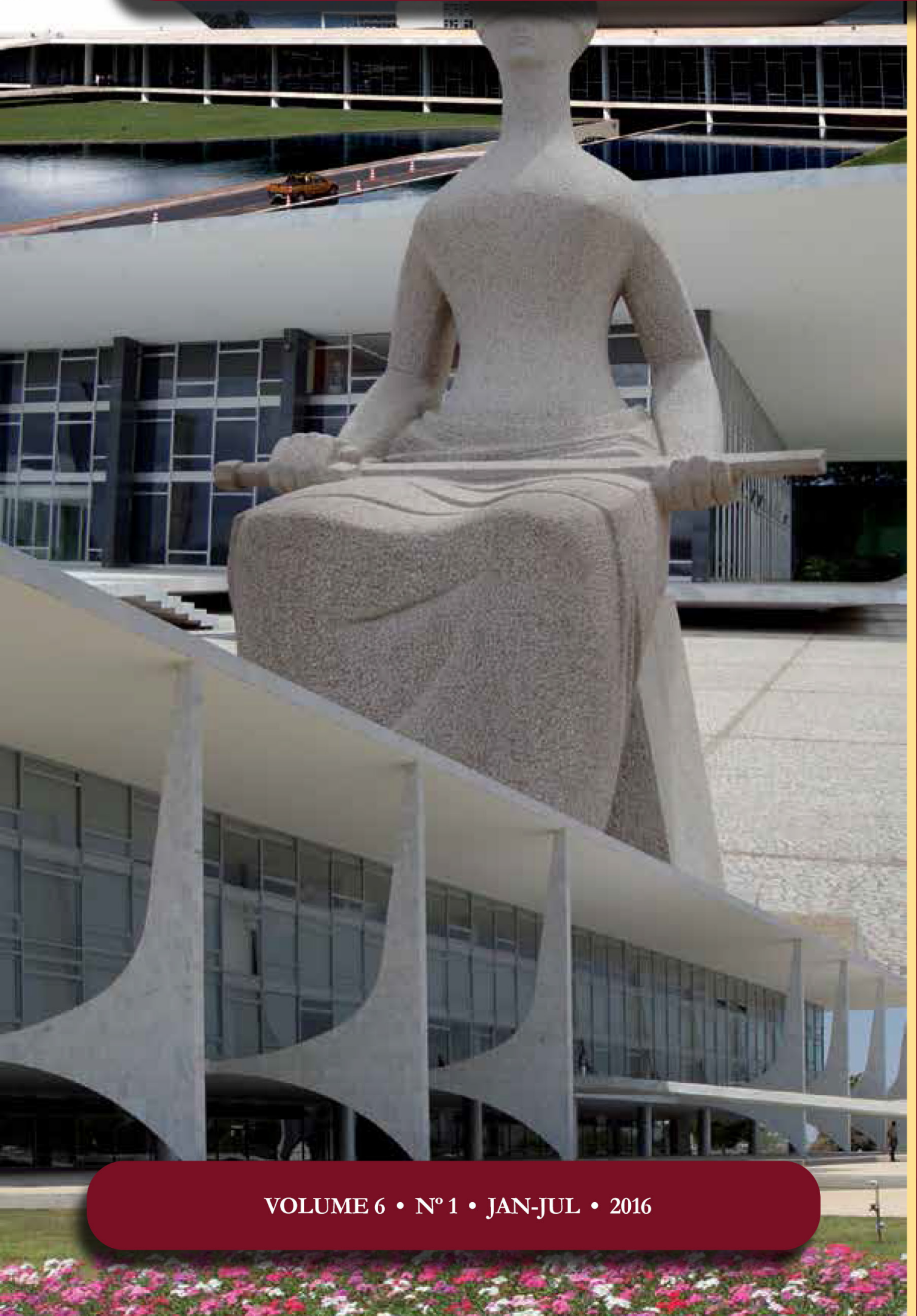

A correlação entre doenças respiratórias e $o$ incremento das queimadas em Alta Floresta e Peixoto de Azevedo, norte do Mato Grosso - Amazônia Legal The correlation between respiratory diseases and the increase in fires in Alta Floresta and Peixoto de Azevedo northern Mato Grosso - Legal Amazon

Lilian Rose Lemos Rocha 


\section{A correlação entre doenças respiratórias e o incremento das queimadas em Alta Floresta e Peixoto de Azevedo, norte do Mato Grosso - Amazônia Legal*}

\author{
The correlation between respiratory diseases \\ and the increase in fires in Alta Floresta and \\ Peixoto de Azevedo northern Mato Grosso - \\ Legal Amazon
}

* Artigo convidado.

** Mestre em políticas públicas e desenvolvimento sustentável e doutoranda em Ciências da Saúde e Tecnologia pela Universidade de Brasília - UnB. Coordenadora da Pós-Graduação do Centro Universitário de Brasília - UniCEUB. E-mail: lilian.rocha@uniceub.br

*** Professor do Programa de Mestrado e Doutorado em Ciências e Tecnologia da Saúde da Universidade de Brasília (UnB).

\section{Resumo}

A subárea do extremo norte de Mato Grosso foi alvo de colonização do INCRA por empresas particulares e assentamentos governamentais, o que ocasionou um modelo econômico baseado na extração de recursos naturais, tendo como consequência o desmatamento. Isso proporcionou aumento considerável de riscos para a saúde e para o meio ambiente. O artigo pretende analisar os efeitos das queimadas na saúde da população dos municípios de Alta Floresta e Peixoto de Azevedo, relacionando-os com o aumento do número de atendimentos ambulatoriais por doenças respiratórias entre crianças de 0 a 5 anos e idosos com mais de 65, no período de 2009 a 2012. A pesquisa foi autorizada pelo Comitê de Ética 532.054, 13 de dezembro de 2013. Utilizou-se o método descritivo empírico do tipo ecológico, com análise estatística, resultante de dados analisados de uma série temporal (avaliando a tendência); foram utilizados dados descritivos e qualitativos. A pesquisa demonstra que existe relação entre o incremento das queimadas e o aumento do número de atendimentos ambulatoriais nas faixas etárias pesquisadas.

Palavras-chave: Queimadas. Doenças respiratórias. Amazônia Legal.

\section{Abstract}

The sub-area of the far north of Mato Grosso was INCRA colonization target by private companies and government settlements, which caused an economic model based on the extraction of natural resources, resulting in deforestation. This provided considerable increase in risks to health and the environment. The article analyzes the effects of fires on health of the population in the municipalities of Alta Floresta and Peixoto de Azevedo, relating to the increase in the number of outpatient visits for respiratory diseases among children 0-5 years and seniors over 65 in the period 2009 to 2012. The study was approved by the Ethics Committee 532 054, December 
13, 2013. We used the empirical descriptive method of ecological type, with statistical analysis resulting data analyzed a time series (evaluating the trend); descriptive and qualitative data were used. Research shows that there is a relationship between the increase in fires and increasing the number of primary care visits in the surveyed age.

Keywords: Burned. Respiratory diseases. Legal Amazon.

\section{INTRODUÇão}

A acelerada dinâmica de uso de terras e a elevada incidência de queimadas observadas na região norte do estado de Mato Grosso, denominada de o "arco do desmatamento" ao longo da BR 163, atingem proporções alarmantes, atraindo a atenção de ambientalistas, políticos e, especialmente, de gestores da área de saúde.

Essa região concentra mais de $85 \%$ das queimadas que ocorrem no Brasil durante o período de estiagem das chuvas na região. A maior parte do desmatamento concentra-se ao longo da BR-163, no "arco" que abrange desde o sudeste do Maranhão, incluindo o norte do Tocantins, o sul do Pará, norte do Mato Grosso, Rondônia, sul do Amazonas, até o sudeste do Acre. ${ }^{12}$

O estado de Mato Grosso, mais especificamente o norte, é resultado de processo de ocupação com características e dinâmicas muito particulares, pois é forte responsável pelo incremento das queimadas e pelo vetor do desmatamento. Nessa região, ocorrem problemas que, de alguma forma, afetam o meio ambiente, tais como a poluição dos rios pelo mercúrio dos garimpos; a contaminação da água por falta de saneamento; a fumaça oriunda de queimadas, gerando alterações respiratórias; e a grilagem de terra, fomentando palco de conflitos em todos os municípios da região.

Destaca-se a abertura de estradas, como a BR-163, a expansão pecuária e a ocupação desordenada do solo. É sabido que, devido aos processos demográficos envolvidos nessas atividades, com maior adensamento populacional, as exposições aos riscos físico-biológicos tendem a ocorrer em escala maior, com repercussões epidemiológicas. Perante todas estas problemáticas que envolvem a saúde e o meio ambiente, torna-se mais difícil avaliar o impacto dos fatores ambientais sobre a saúde, logo se pergunta até que ponto as mudanças ambientais tem afetado a saúde das pessoas?

Sabe-se que os grupos mais suscetíveis aos efeitos das queimadas são os de crianças, idosos e indivíduos portadores de doenças do aparelho respiratório e do sistema cardiovascular. Quanto às crianças, as doenças mais comuns que aumentam a taxa de morbimortalidade são aquelas que afetam o aparelho respiratório, em especial, as infecções respiratórias agudas, asma e bronquite. Esse quadro ainda é agravado pela má nutrição, principalmente no grupo de baixo nível socioeconômico. Existe, então, relação concreta entre o meio ambiente e a saúde, e a influência do primeiro pode ser positiva ou negativa. Positiva quando promove condições que propiciam as melhorias de vida das populações, e negativas quando geram condições para o aparecimento e disseminação de doenças dos mais diversos tipos, influenciando o padrão e o perfil dos níveis de morbimortalidade, nos mais diversos estratos populacionais.

Em Alta Floresta e Peixoto de Azevedo, o aumento das queimadas e os efeitos na saúde das populações estão associados às transformações intensas no meio ambiente, como a abertura de estradas, a expansão pecuária, agricultura extensiva e a exploração de madeira. A seleção dos municípios para este estudo deve-se

1 NEPSTAD, Daniel C. et al. Large sclae improverishment of Amazonian forests by logging and fire. Nature, v. 398, n. 6727, p. 505-508, 1999.

2 BRASIL. Ministério da Ciência e Tecnologia e Inovação e Meio Ambiente. Programa de Desmatamento da Amazônia: monitoramento da floresta amazônica por satélite - PRODES/INPE. Disponível em: <http://www.obt.inpe.br/prodes/index.php>. Acesso em: 30 jun. 2015. 
à localização geográfica, pois estão situados no "arco do desmatamento", ao longo da BR-163, principal área de dispersão de poluentes na região do norte de Mato Grosso. O objetivo deste trabalho consiste em analisar a correlação do incremento das queimadas e o aumento do número de internações por doenças respiratórias em crianças e idosos selecionados no período de 2009 a 2012, residentes em Alta Floresta e em Peixoto de Azevedo, situados no norte do Mato Grosso, na área de influência da rodovia, na Amazônia Legal.

\section{MÉTOdo}

Trata-se de estudo do tipo ecológico de série temporal, em que foi analisada a correlação entre o número de atendimentos ambulatoriais por doenças respiratórias e o aumento das queimadas no mesmo período no norte do estado de Mato Grosso. Os municípios estudados situam-se ao longo do BR-163. A escolha desses municípios deve-se ao fato de que o estado tem registrado anualmente o maior número de focos de queimadas e possuir a maior área desmatada da Amazônia Legal desde o início dos anos 90, motivos pelos quais se optou pelo desenvolvimento do estudo nessa região.

Foram utilizados dados dos registros de internações hospitalares por causas respiratórias obtidos do Sistema de Informações Hospitalares (SIH \SUS) de crianças de 0 a 5 anos e de adultos maiores de 65 anos de idade, por local de residência, durante os anos de 2009 a 2012. Os dados analisados referem-se ao capítulo X da CID 10, que abrange as doenças do aparelho respiratório (DAR), no período 2000 a 2012. Os registros e dados sobre o aumento das queimadas foram obtidos por meio do banco de dados online disponibilizados no endereço eletrônico do Instituto Nacional de Pesquisas Espaciais - INPE ${ }^{3}$, captados pelo sensor PRODES. No Brasil, o monitoramento de queimadas via sensoriamento remoto iniciou-se em julho de 1987, com a implantação do Projeto SEQE- Sensoriamento Remoto de Queimadas por Satélite.

O PRODES utiliza imagens de satélites da classe Landsat (20 a 30 metros de resolução espacial e taxa de revisita de 16 dias) numa combinação que busca minimizar o problema da cobertura de nuvens e garantir critérios de interoperabilidade. As imagens TM do satélite americano Landsat-5, foram, historicamente, as mais utilizadas pelo projeto, mas as imagens CCD do CBERS-2 e do CBERS-2B, satélites do programa sino-brasileiro de sensoriamento remoto, foram bastante usadas. O PRODES também fez uso de imagens LISS-3, do satélite indiano Resourcesat-1, e de imagens do satélite inglês UK-DMC2. Com essas imagens, a área mínima mapeada pelo PRODES é de 6,25 hectares. As estimativas do PRODES são consideradas confiáveis pelos cientistas nacionais e internacionais, entre eles Czaplewski ${ }^{4}$.

Esse sistema tem demonstrado ser de grande importância para ações e planejamento de políticas públicas da Amazônia. Foi necessário excluir os municípios com menos de 25 mil habitantes, por apresentarem estruturas simplificadas de serviços de saúde ou mesmo ausência destes; já os municípios selecionados, ambos com Escritórios Regionais de Saúde, são providos de estrutura de serviço de saúde, seja hospitalar ou de rede básica.

\section{Resultados}

Os dados das variáveis do desmatamento e doenças respiratórias foram dispostos segundo seu comportamento nos anos de 2009 a 2012. A área total desmatada em quilômetros quadrados, no período, em Alta

3 INSTITUTO NACIONAL DE PESQUISAS ESPACIAIS. Disponível em: < http://www.inpe.br/index.php>. Acesso em: 30 jun. 2015.

4 CZAPLEWSKI, Raymond L. Can a sample of Landsat sensor scenes reliably estimate the global extent of tropical deforestation? Int. J. Remote Sens, v. 24, n. 6, p. 1409-1412, 2003. 
Floresta foi de 17,5 $\mathrm{Km}^{2}$ e, em Peixoto de Azevedo, de 145,3 $\mathrm{km}^{2}$. Foi traçada reta de regressão utilizando mínimos quadrados bem como a apresentação da Matriz de Correlação de Pearson. Observa-se alta correspondência entre o desmatamento e a incidência de internações por doenças do aparelho respiratório para as idades abaixo dos 5 anos em Alta Floresta. Essa correlação chega a aproximadamente 83,63\%.

Gráfico I: Alta Floresta - Desmatamento X DRs (< 5 anos)

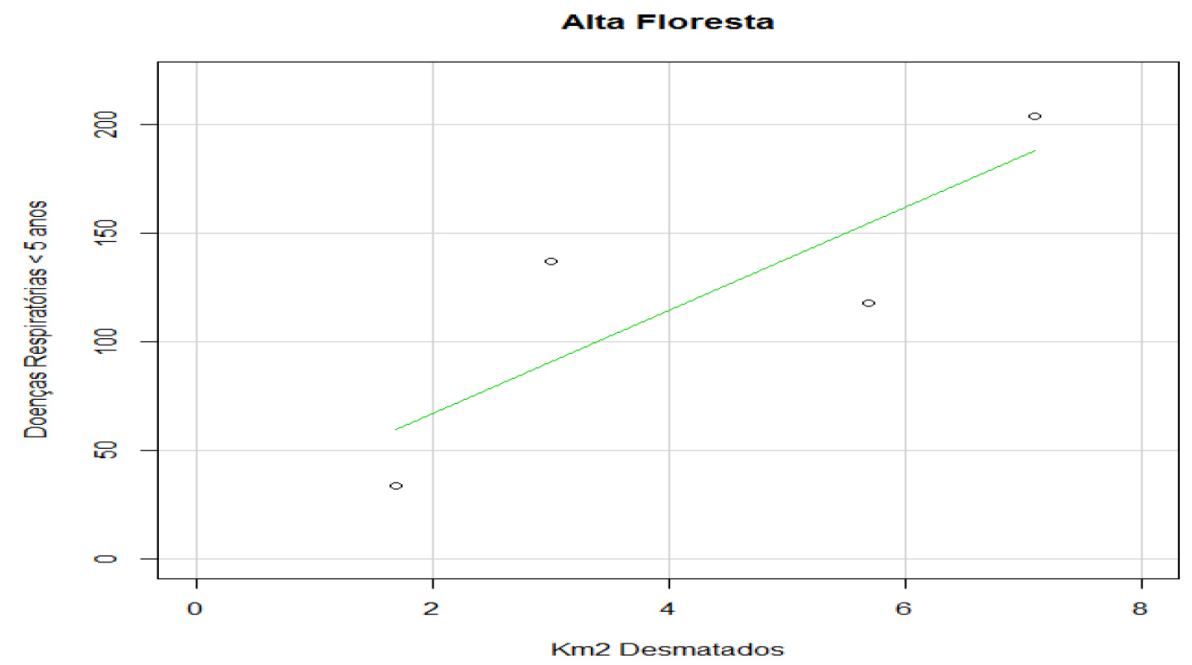

Fonte: O Autor.

Quanto à faixa etária de 60 anos ou mais, observa-se relação moderada do desmatamento com a incidência por DRs, chegando a $66,25 \%$.

Gráfico II: Alta Floresta - Desmatamento X DRs (60 anos ou mais)

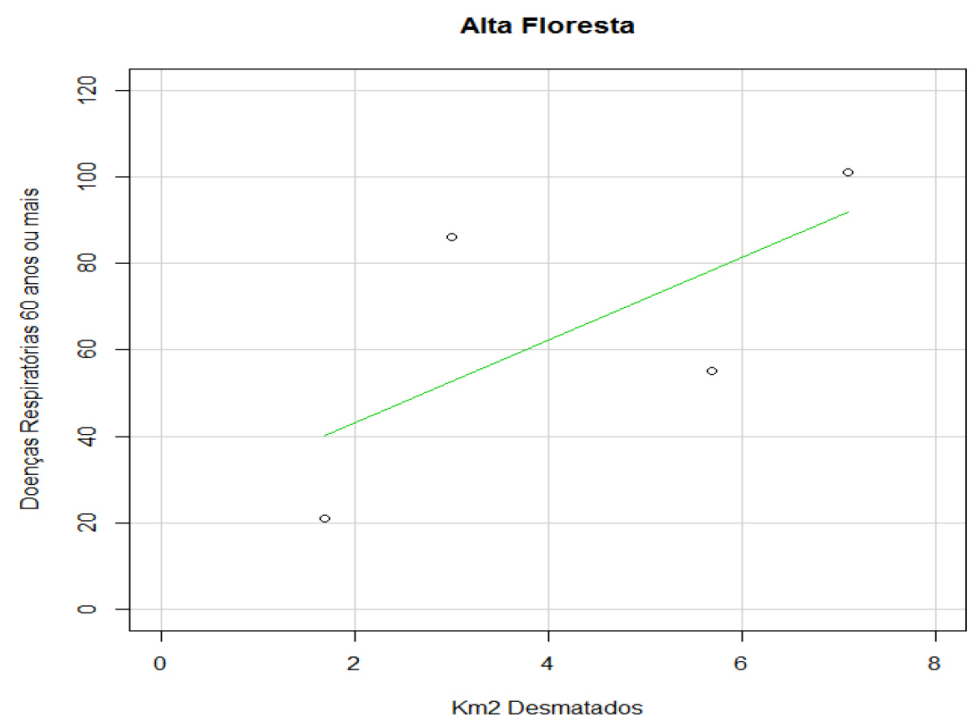

Fonte: O Autor.

No município de Peixoto de Azevedo, observa-se correlação negativa moderada do desmatamento com a incidência de internações por DRs para as idades abaixo de 5 anos $(-61,59 \%)$. 
Gráfico III: Peixoto de Azevedo - Desmatamento X DRs ( $<5$ anos)

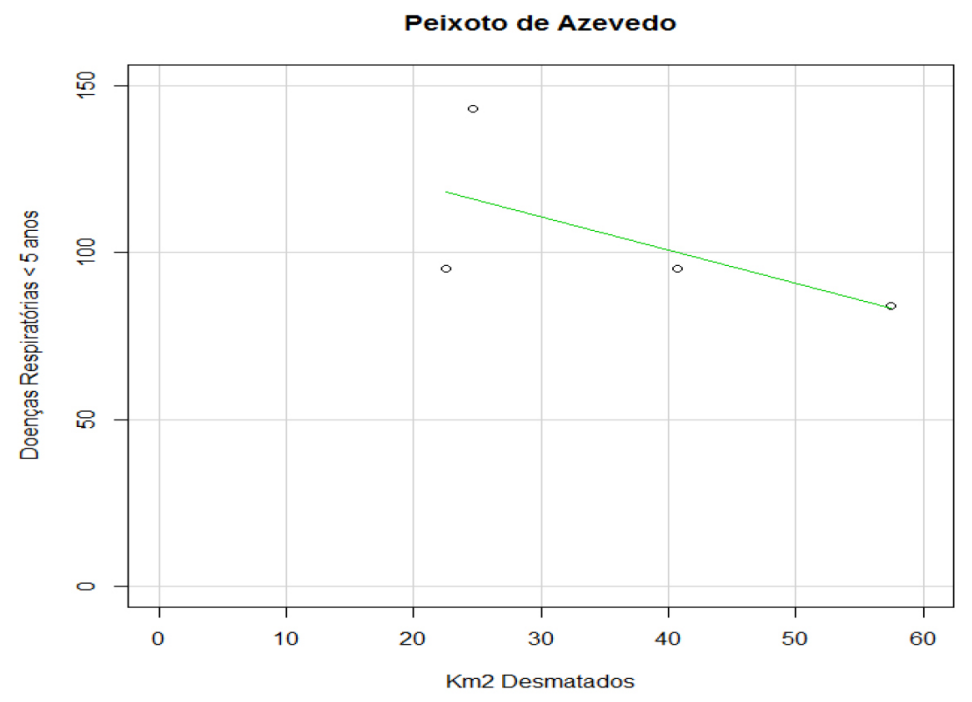

Fonte: O Autor.

Entretanto, na faixa etária de 60 anos ou mais, houve uma correlação de moderada para alta de 77,67\%.

Gráfico IV: Peixoto de Azevedo - Desmatamento X DRs (60 anos ou mais)

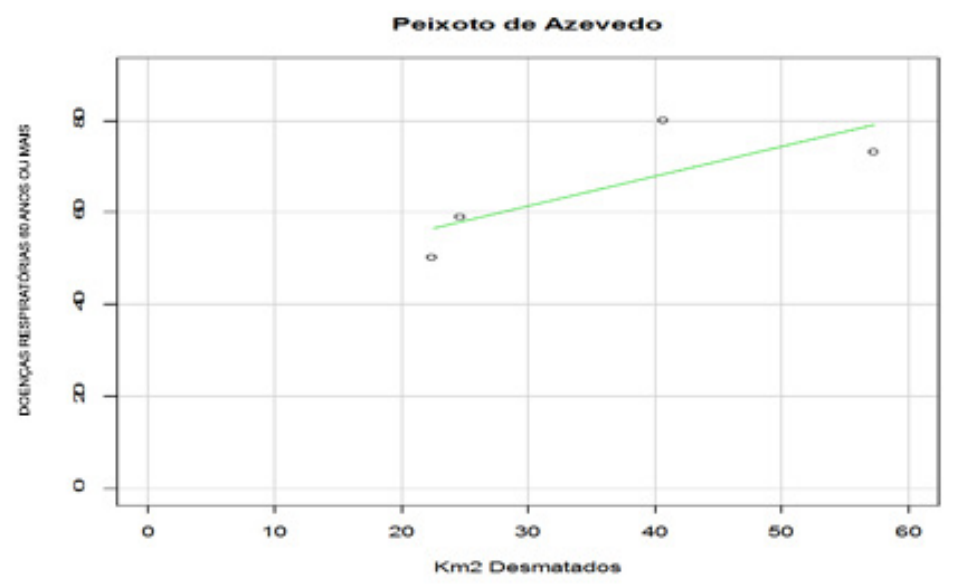

Fonte: O Autor.

\section{DiscUSSÃo}

Alguns autores têm desenvolvido estudos que demonstram a associação entre o aumento de atendimentos clínicos de doenças respiratórias com picos de poluição. Trabalhos internacionais realizados entre 1997 e 1998 mostram incêndios que ocorreram na Indonésia e atingiram grandes proporções afetando países vizinhos como Brunei, Malásia e Filipinas. Dentre os efeitos, destaca-se a elevada morbimortalidde por doenças respiratórias. Emmanuel ${ }^{5}$ realizou investigação sobre o impacto na saúde da população exposta à fumaça dos incêndios florestais na Indonésia. A análise demonstrou que a distribuição do material particulado oriundo das fumaça aumentou em $30 \%$ o número de atendimentos ambulatoriais por problemas respiratórios. Mott ${ }^{6}$ investigou os efeitos cadiorespiratórios.

5 EMMANUEL, Bishop S. Impact to lung heath of haze from forest fire: The Singapore experience. Respirology, v. 5, n. 2, p. 175-182, 2000.

6 MOTT, Joshua A. et al. Cardiorespiratory hospitalizations associated with smoke exposure during the 1997, Southeast Asian 
Estudos nacionais também foram desenvolvidos como o de Lopes ${ }^{7}$, realizado na mesorregião de Bauru, São Paulo, onde foi verificada uma possível correlação entre as emissões das queimadas de cana-de-açúcar e o aumento de problemas respiratórios, utilizando técnicas de geoprocessamento, adotando como variáveis os focos de calor detectados por satélite, no período de 2000 a 2004. Mascarenhas ${ }^{8}$, em Rio Branco, também desenvolveu estudo ecológico onde foi avaliada a relação entre a concentração de PM 2,5 e o número de atendimentos ambulatoriais. Os resultados revelaram correlação positiva entre a concentração do material particulado e os atendimentos de asma em crianças. Os resultados alcançados com essa pesquisa demonstraram que as doenças do aparelho respiratório estão entre as principais causas de internações em crianças e idosos.

No município de Alta Floresta, a correlação para a faixa de 0 a 5 anos foi de 83,63\% dos casos de internações para este tipo de agravo, entretanto na faixa etária de 60 anos ou mais a correlação foi moderada na faixa de $62,25 \%$. O município continua em processo elevado de taxas de desmatamento \queimadas, sendo permanente e continuo, devido ao modelo de exploração da terra, com um vetor forte de desmatamento presente no município que é a introdução da sojicultora, plantio de lavouras extensivas de algodão, aliados ao problema fundiário que afeta toda a região. O que confirma os dados secundários apresentados no relatório de informações de saúde do estado do Mato Grosso, onde as doenças do aparelho respiratório aparecem como a primeira causa de internação com 25,4\% (2009), permanecendo em primeiro lugar até 2012 com 20,5\%, mantendo-se durante todo o período estudado desta pesquisa, em primeiro lugar das causas de internações. É importante frisar que Alta Floresta possui apenas 1 hospital municipal e 4 da rede privada, os quais atendem os municípios de Apiacás, Carlinda, Nova Bandeirantes, Nova Monte Verde e Paranaíta, o que gera forte pressão por atendimento médico no município.

Quanto ao município de Peixoto de Azevedo, o resultado que mais chama a atenção está na correlação negativa para amostra de crianças menores de 5 anos de idade (-61,59\%), demostrando que, quando o desmatamento aumentou, o número de internações diminuiu. O que efetivamente evidencia que algo está acontecendo na região, pois Peixoto de Azevedo já esteve na "lista negra" dos municípios com o maior índice de desmatamento no período de 2005 a 2008. As doenças do aparelho respiratório, de acordo com dados do Escritório Regional de Saúde-ERS ${ }^{9}$, variam entre o terceiro e quarto lugares da principal causa de internações variando de $19,0 \%$ e caindo para 4,9\%, o que valida os resultados apresentados por serem relativamente baixos para o período estudado. Entretanto, a explicação deve ser bem mais complexa para o caso de Peixoto de Azevedo. Várias hipóteses podem ser consideradas.

O município possui população rural expressiva $(35,64 \%)$ em relação ao restante do estado de Mato Grosso (18,10\%). Devido à distância do centro urbano, os pacientes da área rural, por falta de transporte público, número limitado de instalações de saúde e dificuldades de acessar os serviços médicos tratam as doenças em casa ou recorrem, em último caso, ao atendimento ambulatorial, que são maneiras mais fáceis de resolver problemas de menor gravidade, deixando esses procedimentos fora das estatísticas de morbidade ${ }^{10}$. Carmo et al. ${ }^{11}$ salientam que os pacientes também podem aguardar uma situação mais grave para procurar os

forest fires. Int J Hyg Environ Health, v. 208, n. 1-2, p. 75-85, 2005.

7 LOPES, Fábio Silva; RIBEITO, Helena. Mapeamento de internações hospitalares por problemas respiratórios e possíveis associações à exposição humana aos produtos de queima da palha de cana-de-açúcar no Estado de São Paulo. Bras. Epidemol, v. 9 , n. 2, p. 215-225, 2006.

8 MASCARENHAS, Márcio Dênis Medeiros et al. Poluição atmosférica devido à queima de biomassa florestal e atendimentos de emergência por doença respiratória em Rio Branco, Brasil - Setembro, 2005. J. Bras. Pneumol, São Paulo, v. 34, n. 1, p. 42-46, jan. 2008. 9 BRASIL. Mato Grosso. Secretaria de Estado de Saúde - Cuiabá, 2011 e 2013. Superintendência de Políticas de Saúde. Coordenadoria de Gestão da Informação em Saúde. Informações regionais de saúde do Estado do Mato Grosso: Alta Floresta e Peixoto de Azevedo. Disponível em: <http://www.saude.mt.gov.br>. Acesso em: 10 jan. 2014.

10 INSTITUTO NACIONAL DE PESQUISA ESPACIAL. Monitoramento dos focos ativos por Estado: MATO GROSSO - Brasil. Disponível em: <http://www.inpe.br/queimadas/estatisticas_estado.php?estado=MT\&nomeEstado=MATO $\% 20$ GROSSO > . Acesso em: 30 jun. 2015.

11 CARMO, Cleber Nascimento do et al. Associação entre material particulado de queimadas e doenças respiratórias na Região Sul da Amazônia brasileira. Panam Salud Pública, v. 27, n. 1, p. 106, 2010. 
serviços de saúde. Outra hipótese a ser considerada é a de que as políticas públicas ambientais de controle ao desmatamento, aliados à rígida fiscalização no município estejam surtindo resultados positivos. O município apresenta apenas um hospital público e um privado, atendendo mais quatro municípios, o que demonstra baixa oferta de atendimento médico em Peixoto de Azevedo.

Para os dois grupos sensíveis incluídos no estudo, grande parte das prevalências ocorreu nos municípios pertencentes ao "arco do desmatamento" BR-163, caracterizado por grandes áreas desmatadas e grandes concentrações de queimadas. Isso torna o resultado para Peixoto de Azevedo bastante intrigantes, pois diversos autores sustentam que os atores mais sensíveis à exposição de poluentes proveniente de queimadas são as crianças de 0 a 5 anos de idade. $O$ município continua apresentando fatores de risco ligados a condições sociossanitárias, as quais continuam precárias, com grande impacto ambiental provocado pela pecuária extensiva, soja e desmatamento, e todos esses fatores estão associados ao desenvolvimento de doenças respiratórias na infância. Uma forma de resposta para esse dado pode ter fundamento no estudo realizado por Marques e Arretche ${ }^{12}$, em um artigo de revisão, no qual demonstraram que o número de internações per capita varia com existência local de hospital. Peixoto de Azevedo, conforme dito, possui apenas um hospital municipal, tendo disponíveis nas especialidades de pediatria apenas 7 leitos.

Percebe-se que são precários os serviços de assistência à saúde, o que dificulta o acesso dos doentes ao atendimento médico. Essa ausência de assistência médica adequada pode refletir nas atividades de prevenção em saúde, o que, consequentemente, poderia levar a maior demanda pelos atendimentos hospitalares em alguns municípios.

Esse resultado condiz com o apresentado por Rosa et al. ${ }^{13}$, no município de Tangará da Serra (MT). Nesse estudo, os autores levantam a hipótese de que os registros não classificados podem ter sido codificados como virose ou processo viral, os quais seriam relacionados à rinofaringite. Talvez isso explique o resultado negativo para crianças, apesar do incremento de queimadas no período. É importante destacar que a alta proporção de diagnóstico sem a localização específica implica déficit na qualidade dos registros analisados. Esse fato configura medida para a avaliação quantitativa dos serviços de saúde. Outro dado importante refere-se à correlação alta de 77,67\% para idosos. Esse índice remete a vários questionamentos. O primeiro deles seria quais os motivos ensejariam este percentual se comparados a Alta Floresta? Quanto ao aumento do percentual de idosos que buscam atendimento hospitalar por DRs, Alves e Rodrigues ${ }^{14}$, em estudo sobre determinantes de saúde em idosos, relatam que o nível de escolaridade, entre outras variáveis socioeconômicas, estava associado à percepção de saúde, e a idade teve uma significativa influência.

Os resultados da pesquisa proposta neste artigo apontam para a importância da avaliação das causas das doenças respiratórias e sua relação com as queimadas. Sinalizam, ainda, prioridades para os gestores dos serviços de saúde da região, no sentido de reforçar o efetivo diagnóstico de doenças respiratórias nos grupos populacionais sensíveis. Talvez o grau de escolaridade contribua para que idosos percebam, com mais clareza, determinadas condições de saúde que demandam atendimento médico, o que refletiria na maior utilização dos serviços de saúde em determinados municípios. Neste trabalho foram utilizadas as prevalências de internações por doenças do aparelho respiratório. Bittencourt, Camacho e Leal ${ }^{15}$, destacam que o sistema de informações hospitalares, de onde provêm as informações, utiliza como unidade de análise a autorização de internação (AIH) e não o indivíduo doente. Como o mesmo indivíduo pode ser internado mais de uma vez ou até mesmo não ser internado, embora doente, por limitações na estrutura hospital ou estrutura de mobi-

12 MARQUES, Eduardo; ARRETCHE, Marta. Condicionantes locais da descentralização de políticas de saúde. Caderno Crh, Salvador, v. 39, p. 55-81, 2003.

13 ROSA, Antonia Maria et al. Prevalência de asma em escolares e adolescentes em um Município na Região amazônica brasileira. J Bras Pneumol, v. 35, n. 1, p. 7-13, 2009.

14 ALVES, Luciana Correia; RODRIGUES, Roberto Nascimento. Determinantes da autopercepção de saúde entre idosos do município de São Paulo, Brasil. Panam Salud Pública, v. 17, n. 5/6, p. 333-41, 2005.

15 BITTENCOURT, Sonia Azevedo; CAMACHO, Luiz Antonio Bastos; LEAL, Maria do Carmo. Sistema de informação hospitalar e sua aplicação na saúde coletiva. Cad. Saúde Pública, v. 22, n. 1, p. 19-30, 2006. 
lidade, tem-se como frágil a utilização das internações como aproximação de casos de doença. Todavia, este vem sendo apontado como um dos melhores indicadores dos agravos às doenças respiratórias. Por outro lado, a participação do sistema de saúde suplementar não é relevante na região, existindo inclusive cidades onde o SUS é responsável por 100\% de atendimentos ambulatoriais e hospitalares, o que possibilita que os dados utilizados no estudo tenham boa cobertura populacional.

\section{Considerações finais}

Os resultados da presente pesquisa apontam para a importância da avaliação, as causas das doenças respiratórias e sua relação com as queimadas da floresta. Os resultados indicam, ainda, prioridades para os gestores dos serviços de saúde da região, no sentido de reforçar o efetivo diagnóstico de doenças respiratórias nos grupos populacionais sensíveis. Fazem-se necessárias, ainda, a realização de novos estudos, a utilização de métodos aprimorados, permitindo o aprofundamento da análise das variáveis envolvidas e a melhor compreensão dos processos que interferem na dinâmica saúde/ambiente no norte do estado de Mato Grosso.

\section{REFERÊNCIAS BIBLIOGRAFICAS}

ALVES, Luciana Correia; RODRIGUES, Roberto Nascimento. Determinantes da autopercepção de saúde entre idosos do município de São Paulo, Brasil. Panam Salud Pública, v. 17, n. 5/6, p. 333-41, 2005.

BITTENCOURT, Sonia Azevedo; CAMACHO, Luiz Antonio Bastos; LEAL, Maria do Carmo. Sistema de informação hospitalar e sua aplicação na saúde coletiva. Cad. Saúde Pública, v. 22, n. 1, p. 19-30, 2006.

BRASIL. Mato Grosso. Secretaria de Estado de Saúde - Cuiabá, 2011 e 2013. Superintendência de Políticas de Saúde. Coordenadoria de Gestão da Informação em Saúde. Informações regionais de saúde do Estado do Mato Grosso: Alta Floresta e Peixoto de Azevedo. Disponível em: <http://www.saude.mt.gov.br>. Acesso em: 10 jan. 2014.

BRASIL. Ministério da Ciência e Tecnologia e Inovação e Meio Ambiente. Programa de Desmatamento da Amazônia: monitoramento da floresta amazônica por satélite - PRODES/INPE. Disponível em: <http:// www.obt.inpe.br/prodes/index.php>. Acesso em: 30 jun. 2015.

CARMO, Cleber Nascimento do et al. Associação entre material particulado de queimadas e doenças respiratórias na Região Sul da Amazônia brasileira. Panam Salud Pública, v. 27, n. 1, p. 106, 2010.

CZAPLEWSKI Raymond L. Can a sample of Landsat sensor scenes reliably estimate the global extent of tropical deforestation? Int. J. Remote Sens, v. 24, n. 6, p. 1409-1412, 2003.

EMMANUEL, Bishop S. Impact to lung heath of haze from forest fire: The Singapore experience. Respiro$\log y$, v. 5, n. 2, p. 175-182, 2000.

INSTITUTO NACIONAL DE PESQUISA ESPACIAL. Monitoramento dos focos ativos por Estado: MATO GROSSO - Brasil. Disponível em: < http://www.inpe.br/queimadas/estatisticas_estado. php?estado=MT\&nomeEstado=MATO $\% 20$ GROSSO $>$. Acesso em: 30 jun. 2015.

INSTITUTO NACIONAL DE PESQUISAS ESPACIAIS. Disponível em: < http://www.inpe.br/index. php>. Acesso em: 30 jun. 2015.

LOPES, Fábio Silva; RIBEITO, Helena. Mapeamento de internações hospitalares por problemas respiratórios e possíveis associações à exposição humana aos produtos de queima da palha de cana-de-açúcar no Estado de São Paulo. Bras. Epidemol, v. 9, n. 2, p. 215-225, 2006. 
MARQUES, Eduardo; ARRETCHE, Marta. Condicionantes locais da descentralização de políticas de saúde. Caderno Crh, Salvador, v. 39, p. 55-81, 2003.

MASCARENHAS, Márcio Dênis Medeiros et al. Poluição atmosférica devido à queima de biomassa florestal e atendimentos de emergência por doença respiratória em Rio Branco, Brasil - Setembro, 2005. J. Bras. Pneumol, São Paulo, v. 34, n. 1, p. 42-46, jan. 2008.

MOTT, Joshua A. et al. Cardiorespiratory hospitalizations associated with smoke exposure during the 1997, Southeast Asian forest fires. Int J Hyg Environ Health, v. 208, n. 1-2, p. 75-85, 2005.

NEPSTAD, Daniel C. et al. Large sclae improverishment of Amazonian forests by logging and fire. Nature, v. 398 , n. 6727 , p. $505-8,1999$.

ROSA, Antonia Maria et al. Prevalência de asma em escolares e adolescentes em um Município na Região amazônica brasileira. J Bras Pneumol, v. 35, n. 1, p. 7-13, 2009. 


\section{Políticas públicas, agricultura familiar e cidadania no Brasil: o caso do PRONAF*}

\section{Public policies, family farming and citizenship in Brazil: the case of PRONAF}

Edir Vilmar Henig**

Irenilda Ângela dos Santos***
* Recebido em 29/04/2015

Aprovado em 08/12/2015

** Mestre em políticas públicas e desenvolvimenDoutorando em Território, Risco e Políticas Públicas (Universidade de Coimbra). Mestre em Política Social - UFMT. Bacharel em Ciências Contábeis (UNIC). Bacharel em Administração (UFMT). E-mail: edirhenig@ hotmail.com

*** Doutora em Desenvolvimento Sustentável (UnB). Mestre em Serviço Social (PUC-Rio). Graduada em Serviço Social (UFMT). Professora do Curso de Serviço Social e do Programa de Pós-Graduação em Política Social da Universidade Federal de Mato Grosso. E-mail: irepanta@gmail.com

\section{Resumo}

O presente artigo aborda os reflexos do Pronaf enquanto política pública que viabiliza a construção de uma agricultura familiar forte, capaz de alavancar a promoção social do trabalhador rural, e trazer às famílias envolvidas recursos econômicos capazes de garantir sua reprodução social. Motivados pela inovação tecnológica ocorridas no campo nas últimas décadas, a atividade vem alterando as relações sociais de trabalho e renda, pois, à medida que as pequenas propriedades implementam infraestrutura mecanizada, esta tende a aumentar o coeficiente de produção, tendo, nas políticas públicas, os incentivos necessários para que isso ocorra. Portanto, este trabalho tem o objetivo de estudar o Pronaf na distribuição de renda no campo, como política garantidora da permanência dos pequenos produtores em suas terras, o que inibi o êxodo rural, sendo responsável pela geração de emprego e subsistência, e, principalmente, pela emancipação humana, econômica, social e cultural da classe. Temos como metodologia o levantamento bibliográfico e o debate conceitual, em que se busca ressaltar a importância da discussão em torno do tema, pois este reflete na realidade social construída por meio de anos de luta por parte dos movimentos sociais e dos trabalhadores, e tem fomentado criação políticas públicas para o setor como o caso do Pronaf. Por fim, pode-se concluir que uma atividade como a dos pequenos produtores necessita de planejamento e conta com participação de todos os atores envolvidos. Contudo, o Pronaf surge como resposta e possibilidade de transformação social no meio rural, e como uma alternativa para o desenvolvimento sustentável da agricultura brasileira.

Palavras-chave: Agricultura familiar. Pronaf. Políticas públicas.

\section{Abstract}

This article discusses the reflections of Pronaf as a public policy that enables the construction of a strong family farm, able to leverage the social promotion of rural workers, and bring to the families involved economic resources capable of ensuring their social reproduction. Driven by technological innovation occurred in the field in recent decades, the activity is altering the social relations of work and income, because as small farms implement mechanized infrastructure, this tends to increase the coefficient of 
production with the necessary incentives in public policy for this to occur. So this work to study the Pronaf in income distribution in the field, as guarantor policy permanence of small farmers on their land, which inhibit the rural exodus, and being responsible for the generation of employment and livelihood, especially the emancipation human, economic, social and cultural class. We can approach the literature and the conceptual debate, which aims to emphasize the importance of discussion on the topic, as it reflects the social reality built through years of struggle by the social movements and workers, and that has fostered creating public policies for the sector as the case of Pronaf. Finally, one can conclude that an activity such as small producers, needs planning, and count with the participation of all stakeholders. However, the Pronaf is a response and the possibility of social change in rural areas, and an alternative to the sustainable development of Brazilian agriculture.

Key words: Family agriculture. Pronaf. public policy.

\section{INTRODUÇÃO}

O país sofreu, desde a década de 1960, uma forte modernização no setor agrícola, visando ao aumento da produtividade intensiva, ou seja, aumento da produção utilizando a mesma área plantada, consequentemente aumentando o grau de mecanização e a quimificação das lavouras. No decorrer dos anos, com a modernização da agricultura, a população rural passou a obter rendimentos nas adjacências das cidades, a indústria ocupou os espaços rurais e as diferenças culturais entre campo e cidades foram transformadas.

Seguindo essa perspectiva de mudanças no mundo rural, as divisões das terras também sofreram alterações, motivado pelo êxodo rural fortemente identificado nesse período histórico que é resultante de programas governamentais de industrialização no país, que incentivavam os agricultores a deixassem suas terras em busca da possibilidade de melhorar suas condições de vida na cidade, o que também permitiu o aumento dos grandes latifúndios, contribuindo e acentuando ainda mais a desigualdade social no meio rural.

Outro fator que contribuiu para o êxodo rural foi a substituição da mão de obra humana pelo maior desempenho e eficiência de tratores e colheitadeiras cada vez mais equipados com tecnologia de ponta, o sistema de produção obrigou os trabalhadores rurais a migrarem em direção aos grandes centros onde se localizavam os centros industriais.

As inovações tecnológicas, nas últimas décadas, bem como as transformações ocorridas no meio rural, têm incentivado os pequenos produtores a buscar alternativas para melhorar sua renda e a viabilidade da atividade e para não serem sucumbidos pelas grandes corporações agrícolas, buscando alternativas como a floricultura, fruticultura, piscicultura e criação de pequenos animais como rãs, coelhos, codornas, bem como a produção de orgânicos, que, agora, disputam uma fatia de mercado enfrentando os produtos de culturas mais tradicionais e intensivas. Apontam, dessa forma, como alternativa viável para a reprodução econômica dos agricultores familiares, e produzirem alimentos com maior qualidade, sem uso de agrotóxicos e fertilizantes químicos.

Diante dessas características, o rural deixou de ser somente sinônimo de agrícola e se tornou pluriativo e multifuncional, o que possibilita o surgimento de diversas formas de agricultura familiar que incorporam uma diversidade de situações específicas e particulares, que variam desde o modo camponês de subsistência até as formas especializadas de produção e comercialização mercantil.

E é, neste sentido, que se faz necessário ressaltar a importância e o reconhecimento dos agricultores familiares como sujeitos de direitos, reconhecimento que é recente na história brasileira, sendo datado a partir de 1990, estabelecido com o surgimento das primeiras políticas públicas específicas para a agricultura 
familiar. A principal política pública que surge voltada para os agricultores familiares é o Pronaf ${ }^{1}$, criado em 1996, tem por objetivo aumentar a produção, melhorar a qualidade de vida e ampliar a cidadania dos agricultores familiares.

Somente dez anos depois, em 2006, a atividade passa a ser reconhecida e passa a ter um marco legal, que é estabelecido pela da Lei da Agricultura Familiar ${ }^{2}$, sendo esta, considerada o marco oficial que define a Agricultura Familiar como categoria produtiva e como profissão no mundo do trabalho. Dessa forma estabelece as diretrizes para a formulação da Política Nacional da Agricultura Familiar e Empreendimentos Familiares Rurais. Apesar dessas importantes conquistas alcançadas pela categoria, a trajetória de lutas dos trabalhadores rurais é longa e apresentam vários entraves e avanços.

Ao seguir essa perspectiva, o presente artigo se objetiva a debater a distribuição de renda e a inclusão social proporcionada pelo PRONAF para com os trabalhadores da agricultura familiar no Brasil, oferecendo referencial que permita entendê-la e dar a devida base para o debate e demonstrar a importância do tema.

No contexto deste trabalho, a justificativa apresentada consiste em somar aos debates anteriores realizados por outros autores e utilizar-se de referenciais teóricos que destaquem a relevância dessa política pública tão importante para a agricultura familiar e ressalta que a atividade é responsável pela sustentação do trabalho e da renda de inúmeras famílias camponesas que tem na produção agrícola a possibilidade de reprodução e sobrevivência.

O caminho metodológico trilhado para explorar a importância da trajetória das do PRONAF como políticas públicas e na consolidação da distribuição de renda e da inclusão social dos trabalhadores rurais no Brasil, bem como o surgimento dos agricultores familiares como categoria e sujeitos de direitos, frutos de embate e disputas que culminaram na efetivação ou, pelo menos, nos marcos legais das políticas a eles voltados.

\section{A AGRICULTURA famiLIAR COMO SUJEITO de POLÍticas PÚBLICAS}

Historicamente, colocada à margem do processo de desenvolvimento brasileiro, a agricultura familiar passa, atualmente, a assumir papel de destaque outrora negado, como importante sujeito social do segmento produtivo, capaz de gerar emprego e renda.

O ingresso do capitalismo no meio rural brasileiro tem sua acentuação na década de 1960, com o intuito de modernizar tecnológicas na agricultura, o que acarretou, de forma significativa, o desenvolvimento da agricultura familiar, uma vez que os trabalhadores que estão inseridos nesse contexto sofrem com as transformações econômicas, sociais e territoriais, o que obriga esses agricultores a se adaptarem ao novo cenário proposto pelo mercado, mediante a conciliação entre as tradições trazidas por meio do tempo, migrando às novas tecnologias que modernizaram o setor.

Dessa forma, para Ian Gough ${ }^{3}$,

[...] o mesmo dinamismo de produção capitalista dissolve todos os modos de produção prévios dentro da sociedade. A agricultura campesina é destruída pela agricultura moderna de capital intensivo [...] O resultado é que uma quantidade maior de força de trabalho tem é proletarizada.

Ao refletir sobre o pensamento de Gough e ao trazer para a contextualização do cenário brasileiro, percebe-se que a produção intensiva, hoje denominada como agronegócio, insere-se na economia nacional a

1 O Programa Nacional de Fortalecimento da Agricultura Familiar (Pronaf) foi criado pelo Decreto presidencial $\mathrm{n}^{\circ}$. 1.946, de julho de 1996.

2 A denominação Lei da Agricultura Familiar refere-se à Lei no 11.326, de 24 de julho de 2006.

3 GOUGH, I. The political economy of the Welfare State. Traducción: Gregorio Rodriguez Cabrero. Madrid: Blume 1982. (Tradução nossa) 
fim de beneficiar um número restrito de produtores, que motivados por políticas governamentais assumem o controle e o domino de grandes latifúndios e, nesse sentido, favorece a intensificação da concentração de terras e a desigualdade social no campo, além de terem uma representatividade política muito expressiva.

De acordo com esse pensamento, Netto e Braz 4 afirmam que "o desemprego em massa não resulta do desenvolvimento das forças produtivas, mas sim do desenvolvimento das forças produtivas [...] sob as relações sociais de produção capitalista". De acordo com a interpretação dos autores, o nível de acumulação é determinado pelo nível de desempregado e, no contexto da agricultura, não é diferente, o novo padrão de desenvolvimento agrícola tem determinado os números do desemprego rural brasileiro.

Nessa perspectiva, o êxodo rural se concretiza na esperança dos trabalhadores rurais em melhorarem de vida na cidade, por meio da venda de sua força de trabalho nas indústrias situadas nas grandes metrópoles, o que resulta em um abarrotamento do espaço urbano e criação de um "exército industrial de reserva 5 " que Marx ${ }^{6}$ já destacava como sendo uma ferramenta do capital para a manutenção da dominação dos capitalistas sobre o proletariado e torna-se um fator contribuinte da intensificação de problemas sociais atuais que fogem ao controle do Estado.

Schneider ${ }^{7}$ destaca a agricultura familiar como uma "descoberta" como parte integrante dos estudos teóricos e analíticos da sociologia e ressalta, ainda, a importância do reconhecimento social ao afirmar que:

“[...] a agricultura familiar é uma forma social reconhecida e legitimada na maioria dos países envolvidos, nos quais a estrutura agrária é majoritariamente composta por explorações nas quais o trabalho família assume uma importância decisiva."

Renegada por tantos anos de ser atividade produtiva, a agricultura familiar se vê assumindo um papel de destaque outrora lhe negado como importante ator social e segmento produtivo, capaz de gerar ocupação, emprego e renda e, dessa forma, contribuir para a fixação da população rural no campo, inibindo, assim, a continuação do êxodo rural e proporcionando a esses sujeitos condições produtivas efetivas, para sua manutenção social e econômica.

De acordo com dados da Food and Agriculture Organization - FAO 8 , em 2012 a agricultura familiar foi responsável por $77 \%$ dos postos de trabalhos agrícolas no Brasil, o que reafirma o importante contributo da atividade na geração de renda de parcela considerável da população brasileira.

Ao pensar sobre as trajetórias possíveis da transformação social no meio rural, podemos perceber que são múltiplas e dadas de muitas formas, mas também, que, principalmente, a escolha por parte dos trabalhadores em permanecer, investir, ou sair da agricultura depende, entre outros fatores, de políticas públicas fortes voltadas para essa atividade, consolidando-a com meio possível de reprodução social.

O desenvolvimento necessário para a agricultura familiar se firmar cada vez mais no campo econômico possível de competir com a agricultura conservadora só se dará por meio da intervenção do Estado no processo produtivo, com incentivos e políticas que venham ao encontro das necessidades dos agricultores familiares, pois, como salienta Salama", "é inaceitável viver em uma sociedade que se fratura cada vez mais, onde as desigualdades na distribuição de renda são tão gritantes e continua em franca expansão".

4 NETTO, J. P.; BRAZ, M. Economia política: uma introdução crítica. 5. ed. São Paulo: Cortez, 2009.

5 Conceito de Karl Marx: "Ela constitui o exército industrial de reserva disponível, que pertence ao capital de maneira tão absoluta como se fosse criado e mantido por ele. Ela proporciona o material humano a necessidades variáveis de expansão do capital e sempre pronto para ser explorado, independentemente dos limites do verdadeiro incremento da população.” MARX, K. O capital: crítica da economia política. Tradução de Reginaldo Sant'Anna. 29. ed. Rio de Janeiro: Civilização brasileira, 2011. v. 2. p. 735.

6 MARX, K. O capital: crítica da economia política. Tradução de Reginaldo Sant'Anna. 29. ed. Rio de Janeiro: Civilização brasileira, 2011. v. 2.

7 SCHNEIDER, S. A pluriatividade na agricultura familiar. 2 ed. Porto Alegre: UFRGS, 2009. p.

8 Organização das Nações Unidas para a Agricultura e Alimentação.

9 SALAMA, Pierre. Para uma nova compreensão da crise. In: SADER, Emir; GENTILI, Pablo. Pós-neoliberalismo: as políticas sociais e o estado democrático. Rio de Janeiro: Paz e Terra, 1995. 
O desafio proposto para a década de 1990 foi de fato romper com a ideia de agricultura de subsistência, agricultura desqualificada e a considerá-la como alternativa de produção, capaz de proporcionar ao trabalhador renda e ocupação digna e decente para o bem estar de sua família. De acordo com Sauer ${ }^{10}$, "a agricultura familiar é consolidada dentro dos movimentos sindicais, no âmbito acadêmico e governamentais".

O Censo Agropecuário de 2006, do Instituto Brasileiro de Geografia e Estatística (IBGE) ${ }^{11}$, revelou que a agricultura familiar foi responsável por 38\% dos valores produzidos no campo, sendo líder na produção de mandioca, feijão, leite de vaca, suínos, milho, arroz, café, trigo, ovos e soja, o que demostra a importância econômica da categoria, sendo digna de políticas públicas fortes e efetivas.

\section{Políticas públicas}

As áreas de estudos das políticas públicas surgem nos Estados Unidos e rompem com a linha europeia que se concentrava na análise do Estado e em suas instituições no que diz respeito à governação, à área de política pública, uma vez que, na Europa, surge como um desdobramento dos trabalhos baseados em explicações em torno das Teorias do Estado e do Estado em quanto componente institucionais - o governo —, produtor, por excelência, de políticas públicas. Entretanto nos Estado Unidos, acontece o contrário, inicia no mundo acadêmico sem estabelecer relações com as bases da Teoria do Estado, e passa direto para a ênfase nos estudos sobre a ação dos governos.

Para Heidemann ${ }^{12}$, o conceito de políticas públicas é descrito como "o conjunto de decisões e ações dos governos dos Estados nacionais, subnacionais e supranacionais juntamente com os outros sujeitos sociais". Ao percorrer o pensamento desse autor, podemos delimita três significados importantes atribuídos a nomenclatura "política". A primeira diz respeito a tudo que envolve a vida coletiva; a segunda é utilizada por grupos ou indivíduos para conquistar/manter o poder e, a terceira refere-se à arte de governar e gerir os bens coletivos - públicos - ao tratar os organismos sociais em sua totalidade e não na individualidade.

Essas delimitações nos conceitos de políticas públicas elencados acima estão localizadas no contexto operacional, sendo compreendidas como ações, práticas, diretrizes políticas embasadas em leis e empregadas por um governo para resolver as demandas sociais. Conforme destaca Teixeira (2002).

[...] diretrizes, princípios norteadores de ação do poder público: regras e procedimentos para as relações entre poder público e sociedade, mediações entre atores da sociedade e do Estado. São, neste caso, políticas explicitadas, sistematizadas ou formuladas em documentos (leis, programas, linhas de financiamento) que orientam ações que normalmente envolvem aplicações de recursos públicos.

Nessa perspectiva, as políticas públicas têm por objetivo primordial fornecer respostas as demandas sociais que se encontram vulneráveis na sociedade, além de fomentar o desenvolvimento, com medidas que gerem emprego e rendas, e serve também como mediador de conflitos entre outros sujeitos sociais que se encontram em desajustes.

Lucchese $^{13}$ ressalta que as políticas públicas podem ser entendidas como ações governamentais e podem ser de caráter direto do Estado na promoção de serviços ou indiretos na regulação das atividades econômicas, sociais, ambientais, culturais. Dessa forma, as políticas públicas podem sofrer variações conforme a

10 SAUER, Sérgio. Terra e modernidade: a dimensão do espaço na aventura da luta pela terra. 2002. ?f. Tese (Doutorado em Sociologia) - Universidade de Brasília, Brasília, 2002.

11 BRASIL. Instituto Brasileiro de Geografia e Estatística. Disponível em: <www.ibge.br>. Acesso em: 09 fev. 2015.

12 HEIDEMANN, F. G. Do sonho do progresso a política de desenvolvimento. In: HEIDEMANN, F. G.; SALM, J. F. Politicas públicas e desenvolvimento: base epistemológica e modelo de análise. Brasília: UNB, 2010.

13 LUCCHESE, P. Introdução: políticas públicas em saúde. Biblioteca Virtual em Saúde, 30 jul. de 2004. Disponível em: <http:// itd.bvs.br-mod/public/scripts/php/page_show_introdution.php?lang=pt\&menuId=2\&subject=healthPolicies\&search= $(\$) *($ intro dution/(channel))>. Acesso em: 20 jan. 2016. 
diversidade econômica, a realidade social, a percepção por parte dos governantes do papel que o Estado deve desempenhar nas intervenções e mediações entre as classes e grupos sociais, como partidos, ONGs, sindicatos, movimentos sociais, entre outros modos de organização da sociedade ${ }^{14}$.

É importante salientar que as políticas públicas são complexas e particulares para determinado tempo e espaço, ao passo que há a expectativa de sanar anomalias sociais que surgem do processo de desenvolvimento do país e que, ao passar do tempo, necessita de ajustes e recortes, tendo sempre um fim comum que é o de melhorar as condições de vida de um grupo de pessoas. Pochmann ${ }^{15}$ destaca que as "políticas públicas são essencialmente calcadas em um terreno de incertezas, onde as limitações orçamentárias, as transformações sociais e as readequações normativas podem interferir diretamente no andamento da ação do Estado".

Podemos ressaltar, ainda, que as políticas públicas se materializam mediante ações dos sujeitos sociais e de intervenções institucionais realizadas em contextos sociais particulares e que, dessa forma, condicionam seus resultados, ou seja, é na manifestação dos organismos sociais que as políticas são idealizadas, elaboradas, implementadas e efetivadas, para suprir demandas existentes e responder as questões sociais presentes no seio da sociedade.

Nessa perspectiva, as políticas públicas se tornam instrumentos do governo para intervir em vários setores da economia e da sociedade, como exemplo podemos utilizar o caso da agricultura. Para Delgado ${ }^{16}$, o Estado pode interferir de duas formas distintas ou dois tipos particulares de políticas e uma tem o caráter macroeconômico em que afetam os grandes agregados da econômica e as políticas setoriais e estas podem se subdividir no caso da agricultura em três formas, as políticas agrícolas, agrárias e política diferenciada de desenvolvimento rural.

A primeira delas, as políticas agrícolas são objetivas em influenciar os fatores estruturais como infraestrutura, tecnologia e também em relação à conjuntura dos mercados agropecuários e ao comportamento dos agricultores. Orientando e regularizando as condições de comercialização e financiamentos, as relações de preços de produtos, incentivos fiscais, são alguns exemplos de como esse modelo de políticas pode contribuir para o desenvolvimento local.

Rocha ${ }^{17}$ destaca que as políticas agrícolas são aquelas voltadas para as grandes propriedades e para os grandes latifúndios, enquanto a política agrária, de caráter meramente compensatório, destina-se em favor dos pequenos agricultores, sejam eles posseiros, indígenas, quilombolas e demais produtores.

Em um segundo momento e considerada como uma política estrutural de longo prazo, as políticas agrárias visam intervir da distribuição das terras, na regulamentação das posses e propriedades de terras no meio rural. Dessa forma a função desse modelo consiste em interferir na distribuição das terras por meio da reforma agrária e da ocupação de novos espaços considerados de fronteira agrícola por meio dos programas de colonizações.

Esses dois tipos de políticas compartilham em momentos de intersecção ao passo que a política agrícola sempre traz implícita uma política agrária determinada, ou seja, os instrumentos utilizados pela política agrícola podem influenciar ou determinar as estratégias de estrutura fundiária adotado. É o caso, da política de modernização conservadora que ocorreu na década de 1970 no Brasil, em que se determinaram as estruturas fundiárias brasileiras, com forte e intensa concentração de terra e renda, o que resultou em um agravamento social, decorrente das desigualdades sociais por ela criadas.

O terceiro modelo de política diz respeito às políticas ou programas diferenciados de desenvolvimento rural, os quais são meios de intervenção estatal no campo, sendo que estas políticas são destinadas a cam-

14 BOBBIO, N.; MATTEUCCI, N.; PASQUINO, G. Dicionário de politica. Tradução de Carmen C. Varrialle. Brasília: UnB, 1993.

15 POCHMANN, Marcio. Outra cidade é possivel. São Paulo: Cortez, 2003.

16 DELGADO, N. G. Política macroeconômica, ajuste externo e agricultura. In: LEITE, Sérgio. Políticas públicas e agricultura no Brasil. Porto Alegre: UFRGS, 2001.

17 ROCHA, J. H. de M. V. Políticas públicas voltadas para o desenvolvimento rural e educação técnica: uma reflexão. Caderno de Relações Internacionais e Desenvolvimento Regional, Boa Vista, n. 27, periodicidade, 2010. 
poneses empobrecidos e desapropriados de meios possíveis para sua manutenção. Tendo uma conotação de desenvolvimento regional, potencializa a produção dos pequenos produtores, tendo sempre em vistas os menos favorecidos, excluídos ou deixados a margem de políticas públicas que fomentavam apenas as grandes propriedades. Este modelo tem ainda a preocupação nas particularidades de cada região e formas de produção.

O debate teórico em torno das políticas públicas na concepção de Pereira (2009) ${ }^{18}$, trata como produto da dialética contraditória histórica e estrutura, portanto, reflexo do antagonismo entre "capital versus trabalho", "Estado versus sociedade", e dos princípios de igualdade e liberdade estabelecidos por Rousseau, e deve ser nutrido o debate nas teorias fundamentais das políticas públicas, o que podemos trazer para o viés do agrário, por meio das novas concepções do mundo rural e do desenvolvimento agrícola no país, ao trazer a realidade sócia histórica da desigualdade social brasileira.

Nessa perspectiva de política pública, podemos afirmar que as demandas dos trabalhadores rurais por créditos são manifestadas por ações sociais coletivas e reivindicatórias com a finalidade de suprir a dificuldades encontradas primordialmente da disputa de mercado desigual com o agronegócio, sempre favorecido pelo Estado frente aos pequenos produtores, que almejam mais espaço no cenário econômico e que só poderiam fazê-lo mediante acesso ao crédito.

Seguindo essa perspectiva, podemos reforçar esse debate com as afirmações trazidas por Paula ${ }^{19}$ que explicita essa característica ao dizer que "O PRONAF nasce com o objetivo de oferecer crédito rural aos pequenos agricultores rurais que se encontravam com dificuldade de se manter no campo", ao considerar diferentes estratos sociais, as políticas diferenciadas assumem particularidades e importante papel no contexto da inserção social e da distribuição da renda no Brasil.

O PRONAF é um exemplo de políticas diferenciadas para o desenvolvimento local, ao destinar atenção aos produtores familiares suprindo as demandas por créditos rurais, tendo linhas de créditos particulares para cada modalidade de produção e de produtores. Nesse sentido, SILVA ${ }^{20}$ afirma que "as políticas públicas orientadas ao microcrédito são importantes para corrigir ou ao menos minimizar certas assimetrias de informações que implicam em imperfeições na dinâmica do mercado de créditos tradicionais".

\section{PRONAF}

Possuidora de números expressivos na economia nacional e com crescente representação social, a agricultura familiar passou a reivindicar maior atenção do Estado, com políticas públicas que incentivassem a produção e que possibilitassem a permanecia dos trabalhadores no campo, fortalecendo ainda o desenvolvimento local.

Nesse sentido, a agricultura familiar passa a ser reconhecida por sua capacidade de produção, interferindo diretamente no Produto Interno Bruto - PIB brasileiro, levando em conta também influência na absorção de força de trabalho e, consequentemente, na geração de renda das famílias envolvidas na atividade, e assume o papel de protagonista de política pública voltada especificamente para o seu fortalecimento, com a criação do Plano Nacional de Fortalecimento da Agricultura Familiar (PRONAF), criado em 1995.

18 PEREIRA, Potyara A. P. Política social: temas e questões 2. ed. São Paulo: Cortez, 2009.

19 PAULA, E. K. L. de; Políticas públicas para a agricultura familiar: uma avaliação sobre a correspondência do PAA e do PRONAF nos territórios da Cidadania do Rio Grande do Norte - 2008 a 2010. 2012. 82f. Dissertação (Mestrado em Ciências Econômicas) Universidade Federal do Rio Grande do Norte, Natal, 2012.

20 SILVA, Sandro Pereira. Políticas públicas, agricultura familiar e desenvolvimento territorial: uma análise dos impactos socioeconômicos do PRONAF no território médio Jequitinhonha - MG. Brasília: IPEA, 2012. (Textos para discussão 1693). 
O PRONAF tem como seu marco legal o Decreto no 1.946 , de 28 de junho de 1996, assinado pelo então Presidente da República Fernando Henrique Cardoso, tendo por objetivo "promover o desenvolvimento sustentável do segmento rural constituído pelos agricultores familiares, de modo a propiciar-lhes o aumento da capacidade produtiva, a geração de empregos e a melhoria da renda" ${ }^{21}$.

Segundo o Banco Central do Brasil (2011), o PRONAF é um programa que se destina a oferecer crédito às atividades agropecuárias e não agropecuárias exploradas por produtores rurais e suas famílias, e pode financiar projetos individuais ou coletivos que fomentem a geração de renda para famílias agricultoras e aos assentados da reforma agrária.

O Programa Nacional de Fortalecimento da Agricultura Familiar foi a primeira conquista dos pequenos produtores rurais enquanto políticas pública efetiva, sendo resposta as demandas há muito reivindicadas pelos trabalhadores do campo motivada por pressões dos movimentos sociais e sociedade civil organizada pautada nos dados fornecidos por estudos realizados pelo Instituto Nacional de Colonização e Reforma Agrária (INCRA) em consórcio com a FAO (Food and Agriculture Organization of the United Organization) que atestavam a importância da agricultura familiar na participação econômica do Produto Interno Bruto (PIB) do país.

Para além disso, Carmo ${ }^{22}$ diz que, dentro das tendências mundiais, a agricultura sustentável insere-se como um campo promissor dentro das políticas de agricultura familiar, visto que suas potencialidades como sustentabilidade agrícola é entendida como um conjunto de técnicas capazes de minimizar impactos ambientais e sociais em curto prazo, para exemplificar e afixar a ideia de sustentabilidade na agricultura familiar, Moreira $^{23}$ destaca que:

[...] as tecnologias da biodiversidade parecem indicar para um uso mais intensivo da força de trabalho familiar bem como para a transformação de resíduos de alguns processos produtivos como insumos de outros. A implantação de tais procedimentos poderá levar à substituição progressiva dos insumos metal-mecânicos e químicos, o que poderá reduzir os custos monetários da produção agropecuária na medida em que os insumos das técnicas da sustentabilidade estiverem dissociados dos mercados. Estes processos apontam para uma redução dos custos monetários da produção agropecuária.

A agricultura familiar ganha espaço, com destaque na construção de um desenvolvimento baseado na não agressão ao meio ambiente, bem como nas perspectivas de reaproveitamento de resíduos, antes descartados, para a adubação, e, também, como defensivos naturais, além de possibilitar a diversificação da produção ao evitar que pragas se proliferem na plantação e, consequentemente, se elimina a utilização de agrotóxicos.

Contudo há necessidade de que as regras de poder e de controle se voltem ao acompanhamento das atividades no campo conexas ao meio ambiente, para que, além de agregarem valor, possam oferecer menor agravo aos recursos naturais, além de se enquadrar no contexto de políticas públicas que promovam a sustentabilidade para efeito de financiamento como é o caso do PRONAF.

O programa traz consigo a incumbência de dinamizar o espaço rural brasileiro, por meio da viabilização de uma série de ações, em especial as de construção de infraestrutura necessária e as de financiamento de crédito aos agricultores familiares. Essas ações se constituem em eixos objetivados para garantir o aumento da produtividade e de melhoria das condições de vida de uma população que sempre esteve à margem do processo de desenvolvimento e da modernização conservadora, ocorrida na agricultura brasileira a partir de meados da década de 1960.

21 BRASIL. Decreto n 1.946 de junho de 1996. Cria o Programa Nacional de Fortalecimento da Agricultura Familiar (PRONAF), e dá outras providências. Brasília: Congresso Nacional, 1996. p. 1. Disponível em:<http://goo.gl/Y9EDXq>. Acesso em: 09 fev. 2015.

22 CARMO, Maristela S. do. A produção familiar como locus ideal da agricultura sustentável, agricultura em São Paulo. São Paulo: Instituto de Economia Agrícola, 1998.

23 MOREIRA, Roberto José. Críticas ambientalistas à revolução verde: estudos sociedade e agricultura. BRAZILIAN CONGRESS OF RURAL ECONOMIC AND SOCIOLOGY - Sober, 37., Rio de Janeiro, 2000. 
A proposta do programa é o fortalecimento da agricultura familiar (PRONAF) que antes voltada para a subsistência, o que tem por objetivo geral para além de fortalecer a capacidade produtiva da agricultura familiar, também procura dinamizar a atividade e, por meio de toda essa cadeia produtiva, contribuir para a geração de emprego e renda nas áreas rurais, o que possibilita a melhora na qualidade de vida das famílias agricultoras.

No Brasil, esse modelo vem, desde sua redação, com o objetivo de alavancar o desenvolvimento rural por meio da relação da agricultura familiar e do desenvolvimento sustentável, que busca representar a inclusão do segmento da agricultura familiar na política pública brasileira, até então voltada somente para a agricultura de grande porte e, posteriormente, o agronegócio.

O PRONAF-M visa promover investimentos baseados em compromissos negociados entre os beneficiários, os poderes municipais e estaduais e a sociedade civil organizada para possibilitar: (i) a implantação, ampliação, modernização, racionalização e relocalização de infraestrutura necessária ao fortalecimento da agricultura familiar; e (ii) a ampliação e cobertura de serviços de apoio, a exemplo da pesquisa agropecuária e da assistência técnica e extensão rural. ${ }^{24}$

O PRONAF surge como divisor de águas na intervenção do Estado na agricultura e na ruralidade brasileira. O despontar dessa política vem ao encontro aos anseios de duas correntes sociais muito importantes, primeiramente os movimentos sociais que tencionam o Estado por transformações estruturais e por democratização de políticas públicas para a atividade, em um segundo momento, pelo reconhecimento dos intelectuais como categoria de análise social, econômica e política.

O debate atual sobre a noção de agricultura familiar foi intensificado devido a um fato político: a opção do governo de eleger essa forma de produção agrícola como protagonista do desenvolvimento rural, baseando-se em análises que atribuem à agricultura familiar condições mais favoráveis de competitividade quando comparada à agricultura patronal no que se refere aos rendimentos físicos obtidos e mesmo à capacidade de empregar mão de obra. ${ }^{25}$

Nesse sentido, o PRONAF marca um momento ímpar da história agrária no Brasil, datado de um comprometimento nunca antes visto ao setor, menosprezado como pequeno produtor, mas responsável por uma fatia expressiva da produção, na geração de emprego e do PIB nacional. E passa a ser percebida como catalizadora e mão de obra no campo.

A instituição do PRONAF como política pública nos remete à ideia de Pereira ${ }^{26}$, que afirma que: [...] o que chama a atenção nessa tendência é que o destaque dado ao social e à dimensão pública da política está ocorrendo numa época regida pela ideologia neoliberal em que a política como indicação de governo socialmente ativo e responsivo tornou-se um anacronismo.

Eleger a agricultura familiar como protagonista da política orientada para o desenvolvimento rural, apesar de todos os impasses da ação pública, não deixa de ser um indicativo de mudanças na orientação, ao menos no discurso, do governo em relação à agricultura e aos próprios agricultores, que procuram suprir o estado de bem-estar da categoria, relevante enquanto políticas a serem efetivadas e disponibilizadas ao alcance de todos os que delas necessitarem.

Nesta perspectiva, a incapacidade da unidade familiar de se sustentar exclusivamente da agricultura é vista como evidência de impossibilidade desse tipo de produtor de assimilar as demandas e a própria lógica do mercado e de incorporar as inovações tecnológicas. Por conseguinte, o seu enquadramento em uma categoria social periférica, acaba por reforçar e cristalizar a marginalização desse grande contingente da população rural que terá a sua sobrevivência dependente das políticas sociais sem que lhe seja atribuída a oportunidade de participar do desenvolvimento rural, aprofundando mais ainda o abismo entre as camadas sociais no campo. ${ }^{27}$

24 ABRAMOVAY, Ricardo; VEIGA, José Eli da. Novas instituições para o desenvolvimento rural: o caso do Programa Nacional de Fortalecimento da Agricultura Familiar (PRONAF). Brasília: IPEA, 1999.

25 CARNEIRO, M. J. Agricultores familiares e pluriatividade: tipologias e políticas. SEMINÁRIO O NOVO RURAL. Unicamp, 1999.

26 PEREIRA, P. A. P. Política social: temas e questões. 2. ed. São Paulo: Cortez, 2009.

27 CANEIRO, M. J. Politica pública e agricultura familiar: uma leitura do PRONAF. Rio de Janeiro: UFRRJ, 1997. (Estudos Sociedade 
$\mathrm{O}$ ataque neoliberal às forças produtivas menos expressivas nos levam a reflexão de outras questões ligadas à produção agrícola. O fato de a agricultura familiar ser vista atualmente como alternativa para a empregabilidade e renda no campo não pode ser a única a se analisar, é muito mais que isso, a agricultura conservadora possui uma incapacidade de produzir gêneros alimentícios que compõe a cesta básica do brasileiro, uma vez que esta tem o foco principal na produção de commodities, o que traz ao debate a questão da segurança alimentar. Por sua vez, também, esse modelo de produção não garante um controle do êxodo rural, pois tem na mecanização a troca de mão-de-obra humana por maquinários de última geração, conforme salienta Veiga ${ }^{28}$.

os países que hoje fazem parte do Primeiro Mundo optaram por não frear o progresso tecnológico e, por isso mesmo, adotaram no início deste século uma série de políticas que permitiram a regulação do êxodo rural e, sobretudo, um certo monitoramento do processo de transformação de atividades exclusivamente agrícolas na chamada "pluriatividade", isto é, a simbiose familiar de ocupações agrícolas e não-agrícolas.

Percebe-se que essas políticas adotadas no Brasil não vislumbram atender, apenas, ao combate à pobreza rural e à desigualdade, não tendo por objetivo somente a distribuição de renda. E torna-se importante destacar que o reflexo dessas políticas para a economia brasileira tem a nítido intensão de regular e inibir o êxodo rural, que abarrota a periferia das grandes cidades, implicando problemas estruturais da questão urbana, a indústria moderna não tem mais capacidade de empregar todos esses desempregados da cidade, desencadeando problemas sociais que fogem da capacidade do Estado em resolvê-los.

Nesse sentido, Polanyi ${ }^{29}$ já enfatizava que "o credo liberal só assumiu seu fervor evangélico em resposta às necessidades de uma economia de mercado plenamente desenvolvida", mas, de qualquer forma, não se pode negar a validade desse esforço do Estado em eleger a agricultura familiar com importante seguimento produtivo, social e econômico.

O mercado tem criado necessidades compensatórias de políticas que venha ao encontro do desemprego por ele mesmo gerado, atrelado às particularidades do desenvolvimento econômico brasileiro que precisa de intervenção do Estado na criação de política de emprego e renda, como destaca Alencar ${ }^{30}$ :

as políticas públicas de emprego e renda voltadas para o apoio e o incentivo aos pequenos empreendimentos econômicos são tributárias do conjunto de transformações econômicas, produtivas e organizacionais e que vêm conferindo uma nova centralidade às pequenas unidades econômicas.

O autor destaca que essas políticas de emprego e renda são de interesse do modelo neoliberal de contra reforma do Estado, em que este abandona o projeto de desenvolvimento econômico e social, desregulando e enfraquecendo a investida estatal de promover o bem estar social, ou seja, utilizando-se da desregulamentação e flexibilização das relações de trabalho, para tomar de assalto os direitos sociais conquistados pela classe trabalhadora, a fim de criar uma massa de desempregados, o que impulsionaria os salários para baixo, devido à grande oferta de mão de obra no mercado.

Em contrapartida, como política pública, o Pronaf é encarado claramente como meio de compensação. Para Carvalho "31, "a escandalosa desigualdade que concentra nas mãos de poucos a riqueza nacional tem como consequência níveis dolorosos de pobreza e miséria”, podemos perceber, então, a clara construção histórica da desigualdade da questão agrária brasileira e muito presente na atual conjuntura econômica, em

e Agricultura).

28 VEIGA, J. E. da. Pobreza rural, distribuição da riqueza e crescimento: a experiência brasileira. In. TEOFILO, E. (Org.) Distribuição de riqueza e crescimento econômico. Brasília: Núcleo de Estudos Agrários e Desenvolvimento Rural; Conselho Nacional de Desenvolvimento Rural Sustentável; Ministério do Desenvolvimento Agrário, 2000, p. 187.

29 POLANYI, Karl. A grande transformação: as origens de nossa época. Trad. Fanny Wrobel. 2. ed. São Paulo: Elsevier, 2012.

30 ALENCAR, M. M. T. de. As políticas públicas de emprego e renda no Brasil: do "nacional-desenvolvimento" ao "nacionalempreendedorismo". In. BEHRING, E. R.; ALMEIDA, M. H. T. de. (Org.). Trabalho e seguridade social: percursos e dilemas. 2 ed. São Paulo: Cortez; Rio de Janeiro: FSS/UERJ, 2010.

31 CARVAlHO, J. M. de. Cidadania no Brasil: um longo caminho. 13. ed. Rio de Janeiro: Civilização Brasileira, 2010. 
que o agronegócio e a produção de commodities em larga escala são elencados e privilegiados por incentivos fiscais e amplas linhas de créditos.

Quando se fala de políticas compensatórias, trata-se de reparar anomalias históricas na construção social do país, em que categorias, classes, segmentos da sociedade foram direta ou indiretamente excluídos e/ou colocados à margem do desenvolvimento social. Nesse sentido, cabe ao Estado intervir mediante ações afirmativas (políticas públicas) que tragam esses atores ao âmbito social de forma igualitária as demais nos terrenos de disputa.

Os programas de políticas públicas compensatórias servem para suprir uma demanda de exclusão social histórica e para alterar esse quadro discriminatório. São programas com características temporárias e focalizados em grupos discriminados. Tais grupos enfrentam a imagem preconceituosa de naturalidade e a falta de esforço pessoal. [...] Mas essa política tem o caráter de compensar discriminações passadas e permitir a abertura de uma inclusão social. Não é uma questão só de desigualdade social e econômica, e sim de acato à diversidade, pois a igualdade para todos significa todos terem as mesmas coisas; dar condições de vida às pessoas de acordo com os seus interesses, ainda que estas sejam diferentes." ${ }^{\text {32 }}$

O PRONAF tem uma característica peculiar enquanto política pública compensatória, pois visa alcançar os pequenos produtores. Ao longo do desenvolvimento rural do país, foram esquecidos e colocados à margem da evolução histórica da sociedade que é a garantia de cidadania aos trabalhadores que buscam seu sustento nas pequenas propriedades, e nesta perspectiva Marshall ${ }^{33}(1964$, p. 84$)$ destaca que:

a cidadania exige um elo de natureza diferente, um sentimento de direito de participação numa comunidade baseado numa lealdade a uma civilização que é um patrimônio comum. Compreende a lealdade de homens livres, imbuídos de direitos e protegidos por uma lei comum. Seu desenvolvimento é estimulado tanto pela luta para adquirir tais direitos quanto pelo gozo dos mesmos, uma vez adquiridos.

A cidadania nada mais é do que a conquista de direitos pela sociedade, grupos sociais, comunidades que garantam igualdade, justiça e liberdade entre os diferentes atores que figuram a questão social. Ainda podemos afirmar que a cidadania pode ser o conjunto de direitos conquistados ao longo dos anos e, nesse contexto, o PRONAF garante ao pequeno trabalhador rural as mesmas condições produtivas mediante financiamentos, já antes garantida ao agronegócio como um todo.

A celebre frase de Hannah Arendt ${ }^{34}$ "o direito a ter direito" define muito bem a cidadania no âmbito contemporâneo da sociedade, em que os poderes do Estado estão tomados por interesses particulares de uma bancada ruralista que legisla em favor do agronegócio, ou seja, em favor próprio e essa realidade se faz presente desde de a colonização e se arrasta até os dias atuais. As conquistas que garantam o pequeno produtor no campo e produzindo para a sua subsistência representam, de fato, uma conquista.

Dessa forma, devem ser comemorados os dados disponibilizados por Abramovay ${ }^{35}$ em seu relatório de pesquisa sobre o Pronaf em que ressaltou que, ao longo dos seus seis anos de existência do programa, elencam três importantes inovações, a saber: o reconhecimento dos agricultores familiares como protagonistas das políticas públicas; a criação de um processo de negociação entre os agricultores e suas organizações e o governo; e o estabelecimento de um enfoque territorial para as políticas públicas.

Essa política, ainda, precisa ser aprimorada e ampliada para que mais famílias sejam contempladas e suas vidas possam galgar novos patamares evolutivos, e serem associados a outros programas que fomente a produção de alimentos e um desses será tratado a seguir.

32 MENDES, A. M. C. P. et al. Políticas públicas, desenvolvimento e as transformações do Estado brasileiro. In. SILVA, C. L. da; SOUZA-LIMA, J. E. de. (Org.) Políticas públicas e indicadores para o desenvolvimento sustentável. São Paulo: Saraiva, 2010. p. 11-12.

33 MARSHALL, T. H.; Cidadania, classe social e status. Trad. Meton Porto Gadelha. Rio de Janeiro: Zahar, 1964.

34 ARENDT, Hannah. As origens do totalitarismo: antissemitismo, imperialismo, totalitarismo. Trad. Roberto Raposo. São Paulo: Companhia das Letras, 1989.

35 ABRAMOVAY, R. Relatório institucional da Secretaria da Agricultura Familiar. Brasília: PNUD, jun. 2002. (Relatório de Pesquisa, projeto BRA-98/012). 
Necessitamos destacar ainda que o PRONAF foi a porta de entrada de muitas famílias para a participação no mercado, além de garantir a estas a permanência no campo. Outro ponto que merece ser salientado é que foi a primeira de muitas outras políticas públicas que surgiram posteriormente para promover a agricultura familiar, principalmente o reconhecimento desta enquanto categoria econômica e social por meio da Lei n ${ }^{\circ}$ 11.326, de 24 de julho de 2006, conhecida como Lei da Agricultura Familiar, estabelece as diretrizes para a formulação da Política Nacional da Agricultura Familiar e Empreendimentos Familiares Rurais.

\section{Considerações finais}

A revisão literária apresentada, seguida de conceituação e discussão sobre as relações sociais do Pronaf e as influências sobre as famílias alcançadas, não podem ser encaradas como receita ou indicações infalíveis, mas como uma contribuição ao debate.

A democratização das políticas públicas representa um caminho promissor para a construção de uma nova realidade social, com desenvolvimento que seja além de econômico, sustentável, social e também políticos. As trajetórias possíveis de promoção social no meio rural são várias e a escolha de permanecer, investir, ou sair da agricultura depende, entre outros fatores, destas e outras políticas públicas voltadas para esse segmento.

Criar alternativas para fixar essas pessoas no campo significa diminuir a migração destas para as zonas urbanas, atraídas pela expectativa de melhores condições salariais e mudança no padrão de vida, o que já tem ocasionado acúmulo populacional nos centros urbanos, que corroboram a produção de desigualdades sociais em consequência, o que possibilita o aumento dos índices de criminalidade, miséria, entre tantos outros problemas resultantes da concentração de terras e renda presente no cenário brasileiro, e que é construído historicamente.

Aflorar o debate e estudo do caráter social da atividade rural é preciso, e nesse processo, ouvir os agricultores é fundamental, com os movimentos sociais do campo que pela experiência de anos de luta compreendem as principais demandas que carecem de solução e nessa perspectivas criar políticas verticalizadas impende que elas se efetivem, de fato, mas que proporcione ao campo a geração de emprego, a renda, e a permanência das famílias na zona rural, a atividade utiliza-se de métodos eficientes na distribuição de recurso no campo.

Percebemos também que o debate atual em torno da agricultura familiar se apresenta de forma polarizado em duas vertentes: de um lado, aqueles que pensam esse tipo de agricultura como objetivo pautado em projetos, e, de outro, os que querem estabelecer e implantar um conjunto de práticas ou regras produtivas voltadas para os movimentos sociais fazendo frente ao modelo de economicista de agricultura.

Nesse sentido é importante destacar a realização contínua de estudos sobre a agricultura familiar e as políticas públicas de distribuição, tendo como foco a produção de alimentos e a reprodução econômica e social dos sujeitos envolvidos. A agricultura familiar é um sistema economicamente viável que permite a utilização de técnicas que e conhecimentos empíricos das tradições populares, com o emprego de tecnologias modernas, eficazes que minimizem os impactos ao meio ambiente, mas que precisa de apoio público, muito embora não tenha representatividade política para fazer frente a bancada ruralista que sufoca o pequeno agricultor e privilegia os grandes fazendeiros.

Os agricultores familiares desenvolvem formas de organização social e de solidariedade, mas que ainda têm tímidos investimentos governamentais, para além do reconhecimento da atividade, que já existe. As políticas públicas necessitam de amplitude e a desburocratização do sistema de financiamento que existe e limita o acesso aos recursos do PRONAF precisa ser derrubada. Dessa forma, é possível facilitar para os trabalhadores que, na maioria das vezes, possuem pouca instrução. 
Pereira (2009) defende que, diante da política social, direitos sociais se concretizam e necessidades humanas são atendidas na perspectiva da cidadania ampliada. Por isso, de uma forma genérica, a agricultura familiar deve ser valorizada como segmento gerador de emprego e renda, de modo a estabelecer um padrão de desenvolvimento sustentável, o que resultaria na fixação de parte da população no campo.

Atualmente o meio rural, sempre visto como fonte de problemas, hoje aparece também como portador de soluções, vinculadas à melhoria do emprego, renda e da qualidade de vida, além da preservação ambiental que está entre as principais preocupações dos últimos tempos na sociedade, com a oferta de oportunidades de desenvolvimento humano em todas as regiões do país diversificando as economias locais a começar pela própria agropecuária.

Eleger a agricultura familiar como protagonista da política orientada para o desenvolvimento rural, apesar de todos os impasses da ação pública, não deixa de ser um indicativo de mudanças na orientação (ao menos no discurso) do governo em relação à agricultura e aos próprios agricultores, que procuram suprir o estado de bem estar da categoria.

\section{REFERÊNCIAS BIBLIOGRÁFICAS}

ABRAMOVAY, R. Relatório institucional da Secretaria da Agricultura Familiar. Brasilia: PNUD, jun. 2002. (Relatório de Pesquisa, projeto BRA-98/012).

ABRAMOVAY, Ricardo; VEIGA, José Eli da. Novas instituições para o desenvolvimento rural: o caso do Programa Nacional de Fortalecimento da Agricultura Familiar (PRONAF). Brasilia: IPEA, 1999.

ALENCAR, M. M. T. de. As políticas públicas de emprego e renda no Brasil: do "nacional-desenvolvimento" ao "nacional-empreendedorismo". In. BEHRING, E. R.; ALMEIDA, M. H. T. de. (Org.). Trabalho e seguridade social: percursos e dilemas. 2 ed. São Paulo: Cortez; Rio de Janeiro: FSS/UERJ, 2010.

ARENDT, Hannah. As origens do totalitarismo: antissemitismo, imperialismo, totalitarismo. Trad. Roberto Raposo. São Paulo: Companhia das Letras, 1989.

BRASIL. Decreto $n^{\circ} 1.946$ de junbo de 1996. Cria o Programa Nacional de Fortalecimento da Agricultura Familiar (PRONAF), e dá outras providências. Brasília: Congresso Nacional, 1996. Disponível em: < http:// goo.gl/Y9EDXq >. Acesso em: 09 fev. 2015.

BRASIL. Instituto Brasileiro de Geografia e Estatística. Disponível em: <www.ibge.br>. Acesso em: 09 fev. 2015. BOBBIO, N.; MATTEUCCI, N.; PASQUINO, G. Dicionário de Política. Tradução de Carmen C. Varrialle er al. Brasília: UnB, 1993.

CANEIRO, M. J. Politica pública e agricultura familiar: uma leitura do PRONAF. Rio de Janeiro: UFRRJ, 1997. (Revista Estudos Sociedade e Agricultura)

CARNEIRO, M. J. Agricultores familiares e pluriatividade: tipologias e políticas. SEMINÁRIO O NOVO RURAL. São Paulo: Unicamp, 1999.

CARMO, Maristela S. do. A produção familiar como locus ideal da agricultura sustentável, agricultura em São Paulo. São Paulo: Instituto de Economia Agrícola, 1998, pp. 1-15.

CARVALHO, J. M. de. Cidadania no Brasil: um longo caminho. 13. ed. Rio de Janeiro: Civilização Brasileira, 2010.

DELGADO, N. G. Política macroeconômica, ajuste externo e agricultura. In. LEITE, Sérgio. Políticas públicas e agricultura no Brasil. Porto Alegre: UFRGS, 2001. 
GOUGH, I. The political economy of the Welfare State. Traducción: Gregorio Rodriguez Cabrero. Madrid: Blume 1982.

HEIDEMANN, F. G. Do sonho do progresso a política de desenvolvimento. In: HEIDEMANN, F. G.; SALM, J. F. Políticas públicas e desenvolvimento: base epistemológica e modelo de análise. Brasília: UNB, 2010.

LUCCHESE, P. Introducão: políticas públicas em saúde. Biblioteca Virtual em Saúde, 30 jul. 2004. Disponível em: <http://itd.bvs.br-mod/public/scripts/php/page_show_introdution.php?lang=pt\&menuId=2\&subj ect=healthPolicies\&search $=(\$) *($ introdution/(channel) $)>$. Acesso em: 20 de jan. de 2016.

MARSHALL, T. H. Cidadania, classe social e status. Trad. Meton Porto Gadelha. Rio de Janeiro: Zahar, 1964.

MARX, K. O capital: crítica da economia política. Tradução de Reginaldo Sant'Anna. 29. ed. Rio de Janeiro: Civilização brasileira, 2011. v.2.

MENDES, A. M. C. P. et al. Políticas públicas, desenvolvimento e as transformações do Estado brasileiro. In. SILVA, C. L. da; SOUZA-LIMA, J. E. de. (Org.) Politicas públicas e indicadores para o desenvolvimento sustentável. São Paulo: Saraiva, 2010.

MOREIRA, Roberto José. Críticas ambientalistas à revolução verde: estudos sociedade e agricultura. BRAZILIAN CONGRESS OF RURAL ECONOMIC AND SOCIOLOGY - Sober, 37., Rio de Janeiro, 2000.

NETTO, J. P.; BRAZ, M. Economia política: uma introdução crítica. 5. ed. São Paulo: Cortez, 2009.

PAULA, E. K. L. de; Políticas públicas para a agricultura familiar: uma avaliação sobre a correspondência do PAA e do PRONAF nos territórios da Cidadania do Rio Grande do Norte - 2008 a 2010. 2012. 82f. Dissertação (Mestrado em Ciências Econômicas) - Universidade Federal do Rio Grande do Norte, Natal, 2012.

PEREIRA, Potyara A. P. Politica social: temas e questões 2. ed. São Paulo: Cortez, 2009.

POCHMANN, Marcio. Outra cidade é possivel. São Paulo: Cortez, 2003.

POLANYI, K. A grande transformação: as origens da nossa época. Trad. Fanny Wrobel. 2. ed. Rio de Janeiro: Elsevier, 2000.

ROCHA, J. H. de M. V. Políticas públicas voltadas para o desenvolvimento rural e educação técnica: uma reflexão. Caderno de Relacõoes Internacionais e Desenvolvimento Regional, Boa Vista, n. 27, 2010.

SALAMA, Pierre. Para uma nova compreensão da crise. In: SADER, Emir. GENTILI, Pablo. Pós-neoliberalismo: as políticas sociais e o estado democrático. Rio de Janeiro: Paz e Terra, 1995, p. 53.

SAUER, Sérgio. Terra e modernidade: a dimensão do espaço na aventura da luta pela terra. 2002. ?f. Tese (Doutorado em Sociologia) - Universidade de Brasília, Brasília, 2002.

SCHNEIDER, S. A pluriatividade na agricultura familiar. 2. ed. Porto Alegre:UFRGS, 2009.

SILVA, Sandro Pereira. Políticas públicas, agricultura familiar e desenvolvimento territorial: uma análise dos impactos socioeconômicos do PRONAF no território médio Jequitinhonha - MG. Brasília: IPEA Textos para discussão 1693, 2012.

TEIXEIRA, E. C. O papel das políticas públicas no desenvolvimento local e na transformação da realidade. Disponível em:<www.aatr.org.br>. Acesso em: abr. de 2014.

VEIGA, J. E. da. Pobreza rural, distribuição da riqueza e crescimento: a experiência brasileira. In. TEOFILO, E. (Org.) Distribuição de riqueza e crescimento econômico. Brasília: Núcleo de Estudos Agrários e Desenvolvimento Rural; Conselho Nacional de Desenvolvimento Rural Sustentável; Ministério do Desenvolvimento Agrário 2000, p. $187-200$. 


\section{Ativismo judicial e promoção da cidadania: desafios para a efetivação dos direitos sociais constitucionalizados*}

\author{
Judicial activism and promoting citizenship: \\ challenges for the implementation of social \\ rights constitutional
}

\author{
Gerardo Clésio Maia Arruda** \\ Adriana Rossas Bertolini*** \\ Jânio Pereira Cunha ${ }^{* * * *}$
}

* Recebido em 14/04/2016

Aprovado em 22/06/2016

** Doutor e mestre em sociologia, especialista em geografia e graduado em ciências econômicas. Professor de sociologia jurídica do Centro Universitário Christus (UNICRISTUS) e da Universidade de Fortaleza (UNIFOR)

*** Mestranda em direito internacional pela Universidade de Lisboa e graduada em direito pela Universidade de Fortaleza (UNIFOR)

Doutor e mestre em direito constitucional. Professor do Centro Uniiversitário Christus (UNICHRISTUS) e da Universidade de Fortaleza (UNIFOR).

\section{Resumo}

O artigo objetiva desenvolver uma reflexão acerca dos obstáculos que se interpõe à efetivação dos comandos constitucionais concernentes aos direitos sociais no Brasil, assim inibindo a extensão do status de cidadania para os membros de todos os segmentos populacionais. As análises se apoiam em fatores socioeconômicos e sociopolíticos estruturais que corroboram para a limitação e instabilidade da forma sujeito de direito. Com esse intuito, o trabalho foi dividido em três tópicos. No primeiro, faz-se um exame dos aspectos da cidadania e da sua evolução no capitalismo industrial; no segundo tópico, realiza-se um esforço para trazer à luz a dinâmica do processo de industrialização brasileiro, caracterizado como uma modernização conservadora, onde se institucionalizou práticas fundantes de uma estrutura social, cultural, política e econômica desigual, que erigiu um hiato secular entre os despossuídos de bens materiais e simbólicos e os que possuem amplo acesso a riqueza coletivamente produzida; por último, analisa-se o ativismo jurídico enquanto fenômeno capaz de atribuir sentido factível aos fundamentos constitucionais realizadores da cidadania. A metodologia adotada no estudo privilegiou a pesquisa bibliográfica, considerando que o objeto reivindica uma abordagem que contemple, simultaneamente, os campos jurídico-político, econômico e sociocultural. As ilações realizadas estão assentadas em análises de caráter descritiva e exploratória, alicerçada numa perspectiva multidisciplinar. Conclui o artigo que o poder judiciário é extremamente limitado na sua capacidade de promover a efetivação e ampliação dos direitos sociais.

Palavras-Chaves: Ativismo Judicial; Direitos Sociais; Cidadania; Desigualdade Social.

\section{Abstract:}

This article goal is to develop a reflection about the obstacle that interposes the realization of constitutionals concerning social rights in Brazil, 
therefore inhibiting the extension of citizenship status towards members of all populacional segments. The analyses are supported in socioeconomic and socio-political structural factors that corroborate to limit the instability of form under the law. This strengthening of this study was composed in three topics. The first is made an study of citizenship aspects and its evolution on industrial capitalism, the second topic, held an effort to bring to light the dynamic of Brazilian industrialization process, distinguished as a conservative modernization, where were instutionalized the founding practices of our social, cultural, political and economic unequal structure, that has erected a secular gap between economic good and symbolic dispossessed and the ones that possessed wider access to the benefits of wealth that were collectively produced; Finally, is examined the juridical activism while phenomenon capable of apply feasible meaning to the constitutional founding citizenship maker. The approach adopted focused on bibliographic research, regarding the goal that claim, simultaneously, the juridic-political, economic and sociocultural field. The connections made are settled in detailed analyse and exploratory, supported by a multifocused perspective. The article is concluded by the juridical power being extremely limited in its capacity to promote effective and wide social rights.

Key-Words: Juridical Activism, Social Rights, Citizenship, Social Inequality

\section{INTRODUÇÃo}

Entre 1995 e 2008 ocorreu uma redução de 33,6\% de pessoas sobrevivendo na situação de pobreza absoluta, resultado de um conjunto de medidas, dentre outras, que compreende o aumento real do salário mínimo, ampliação do número de empregos formais e políticas assistenciais compensatórias. Entretanto, a quantidade de indivíduos nessa condição socioeconômica, ou seja, com rendimento médio domiciliar per capita de até meio salário mínimo mensal, no ano de 2008 , alcançava um percentual de $28,8 \%$ da população total $^{1}$. A formação deste quase um terço populacional de pessoas imersas nessa condição de vida remonta ao período colonial, quando se instituiu o modelo econômico assentado na empresa agroexportadora. Enraízam-se aí as bases do monopólio da terra e da produção de riqueza, que originaram uma política excludente, alicerce sobre o qual se erigiu as barreiras impeditivas para o desenvolvimento da cidadania. Isto porque a reprodução do poder econômico e político aí instituído engendrou os mecanismos de apropriação extremamente desproporcional da riqueza, elemento determinante para a formação do estrato populacional que mesmo após a modernização industrial se manteve à margem dos direitos promotores da dignidade humana, como à alimentação, trabalho, saúde, educação, cultura, lazer e habitação.

A trajetória da modernização industrial, simultaneamente ao republicanismo, consolidou um modelo de sociabilidade no Brasil, com base num crescimento econômico com exclusão social, que viabilizou a acumulação de capital através de uma política protecionista às empresas nacionais associada a uma regulação que escorchou o salário e impediu a organização política dos trabalhadores. Estas foram as bases sobre a qual se edificou uma sociedade permeada de contradições, que combina a detenção do sétimo Produto Interno Bruto (PIB) mais elevado do planeta com um Índice de Desenvolvimento Humano (IDH) que a situa na octogésima quarta colocação mundial; uma estrutura social extremada no concernente à distribuição da riqueza, de sorte que, em 2013 , verificou-se que $10 \%$ da população detinha $40 \%$ da renda nacional e $42 \%$ limitava-se a $13 \% .^{2}$

A construção desse bolsão de pobreza no interior da sociedade brasileira é o resultado de uma estrutura político-econômica que organizou uma sociedade de baixa mobilidade social, atualmente, segmentada num grupo diminuto da população que detém o poder econômico e, por decorrência, o poder político; um grupo

1 BRASIL. Instituto de Pesquisa Econômica Aplicada (IPEA). Dimensão, evolução e projeção da pobreza por região e por estado no Brasil. Rio de Janeiro: IPEA, 2010.

2 PNUD. Programa das Nações Unidas para o Desenvolvimento. Relatório de Desenvolvimento Humano 2013. Disponível em: www.pnud.org.br/arquivos/rdh-2013.pdf. Acesso em: 10/04/2016. 
beneficiário das políticas públicas concedidas pela anterior, com acesso à educação, habitação, saúde e lazer de qualidade comparada às das sociedades europeias de bem-estar social; um outro, plasmado em todo o espaço territorial, os produtores da riqueza nas inumeráveis atividades produtivas e que, no fio da navalha, desafia o dia a dia sonhando em reproduzir-se nas condições do grupo anterior, mas que, na realidade, está mais próximo do um terço imerso na miséria, que são os destituídos até mesmo da possibilidade de sonhar.

Portanto, para entender a formação da pobreza no Brasil é preciso uma análise que coteje os elementos que substanciam o processo de exclusão, que antes de ser social é econômico, político e cultural. E a análise conjuntural, entendida como o estudo de um fenômeno no aqui e agora, considerando as variáveis que influem na conformação da situação enfocada, é um caminho insuficiente para identificar suas causas. Isto porque, ao se compreender a pobreza como fenômeno social, o seu entendimento só se efetiva verdadeiramente quando se procura interpretar o seu fazer-se no presente à luz de sua construção histórica, pois o agir humano no tempo presente é influenciado pelos costumes e hábitos enraizados.

É verdade que o Brasil atual avançou significativamente na estruturação de um sistema jurídico de proteção social, principalmente com a promulgação da Constituição de 1988. A previsão de um extenso catálogo de direitos sociais nesse documento, no entanto, é somente um ponto de partida para a sua realização. E a razão disso é que, apesar do aspecto sobremodo positivo e necessário de um marco normativo de direitos e garantias fundamentais das pessoas, a efetivação concreta dos bens e serviços essenciais à promoção da cidadania depende de uma atuação ativa e republicana do Poder Judiciário, mas, essencialmente, de políticas públicas desenvolvidas pelos Poderes Legislativo e Executivo, a fim de implementar os objetivos fundamentais da República Federativa do Brasil, em especial a realização de uma sociedade livre, justa e solidária, o que implica, antes de tudo, a eliminação da pobreza e da miséria e a redução das desigualdades sociais. O Judiciário, rigorosamente falando, é um poder fundamental em Estados democráticos de direito, mas, ante os seus limites jurídicos e em razão dos condicionantes históricos desfavoráveis à efetivação dos direitos fundamentais, o problema de promoção da cidadania é mais político, econômico e cultural do que jurídico.

\section{O STATUS DE CIDADANIA NO CAPITALISMO INDUSTRIAL}

Ao se abordar o tema cidadania é sempre recomendável, mesmo que sumariamente, referenciar as causas que historicamente se constituíram como pilares do padrão evolutivo dos direitos republicanos. Isto porque a noção moderna de cidadania está assentada na concepção ocidental de Estado, política e espaço público. Assim, o tema remete para a Antiguidade Clássica, uma vez que aí se localizam embrionariamente os elementos substantivos das ideias primeiras da vida pública animada a partir da cooptação e inclusão de grupos emergentes, notadamente os comerciantes e militares. A convivência social formatada com base nesta premissa favoreceu o desenvolvimento de um campo político perquiridor da organização e regulamentação. A valorização da vida pública entre os gregos antigos foi-se tornando crescentemente significativa à medida que seus participantes iam compondo um campo político densamente participativo, em que pululavam opiniões, votações e julgamentos. Eis o cenário germinador do entendimento de cidadania alicerçado na ideia de pertencimento e participação nos destinos da coletividade.

O movimento iluminista recuperou e atribuiu universalidade ao conceito de cidadania no rastro da emergência política da burguesia renascentista, palmilhada pelo crescimento econômico comercial e o desenvolvimento tecnológico marítimo, que associado ao pensamento filosófico e científico, erodiu as estruturas da sociedade feudal, ou seja, de sua economia agrária, sua forma de governo e seus padrões de dominação e ordenamento jurídico. Vivia-se um momento em que se ansiava por uma nova ordem político-jurídica, de sorte a ampliar o espaço dos debates públicos, permitir a apreciação pública do exercício do poder do soberano e, sobremaneira, destravar as amarras impeditivas da expansão dos mercados. A cidadania moldada pela ascensão política da burguesia moderna proclamava a igualdade entre aqueles que constituíam as nações 
recém instituídas, de tal maneira a estabelecer condições legítimas de participação na vida pública de seus membros sob a égide protetora do Estado-nação.

Outrossim, o surgimento da ideia de que os homens são portadores, simultaneamente, de direitos e deveres, originou-se juntamente com a concepção e institucionalização do Estado moderno no transcurso do século XVIII. Este ambiente propiciou a inauguração de um modelo de consecução de normas legislativas substancialmente transformadoras da concepção de desigualdade e de igualdade entre os homens na esfera jurídica. Assim, como resultado da construção histórica deste modelo de sociabilidade, o indivíduo ascendeu a condição de superior e anterior ao Estado.

O poder, como deslindado nos pensamentos de Hobbes, Locke e Rousseau, torna-se a partir daí uma construção derivada de consensos contextuais, uma estrutura contraditória erigida com base em interesses antagônicos. Concepção esta que ocasionou profundas mudanças na dimensão jurídica, fermento no qual se gestaram declarações de direitos, como a Declaração de Virgínia, de 1776, e a Declaração da França, de 1789. Ordenamentos que, segundo LAFER, representou "o triunfo do individualismo no sentido mais amplo"3. Uma vez que estes marcos normativos inauguraram a Era dos Direitos, o que incrustou na cultura ocidental os direitos do homem como elemento obrigatório nas agendas de debates político-jurídicos dos Estados modernos.

A cidadania enquanto ideia basilar da promoção de justiça social e, por conseguinte, na geração de bem-estar recrudesceu na trajetória de um longo e contínuo debate remonta a aproximadamente 300 anos. A reflexão de MARSHALL ${ }^{4}$, que contempla o desenvolvimento econômico e tecnológico e suas consequências sobre as instituições e valores políticos, salienta a interdependência existente entre os processos de mudanças dos direitos nos Estados modernos e o estabelecimento de uma distinção entre cidadanias civil, política e social. O desenvolvimento de suas ideias traz à luz a relação entre a crescente igualdade política e o constante refreamento da desigualdade econômica. Com isto, demonstra que por intermédio do alargamento da participação política foram-se verificando mudanças qualitativas nas estruturas sociais. No quadro a seguir faz-se uma síntese contextual relacionando as formas de Estado e os seus desdobramentos no concernente aos marcos ordenadores e os reflexos sobre a compreensão e abrangência do status de cidadania

Quadro I - Relação Estado, direito e cidadania

\begin{tabular}{|c|c|c|c|}
\hline Forma Política de Estado & Principais Dispositivos Legais & $\begin{array}{c}\text { Direitos } \\
\text { Conquistados }\end{array}$ & $\begin{array}{c}\text { Status de Cidadania } \\
\text { para Marshall }\end{array}$ \\
\hline $\begin{array}{l}\text { Estado Liberal } \\
\text { (séc. XVIII) }\end{array}$ & $\begin{array}{c}\text { Declaração de Direitos de Virgínia de } \\
1776 \text { e a Declaração de Direitos da } \\
\text { França de } 1789\end{array}$ & Direitos Civis & Cidadania Civil \\
\hline $\begin{array}{l}\text { Estado Liberal } \\
\text { Democrático } \\
\text { (séc. XIX) }\end{array}$ & Constituição Inglesa de 1832 & Direitos Políticos & Cidadania Política \\
\hline Estado Social (séc. XX) & $\begin{array}{c}\text { Constituição Mexicana de } 1917 \\
\text { Constituição de Weimar de } 1919\end{array}$ & Direitos Sociais & Cidadania Social \\
\hline
\end{tabular}

Fonte: Marshall; elaboração própria.

Neste diapasão, os direitos civis teriam surgido no século XVIII, os direitos políticos no século XIX e os direitos sociais no século XX. A emergência de modo sequencial dos direitos fundantes do status da cidadania enquanto fenômeno histórico, aparece no pensamento de Marshall, para além de uma sequência cronológica, como uma lógica assentada na trajetória da marcha civilizatória ocidental. Esta formulação levou CARVALHO a discorrer acerca do exemplo Inglês como o da cidadania sequencialmente constituído a partir das dimensões civis, políticos e sociais:

3 LAFER, Celso. Ensaios liberais. São Paulo: Siciliano, 1991. p.36

4 MARSHALL, T. H. Cidadania, classe social e status. Rio de Janeiro: Zahar, 1967. 
Foi com base no exercício dos direitos civis, nas liberdades civis, que os ingleses reivindicaram o direito de votar, de participar do governo de seu país. A participação permitiu a eleição de operários e a criação do Partido Trabalhista, que foram os responsáveis pela introdução dos direitos sociais. ${ }^{5}$

A cidadania entendida em seu amplo sentido, após consolidação da sociedade industrial, como sendo investido dos três direitos. Os direitos civis compreendem os direitos necessários à liberdade individual, ou seja, a liberdade de ir e vir, de manifestar pensamento, o direito à propriedade, de organizar-se, e o direito à justiça eficiente, independente e acessível a todos. Este último se refere ao direito de defender-se, do direito ao devido processo legal. Os direitos políticos, por sua vez, relacionam-se com o direito de participação do cidadão no governo da cidade. E, por fim, os direitos sociais referem-se ao direito do cidadão a um mínimo de bem-estar econômico e segurança; portanto, como explicita MARSHALL ${ }^{6}$, ao direito de trabalhar, no lugar de escolha, sujeito apenas à legitima exigência do treinamento técnico preliminar.

Os direitos civis, ou liberdades civis, surgiram com as Declarações de direitos de Virgínia de 1776 e a Declaração da França em 1789, como axioma econômico de liberdade de comércio, como já foi mencionado, elemento fundante do processo de ruptura com a economia agrária do velho regime feudal, e na completa liberdade de cada indivíduo dispor de seu tempo e de seu trabalho na maneira que julgue melhor para seus interesses. Nas palavras de $\mathrm{BOBBIO}^{7}$, entre eles, estão "todos aqueles direitos que tendem a limitar o poder do Estado e a reservar para o indivíduo, ou para os grupos particulares, uma esfera de liberdade em relação ao Estado". Tratam-se dos chamados direitos negativos, ou seja, os direitos estabelecidos contra o Estado, basilares para separação entre a esfera pública e a esfera privada, característica da sociedade moderna e sustentáculo do pensamento liberal e democrático. Pois, como explicita TOCQUEVILLE ${ }^{8}$, o desejo por igualdade de condições, por democracia e liberdade, possibilitou o triunfo do Estado Liberal, resultado das revoluções americana de 1776 e francesa de 1789, que patrocinaram por sua vez, o desenvolvimento dos direitos individuais no século XVIII.

O desdobramento natural dos direitos civis fez surgir no início do século XIX, os denominados direitos políticos ou liberdades políticas, formados com a conquista da liberdade e do status de cidadania ligados aos direitos civis. De início não se tratava da criação de novos direitos, mas de alargamento do status já gozado por todos, uma vez que se resumia a doação de velhos direitos a novos setores da população?. De todo modo, os direitos políticos se alteraram para a condição de status pessoal e não mais econômico, dado que anteriormente os direitos políticos se constituíam em privilégios de classes econômicas favorecidas. De acordo com BEDIN ${ }^{10}$, "esta segunda geração de direitos, por outro lado, se caracteriza ou se distingue pelo fato de os direitos por ela compreendidos serem considerados direitos positivos, isto é, direitos de participar no Estado". Deste modo, o direito do indivíduo de participar da formação do poder do Estado apresenta-se pelo direito ao sufrágio universal, o direito de constituir partidos políticos e pelo direito de plebiscito, de referendo e de iniciativa popular.

A consolidação da sociedade industrial recrudesceu as demandas por direitos econômicos e sociais na tentativa de diminuir o ônus da pobreza e das desigualdades produzidas pelo sistema liberal capitalista ${ }^{11}$. Um

5 CARVAlHO, José Murilo de. Cidadania no Brasil: o longo caminho. 16a ed. Rio de Janeiro: Civilização brasileira, 2013 . p.11.

6 MARSHALL, T. H. Cidadania, classe social e status. Rio de Janeiro: Zahar, 1967.

7 BOBBIO, Norberto. A era dos direitos. Nova ed. Rio de Janeiro: Elsevier, 2004. p.32.

8 TOCQUEVILLE, Aléxis de. A democracia na América: leis e costumes. São Paulo: Martins Fontes, 1998.

9 MARSHALL, T. H. Cidadania, classe social e status. Rio de Janeiro: Zahar, 1967.

10 BEDIN, Gilmar Antonio. Os direitos do homem e o neoliberalismo. $3^{\text {a }}$ ed. Ijuí-Rio Grande do Sul: 2002. p. 56.

11 Karl MARX, denunciou a crescente polarização de interesses materiais no Estado Liberal, com nitidez até então única; mostrou que as classes sociais passaram a ter distinções econômicas e com efeito, tornaram-se mais móvel e instável. MARX, Karl. O capital: crítica da economia política. São Paulo: Abril cultural, 1988. Apoiado na perspectiva de análise materialista histórica, SOUZA enfatiza que "o liberalismo produziu os abastados e os paupérrimos, deixando entre eles um claro na escala das riquezas. Aqueles possuindo mais do que o supérfluo; estes, menos do que o indispensável. Ambos corrompidos e desumanizados: uns, pela opulência, outros, pela miséria. Aí está a simples desigualdade econômica, nítida como num esquema. As outras desigualdades vieram depois: a política, pela dependência econômica dos necessitados; a jurídica, porque os abastados, valendo-se da sua pre- 
movimento também influenciado, na segunda década do século XX, pelos seguintes eventos: Revolução Russa, Constituição Mexicana de 1917 e Constituição de Weimar de 1919. Na esfera internacional, foram reconhecidos em 1948 por intermédio da Declaração Universal dos Direitos Humanos da ONU e, posteriormente, pelo Pacto Internacional dos Direitos Econômicos, Sociais e Culturais, em 1966. FONSECA ${ }^{12}$, resume a propagação da ideia de combate de redução da pobreza e da luta pela melhoria da qualidade de vida, ao afirmar que, "quer no bloco socialista, quer no ocidente, surge e se impõe cada vez mais um conjunto de normas que tem por finalidade conduzir, regrar, disciplinar o fenômeno econômico".

Os direitos sociais, portanto, são compreendidos como direitos de crédito, em que o Estado se torna devedor dos indivíduos, principalmente os marginalizados e os trabalhadores, de tal maneira a garantir um patamar mínimo de igualdade e bem-estar social. Estes direitos, como esclarece BEDIN ${ }^{13}$, não são direitos estabelecidos "contra o Estado" ou direitos de "participar no Estado", mas sim direitos garantidos "através ou por meio do Estado". Outrossim, os direitos sociais e econômicos, compreendem os direitos do homem trabalhador, do direito à seguridade social, direito à educação, direito à alimentação, direito à habitação, direito à saúde e direito à segurança. O que leva MARSHALL ${ }^{14}$ a propugnar a cidadania social como instrumento investidor dos indivíduos ao acesso à padrões básicos de vida e, consequentemente, habilitador de suas possibilidades de participar em condições minimante igualitárias enquanto membros de uma comunidade.

A conquista de direitos, sempre se deu dentro da conjuntura política do Estado-Nação. Para CARVA$\mathrm{LHO}^{15}$, "isto quer dizer que a construção da cidadania tem a ver com a relação das pessoas com o Estado e com a nação. As pessoas se tornavam cidadãs à medida que passavam a se sentir parte de uma nação e de um Estado". Assim, como explicita ainda o autor, tem-se que, em alguns países, o Estado teve maior participação na promoção de direitos, em outros, foi necessária uma maior ação dos próprios cidadãos para efetivá-los.

Os diretos sociais e a cidadania social continuam em constante movimento, bem como as demandas para proteção desse status, intensificadas no pós-segunda guerra, marco na evolução destes direitos ${ }^{16}$. No Brasil, a Constituição de 1988 mereceu título de Constituição Cidadã pelo caráter liberal e democrático de seu texto. No entanto, o percurso de aquisição desses direitos não seguiu a mesma sequência descrita por MARSHALL:

Aqui, primeiro vieram os direitos sociais, implantados em período de supressão dos direitos políticos e redução dos direitos civis por um ditador que tornou popular. Depois vieram os direitos políticos, de maneira também bizarra. A maior expansão do direito do voto deu-se em outro período ditatorial e que os órgãos de representação política foram transformados em peça decorativa do regime. Finalmente, ainda hoje muitos direitos civis, a base da sequência de Marshall, continuam pouco acessível à maioria da população. A pirâmide dos direitos foi colocada de cabeça para baixo. ${ }^{17}$

A inversão da sequência no caminho da cidadania no Brasil provocou impactos na democracia brasileira e na noção prática de participação da sociedade, principalmente no que tange à solução de problemas

ponderância política, obtiveram o monopólio da função legislativa; a orgânica, a mental, a intelectual, a moral e todas as demais, porque a miséria acarreta a debilidade, o atraso do espírito, a ignorância, a degradação dos sentimentos”. SOUZA, Daniel Coelho de. Interpretação e democracia. $2^{a}$ ed. São Paulo: Revista dos tribunais, 1979. p. 149. Portanto, a tensão econômica bipolar, na sociedade liberal do século XIX e início do século XX, influenciou a progressiva mudança nos sistemas político e jurídico do período, resultando no nascimento dos direitos sociais e econômicos.

12 FONSECA, João Bosco Leopoldino da. Direito econômico. $4^{\mathrm{a}}$ ed. Rio de Janeiro: Forense, 2001. p. 10.

13 BEDIN, Gilmar Antonio. Os direitos do homem e o neoliberalismo. $3^{\text {a }}$ ed. Ijuí-Rio Grande do Sul: 2002 . p. 62.

14 MARSHALL, T. H. Cidadania, classe social e status. Rio de Janeiro: Zahar, 1967.

15 CARVALHO, José Murilo de. Cidadania no Brasil: o longo caminho. 16ª ed. Rio de Janeiro: Civilização brasileira, $2013 . p .12$.

16 O respeito à dignidade humana passou a ser considerado princípio basilar das Constituições promulgadas neste período, disciplinando a ordem econômica e social. A Constituição brasileira de 1988, destaca a dignidade da pessoa humana no art. $1^{\circ}$, III, no título I, relativo aos princípios fundamentais da República Federativa do Brasil. Para ilustrar a intensidade em consagrar o princípio, basta observar os textos de algumas Constituições: na França o princípio ficou implícito nos incisos $10^{\circ}$ e $11^{\circ}$ do Preâmbulo da Constituição de 1946, na Itália de 1947 (art. 3º), Alemanha de 1949 (art. 1.1), Portugal de 1976 (art. $1^{\circ}$ ), Espanha de 1978 (art. 10), Colômbia de 1991 (art. 1º), Rússia de 1993 (art. 21), África do Sul de 1996 (arts. 1, $10^{\circ}$ e 39º e Venezuela de 1999 (Preâmbulo).

17 CARVALHO, José Murilo de. Cidadania no Brasil: o longo caminho. 16ª ed. Rio de Janeiro: Civilização brasileira, $2013 . p .219$. 
sociais. Entretanto, o longo processo de aquisição de direitos sociais não foi capaz ainda de enfrentar fortemente as desigualdades entre os pertencentes aos andares de cima e de baixo da pirâmide social brasileira. Porém, deve ser observado que mais recentemente na história republicana houve substancial avanço na participação política, sobretudo no concernente às ações demandantes de políticas públicas garantidoras de direitos sociais. Esse processo, por sua vez, vem se refletindo, paulatinamente, em pressão popular pelo alargamento dos direitos civis, uma vez que se assiste a movimentos reivindicativos de um judiciário mais ativo e mais independente do poder executivo, principalmente após a redemocratização ${ }^{18}$ do país após a promulgação da Constituição de 1988. Neste contexto, vários segmentos da sociedade passaram a buscar proteção de seus interesses perante juízes e tribunais. Para BARROSO ${ }^{19}$, essa tendência constitui-se numa das causas do fenômeno do ativismo judicial presente hoje não apenas na realidade brasileira, mas com fluidez no mundo contemporâneo.

\section{Modernização Capitalista Conservadora e a pobreza no Brasil}

Para entender a formação da pobreza no Brasil é preciso uma análise que coteje os elementos que substanciam o processo de exclusão, que antes de ser social é econômico e político. Como chama a atenção OLIVEIRA $^{20}$, o subdesenvolvimento latino-americano, com raras exceções, é resultado da expansão capitalista mundial. Isto porque a economia deste continente funcionou como uma reserva de acumulação primitiva do sistema global. Por outro lado, ao se enfatizar a dependência econômica faz-se necessário considerar também as questões concernentes à estrutura de dominação que dão forma e conteúdo à acumulação de capital realizada em países como o Brasil. Assim, um desenvolvimento capaz de superar a abissal distância socioeconômica, em que se encontram os grupos populacionais situados na base e no topo da pirâmide social, demanda a priori uma profunda transformação no tradicionalismo culturalmente herdado. Uma vez que "os riscos e os ganhos relacionados com a estrutura e a dinâmica do poder, principalmente, contam de modo decisivo nas polarizações do comportamento coletivo, operando como uma espécie de regulador da tomada de consciência. "21

ARRUDA e GONÇALVES ${ }^{22}$, na busca de trazerem à tona os obstáculos à universalização da educação na sociedade brasileira, ponderam que a economia na periferia se constituiu, para além de dependente, submissa às necessidades da economia europeia, têm-se que na origem estruturou-se uma divisão do trabalho na qual a acumulação de capital se realizou mais fortemente no centro, enquanto a produção colonial deu partida a uma especialização de sua produção marcadamente subsidiária, detendo assim uma acumulação de capital sempre inferior, enfim, uma produção marcadamente demandante de extensas faixas geográficas e de baixa remuneração. Tomando como referência o Brasil Colônia, observa-se que o jogo de forças instituidoras da divisão internacional do trabalho o transformou numa grande plantation especializada na cana-de-açúcar, algodão e café.

18 A democratização social, fruto das políticas do Welfare State, o advento da democracia no segundo pós-guerra e a redemocratização de países que saíram de regimes autoritários/ditatoriais, trazem à lume Constituições cujos textos positivam os direitos fundamentais e sociais. Esse conjunto de fatores redefine a relação entre os Poderes do Estado, passando o Judiciário (ou os tribunais constitucionais) a fazer parte da arena política". STRECK, Lenio Luiz. O papel da jurisdição constitucional na realização dos direitos sociais-fundamentais. In: SARLET, Ingo Wolfgang (org.). Direitos Fundamentais Sociais: estudos de direito constitucional internacional comparado. Rio de Janeiro - São Paulo: Renovar, 2003. p. 171. Neste sentido, complementa BARROSO, constitucionalizar uma matéria, dentro do processo constitucional democrático contemporâneo, significa transformar política em direito. BARROSO, Luís Roberto. Judicialização, ativismo judicial e legitimidade democrática. Suffragium - Revista do Tribunal Regional Eleitoral do Ceará, Fortaleza, v. 5. n.8. p. 11-22, jan-dez. 2009. p. 12.

19 BARROSO, Luís Roberto. Judicialização, ativismo judicial e legitimidade democrática. Suffragium - Revista do Tribunal Regional Eleitoral do Ceará, Fortaleza, v. 5. n.8. p. 11-22, jan-dez. 2009.

20 OLIVEIRA, Francisco de. A economia brasileira: crítica à razão dualista. Petrópolis: Editora Vozes, 1987.

21 FERNANDES, Florestan. A sociologia numa era de revolução social. Rio de Janeiro: Zahar Editores, 1976. p. 202.

22 ARRUDA, Gerardo Clésio Maia; GOLÇALVES, Flávio José Moreira. Paideia dos degredados: raízes dos condicionantes inibidores da universalização do direito à educação no Brasil. Fortaleza: Revista Opinião Jurídica. V. 13. 2015. 
É na submissão da economia local à produção de fora que se elaboram as condições para a organização de uma economia pré-capitalista. Isto porque a acumulação aqui realizada estava atrelada a uma dinâmica externa, de sorte que escapava à lógica da busca permanente pela produtividade, via aperfeiçoamento dos processos produtivos. Uma vez que o motor impulsionador do desenvolvimento tecnológico não se dava a partir da dinâmica interna, da busca pela inovação motivada pela conquista de novos mercados, a qualidade e variedade da produção eram determinados pela produção do centro, o que levou a obrigatoriedade de aqui se produzir matérias primas de baixo custo e com parcos investimentos de capital, ou seja, com elevada concentração de trabalho de baixo conteúdo tecnológico, baseado no dispêndio de energia muscular e não requerente de habilidades cognitivas. ${ }^{23}$

Com efeito, a força de trabalho na economia do centro se punha como produtora direta da riqueza e fonte de realização do ciclo de produção, pois funcionava também como consumidora das mercadorias. Ao contrário do que se assistiu na periferia, onde a produção era quase em sua totalidade direcionada para o mercado externo, a força de trabalho aparecia basicamente como consumidora de gêneros de sobrevivência. Ressalvando que a produção de alimentos se tratava de uma atividade geradora de baixo lucro, por isto legada à produção familiar exercida em minifúndios de baixa produtividade. Esse setor da economia se constituiu como subsidiário no interior da economia dependente, um mercado limitado porque as necessidades de consumo dos dominantes eram atendidas por intermédio da importação. Eis a origem da escassez de alimentos e do expressivo contingente populacional imerso numa economia de subsistência, que deu início no período colonial a uma reprodução social miserável de milhares de pessoas.

DOWBOR ${ }^{24}$ entende que, além da distância de acumulação de capital que favorecia exponencialmente um lado da divisão internacional do trabalho, a relação de produção entre nações do centro e da periferia gerava as condições para a produção pré-capitalista no Brasil, uma vez que na dinâmica da economia colonial a força de trabalho só participava da produção e não de sua realização, via consumo, assim foi possível manter o Brasil integrado à lógica do capitalismo mesmo com a prática do trabalho escravo, servil ou assalariado precário, de extensa jornada e de baixa remuneração. Ao contrário da América do Norte, que rompeu com o capitalismo dependente após a Guerra da Independência e da Guerra da Sucessão, e assim redirecionou a sua produção agrícola para o mercado interno. O Brasil manteve a orientação de sua produção mesmo após o advento da Independência e da Abolição da Escravatura. A estrutura de produção permaneceu inalterada e marchou para a consolidação da grande empresa agroexportadora monopolista, assentada em relações de trabalho pré-capitalistas. Esses mesmos atores possuíam a primazia das trocas no mercado externo, portanto, assumiam simultaneamente o papel de exportadores e importadores, obstaculizando a emergência de empreendimentos de médio e pequeno porte direcionados para o abastecimento do mercado interno. ${ }^{25}$

Esse modelo de produção econômica engendrou um sistema que fomentou a existência de um grupo populacional de agricultores empobrecidos, que só marginalmente participava da apropriação da riqueza. Além do que, a passagem do trabalho escravo para o trabalho assalariado funcionou como mecanismo de alargamento do contingente populacional sobrevivendo na condição de pobreza. Isto porque, de acordo com PRADO JUNIOR ${ }^{26}$, com a abolição da escravidão deu-se origem, de um lado, a constituição de uma massa de trabalhadores rurais submetidos a uma exploração que os punha na condição de sobrevivência miserável no campo e, de outro lado, a uma massa marginal formadora de um exército industrial de reserva das atividades econômicas urbanas. É por sobre essa base socioeconômica que se erigiu a estrutura de poderes locais e regionais garantidores de uma ordem sociopolítica que possibilitou a passagem para a produção industrial sem grandes alterações na estrutura social.

23 ARRUDA, Gerardo Clésio Maia; GOLÇALVES, Flávio José Moreira. Paideia dos degredados: raízes dos condicionantes inibidores da universalização do direito à educação no Brasil. Fortaleza: Revista Opinião Jurídica. V. 13. 2015. p. 213-214.

24 DOWBOR, Ladislau. A formação do capitalismo dependente no Brasil. São Paulo: Brasiliense, 1982.

25 PRADO JÚNIOR, Caio. História econômica do Brasil. São Paulo: Brasiliense, 2006.

26 PRADO JÚNIOR, Caio. História econômica do Brasil. São Paulo: Brasiliense, 2006. 
OLIVEIRA ${ }^{27}$ salienta a Revolução de 1930 como o marco do fim de um ciclo econômico e da emergência de um novo ciclo. É desde aí que se deu partida à construção da ordem urbano-industrial, embora tenha subsistido com diferentes influências na dinâmica regional do país a estrutura produtiva baseada na empresa agroexportadora. $\mathrm{CANO}^{28}$ distingue duas fases, em sua análise acerca dos desequilíbrios regionais decorrentes da industrialização brasileira, do padrão de acumulação industrial; sendo que uma fase compreende os anos de 1930 a 1955, denominada de um período de industrialização "restringida", e a fase de 1956 a 1970, concernente à implantação do setor industrial de bens de produção e a consolidação do setor de produção industrial de bens duráveis. O enfoque dado a esse ciclo do processo de industrialização é adequado ao nosso interesse, pois encontram-se aí as bases edificadoras da modernização conservadora. Esse conceito, como explicam PIRES E RAMOS ${ }^{29}$, foi cunhado por MOORE JUNIOR ${ }^{30}$, para retratar os países que experimentaram uma revolução burguesa vinda de cima. Em suma, no Brasil se adotou esse conceito para explicar que o pacto político conservador promovido pela nascente burguesia nacional e os grandes proprietários rurais delineou a dinâmica do desenvolvimento capitalista brasileiro. O pacto constituído pela elite dominante formatou uma estrutura sociopolítica que erigiu barreiras impeditivas "para o acesso democrático das demais classes sociais aos mercados de terras, de capital, de trabalho e à democracia e à cidadania." 31

Trazendo à tona os fundamentos do processo de industrialização relativo ao primeiro mandato de Getúlio Vargas (1930 a 1945), que se inicia após a grande crise econômica mundial de 1920/30, que reduziu extraordinariamente os fluxos comerciais e financeiros entre as nações e obrigou as economias a se voltarem para dentro, far-se-á uma reflexão das ações estatais direcionadas para a reestruturação da produção nacional e os seus desdobramentos sobre a organização sociopolítica.

No auge da crise mundial, quando os preços das importações aumentavam enquanto os preços das exportações se retraiam, associado a uma queda abrupta das reservas cambiais, que vai de 31 milhões de libras em setembro de 1929 a completa ausência de reservas em 1931, o governo provisório, como aponta $\mathrm{ABREU}^{32}$, foi obrigado a declarar sucessivas moratórias relativas às dívidas em moedas estrangeiras, até chegar em 1931 a completa suspenção dos pagamentos das dívidas públicas externas. No início desta década, como explicita $\mathrm{ABREU}^{33}$ se operou uma alteração na composição dos investimentos externos diretos no Brasil, resultado da redução da participação dos britânicos e aumento dos estadunidenses. Mas essa mudança foi também de ordem qualitativa, uma vez que os investimentos britânicos estavam direcionados principalmente para os serviços públicos (especialmente ferrovias), já os capitais norte-americanos visavam os setores modernos, como a indústria de transformação e atividades comerciais.

O ciclo do café propiciou que os seus grandes produtores se assenhoreassem do poder, o que gestou um tipo de governança marcado por uma contradição entre o discurso e as ações governamentais; pois, simultaneamente, se colocavam como defensores do liberalismo econômico, mas desenvolviam políticas econômicas fortemente intervencionistas. De tal maneira que os investimentos realizados a partir de recursos captados no mercado internacional, que levaram o Estado a grande endividamento, concentraram na região cafeicultora (São Paulo, Rio de Janeiro e Minas Gerais) as obras de infraestrutura, o que tornou

27 OLIVEIRA, Francisco de. A economia brasileira: crítica à razão dualista. Petrópolis: Editora Vozes, 1987.

28 CANO, Wilson. Desequilíbrios regionais e concentração industrial no Brasil 1930 - 1970. São Paulo: Editora UNESP, 2007.

29 PIRES, Murilo José de Souza e RAMOS, Pedro. O termo modernização conservadora: sua origem e utilização no Brasil. Fortaleza: Revista Econômica do Nordeste - REN. V. 40. 2009.

30 MOORE JUNIOR, B. As origens sociais da ditadura e da democracia: senhores e camponeses na construção do mundo moderno. São Paulo: Martins Fontes, 1975.

31 PIRES, Murilo José de Souza e RAMOS, Pedro. O termo modernização conservadora: sua origem e utilização no Brasil. Fortaleza: Revista Econômica do Nordeste - REN. V. 40. 2009. p. 416

32 ABREU, Marcelo de Paiva. Crise, crescimento e modernização autoritária. In: ABREU, Marcelo de Paiva. A ordem do progresso: cem anos de política econômica republicana 1889-1989. Rio de Janeiro: Campus, 1990.

33 ABREU, Marcelo de Paiva. Crise, crescimento e modernização autoritária. In: ABREU, Marcelo de Paiva. A ordem do progresso: cem anos de política econômica republicana 1889-1989. Rio de Janeiro: Campus, 1990. 
esse espaço geográfico como o melhor dotado de integração de vias de transportes, de fornecimento de energia e de portos. Considerando o capital aí concentrado aliado às condições de infraestrutura, a zona de produção cafeeira se colocava como a mais adequada a passagem da centralidade da economia brasileira eminentemente assentada na empresa agroexportadora para a produção industrial. Acrescente-se ainda o crescimento urbano de São Paulo e Rio de Janeiro, mais acelerado do que as demais cidades brasileiras, e o fluxo de imigrantes originários de regiões com atividades comerciais, de artesanatos e oficinas e de trabalho fabril, que resultaram na aglomeração de mão-de-obra com melhor qualificação para a produção industrial e na formação de um mercado consumidor. Eis aí os elementos fundantes da desigualdade regional, que nos desdobramentos do avanço da industrialização foi consolidando as regiões com menor e maior incidência de famílias sobrevivendo na pobreza e na extrema pobreza. ${ }^{34}$

Apesar do setor industrial brasileiro caminhar a passos mais largos a partir de 1930, é preciso considerar que, após a abolição da escravidão, do advento da República e do crescimento urbano de São Paulo e do Rio de Janeiro, se registrou a emergência de uma produção industrial incipiente, mas que deve ser salientada uma vez que esta produção embrionária implicará na definição da sua regionalização. DOWBOR ${ }^{35}$ indica que o censo industrial de 1907 "acusava a existência de cerca de 3.500 empresas industriais, que empregavam um total de mais ou menos 150.000 operários.” Já para o ano de 1920, o autor discrimina o seguinte quadro: 13.336 indústrias e um total de 275.512 operários. Assistiu-se, neste período, o desenvolvimento de indústrias nacionais que seguem o padrão do lento crescimento com base no artesanato e manufatura, influenciado pelo surgimento de um mercado interno. Esses empreendimentos do começo do século XX se direcionavam para a produção de bens de consumo, destacando-se têxteis, vestuário e alimentos. Entretanto, não se verificou em paralelo a emergência de uma indústria voltada para os bens de produção, o que se gerou no Brasil um modelo de industrialização assentado na indústria leve, diferentemente do que ocorreu nos países de primeira industrialização e mesmo naqueles de industrialização tardia, como Japão e Itália. ${ }^{36}$ Ao dar início à produção industrial quando já haviam muitas nações já industrialmente avançadas, assim bastante competitivas na fabricação de bens de produção, o Brasil estruturou esse setor dependente da importação de máquinas, tornando-se assim destituído de uma dinâmica interna autônoma e vinculado às oscilações conjunturais do mercado externo.

Resta ainda explicitar como característica da industrialização nas duas primeiras décadas do século XX, o fato de que a presença do capital norte-americano, por intermédio de investimentos diretos, se consolidou na economia brasileira ultrapassando o capital britânico. De acordo com DOWBOR ${ }^{37}$, a importação de produtos que atendia o segmento populacional detentor da maior parcela da riqueza nacional foi sendo substituída pela produção agora realizada no Brasil, em função da instalação de filiais de empresas norte-americanas, o mercado embora restrito era atrativo dado o baixo custo da mão-de-obra. Isto permitia que as empresas internacionais aqui se instalassem com o objetivo de atender, além do mercado local, segmentos dos mercados das economias desenvolvidas, de sorte que algumas empresas estavam direcionadas exclusivamente para a exportação, como por exemplo as empresas de alimentos, dentre outras, Wilson, Swift, Continental. Por outro lado, a indústria nacional continuou abastecendo com mercadorias de qualidade inferior a demanda dos trabalhadores urbanos, rurais e autônomos de baixa renda.

A grande crise de 1929/30 provocou uma drástica redução das exportações de café, e mesmo com quedas sucessivas no preço da saca continuou se observando redução na demanda internacional por essa mercadoria, o que redundou numa forte retração desse setor econômico. Essa crise conjuntural associada ao crescente fortalecimento da indústria robusteceu a construção de um novo consenso, que já vinha se construindo e que almejava o delineamento de uma nova ordem da gestão estatal e das políticas econômicas. $\mathrm{Na}$

34 DOWBOR, Ladislau. A formação do capitalismo dependente no Brasil. São Paulo: Brasiliense, 1982.

35 DOWBOR, Ladislau. A formação do capitalismo dependente no Brasil. São Paulo: Brasiliense, 1982. p. 128.

36 DOWBOR, Ladislau. A formação do capitalismo dependente no Brasil. São Paulo: Brasiliense, 1982.

37 DOWBOR, Ladislau. A formação do capitalismo dependente no Brasil. São Paulo: Brasiliense, 1982. 
verdade, a luta política dos anos 1930 tratou-se de uma disputa por uma desconcentração do Estado, que se organizara no sentido de atender aos interesses dos cafeicultores. A tensão política se estabeleceu a partir de interesses dos estratos situados no topo da pirâmide social, que redundou na tomada do poder por Getúlio Vargas com o apoio de militares revoltosos. Portanto, a alternância de poder aí verificada não significou uma mudança substancial em sua estrutura. Como afirma FURTADO ${ }^{38}$, o movimento revolucionário foi protagonizado por membros da população urbana inseridos na burocracia militar, civil e nas organizações industriais, que em última instância buscavam espaço político e se colocavam contra a hegemonia dos produtores de café, que monopolizavam o Estado levando-o a priorizar o atendimento de seus interesses.

O novo arranjo que se estabeleceu nas estruturas de poder, que passou a comportar novos atores também situados entre os dominantes do capital, não se tratou de uma ruptura. Isto é explicitado por FURTADO ${ }^{39}$ quando aponta que, somente dois anos após a instalação do novo governo, os grupos econômicos vinculados ao café forçaram o governo a reduzir em $50 \%$ suas dívidas bancárias. DOWBOR ${ }^{40}$ deslinda a dinâmica e os desdobramentos futuros dessa conciliação de interesses quando afirma que: "a revolução de 1930 inaugura uma fase de equilíbrio caracterizada pela aliança dos diferentes grupos patronais e que levará, em 1964, à tomada de poder pelo núcleo da burguesia ligado às multinacionais que dominam o eixo Rio-São Paulo."

$\mathrm{Na}$ opinião de $\mathrm{FIORI}^{41}$ a compreensão da questão social brasileira passa pelo entendimento da relação da burguesia brasileira com o Estado, uma relação esquizofrênica que se explicita no discurso antiestatismo dos empresários liberais, simultaneamente, ao culto de uma forte relação de dependência clientelística. Por outro lado, o discurso dos sociais-democratas não consegue se efetivar e, portanto, não ocasionam reformas substanciais no Estado, uma vez que não rompem com os elementos fundantes da relação clientelística entre o setor produtivo privado e o Estado. De sorte, que no século XX foi constante a ampliação da participação do Estado no setor produtivo. "Até os anos 1930, o Brasil dispunha apenas de 14 empresas estatais. Entre 1930 e 1954, na Era Vargas, o Estado gerou 15 novas empresas; nos cinco anos de governo Kubitschek, 23; com Goulart foram criadas 33; e durante os 20 anos de regime militar, 302." ${ }^{2}$ Além de uma participação na economia por intermédio de empresas produtoras, a presença do Estado foi crescente via órgãos de controle, de prestação de serviços e de financiamentos, o que segundo FIORI ${ }^{43}$, levou alguns a definirem o capitalismo brasileiro como detentor de uma especificidade em que é o Estado e não a iniciativa privada que opera o processo de acumulação, dado principalmente sua participação na indústria de bens de produção e no gerenciamento das operações de financiamento industrial.

É preciso considerar que todas as experiências de industrialização tardia se deram com base no amplo apoio dos Estados nacionais, tendo a Alemanha como exemplaridade de crescimento acelerado a partir do Estado indutor do processor de acumulação, seja como estruturador de fundos de investimentos, produtor de insumos e energia ou fornecedor da infraestrutura necessária à produção industrial. Por outro lado, a popularização do pensamento de John Maynard Keynes, após a crise de 1929, inaugurou uma onda de políticas econômicas alicerçadas no ideário da social democracia, que levou países do Norte e do Sul, de industrialização originária ou tardia, a adotar o Estado como instrumento de fomento direto de investimentos e de manutenção dos níveis de emprego, de renda e de consumo. Enfim, o Estado se especializou no desenvolvimento de políticas fomentadoras do bem-estar social.

FIORI $^{44}$ pontilha os governos de Vargas e de Geisel como os que procuraram de maneira mais acentuada a realização do sonho do modelo prussiano de industrialização, mas ambos os intentos foram frustrados

38 FURTADO, Celso. Formação econômica do Brasil. São Paulo: Companhia das Letras, 2007.

39 FURTADO, Celso. Formação econômica do Brasil. São Paulo: Companhia das Letras, 2007.

40 DOWBOR, Ladislau. A formação do capitalismo dependente no Brasil. São Paulo: Brasiliense, 1982. p. 149

41 FIORI, José Luís. Em busca do dissenso perdido: ensaios críticos sobre a festejada crise do Estado. Rio de Janeiro: Insight, 1995.

42 FIORI, José Luís. Em busca do dissenso perdido: ensaios críticos sobre a festejada crise do Estado. Rio de Janeiro: Insight, 1995. p. 58.

43 FIORI, José Luís. Em busca do dissenso perdido: ensaios críticos sobre a festejada crise do Estado. Rio de Janeiro: Insight, 1995.

44 FIORI, José Luís. Em busca do dissenso perdido: ensaios críticos sobre a festejada crise do Estado. Rio de Janeiro: Insight, 1995. 
e não reeditaram o desenvolvimento acelerado experimentado pela Alemanha. Não é exagero afirmar que no governo Vargas encontra-se o delineamento da matriz institucional que balizou a consolidação e modernização industrial brasileira, observada na perspectiva estatal. As ações de controle se estenderam da sistematização de informações, da coleta de dados a análise e reflexão estatísticas, às ações organizacionais, compreendendo um amplo leque que abarcou a regulação de serviços, de salários e preços. Foram desenvolvidos esforços para a criação e ampliação da indústria pesada e fornecimento de energia, destacam-se as seguintes empresas estatais: Companhia Siderúrgica Nacional, Companhia Vale do Rio Doce e Companhia Hidrelétrica do Vale do São Francisco. Contudo, as ações nesta área não foram suficientes para dotar o setor industrial de uma dinâmica endógena capaz de gerar um autodesenvolvimento. Como chama a atenção FIORI $^{45}$, os planos do governo Getúlio Vargas "esbarraram permanentemente na oposição política à estatização e na falta de esforço financiador, o qual foi reduzido a complicadas transferências cambiais."

É preciso considerar que o autoritarismo que marcou o getulismo se sustentava num equilíbrio de forças que se antagonizavam em seus interesses, que passava tanto pelos grandes produtores locais e internacionais, como por aqueles vinculados à produção rural e urbana e interessados na exportação e/ou importação. Emergiu do cerne desse arranjo de forças que constituíam a base política do governo a oposição que obstaculizou a formação de fundos de financiamento, que demandava esforços da iniciativa privada e do Estado, para a consolidação da indústria pesada. Esse plano foi "vetado politicamente pelas classes dominantes brasileiras, predominantemente agrárias e partidárias de um liberalismo econômico antiestatal e internacionalizante. “46. Eis o que levou a frustração dos sonhos de uma industrialização prussiana nos trópicos. Tal fato, redundou já no governo de Juscelino Kubitsckek a formatação de um modelo de uma industrialização baseada no investimento direto internacional voltado para a produção de bens de consumo. Essa opção delineou o modelo de industrialização que se seguiu nas décadas seguintes e estruturou as forças políticas que deram sustentação ao governo militar e que mantiveram e mantêm uma influência marcante após a abertura política:

Fez-se a opção definitiva por um padrão de financiamento fortemente dependente do capital estrangeiro e do uso pelo Estado do endividamento interno e externo, ou mesmo da inflação, como forma de escorar uma burguesia empresarial extremamente conservadora, protecionista e antipopular. Sendo que, a partir daí, foi vetado também ao Estado qualquer movimento de monopolização (que não fosse setorial) ou centralização financeira, ainda quando ele fosse responsabilizado, simultaneamente, pela estabilidade de uma moeda desvinculada de qualquer padrão internacional, pela extensão de créditos e subsídios e pelos investimentos básicos responsáveis pela alavancagem da industrialização e pela sustentação das margens de lucro de setores econômicos fortemente protegidos. ${ }^{47}$

Por um lado, a estrutura fundiária criou um segmento populacional trabalhando em minifúndios incapazes de garantir a sobrevivência da família proprietária, o que obriga essas pessoas a demandarem sazonalmente trabalho nas empresas agroexportadoras, além do que a modernização dessas empresas, provocou a formação de um exército industrial de reserva para a produção rural e urbana. De outro lado, como assevera OLIVEIRA $^{48}$, a regulação do salário mínimo legislado como salário de subsistência funcionou para manter em patamares reduzidos o custo da força de trabalho industrial, na medida em que se considerou para sua composição "as necessidades alimentares (em termos de calorias, proteínas, etc.) para o padrão de um trabalhador que devia enfrentar um certo tipo de produção, com um certo tipo de uso de força mecânica, comprometimento psíquico, etc." Como não se levou em conta outros critérios, como ganhos de produtividade do trabalho, por exemplo, a institucionalização do salário mínimo se constituiu num instrumento

45 FIORI, José Luís. Em busca do dissenso perdido: ensaios críticos sobre a festejada crise do Estado. Rio de Janeiro: Insight, 1995. p. 64.

46 FIORI, José Luís. Em busca do dissenso perdido: ensaios críticos sobre a festejada crise do Estado. Rio de Janeiro: Insight, 1995. p. 66.

47 FIORI, José Luís. Em busca do dissenso perdido: ensaios críticos sobre a festejada crise do Estado. Rio de Janeiro: Insight, 1995. p. 70.

48 OLIVEIRA, Francisco de. A economia brasileira: crítica à razão dualista. Petrópolis: Editora Vozes, 1987. p. 16. 
de reordenação do novo modo de acumulação de capital. Em suma, a existência de um expressivo exército industrial de reserva inibe os movimentos de aumentos reais dos salários, o que garante a manutenção dos baixos custos de remuneração da força de trabalho.

Vê-se então que foi na exploração da riqueza, iniciada como base no latifúndio, na monocultura e no trabalho escravo, e, posteriormente, num sistema industrial extremamente complexo que combina a produção intensiva em mão-de-obra de baixa tecnologia com setores modernos e sofisticados, como é o caso da produção de aeronaves e da indústria petrolífera, que se constituiu uma formação social estruturada na existência de um grupo diminuto detentor de um colossal poder econômico e político e de uma massa de pobres e miseráveis. Portanto, o trabalho urbano industrial, comercial e de serviços, que predomina atualmente na sociedade brasileira, não foi capaz de reduzir a distância entre as classes sociais, pois as suas causas que remontam ao período de sua ocupação territorial e ao início da exploração de suas riquezas permaneceram praticamente inalteradas em sua essência, ou seja, manteve-se desde sempre a superexploração do trabalho.

Essa assertiva se demonstra com base em dados sistematizados pelo Instituto de Pesquisa Econômica Aplicada (IPEA) ${ }^{49}$ que mediu, para o período de 1995 a 2008, apoiado na Pesquisa Nacional por Amostra de Domicílios (PNAP), as taxas de pessoas que se encontram na condição de pobreza absoluta e extrema, sendo a primeira condição formada pelas pessoas com rendimento médio domiciliar per capita de até meio salário mínimo e a segunda pelas pessoas de até um quarto de salário mínimo mensal.

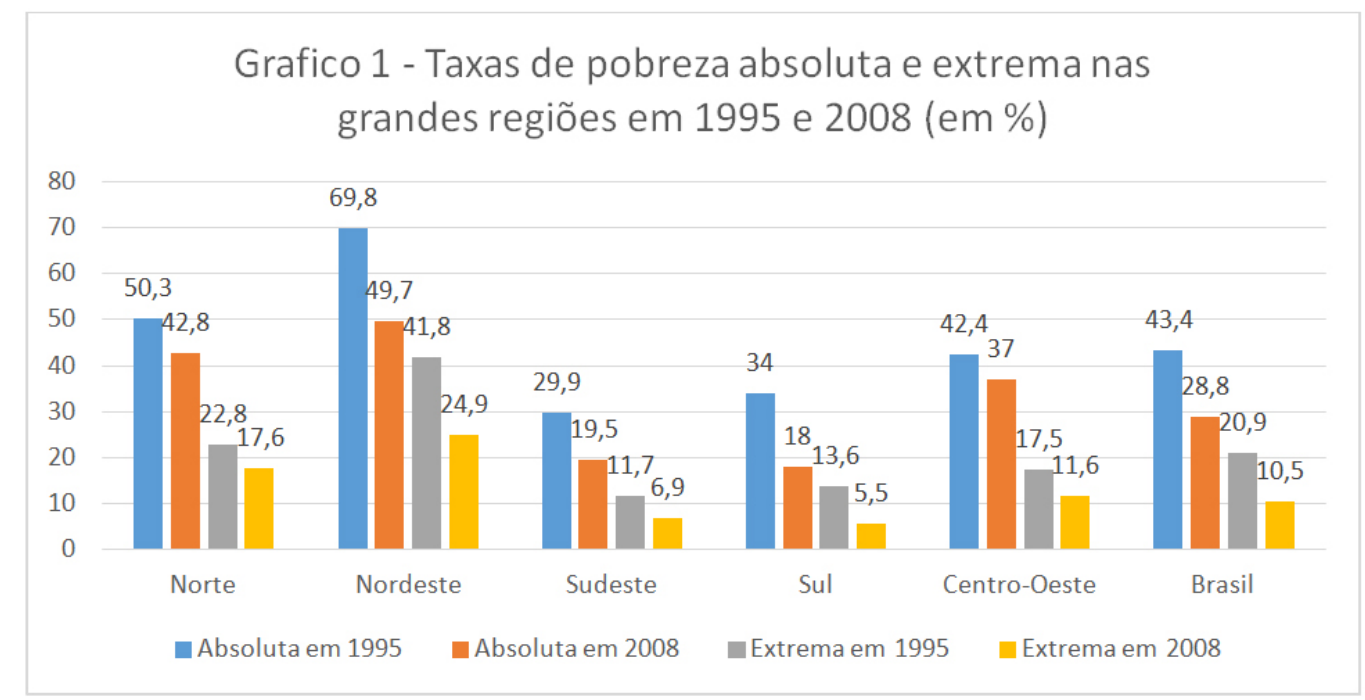

Fonte: Instituto de Pesquisa Econômica Aplicada (IPEA)

Os 13 anos pesquisados indicam que as taxas de todas as regiões apresentaram um comportamento decrescente, mas a região Nordeste ainda permanece com a maior taxa para a pobreza absoluta; e quanto à pobreza extrema, percebe-se que a sua taxa é disparadamente mais elevada do que as das demais regiões do Brasil. Isto demonstra que há uma necessidade de empreender esforços ainda mais relevantes, principalmente se considerarmos que este quadro é resultante de um longo processo histórico que remete para os primeiros momentos da ocupação da região.

Em suma, como observa ARRUDA ${ }^{50}$ (2010), quando se reflete acerca da formação econômica brasileira vis-à-vis a estrutura sociopolítica, percebe-se que as implicações que se colocam à adoção de medidas promotoras de direitos equivalentes aos previstos na declaração internacional dos direitos humanos, em um contexto semelhante ao da sociedade brasileira, devem ser consideradas as barreiras ideológicas, como

49 Brasil. Instituto de Pesquisa Econômica Aplicada (IPEA). Dimensão, evolução e projeção da pobreza por região e por estado no Brasil. Rio de Janeiro: IPEA, 2010.

50 ARRUDA, Gerardo Clésio Maia. Exclusão social, direitos humanos e cidadania no Brasil. In: COSTA, Andreia da Silva e LEITÃO, Cláudia Souza. Direitos humanos: uma reflexão plural e emancipatória. Fortaleza: Faculdade Christus, 2010. 
provavelmente as mais eficazes no impedimento desse intento. $\mathrm{Na}$ verdade, não se resume tão-somente a um problema de gerenciamento de recursos o fato de que, na sociedade brasileira, existe um número elevado de jovens sem acesso à educação; de que um segmento considerável daqueles que frequentam regularmente a escola o fazem em precárias condições pessoais e/ou pedagógicas; que aproximadamente cinquenta por cento dos empregos gerados na sua economia são precários, mal remunerados e exercidos à margem de benefícios trabalhistas. Outrossim, a compreensão desses problemas passa pelo entendimento de que, ao se buscar a elaboração e a execução de políticas públicas direcionadas para a melhoria das condições de vida de segmentos populacionais marginalizados no Brasil, logo alguns espíritos se colocam radicalmente contrários a tal empreendimento.

Enfim, como chamam a atenção ARRUDA, BERTOLINI e SOUZA ${ }^{51}$, na Constituição de 1988 já estão dados os fundamentos capazes de promover mudanças substanciais na sociabilidade brasileira, de modo a viabilizar a superação do fosso abissal que distingue segmentos populacionais na categoria de "supercidadão", formada pelos que se situam numa posição hierárquica da estrutura social que só pontualmente é alcançada por atos jurídicos coercitivos, mas que, por outro lado, são os beneficiários prioritários das políticas públicas de toda ordem, do campo tributário ao cultural; e os que se encontram enredados na categoria de "subcidadão", constituintes do extrato do edifício social caracterizado por ser objeto constante da omissão estatal, ou seja, a parcela da população que, mesmo após a passagem do regime de trabalho escravo para o do trabalho assalariado, manteve-se à margem dos direitos norteadores das modernas sociedades contratuais, de sorte que se formaram historicamente como um expressivo contingente que diuturnamente tem seus direitos vitais violados.

\section{Ativismo judicial e os direitos sociais no Brasil}

A Constituição de 1988 prevê um extenso rol de direitos sociais. Tanto é assim que reservou um capítulo próprio para explicitá-los. Fixou ainda que as normas declaratórias de direitos e garantias fundamentais possuem aplicabilidade imediata. Dito de outro modo, "a exemplo das demais normas de direitos fundamentais, as normas consagradoras de direitos sociais possuem aplicabilidade direta e eficácia imediata" 52 , mesmo que "O alcance desta eficácia deva ser avaliado sempre no contexto de cada direito social e à luz de outros direitos e princípios". ${ }^{53}$ Assim sendo, se verifica que, pelo menos do ponto de vista normativo, a Constituição atual resolveu a antiga questão da eficácia e aplicabilidade dos direitos e garantias fundamentais.

É certo, não obstante o imperativo de aplicabilidade incontinente, que a temática dos direitos fundamentais é extremamente complexa. Mas não em razão do problema da sua positivação e justificação, já relativamente resolvido. Na verdade, explica Norberto Bobbio, a real questão dos direitos do homem hoje é de efetivação, pois se trata de uma questão não filosófica, mas política e jurídica. ${ }^{54}$ Em outras palavras, o grande desafio é "impedir que, apesar das solenes declarações, eles sejam continuamente violados". ${ }^{55}$ Ora, se os direitos clássicos de liberdade (civis) e de participação democrática (políticos) são difíceis de serem

51 ARRUDA, Gerardo Clésio Maia; BERTOLINI, Adriana Rossas; SOUZA, Ana Laíse Pacheco de. Direitos sociais no Brasil à luz do primado da diferenciação social. In: RODRIGUES, Francisco Lisboa; CUNHA, Jânio Pereira. Pautas Constitucionais Contemporâneas Vol II. Rio de Janeiro: Editora Lumen Juris, 2015/A.

52 SARLET, Ingo Wolfgang. Art $6^{\circ}$. In: CANOTILHO, J. J. Gomes; MENDES, Gilmar Ferreira; SARLET, Ingo Wolfgang; STRECK, Lenio Luiz; LEONCY, Léo Ferreira (Coords.). Comentários à Constituição do Brasil. São Paulo: Saraiva/Almedina, 2013, p. 541.

53 SARLET, Ingo Wolfgang. Art $6^{\circ}$. In: CANOTILHO, J. J. Gomes; MENDES, Gilmar Ferreira; SARLET, Ingo Wolfgang; STRECK, Lenio Luiz; LEONCY, Léo Ferreira (Coords.). Comentários à Constituição do Brasil. São Paulo: Saraiva/Almedina, 2013, p. 541.

54 BOBBIO, Norberto. A era dos direitos. Tradução de Nelson Coutinho. Rio de Janeiro: Elsevier, 2004, p. 23, 25, 36-37, 40 e 43-44.

55 BOBBIO, Norberto. A era dos direitos. Tradução de Nelson Coutinho. Rio de Janeiro: Elsevier, 2004, p. 25. 
protegidos ${ }^{56}$, os sociais, em razão da natureza, têm um nível de exigência mais amplo e profundo, dado que requerem, para sua concretização, de forte atuação do Poder Público. ${ }^{57} \mathrm{E}$ isso é assim porque a efetivação de tais direitos opera-se, a rigor, por meio de políticas de prestação de serviços públicos como saúde, educação, moradia, trabalho, assistência social, os quais requerem uma soma considerável de recursos econômicos e financeiros para a devida e a necessária promoção desses bens fundamentais.

Diretamente relacionado com o tema dos direitos fundamentais está a questão do acesso à justiça. E a razão disso é que, apesar da existência de várias instituições importantes e responsáveis pela proteção de direitos, o Poder Judiciário, pela natureza e finalidade, é a que detém o dever de assegurar juridicamente a proteção dos bens fundamentais das pessoas. Pode-se dizer, nesse sentido, que a possibilidade de buscar a instância judiciária é pressuposto essencial e universal para efetivação de direitos e garantias fundamentais. Realmente, o direito de acesso à justiça é, utilizando-se da feliz expressão cunhada por Hannah Arendt, o verdadeiro "direito a ter direitos", pois a abertura do Judiciário aos cidadãos é o direito "sem o qual nenhum dos demais se concretiza". ${ }^{58}$ Numa frase, a previsão de direitos e a existência de um aparelho judicial são condições indispensáveis para promoção, proteção e efetivação dos direitos e, por isso, é lícito afirmar que o não acesso à justiça é uma das formas mais graves e hediondas de negação à cidadania e desrespeito à dignidade humana. Na ponderação de Rubens Goyatá CAMPANTE,

Não há dúvida de que, sem facilitar o acesso de toda a população à prestação jurisdicional efetiva e razoavelmente rápida, a cidadania e os direitos sociais no Brasil ficam travados. E o Poder Judiciário brasileiro mostra, realmente, sérios problemas estruturais e culturais que o impedem de ser mais responsivo às demandas da sociedade. De um modo geral, a Justiça brasileira é lenta, elitista e insulada. E boa parte dos problemas que [Mauro] Cappelletti diagnosticou como comprometedores do acesso à Justiça nos sistemas judiciários dos países ocidentais repete-se aqui. Entretanto, como o autor também concluiu, a solução para essa questão - e para o problema correlato da efetivação dos direitos sociais sendo política, é inerentemente complexa e sistêmica, e não pontual. ${ }^{59}$

É inegável que, no caso brasileiro, não tem sido fácil a luta pela concretização de direitos sociais fundamentais. Veja-se que é corrente na literatura política e jurídica um discurso de viés liberal e conservador que critica inclusive a previsão constitucional de direitos sociais, uma vez que estes, por não serem normas tipicamente constitucionais, deveriam estar previstos, no máximo, em leis ordinárias. Registre-se que a Constituição vigente foi objetada pelo próprio Presidente da República, à época, José Sarney, para quem o diploma jurídico supremo elevaria sobremodo os gastos públicos e traria o risco de tornar o país destituído de governabilidade "nas relações de trabalho, na família e na sociedade". ${ }^{60}$ Noutras palavras, ante o caráter essencialmente social da Constituição, "Seria 'impossível' para um país de renda média como o Brasil garantir tantos direitos aos seus cidadãos; tentar garanti-los significaria tornar o país 'ingovernável". ${ }^{61}$ A história de sucesso da Constituição vigente, no entanto, se encarregou de desconstruir essas e outras acusações de caráter ideológico contra a parte social do texto constitucional.

56 Para Bresser-Pereira, "Os direitos civis estão basicamente garantidos, mas para os ricos e a classe média. O respeito é um direito civil fundamental, mas os mais pobres, as mulheres, os negros e os mestiços continuam a serem desrespeitados." BRESSERPEREIRA, Luiz Carlos. A construção política do Brasil: sociedade, economia e estado desde a Independência. 2. ed. São Paulo: Editora 34, 2015, p. 285.

57 BRESSER-PEREIRA, Luiz Carlos. A construção política do Brasil: sociedade, economia e estado desde a Independência. 2. ed. São Paulo: Editora 34, 2015, p. 66-67 e 206-207.

58 SADEK, Maria Tereza Aina. Justiça e direitos: a construção da igualdade. In: BOTELHO, André; SCHWARCZ, Lilia Moritz (Orgs.). Agenda brasileira: temas de uma sociedade em mudança. São Paulo: Companhia das Letras, 2011, p. 331. p. $324-333$.

59 CAMPANTE, Rubens Goyatá. Direito sociais e justiça. In: AVRITZER, Leonardo; BIGNOTTO, Newton; FILGUEIRAS, Fernando; GUIMARÃES, Juarez; STARLING, Heloísa (Orgs.). Dimensões políticas da justiça. Rio de Janeiro: Civilização Brasileira, 2013, p. 379.

60 BONAVIDES, Paulo; ANDRADE, Paes de. História constitucional do Brasil. 6. ed. Brasília: OAB Editora, 2004, p. 498499.

61 BRESSER-PEREIRA, Luiz Carlos. A construção política do Brasil: sociedade, economia e estado desde a Independência. 2. ed. São Paulo: Editora 34, 2015, p. 292. 
Efetivamente, nas últimas duas décadas os indicadores sociais do Brasil melhoraram significativamente. Houve uma diminuição considerável da desigualdade social e melhoria da vida de milhares de pessoas, em especial da população pobre e miserável. A melhoria da qualidade de vida no País foi resultado direto do aumento real do salário mínimo e ampliação dos recursos destinados aos gastos sociais, máxime os relativos ao programa de transferência de renda conhecido por Bolsa Família, bem como em virtude da redução do desemprego e aumento de verbas para cobertura de serviços públicos essenciais nas áreas de educação, saúde e previdência. ${ }^{62}$

É verdade que, a despeito do avanço do padrão de vida decorrente do esforço de inclusão social, "o desafio social permanece central para o Brasil", cracia, a demanda dos trabalhadores por meio maiores e melhores gastos sociais é muito forte" ${ }^{64}$ Realmente, inúmeros são ainda os obstáculos, inclusive normativos, para a realização de um Estado de Bem-Estar Social forte, democrático e republicano no Brasil.

$\mathrm{Na}$ perspectiva jurídica, tem-se que sequer os direitos sociais previstos constitucionalmente são todos efetivamente garantidos, pois muitos deles ainda aguardam a devida regulamentação para sua real concretização. Indubitavelmente, além de problemas sistêmicos e estruturais, inclusive já seriamente estudados por CAPPELLETI, em colaboração com GARTH, ${ }^{65}$ a falta de regulamentação das normas constitucionais por parte do Poder Público é um importante fator de baixa efetividade dos direitos sociais. Com intuito de combater a crônica "síndrome de inefetividade" ${ }^{66}$ que acomete historicamente os textos constitucionais brasileiros, estabeleceu a Constituição vigente instrumentos jurídicos de implementação dos direitos fundamentais, entre os quais se pode apontar o mandado de injunção.

Ora, tendo o Texto Constitucional reconhecido a natureza eficacial imediata das normas definidoras de direitos fundamentais, era preciso, com efeito, estabelecer um meio judicial para que fosse assegurada a efetividade desses direitos. Para tanto, o legislador constituinte de 1988 previu a ação de mandado de injunção. Inegavelmente, repita-se, a preocupação de que a Constituição atual se convertesse, tal qual as anteriores, em "letra morta" foi a principal causa da previsão da ação injuncional, pois, como é óbvio, não é suficiente apenas declarar expressamente direitos, sendo, igualmente, imprescindível a institucionalização de mecanismos jurídicos asseguradores de sua efetivação. ${ }^{67}$ Frise-se, nesse sentido, que o mandado de injunção deve ser utilizado sempre que o exercício concreto de direitos, liberdades e prerrogativas constitucionais estiver sendo prejudicado pela falta de norma regulamentadora. Mas é preciso considerar que os direitos sociais geralmen-

62 BRESSER-PEREIRA, Luiz Carlos. A construção política do Brasil: sociedade, economia e estado desde a Independência. 2. ed. São Paulo: Editora 34, 2015, p. 33, 322, 347-348, 373, 377 e 402. O referido autor ainda critica a análise conservadora de que "o gasto social brasileiro tem se concentrado em atividades puramente assistenciais". Pondera o autor que "De fato, houve um aumento importante no gasto e assistência social no Brasil, sobretudo com a adoção de mecanismos de renda mínima que hoje se concentram no Bolsa Família. Entretanto, a política assistencial através dos esquemas de renda mínima no atual governo [do Partido dos Trabalhadores], reunidos e ampliados com o título Bolsa Família, logrou eliminar ou reduzir substancialmente a pobreza absoluta". Ibid., p. 375.

63 BRESSER-PEREIRA, Luiz Carlos. A construção política do Brasil: sociedade, economia e estado desde a Independência. 2. ed. São Paulo: Editora 34, 2015, p. 377.

64 BRESSER-PEREIRA, Luiz Carlos. A construção política do Brasil: sociedade, economia e estado desde a Independência. 2. ed. São Paulo: Editora 34, 2015, p. 377.

65 CAPPELLETTI, Mauro; GARTH, Bryan. O acesso à justiça. Porto Alegre: Sérgio Antonio Fabris, 2002. Têm-se, entre as causas que dificultam o acesso à justiça, as de ordem econômica (alto custo financeiros da litigância, particularmente, os honorários do advogado e morosidade) e cognitivo-educacional (desconhecimento dos direitos ou falta de conhecimento para buscar a sua efetividade). Confira: CAMPANTE, Rubens Goyatá. Direito sociais e justiça. In: AVRITZZER, Leonardo; BIGNOTTO, Newton; FILGUEIRAS, Fernando; GUIMARÃES, Juarez; STARLING, Heloísa (Orgs.). Dimensões políticas da justiça. Rio de Janeiro: Civilização Brasileira, 2013, p. 376.

66 BARROSO, Luís Roberto. BARROSO, Luís Roberto. A doutrina brasileira da efetividade. In: Constituição e democracia: estudos em homenagem ao professor J. J. Gomes Canotilho. São Paulo: Malheiros, 2006, p. 435-448.

67 CITTADINO, Gisele. Mandado de injunção. In: AVRITZER, Leonardo; BIGNOTTO, Newton; FILGUEIRAS, Fernando; GUIMARÃES, Juarez; STARLING, Heloísa (Orgs.). Dimensões políticas da justiça. Rio de Janeiro: Civilização Brasileira, 2013, p. $514-515$. 
te exigem complementação legislativa para sua concreta aplicabilidade, porquanto são direitos veiculados em normas constitucionais que traçam "programas de ação ou afirmações de princípios e não possuem uma regulamentação perfeita e completa, sendo quase sempre pouco descritivas, vagas e esquemáticas". ${ }^{68}$

Anote-se, nessa linha, que o Poder Judiciário brasileiro vem nos últimos anos atuando no sentido de efetivar direitos constitucionais, especialmente os direitos sociais. Exemplo emblemático foi o julgamento da questão do direito de greve dos servidores públicos civis. Malgrado a Constituição de 1988 estabelecer como direito social a liberdade de greve na esfera pública, esse direito necessita de regulamentação por meio de edição de lei ordinária para produção de efeitos concretos. Ocorre que tal direito, mesmo após quase três décadas de promulgação da Constituição vigente, nunca foi regulamentado pelo Congresso Nacional. E em razão da inércia legislativa o Supremo Tribunal Federal (STF), provocado por categorias profissionais, por meio de mandados de injunção ${ }^{69}$, decidiu, em 2007, pela aplicabilidade da legislação pertinente à greve dos trabalhadores do setor privado (Lei $n^{\circ} 7.778 / 1989$ ) aos servidores públicos. Veja-se que, no caso, o STF, além de reconhecer a inércia parlamentar, indicou diretamente a norma a concretizar o exercício do direito de greve dos servidores públicos. ${ }^{70}$ Em suma, a Suprema Corte "resolveu a questão não somente para as partes envolvidas, mas suprimiu a omissão, resolvendo a questão para todos os casos, abstratamente". ${ }^{11}$

Outra matéria importante julgada pelo STF diz respeito ao questionamento da constitucionalidade da reserva de vagas em universidades públicas para alunos egressos de escolas públicas, negros, pardos e índios. Em um dos casos, a questão girou em torno da constitucionalidade de percentual das vagas na Universidade de Brasilia (UNB) para estudantes negros (cota racial) e índios (cota étnica). Por ocasião do julgamento da Ação de Descumprimento de Preceito Fundamental (ADPF) no 186, o STF decidiu, em 2012, pela constitucionalidade dessa reserva, sob a fundamentação de que tal política se traduz em ação afirmativa para correção de desigualdades materiais históricas e, portanto, compatível com os valores e princípios albergados pela Constituição. No mesmo sentido, a Suprema Corte brasileira considerou legítima a Lei nº 11.096/2005, que previu o Programa Universidade para Todos (PROUNI), isto é, a política de concessão de bolsas estudantis no ensino superior privado para alunos que tenha cursado o ensino médio em estabelecimentos públicos de ensino. Nesse caso, a Suprema Corte considerou improcedente a ação direta de inconstitucionalidade proposta pela Confederação Nacional dos Estabelecimentos de Ensino (CONFENEN), bem como outra de mesmo teor ajuizada pelo Partido Democratas (DEM) ${ }^{72}$. Para o Supremo Tribunal, o PROUNI se compatibiliza com os preceitos constitucionais que estabelecem como um dos objetivos fundamentais da República brasileira a redução das desigualdades sociais, além de considerar tal programa um "fator de inserção social" para alunos de baixa renda, dado que o gozo dessa cota social exige uma renda máxima por família do beneficiado.

Registre-se, ainda, a discussão pela Suprema Tribunal do direito social ao aviso prévio proporcional ao tempo de serviço. Em sede de mandado de segurança, no ano de 2011, o STF encaminhava-se para dar cumprimento à norma constitucional que expressamente traz como direito fundamental dos trabalhadores o “aviso prévio proporcional”. E a razão disso era que o legislador ordinário deixara de regulamentar referida norma por mais de vinte anos, fato esse que tornava inviável a efetividade desse direito social constitucional.

68 CITTADINO, Gisele. Mandado de injunção. In: AVRITZER, Leonardo; BIGNOTTO, Newton; FILGUEIRAS, Fernando; GUIMARÃES, Juarez; STARLING, Heloísa (Orgs.). Dimensões políticas da justiça. Rio de Janeiro: Civilização Brasileira, 2013, p. 514.

69 Os mandados de injunção números 670, 708 e 712 foram, respectivamente, ajuizados pelo Sindicato dos Servidores Policiais Civis do Espírito Santo, pelo Sindicato dos Trabalhadores em Educação do Município de João Pessoa e pelo Sindicato dos Trabalhadores do Poder Judiciário do Estado do Pará.

70 CITTADINO, Gisele. Mandado de injunção. In: AVRITZER, Leonardo; BIGNOTTO, Newton; FILGUEIRAS, Fernando; GUIMARÃES, Juarez; STARLING, Heloísa (Orgs.). Dimensões políticas da justiça. Rio de Janeiro: Civilização Brasileira, 2013, p. 521.

71 FIGUEIREDO, Marcelo. Direito constitucional: estudos interdisciplinares sobre federalismo, democracia e administração pública. Belo Horizonte: Editora Fórum, 2012, p. 133.

72 Confira as ADIs no 3314 (DEM) e 3330 (CONFENEN). 
Ocorre, entretanto, que o Congresso Nacional, pressionado pela iminência de uma decisão judicial estabelecendo os critérios de regulação da questão, aprovou a Lei n ${ }^{\circ} 12.506 / 2011$, que fixou as condições para o gozo do direito ao aviso prévio em alusão. ${ }^{73}$

Como se observa dos casos acima, o Poder Judiciário no Brasil vem desempenhando um papel ativo na garantia de alguns direitos constitucionais sociais ${ }^{74}$, inclusive em relação àqueles que dependem de regulamentação para efetiva concretização. Especificamente no tocante ao direito à educação, o órgão de cúpula do Judiciário brasileiro parece reconhecer que, na lição de SADEK, "políticas afirmativas traduzem a ideia de que cabe à lei e também ao poder público interferir na desigualdade" ${ }^{75}$ Ocorre, no entanto, que a atuação proativa do Judiciário na esfera social não está isenta de questionamentos. $\mathrm{O}$ ativismo judicial em matérias de direitos sociais nem sempre é visto de forma positiva por parte dos estudiosos. É que se, para alguns, a participação mais intensa do Judiciário é tida como extremamente positiva para a consolidação e aprofundamento da democracia social, particularmente para assegurar a efetividade de direitos sociais ${ }^{76}$, para outros, a expansão judicial é um fator problemático do ponto de vista normativo, político e jurídico.

Veja-se que os direitos sociais foram idealizados e positivados em textos constitucionais com a finalidade de garantir o gozo de bens e serviços coletivos ${ }^{77}$ pela sociedade, numa perspectiva de realizar o denominado juridicamente de "mínimo existencial", sem o qual a dignidade humana não poderia ser minimamente respeitada.

Aqui é importante frisar que o aparelho judiciário pode exercer um duplo papel no Estado: um conservador e outro progressista. O primeiro se divide em um aspecto negativo e outro positivo. No negativo, a função judicial reside fundamentalmente na manutenção do status quo, isto é, sem qualquer atuação com o fito de transformar as condições de privilégios e injustiças sociais presentes na sociedade. Tem-se, no segundo, um comportamento do órgão judicial no sentido de evitar retração na proteção social em observância ao princípio da vedação do retrocesso social. Impede-se, por este postulado, a extinção de direitos sociais já efetivados pelo Poder Público, uma vez que já se encontrariam incorporados "ao patrimônio jurídico da cidadania" ${ }^{78}$. E a razão no Brasil que explicaria a necessidade de participação do Judiciário em proteger o princípio em comento é o fato da Constituição brasileira albergar como uma de suas marcas a "progressividade social", pela qual o "Poder Público deve avançar sem refluxo na realização cumulativa dos objetivos fundamentais da nossa República" "79, quer dizer, "na construção permanente de uma sociedade justa e solidária, sem miséria e gritantes e inaceitáveis desigualdades sociais e regionais". ${ }^{80}$ No tocante à função progressista, o Judiciário deve exercer, nas democracias, uma atividade visando sempre a "ampliação de direitos existentes" e a "criação de novos direitos" ${ }^{11}$, principalmente em sociedades da periferia do capitalismo com problemas crônicos de consolidação e aprimoramento da cidadania social. ${ }^{82}$

Ocorre que a efetivação dos direitos sociais é algo tão complexo, materialmente falando, que não bastam para a sua concretização a mera previsão expressa na Constituição e a existência de um aparelho judiciário

73 MELLO, Patrícia Perrone Campos. Nos bastidores do STF. Rio de Janeiro: Forense, 2015, p. 290.

74 Advirta-se, entretanto, que o Supremo Tribunal Federal, em algumas situações, manifestou-se no sentido de negar proteção a direitos sociais previstos na Constituição, como foi o caso do direito fundamental à moradia. Veja-se que no julgamento do Recurso Extraordinário o STF decidiu pela permissão de penhora, nos contratos de locação, do bem de família do fiador.

75 SADEK, Maria Tereza Aina. Justiça e direitos: a construção da igualdade. In: BOTELHO, André; SCHWARCZ, Lilia Moritz (Orgs.). Agenda brasileira: temas de uma sociedade em mudança. São Paulo: Companhia das Letras. p. 331.

76 VIANNA, Luiz Werneck et al. A Judicialização da política e das relações sociais no Brasil. Rio de Janeiro: Revan, 1999. 77 SADEK, Maria Tereza Aina. Justiça e direitos: a construção da igualdade. In: BOTELHO, André; SCHWARCZ, Lilia Moritz (Orgs.). Agenda brasileira: temas de uma sociedade em mudança. São Paulo: Companhia das Letras. p. 329.

78 BARROSO, Luís Roberto. O direito constitucional e a efetividade de suas normas. 5. Ed. Rio de Janeiro: Renovar, 2001, p. 158.

79 CUNHA, Jânio Pereira da. Proibição de retrocesso. Jornal O Povo. Caderno Opinião. Fortaleza-CE, 27 abril de 2010 , p. 06. 80 CUNHA, Jânio Pereira da. Proibição de retrocesso. Jornal O Povo. Caderno Opinião. Fortaleza-CE, 27 abril de 2010 , p. 06.

81 CHAUI, Marilena. O que é política? In: O esquecimento da política. Adauto Novaes (org.). Rio de Janeiro: Agir, 2007, p. 53.

82 Esse parágrafo foi construindo parcialmente com ideias extraídas de CASTRO, Marcus Faro de. Formas jurídicas e mudança social: interações entre o direito, a filosofia, a política e a economia. São Paulo: Saraiva, 2012. 
de viés ativista. É verdade que a positivação de direitos em diplomas constitucionais é extremamente importante. Aliás, como já registrado, no Brasil isso sequer é mais um problema essencial, pois se tem um amplo rol de direitos sociais na Constituição de 1988. Indubitavelmente, à luz da advertência de Oliveira VIANNA, em crítica ao tradicional idealismo constitucional brasileiro, cuja base reside na "crença no poder das fórmulas escritas" ", o "normativismo constitucional" é "incapaz, por si só, de operar mudanças sociais e políticas efetivas" ${ }^{84}$. Noutras palavras, "não é suficiente a qualidade formal de uma Constituição para assegurar a transformação social, política e econômica". ${ }^{85}$ Portanto, "não bastam artifícios normativos e, muito menos arroubos retóricos de juristas e operadores do direito para a efetivação dos postulados constitucionais". ${ }^{86}$

Trata-se, assim, de uma ilusão jurídica, "fundada na concepção providencialista de que a Constituição tudo pode" ${ }^{87}$, o denominado "normativismo constitucional", isto é, a "certeza de que a efetivação constitucional ou as deficiências de nossa democracia residem na interpretação das normas; ou que todos os desafios poderiam ser resolvidos com a articulação interna dos dispositivos constitucionais". ${ }^{88}$ Nessa perspectiva, o "papel da política, com todos os seus autores, é praticamente desprezado. Não é necessário ir muito longe para enxergar a extrema fragilidade dessas teses e a pobreza de sua força explicativa para dar conta dos conflitos democráticos". ${ }^{89}$

Nessa linha realista, adverte LOEWENSTEIN que o diploma constitucional não detém força suficiente para eliminar a diferença entre a pobreza e a riqueza, dado que a Constituição "não pode dar nem comida, nem casa, nem roupa, nem educação, nem lazer, isto é, as necessidades essenciais da vida".90

Ora, se a realidade não pode ser direta, unilateral e completamente transformada pelo jurídico, é lícito afirmar que a efetivação dos direitos sociais no Brasil depende muito mais de ações do Poder Legislativo e Executivo do que de decisões do Poder Judiciário. Pensar diferente é eleger um órgão do Estado destituído de competência e capacidade para uma missão cujos obstáculos materiais - leia-se, políticos, econômicos e financeiros - são tão fortes que decerto sempre produzirá frustrações naqueles que enxergam o Judiciário como a entidade ideal para realização das promessas civilizatórias da modernidade, vale dizer, dos direitos e garantias previstos nos textos constitucionais. É certo pontuar, por conseguinte, que a concretização de direitos sociais não depende exclusivamente da simples vontade ou desejo dos atores judiciais.

Com efeito, a sociedade brasileira já avançou muito na formulação e efetivação de um sistema social protetivo, "em parte responsável pela significativa redução dos níveis de pobreza e desigualdade". ${ }^{91}$ Porém, a herança histórica de uma sociedade marcada pela exclusão e hierarquia sociais e com baixo desenvolvimento econômico constitui, no entanto, grande e sério obstáculo para superação profunda e duradoura dos problemas sociais e econômicos constantes no Brasil.

83 VIANNA, Oliveira. O idealismo constitucional. 2. Ed. São Paulo: Companhia Editora Nacional, 1939, p. 81.

84 CUNHA, Jânio Pereira da. Oliveira Vianna: contribuição para o pensamento constitucional realista. In: Temas de pensamento constitucional brasileiro. LIMA, Martonio Mont'Alverne Barreto; ALBUQUERQUE, Newton de Menezes (Coords.). COUTINHO, Júlia Maia e Meneses; PASSOS, Daniela Veloso Souza (Orgs.). Temas de pensamento constitucional brasileiro. Vol. IV, Belo Horizonte: Arraes Editores, 2015, p. 92-93.

85 CUNHA, Jânio Pereira da. Oliveira Vianna: contribuição para o pensamento constitucional realista. In: Temas de pensamento constitucional brasileiro. LIMA, Martonio Mont'Alverne Barreto; ALBUQUERQUE, Newton de Menezes (Coords.). COUTINHO, Júlia Maia e Meneses; PASSOS, Daniela Veloso Souza (Orgs.). Temas de pensamento constitucional brasileiro. Vol. IV, Belo Horizonte: Arraes Editores, 2015, p. 92.

86 CUNHA, Jânio Pereira da. Oliveira Vianna: contribuição para o pensamento constitucional realista. In: Temas de pensamento constitucional brasileiro. LIMA, Martonio Mont'Alverne Barreto; ALBUQUERQUE, Newton de Menezes (Coords.). COUTINHO, Júlia Maia e Meneses; PASSOS, Daniela Veloso Souza (Orgs.). Temas de pensamento constitucional brasileiro. Vol. IV, Belo Horizonte: Arraes Editores, 2015, p. 93.

87 HORTA, Raul Machado. Direito Constitucional. 3. ed., rev. atual. e ampl. Belo Horizonte: Del Rey, 2002, p. 65.

88 BERCOVICI, Gilberto; LIMA, Martônio Mont'Alverne Barreto. Separação de poderes e constitucionalidade da PEC $\mathrm{n}^{\circ}$ 33/2011. Pensar - Revista do Curso de Direito da Universidade de Fortaleza (Unifor). Fortaleza, v. 18, no 3, set./ dez. 2013 , p. 791. 89 BERCOVICI, Gilberto; LIMA, Martônio Mont'Alverne Barreto. Separação de poderes e constitucionalidade da PEC $\mathrm{n}^{\circ}$ 33/2011. Pensar - Revista do Curso de Direito da Universidade de Fortaleza (Unifor). Fortaleza, v. 18, no 3, set./dez. 2013 , p. 791.

90 LOWENSTEIN, Karl. Teoría de la constitución. Tradução de Alfredo Gallego Anabitarte. Barcelona: Ariel, 1976, p. 229.

91 ALMEIDA, Maria Hermínia Tavares de. A experiência democrática recente: resultados e percepções. In: ALONSO, Angela; DOLHNIKOFF, Miriam (Orgs.). 1964: do golpe à democracia, São Paulo: Hedra, 2015, p. 292. 
É preciso ponderar, finalmente, que o ativismo judicial implica problemas teórico-constitucionais difíceis de serem contornados, entre os quais o mais grave é a acusação de que o protagonismo dos atores judiciais ofende o princípio da separação de poderes, da legalidade e o da legitimidade democrática da instituição judicial para decidir questões propriamente políticas. ${ }^{92}$ Não se pode olvidar, ademais, que, ante a reserva do financeiramente possível, os direitos sociais, cuja efetivação depende de prestações efetivas por parte do Estado, sofrem restrições e limites materiais para sua realização, pois necessitam de recursos econômico-financeiros para a devida e ampla concretização. É inegável, com efeito, que o desenvolvimento social pressupõe, em certa medida, o crescimento econômico ${ }^{93}$, de tal sorte que a efetivação dos direitos sociais fundamentais "precisa combinar crescimento com estabilidade e redução das desigualdades, o que, definitivamente, não é fácil". ${ }^{4}$

\section{Considerações finais}

A história da objetivação dos direitos sociais, de sua positivação no processo civilizatório, seja na perspectiva da sociedade mundial ou das sociedades determinadas, é bem melhor apreendida se analisada como resultado do confronto de interesses no cerne de um todo orgânico. Daí, então, que a institucionalização desses direitos e sua efetivação devam ser compreendidas como resultado da evolução do processo político-jurídico vis-à-vis ao desenvolvimento socioeconômico. Como observado, neste artigo, a evolução do status de cidadania se verificou em meio às contradições que pululam no cerne do processo civilizatório da moderna sociedade industrial, mas seguiu uma sequência em que, no século XVIII, se assistiu a consolidação dos direitos civis, no século XIX, dos direitos políticos, no século XX, dos direitos sociais; entretanto, entre nós, os direitos sociais foram frustrados pela constante interrupção da normalidade democrática, a partir da institucionalização de governos civis e militares autoritários.

A estrutura sociopolítica brasileira é norteada por objetivos elaborados na luta dos grupos de interesses interno e de outras estruturas sociais. Seus pilares foram fincados já na Monarquia: a busca do progresso. Nos primeiros anos da República a ordem estava consolidada; as rotinas instituídas deram início a edificação de uma economia robusta assentada em parte de sua população, com riqueza usufruída por ínfima minoria e um expressivo contingente de miseráveis, excluídos da vida material e cultural, inseridos numa rotina que só, marginal ou de forma subserviente, tangencia aquelas socialmente legítimas.

Alternaram-se governos, democráticos e de exceções, que gerenciaram os recursos públicos intentando alcançar o objetivo social estabelecido; mudanças foram realizadas, mas todas no sentido de aperfeiçoar as rotinas das instituições e não de transformá-las. O esgotamento desse consenso, que simultaneamente fomentou a riqueza e a miséria, despontou nos movimentos populares por abertura democrática que erodiu o governo militar. Foi-se estruturando a partir daí uma força construtora do consenso do bem-estar social. No rastro desse consenso se observou, por intermédio da promulgação da Constituição de 1988, a criação de um sistema jurídico de proteção social capaz de viabilizar ações promotoras do alargamento do bem-estar social aos membros de todos os estratos populacionais. Entrementes, como se procurou aqui demonstrar a previsão constitucional é um ponto de partida extraordinário para sua efetivação, mas não é um marco funcional exclusivo, pois se faz necessária, exponencialmente, a ação de políticas públicas desenvolvidas nos poderes Legislativo e Executivo.

92 FIGUEIREDO, Marcelo. Direito constitucional: estudos interdisciplinares sobre federalismo, democracia e administração pública. Belo Horizonte: Editora Fórum, 2012, p. 131.

93 CAMPANTE, Rubens Goyatá. Direito sociais e justiça. In: AVRITZER, Leonardo; BIGNOTTO, Newton; FILGUEIRAS, Fernando; GUIMARÃES, Juarez; STARLING, Heloísa (Orgs.). Dimensões políticas da justiça. Rio de Janeiro: Civilização Brasileira, 2013, p. 379.

94 BRESSER-PEREIRA, Luiz Carlos. A construção política do Brasil: sociedade, economia e estado desde a Independência. 2. ed. São Paulo: Editora 34, 2015, p. 400. 


\section{ReferênCIAs Bibliográficas}

ABREU, Marcelo de Paiva. Crise, crescimento e modernização autoritária. In: ABREU, Marcelo de Paiva. A ordem do progresso: cem anos de política econômica republicana 1889-1989. Rio de Janeiro: Campus, 1990.

ALMEIDA, Maria Hermínia Tavares de. A experiência democrática recente: resultados e percepções. In: ALONSO, Angela; DOLHNIKOFF, Miriam (Orgs.). 1964: do golpe à democracia, São Paulo: Hedra, 2015. p. 289-303.

ARRUDA, Gerardo Clésio Maia; GOLÇALVES, Flávio José Moreira. Paideia dos degredados: raízes dos condicionantes inibidores da universalização do direito à educação no Brasil. Fortaleza: Revista Opinião Jurídica. V. 13. 2015. p. 203-231.

Gerardo Clésio Maia; BERTOLINI, Adriana Rossas; SOUZA, Ana Laíse Pacheco de. Direitos sociais no Brasil à luz do primado da diferenciação social. In: RODRIGUES, Francisco Lisboa; CUNHA, Jânio Pereira. Pautas Constitucionais Contemporâneas Vol II. Rio de Janeiro: Editora Lumen Juris, 2015/A.

Gerardo Clésio Maia. Exclusão social, direitos humanos e cidadania no Brasil. In: COSTA, Andreia da Silva e LEITÃO, Cláudia Souza. Direitos humanos: uma reflexão plural e emancipatória. Fortaleza: Faculdade Christus, 2010.

BARROSO, Luís Roberto. Judicialização, ativismo judicial e legitimidade democrática. Suffragium Revista do Tribunal Regional Eleitoral do Ceará, Fortaleza, v. 5. n.8. p. 11-22, jan-dez. 2009.

A doutrina brasileira da efetividade. In: Constituição e democracia: estudos em homenagem ao professor J. J. Gomes Canotilho. São Paulo: Malheiros, 2006. p. 435-448.

O direito constitucional e a efetividade de suas normas. 5. Ed. Rio de Janeiro: Renovar, 2001.

BEDIN, Gilmar Antonio. Os direitos do homem e o neoliberalismo. $3^{a}$ ed. Ijuí-Rio Grande do Sul: 2002.

BERCOVICI, Gilberto; LIMA, Martonio Mont'Alverne Barreto. Separação de poderes e constitucionalidade da PEC no 33/2011. Pensar - Revista do Curso de Direito da Universidade de Fortaleza (Unifor). Fortaleza, v. 18, no 3, p. 785-801, set./dez. 2013.

BOBBIO, Norberto. A era dos direitos. Tradução de Nelson Coutinho. Rio de Janeiro: Elsevier, 2004.

BONAVIDES, Paulo; ANDRADE, Paes de. História constitucional do Brasil. 6. ed. Brasília: OAB Editora, 2004.

BRASIL. Instituto de Pesquisa Econômica Aplicada (IPEA). Dimensão, evolução e projeção da pobreza por região e por estado no Brasil. Rio de Janeiro: IPEA, 2010.

BRESSER-PEREIRA, Luiz Carlos. A construção política do Brasil: sociedade, economia e estado desde a Independência. 2. ed. São Paulo: Editora 34, 2015.

CAMPANTE, Rubens Goyatá. Direito sociais e justiça. In: AVRITZER, Leonardo; BIGNOTTO, Newton; FILGUEIRAS, Fernando; GUIMARÃES, Juarez; STARLING, Heloísa (Orgs.). Dimensões políticas da justiça. Rio de Janeiro: Civilização Brasileira, 2013. p. 369-382.

CANO, Wilson. Desequilíbrios regionais e concentração industrial no Brasil 1930 - 1970. São Paulo: Editora UNESP, 2007.

CAPPELLETTI, Mauro; GARTH, Bryan. O acesso à justiça. Porto Alegre: Sérgio Antonio Fabris, 2002. 
CARVALHO, José Murilo de. Cidadania no Brasil: o longo caminho. 16ª ed. Rio de Janeiro: Civilização brasileira, 2013.

CASTRO, Marcus Faro de. Formas jurídicas e mudança social: interações entre o direito, a filosofia, a política e a economia. São Paulo: Saraiva, 2012.

CHAUI, Marilena. O que é política? In: O esquecimento da política. Adauto Novaes (org.). Rio de Janeiro: Agir, 2007.

CITTADINO, Gisele. Mandado de injunção. In: AVRITZER, Leonardo; BIGNOTTO, Newton; FILGUEIRAS, Fernando; GUIMARÃES, Juarez; STARLING, Heloísa (Orgs.). Dimensões políticas da justiça. Rio de Janeiro: Civilização Brasileira, 2013. p. 513-521.

CUNHA, Jânio Pereira da. Oliveira Vianna: contribuição para o pensamento constitucional realista. In: Temas de pensamento constitucional brasileiro. LIMA, Martonio Mont'Alverne Barreto; ALBUQUERQUE, Newton de Menezes (Coords.). COUTINHO, Júlia Maia e Meneses; PASSOS, Daniela Veloso Souza (Orgs.). Temas de pensamento constitucional brasileiro. Vol. IV, Belo Horizonte: Arraes Editores, 2015, p. 92. p. 86-96.

Proibição de retrocesso. Jornal O Povo. Caderno Opinião. Fortaleza-CE, 27 abril de 2010, p. 06.

DOWBOR, Ladislau. A formação do capitalismo dependente no Brasil. São Paulo: Brasiliense, 1982.

FERNANDES, Florestan. A sociologia numa era de revolução social. Rio de Janeiro: Zahar Editores, 1976.

FIGUEIREDO, Marcelo. Direito constitucional: estudos interdisciplinares sobre federalismo, democracia e administração pública. Belo Horizonte: Editora Fórum, 2012.

FIORI, José Luís. Em busca do dissenso perdido: ensaios críticos sobre a festejada crise do Estado. Rio de Janeiro: Insight, 1995.

FONSECA, João Bosco Leopoldino da. Direito econômico. $4^{a}$ ed. Rio de Janeiro: Forense, 2001.

FURTADO, Celso. Formação econômica do Brasil. São Paulo: Companhia das Letras, 2007.

HORTA, Raul Machado. Direito Constitucional. 3. ed., rev. atual. e ampl. Belo Horizonte: Del Rey, 2002.

LAFER, Celso. Ensaios liberais. São Paulo: Siciliano, 1991.

LOWENSTEIN, Karl. Teoría de la constitución. Tradução de Alfredo Gallego Anabitarte. Barcelona: Ariel, 1976.

MARSHALL, T. H. Cidadania, classe social e status. Rio de Janeiro: Zahar, 1967.

MARX, Karl. O capital: crítica da economia política.São Paulo: Abril cultural, 1988.

MELLO, Patrícia Perrone Campos. Nos bastidores do STF. Rio de Janeiro: Forense, 2015.

MOORE JUNIOR, B. As origens sociais da ditadura e da democracia: senhores e camponeses na construção do mundo moderno. São Paulo: Martins Fontes, 1975.

OLIVEIRA, Francisco de. A economia brasileira: crítica à razão dualista. Petrópolis: Editora Vozes, 1987.

PIRES, Murilo José de Souza e RAMOS, Pedro. O termo modernização conservadora: sua origem e utilização no Brasil. Fortaleza: Revista Econômica do Nordeste - REN. V. 40. 2009. p. 411-424.

PNUD. Programa das Nações Unidas para o Desenvolvimento. Relatório de Desenvolvimento Humano 2013. Disponível em: www.pnud.org.br/arquivos/rdh-2013.pdf. Acesso em: 10/04/2016.

PRADO JÚNIOR, Caio. História econômica do Brasil. São Paulo: Brasiliense, 2006. 
SADEK, Maria Tereza Aina. Justiça e direitos: a construção da igualdade. In: BOTELHO, André; SCHWARCZ, Lilia Moritz (Orgs.). Agenda brasileira: temas de uma sociedade em mudança. São Paulo: Companhia das Letras. p. 324-333.

SARLET, Ingo Wolfgang. Art 6․ In: CANOTILHO, J. J. Gomes; MENDES, Gilmar Ferreira; SARLET, Ingo Wolfgang; STRECK, Lenio Luiz; LEONCY, Léo Ferreira (Coords.). Comentários à Constituição do Brasil. São Paulo: Saraiva/Almedina, 2013. Série IDP.

SOUZA, Daniel Coelho de. Interpretação e democracia. $2^{\mathrm{a}}$ ed. São Paulo: Revista dos tribunais, 1979.

STRECK, Lenio Luiz. O papel da jurisdição constitucional na realização dos direitos sociais-fundamentais. In: SARLET, Ingo Wolfgang (org.). Direitos Fundamentais Sociais: estudos de direito constitucional internacional comparado. Rio de Janeiro - São Paulo: Renovar, 2003.

TOCQUEVILLE, Aléxis de. A democracia na América: leis e costumes. São Paulo: Martins Fontes, 1998.

VIANNA, Luiz Werneck et al. A Judicialização da política e das relações sociais no Brasil. Rio de Janeiro: Revan, 1999.

VIANNA, Oliveira. O idealismo constitucional. 2. Ed. São Paulo: Companhia Editora Nacional, 1939. 


\section{Normas Editoriais}

1. Serão aceitas colaborações inéditas e a publicação de um artigo está condicionada à sua adequação às normas editoriais, e seu simples recebimento desobriga a sua publicação. A revista Prismas: Direito, Políticas Públicas e Mundialização classificará as colaborações de acordo com as seguintes seções:

1.1 Artigos: compreende textos que contenham relatos completos de estudos ou pesquisas concluídas, matérias de caráter opinativo, revisões da literatura e colaborações assemelhadas.

1.2 Resenhas: compreende análises críticas de livros, de periódicos recentemente publicados, dissertações e teses.

2. Excepcionalmente, a equipe editorial poderá aceitar a submissão de trabalhos que já tenham sido publicados e caso isso ocorra, serão submetidos ao mesmo processo de avaliação pelos pares que aqueles inéditos. $\mathrm{O}$ autor deverá apresentar autorização por escrito do editor da revista na qual seu trabalho tenha sido originalmente publicado, acompanhado de cópia do mesmo.

3. O processo de avaliação dos artigos e resenhas compreende duas fases: a primeira destinada à análise da adequação do trabalho à linha editorial da revista (Equipe Editorial) e a segunda referente à avaliação do conteúdo e qualidade dos trabalhos. Esta segunda fase é realizada mediante o processo de avaliação pelos pares, ou seja, os artigos serão submetidos à aprovação de no mínimo 2 pareceristas adhoc.

4. Os trabalhos serão enviados para a avaliação sem a identificação de autoria

5. Os trabalhos devem ser enviados no seguinte padrão:

$1^{a}$ Página: Começar com o título do título do trabalho, seguido do texto. Não inseriro nome dos autores ou outros elementos queidentifiquem a autoria. A autoria do artigo e a qualificação dos autores são inseridas nos campos específicos do formulário eletrônico. O objetivo aqui é garantir uma avaliação cega por pares. Os textos deverão ser digitados em Arial 12, espaço 1,5 margem de 2,5 $\mathrm{cm}$, numeração arábica das páginas no ângulo superior direito, em programa compatível com o Word para Windows.

Título do trabalho: o título deve ser breve e suficientemente específico e descritivo para representar o conteúdo do texto e deverá ter a sua tradução para o inglês.

Resumo: em todos os artigos submetidos deve ser incluído um resumo informativo com o máximo de 250 palavras e espaço entre linhas simples. O resumo deve ser estruturado com as seguintes informações:

Objetivo do artigo (obrigatório);

Metodologia (obrigatório);

Conclusões (obrigatório);

Limitações da pesquisa e suas implicações (se aplicável);

Limitações práticas (se aplicável)

Originalidade ou valor (obrigatório); 
A evolução da comunicação científica e da transmissão de conhecimentos possibilitou ao UniCEUB a criação de meios para o intercâmbio de idéias entre pares e a disseminação de informações.

As novas tecnologias da informação produzem sensíveis alterações nos processos de comunicação científica. Atualmente, a editoração das publicações acadêmicas do UniCEUB é informatizada em todas as suas etapas, com a utilização da plataforma SEER, Sistema de Editoração Eletrônico de Revistas. A aplicação do SEER permitiu acrescentar, no processo editorial, a avaliação dos pareceristas ad hoc e deu aos membros dos comitês editoriais e aos editores condições para consolidar a produção científica no UniCEUB e difundi-la por meio dos periódicos acadêmicos em mídia impressa e eletrônica.

Todas as edições das publicações científicas do UniCEUB estão disponíveis no site www.publicacoesacademicas.uniceub.br, com infraestrutura para acesso livre.

O UniCEUB publica as seguintes revistas:

- Revista Brasileira de Políticas Públicas

- Revista de Direito Internacional

- Universitas Arquitetura e Comunicação Social

- Universitas Ciências da Saúde

- Universitas Gestão e TI

- Universitas Humanas

- Universitas JUS

- Universitas Relações Internacionais

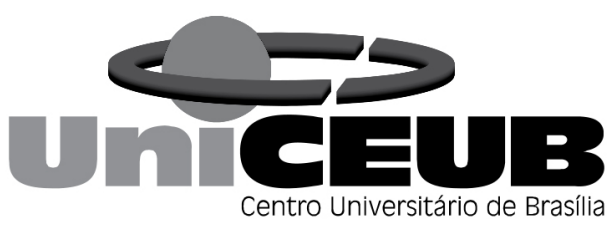


Destacar no mínimo três e no máximo seis palavraschave que representem o conteúdo do texto. O resumo e as palavras-chave deverão ter a sua tradução para o inglês.

Agradecimentos: agradecimentos a auxílios recebidos para a elaboração do trabalho deverão ser mencionados no final do artigo.

Notas: notas referentes ao corpo do artigo deverão vir no rodapé do texto.

Apêndices: apêndices podem ser empregados no caso de listagens extensivas, estatísticas e outros elementos de suporte.

Materiais gráficos: fotografias nítidas e gráficos (estritamente indispensáveis à clareza do texto) poderão ser aceitos e cada fotografia ou gráfico deverá vir no texto e além disso cada um deverá ser enviado em arquivo separado. Se as ilustrações enviadas já tiverem sido publicadas, mencionar a fonte e a permissão para reprodução.

Quadros: os quadros deverão ser acompanhados de cabeçalho que permita compreender o significado dos dados reunidos, sem necessidade de referência ao texto. Assinalar, no texto, pelo seu número de ordem, os locais onde os quadros devem ser intercalados.

Referências: as referências redigidas segundo a norma NBR 6023/2002 da Associação Brasileira de Normas Técnicas (ABNT), deverão ser apresentadas por ordem alfabética e constituir uma lista única no final do artigo. A exatidão e adequação das referências a trabalhos que tenham sido consultados e mencionados no texto do artigo são da responsabilidade do autor. Informações procedentes de comunicação pessoal, de trabalhos em andamento ou não publicados não devem ser incluídas na lista de referências, mas indicada em nota de rodapé. Não utilizar o sistema Autor data para citações. O formato utilizado pela revista é o sistema numérico, onde a citação é indicada por número sobrescrito e a referência mencionada em nota de rodapé.

Recomendações: recomenda-se que se observem as normas da ABNT referentes à apresentação de artigos em publicações periódicas (NBR 6022/2002), apresentação de citações em documentos (NBR 10520/2002), apresentação de originais (NBR 12256), norma para datar (NBR 892), numeração progressiva das seções de um documento (NBR 6024/2003) e resumos (NBR $6028 / 2003)$.

A revista se reserva o direito de efetuar nos originais alterações de ordem normativa, ortográfica e gramatical, com vistas a manter o padrão culto da língua, respeitando, porém, o estilo dos autores.

A partir de 2009, consideramos útil formular algumas sugestões (não obrigatórias) aos autores, com base nos principais motivos por recusa de artigos nos anos anteriores.

8. Responsabilidades e conflitos de interesse: A responsabilidade pelas informações e opiniões indicadas nos artigos é exclusiva dos autores. Eventuais conflitos de interesse serão de responsabilidade dos próprios autores e não do periódico.

\section{Envio dos trabalhos:}

1. Os trabalhos deverão ser enviados para a equipe editorial da revista no endereço eletrônico www.rdi.uniceub.br

2. Cada autor deve enviar declaração de responsabilidade nos termos abaixo:

“Eu XXXX certifico que participei da concepção do trabalho tornar pública minha responsabilidade pelo seu conteúdo, que não omiti quaisquer ligações ou acordos de financiamento entre os autores e companhias que possam ter interesse na publicação deste artigo."

3. Para as colaborações inéditas, cada autor deve enviar a transferência de direitos autorais nos termos abaixo:

"Eu XXXX declaro que em caso de aceitação do artigo inédito, a revista Revista Brasileira de Políticas Públicas passa a ter os direitos autorais a ele referentes. 


\section{REVISTA BRASILEIRA DE POLÍTICAS PÚBLICAS \\ V. 6, n०1}

Empresa que financia campanha eleitoral comete abuso de poder econômico

Carlos Ayres Britto

Reflexões sobre o futuro do estado constitucional moderno

Cesar Luiz Pasold, Gabriel Real Ferrer e Paulo Márcio Cruz

Contratos públicos y mercado global: un abordaje desde el derecho administrativo del siglo XXI

Bruno Ariel Rezzoagli

Contratos administrativos: conceito e critérios distintivos

Carlos Bastide Horbach

Os incentivos econômicos à compra de colhedoras pelo Pronaf-Mais alimentos para os produtores de arroz irrigado do Rio Grande do Sul

João Mairton Moura de Araújo, Mário Conill Gomes e André Carraro

Limitações à extrafiscalidade aplicáveis ao fator acidentário de prevenção - FAP

Daniel de Magalhães Pimenta

Desconstruindo a ineficácia dos direitos sociais: por uma reconstrução dos direitos sociais democrática, participativa e transnacional

Daniela Lopes de Faria, Christian Norimitsu Ito e Inês Moreira da Costa

Direito processual de grupos sociais atual: entre 0 ativismo judicial e o garantismo processual

Jefferson Carús Guedes

Políticas públicas, mínimo existencial e Poder Judiciário: a questão do direito à moradia

Diogo de Calasans Melo Andrade

Benefícios de renda mínima como um direito fundamental: acesso à justiça e inclusão social

Pedro Bastos de Souza

Desenvolvimento humano sustentável e erradicação da pobreza extrema: uma análise sobre a experiência portuguesa

Veyzon Campos Muniz

A ação popular ambiental como forma de participação social na defesa do meio ambiente

Luciano Marcos Paes e Paulo Roberto Polesso

Direito penal ambiental como tutela de sustentação à atuação administrativa e civil nos Estados Unidos da América e no Japão

Luiz Gustavo Gonçalves Ribeiro e Lorena Machado Rogedo Bastianetto

Construção social do projeto polos de produção de biodiesel no contexto do PNPB: uma análise perceptiva

Érika Cristine Silva, Maria das Dores Saraiva de Loreto. Haudrey Germiniani Calvelli e Ronaldo Perez

A correlação entre doenças respiratórias e o incremento das queimadas em Alta Floresta e Peixoto de Azevedo, norte do Mato Grosso - Amazônia Legal

Lilian Rose Lemos Rocha e Christopher William Fagg

Políticas públicas, agricultura familiar e cidadania no Brasil: o caso do PRONAF

Edir Vilmar Henig e Irenilda Ângela dos Santos 